Prepared in cooperation with the Bureau of Reclamation and the Oklahoma Water Resources Board

\title{
Simulation of Groundwater Flow and Analysis of Projected Water Use for the Rush Springs Aquifer, Western Oklahoma
}

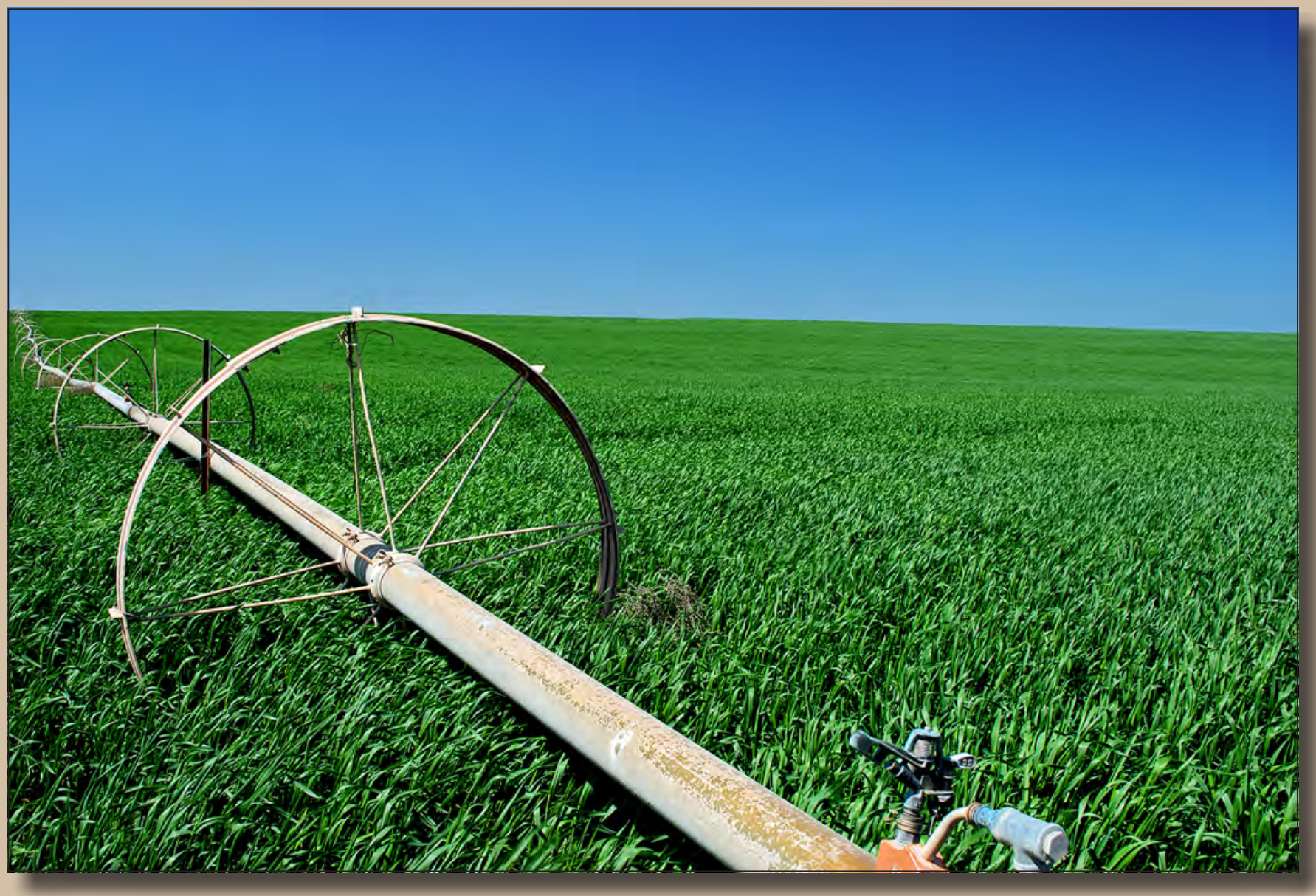

Scientific Investigations Report 2018-5136

U.S. Department of the Interior

U.S. Geological Survey 
Cover photograph: Wheat field irrigated by the Rush Springs aquifer, between Weatherford and Thomas, 0klahoma, March 27, 2012. Photograph courtesy of Chris Neel, Oklahoma Water Resources Board. 


\section{Simulation of Groundwater Flow and Analysis of Projected Water Use for the Rush Springs Aquifer, Western Oklahoma}

By John H. Ellis

Prepared in cooperation with the Bureau of Reclamation and the

Oklahoma Water Resources Board

Scientific Investigations Report 2018-5136 


\section{U.S. Department of the Interior \\ RYAN K. ZINKE, Secretary}

\section{U.S. Geological Survey James F. Reilly II, Director}

\section{U.S. Geological Survey, Reston, Virginia: 2018}

For more information on the USGS - the Federal source for science about the Earth, its natural and living resources, natural hazards, and the environment-visit https://www.usgs.gov or call 1-888-ASK-USGS.

For an overview of USGS information products, including maps, imagery, and publications, visit https://store.usgs.gov.

Any use of trade, firm, or product names is for descriptive purposes only and does not imply endorsement by the U.S. Government.

Although this information product, for the most part, is in the public domain, it also may contain copyrighted materials as noted in the text. Permission to reproduce copyrighted items must be secured from the copyright owner.

Suggested citation:

Ellis, J.H., 2018, Simulation of groundwater flow and analysis of projected water use for the Rush Springs aquifer, western Oklahoma: U.S. Geological Survey Scientific Investigations Report 2018-5136, 156 p., https://doi. org/10.3133/sir20185136.

ISSN 2328-031X (print)

ISSN 2328-0328 (online)

ISBN 978-1-4113-4268-2 


\section{Acknowledgments}

The project documented in this report was conducted by the U.S. Geological Survey (USGS) in cooperation with the Bureau of Reclamation (Reclamation) and the Oklahoma Water Resources Board (OWRB). Appreciation is extended to Collins Balcombe (Reclamation) for initiating and supporting this project and to Anna Hoag (Reclamation) for assistance with data compilation and analysis for the Foss and Fort Cobb Reservoirs. The author also thanks Polly Edwards with the Caddo Nation, whose initiative led to the installation of the five continuous-observation wells used in this study. Since installation, funding for the five continuous-observation wells has been provided by the U.S. Bureau of Indian Affairs. The Reclamation Native American Affairs Technical Assistance to Tribes Program funded data collection and analysis for previous studies about the Rush Springs aquifer.

The author also thanks Michael Fienen (USGS) for his assistance with the uncertainty analysis and Nicole Paizis (USGS) for assistance with report figures. 


\section{Contents}

Acknowledgments .......................................................................................................................ii

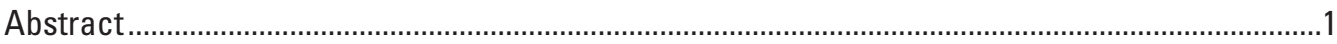

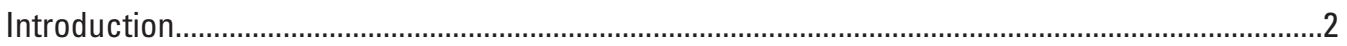

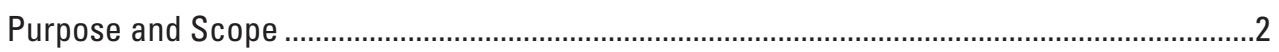

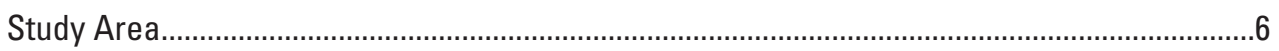

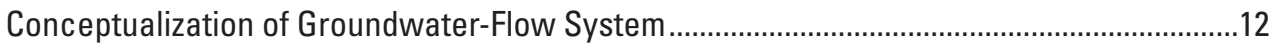

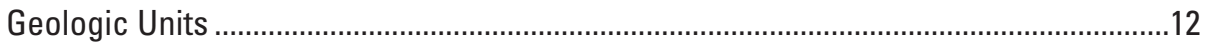

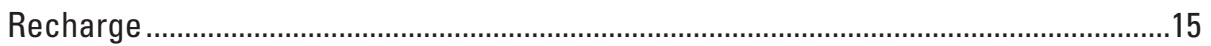

Using the RORA Method to Estimate Recharge ……….......................................15

Using the Soil-Water-Balance Code to Estimate Recharge ....................................15

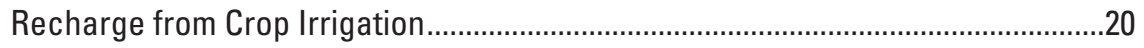

Saturated-Zone Evapotranspiration ...............................................................................20

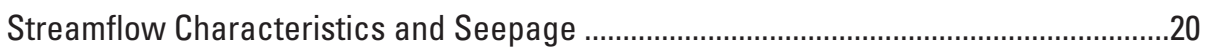

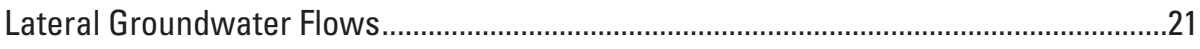

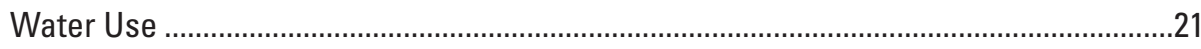

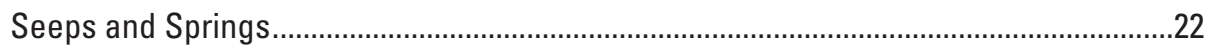

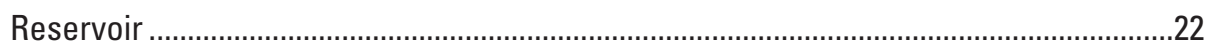

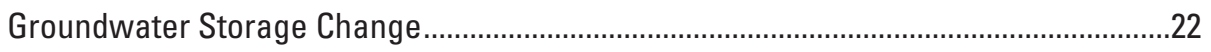

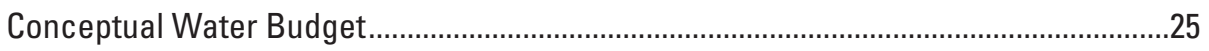

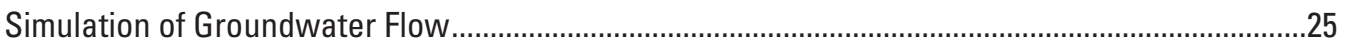

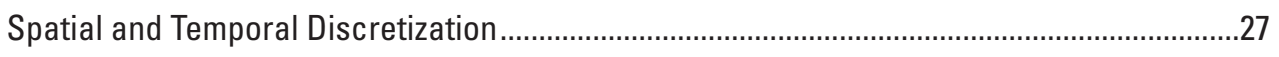

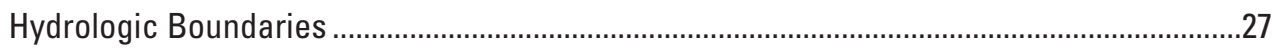

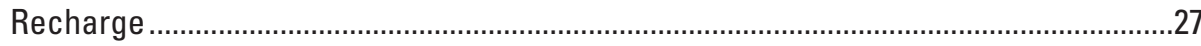

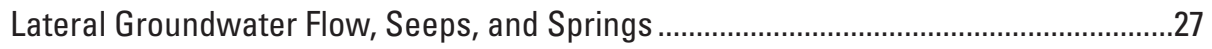

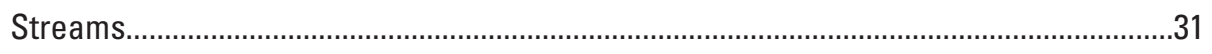

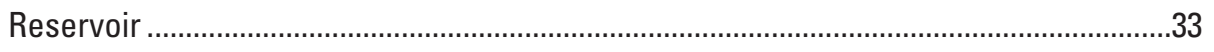

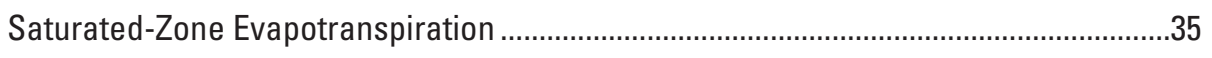

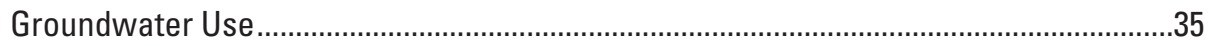

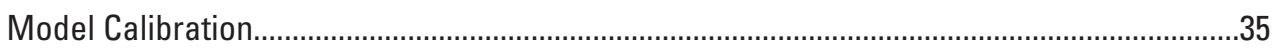

Calibration Parameters .........................................................................................37

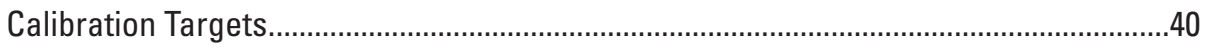

Groundwater-Level Observations .......................................................................

Fort Cobb Reservoir Stage Observations...............................................................40

Base-Flow and Stream-Seepage Estimates ........................................................4

Calibration-Target Uncertainty and Weighting ......................................................4

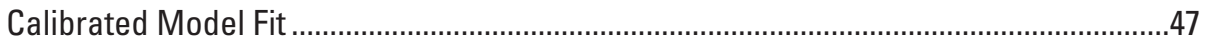

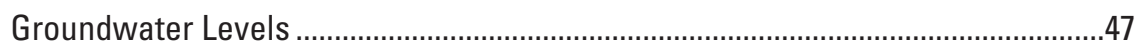

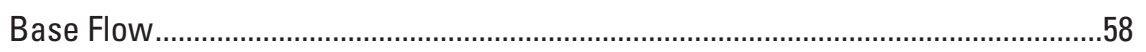

Reservoir Stage and Water Budget.......................................................................63

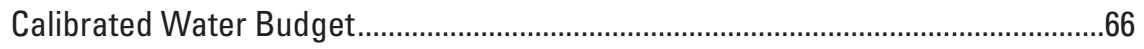

Calibrated Parameter Values.........................................................................................

Calibrated GHB and Drain Conductance ................................................................. 
Calibrated Recharge .............................................................................................70

Calibrated Evapotranspiration from Groundwater .....................................................73

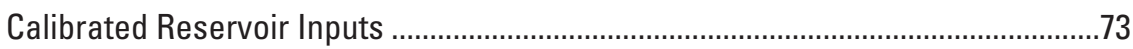

Calibrated Hydraulic Conductivity and Vertical Anisotropy .......................................73

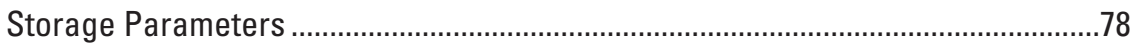

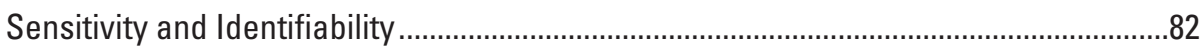

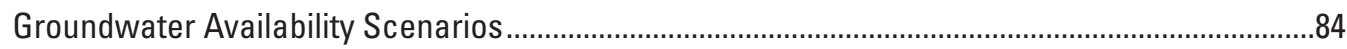

Equal Proportionate Share ............................................................................................. 84

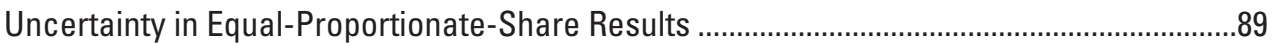

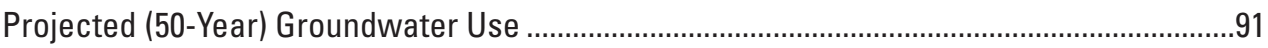

Hypothetical (10-Year) Drought ...........................................................................................99

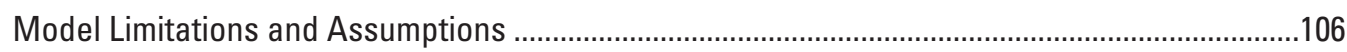

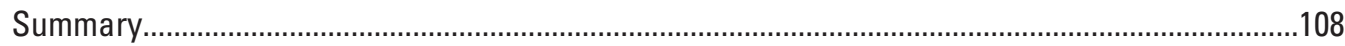

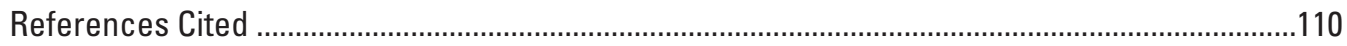

\section{Figures}

1. Map showing the Rush Springs aquifer study area, western Oklahoma...........................3

2. Map showing the surficial geologic units of the Rush Springs aquifer study area, western Oklahoma

3. Stratigraphic chart showing surficial geologic and hydrogeologic units of the Rush Springs aquifer study area, western Oklahoma ........................................................

4. Map showing land-surface altitudes of the Rush Springs aquifer study area, western Oklahoma.

5. Map showing land and crop cover over the Rush Springs aquifer, western Oklahoma, 2011-15

6. Pie charts showing land and crop cover over the Rush Springs aquifer, western Oklahoma, 2011-15

7. Graph showing annual precipitation and recharge computed by using the Soil-Water-Balance code for the Rush Springs aquifer, western Oklahoma, 1979-2015.

8. Graphs showing mean monthly precipitation and recharge computed by using the Soil-Water-Balance code for the Rush Springs aquifer, western Oklahoma, 1979-2015.

9. Map showing mean annual groundwater recharge computed by using the Soil-Water-Balance code for the Rush Springs aquifer, western Oklahoma, 1979-2015.

10. Map showing locations of permitted groundwater wells and surface-water diversions for the Rush Springs aquifer, western Oklahoma, 1979-2015.

11. Map showing locations of long-term and continuous groundwater-level observation wells for the Rush Springs aquifer, western Oklahoma, 1979-2015

12. Graphs showing depth to water for selected wells in Rush Springs aquifer and Fort Cobb Reservoir surface watershed, western Oklahoma, 1974-2016.

13. Map showing hydrogeologic units of the Rush Springs aquifer study area, western Oklahoma.

14. Vertical cross section of the Rush Springs groundwater-flow model, western Oklahoma. 
15. Map showing active area, hydrologic boundaries, and selected parameter zones for the numerical groundwater-flow model of the Rush Springs aquifer, western Oklahoma

16. Map showing Streamflow-Routing package stream channel widths for the numerical groundwater-flow model of the Rush Springs aquifer, western Oklahoma.

17. Graph showing Fort Cobb Reservoir volume, surface area, and stage relationship ......33

18. Lake package cross-section and discretization for the Rush Springs aquifer, western Oklahoma

19. Graph showing monthly water demand by groundwater-use type for the Rush Springs aquifer, western Oklahoma

20. Map showing spatial distribution of recharge zones for the Rush Springs aquifer model, western Oklahoma, 1979-2015

21. Map showing spatial distribution of pilot points for the Rush Springs aquifer model, western Oklahoma, 1979-2015

22. Pie charts showing components of the objective function for the calibration of the numerical groundwater-flow model of the Rush Springs aquifer, western Oklahoma, 1979-2015

23. Map showing spatial distribution of groundwater-level observations in layers 1 and 2 for the Rush Springs aquifer model, western Oklahoma.

24. Graph showing number of groundwater-level observations for each well for the Rush Springs aquifer model, western Oklahoma, 1979-2015

25. Map showing spatial distribution of groundwater-level observations per well for the Rush Springs aquifer model, western Oklahoma, 1979-2015.

26. Graphs showing annual and monthly distribution of groundwater-level observations for the Rush Springs aquifer model, western Oklahoma, 1979-2015

27. Graph showing temporal distribution of streamflow observations used for the calibration of the Rush Springs aquifer model, western Oklahoma, 1979-2015

28. Graphs showing observed and simulated groundwater levels and groundwaterlevel residual distributions for the numerical groundwater-flow model of the Rush Springs aquifer, western Oklahoma, 1979-2015

29. Graphs showing residuals by quality category, weighted residuals by quality category, residuals by layer, and weighted residuals by layer for the numerical groundwater-flow model of the Rush Springs aquifer, western Oklahoma, 1979-2015

30. Map showing spatial distribution of mean groundwater-level residuals for the numerical groundwater-flow model of the Rush Springs aquifer, western Oklahoma, 1979-2015

31. Map showing spatial distribution of mean weighted groundwater-level residuals for the numerical groundwater-flow model of the Rush Springs aquifer, western Oklahoma, 1979-2015.

32. Graph showing temporal distribution of mean, minimum, and maximum groundwater-level residuals for the numerical groundwater-flow model of the Rush Springs aquifer, western Oklahoma, 1979-2015

33. Graphs showing observed and simulated groundwater levels in long-term and continuous groundwater-level observation wells for the Rush Springs aquifer, western Oklahoma, 1979-2015. 
34. Graphs showing observed streamflow, estimated base flow, and simulated base flow at Hammon streamgage on Washita River; Clinton streamgage on Washita River; Carnegie streamgage on Washita River; Anadarko streamgage on Washita River; Bridgeport streamgage on Canadian River; Cement streamgage on Little Washita River; Cobb Creek streamgage on Cobb Creek; Lake Creek streamgage on Lake Creek; and Willow Creek streamgage on Willow Creek for the numerical groundwater-flow model of the Rush Springs aquifer, western Oklahoma, 1979-2015 .

35. Graphs showing Fort Cobb Reservoir observed and simulated stage and storage for the numerical groundwater-flow model of the Rush Springs aquifer, western Oklahoma, 1979-2015

36. Graphs showing annual reservoir inflows and outflows and change in storage for Fort Cobb Reservoir in the numerical groundwater model of the Rush Springs aquifer, western Oklahoma, 1979-2015

37. Pie charts showing mean annual calibrated water budget for the numerical groundwater model of the Rush Springs aquifer, western Oklahoma, 1979-2015...........66

38. Map and pie chart showing simulated stream seepage for the numerical groundwater-flow model of the Rush Springs aquifer, western Oklahoma, 1979-2015

39. Graphs showing annual mean inflows and outflows and annual change in groundwater storage for the numerical groundwater-flow model of the Rush Springs aquifer, western Oklahoma, 1979-2015

40. Graphs showing mean monthly aquifer inflows and outflows and mean monthly change in groundwater storage for the Rush Springs aquifer, western Oklahoma, 1979-2015.

41. Map showing calibrated mean annual recharge for the numerical groundwaterflow model of the Rush Springs aquifer, western Oklahoma, 1979-2015.

42. Graph showing change from initial Lake package inputs for the numerical groundwater-flow model of the Rush Springs aquifer, western Oklahoma, 1979-2015

43. Maps showing calibrated horizontal hydraulic conductivity of the Cloud Chief Formation, alluvium and terrace, and lower Whitehorse Group for the Rush Springs aquifer numerical groundwater-flow model, western Oklahoma

44. Histograms showing horizontal hydraulic conductivity and calibrated horizontal hydraulic conductivity for Canadian River alluvium and terrace and lower Whitehorse Group for the groundwater-flow model of the Rush Springs aquifer, western Oklahoma

45. Histograms showing specific yield for the Cloud Chief Formation; Canadian River alluvium and terrace; and lower Whitehorse Group for the Rush Springs aquifer, western Oklahoma

46. Maps showing specific yield of the Cloud Chief Formation, alluvium and terrace, and lower Whitehorse Group for the Rush Springs aquifer numerical groundwater-flow model, western Oklahoma

47. Graph showing observation group sensitivity by parameter group in the numerical groundwater-flow model for the Rush Springs aquifer, western Oklahoma

48. Graph showing parameter identifiability in the numerical groundwater-flow model for the Rush Springs aquifer, western Oklahoma. 
49. Map showing simulated saturated thickness and simulated base flow after 20 years of continuous equal-proportionate-share groundwater pumping in the Rush Springs aquifer, western Oklahoma.....

50. Vertical cross section of the Rush Springs groundwater-flow model after 20 years of equal-proportionate-share groundwater pumping in the Rush Springs aquifer, western Oklahoma

51. Graphs showing changes in simulated groundwater storage during 20,40 , and 50 years of continuous equal-proportionate-share groundwater pumping in the Rush Springs aquifer, western Oklahoma

52. Graph showing changes in simulated base flow in Cobb, Lake, and Willow Creeks and in simulated stage in Fort Cobb Reservoir during 20 years of continuous equal-proportionate-share groundwater pumping in the Rush Springs aquifer, western Oklahoma

53. Graphs showing parameter distribution of layer 3 specific yield multiplier and recharge zone 12 multiplier for the equal-proportionate-share uncertainty analysis for the Rush Springs aquifer, western Oklahoma

54. Graph showing probabilistic equal-proportionate-share pumping rates for the Rush Springs aquifer, western Oklahoma

55. Graphs showing simulated groundwater storage during 50 years of groundwater use at selected rates for the Rush Springs aquifer and Fort Cobb Reservoir watershed, western Oklahoma

56. Maps showing simulated change in saturated thickness after 50 years of no groundwater use; mean groundwater use, 1979-2015; increasing groundwater use; and 2015 groundwater use for the Rush Springs aquifer, western Oklahoma

57. Graphs showing simulated annual mean base flow through 50 years of groundwater use at selected rates in the Rush Springs aquifer, western Oklahoma.

58. Graph showing change in groundwater storage during a hypothetical 10-year drought for the Rush Springs aquifer, western Oklahoma, 1979-2007 100

59. Map showing simulated change in saturated thickness after a hypothetical 10-year drought for the Rush Springs aquifer, western Oklahoma, 1979-2007 101

60. Graphs showing changes in simulated base flow at Hammon streamgage on Washita River; Clinton streamgage on Washita River; Carnegie streamgage on Washita River; Anadarko streamgage on Washita River; Bridgeport streamgage on Canadian River; Cement streamgage on Little Washita River; Cobb Creek streamgage; Lake Creek streamgage; and Willow Creek streamgage for the numerical groundwater-flow model of the Rush Springs aquifer, western Oklahoma, 1979-2007

61. Graphs showing changes in Fort Cobb Reservoir stage and Fort Cobb Reservoir storage during a hypothetical 10-year drought for the Rush Springs aquifer, 1979-2007 


\section{Tables}

1. Location, period of record, and coefficient of variation for selected streamgages in the Rush Springs aquifer study area, western Oklahoma.

2. Mean annual streamflow and mean annual base flow for selected streamgages in and near the Rush Springs aquifer study area, western Oklahoma, 1979-2015.

3. Conceptual water budget for the Rush Springs aquifer, western Oklahoma, 1979-2015.

4. Selected climate stations in and near the Rush Springs aquifer study area, western Oklahoma

5. Components of the objective function for the automated calibration of the numerical groundwater-flow model of the Rush Springs aquifer, western Oklahoma, 1979-2015.

6. Calibration parameters, parameter values, parameter sensitivity, and parameter identifiability for the automated calibration of the numerical groundwater-flow model of the Rush Springs aquifer, western Oklahoma, 1979-2015

7. Selected groundwater-level observation wells in the Rush Springs aquifer study area, western Oklahoma .142

8. Statistical summary of groundwater-level residuals for the numerical groundwaterflow model of the Rush Springs aquifer, western Oklahoma, 1979-2015.

9. Statistical summary of base-flow residuals for the numerical groundwater-flow model of the Rush Springs aquifer, western Oklahoma, 1979-2015

10. Statistical summary of Fort Cobb Reservoir stage residuals for the numerical groundwater-flow model of the Rush Springs aquifer, western Oklahoma, 1979-2015

11. Mean annual calibrated water budget for the numerical groundwater-flow model of the Rush Springs aquifer, western Oklahoma, 1979-2015

12. Equal-proportionate-share (EPS) pumping rates for the Rush Springs aquifer, western Oklahoma, 1979-2015

13. Changes in groundwater storage after 50 years of groundwater use at selected rates for the Rush Springs aquifer, western Oklahoma 


\section{Conversion Factors}

U.S. customary units to International System of Units

\begin{tabular}{|c|c|c|}
\hline Multiply & By & To obtain \\
\hline \multicolumn{3}{|c|}{ Length } \\
\hline inch (in.) & 2.54 & centimeter $(\mathrm{cm})$ \\
\hline foot (ft) & 0.3048 & meter (m) \\
\hline mile (mi) & 1.609 & kilometer $(\mathrm{km})$ \\
\hline \multicolumn{3}{|c|}{ Area } \\
\hline acre & 4,047 & square meter $\left(\mathrm{m}^{2}\right)$ \\
\hline acre & 0.4047 & hectare (ha) \\
\hline section (640 acres or 1 square mile) & 259.0 & square hectometer $\left(\mathrm{hm}^{2}\right)$ \\
\hline square mile $\left(\mathrm{mi}^{2}\right)$ & 259.0 & hectare (ha) \\
\hline \multicolumn{3}{|c|}{ Volume } \\
\hline gallon (gal) & 0.003785 & cubic meter $\left(\mathrm{m}^{3}\right)$ \\
\hline acre-foot (acre-ft) & 1,233 & cubic meter $\left(\mathrm{m}^{3}\right)$ \\
\hline \multicolumn{3}{|c|}{ Flow rate } \\
\hline acre-foot per year (acre-ft/yr) & 1,233 & cubic meter per year $\left(\mathrm{m}^{3} / \mathrm{yr}\right)$ \\
\hline acre-foot per year (acre-ft/yr) & 0.001233 & cubic hectometer per year $\left(\mathrm{hm}^{3} / \mathrm{yr}\right)$ \\
\hline foot per day (ft/d) & 0.3048 & meter per day $(\mathrm{m} / \mathrm{d})$ \\
\hline cubic foot per second $\left(\mathrm{ft}^{3} / \mathrm{s}\right)$ & 0.02832 & cubic meter per second (m³/s) \\
\hline gallon per minute (gal/min) & 0.06309 & liter per second $(\mathrm{L} / \mathrm{s})$ \\
\hline inch per year (in/yr) & 25.4 & millimeter per year (mm/yr) \\
\hline \multicolumn{3}{|c|}{ Hydraulic conductivity } \\
\hline foot per day (ft/d) & 0.3048 & meter per day $(\mathrm{m} / \mathrm{d})$ \\
\hline \multicolumn{3}{|c|}{ Hydraulic gradient } \\
\hline foot per mile (ft/mi) & 0.1894 & meter per kilometer $(\mathrm{m} / \mathrm{km})$ \\
\hline \multicolumn{3}{|c|}{ Leakance } \\
\hline foot per day per foot [(ft/d)/ft] & 1 & meter per day per meter \\
\hline \multicolumn{3}{|c|}{ Transmissivity } \\
\hline foot squared per day ( $\left.\mathrm{ft}^{2} / \mathrm{d}\right)$ & 0.09290 & meter squared per day $\left(\mathrm{m}^{2} / \mathrm{d}\right)$ \\
\hline
\end{tabular}

Temperature in degrees Celsius $\left({ }^{\circ} \mathrm{C}\right)$ may be converted to degrees Fahrenheit $\left({ }^{\circ} \mathrm{F}\right)$ as ${ }^{\circ} \mathrm{F}=\left(1.8 \times{ }^{\circ} \mathrm{C}\right)+32$.

Temperature in degrees Fahrenheit $\left({ }^{\circ} \mathrm{F}\right)$ may be converted to degrees Celsius $\left({ }^{\circ} \mathrm{C}\right)$ as ${ }^{\circ} \mathrm{C}=\left({ }^{\circ} \mathrm{F}-32\right) / 1.8$. 


\section{Datum}

Vertical coordinate information is referenced to the North American Vertical Datum of 1988 (NAVD 88). Vertical coordinate information for Foss and Fort Cobb Reservoirs is referenced to the National Geodetic Vertical Datum of 1929 (NGVD 29).

Horizontal coordinate information is referenced to the North American Datum of 1983 (NAD 83).

Altitude, as used in this report, refers to distance above the vertical datum.

\section{Abbreviations}

$\begin{array}{ll}\text { BFI } & \text { base-flow separation code } \\ \text { DEM } & \text { digital elevation model } \\ \text { EPS } & \text { equal proportionate share } \\ \text { ET } & \text { evapotranspiration } \\ \text { ETg } & \text { saturated-zone evapotranspiration } \\ \text { GHB } & \text { General-Head Boundary } \\ \text { GPS } & \text { Global Positioning System } \\ \text { Kh } & \text { horizontal hydraulic conductivity } \\ \text { MAY } & \text { maximum annual yield } \\ \text { NHDPlus } & \text { National Hydrography Dataset Plus } \\ \text { NWIS } & \text { National Water Information System } \\ \text { OWRB } & \text { Oklahoma Water Resources Board } \\ \text { Reclamation } & \text { Bureau of Reclamation } \\ \text { RMSE } & \text { root-mean-square error } \\ \text { SFR } & \text { Streamflow-Routing package, version 2 } \\ \text { Ss } & \text { specific storage } \\ \text { SVD } & \text { singular value decomposition } \\ \text { SVDA } & \text { singular value decomposition-assist } \\ \text { SWB } & \text { soil-water-balance } \\ \text { Sy } & \text { specific yield } \\ \text { USGS } & \text { U.S. Geological Survey }\end{array}$





\title{
Simulation of Groundwater Flow and Analysis of Projected Water Use for the Rush Springs Aquifer, Western Oklahoma
}

\author{
By John H. Ellis
}

\section{Abstract}

The U.S. Geological Survey, in cooperation with the Bureau of Reclamation and the Oklahoma Water Resources Board, (1) quantified the groundwater resources of the Rush Springs aquifer in western Oklahoma by developing a numerical groundwater-flow model, (2) evaluated the effects of estimated equal-proportionate-share (EPS) pumping rates on aquifer storage and streamflow for time periods of 20 , 40, and 50 years into the future, (3) assessed the uncertainty in the EPS scenario results, and (4) evaluated the effects of (a) projected groundwater-use rates extended 50 years into the future and (b) sustained hypothetical drought conditions over a 10 -year period on stream base flow and groundwater in storage.

The Rush Springs aquifer is an important source of water for municipal and irrigation use by many communities and agricultural users in the study area. The study area is composed of about 4,970 square miles (3,181,003 acres) of Rush Springs aquifer bedrock deposits located in 14 counties. The study area also includes the alluvium and terrace deposits of the Canadian and Washita Rivers, as well as alluvium along the Little Washita River, Deer Creek, and a number of smaller tributaries of the Washita River that overlie the bedrock.

A numerical groundwater-flow model of the Rush Springs aquifer was constructed by using MODFLOW with the Newton solver. Groundwater flow was simulated for January 1979-December 2015 by using monthly stress periods, and an initial steady-state stress period was configured to represent mean annual inflows and outflows. The model was calibrated to groundwater-level observations at selected wells, monthly base flow at nine streamgages, stream seepage as estimated for the conceptual water budget, and Fort Cobb Reservoir stage.

The EPS scenarios for the Rush Springs aquifer were run for periods of 20, 40, and 50 years. The 20-, 40-, and 50-year EPS pumping rates under normal recharge conditions were $0.82,0.49$, and 0.43 acre-foot per acre per year, respectively. Given the 2,954,545-acre aquifer area used for the EPS scenarios, the 20-year rate corresponds to an annual yield of about 2,422,727 acre-feet per year. Groundwater storage at the end of the 20-year EPS scenario was about 13,321,000 acre-feet, or about 31,516,437 acre-feet (70 percent) less than the starting EPS scenario storage. This decrease in storage was equivalent to a mean groundwater-level decline of about 152 feet. Water availability under the EPS pumping rate was primarily from the western area of the model. Saturation was sustained though the entire EPS scenario where the aquifer was sufficiently thick or a shallow hydraulic gradient was present. Fort Cobb Reservoir stage was below the dead-pool stage after about 5 years of 20-year EPS pumping.

An uncertainty analysis was conducted to assess the uncertainty in the EPS scenario results. An ensemble of 400 random sets of possible parameter values was performed for the uncertainty analysis by using a multivariate normal distribution centered on the calibrated parameter values. The parameter bounds for the uncertainty analysis were determined by using the posterior covariance matrix, which allows for the incorporation of knowledge gained during the calibration process as well as observation uncertainty and the correlation between estimated parameters. The uncertainty results indicate a 95-percent confidence interval for the 20-year EPS pumping rate between 0.73 and 0.95 acre-foot per acre per year.

Projected 50-year pumping scenarios were used to simulate the effects of selected well withdrawal rates on groundwater storage of the Rush Springs aquifer. The effects of well withdrawals were evaluated by comparing changes in groundwater storage between four 50-year scenarios using (1) no groundwater use, (2) mean groundwater use for the study period (1979-2015), (3) increasing groundwater use, and (4) groundwater use at the 2015 rate. The increasinguse scenario assumed a 38-percent increase in pumping over 50 years on the basis of 2010-60 demand projections for western Oklahoma. Simulated groundwater storage changes ranged between an increase of 6.3 percent for the scenario with no groundwater use, and 0.9 percent for the scenario with 2015 groundwater-use rates. For the Fort Cobb Reservoir surface watershed, simulated groundwater storage changes ranged between an increase of 23.6 percent for the scenario 
with no groundwater use and a decrease of 4.0 percent for the increasing groundwater-use scenario. Groundwaterlevel changes were generally greater in areas with a large concentration of groundwater wells and groundwater use such as the Fort Cobb Reservoir surface watershed.

A hypothetical 10-year drought scenario was used to simulate the effects of a prolonged period of reduced recharge on the Rush Springs aquifer groundwater storage and Fort Cobb Reservoir stage and storage. Drought effects were quantified by comparing the results of the drought scenario to those of the calibrated numerical model. To simulate the hypothetical drought, recharge in the calibrated numerical model was reduced by 50 percent during the simulated drought period (1983-1992), and upstream inflows to the Canadian and Washita Rivers and associated tributaries were reduced by 37 percent. Groundwater storage at the end of the hypothetical drought period in December 1992 was about 42,983,000 acre-feet, or about 3,525,000 acre-feet (7.6 percent) less than the groundwater storage of the calibrated numerical model. This change in groundwater storage is equivalent to a mean groundwater-level decline of 15.8 feet. Simulated mean baseflow declines at the Canadian and Washita River streamgages were between 39 and 59 percent during the drought period. The minimum stage in Fort Cobb Reservoir at the end of the hypothetical drought period was 1,311 feet, indicating a storage capacity of only 10 percent of active conservation pool storage. The Fort Cobb Reservoir storage declines mostly resulted from reduced base flows in Cobb, Lake, and Willow Creeks upstream from the reservoir.

\section{Introduction}

The 1973 Oklahoma Water Law (82 OK Stat § 82-1020.5) requires the Oklahoma Water Resources Board (OWRB) to conduct hydrologic investigations of the State's aquifers (called groundwater basins by the OWRB) to determine the maximum annual yield (MAY) for each aquifer. The MAY is defined as the total amount of fresh groundwater that can be withdrawn annually from an aquifer while ensuring a minimum 20-year life of that aquifer. For bedrock aquifers, the aquifer-life requirement is satisfied if, after 20 years of MAY withdrawals, 50 percent of the aquifer retains a saturated thickness of 15 feet (ft). When a MAY has been established, the amount of land owned or leased by a permit applicant determines the annual volume of water allocated to that permit applicant. The annual volume of water allocated per acre of land is known as the equal-proportionate-share (EPS) pumping rate.

Prior to the OWRB determination of the MAY, a hydrologic investigation is needed to obtain data and information related to the geology, hydrogeologic framework, and hydrogeology of an aquifer. To address this need, the hydrologic investigation for the Rush Springs aquifer includes Neel and others (2018) and the study documented in this report by the U.S. Geological Survey (USGS) in cooperation with Bureau of Reclamation (Reclamation) and OWRB. Neel and others (2018) described the climate, geology, hydrogeology, hydraulic properties, water use, streamflow, base flow, and groundwater quality of the Rush Springs aquifer. Data from Neel and others (2018) were used in the conceptualization of the groundwater-flow system and in the construction of a numerical groundwater-flow model (hereinafter, "groundwater model") that was used to simulate groundwater flow and run groundwater availability scenarios during this study.

This study also was conducted to evaluate water management issues in Fort Cobb Reservoir. Water demands are projected to increase substantially by 2060 for all uses in west-central Oklahoma (OWRB, 2012); thus, there is a need to estimate long-term water supplies from this reservoir. Additionally, the growing recognition of coupled surfacewater and groundwater interaction has prompted an evaluation of the flows between the Rush Springs aquifer and Fort Cobb Reservoir and the effects of pumping on surface-water inflows and groundwater levels surrounding the reservoir.

\section{Purpose and Scope}

The purpose of this report is to describe the simulation of groundwater flow and analysis of projected water use for the Rush Springs aquifer. Specifically, the report (1) quantifies the groundwater resources of the Rush Springs aquifer simulated by using a groundwater model, (2) presents the effects of estimated EPS pumping on aquifer storage and streamflow for time periods of 20,40, and 50 years into the future, (3) presents the uncertainty in the EPS scenario results, and (4) presents the effects of (a) projected groundwater-use rates extended 50 years into the future, and (b) sustained hypothetical drought conditions on stream base flow and groundwater in storage over a 10-year period. The study period, for which a water-budget analysis was performed, includes years 1979-2015.

The geographic extent of the Rush Springs aquifer (fig. 1), as defined in this report, is composed of the Rush Springs Formation and Marlow Formation bedrock units (Whitehorse Group) and the overlying alluvium and terrace deposits collectively referred to as the Rush Springs aquifer (figs. 2-3). Although previous reports have defined the base of the Rush Springs aquifer as the top of the Marlow Formation, this unit is included as a part of the aquifer in this investigation based on Neel and others (2018). Thus, the base of the Rush Springs aquifer is the top of the Dog Creek Shale, which is a member of the El Reno Group (Neel and others, 2018) (fig. 3). 


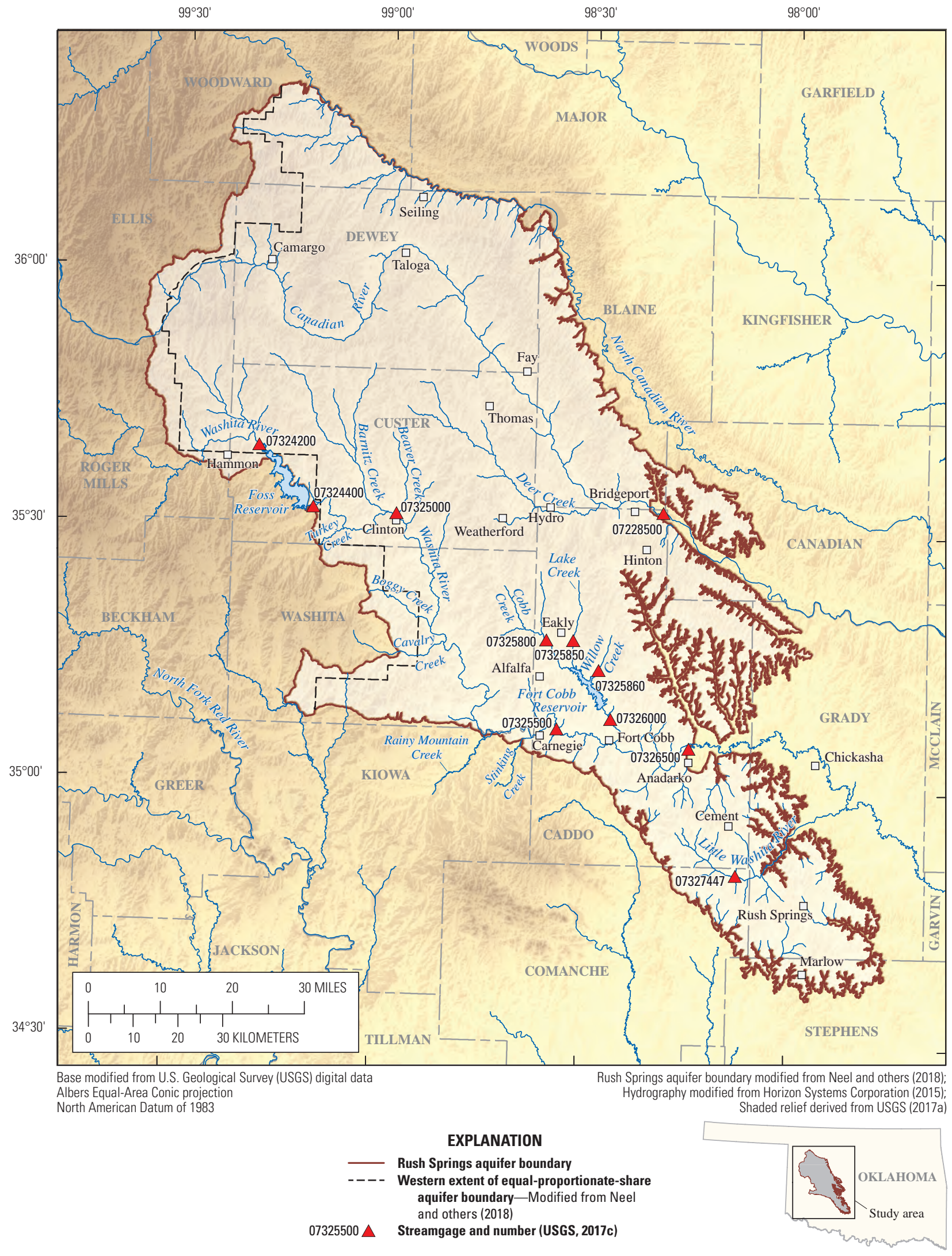

Figure 1. The Rush Springs aquifer study area, western Oklahoma. 


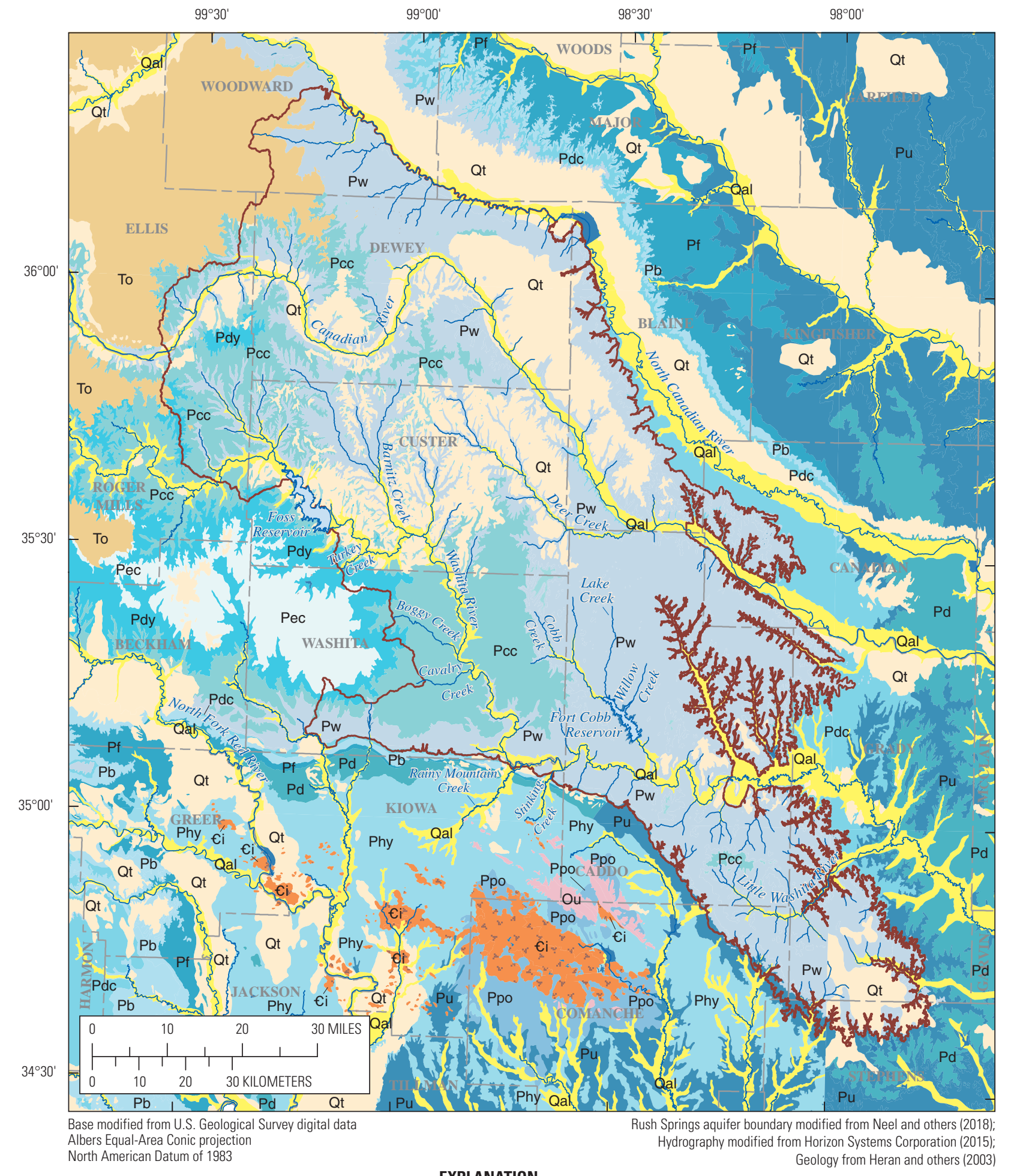

\begin{tabular}{|ll}
\hline Pdy & Doxey Shale (Permian) \\
\hline Pcc & Cloud Chief Formation (Permian) \\
\hline Pw & Whitehorse Group (Permian) \\
\hline Pdc & Dog Creek Shale (Permian) \\
\hline Pb & Blaine Formation (Permian) \\
\hline
\end{tabular}

$\begin{array}{cl}\text { Pf } & \begin{array}{l}\text { Flower-pot Shale (Permian) } \\ \text { Duncan Sandstone of the } \\ \text { Pd }\end{array} \\ \text { Phy } & \text { El Reno Group (Permian) } \\ \text { Pennessey Group (Permian) } \\ \text { Ppo } & \text { Post Oak Conglomerate (Permian) }\end{array}$

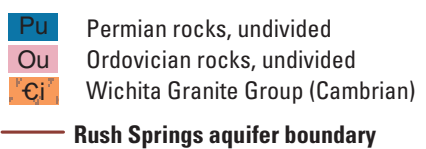

Figure 2. The surficial geologic units of the Rush Springs aquifer study area, western Oklahoma. 


\begin{tabular}{|c|c|c|c|c|c|}
\hline System & \multicolumn{2}{|c|}{ Geologic unit } & $\begin{array}{l}\text { Hydrogeologic } \\
\text { unit }\end{array}$ & $\begin{array}{c}\text { Thickness, } \\
\text { in feet }\end{array}$ & Description \\
\hline Quaternary & \multicolumn{2}{|c|}{$\begin{array}{l}\text { Alluvium and terrace } \\
\text { deposits }\end{array}$} & $\begin{array}{l}\text { Alluvial aquifers } \\
\text { or Rush Springs } \\
\text { aquifer where } \\
\text { overlying the } \\
\text { Whitehorse Group }\end{array}$ & $0-130^{a, b, c}$ & $\begin{array}{l}\text { Silt, sand, and clay deposited by North Fork Red River } \\
\text { and tributaries often reworked by wind; occasionally } \\
\text { containing quartzitic gravel and slightly cemented by } \\
\text { calcium carbonate }\end{array}$ \\
\hline Tertiary & \multicolumn{2}{|c|}{ Ogallala Formation } & $\begin{array}{l}\text { High Plains } \\
\text { (Ogallala) } \\
\text { aquifer }\end{array}$ & $0-600$ & $\begin{array}{l}\text { Brown to light tan to salmon, mostly unconsolidated clay, } \\
\text { silt, sand, and gravel with zones of caliche near the } \\
\text { surface }\end{array}$ \\
\hline \multirow{10}{*}{ Permian } & \multirow{2}{*}{ 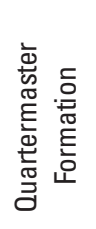 } & $\begin{array}{l}\text { Elk City } \\
\text { Sandstone }\end{array}$ & & \multirow{2}{*}{$0-400$} & $\begin{array}{l}\text { Reddish-brown, fine-grained sandstone with silt and } \\
\text { clay, weakly cemented by iron oxide, calcium carbonate, } \\
\text { and gypsum }\end{array}$ \\
\hline & & Doxey Shale & & & Reddish-brown, silty shale and siltstone \\
\hline & \multicolumn{2}{|c|}{ Cloud Chief Formation } & $\begin{array}{l}\text { Cloud Chief } \\
\text { confining unit }\end{array}$ & $0-300^{b, c}$ & $\begin{array}{l}\text { Reddish-brown to orange-brown shale interbedded with } \\
\text { siltstone and sandstone; some dolomite and much } \\
\text { gypsum near base }\end{array}$ \\
\hline & \multirow{2}{*}{ 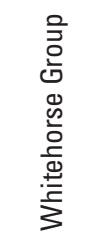 } & $\begin{array}{l}\text { Rush Springs } \\
\text { Formation }\end{array}$ & \multirow{2}{*}{$\begin{array}{l}\text { Rush Springs } \\
\text { aquifer }\end{array}$} & $0-560^{d}$ & $\begin{array}{l}\text { Reddish-brown to orange-brown cross-bedded } \\
\text { sandstone }^{e}\end{array}$ \\
\hline & & $\begin{array}{l}\text { Marlow } \\
\text { Formation }\end{array}$ & & $0-128^{b}$ & $\begin{array}{l}\text { Orange-brown, fine-grained sandstone and siltstone with } \\
\text { some dolomite and gypsum }\end{array}$ \\
\hline & \multirow{4}{*}{ 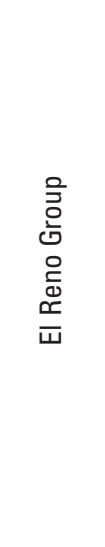 } & $\begin{array}{l}\text { Dog Creek } \\
\text { Shale }\end{array}$ & $\begin{array}{l}\text { Dog Creek } \\
\text { confining unit }\end{array}$ & $0-400$ & $\begin{array}{l}\text { Red, brown, and green gypsiferous shales with several } \\
\text { beds of siltstone, sandstone, and dolomite }\end{array}$ \\
\hline & & $\begin{array}{l}\text { Blaine } \\
\text { Formation }\end{array}$ & & $0-140$ & $\begin{array}{l}\text { Beds of white massive gypsum and thin beds of gray } \\
\text { medium-grained dolomite or dolomitic limestone } \\
\text { separated by well-defined units of red and green shale }\end{array}$ \\
\hline & & $\begin{array}{l}\text { Flower-pot } \\
\text { Shale }\end{array}$ & & $0-150$ & $\begin{array}{l}\text { Red, brown. and maroon blocky shales with green and } \\
\text { gray shales and thin beds of gypsum and dolomite; } \\
\text { satin spar gypsum occurs throughout }\end{array}$ \\
\hline & & $\begin{array}{c}\text { Duncan } \\
\text { Sandstone } \\
\text { of the } \\
\text { El Reno Group }\end{array}$ & & $0-40$ & $\begin{array}{l}\text { Grayish-brown to buff, indurated, highly cross-bedded, } \\
\text { ripple-marked, nonfossiliferous, silty to fine-grained } \\
\text { dolomitic sandstone with interbedded shale }\end{array}$ \\
\hline & $\begin{array}{l}\text { Henne } \\
\text { Post 0a }\end{array}$ & $\begin{array}{l}\text { sey Group or } \\
\text { Conglomerate }\end{array}$ & & $0-500$ & $\begin{array}{l}\text { Yellowish-gray to buff nonfossiliferous shale with } \\
\text { calcareous fine-grained siltstone and limestone } \\
\text { conglomerate }\end{array}$ \\
\hline Ordovician & $\begin{array}{r}\text { Cool Cre } \\
\text { Hill }\end{array}$ & $\begin{array}{l}\text { k or McKenzie } \\
\text { Eormations }\end{array}$ & & & $\begin{array}{l}\text { Limestone and conglomerate with abundant quartz sand } \\
\text { and cherty zones }\end{array}$ \\
\hline Cambrian & Wichit & Granite Group & & & Igneous rocks of Wichita uplift \\
\hline
\end{tabular}

Figure 3. Surficial geologic and hydrogeologic units of the Rush Springs aquifer study area, western Oklahoma. 


\section{Study Area}

The Rush Springs aquifer includes about 4,970 square miles $\left(\mathrm{mi}^{2}\right)(3,181,003$ acres$)$ of bedrock and alluvium and terrace deposits located in Blaine, Caddo, Canadian, Comanche, Custer, Dewey, Ellis, Grady, Kiowa, Major, Roger Mills, Stephens, Washita, and Woodward Counties (fig. 1). The physiography of the Rush Springs aquifer is characterized by gently rolling hills that are dissected by incised deep drainage channels and surface-water features. Gypsum beds in the western part of the study area create erosion-resistant caprocks that form steep-sided ledges when located near alluvial valleys (Becker and Runkle, 1998). Land-surface altitudes in the Rush Springs aquifer (fig. 4) range from about 1,100 to 2,400 ft above the North American Vertical Datum of 1988 (NAVD 88) (USGS, 2017a).

The northern and northeastern boundary of the Rush Springs aquifer includes the water-bearing portions of the Marlow Formation (Neel and others, 2018) situated west of the North Canadian River alluvium and terrace deposits (fig. 2). The northwestern boundary is the Ogallala Formation of Tertiary age. The southwestern boundary is the geologic contact with the Dog Creek Shale of Permian age. The southern and southeastern boundaries are the erosional extent of the Rush Springs Formation defined by Becker and Runkle (1998). The Rush Springs aquifer dips south-southwest and becomes buried westward. Neel and others (2018) defined the western boundary of this aquifer based on an increase in total dissolved solids, but that boundary was modified for this study to align with the overlying surface-watershed boundaries defined by the National Hydrography Dataset (USGS, 2017b). This modification was used so that the groundwater model could account for runoff that would otherwise have been routed outside the aquifer area.

The primary streams that drain the Rush Springs aquifer include the Canadian and Washita Rivers (fig. 1) (Tanaka and Davis, 1963; Ellis and others, 2017; Neel and others, 2018). Additionally, the Rush Springs aquifer includes a number of smaller streams and tributaries to these rivers. Mean annual streamflow data (USGS, 2017c) recorded at streamgages (fig. 1; table 1) are summarized in table 2 . Although the Bridgeport streamgage (07228500) is located about 2.5 miles (mi) downstream from the study area, flows from this streamgage are included because it is near the aquifer. Streamgage data are not available for tributaries of the Washita River other than for the Fort Cobb streamgage below the Fort Cobb Reservoir (07326000) (fig. 1; table 1); however, it is estimated that these tributaries carry only minor streamflows.

The climate of the study area is classified as semi-arid, and mean annual temperatures for the period 1905-2015 ranged from about 58 degrees Fahrenheit in the northern part of the study area to 61 degrees Fahrenheit in the southern part (Neel and others, 2018). The mean annual precipitation for the period 1905-2015 was 28.2 inches (in.), with a period of above-mean annual precipitation between 1985 and 2008 (Neel and others, 2018). For the period 1905-2015, the greatest mean monthly precipitation (4.4 in.) occurred in May, and the least mean monthly precipitation (1.0 in.) occurred in January (Neel and others, 2018). 


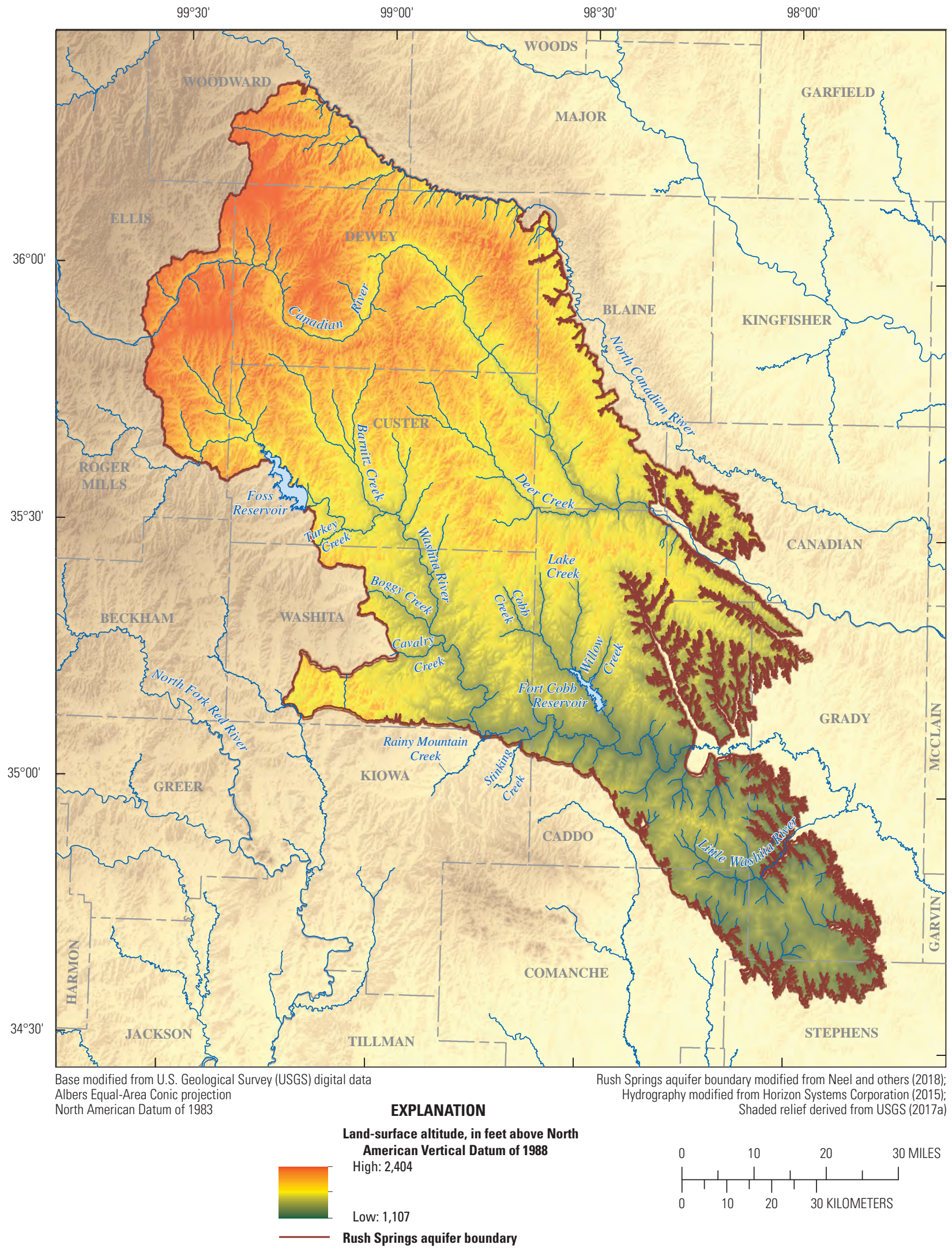

Figure 4. Land-surface altitudes of the Rush Springs aquifer study area, western Oklahoma. 
Table 1. Location, period of record, and coefficient of variation for selected streamgages in the Rush Springs aquifer study area, western Oklahoma.

[USGS, U.S. Geological Survey; M/Y, month/year; --, no analysis performed]

\begin{tabular}{|c|c|c|c|c|c|c|c|}
\hline $\begin{array}{c}\text { USGS } \\
\text { station } \\
\text { number } \\
\text { (fig. 1) }\end{array}$ & $\begin{array}{l}\text { Station } \\
\text { identifier }\end{array}$ & Station name & $\begin{array}{l}\text { Latitude } \\
\text { (decimal } \\
\text { degrees) }\end{array}$ & $\begin{array}{l}\text { Longitude } \\
\text { (decimal } \\
\text { degrees) }\end{array}$ & $\begin{array}{l}\text { Period } \\
\text { (may con }\end{array}$ & $\begin{array}{l}\text { record } \\
\text { ain gaps) }\end{array}$ & $\begin{array}{l}\text { Coefficient of } \\
\text { variation of } \\
\text { streamgage } \\
\text { data during } \\
\text { study period } \\
\text { (1979-2015) }\end{array}$ \\
\hline \multicolumn{8}{|c|}{ Continuous-record streamgages (USGS, 2017c) } \\
\hline 07324200 & Hammon streamgage & Washita River near Hammon, Okla. & 35.47310 & -100.12095 & $10 / 1969$ & present & 0.08 \\
\hline 07324400 & Foss streamgage & Washita River near Foss, Okla. & 35.65644 & -99.30621 & 3/1956 & present & -- \\
\hline 07325000 & Clinton streamgage & Washita River near Clinton, Okla. & 35.42227 & -99.96928 & 10/1935 & present & 0.08 \\
\hline 07325850 & $\begin{array}{l}\text { Lake Creek } \\
\text { streamgage }\end{array}$ & Lake Creek near Eakly, Okla. & 35.01172 & -99.90371 & $10 / 1969$ & present & 0.08 \\
\hline 07325860 & $\begin{array}{r}\text { Willow Creek } \\
\text { streamgage }\end{array}$ & Willow Creek near Albert, Okla. & 34.91423 & -99.11397 & $10 / 1970$ & present & 0.08 \\
\hline 07326000 & Fort Cobb streamgage & Cobb Creek near Fort Cobb, Okla. & 35.29061 & -98.59423 & 10/1939 & present & -- \\
\hline 07326500 & Anadarko streamgage & Washita River at Anadarko, Okla. & 34.63813 & -99.10369 & $1 / 1903$ & present & 0.08 \\
\hline 07327447 & Cement streamgage & $\begin{array}{l}\text { Little Washita River near Cement, } \\
\text { Okla. }\end{array}$ & 34.63785 & -98.99869 & 2/1992 & present & 0.08 \\
\hline
\end{tabular}


Table 2. Mean annual streamflow and mean annual base flow for selected streamgages in and near the Rush Springs aquifer study area, western Oklahoma, 1979-2015.

[Annual base flow computed by using a base-flow separation code (BFI; Wahl and Wahl, 1995) integrated into the U.S. Geological Survey Groundwater Toolbox (Barlow and others, 2015); ft³/s, cubic feet per second; \%, percent; acre-ft/yr, acre-feet per year; --, data not available or not applicable]

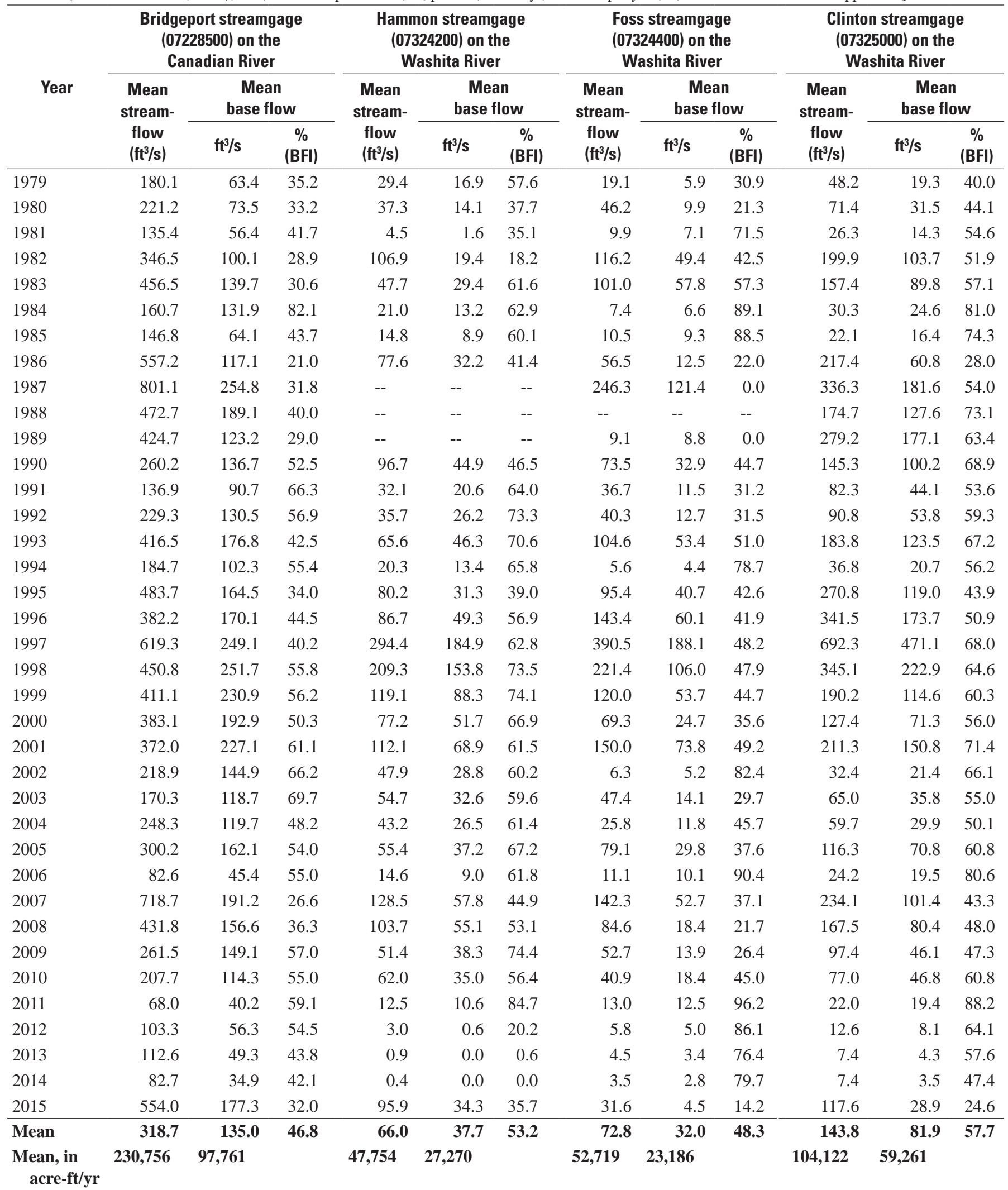


Table 2. Mean annual streamflow and mean annual base flow for selected streamgages in and near the Rush Springs aquifer study area, western Oklahoma, 1979-2015.-Continued

[Annual base flow computed by using a base-flow separation code (BFI; Wahl and Wahl, 1995) integrated into the U.S. Geological Survey Groundwater Toolbox (Barlow and others, 2015); ft³/s, cubic feet per second; \%, percent; acre-ft/yr, acre-feet per year; --, data not available or not applicable]

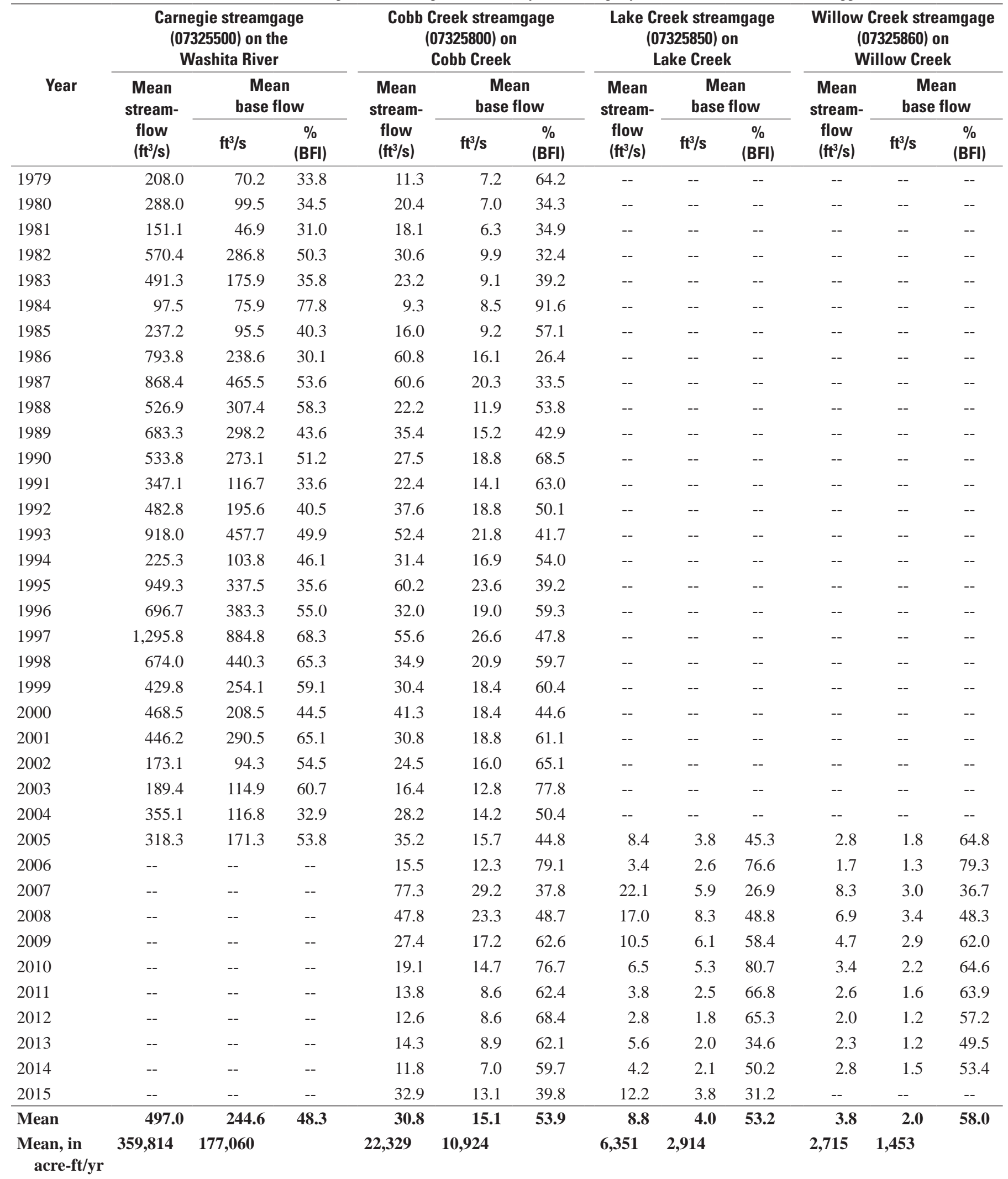


Table 2. Mean annual streamflow and mean annual base flow for selected streamgages in and near the Rush Springs aquifer study area, western Oklahoma, 1979-2015.-Continued

[Annual base flow computed by using a base-flow separation code (BFI; Wahl and Wahl, 1995) integrated into the U.S. Geological Survey Groundwater Toolbox (Barlow and others, 2015); fts/s, cubic feet per second; \%, percent; acre-ft/yr, acre-feet per year; --, data not available or not applicable]

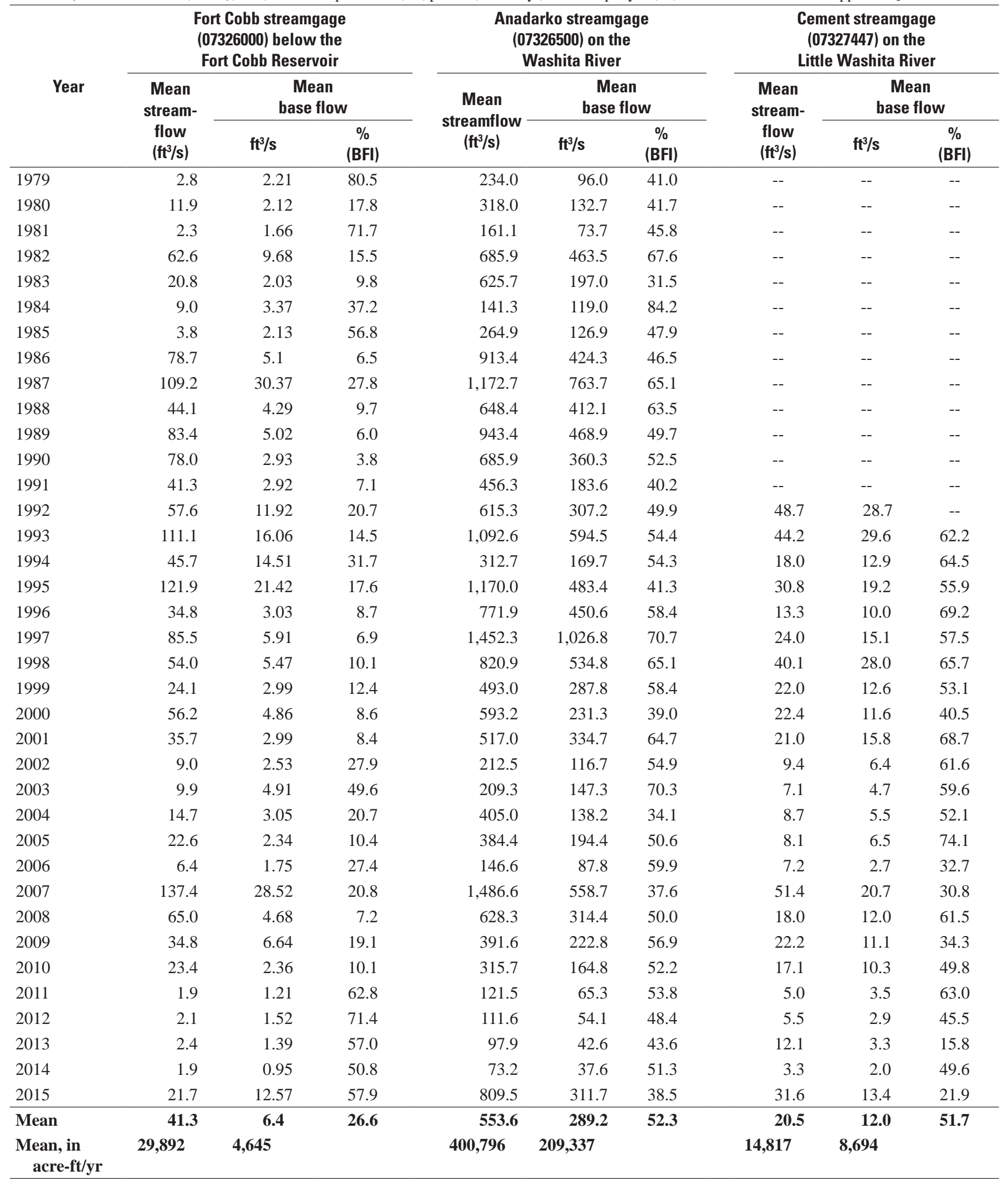


Land-cover data for the Rush Springs aquifer were obtained from the CropScape database (National Agricultural Statistics Service [NASS], 2017) (figs. 5-6). This database included information about land-cover characteristics at a 30-meter resolution for land overlying the Rush Springs aquifer for the period 2011-15. During this period, land cover was primarily for grass/pasture (52.2 percent) and cropland (31.7 percent). Winter wheat, which accounted for 80.3 percent of cropland by area, was the dominant crop type overlying the Rush Springs aquifer. Cotton (2.8 percent), alfalfa (2.8 percent), rye (1.8 percent), and sorghum (1.8 percent) were the only other crop types accounting for at least 1 percent of cropland by area (figs. 5-6). About 4.7 percent of cropland by area was fallow or idle. Although crop types may change on the basis of economic conditions and hydrologic factors such as flooding or drought conditions, the percentages of total crop land cover and individual crop types did not change much during the period 2011-15 for which data were available (NASS, 2017).

\section{Conceptualization of Groundwater-Flow System}

The Rush Springs aquifer conceptualized groundwaterflow system is a simplified description of the aquifer system accounting for (1) the definition of the aquifer geologic units, (2) major inflow and outflow sources between the aquifer and surrounding units (hydrologic boundaries), and (3) the amount of water that moves between each boundary (conceptual water budget) during the study period (table 3). The information from these components was used in the design, construction, and simulation of the groundwater model.

\section{Geologic Units}

The Rush Springs aquifer includes alluvium and terrace deposits of Quaternary age and bedrock of Permian age; overlying and underlying confining units are of Permian age (figs. 2-3). The units of Quaternary age include the alluvium and terrace deposits of the Canadian and Washita Rivers and associated tributaries. The primary hydrogeologic units of Permian age include the Cloud Chief Formation, Whitehorse Group, and Dog Creek Shale.

The Quaternary alluvium and terrace deposits of the Canadian River and Washita River and associated tributaries consist of sand, silt, and clay deposits (Tanaka and Davis, 1963) that typically yield 200-400 gallons per minute (gal/min) but can yield as high as $1,000 \mathrm{gal} / \mathrm{min}$ (Fay, 1978). These deposits were formed by an initial period of downcutting of the stream channels into the bedrock units of Permian age and gradual filling with sand, silt, and clay sediments through subsequent cycles of erosion and deposition. The estimated thickness of the Canadian River alluvium and terrace deposits is about $120 \mathrm{ft}$ (Ellis and others, 2017). The estimated thickness of the Washita River alluvium and terrace deposits is about $130 \mathrm{ft}$ in Custer County (Fay, 1978) and as much as $90 \mathrm{ft}$ in Caddo County (Tanaka and Davis, 1963). The maximum thickness of the Deer Creek alluvium deposits is estimated to be $40 \mathrm{ft}$ (Fay, 1978). The thickness of the alluvium underlying other tributaries to the Washita River has not been studied but is estimated to be $30 \mathrm{ft}$.

The bedrock units of Permian age, or "red beds," underlie most of the Quaternary alluvium and terrace deposits in the study area (figs. 2-3). These bedrock units are generally fine grained and are composed of reddish-brown to orangebrown fine- to very fine-grained sandstone, shale, and siltstone interbedded with gypsum and dolomite (Miller and Stanley, 2004). The Cloud Chief Formation is described as an interbedded reddish-brown to orange-brown shale (Carr and Bergman, 1976) that is not a substantial water source and only yields a few gallons of water per day (Tanaka and Davis, 1963). The estimated thickness of the Cloud Chief Formation ranges from $100 \mathrm{ft}$ (Becker and Runkle, 1998) to more than $300 \mathrm{ft}$ (Tanaka and Davis, 1963; Fay, 1978). The Cloud Chief Formation is exposed in Custer, Dewey, Roger Mills, and Washita Counties as erosional remnants on hills and upland areas and is a confining unit where it overlies the Rush Springs Formation.

Stratigraphically below the Cloud Chief Formation is the Rush Springs Formation of the Whitehorse Group, which is the principal hydrogeologic unit of the Rush Springs aquifer. Well yields are spatially variable, ranging from less than $50 \mathrm{gal} / \mathrm{min}$ in the western half of Custer County to between 200 and $700 \mathrm{gal} / \mathrm{min}$ in eastern Custer County (Fay, 1978) and more than 1,000 gal/min in Caddo County (Tanaka and Davis, 1963). The Rush Springs Formation is typically a redto orange-brown cross-bedded sandstone (Carr and Bergman, 1976) with calcite- or gypsum-cemented fine- to very finegrained quartz grains (Becker and Runkle, 1998). The Rush Springs Formation is between 200 and $560 \mathrm{ft}$ thick in the western and southeastern parts of Custer County, respectively (Fay, 1978).

The Marlow Formation of the Whitehorse Group underlies the Rush Springs Formation and consists of interbedded sandstones, siltstones, mudstones, gypsumanhydrite, and dolomite (Becker and Runkle, 1998). The Marlow Formation forms the lower part of the Rush Springs aquifer, is typically well-cemented, has low hydraulic conductivity, and in most areas yields only 1-2 gal/min (Tanaka and Davis, 1963). As a result, the Marlow Formationgenerally $0.5-1.0 \mathrm{mi}$ wide-limits the water that is exchanged laterally with adjoining hydrogeologic units. The Marlow Formation thickness can be as great as $128 \mathrm{ft}$ in the study area (Tanaka and Davis, 1963).

The Dog Creek Shale consists of red clay and shale with intermixed gypsum and dolomite (Six, 1930) and, therefore, has a very low permeability and is not a predominant source of water (Mogg and others, 1960; Wood and Stacy, 1965). The Dog Creek Shale forms the underlying confining unit to the Rush Springs aquifer and is about $400 \mathrm{ft}$ thick in Blaine County and about 90 to $115 \mathrm{ft}$ thick in Caddo and Grady Counties. 


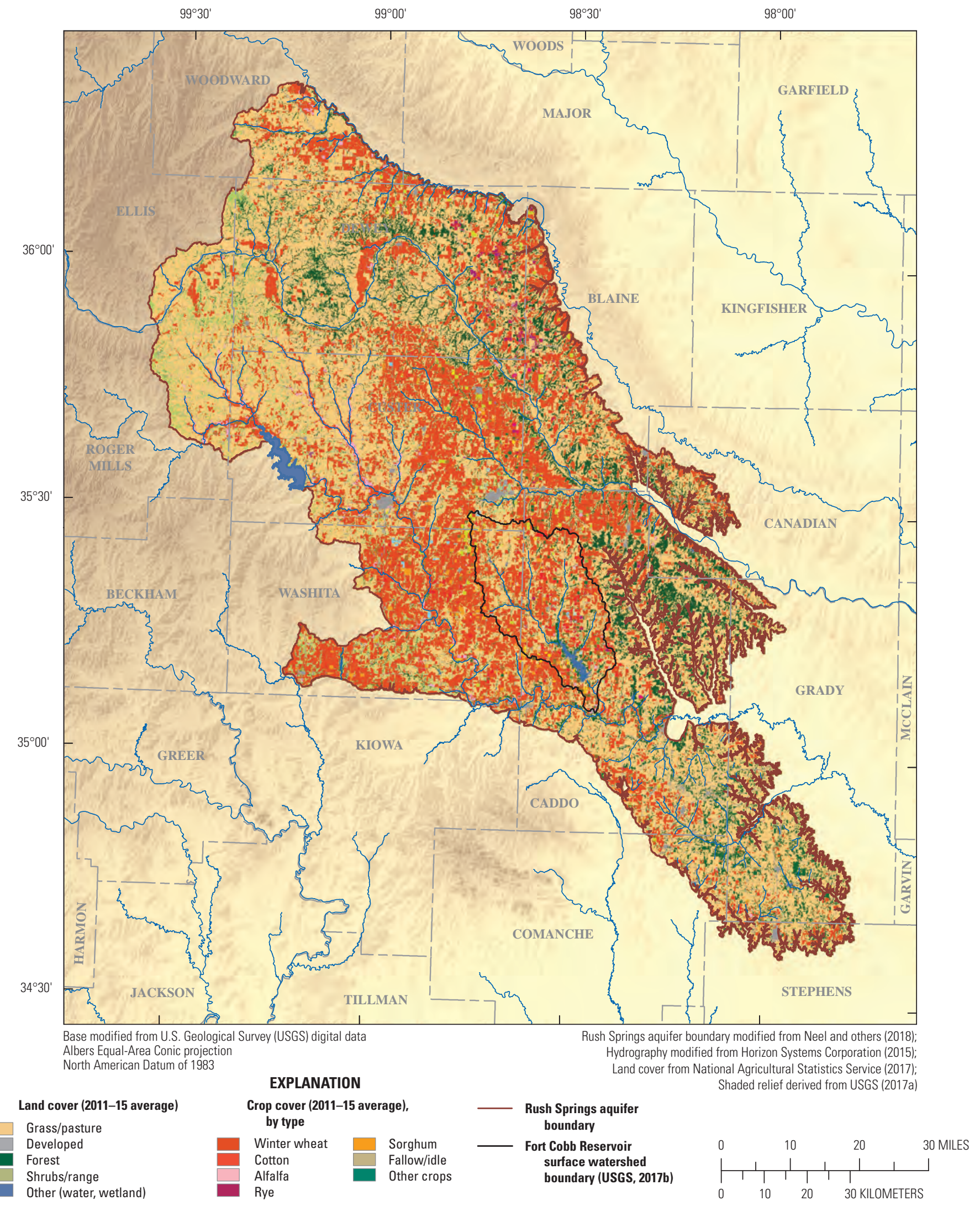

Figure 5. Land and crop cover over the Rush Springs aquifer, western Oklahoma, 2011-15. 


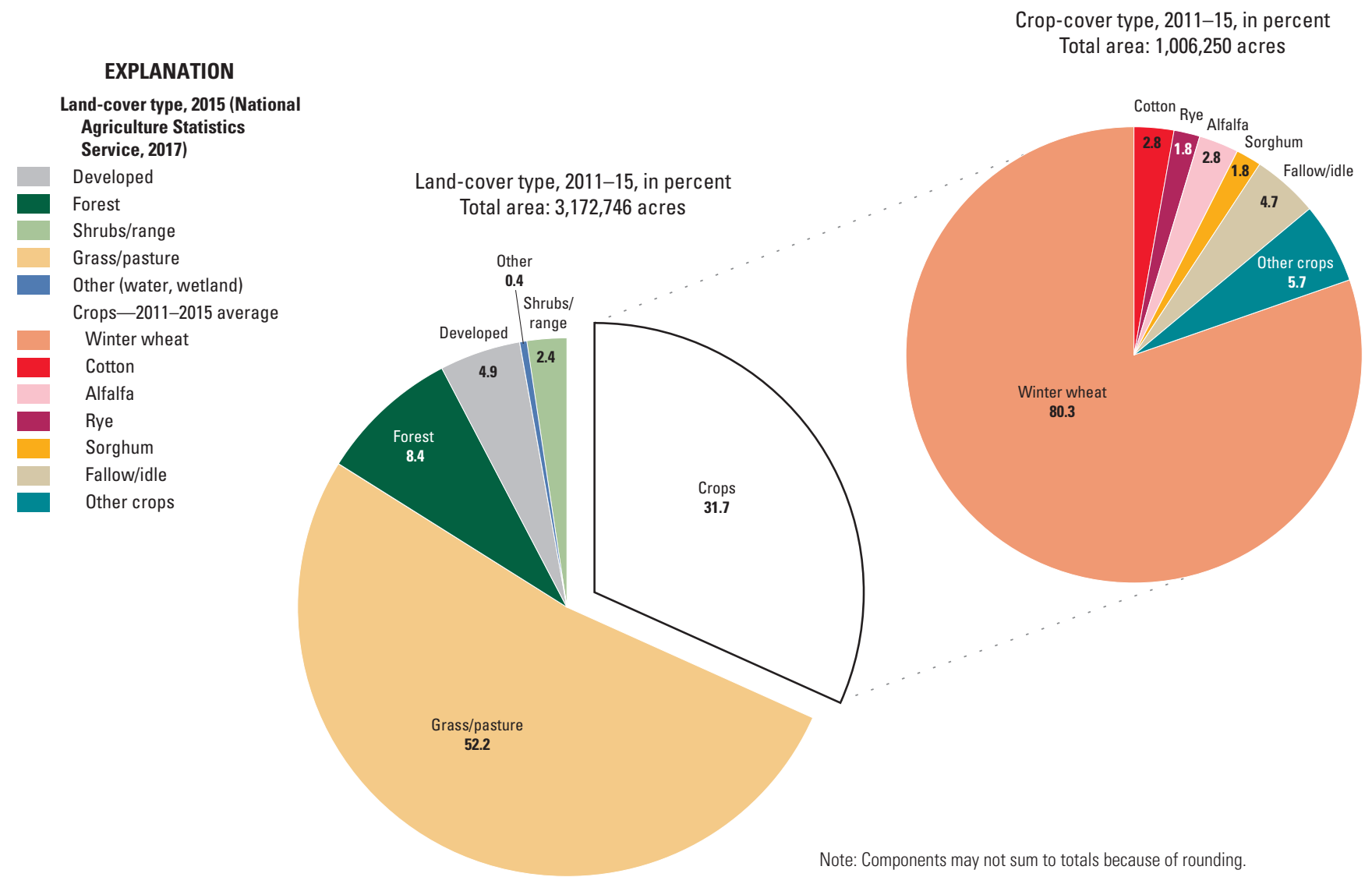

Figure 6. Land and crop cover over the Rush Springs aquifer, western Oklahoma, 2011-15.

Table 3. Conceptual water budget for the Rush Springs aquifer, western Oklahoma, 1979-2015.

$[--$, negligible change or amount; outflows do not sum to total because of rounding]

\begin{tabular}{|c|c|c|}
\hline Water-budget category & $\begin{array}{c}\text { Amount } \\
\text { (acre-feet } \\
\text { per year) }\end{array}$ & $\begin{array}{c}\text { Percentage } \\
\text { of inflows } \\
\text { or outflows }\end{array}$ \\
\hline \multicolumn{3}{|l|}{ Inflows } \\
\hline Recharge $^{2}$ & 556,675 & $97 \%$ \\
\hline Lateral flow ${ }^{1}$ & 16,700 & $3 \%$ \\
\hline Lakebed seepage & -- & -- \\
\hline Total inflow & 573,375 & $100 \%$ \\
\hline \multicolumn{3}{|l|}{ Outflows } \\
\hline Stream seepage $^{1}$ & 259,161 & $45 \%$ \\
\hline Seeps and springs & 155,507 & $27 \%$ \\
\hline Saturated-zone evapotranspiration (ETg) & 92,945 & $16 \%$ \\
\hline Groundwater use & 65,763 & $11 \%$ \\
\hline Net change in groundwater storage & -- & -- \\
\hline Total outflow & 573,376 & $100 \%$ \\
\hline
\end{tabular}




\section{Recharge}

Groundwater recharge, in this report, is defined as water that infiltrates from the land surface through the unsaturated zone and to the top of the water table. Other processes that may be included in a broader definition of recharge, such as stream seepage, lateral groundwater flow from adjacent hydrogeologic units, or lakebed seepage, are accounted for separately in the Rush Springs aquifer conceptual water budget.

Recharge rates are controlled by a number of factors, including precipitation rates, evapotranspiration (ET) rates, unsaturated-zone permeability and moisture capacity, and slope of the land surface. Although recharge rates are difficult to measure because of high spatial and temporal variability, methods using a mass balance, streamflow-hydrograph techniques, environmental tracers, physical measurements, and computer code have been used to estimate recharge rates. Estimates of recharge for the study area were obtained from Neel and others (2018) and the soil-water-balance (SWB) code (Westenbroek and others, 2010), a mass-balance method.

\section{Using the RORA Method to Estimate Recharge}

Neel and others (2018) used the RORA method to estimate annual recharge to the Rush Springs aquifer. Selected sites included streamgages on Barnitz Creek, Cobb Creek (07325800), Deer Creek, Lake Creek (07325850), Little Washita River, and Willow Creek (07325860). The RORA method uses a streamflow-recession-curve displacement method to estimate groundwater recharge (Rorabaugh, 1964; Rutledge, 1998). This method assumes an idealized aquifer with uniform hydraulic parameters and thickness and a fully penetrating stream where the streambed altitude is equal to the aquifer-base altitude. Mean annual recharge rates ranged from 0.24 in. at Barnitz Creek for the period 1946-63 to 2.26 in. at Little Washita River for the periods 1969-78 and 2005-15 (Neel and others, 2018). Recharge at the Barnitz Creek streamgage may be low because of the presence of the Cloud Chief Formation confining unit that may limit areal recharge in the area of the streamgage (Neel and others, 2018). The aquifer-base altitude is generally at least $100 \mathrm{ft}$ below the streambed altitude at each streamgage; therefore, the streambed is not fully penetrating through the aquifer.

\section{Using the Soil-Water-Balance Code to Estimate Recharge}

Spatially distributed recharge to the Rush Springs aquifer was computed for each month of the study period by using the SWB code (Westenbroek and others, 2010). The SWB code is based on a modified Thornthwaite-Mather method (Thornthwaite and Mather, 1957) and requires gridded climatological and landscape-characteristic data inputs including precipitation, temperature, soil-water storage capacity, hydrologic soil group, land-surface gradient, and land-cover type. The SWB code uses a mass-balance approach to compute gridded recharge as the difference between sources and sinks for each grid cell, while accounting for the cumulative effects of the change in soil moisture. The massbalance equation (modified from Westenbroek and others, 2010) has the form:

$$
R=\left(P+S+R_{i}\right)-\left(\operatorname{Int}+R_{o}+P_{e t}\right)-\Delta S m
$$

where

$\begin{aligned} R & \text { is recharge, } \\ P & \text { is precipitation, } \\ S & \text { is snowmelt, } \\ R_{i} & \text { is surface runoff inflow, } \\ \text { Int } & \text { is plant interception, } \\ R_{0} & \text { is surface runoff outflow, } \\ P_{\text {et }} & \text { is potential evapotranspiration, and } \\ \Delta S \mathrm{Sm} & \text { is the change in soil moisture. }\end{aligned}$

SWB-estimated recharge for the Rush Springs aquifer was previously computed by Neel and others (2018). However, because the aquifer areal extent for this report was larger than that of Neel and others (2018), SWBestimated recharge was recomputed by using the same input datasets for this larger areal extent. Daily climate data, including precipitation $(\mathrm{P})$ and minimum and maximum air temperature, were obtained for 33 climate stations (National Climatic Data Center, 2017; Oklahoma Mesonet, 2017) (table 4) and interpolated to a grid using a 500-ft uniform spacing. Soil properties (soil-water storage capacity and hydrologic soil group) and land cover were derived from the Digital General Soil Map database (STATSGO; Natural Resources Conservation Service, 2015), which is an inventory of generalized soil characteristics at a 1:250,000 scale. Precipitation and snowmelt (S) were differentiated, based on the daily minimum and maximum air temperatures. Surface runoff inflow $\left(R_{i}\right)$ was calculated by using a flow-direction grid derived from a digital elevation model (DEM) (USGS, 2017a) whereby values representing land-surface altitudes were assigned to each SWB grid cell and runoff was routed to downslope cells. To ensure correct routing of surface runoff and to eliminate areas of internal drainage that can result in unrealistic amounts of recharge, depressions in the DEM (USGS, 2017a) were filled. Plant interception (Int) occurs when precipitation is captured by vegetation prior to reaching the top of the soil profile, and Int was specified for each landcover type during the growing season. Surface runoff outflow $\left(R_{0}\right)$ was calculated by using Natural Resources Conservation Service curve numbers that relate rainfall and runoff (Westenbroek and others, 2010). Potential evapotranspiration $\left(\mathrm{P}_{\mathrm{et}}\right)$ in the SWB code was calculated by using methods from Hargreaves and Samani (1985), discussed further in the “Saturated-Zone Evapotranspiration" section of this report. 
Table 4. Selected climate stations in and near the Rush Springs aquifer study area, western Oklahoma.

[M/D/Y, month/day/year. Present is defined as 2015 for the period of record]

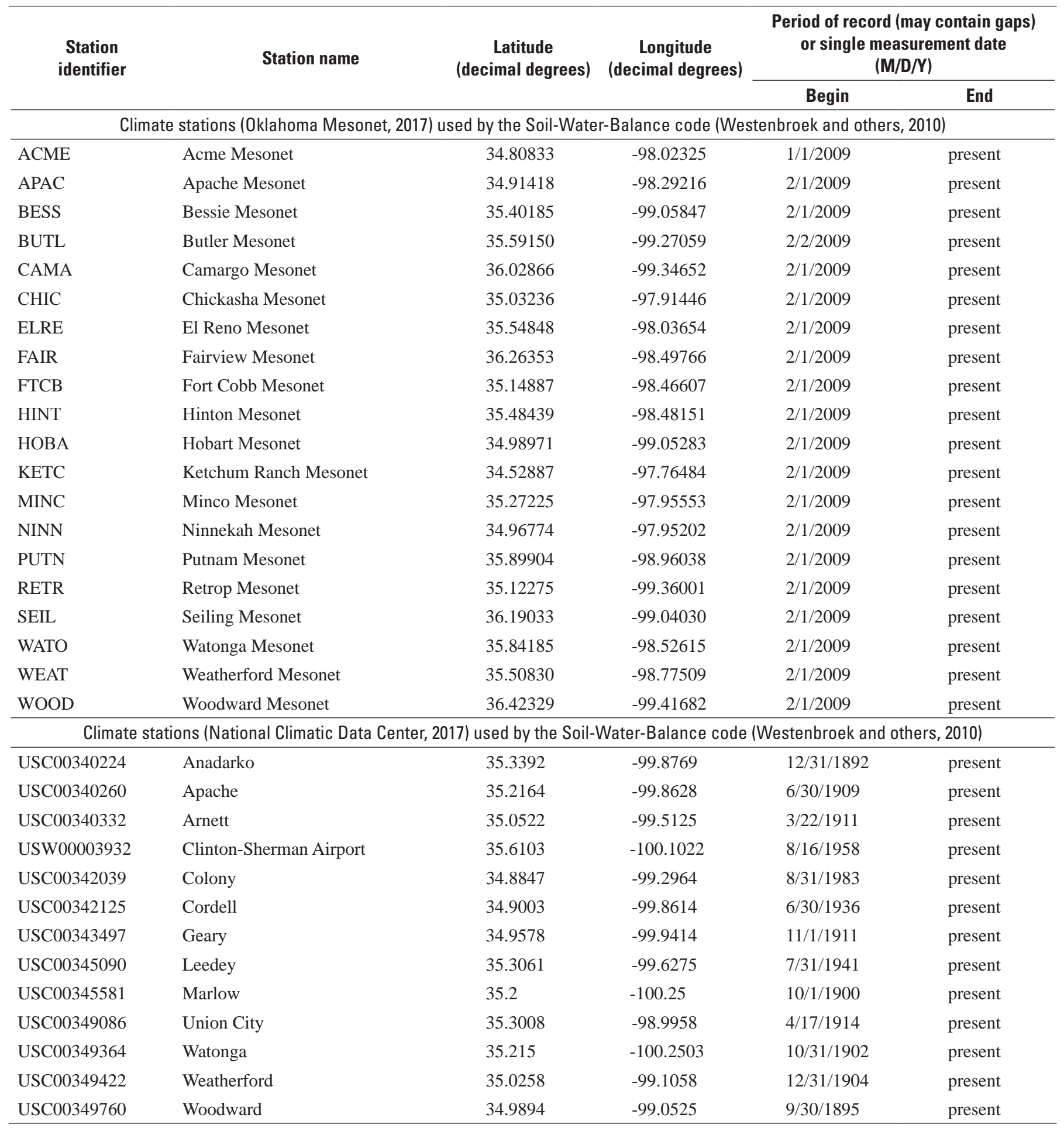


Root-zone depths represent the maximum depth to which various types of vegetation will grow and are classified based on land-cover and soil type. Greater plant root-zone depths result in the increased uptake of water in the soilmoisture zone, thus decreasing recharge, whereas smaller values increase recharge to the water table. Winter wheat, the dominant crop type overlying the Rush Springs aquifer (NASS, 2017; figs. 5-6), has mean and maximum rooting depths of about 1.0 and $4.6 \mathrm{ft}$, respectively, in Oklahoma (Patrignani and others, 2012; David Marburger, Oklahoma State University, written commun., 2018). To account for this root-zone depth range, the default root-zone depth for each land-cover type was scaled by 70 percent, which resulted in root-zone depths for crops between 1.4 and $2.1 \mathrm{ft}$.

The SWB-estimated mean annual recharge for the study period was about 1.7 inches per year (in/yr), or 5.6 percent of the mean annual precipitation of 30 in. (fig. 7). For the Fort Cobb Reservoir surface watershed (hereafter, "Fort Cobb Reservoir watershed") - defined by a 10-digit hydrologic unit code (USGS, 2017b) — the mean annual recharge for the study period was about $1.8 \mathrm{in} / \mathrm{yr}$. The minimum and maximum SWB-estimated annual recharge for the study period were about $0.03 \mathrm{in} / \mathrm{yr}$ (2003) and $4.6 \mathrm{in} / \mathrm{yr}$ (2007), respectively (fig. 7). Mean monthly recharge tended to be greatest from January through March and in May (fig. 8B). Recharge in these months corresponds to between 12 and 15 percent of mean annual precipitation. Mean monthly recharge was least between July and September. Recharge in these months corresponds to between 1 and 4 percent of mean annual precipitation.

Spatially, mean annual recharge for the study period was greatest in the southeastern part of the aquifer, the alluvium,

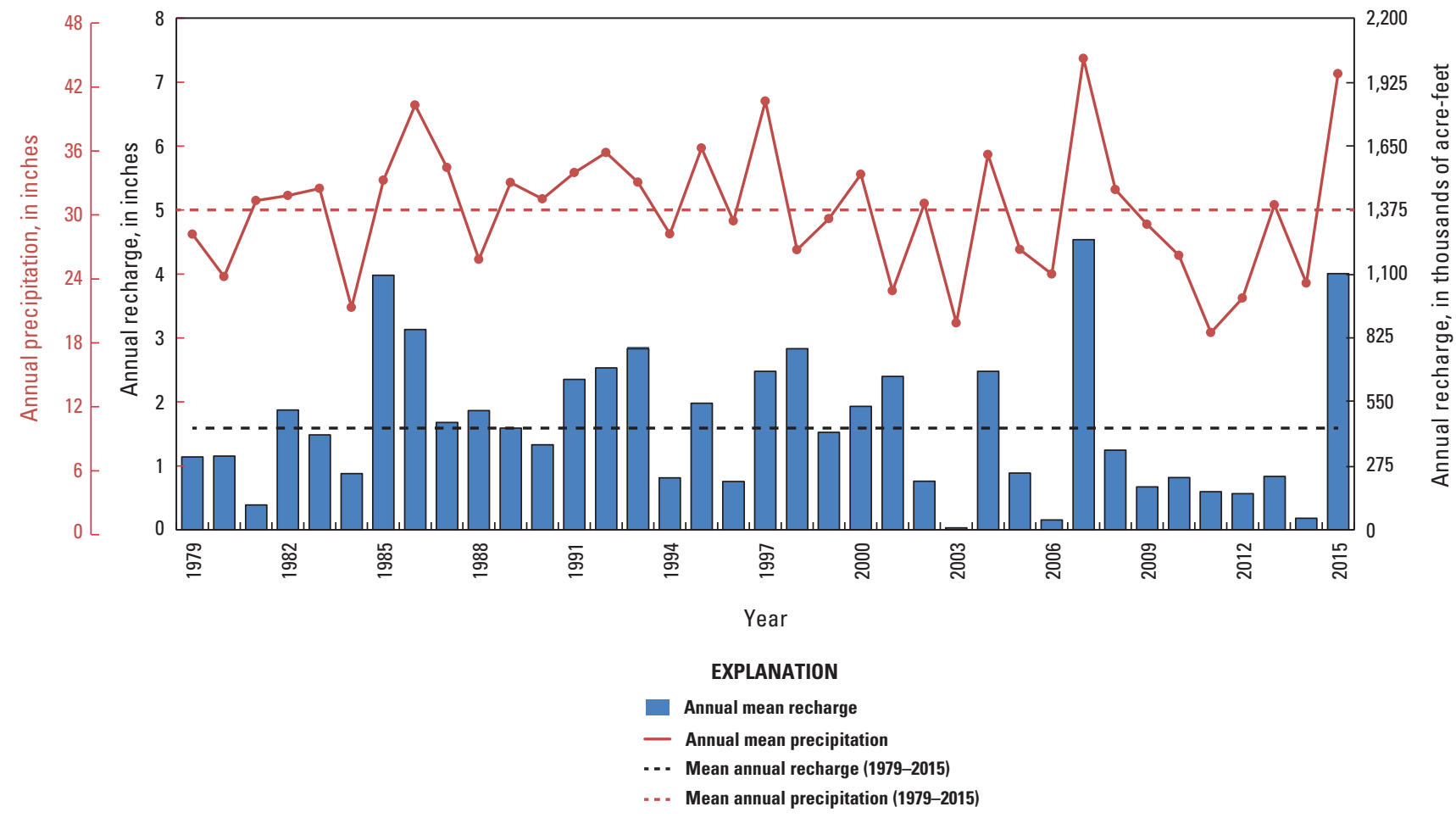

Figure 7. Annual precipitation and recharge computed by using the Soil-Water-Balance code (Westenbroek and others, 2010) for the Rush Springs aquifer, western Oklahoma, 1979-2015. 

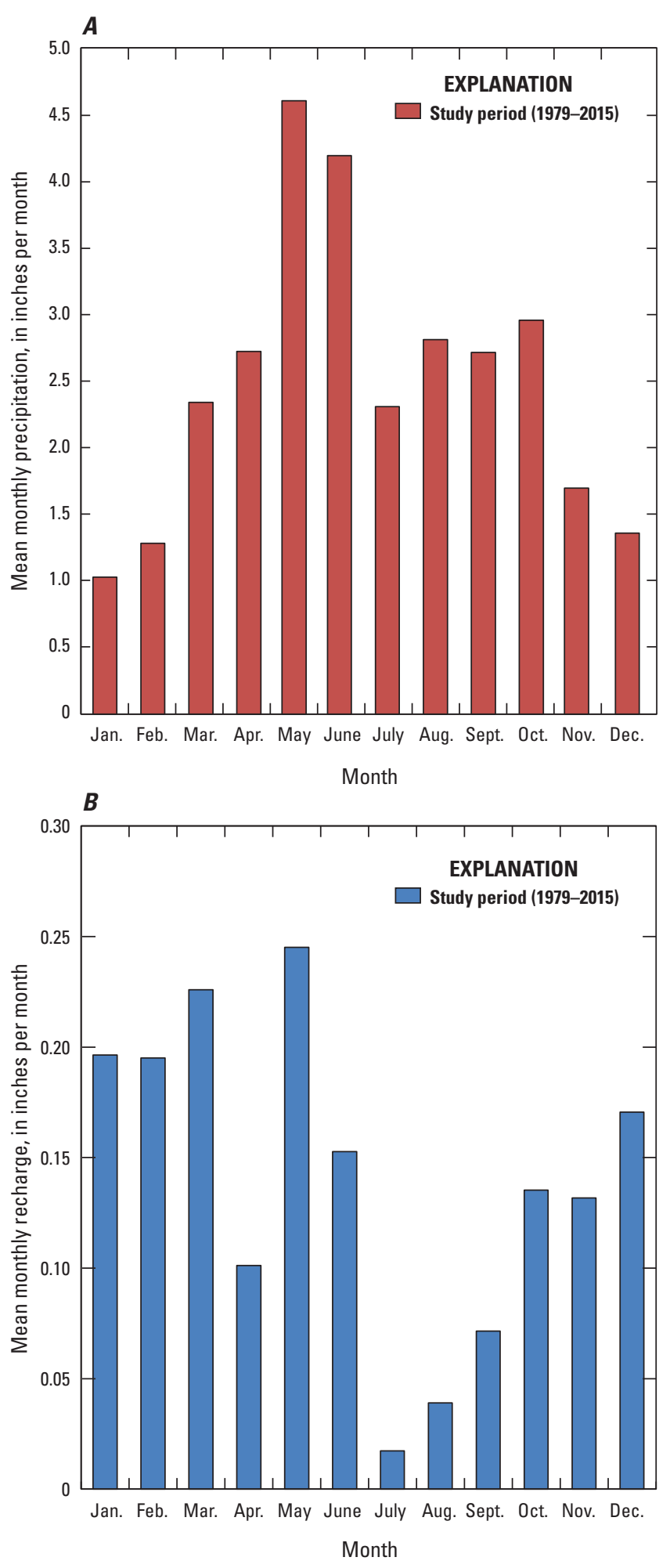

Figure 8. Mean monthly $A$, precipitation and $B$, recharge computed by using the Soil-Water-Balance code (Westenbroek and others, 2010) for the Rush Springs aquifer, western Oklahoma, 1979-2015. and the terrace between the Canadian and North Canadian Rivers (fig. 9); this terrace contains windblown sand deposits and dunes that allow for rapid infiltration of precipitation (Six, 1930; Fay, 1962). Greater recharge occurred in the alluvial and terrace deposits than in the bedrock deposits because of a more sandy soil type in the alluvium and terrace deposits that had a lower available water capacity (Westenbroek and others, 2010, table 7). Recharge was least where the Cloud Chief Formation was present (fig. 2), particularly in western Custer, southwestern Dewey, and eastern Roger Mills Counties (fig. 9). Soil-water properties are generalized on a county scale in the STATSGO database; thus, changes in recharge can occur at county boundaries between hydrologic soil or available water capacity groups, such as the recharge change in an area where the Canadian River runs parallel to the North Canadian River in western Blaine County (fig. 9).

Mean annual recharge rates estimated from the SWB code were compared to published estimates of mean annual recharge. Tanaka and Davis (1963) estimated mean annual recharge for the Fort Cobb Reservoir watershed to be $2.8 \mathrm{in} / \mathrm{yr}$, or about 10 percent of mean annual precipitation for the period 1953-56. Precipitation during three of the four years (1953-56) of the Tanaka and Davis (1963) study was below the mean annual precipitation for the period of 1905-2015 (28.2 in/yr) estimated from Neel and others (2018). Becker and Runkle (1998) estimated mean annual recharge between March 1989 and January 1991 to be 1.8 in/yr, or about 7 percent of mean annual precipitation for that period. That recharge value was based on the assumption that aquifer recharge was equal to stream discharge between March 1989 and January 1991 (Becker and Runkle, 1998). The mean annual precipitation between March 1989 and January 1991 was estimated at $29 \mathrm{in} / \mathrm{yr}$ (Becker and Runkle, 1998), which is about 3 percent greater than mean annual precipitation from Neel and others (2018). Becker (1998) estimated a mean recharge of $1.3 \mathrm{in} / \mathrm{yr}$ for the Rush Springs aquifer through calibration of a steady-state groundwater model. Wyatt and others (2017) estimated a mean annual recharge of $2.6 \mathrm{in} / \mathrm{yr}$ by using soil-moisture drainage rates at a 60 -centimeter (23.6 in.) depth below land surface to approximate recharge based on soil-moisture data from five climate stations between 1998 and 2014. This recharge estimate is about 9 percent of mean annual precipitation estimated from Neel and others (2018). The soil-moisture-based drainage results could overstate recharge in locations where plant root-zone depths exceed 23.6 in., or where the water table is near this depth below land surface.

The mean annual recharge rate estimated by using the SWB code for this study is generally lower than these published estimates of recharge for the Rush Springs aquifer. The average of mean annual recharge rates from Tanaka and Davis (1963), Becker and Runkle (1998), Becker (1998), and Wyatt and others (2017) is about $2.1 \mathrm{in} / \mathrm{yr}$, or approximately 7 percent of precipitation from Neel and others (2018). When applied across the land-surface area of the Rush Springs aquifer (3,181,003 acres), the mean annual recharge of $2.1 \mathrm{in} / \mathrm{yr}$ 


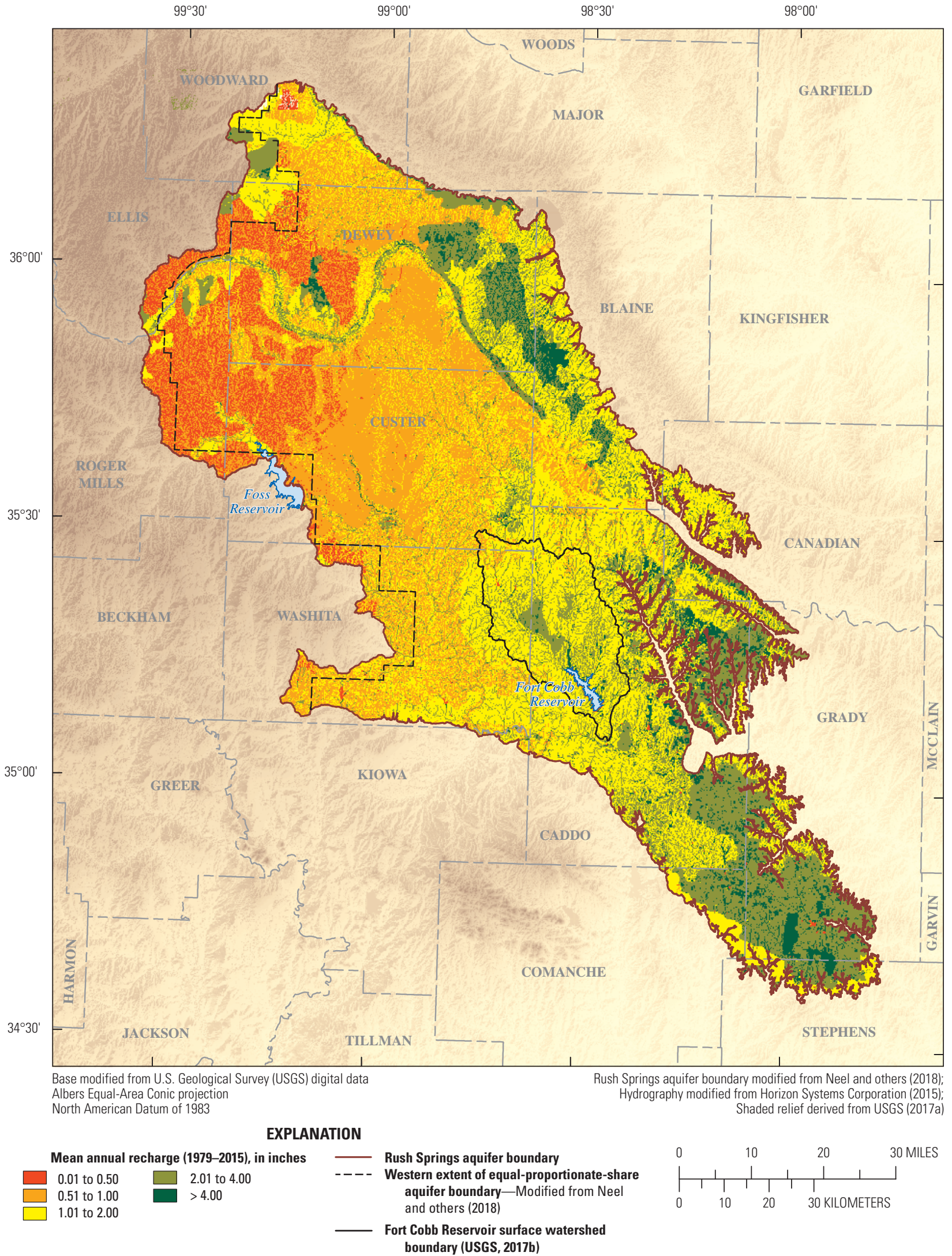

Figure 9. Mean annual groundwater recharge computed by using the Soil-Water-Balance code (Westenbroek and others, 2010) for the Rush Springs aquifer, western Oklahoma, 1979-2015. 
corresponds to a mean annual recharge volume of about 556,675 acre-feet per year (acre-ft/yr), or about 97 percent of aquifer inflows in the conceptual water budget (table 3 ).

\section{Recharge from Crop Irrigation}

Additional recharge from crop irrigation (sometimes called irrigation return flows) could also be expected to infiltrate through the unsaturated zone to the water table. Tanaka and Davis (1963) determined that recharge from irrigation was probably small in the Rush Springs aquifer study area because the irrigation method used is application of water from sprinklers to only the upper few inches of soil. However, studies in Nebraska have found that irrigation increases groundwater recharge (Roark and Healy, 1998; McMahon and others, 2011), and recharge rates are greater in irrigated cropland areas compared to natural rangeland or nonirrigated cropland (Scanlon and others, 2005). Stanton and others (2010) described annual increases in recharge of $0.13-0.30 \mathrm{in} / \mathrm{yr}$ in irrigated cropland compared to nonirrigated cropland (Dugan and Zelt, 2000) and 1.3-1.6 in/yr in irrigated cropland compared to rangeland (McMahon and others, 2006). However, the soil properties (soil-water storage capacity and hydrologic soil group), irrigation methods, and irrigation rates in Nebraska may differ from cropland areas in the Rush Springs aquifer. A constrained range for the recharge from crop irrigation could not be established; thus, this term was not quantified in the conceptual water budget.

\section{Saturated-Zone Evapotranspiration}

ET is the process by which water is transferred to the atmosphere directly by evaporation or indirectly by plant transpiration. This process occurs in both the saturated and soil-moisture (unsaturated) zones typically in areas where the water table is at or near land surface, such as lakes or wetlands. The soil-moisture-zone component of ET was not considered to be a part of the conceptual water budget because it occurs before infiltrating precipitation has become groundwater recharge. For this investigation, evapotranspiration by plants from the saturated zone-or saturated-zone evapotranspiration (ETg) — was quantified in the water budget. The ETg rate was estimated by using the SWB code, a daily groundwater-level fluctuation method from White (1932), and previously published literature. The ETg area $(63,734$ acres) was defined by using the National Wetlands Inventory (U.S. Fish and Wildlife Service, 2017).

ETg rates were assumed to be proportional to the difference between potential ET ( $\mathrm{P}_{\mathrm{e}}$; eq. 1) and actual ET $\left(\mathrm{A}_{\mathrm{et}}\right)$ computed by using the SWB code. $P_{\text {et }}$ was calculated by using the Hargreaves and Samani (1985) method and represents the maximum rate at which groundwater could be evapotranspired with unlimited soil-moisture availability. The SWB code computes the change in soil moisture whereby $P_{\text {et }}$ is subtracted from daily precipitation. If the resulting value is positive, $A_{e t}$ equals $P_{\text {et }}$. If the resulting value is negative, $A_{\text {et }}$ is limited to the change in soil moisture and is less than $\mathrm{P}_{\text {et }}$. Because SWB computes soil-moisture-zone ET without regard to the location of groundwater levels in relation to land surface, the difference between $P_{\text {et }}$ and $A_{\text {et }}$ can be used to approximate ETg. The mean annual ETg rate $\left(P_{\text {et }}-A_{\text {et }}\right)$, computed by using the SWB code, was $24.5 \mathrm{in} / \mathrm{yr}$.

White (1932) estimated annual ETg rates by using specific yield (Sy) from soil columns and groundwater levels measured every hour from a continuous well. This method was applied for undisturbed salt grass cover in southwest Utah with a mean depth to water of 12-24 in. By using this method, the mean annual ETg was estimated as 16 in/yr. By comparison, a mean annual ETg of $12 \mathrm{in} / \mathrm{yr}$ was obtained by using the same method for the North Fork Red River in Oklahoma (Smith and others, 2017).

The ETg rates from the SWB code (24.5 in/yr), White (1932) (16 in/yr), and Smith and others (2017) (12 in/yr) were averaged to obtain a mean annual ETg rate of $17.5 \mathrm{in} / \mathrm{yr}$. When applied across the ETg area, this ETg rate was 92,945 acre-ft/yr, or about 16 percent of aquifer outflows (table 3). This annual ETg rate was expected to be a reasonable balance between the various ETg estimates for the Rush Springs aquifer.

\section{Streamflow Characteristics and Seepage}

Base flow, or the part of streamflow that is not from runoff and is discharged from aquifers adjoining a stream, was quantified over the study period 1979-2015 for the studyarea streamgages by using a base-flow separation code (BFI; Wahl and Wahl, 1995) integrated into the USGS Groundwater Toolbox (Barlow and others, 2015) (table 1). This technique identifies the minimum streamflow for user-specified n-day moving increments and compares this streamflow to adjacent minimums to determine turning points on a base-flow hydrograph. The ratio of base flow to the total streamflow is the base-flow index. A base-flow index of 1 indicates that all streamflow occurs from groundwater, and a base-flow index of 0 indicates that no streamflow occurs from groundwater.

The Canadian River is regulated by an upstream surfacewater reservoir in Texas, but no releases from the reservoir were recorded during the study period. The Washita River is regulated by Foss Reservoir and Fort Cobb Reservoir, and a number of reservoir releases to the Washita River were recorded during the study period. Thus, BFI may overestimate base flows at regulated streamgages on the Washita River (fig. 1), and long-term trends in base flows may be masked by reservoir releases that are indistinguishable from base flows.

The BFI-estimated base flows calculated at streamgages located on the Canadian River, Washita River, Little Washita River, and Fort Cobb Reservoir tributaries (Cobb, Lake, and Willow Creeks) were used to estimate annual stream seepage between the Rush Springs aquifer and these streams. Base flow from the Canadian River upstream from the aquifer was estimated from Ellis and others (2017). Based on the increase in streamflow between streamgages (table 2), the 
estimated mean annual stream seepage is predominantly from the Rush Springs aquifer to the study-area streams. Although flow from the study-area streams, such as Cobb Creek, to the Rush Springs aquifer may occur (Mashburn and Smith, 2014), the substantial increases in mean downstream base flow suggest that this flow is small in comparison to flow from the aquifer to the study-area streams.

Mean annual stream seepage for streams with available streamgage data was calculated as the sum of the mean annual stream seepage from the Canadian (51,016 acre-ft/yr), Washita (146,914 acre-ft/yr), and Little Washita (9,915 acre-ft/yr) Rivers and Cobb (12,392 acre-ft/yr), Lake (3,644 acre-ft/yr), and Willow (1,476 acre-ft/yr) Creeks during the study period. For the Washita River downstream from Foss Reservoir, the mean annual stream seepage was based on the difference between the base flow at the Anadarko (07326500) and Foss (07324400) streamgages and an estimated 3 cubic feet per second ( $\mathrm{ft}^{3} / \mathrm{s} ; 2,173$ acre- $\left.\mathrm{ft} / \mathrm{yr}\right)$ of base flow from five tributaries (Turkey, Boggy, Cavalry, Rainy Mountain, and Stinking Creeks; fig. 1), surface-water diversions, and releases from Fort Cobb Reservoir. Base flow in the Washita River at the upstream Rush Springs aquifer boundary was estimated as 66 percent of the base flow at the Hammon streamgage (07324200). Thus, mean annual stream seepage for the Washita River upstream from Foss Reservoir was the difference of these flows adjusted upward by 8 percent for the 3.9-mi distance downstream to Foss Reservoir. The Little Washita River originates in the Rush Springs aquifer; therefore, the stream seepage was set as the base flow at this gage adjusted upward by 14 percent for the $4.3-\mathrm{mi}$ distance downstream to the Rush Springs aquifer boundary. Mean annual stream seepages for Cobb, Lake, and Willow Creeks were estimated by using the same methods, with upward flow adjustments for Cobb Creek and Lake Creek of 12 and 20 percent, respectively, made to account for the distance between the streamgages and Fort Cobb Reservoir.

Stream seepage is assumed to occur at the numerous ungaged streams in the study area. Because no data are available for these streams, the seepage contribution from these streams was estimated at 15 percent of the mean annual stream seepage for streams with available streamgage data. Thus, mean annual stream seepage for the Rush Springs aquifer-including gaged (225,357 acre-ft/yr) and ungaged streams (33,804 acre-ft/yr) — was estimated at 259,161 acre-ft/yr, or about 45 percent of aquifer outflows (table 3 ).

\section{Lateral Groundwater Flows}

The bedrock deposits of the Ogallala Formation (fig. 2), which are situated upgradient from the Rush Springs aquifer, were assumed to exchange lateral groundwater flow with this aquifer. The flow from the Ogallala Formation to the Rush Springs aquifer is shown by potentiometric-surface contours in this area parallel to the aquifer boundary during 1986 and
1991 (Becker and Runkle, 1998) and during 2013 (Neel and others, 2018), or perpendicular to the direction of lateral groundwater flow.

To the southwest and west of the Rush Springs aquifer, the surrounding bedrock units are composed predominantly of shale and siltstone. Potentiometric-surface contours for this area are generally perpendicular to the aquifer boundary (Neel and others, 2018); thus, lateral groundwater flows in these areas were assumed to be negligible. Additionally, to the northeast and east, seepage is assumed to occur from the Rush Springs aquifer to the North Canadian alluvium and terrace deposits based on potentiometric-surface contours that are parallel to this boundary (Ryter and Correll, 2016; Neel and others, 2018). The low-permeability Dog Creek Shale at the base of the Rush Springs aquifer is expected to impede flow from the Rush Springs aquifer into underlying units or to the aquifer from underlying units.

No estimates of lateral groundwater flow from the Ogallala Formation to the Rush Springs aquifer are available in published literature; however, based on the configuration of the published potentiometric-surface contours, the lateral groundwater flow from the Ogallala Formation to the Rush Springs aquifer is expected to be small. Thus, mean annual lateral groundwater flow was assumed to be about 3 percent of recharge to the Rush Springs aquifer, or about 16,700 acre-ft/yr (table 3).

\section{Water Use}

Water use in Oklahoma, with the exceptions of groundwater use of less than 5 acre-ft/yr for domestic and agricultural purposes and groundwater use for irrigation of less than 3 acres of land, is regulated by the OWRB. Groundwaterand surface-water-use data are self-reported annually to the OWRB by permitted users, and the OWRB staff reviewed water-use data described in this report to ensure the quality and completeness of the data.

During the study period (1979-2015), groundwater use was estimated for 1,891 irrigation, public supply, industrial, and temporary permits (OWRB, 2017). Mean annual groundwater use for the study period totaled 65,763 acre-ft/yr, or about 11 percent of aquifer outflows (table 3 ). This groundwater-use total includes 58,821 acre-ft/yr for irrigation (89 percent), 5,854 acre-ft/yr for public supply (9 percent), and 1,088 acre-ft/yr for all other use types (2 percent). Mean annual groundwater use was similar to that of the period of record 1967-2015, during which mean annual groundwater use was $68,719 \mathrm{acre}-\mathrm{ft} / \mathrm{yr}$ including 62,501 acre-ft/yr for irrigation (91 percent), 5,362 acre-ft/yr for public supply (8 percent), and 855 acre-ft/yr for all other use types ( 1 percent).

Groundwater-use permits for irrigation were predominantly in agricultural land located in Caddo and eastern Washita Counties (figs. 5, 10), whereas groundwateruse permits for public supply were predominantly in eastern Custer County, central and western Caddo County, and southern Grady County (fig. 10). Irrigation permits account 
for 89 percent of all groundwater use, and annual groundwater use for the Rush Springs aquifer is, therefore, concentrated during summer months. About 85 percent of annual irrigation groundwater use occurs between June and September of each year, and about 60 percent occurs between July and August (OWRB, 2012).

The Fort Cobb Reservoir watershed contained the largest concentration of groundwater use in the Rush Springs aquifer (fig. 10). Although this watershed contains only 6.7 percent of the Rush Springs aquifer surface area (213,895 out of $3,181,003$ acres), mean annual groundwater use from this watershed accounts for 52 percent (34,521 acre-ft/yr) of the mean annual groundwater use in the aquifer $(65,763$ acre-ft/yr, table 3). Additionally, 98 percent of the groundwater permits in this watershed are for irrigation purposes; thus, the groundwater use in this area is concentrated in JuneSeptember of each year. Mean annual groundwater use in the Fort Cobb Reservoir watershed was greater than the mean annual recharge in this watershed estimated by using the SWB code.

Reported surface-water use in the Rush Springs aquifer consists of permitted diversions along the Washita River, Little Washita River, and Deer Creek and associated tributaries (fig. 10). The mean annual withdrawal rate for all surface-water permitted diversions during the study period was 156 acre-ft/yr (OWRB, 2017). During the study period, 30 permitted diversions had mean annual withdrawal rates between 3 and 628 acre-ft/yr. This total withdrawal includes all active and temporary permits in the boundaries of the Rush Springs aquifer for the study period.

\section{Seeps and Springs}

Seeps and springs are commonly present in the Rush Springs aquifer along deeply incised drainage channels (Mashburn and Smith, 2014). One of the primary conduits for groundwater outflows from this aquifer (other than stream seepage) is likely to be seeps and springs along the southeastern boundary of the aquifer (Tanaka and Davis, 1963). That boundary is often parallel to potentiometricsurface contours from Neel and others (2018), indicating that groundwater flows from the Rush Springs aquifer to seeps and springs along that boundary. A total of 25 discharging springs were documented during 2011 (Mashburn and Smith, 2014), although below-mean precipitation during 2011 and several prior years precluded additional springs being located that likely existed. Because spring flow occurred during drought conditions, these springs are likely perennial but are estimated to flow less than $1 \mathrm{ft}^{3} / \mathrm{s}$.

Although discharge data are generally unavailable for seeps and springs in the study area, a substantial component of aquifer outflows is expected to occur along the entire eastern and southeastern boundary of the Rush Springs aquifer, or effectively half of the aquifer boundary — is expected to result in a substantial component of aquifer outflows. Becker (1998) used a steady-state groundwater model to estimate that discharge to seeps and minor streams originating in the Rush Springs aquifer was approximately 82 percent of aquifer outflows. However, this model covered a smaller areal extent and made no delineation between discharge to seeps and seepage to minor streams. Based on the balance of inflows (recharge and lateral groundwater flow) and other outflows (stream seepage, ETg, and groundwater use), mean annual discharge to seeps and springs is estimated to be $155,507 \mathrm{acre}-\mathrm{ft} / \mathrm{yr}$, or about 27 percent of aquifer outflows in the conceptual water budget (table 3 ).

\section{Reservoir}

Streamflows from Cobb Creek, Lake Creek, and Willow Creek are the primary source of surface-water inflow to Fort Cobb Reservoir (fig. 1), a Reclamation reservoir constructed in 1959 for flood control, water supply, and recreation. Fort Cobb Reservoir provides municipal and industrial water to the Public Service Company of Oklahoma, Western Farmers Electric Cooperative, the City of Anadarko, and the City of Chickasha. The active conservation pool storage of Fort Cobb Reservoir is 71,696 acre-ft (Reclamation, 2017a), and the reservoir has mean annual permitted surface-water withdrawals of about 18,000 acre-ft/yr (OWRB, 2012).

Flow to and from Fort Cobb Reservoir and the Rush Springs aquifer (termed "lakebed seepage") was expected to vary seasonally with changes in precipitation and water use. Stage in Fort Cobb Reservoir is generally highest in the early summer after spring rainfall and lowest in the fall after the cumulative effects of increased evaporation and permitted surface-water withdrawals during summer months (Reclamation, 2017a). Thus, lakebed seepage may occur as an inflow to or an outflow from the Rush Springs aquifer during various times of the year.

Streamflow from the Washita River is the primary source of surface-water inflow to Foss Reservoir (fig. 1), a Reclamation reservoir constructed in 1961 for flood control, water supply, and recreation. The active conservation pool storage of Foss Reservoir is 168,732 acre-ft (Reclamation, 2017b), and the reservoir has mean annual permitted surfacewater withdrawals of about 18,000 acre-ft/yr (OWRB, 2012).

\section{Groundwater Storage Change}

To estimate groundwater storage change for the Rush Springs aquifer, an analysis was performed for groundwater levels at 19 of the 26 long-term or continuous observation wells (fig. 11) completed in the unconfined portion of the Rush Springs aquifer. Changes in groundwater levels occur because of changes in the volume of water stored in the aquifer. Longterm changes determined over many years can be indicative of an imbalance between inflows, such as recharge and lateral groundwater flow, and outflows, such as stream seepage, groundwater use, evapotranspiration, or seeps and springs. 


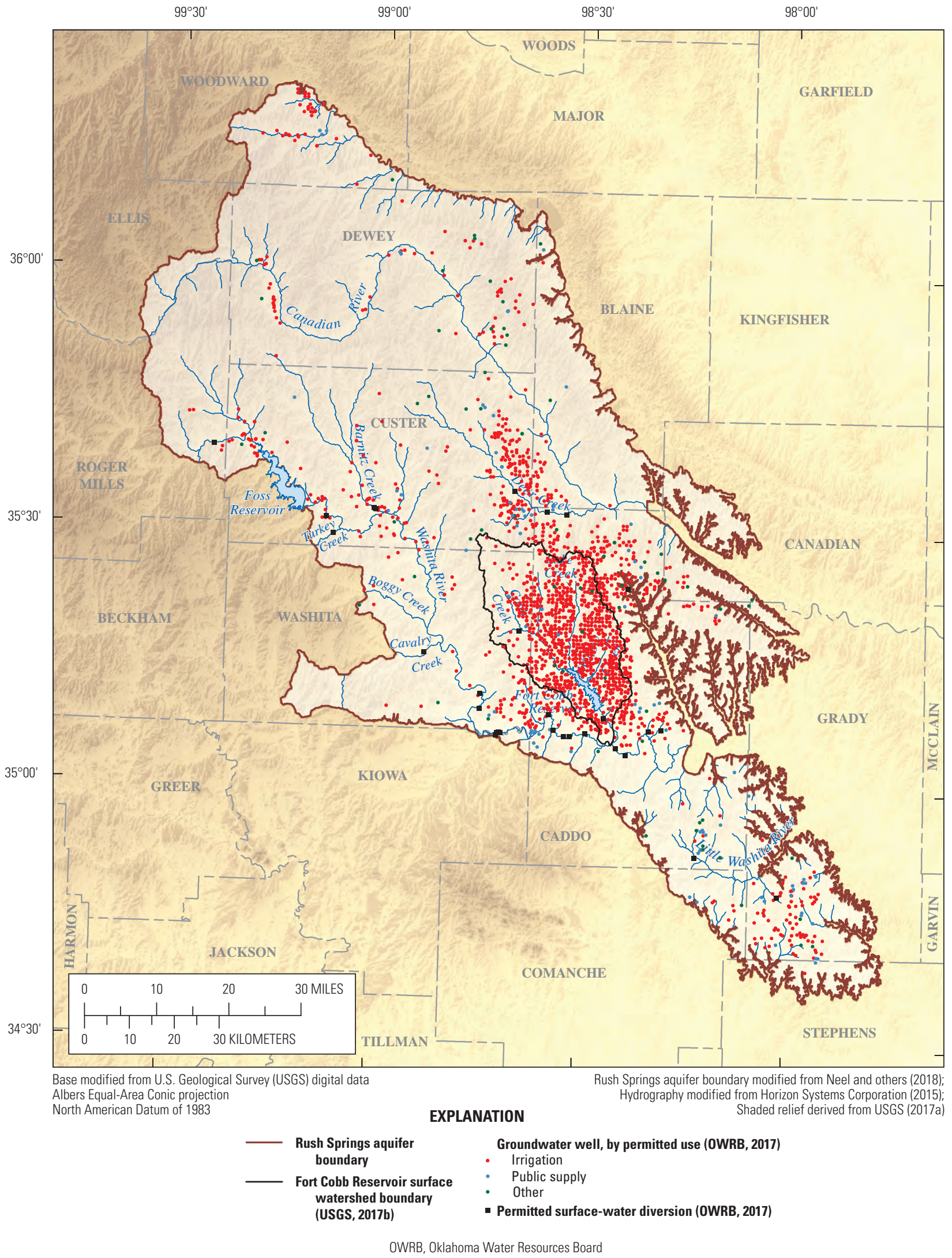

Figure 10. Locations of permitted groundwater wells and surface-water diversions for the Rush Springs aquifer, western Oklahoma, 1979-2015. 


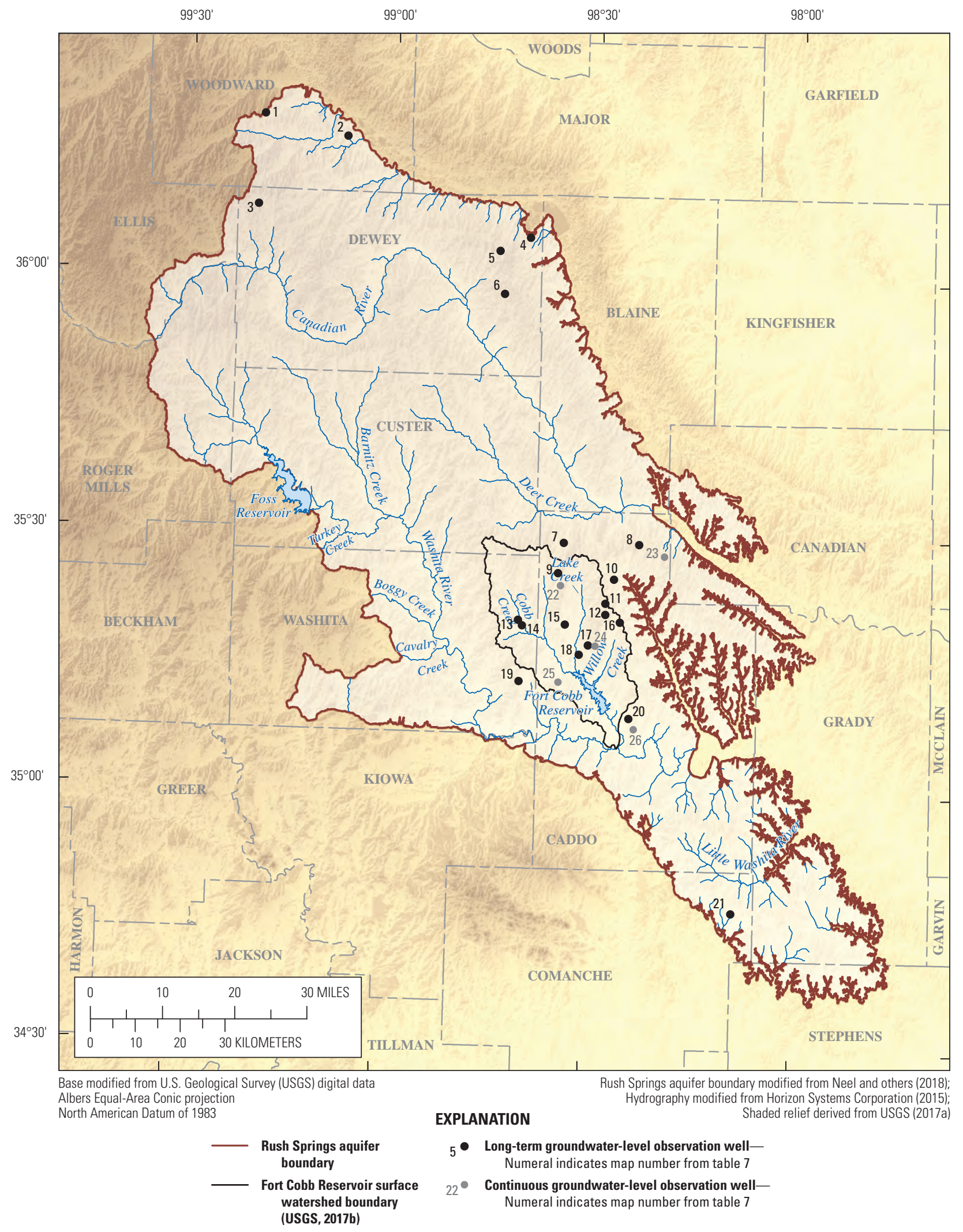

Figure 11. Locations of long-term and continuous groundwater-level observation wells for the Rush Springs aquifer, western Oklahoma, 1979-2015. 
The analysis period began in 1979, after a transition to developed conditions had occurred in the aquifer (Neel and others, 2018), and ended in early 2016. This analysis examined groundwater-level observations conducted during base-flow conditions (generally December to March), when seasonal groundwater use and ETg are minimal. This analysis included only wells for which no pumping was recorded at the time of the groundwater-level observations in the National Water Information System (NWIS) database (USGS, 2017c) or OWRB database (OWRB, 2017).

The results from the analysis of groundwater levels in 19 wells (fig. 12) indicated

- generally stable to slightly declining groundwater levels during an early period with somewhat belownormal precipitation (1979-81; fig. 7),

- increasing groundwater levels during a period with above-normal precipitation (1985-2000; fig. 7), and

- decreasing groundwater levels during periods of belownormal precipitation (2001-06; fig. 7) and drought (2009-14; fig. 7) in western Oklahoma.

For the 19 wells analyzed, mean groundwater levels increased during the analysis period by $3.4 \mathrm{ft}$, including mean increases of $2.6 \mathrm{ft}$ for long-term wells 1-3, $21.9 \mathrm{ft}$ for long-term wells 4-6, and $8.9 \mathrm{ft}$ for long-term wells 7, 8, 10, and 20 (fig. 12). Mean groundwater levels decreased during the analysis period by $4.9 \mathrm{ft}$ for wells in the Fort Cobb Reservoir watershed (longterm wells 11, 12, 14-18, 22, and 25). This groundwater-level decrease corresponds to a groundwater storage change of 73,366 acre-ft for the Fort Cobb Reservoir watershed. This groundwater storage change was calculated by multiplying the groundwater-level change by the Sy $(0.07$; determined as the mean Sy for the Rush Springs aquifer from Neel and others [2018]) and the area of the Fort Cobb Reservoir watershed (213,895 acres).

Based on the similarity of groundwater-levels in 1979 and 2016 from this analysis and Neel and others (2018), it was expected that the groundwater storage change for the analysis period would be negligible for the purposes of calculating the conceptual water budget for the study period (table 3). Although groundwater levels in some areas of the aquifer increased during the analysis period (fig. 12A), these increases were offset by decreases in groundwater levels in the Fort Cobb Reservoir watershed (fig. 12B).

\section{Conceptual Water Budget}

A conceptual water budget for the Rush Springs aquifer (table 3) was developed to quantify the amount of water that moves between each boundary of the aquifer and to guide the construction and calibration of the groundwater model. This water budget provides a generalized estimate of mean annual inflows and outflows for the Rush Springs aquifer during the study period 1979-2015 (table 3). The Rush Springs aquifer bedrock units as well as the alluvium and terrace deposits in the study area are considered a single hydrogeologic unit (Rush Springs aquifer, fig. 3). Water that flows from the Rush Springs aquifer to the study area streams is considered an aquifer outflow, whereas the reverse constitutes an inflow to the aquifer.

Approximately 97 percent of inflows to the Rush Springs aquifer occurred as recharge during the study period, and net lateral flow was estimated to be 3 percent of the aquifer inflow (table 3). Net lakebed seepage at Fort Cobb Reservoir was expected to be a relatively small (less than 1 percent) component of the water budget; thus, this term was not quantified in table 3.

The largest aquifer outflow (45 percent) was net stream seepage (table 3$)$. The remaining aquifer outflows were seeps and springs (27 percent), ETg (16 percent), and groundwater use (11 percent). The amount of surface-water use (mean for 30 permits of 156 acre-ft/yr) is small and variable from year to year and, therefore, is not accounted for in the conceptual water budget (table 3 ).

\section{Simulation of Groundwater Flow}

A groundwater model of the Rush Springs aquifer was constructed by using MODFLOW-2005 (Harbaugh, 2005) with the Newton solver (MODFLOW-NWT; Niswonger and others, 2011). MODFLOW-NWT uses finite-difference methods to solve the three-dimensional groundwater-flow equation and includes more advanced capabilities to solve nonlinear simulations compared to MODFLOW-2005. In the modular design of MODFLOW, each hydrologic boundary, such as stream seepage, recharge, or groundwater use, is included as a package that, when activated, adds new inflow and outflow terms to the groundwater-flow equation being solved. Model space is discretized into orthogonal cells, and the cell size is the finest resolution at which spatially varying properties may be represented and varied. Model time is discretized into time steps within stress periods. The stress period length is the finest resolution at which temporally varying inflows and outflows may be represented and varied, and the time step length is the finest length of time for which model outputs may be written. The calibrated groundwater model inputs and outputs are available in Ellis (2018). 
A. Observation wells in the Rush Springs aquifer

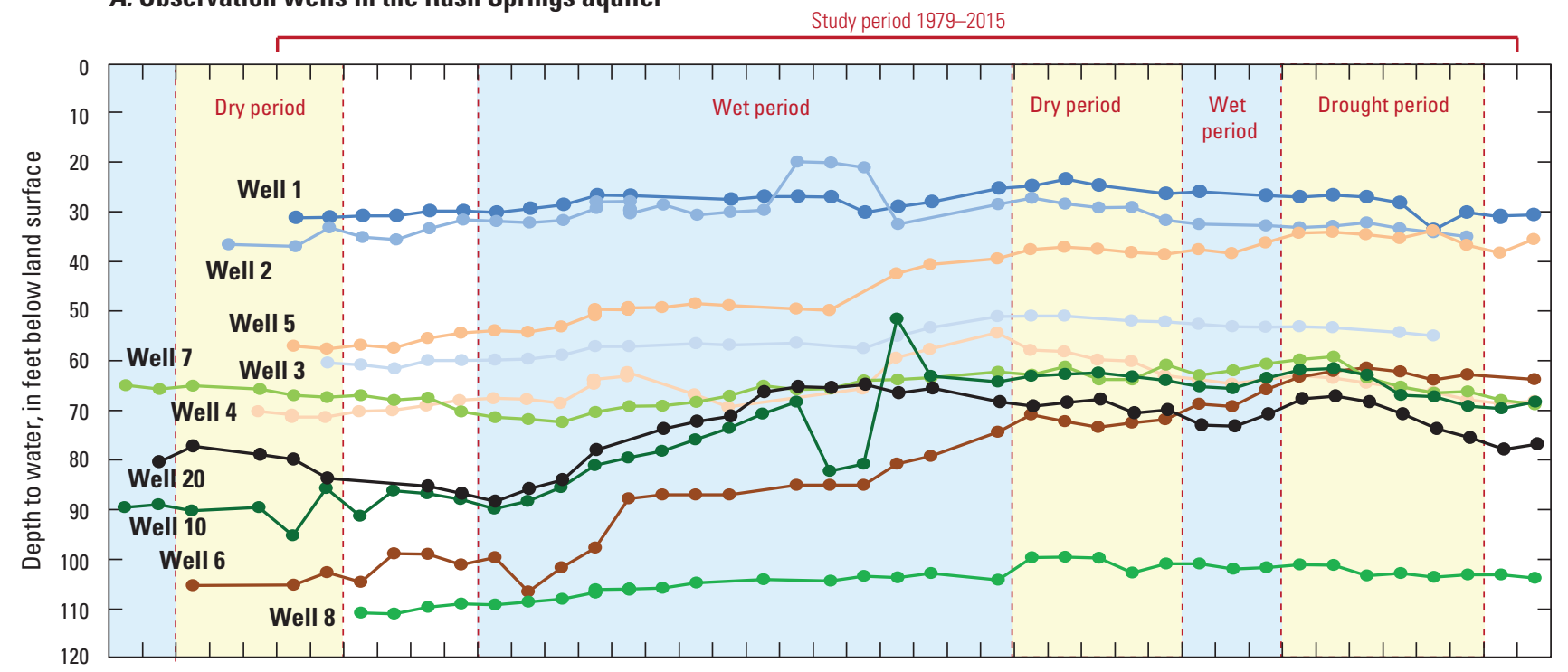

B. Observation wells in the Fort Cobb Reservoir surface watershed

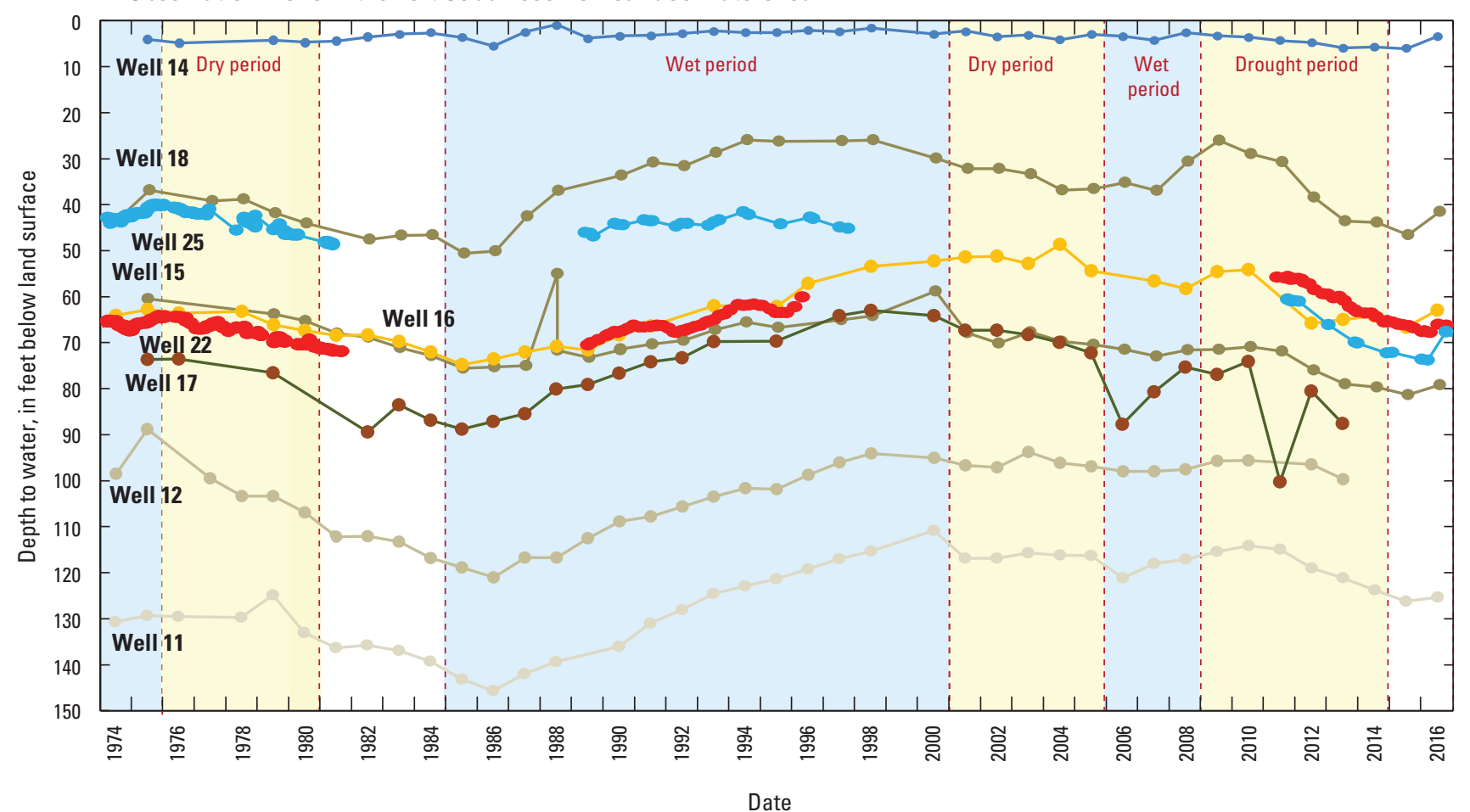

Study area climate periods from Neel and others (2018) based on a 5-year moving average

Figure 12. Depth to water for selected wells in $A$, Rush Springs aquifer and $B$, Fort Cobb Reservoir surface watershed, western Oklahoma, 1974-2016. 


\section{Spatial and Temporal Discretization}

The Rush Springs aquifer groundwater-model grid was spatially discretized into 1,362 rows and 1,083 columns containing $500-\mathrm{ft}$ by $500-\mathrm{ft}$ cells without rotation of the grid. Three layers were used to represent geologic units in the study area (figs. 13-14), and the active area was defined by the boundaries discussed in the "Purpose and Scope" section (fig. 1). The top layer (layer 1) represented the Cloud Chief Formation located in the western part of the study area and was inactive where that geologic unit was absent. The middle layer (layer 2) represented the alluvium and terrace deposits (hereafter, "alluvium and terrace") as well as the upper $30 \mathrm{ft}$ of the Whitehorse Group (hereafter, “upper Whitehorse Group”). This configuration was used to allow lateral groundwater flow to occur between the upper Whitehorse Group and the alluvium and terrace and between the upper Whitehorse Group and Fort Cobb Reservoir. Areas of the terrace outside of those areas shown on figure 13 were determined to be unsaturated based on an analysis of available well logs. The bottom layer (layer 3) represented the remainder of the Whitehorse Group (hereafter, "lower Whitehorse Group”). All model layers were assigned as a convertible-type layer, whereby each layer can convert between confined and unconfined conditions.

The groundwater-model period was temporally discretized into 444 monthly transient stress periods with 1 time step each, representing the period of January 1979 to December 2015. The monthly transient stress periods were used to capture seasonally variable processes such as recharge, ETg, and groundwater use. A lack of sufficient water data prior to the mid-1970s precluded the establishment of predevelopment groundwater levels and flow conditions; therefore, an initial 365-day steady-state stress period was configured to represent mean annual inflows and outflows from the Rush Springs aquifer to establish initial conditions for the study period.

\section{Hydrologic Boundaries}

Hydrologic boundaries in the groundwater model represent the locations where the inflow or outflow of water may occur (fig. 15) and include specified-flux and headdependent boundaries. For a specified-flux boundary, a user-specified discharge rate governs groundwater exchange at that boundary. Simulated specified-flux boundaries include groundwater use and recharge, as well as the no-flow boundary established at the bottom of layer 3. A no-flow boundary was also established at some locations in each layer where adjoining hydrogeologic units do not yield water to the Rush Springs aquifer (fig. 15). A head-dependent boundary simulates flow based on the difference between a user-specified groundwater level and the groundwater level in model cells. Simulated head-dependent boundaries include ETg, lateral groundwater flow, seeps and springs, stream seepage, and lakebed seepage at Fort Cobb Reservoir.

\section{Recharge}

Areally distributed recharge from the SWB code was simulated as a specified-flux boundary by using the Recharge package (Harbaugh, 2005). The steady-state simulation used a mean recharge value calculated for the model period, and the transient simulation used recharge values calculated for each month of the model period. Spatial adjustment of recharge occurred during the calibration phase to obtain better matches between simulated and observed calibration targets. Recharge was applied to the highest active cell, or layer 1 in the area where the Cloud Chief Formation is present and layer 2 in all other locations.

\section{Lateral Groundwater Flow, Seeps, and Springs}

Lateral groundwater flows between the Rush Springs aquifer and the Ogallala Formation in the northwest model area and between the Rush Springs aquifer and Foss Reservoir (fig. 2) were simulated as head-dependent boundaries by using the General-Head Boundary (GHB) package (Harbaugh, 2005) (fig. 15). The GHB package uses a linear relation between flux and the water-table altitude (or water head), and a user-specified reference groundwater level and conductance. Conductance is defined as the product of hydraulic conductivity of the model cell and the cross-sectional area perpendicular to flow, divided by the distance between the general-head boundary and the model cell. When the simulated groundwater level is lower than the reference groundwater level, water flows into the groundwater model. When the simulated groundwater level is higher than the reference groundwater level, water flows out of the groundwater model. The reference groundwater level for each GHB cell simulating flow from the Ogallala Formation was determined from the mean of the nearest measured groundwater levels during the model period (USGS, 2017c). The reference groundwater level for each GHB cell simulating flow between Foss Reservoir and the Rush Springs aquifer was determined as the mean of the reservoir stage (Reclamation, 2017b) during the model period.

Seeps and springs along the model boundary were simulated as a head-dependent boundary by using the Drain package (Harbaugh, 2005). Flow between the aquifer and drain cells is similar to the flow in the GHB package, except that (1) no flow to the drain occurs when the groundwater level in the aquifer is less than the altitude of the drain and (2) flow does not occur from the drain to the aquifer. The altitude of the drains simulating the spring discharge were set at the altitudes recorded for the springs in the NWIS database (USGS, 2017c). In layer 2, the spring altitudes for 3 of the 25 springs were increased because these altitudes occurred below the bottom of the cell. Lateral groundwater flows, springs, and seeps were simulated in layers 2 and 3 of the model. 


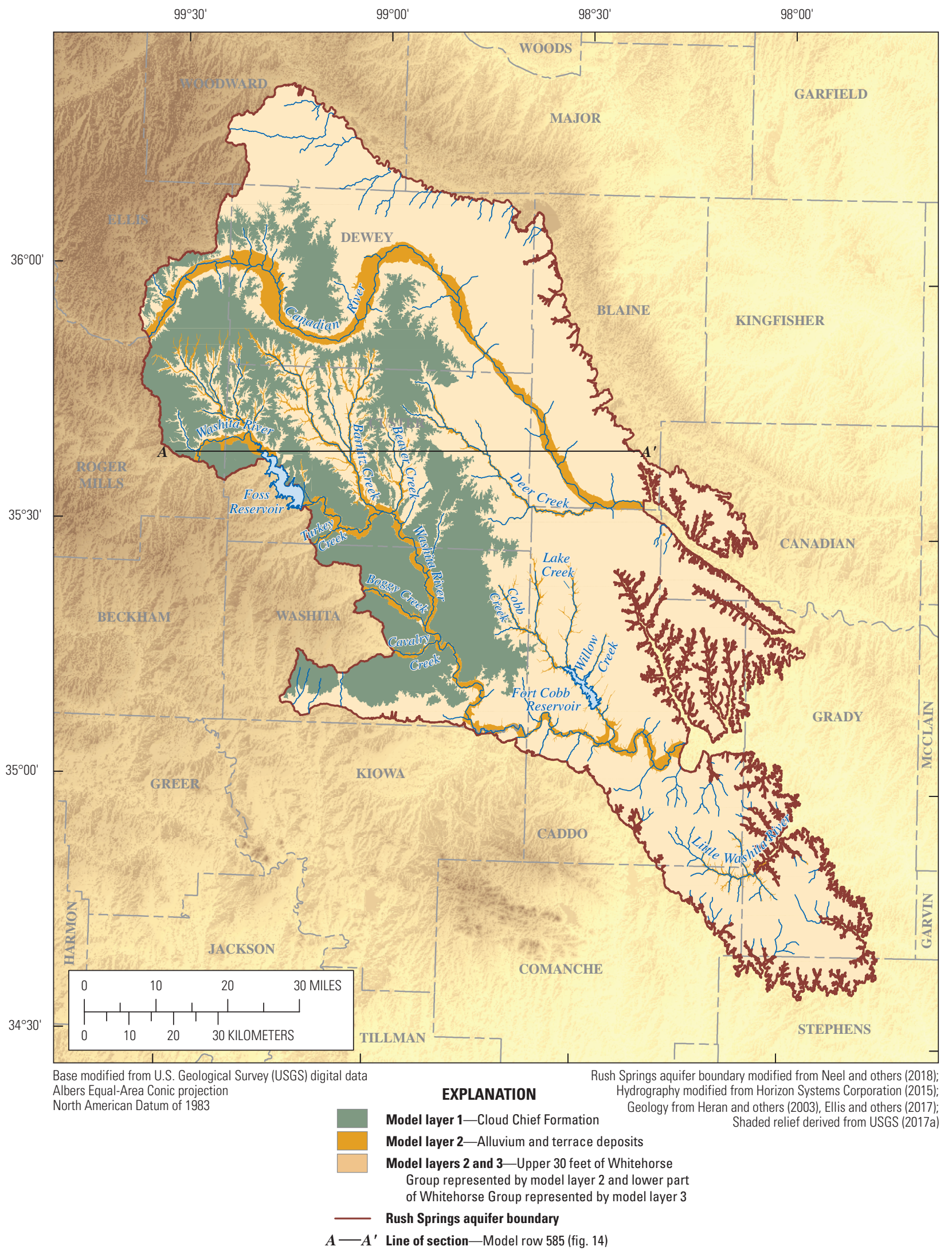

Figure 13. Hydrogeologic units of the Rush Springs aquifer study area, western Oklahoma. 


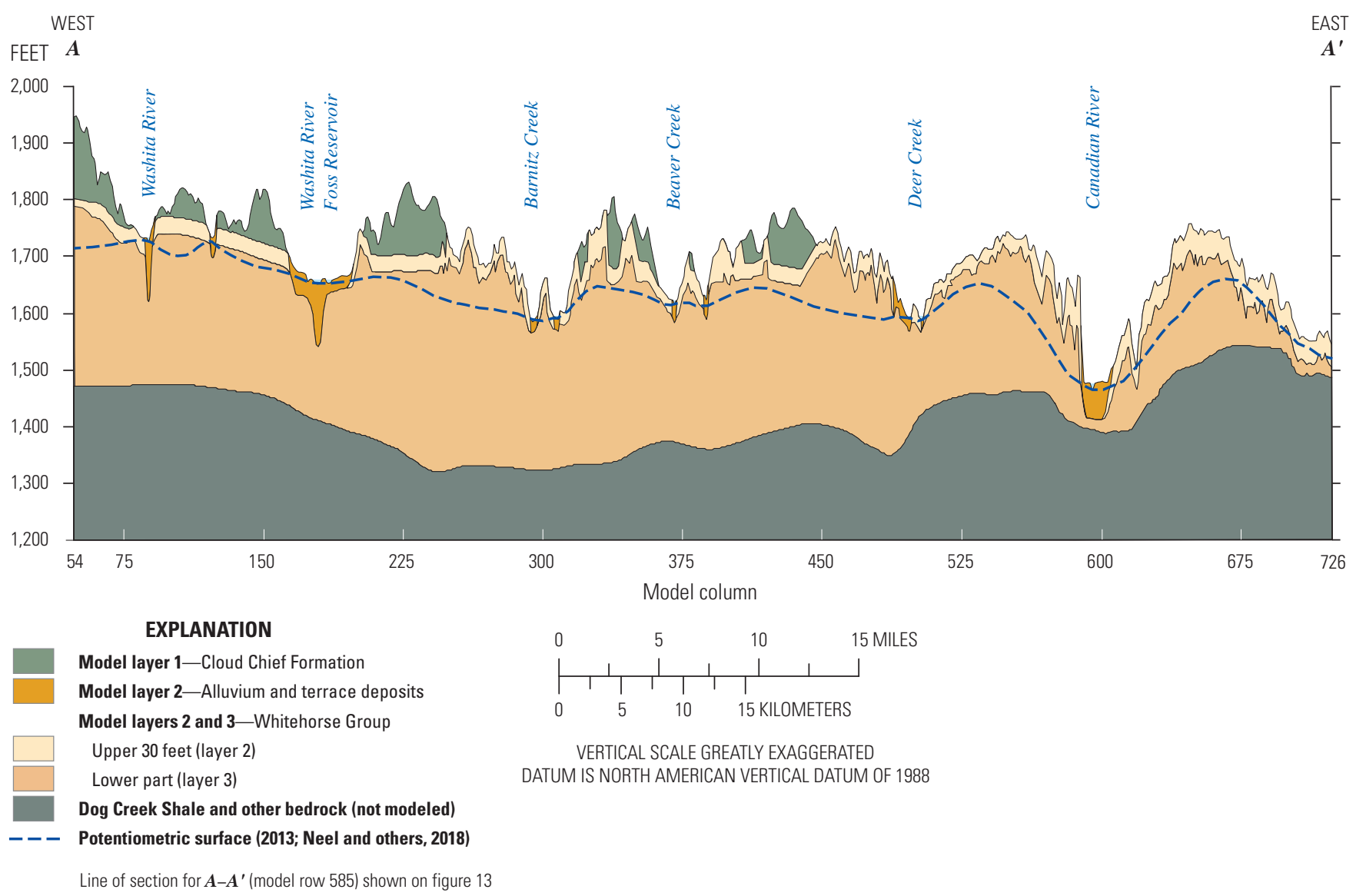

Figure 14. Vertical cross section of the Rush Springs groundwater-flow model, western Oklahoma. 


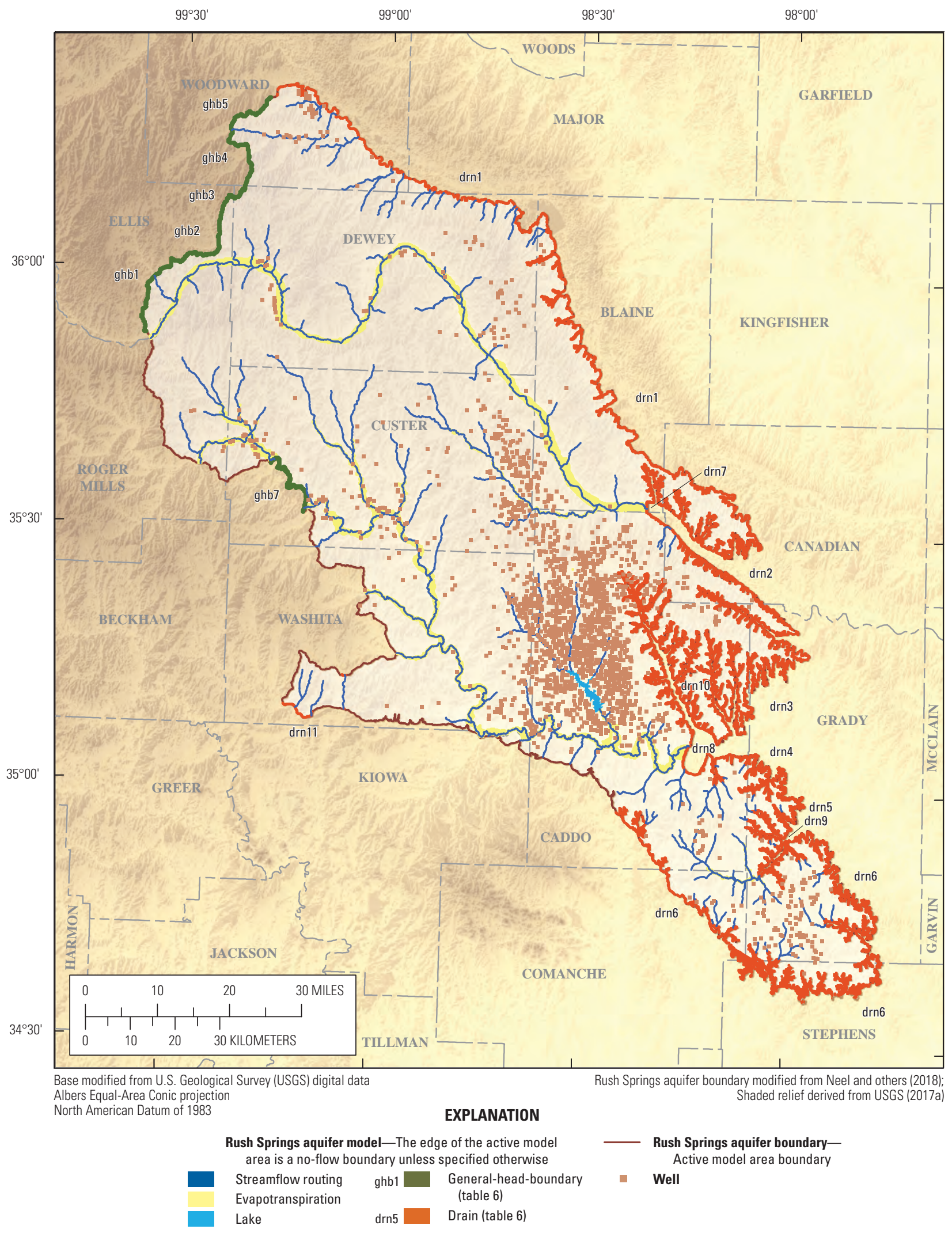

Figure 15. Active area, hydrologic boundaries, and selected parameter zones for the numerical groundwaterflow model of the Rush Springs aquifer, western Oklahoma. 


\section{Streams}

The major streams and associated tributaries in the study area (figs. 15-16) were simulated as a head-dependent boundary by using the Streamflow-Routing package, version 2 (SFR) (Niswonger and Prudic, 2005). SFR exchanges flow between the aquifer and the stream according to Darcy's Law (Darcy, 1856); stream seepage is the product of the streambed conductance and the difference between the groundwater level and the stream stage. The streambed conductance is the product of the hydraulic conductivity of the streambed sediments and the area of the stream channel divided by the streambed thickness. Stream stage is calculated by using Manning's Equation, in which stream stage is a function of flow based on the geometry of the stream channel. Where groundwater levels are lower than stream stage, inflow to the aquifer from the stream occurs (termed "seepage from streams”). Where groundwater levels are higher than stream stage, outflow from the aquifer to the stream occurs at a specified streambed conductance rate from the aquifer (termed "seepage to streams”).

Streamflows are calculated for each part of the stream, known as reaches, contained in a model cell until the end of a segment, or group of reaches with uniform or linear hydraulic properties, is reached during each time step. A stream-water balance computes the amount of water available in each stream reach and the amount of water exchanged between the stream and the aquifer in groundwater-model simulations. Calculation of flows repeats downstream in this manner until water is routed out of the model active area. Inflows $\left(Q_{\text {in }}\right)$ to each stream reach are calculated as

$$
\sum Q_{i n=} Q_{s p}+Q_{t r}+Q_{r o}+Q_{p r}-Q_{g w i}
$$

where

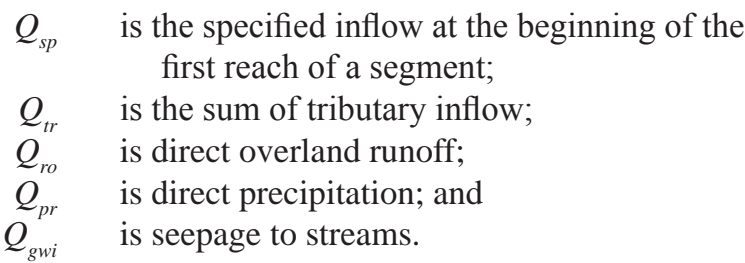

Specified inflows $\left(Q_{s p}\right)$ at the beginning of each stream reach include specified flows at the model boundary from the Canadian and Washita Rivers based on Ellis and others (2017) and flow at the Hammon streamgage (07324200; USGS, 2017 c), respectively. Additionally, specified inflows include releases from Fort Cobb and Foss Reservoirs (Reclamation, $2017 \mathrm{a}, \mathrm{b})$ to the first downstream segment. Tributary inflows $\left(Q_{t r}\right)$ are based on flow routed from upstream segments, which includes the small tributaries associated with the alluvium and terrace of the Canadian and Washita Rivers. A tributary inflow rate of $3 \mathrm{ft}^{3} / \mathrm{s}$ at the model boundary was included for five tributaries: Turkey, Boggy, Cavalry, Rainy Mountain, and Stinking Creeks (fig. 1). All other tributaries at the model boundary were either assumed to be intermittent or ephemeral, with no specified inflows. Tributaries originating in the model active area were assumed to drain the Rush Springs aquifer and were simulated primarily to route groundwater flow to the Canadian River or Washita River. The model is simulated under base-flow conditions; therefore, direct overland runoff $\left(\mathrm{Q}_{\mathrm{ro}}\right)$ and precipitation $\left(\mathrm{Q}_{\mathrm{pr}}\right)$ were not applied to the stream channel. Groundwater discharge from the aquifer simulated by using MODFLOW is a negative value; thus, the groundwater inflow $\left(Q_{\text {gwi }}\right)$ term is subtracted from the other inflow components. Outflows $\left(Q_{\text {out }}\right)$ from each stream reach are calculated as

$$
\sum Q_{o u t=} Q_{s t r}+Q_{d i v}+Q_{e t}+Q_{g w o}
$$

where

$\begin{array}{cl}Q_{\text {str }} & \text { is streamflow out of a reach; } \\ Q_{\text {div }} & \text { is specified diversions; } \\ Q_{\text {et }} & \text { is evapotranspiration; and } \\ Q_{\text {gwo }} & \text { is seepage from streams. }\end{array}$

Streamflow out of each reach $\left(Q_{s t r}\right)$ was routed downstream in all areas except for the stream segments directly above Foss and Fort Cobb Reservoirs, where streamflow was routed into these reservoirs, and stream segments located at the boundary of the model. During the model period, 12 of 30 permitted surface-water diversions had mean annual withdrawal rates $\left(Q_{\text {div }}\right)$ greater than 218 acre- $\mathrm{ft}\left(0.3 \mathrm{ft}^{3} / \mathrm{s}\right)$, and only those diversions were simulated in the model. Diversions can be simulated only from the last reach in any segment; thus, this location may differ somewhat from the actual diversion location. The discrepancies between the actual and simulated diversion locations were not substantial, however, and the diversion rates represented only a small percentage of flow in the SFR cells. Surface-water diversions located on intermittent or ephemeral streams were considered to be supplied from surface runoff and were not included. No evaporative processes $\left(Q_{\mathrm{et}}\right)$ were applied by using the SFR package, although ETg is simulated by using the Evapotranspiration package (Harbaugh, 2005) for alluvium cells that include stream segments.

The extent of the streams (fig. 16) was modified from the National Hydrography Dataset Plus (NHDPlus; Horizon Systems Corporation, 2015), a 1:100,000-scale geospatial dataset of surface-water features. Streams having a stream order (Strahler, 1952) of one-defined as headwater streams that are dominated by runoff-were excluded from the stream extent. Differences in stream channel location occurred between the DEM (USGS, 2017a) and the NHDPlus streamline because of the resampling of DEM cells and migration of the stream channel in the alluvial valleys over time. To ensure correct surface-water routing in the stream, the stream location was adjusted to ensure that the stream channel altitude decreased in a downstream direction in each segment. For segments where the streambed slope was zero, either the 


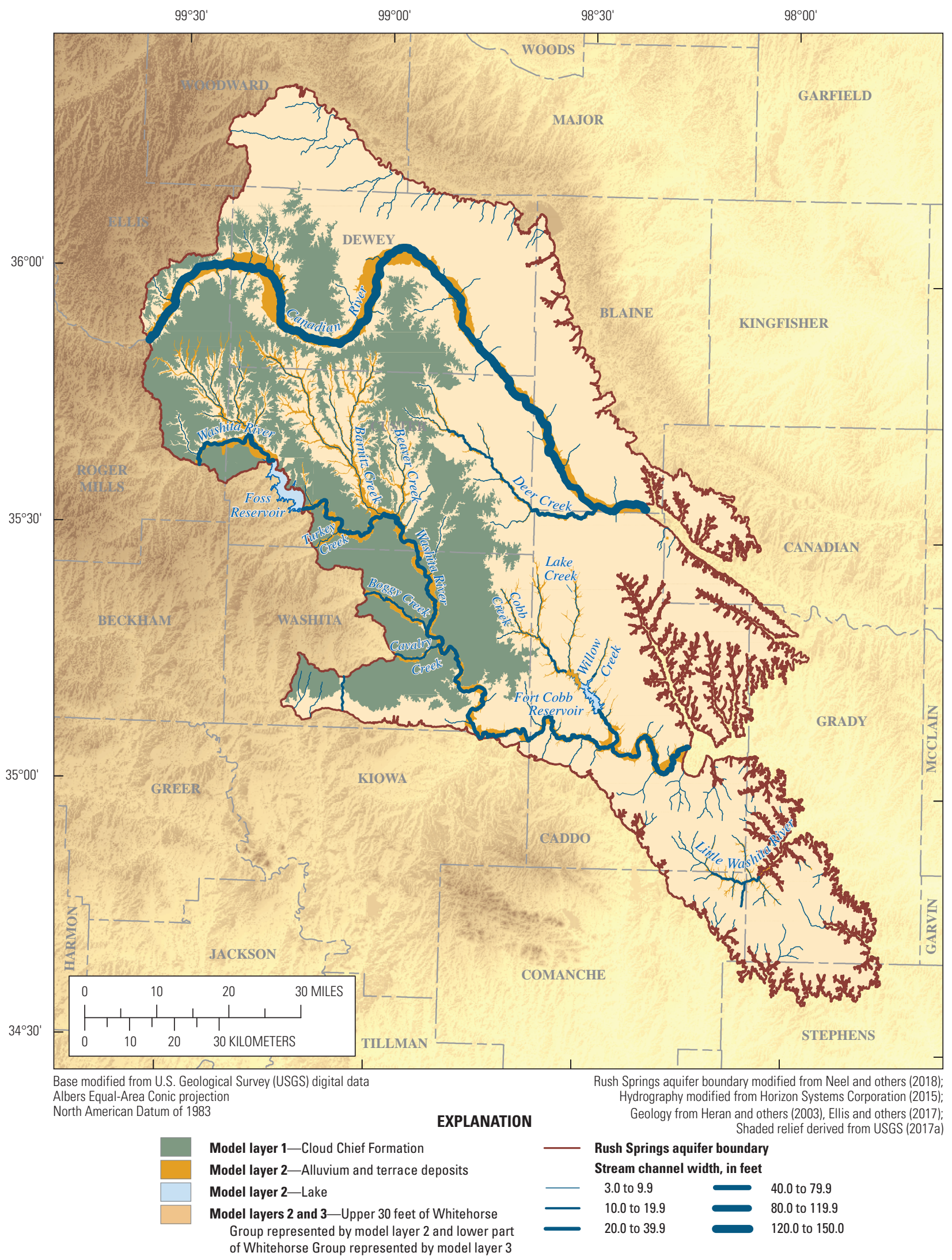

Figure 16. Streamflow-Routing package stream channel widths for the numerical groundwater-flow model of the Rush Springs aquifer, western Oklahoma. 
upstream altitude was slightly increased, or the downstream altitude was slightly decreased.

The SFR streambed thickness was set to $2 \mathrm{ft}$, and a rectangular channel was used to define the stream geometry in all segments of the model. The streambed altitude was derived from a 10-meter DEM, and stream segments were incised between 1 and $5 \mathrm{ft}$ in relation to the DEM altitude. Stream channel widths (fig. 16) were estimated from 2013 aerial photographs (Natural Resources Conservation Service, 2015) and ranged from 100 to $150 \mathrm{ft}$ for the Canadian River, from 21 to $55 \mathrm{ft}$ for the Washita River, and from 3 to $20 \mathrm{ft}$ for the tributaries (fig. 16). Although the streambed conductivity could be expected to vary based on location and discharge rates, the streambed conductivity was set at 5 feet per day (ft/d) based on Ellis and others (2017). Out of 167 stream segments, 164 were assigned to layer 2 of the model; the remaining 3 segments were assigned to layer 1 of the model.

\section{Reservoir}

Fort Cobb Reservoir was simulated as a head-dependent boundary by using the Lake package (Merritt and Konikow, 2000; Niswonger and Prudic, 2005). Lake package cells exchange water with adjacent and underlying active model cells based on the lakebed leakance and simulated groundwater levels for both the reservoir and surrounding active model cells. The Lake package computes a water budget independent of MODFLOW during each time step for the simulated lake, described as

$$
h_{l}^{n}=h_{l}^{n-1}+\Delta t \frac{p-e+r n f-w-s p+Q_{s i}-Q_{s o}}{A_{s}}
$$

where

$$
\begin{aligned}
h_{l}^{n}=h_{l}^{n-1} & \text { are lake (reservoir) stage from the current and } \\
\Delta \mathrm{t} & \text { is the time step length; } \\
\mathrm{p} & \text { is the rate of precipitation applied to the lake; } \\
\mathrm{e} & \text { is the rate of evaporation from the lake; } \\
\mathrm{rnf} & \text { is the rate of surface runoff to the lake; } \\
\mathrm{W} & \text { is the rate of water withdrawals from the lake; } \\
\mathrm{sp} & \text { is the net rate of lakebed seepage between the } \\
Q_{s i} & \text { is the rate of stream inflow to the lake; } \\
Q_{s o} & \text { is the rate of stream outflow from the lake; } \\
\mathrm{A}_{\mathrm{s}} & \text { is the surface area of the lake. }
\end{aligned}
$$

Fort Cobb Reservoir bathymetry and stage-storage relation data (fig. 17) were digitized from a 2007 sedimentation survey (FTN Associates, 2009) and were used by the Lake package to determine reservoir volume and area for a given stage. Only minor differences between the volume and area relation from the sedimentation study and the relation used in the Lake package occurred; thus, the simulated curves are not shown in figure 17. Because layer 1 is inactive where Fort Cobb Reservoir is simulated, that reservoir was simulated by using 697 cells in layer 2; those cells exchange water laterally with other cells in layer 2 and vertically with cells in layer 3 that are directly under the lakebed (fig. 18). These 697 cells correspond to a surface area of 4,000 acres $\left(A_{s}\right)$, which is slightly larger than the active conservation pool surface area of 3,779 acres (Reclamation, 2017a) due to discretization caused by using square cells. The rate of lakebed leakance (sp) — or the quotient of the hydraulic conductivity and thickness between the aquifer and lake-was set at 0.5 day $^{-1}$. This leakance rate governs the lakebed seepage between the aquifer and simulated reservoir.

The rates of precipitation (p), evaporation (e), and withdrawals (w; which include permitted use and floodcontrol releases) during the model period were obtained from Reclamation (2017a). The mean annual precipitation to Fort Cobb Reservoir for the model period was $31.3 \mathrm{in} / \mathrm{yr}$, estimated at Reclamation weather stations in the reservoir area. The mean annual precipitation, when applied over the area of the Lake package cells, was about 10,430 acre-ft/ yr. The mean annual evaporation for the model period was $69.4 \mathrm{in} / \mathrm{yr}$, measured at an evaporation pan (Reclamation, 2017a). The mean annual evaporation, when applied over the area of the Lake package cells, was about 23,130 acre-ft/yr. Mean annual withdrawals (w) during the model period totaled 36,562 acre-ft/yr (Reclamation, 2017a), including permitted use of 10,765 acre-ft/yr and releases of 25,797 acre-ft/yr. Fort Cobb Reservoir flood-control releases were estimated by using data from Reclamation (2017a). Some estimated releases were greater than the flow recorded at Cobb Creek below Fort Cobb Reservoir (07326000) (fig. 1; table 1) about 2 miles downstream from the reservoir; thus, the reported releases were reduced to the flow recorded at this gage during these months. Releases from Fort Cobb Reservoir may occur when the reservoir stage is at the top of the active conservation pool (1,342 ft above the National Geodetic Vertical Datum of 1929 [NGVD 29]).

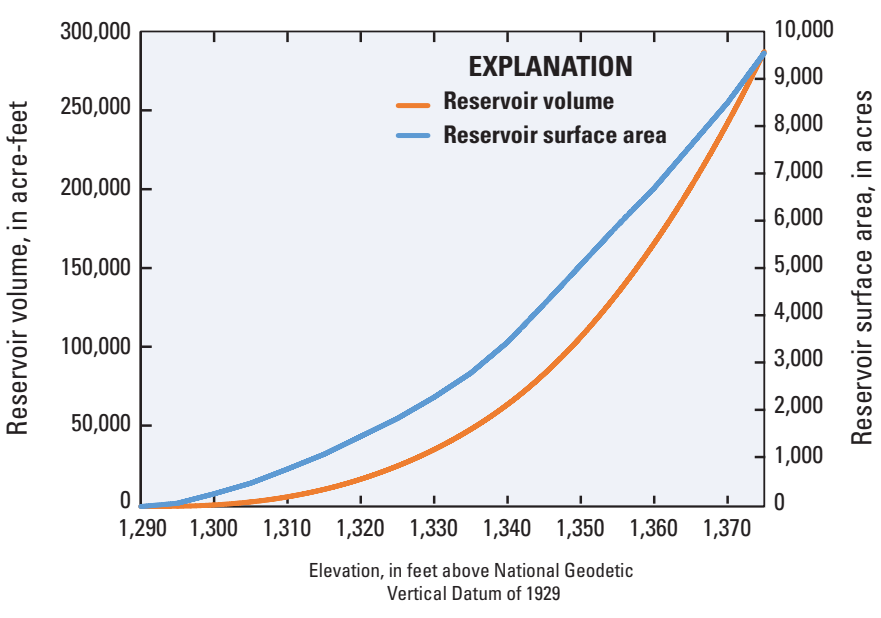

Figure 17. Fort Cobb Reservoir volume, surface area, and stage relationship. 


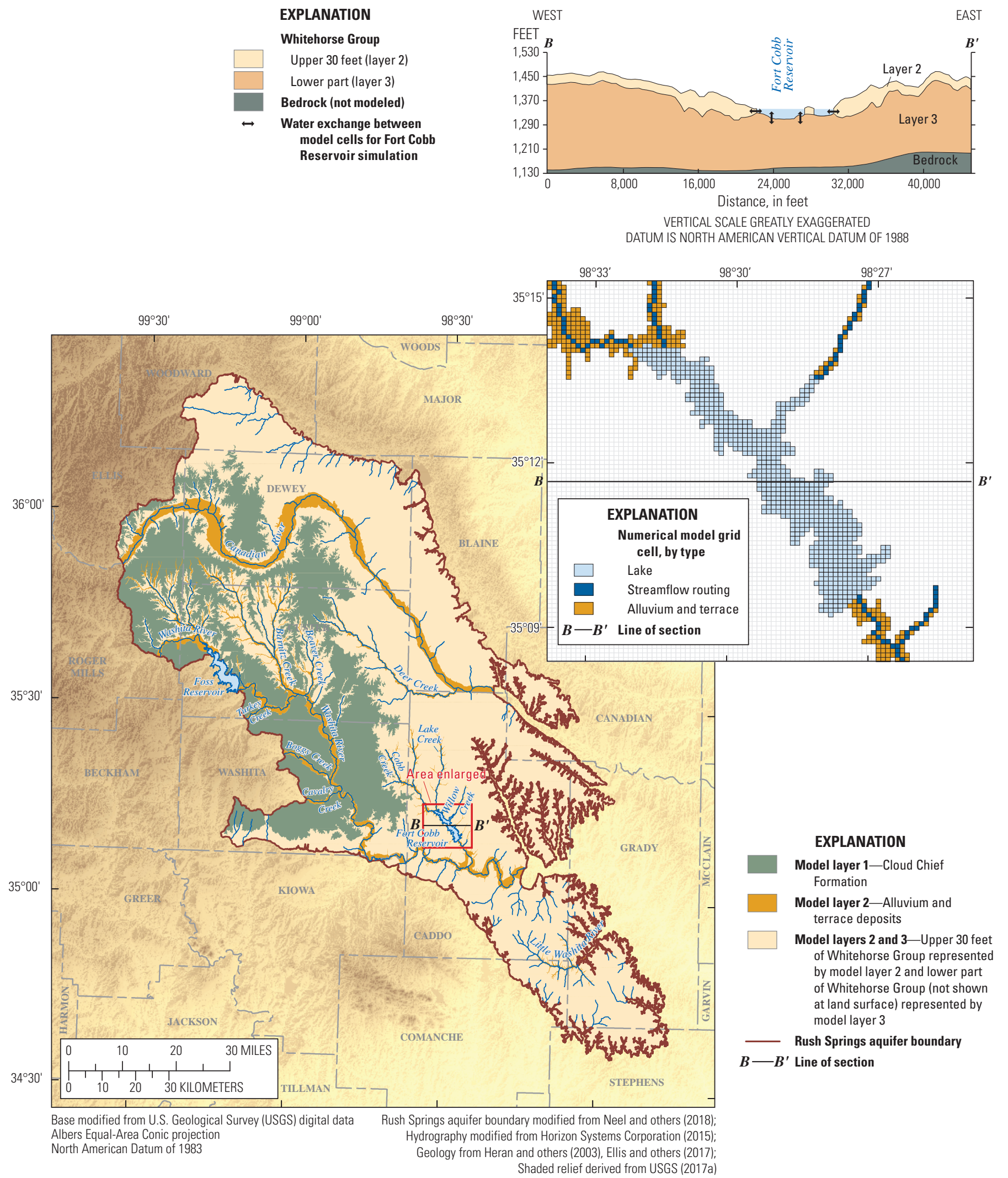

Figure 18. Lake package cross-section and discretization for the Rush Springs aquifer, western Oklahoma. 
Surface runoff (rnf) was estimated at 26,895 acre-ft/yr and includes BFI-estimated runoff and overland flows entering Fort Cobb Reservoir that were not captured by BFI. The BFI-estimated runoff was calculated by using streamflow data from the Cobb (07325800), Lake (07325850), and Willow (07325860) Creek streamgages (fig. 1, table 1). Streamflow data were only available for 1969-78 and 2005-15 at the Lake Creek (07325850) and Willow Creek (07325860) streamgages (table 2); thus, the runoff components at these gages for 1979-2004 were calculated by using ratios of streamflow between Cobb Creek (07325800) and these streamgages. Mean recharge during the model period was 43 percent greater that mean recharge during years when streamgage data were available (1969-78, 2005-15). Therefore, the runoff components from these streamgages during the 1979-2004 period were adjusted upwards by 43 percent. Mean annual BFI-estimated runoff for Fort Cobb Reservoir during the model period was estimated at 17,930 acre-ft/yr. Overland flows from the topographically higher land area adjacent to the reservoir was initially set at 50 percent of the BFI-estimated runoff.

Stream inflows $\left(\mathrm{Q}_{s i}\right)$ to Fort Cobb Reservoir occurred from SFR stream segments representing Cobb, Lake, and Willow Creeks. Mean annual surface-water inflows during the model period were estimated at 15,337 acre-ft between 1979 and 2004. Because the reservoir is managed, releases are passed to stream segments downstream from the reservoir; therefore, the stream outflow term $\left(\mathrm{Q}_{s o}\right)$ is zero.

\section{Saturated-Zone Evapotranspiration}

ETg was simulated as a head-dependent boundary by using the Evapotranspiration package (Harbaugh, 2005). In this package, ETg decreases linearly with decreases in the simulated groundwater level, and no ETg occurs when the simulated groundwater level is below a user-specified rootzone depth. The root-zone depth for the groundwater model was set equal to the SWB root-zone depth for each land-cover type. ETg was not expected to occur from the bedrock because depths to groundwater in the bedrock commonly exceed $30 \mathrm{ft}$; therefore, the Evapotranspiration package (fig. 15) was limited to the ETg area defined by wetlands (U.S. Fish and Wildlife Service, 2017), which are included in the layer 2 alluvium and terrace (fig. 13).

\section{Groundwater Use}

Well withdrawals were simulated as a specified-flux boundary by using the Well package (Harbaugh, 2005). Annual reported groundwater use for each permit was split equally among all the wells attached to a permit (fig. 10) (OWRB, 2017). These annual well withdrawals were then distributed into monthly well withdrawals by using monthly demand distributions (fig. 19) for Basin 19 in the Oklahoma Comprehensive Water Plan (OWRB, 2012). Annual irrigation well withdrawals were multiplied by the monthly irrigation demand (as a percentage of annual groundwater use), and annual public-supply well withdrawals were multiplied by the monthly public-supply demand. Annual well withdrawals for other purposes were distributed evenly to all months of the year. Domestic withdrawals, which are not regulated or reported by the OWRB, were not simulated; these withdrawals were expected to be a minor component of total withdrawals.

Groups of wells attached to a single permit were not allowed to exceed the permitted annual withdrawal amount. Reported annual well withdrawals for 70 irrigation wells (4 percent of all simulated wells) were greater than $807 \mathrm{acre}-\mathrm{ft} / \mathrm{yr}$ (500 gal/min) and were reduced to this value to avoid the simulation of unrealistic pumping rates. Steady-state well withdrawals were determined as the mean of withdrawals during the model period.

\section{Model Calibration}

Model calibration is the process of adjusting initial model input values to improve the fit between model-simulated data and observed or estimated data (calibration targets). During model calibration, the inputs to be adjusted are updated to new values that reduce the discrepancy, or residual, between the observed and simulated data. Calibration outcomes were evaluated based on the reduction of this residual and

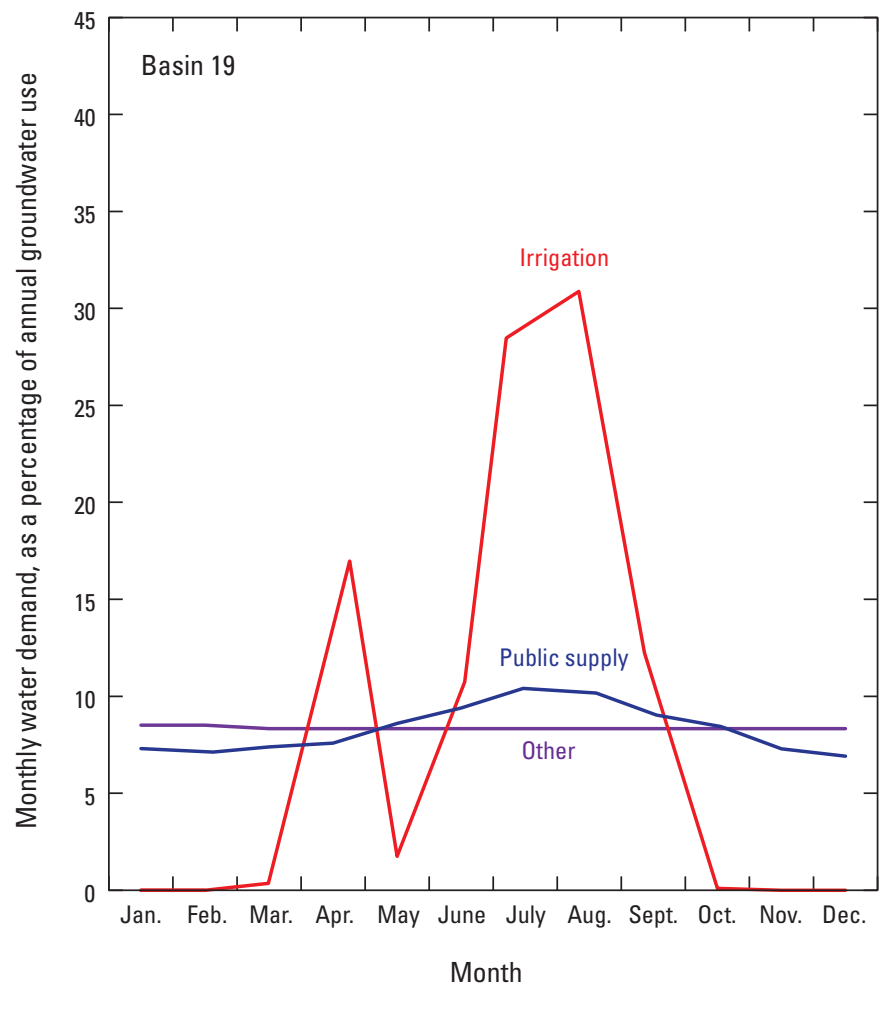

Modified from Oklahoma Water Resources Board (2012)

Figure 19. Monthly water demand by groundwater-use type for the Rush Springs aquifer, western Oklahoma. 
the fit of the calibrated groundwater-model water-budget components to those components of the conceptual water budget. The calibration process for the Rush Springs aquifer model included (1) manual adjustment of model inputs by trial and error, followed by (2) automated adjustment of model inputs (parameters) by using a combination of the nonlinear regression codes PEST (Doherty, 2010) and PEST++ (Welter and others, 2015). The PEST code uses the Gauss-MarquardtLevenberg algorithm to adjust user-specified parameters to minimize a sum of squared weighted residuals, or objective function (table 5). The objective function $(\Phi)$ is expressed as

$$
\Phi=\sum_{i=1}^{n}\left[\omega_{i}\left(s_{i}-o_{i}\right)\right]^{2}
$$

where

$$
\begin{aligned}
n & \text { is the number of observations, } \\
\omega_{i} & \text { is the observation weight, } \\
s_{i} & \text { is the simulated value, and } \\
0_{i} & \text { is the observed or estimated value. }
\end{aligned}
$$

PEST automates calibration by running the model as many times as needed to determine the best parameter values while automatically updating the parameter values during each step of the process. This iterative approach allows for the optimal values of many parameters to be estimated together with greater speed than that of a traditional manual calibration approach. Prior to automated calibration, the calibration targets were weighted to account for error in each type of observation.

The automated calibration approach concurrently applied subspace regularization techniques by using singular value decomposition (SVD; Tonkin and Doherty, 2005) in conjunction with singular value decomposition-assist (SVDA; Tonkin and Doherty, 2005) to reduce automated calibration run time and ensure calibration stability. SVD was implemented with PEST to identify combinations of parameters that are most responsive to the dataset, thus separating parameters that may be useful for calibration from those parameters that are actually useful and have an effect on modeled outputs. To decrease the run time associated with a large number of parameters, SVDA was also implemented

Table 5. Components of the objective function for the automated calibration of the numerical groundwater-flow model of the Rush Springs aquifer, western Oklahoma, 1979-2015. Note: components may not sum to totals because of rounding.

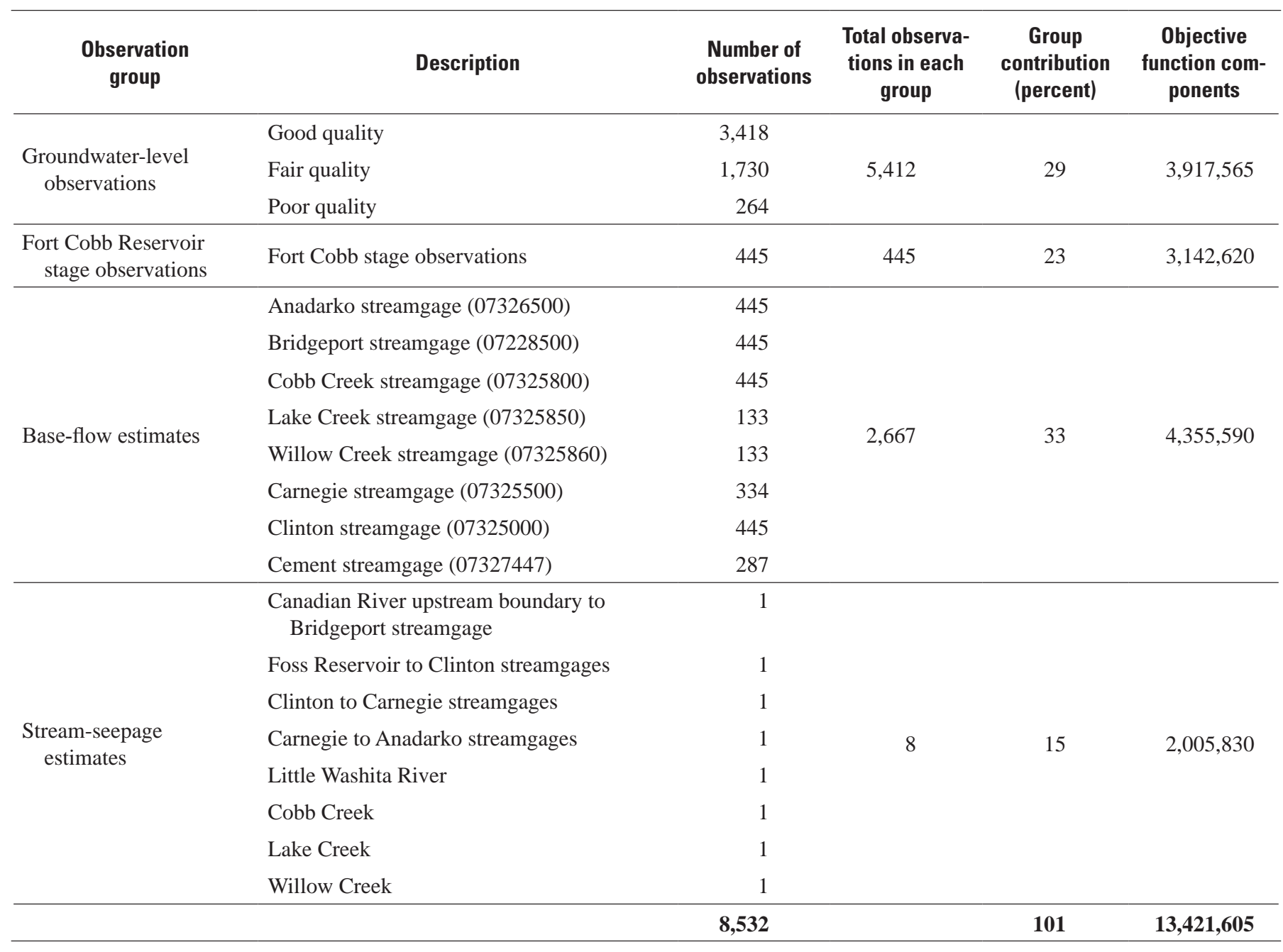


with PEST. SVDA computes a user-specified combination of parameters, or "super parameters," that enables a reduction in the number of parameters used during calibration. PEST requires that the model be run one or two times for either each adjustable parameter or super parameter used in the calibration process multiplied by typically five to seven parameter optimization iterations. Thus, the reduction in the number of parameters by using super parameters resulted in significant time savings during the Rush Springs model calibration. To further reduce the run time associated with the calibration process, model runs were performed in parallel on a highperformance computing cluster using the HTCondor run management software (Condor Team, 2012).

\section{Calibration Parameters}

For the Rush Springs aquifer model, 9 parameter groups representing 842 parameters were defined for the automated calibration (table 6, at end of report). These parameter groups are GHB conductance, drain conductance, recharge rate multipliers, ETg rate and ETg root-zone depth multipliers (1 group), streambed conductance, lakebed leakance, Sy, specific storage (Ss), and horizontal hydraulic conductivity (Kh) and vertical anisotropy pilot points (1 group). The Kh, vertical anisotropy, and Sy values in layer 1 (Cloud Chief Formation, fig. 13) were obtained from Neel and others (2018) and were not adjusted during automated calibration.

The GHB and drain cells were grouped into parameter zones for the adjustment of conductance values. The 6 GHB and 11 drain parameter zones (fig. 15) were created to account for variations in hydraulic properties of bedrock units adjacent to the Rush Springs aquifer. Recharge from the SWB code was divided into zones (fig. 20) based on hydrologic soil group and available water capacity data used as an input to the SWB code. Recharge rate multiplier parameters were applied uniformly across each stress period to adjust recharge for each of these zones. The ETg multiplier parameters were adjusted in the same manner during manual calibration, with zones created for the alluvium and terrace of the Canadian, Washita, and Little Washita Rivers. During automated calibration, entire-array multiplier parameters were used to adjust the ETg rate and ETg root-zone depth uniformly in each transient stress period. A single streambed conductivity parameter was set for all stream segments. A single lakebed leakance parameter was adjusted within a range of values that improved model stability of the reservoir while reducing the stage residual. The initial Sy for pilot points in the layer 2 (Canadian River) alluvium and terrace used values obtained from Ellis and others (2017), which ranged from 0.06 to 0.32 . A Sy value of 0.12 was set for the alluvium and terrace of the Washita River and other model-area tributaries where no storage information was available. The initial Sy for pilot points in layer 3 used values from the lithologic-log analysis from Neel and others (2018) and ranged from 0.03 to 0.23 . The Ss for all three layers was set as a static value of $1 \times 10^{-5}$, which was comparable to values used by Ryter and Correll (2016) and Ellis and others (2017) for Permian bedrock units in Oklahoma.

Kh and vertical anisotropy, or the ratio of horizontalto-vertical hydraulic conductivity, were represented by using pilot point interpolation in the groundwater model in layers 2 and 3 (fig. 21). Pilot points provide a balance between the manipulation of values by parameter zones, often defined where values are thought to be relatively constant, and the manipulation of values in individual model cells, which may require more detailed data than are typically available. Exponentially weighted kriging was used to interpolate the Kh and vertical anisotropy value at each pilot point in each geologic unit of layers 2 and 3. Kh and vertical anisotropy were interpolated independently.

Pilot points representing the alluvium in layer 2 were spaced at 7,500-ft intervals, and pilot points representing the bedrock in layers 2 and 3 were spaced at 25,000-ft intervals. Because the division of the Whitehorse Group into layers 2 and 3 was arbitrary and not based on a geologic contact or change in hydraulic parameters, the pilot point $\mathrm{Kh}$ and vertical anisotropy values representing the Whitehorse Group in layer 2 were tied to the respective pilot points in layer 3 directly underneath.

An initial Kh value of $45 \mathrm{ft} / \mathrm{d}$ was set for pilot points in layer 2 representing the alluvium and terrace of the Canadian and Washita Rivers, and a value of $30 \mathrm{ft} / \mathrm{d}$ was set for the alluvium of the model-area tributaries. This $45-\mathrm{ft} / \mathrm{d}$ value is the calibrated mean $\mathrm{Kh}$ of the Canadian River alluvium and terrace from the Ellis and others (2017) Reach I model. Although literature describing the Kh of the Washita River alluvium and terrace inside the model active area is limited, this alluvium and terrace was assumed to be lithologically similar to the Canadian River alluvium and terrace; thus, the same initial Kh values were applied. An initial Kh of $6.3 \mathrm{ft} / \mathrm{d}$ was set for the pilot points in layers 2 and 3 representing the Whitehorse Group. This mean value was calculated from the lithologic-log analysis from Neel and others (2018) and was applied to the larger aquifer extent from this report. The minimum and maximum $\mathrm{Kh}$ for all pilot points were set at $6 \times 10^{-4}$ and $90 \mathrm{ft} / \mathrm{d}$, respectively. The value of $6 \times 10^{-4} \mathrm{ft} / \mathrm{d}$ represents the mean of siltstone and claystone values from Morris and Johnson (1967). The maximum Kh of $90 \mathrm{ft} / \mathrm{d}$ was modified from the fine-gravel $\mathrm{Kh}$ value $(100 \mathrm{ft} / \mathrm{d})$ used in Ellis and others (2017). Pilot point vertical anisotropy values for the interpolation zones in both layers were set to an initial value of 10, indicating a horizontal-to-vertical Kh ratio of 10:1. 


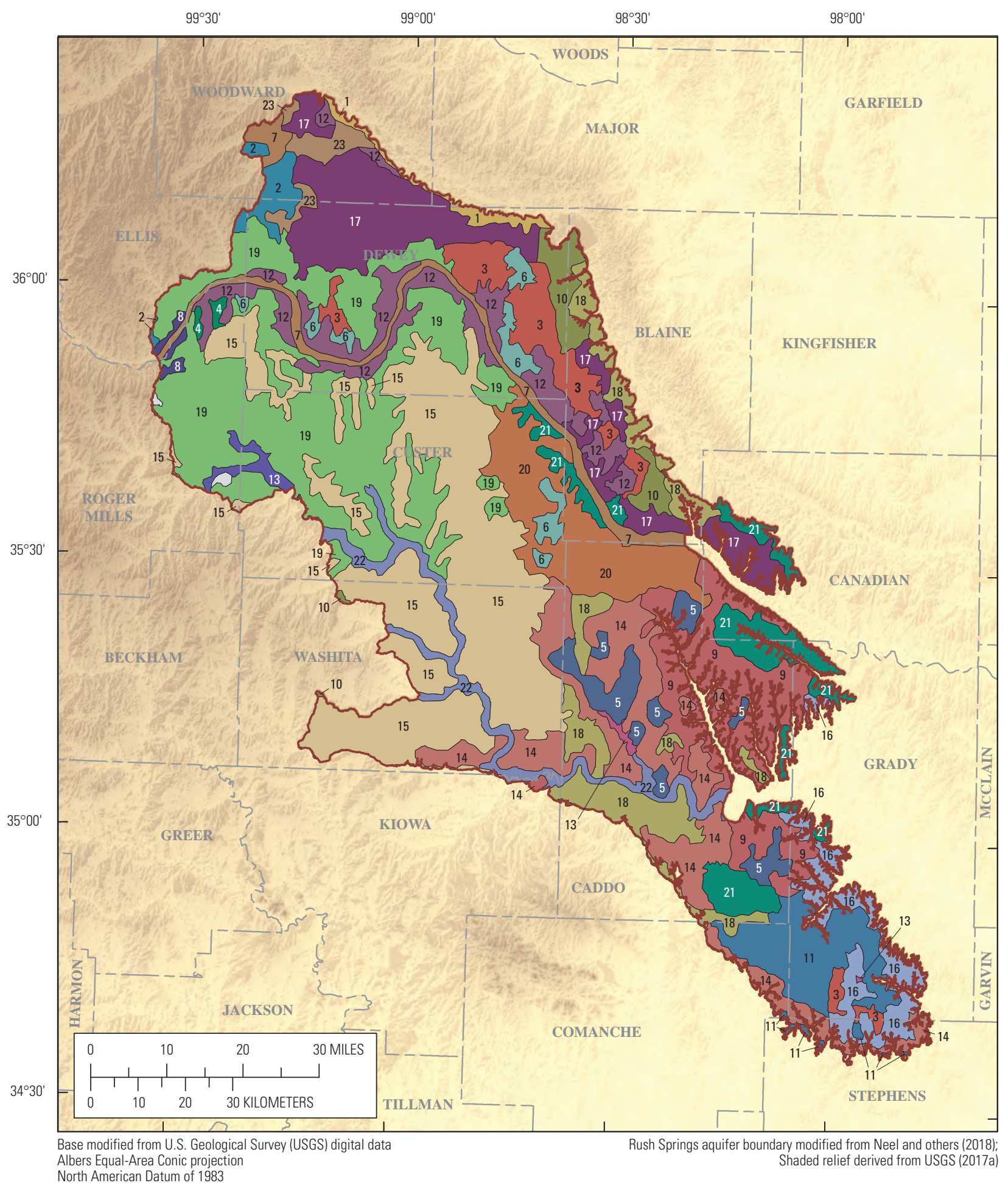

EXPLANATION

Recharge zone area and recharge

multiplier zone number (table 6)

No parameter zone

Rush Springs aquifer boundary

Figure 20. Spatial distribution of recharge zones for the Rush Springs aquifer model, western Oklahoma, 1979-2015. 


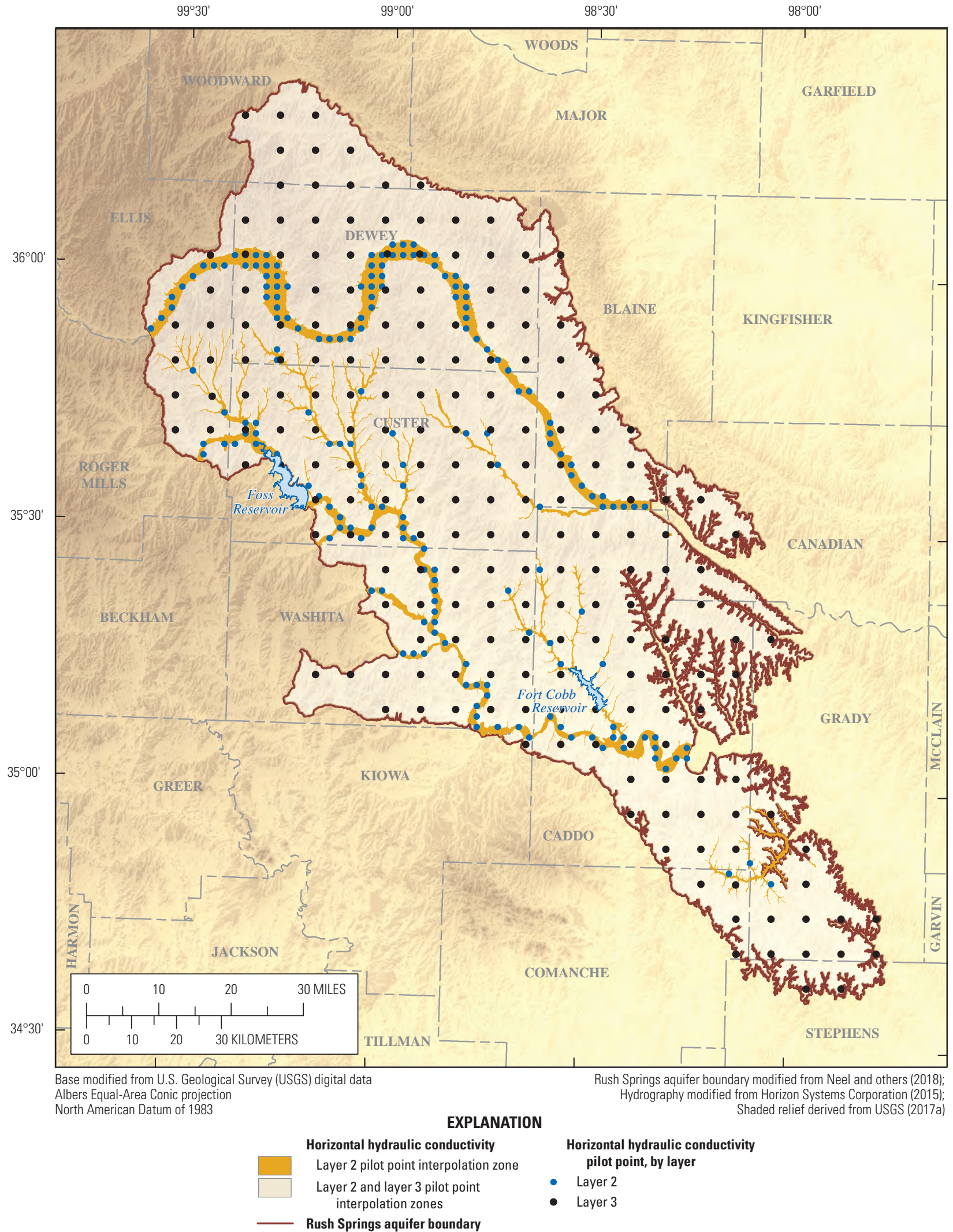

Figure 21. Spatial distribution of pilot points for the Rush Springs aquifer model, western Oklahoma, 1979-2015. 


\section{Calibration Targets}

Calibration targets for the Rush Springs aquifer model included groundwater-level (OWRB, 2017; USGS, 2017c) and reservoir-stage (Reclamation, 2017a) observations, as well as base-flow (table 2) and stream-seepage estimates. For the automated calibration, these targets were weighted and placed into observation groups of the same name (table 5, fig. 22). Groundwater levels at the 25 springs identified from Mashburn and Smith (2014) were also used as calibration targets in the initial stages of model calibration. Because these springs are expected to be perennial and flow as much as $1 \mathrm{ft}^{3} / \mathrm{s}$, the groundwater levels in cells representing these springs were set at land surface. Seepage from these springs was assessed by using the Drain Observation package (Harbaugh, 2005).

\section{Groundwater-Level Observations}

The groundwater model was calibrated to 5,412 groundwaterlevel observations (table 5) at 508 wells in the study area (table 7, at end of report); this total included 505 groundwaterlevel observations for the steady-state simulation and 4,907 groundwater-level observations (table 7) for the transient simulation. A total of 5,301 groundwater-level observations at 481 wells were completed in layer 3 , and the remaining 111 groundwater-level observations at 27 wells were completed in the alluvium and terrace in layer 2 (fig. 23). Although most wells have less than 4 observations during the model period (fig. 24), wells with more than 20 observations were distributed across the model active area (fig. 25). Few groundwater-level observations were available in the part of the Whitehorse Group confined by the Cloud Chief Formation (fig. 25); thus, the groundwater model has a greater uncertainty in this area.
A median of 84 groundwater-level observations per year were available for the model period, but 53 percent of all observations occurred in the first 12 years of the model period (fig. 26A). Therefore, a bias toward the 1979-90 period was incurred during the model calibration. About 58 percent of the observations were measured between January and March of each year (fig. 26B); thus, most observations were minimally affected by local well withdrawals for irrigation that typically occur between March and September (fig. 19).

When available, screened-interval data were analyzed to ensure that observation wells were completed in the Rush Springs aquifer. All groundwater-level observations were originally collected as depth-to-water measurements; groundwater altitudes were calculated by subtracting the measured depth to water from the land-surface altitude specified in the NWIS (USGS, 2017a) or OWRB (2017) databases. The land-surface altitude specified in the NWIS database was compared to the altitude obtained from a DEM, and observations with large land-surface altitude discrepancies were discarded.

\section{Fort Cobb Reservoir Stage Observations}

The groundwater model was calibrated to 445 Fort Cobb Reservoir stage observations (table 5), which included 444 monthly stage observations (Reclamation, 2017a) and 1 steady-state (averaged) stage observation. At active conservation pool stage (1,342 ft above NGVD 29), Fort Cobb Reservoir storage was about 71,696 acre-ft; at dead-pool stage (1,300 ft above NGVD 29), storage was about 1,015 acre-ft. Because the dead-pool storage was relatively small, it was not removed from estimates of Fort Cobb Reservoir storage used in this report. 


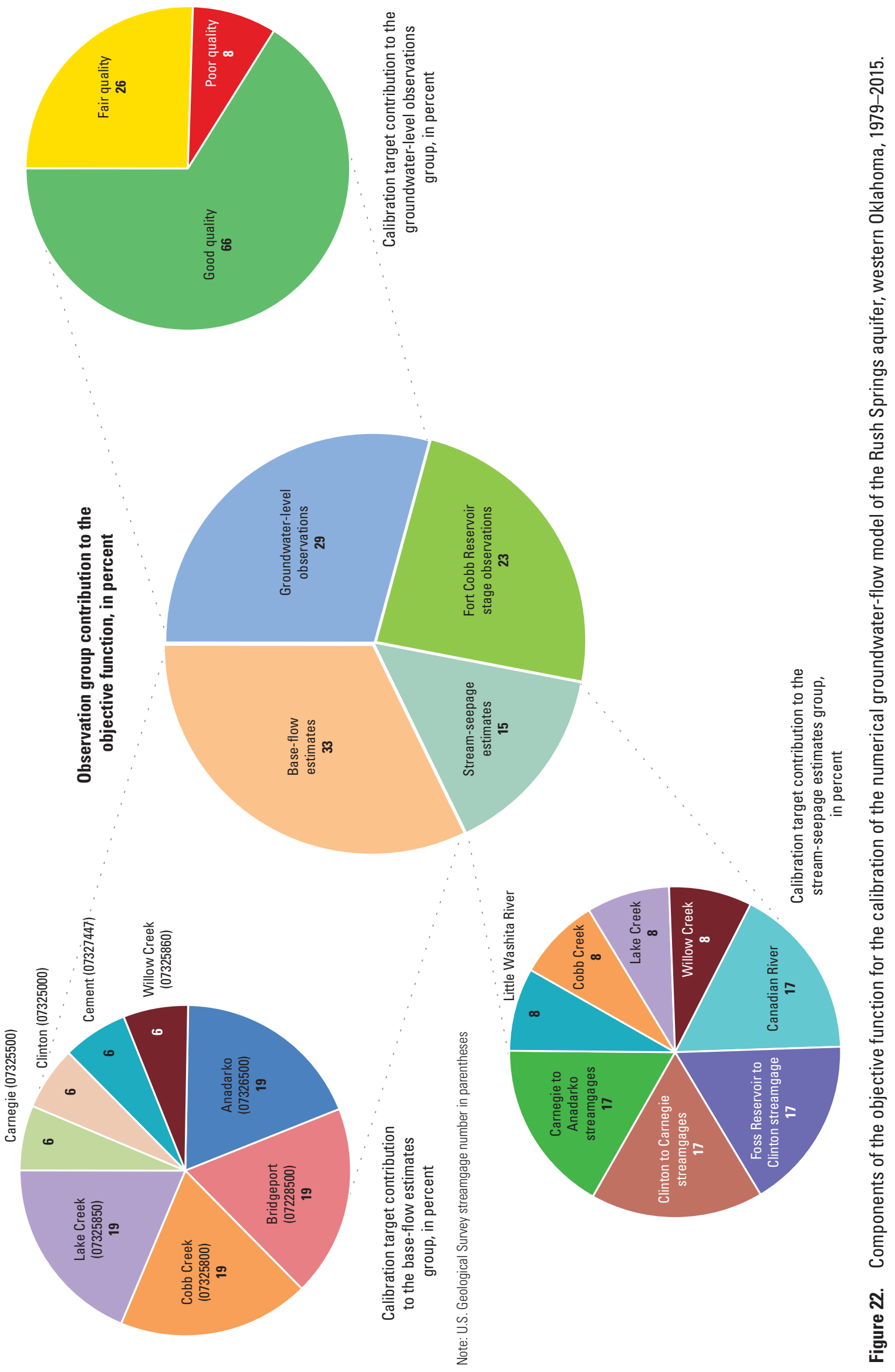




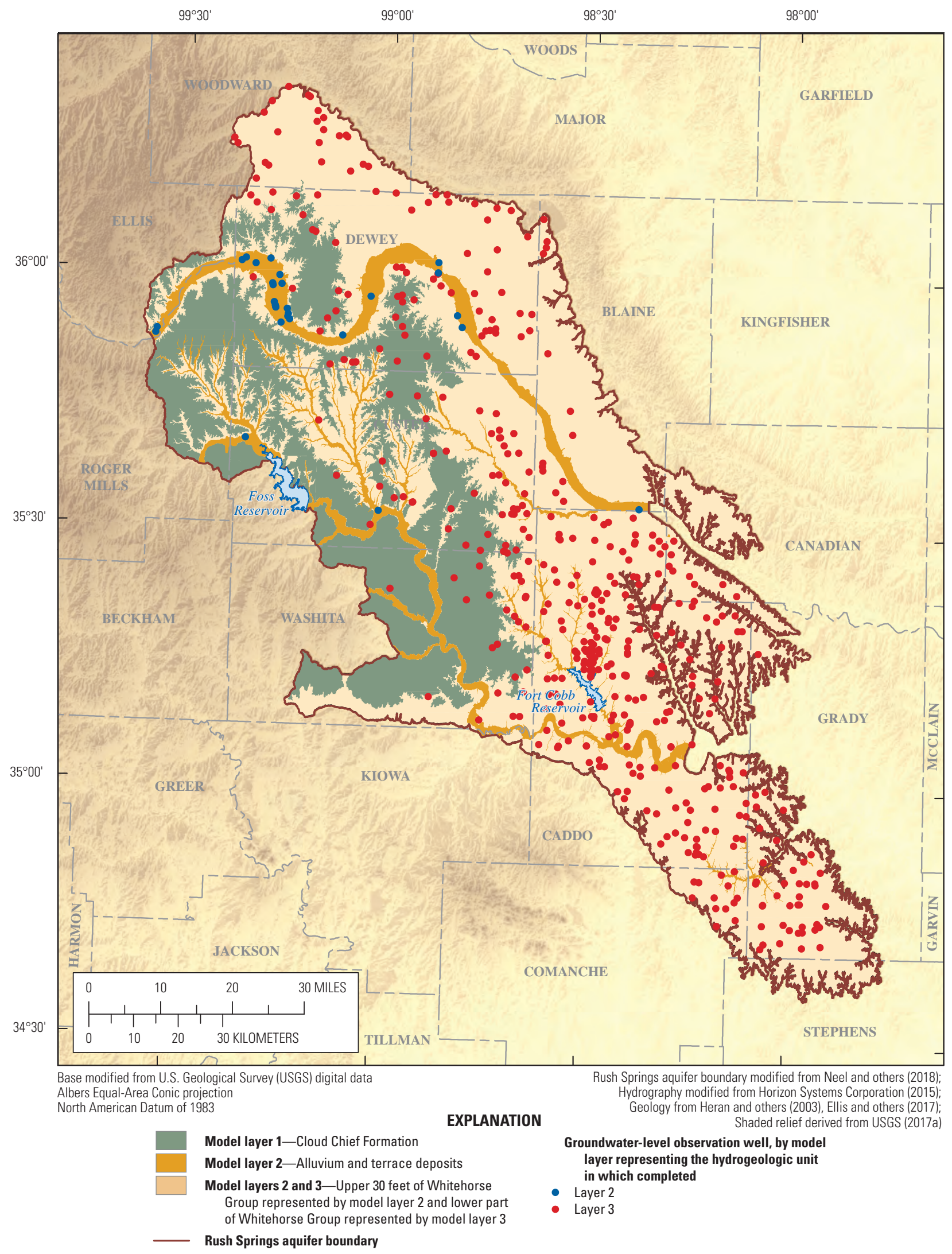

Figure 23. Spatial distribution of groundwater-level observations in layers 1 and 2 for the Rush Springs aquifer model, western Oklahoma. 


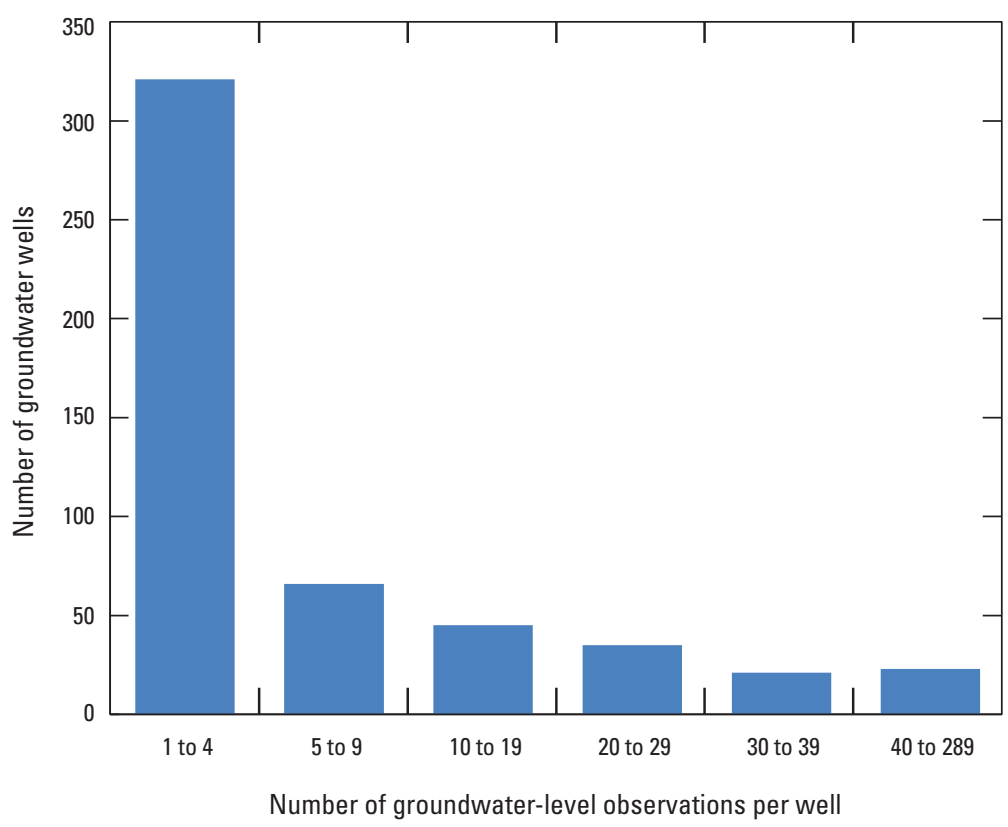

Figure 24. Number of groundwater-level observations for each well for the Rush Springs aquifer model, western Oklahoma, 1979-2015. 


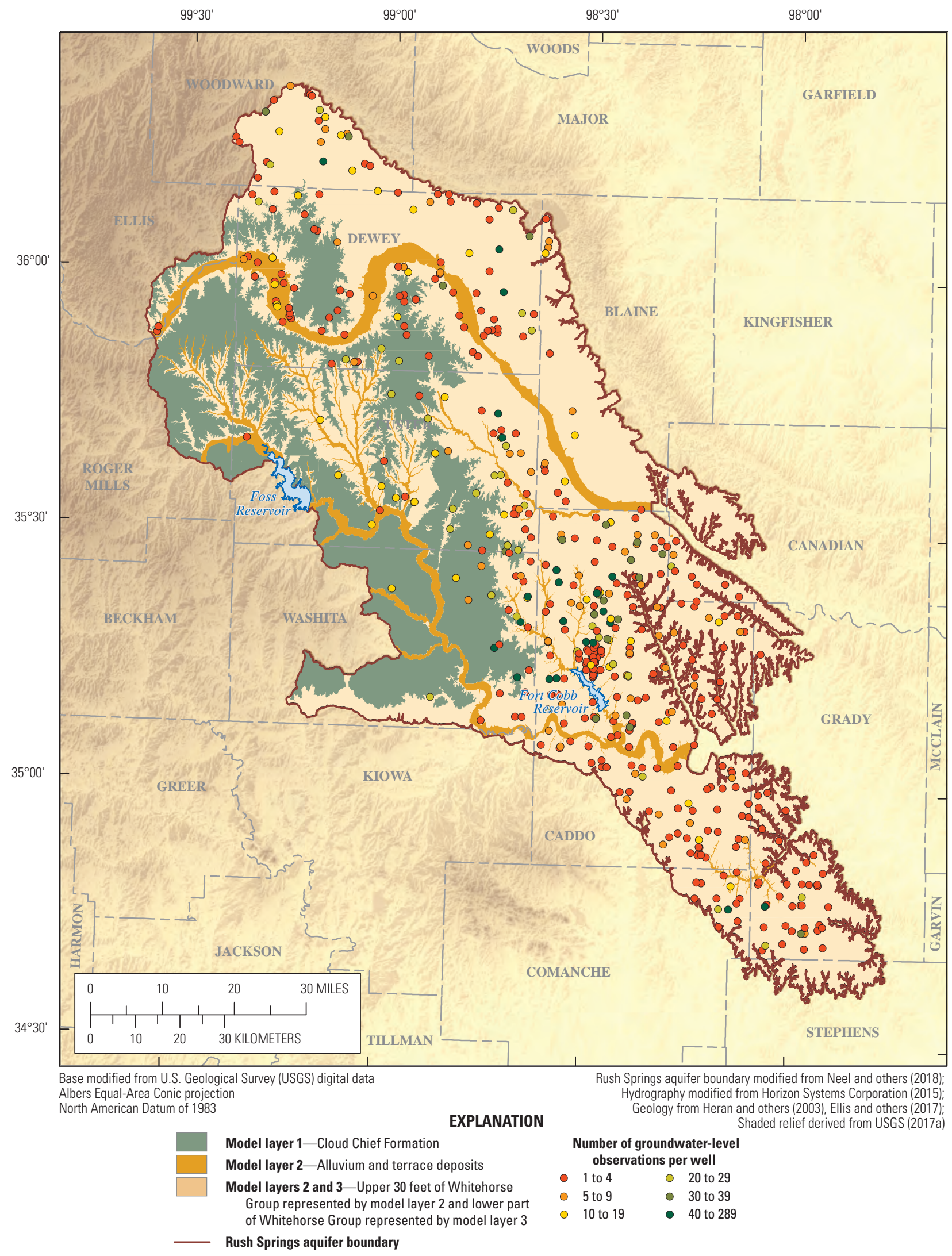

Figure 25. Spatial distribution of groundwater-level observations per well for the Rush Springs aquifer model, western Oklahoma, 1979-2015. 
A.

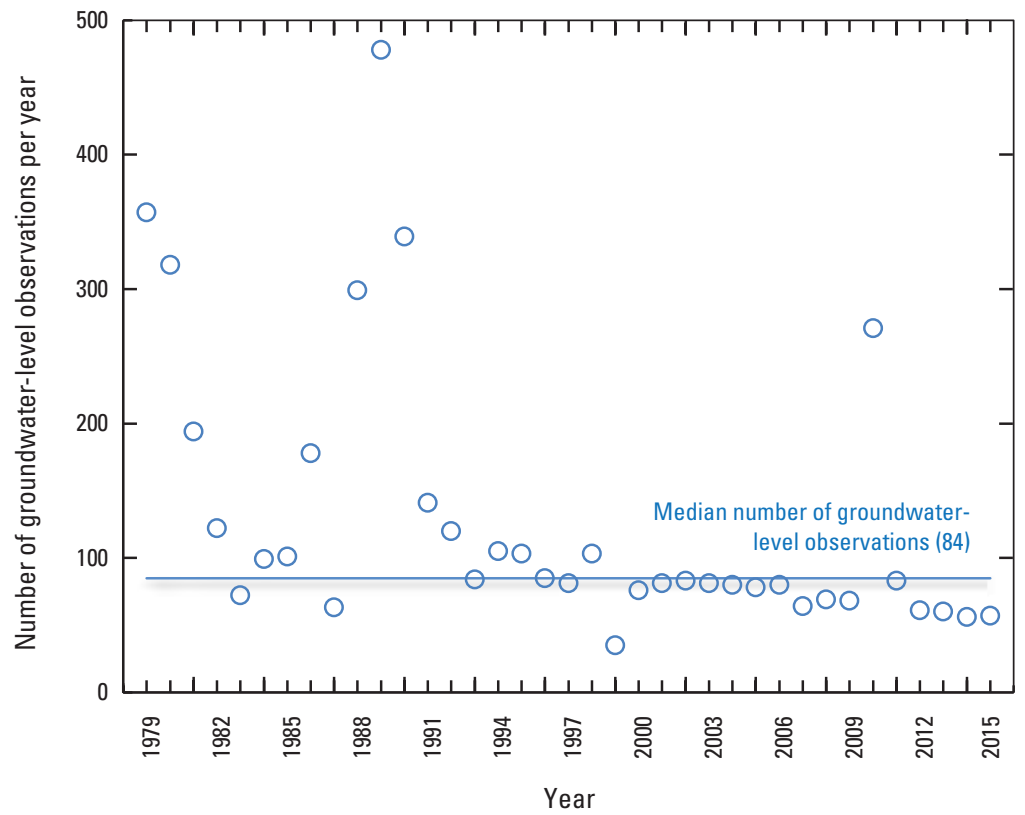

B.

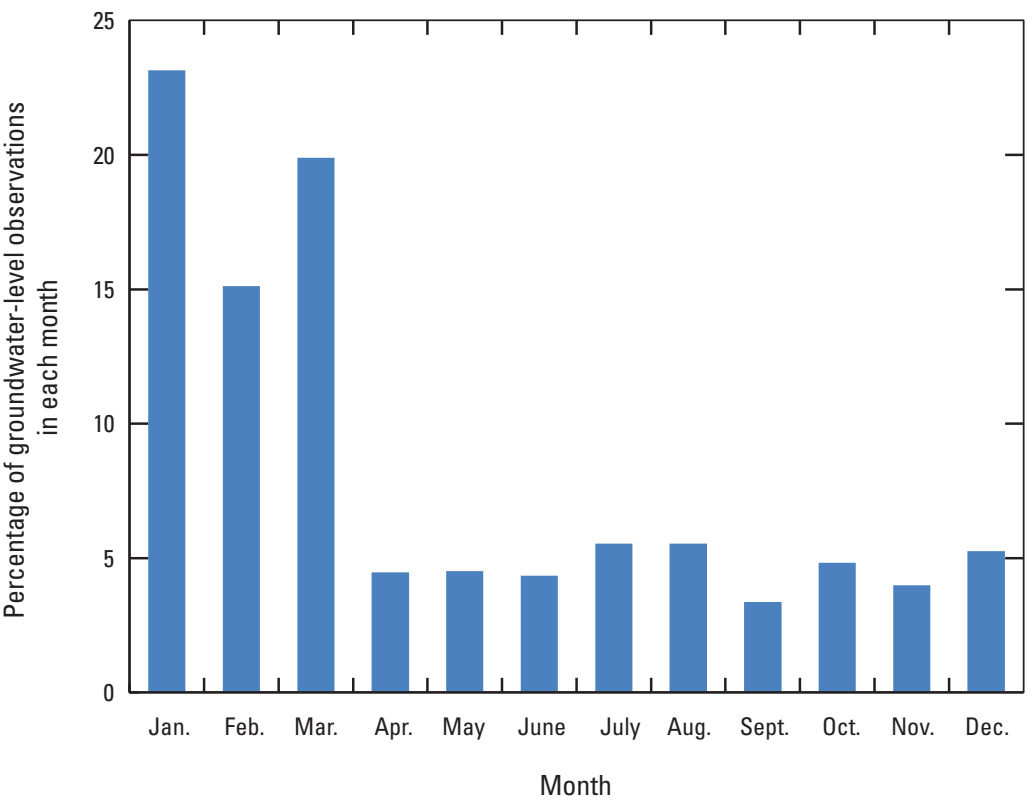

Figure 26. $A$, Annual and $B$, monthly distribution of groundwaterlevel observations for the Rush Springs aquifer model, western Oklahoma, 1979-2015.

\section{Base-Flow and Stream-Seepage Estimates}

The groundwater model was manually calibrated to base-flow estimates at 9 streamgages but the automated calibration used 2,667 baseflow estimates at 8 streamgages (table 5, fig. 27), including 2,659 monthly estimates and 8 steadystate (averaged) estimates. Base-flow estimates were available during each stress period for five streamgages and for shorter periods at the remaining streamgages (fig. 27). For periods when streamflow data were not available - either prior to installation of a streamgage, or when streamflow records were unavailable after installation-weighting was set to zero and no base-flow calibration targets were established.

The groundwater model was calibrated to eight stream-seepage estimates (table 5, fig. 22). The simulated stream seepage was determined as the sum of the "Flow to Aquifer" column in the SFR secondary output file (Ellis, 2018) divided by the 444 monthly stress periods for the transient simulation. Therefore, this value represents the mean stream seepage across the model period.

\section{Calibration-Target Uncertainty and Weighting}

The calibration targets, with the exception of lake-stage observations, were weighted by using error-based weighting from Hill and Tiedeman (2007). Groundwater-level observation weights were defined as $\omega_{i}=1 / \sigma_{i}$, where $\sigma_{i}$ is the error associated with each observation. Base-flow and stream seepage weights were defined as $\omega_{i}=1 /\left(c v_{i} \times o_{i}\right)$, where $\mathrm{cV}_{\mathrm{i}}$ is the coefficient of variation and $o_{i}$ is the observed or estimated value.

Three sources of uncertainty contributing to the error of the groundwater-level observations are (1) the location accuracy, or how precisely the coordinates of the observation wells were known; (2) the altitude accuracy, which is based on the method used to determine the land-surface altitude at observation wells; and (3) the temporal variability of groundwater levels at each observation well. By using methods from Hill and Tiedeman (2007), the error $\left(\sigma_{\mathrm{i}}\right)$ of each groundwater-level observation was calculated as follows:

$$
\sigma_{\mathrm{i}}=\sqrt{\sigma_{\mathrm{l}}^{2}+\sigma_{\mathrm{a}}^{2}+\sigma_{\mathrm{t}}^{2}}
$$

where 


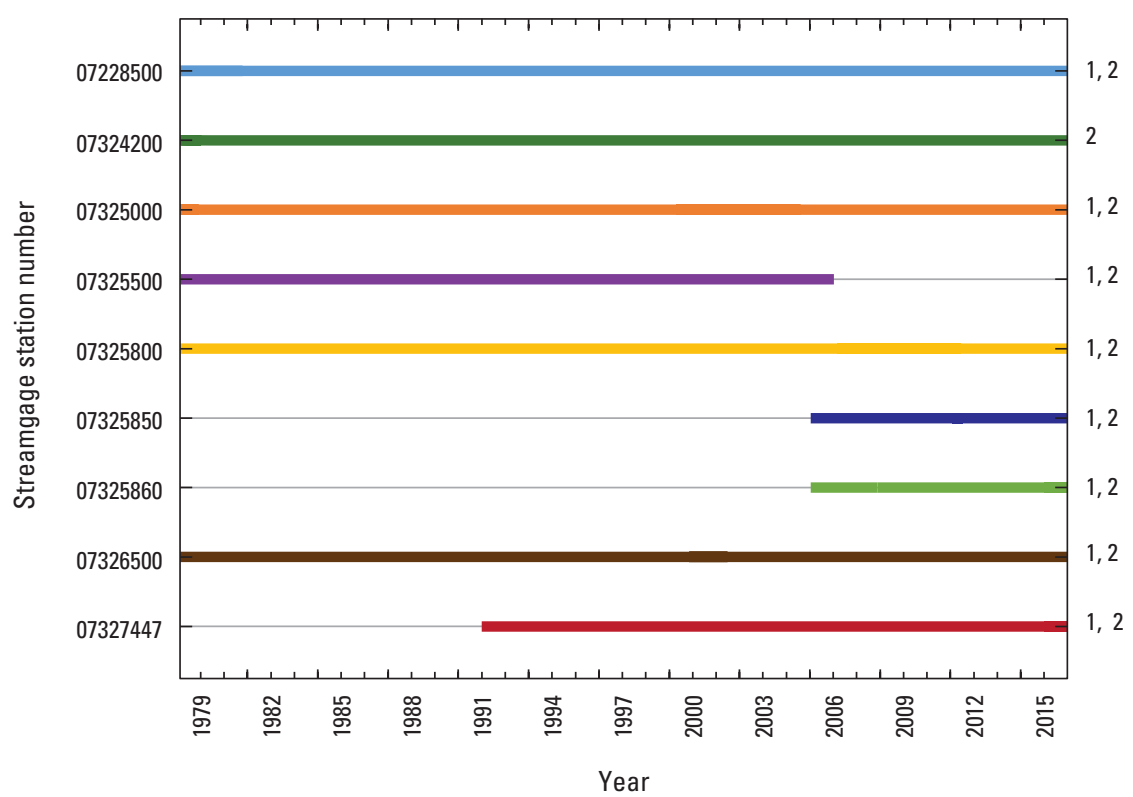

See table 1 for information pertaining to each streamgage and figure 1 for the spatial location of each streamgage

${ }^{1}$ Used for automated groundwater-flow model calibration

${ }^{2}$ Used for manual groundwater-flow model calibration

Figure 27. Temporal distribution of streamflow observations used for the calibration of the Rush Springs aquifer model, western Oklahoma, 1979-2015.

The location and altitude accuracy values recorded in the NWIS and OWRB databases are based on the method used to obtain each observation, typically by using a Global Positioning System (GPS) or a topographic map. The location accuracy of each observation well, as recorded in the NWIS and OWRB databases, was between 0.01 and 10 seconds of latitude or longitude for all but two wells, which had a location accuracy of 60 seconds. Methods from Clark and Hart (2009) were used to determine the location accuracy uncertainty. A radius equal to the location accuracy was created for each observation well, and the standard deviation of the landsurface altitude in that radius was calculated. The standard deviation of the altitude accuracy was calculated by dividing half of the altitude accuracy code (in feet) by the critical value of a 95-percent confidence interval (Hill and Tiedeman, 2007).

The temporal variability at each observation well was determined by using methods from Hill and Tiedeman (2007). The groundwater-level range for each observation well was determined by using either the observed seasonal groundwaterlevel range for wells with four or more observations per year, or a mean value approximating the maximum seasonal groundwater-level range (seasonal approximation) for wells with less than four observations per year. The seasonal approximation was obtained from six observation wells (table 7) that were not coded in NWIS as pumping during the observation and that included observations during each quarter of the year. A value of $1.9 \mathrm{ft}$ was obtained for the seasonal approximation, which included data from 54 annual periods representing 20 of the 32 years in the model period. Assuming that the groundwater-level range represents a 95-percent confidence interval, the temporal variability uncertainty was calculated as the groundwater-level range divided by 4 (Hill and Tiedeman, 2007).

The error (standard deviation of groundwater levels) at each observation well was between about 0.3 and $33 \mathrm{ft}$, with a mean of $5.7 \mathrm{ft}$ (table 7). About 50 percent of these wells had a standard deviation of groundwater levels of less than $3.9 \mathrm{ft}$, and about 90 percent had a standard deviation of groundwater levels of less than $13 \mathrm{ft}$. The largest error component was the location accuracy; approximately half of the groundwaterlevel observations were measured prior to 1990 when survey-grade GPS equipment became commonly available. Based on the error, the groundwater-level observations were grouped into three quality categories ("good," "fair,” and "poor”) representing the value of the groundwater-level observations (fig. 22). The "good," "fair," and "poor" groundwater levels were those observations with standard deviations ranging between 0.3 and $4.9 \mathrm{ft}$, between 5.0 to $14.9 \mathrm{ft}$, and more than $14.9 \mathrm{ft}$, respectively (table 7). The "good," "fair," and "poor” transient groundwater-level groups contained 3,418; 1,730; and 264 groundwater levels, respectively (table 5).

An additional source of uncertainty concerns groundwater levels affected by pumping at the measured well, or a nearby well, as coded in the NWIS database. For the "good," "fair," and "poor" groundwater-level groups, 3, 16, and 14 percent of groundwater levels, respectively, were coded as pumping at the time of an observation. Because of the difficulty associated with determining a standard deviation for pumping conditions, this error is not included in the error for each groundwaterlevel observation, but is noted where the observed values were difficult to simulate in the groundwater model.

Base-flow weights were determined based on the accuracy of field streamflow measurements at each streamgage. Most of these measurements collected during the model period were rated as "fair" in NWIS, which corresponds to a 95-percent confidence interval of plus or minus $( \pm) 15$ percent of true streamflow (USGS, 2017c). The standard deviation of the base-flow estimates at each streamgage was calculated as 15 percent of the base-flow estimate, divided by the critical value of a 95-percent confidence interval. The coefficient of variation was then defined as this standard deviation divided by the mean base flow at each streamgage (table 1). Based on stream order (Strahler, 1952), in which lower order streams drain small groundwater basins and are most susceptible to variations in local properties, the assigned coefficients of variation for Cobb, Lake, and Willow Creeks 
(stream orders 2-4) may understate the uncertainty in the flows for these streams compared the coefficients of variation for the Canadian and Washita Rivers (stream orders 6-7).

Weights for the stream seepage between streamgages were assigned by using methods from Hill and Tiedeman (2007) and were given a 95-percent confidence interval of \pm 15 percent of actual flow. Coefficients of variation ranged from 0.11 for the Washita River between the Foss and Anadarko streamgages to 0.71 for the Washita River between the Carnegie and Anadarko streamgages.

Prior to the automated calibration process, the observation weights for the calibration targets in each group were adjusted by using methods from Doherty and Hunt (2010). An observation group contribution to the objective function was set through a series of trial runs in which various combinations of observation-group weights were tested to determine the best weighting arrangement to reduce the objective function.

\section{Calibrated Model Fit}

The calibrated model fit was evaluated based on the reduction of calibration-target residuals and the fit of the calibrated water-budget components to the components of the conceptual water budget. Residuals were calculated as observed minus simulated values; positive residuals indicate lower simulated than observed values (underpredicted), and negative residuals indicate higher simulated than observed values (overpredicted). Residuals multiplied by the error-based weights discussed in the "Calibration-Target Uncertainty and Weighting" section are referred to as weighted residuals. The root-mean-square error (RMSE) of residuals was calculated by using the following equation:

$$
\text { RMSE }=\sqrt{\frac{1}{n}} \sum_{i=1}^{n}\left(o_{i}-s_{i}\right)^{2}
$$

where

$$
\begin{array}{ll}
\mathrm{n} & \text { is the number of observations, } \\
o_{i} & \text { is the observed (or estimated) value, and } \\
s_{i} & \text { is the simulated value. }
\end{array}
$$

\section{Groundwater Levels}

A good agreement between the observed and simulated groundwater levels was obtained as shown on a 1:1 plot, where the values generally fall along a straight line (fig. 28A). The combined groundwater-level mean residual for steadystate and transient simulations was $-2.3 \mathrm{ft}$, indicating that simulated groundwater levels were slightly overpredicted on average (table 8). The combined groundwater-level RMSE was $26.3 \mathrm{ft}$, and 75 percent of residuals were within $\pm 27.4 \mathrm{ft}$ (table 8). The simulated water-table relief was 1,095 ft, and the combined RMSE as a percentage of this water-table relief was 2.4 percent (table 8 ). Groundwater-level observations in the
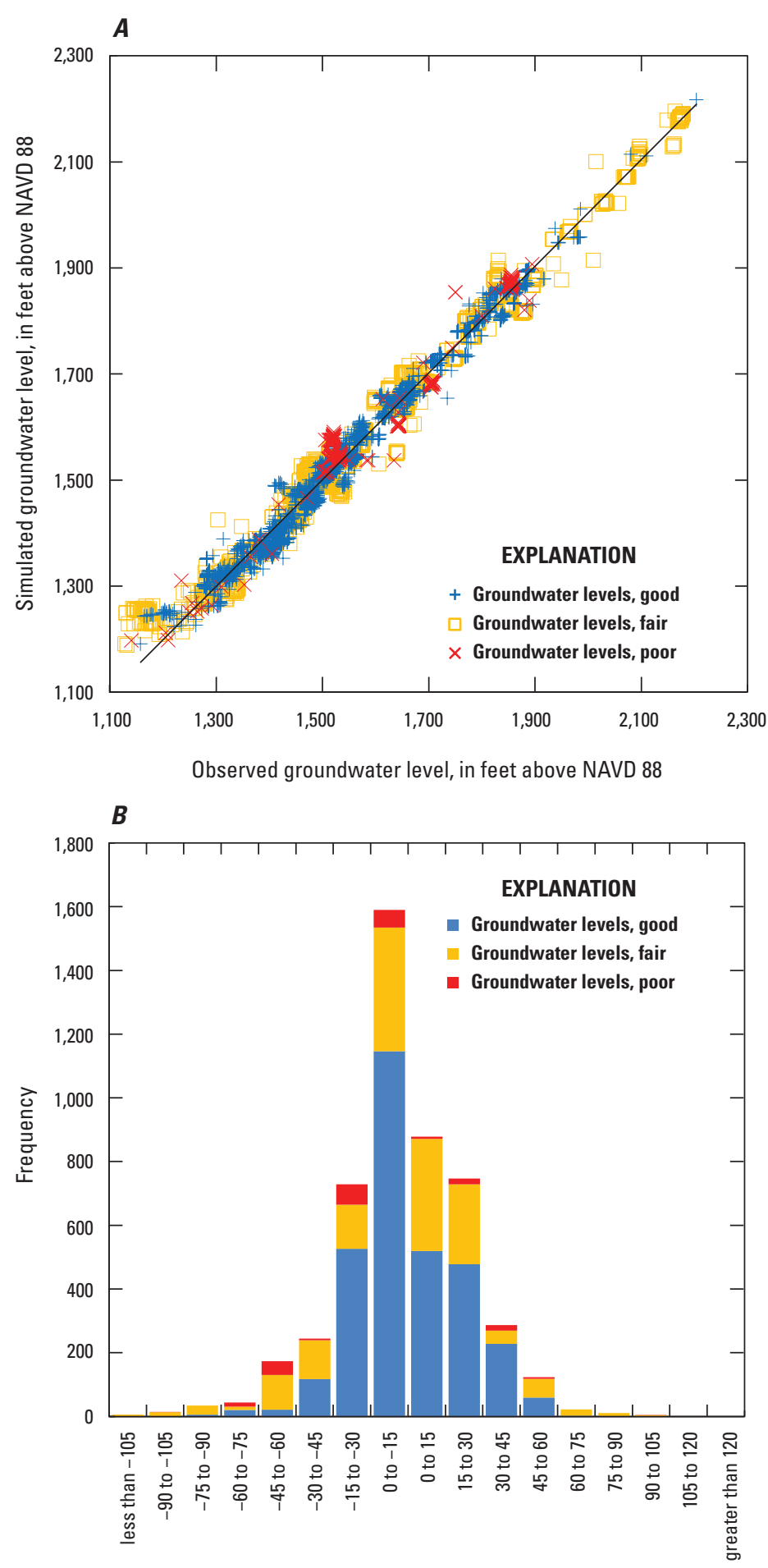

Groundwater-level residual (observed minus simulated), in feet [NAVD 88, North American Vertical Datum of 1988]

Figure 28. $A, 0$ bserved and simulated groundwater levels and $B$, groundwater-level residual distributions for the numerical groundwater-flow model of the Rush Springs aquifer, western Oklahoma, 1979-2015. 
"fair" and "poor" quality categories tended to exhibit larger residuals (simulated values both above and below observed values) compared to the wells in the "good" quality category (figs. 28, 29A). About 85 percent of residuals in the "good" category were between $\pm 30 \mathrm{ft}$, compared to 73 percent and 63 percent of residuals for the "fair" and "poor" categories, respectively (fig. 29A). A total of 99 percent of residuals in the "good" category were between $\pm 60 \mathrm{ft}$, compared to 94 percent and 93 percent residuals for the "fair" and "poor" categories, respectively (fig. 29A).

If groundwater-level observation weights reasonably represent the error inherent in each observation, the weighted groundwater-level residual distribution should be random around a horizontal line (Hill and Tiedeman, 2007). The weighted residuals show a mostly random distribution above and below zero, although some clusters of positive and negative residuals occur with respect to the simulated groundwater levels even after accounting for the quality of the data through the weighting process (figs. 29B).

The overall distribution of groundwater-level residuals was reasonable, although wells in some parts of the model exhibited positive or negative bias in residuals (fig. 30).
Overpredicted groundwater levels in layer 3 typically occurred in wells in the central, eastern, and southeastern parts of the model (fig. 30). One of these wells (long-term well 21; fig. 11) includes overpredicted groundwater levels at elevations around 1,250 ft NAVD 88 (fig. 29A), where the mean residual was $-94 \mathrm{ft}$ during the simulation period (fig. 30 ). No completion or screening information was available for the well, but the well depth recorded in the NWIS database and the aquifer thickness of $100 \mathrm{ft}$ in this area suggest that the well may have been completed in a geologic unit other than the Whitehorse Group. Overpredicted groundwater levels also occurred east of Fort Cobb Reservoir near the model boundary (fig. 30). Deeply incised drainage channels in this area have rapid changes in altitude and hydraulic gradients of as much as 100 feet per mile in some locations. Underpredicted groundwater levels in layer 3 typically occurred in three parts of the model: (1) the confined western part of the model, where the Cloud Chief Formation overlies the Whitehorse Group, (2) the Fort Cobb Reservoir watershed, where pumping wells are most concentrated (fig. 10), and (3) the southern part of the model.

Table 8. Statistical summary of groundwater-level residuals for the numerical groundwater-flow model of the Rush Springs aquifer, western Oklahoma, 1979-2015.

[ \pm , plus or minus; RMSE, root-mean-square error]

\begin{tabular}{|c|c|c|c|}
\hline \multicolumn{4}{|c|}{ All observations } \\
\hline Statistic & Steady-state simulation & Transient simulation & Combined \\
\hline Observation count & 505 & 4,907 & 5,412 \\
\hline 75-percentile residual range, in feet & \pm 32.2 & \pm 25.6 & \pm 27.4 \\
\hline RMSE, in feet & 29.5 & 25.9 & 26.3 \\
\hline \multicolumn{4}{|c|}{ Alluvium and terrace (Layer 2) } \\
\hline Statistic & Steady-state simulation & Transient simulation & Combined \\
\hline Observation count & 26 & 85 & 111 \\
\hline Mean residual, in feet & -0.2 & 1.2 & 0.9 \\
\hline \multicolumn{4}{|c|}{ Rush Springs Formation (Layer 3) } \\
\hline Statistic & Steady-state simulation & Transient simulation & Combined \\
\hline Observation count & 479 & 4,822 & 5,301 \\
\hline Mean residual, in feet & 1.3 & -2.7 & -2.6 \\
\hline 75-percentile residual range, in feet & \pm 32.8 & \pm 25.8 & \pm 26.5 \\
\hline RMSE, in feet & 30.2 & 26.1 & 26.5 \\
\hline RMSE percentage of water-table relief (1,095 feet) & 2.8 & 2.4 & 2.5 \\
\hline
\end{tabular}


A. Residuals by quality category

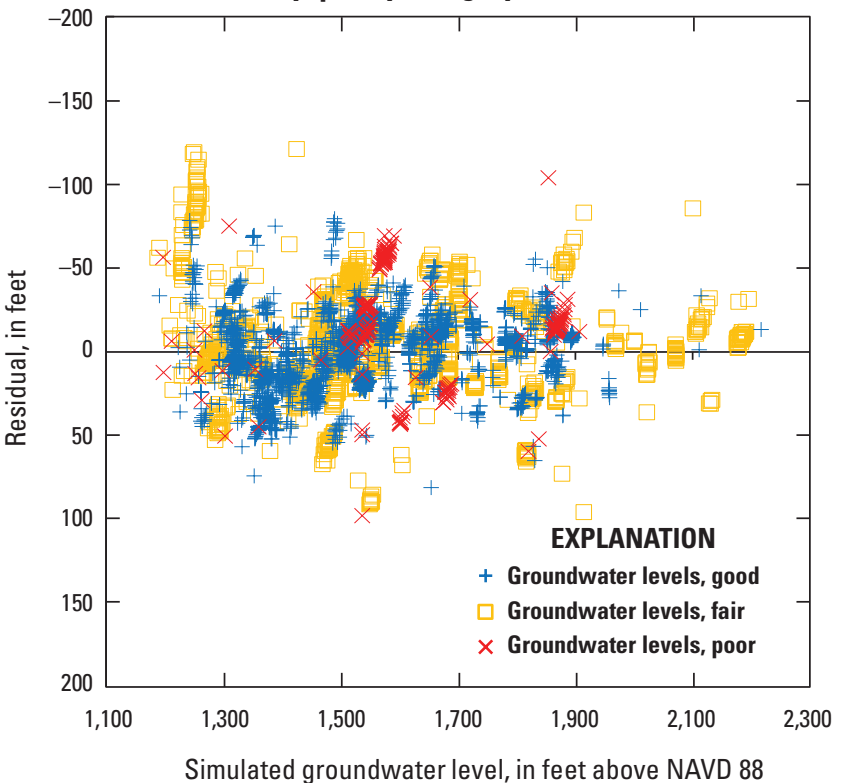

C. Residuals by layer

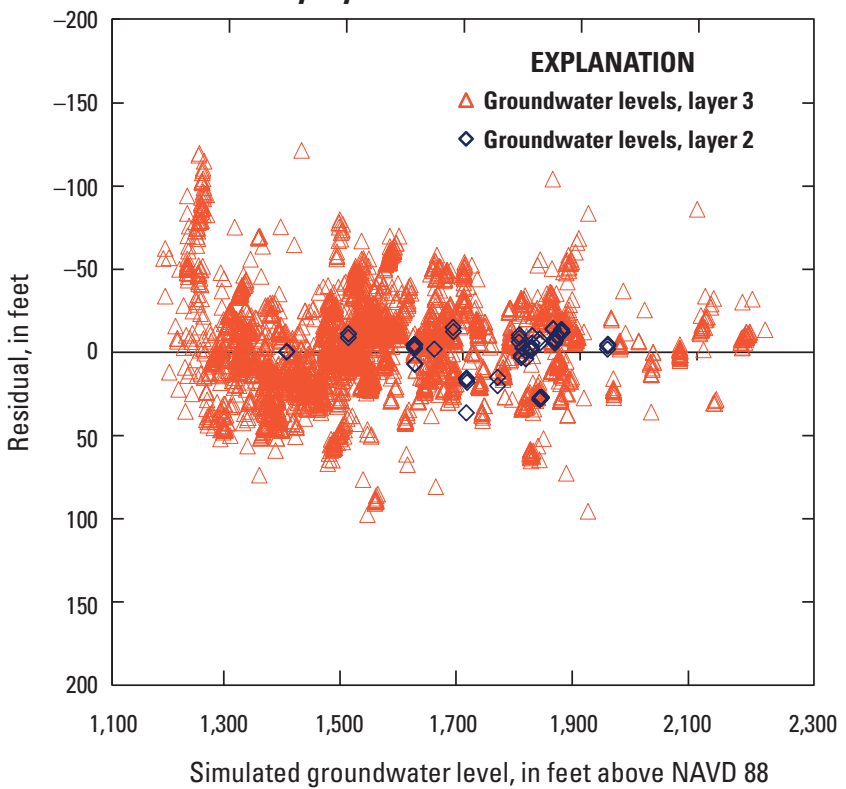

B. Weighted residuals by quality category

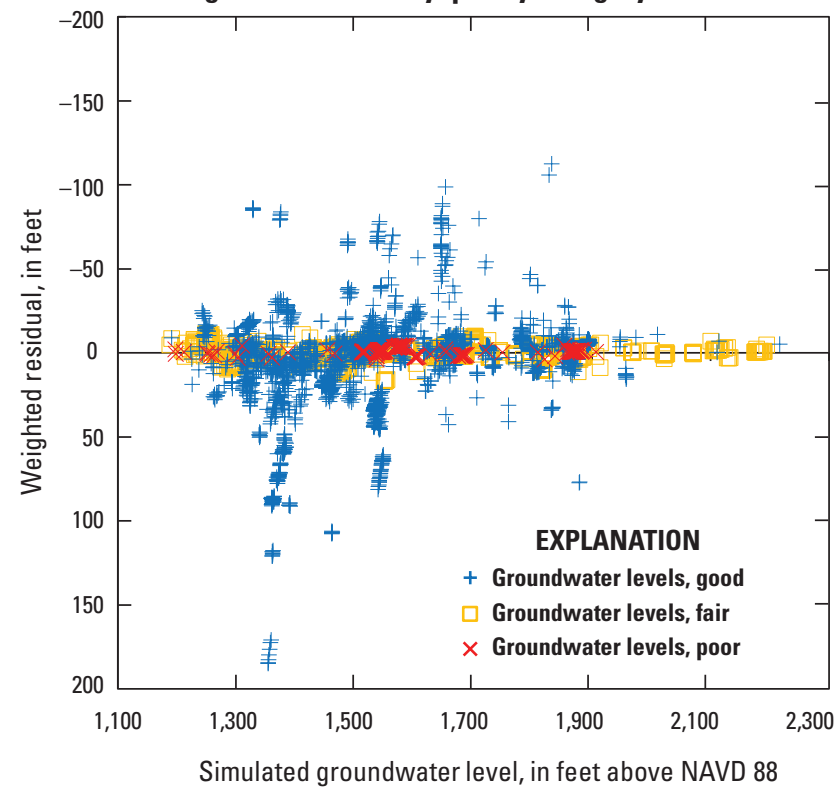

D. Weighted residuals by layer

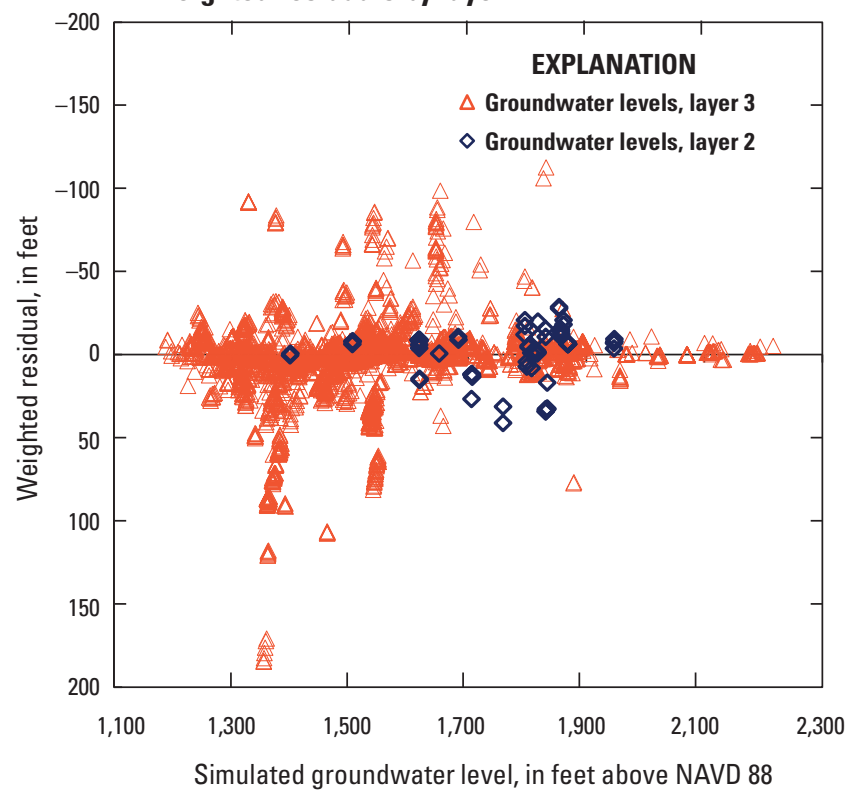

[NAVD 88, North American Vertical Datum of 1988]

Figure 29. $A$, Residuals by quality category, $B$, weighted residuals by quality category, $C$, residuals by layer, and $D$, weighted residuals by layer for the numerical groundwater-flow model of the Rush Springs aquifer, western Oklahoma, 1979-2015. 


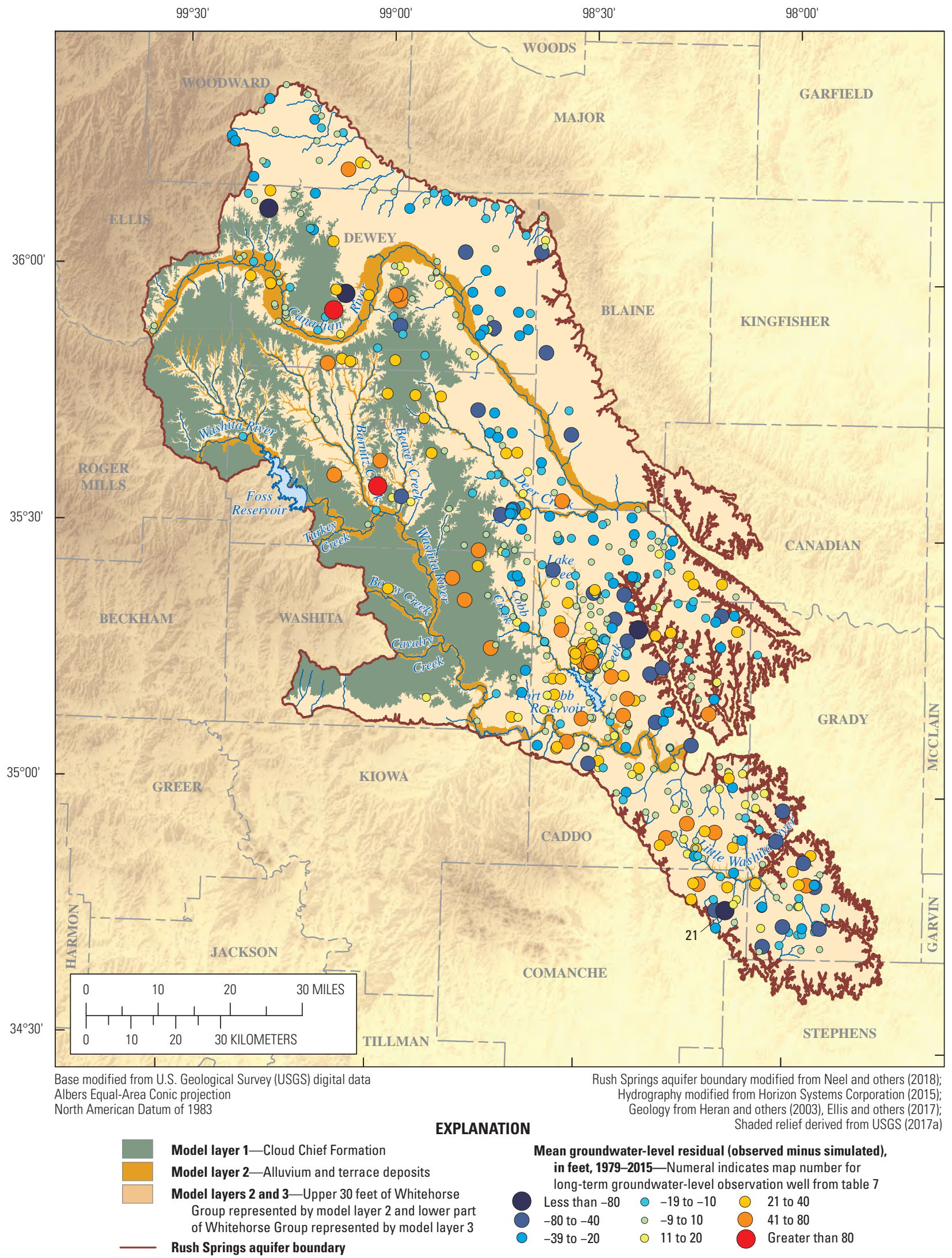

Figure 30. Spatial distribution of mean groundwater-level residuals for the numerical groundwater-flow model of the Rush Springs aquifer, western Oklahoma, 1979-2015. 
For the transient simulation, the mean residual in the layer 2 alluvium and terrace was $1.2 \mathrm{ft}$ (table 8). Groundwater levels in the layer 2 alluvium and terrace generally were underpredicted in the alluvium and terrace in areas closer to the surrounding bedrock, whereas groundwater levels were overpredicted near the stream channel (fig. 30) because of the inability to simulate the full amount of ETg estimated from the SWB code. More wells were completed near the stream channel than near the surrounding bedrock, and those wells near the stream channel contain only a few groundwater-level observations each, shown as scattered negative residuals; the fewer wells near the surrounding bedrock generally contain $6-10$ observations each, shown as clustered positive residuals (figs. 29C, 30).

The distribution of the mean weighted residuals from each observation well is shown on figure 31 . Approximately half of the largest positive and negative weighted residuals occurred in wells located at or near a model boundary; thus, structural error may account for these residuals. Large positive weighted residuals occurred in a small number of wells (fig. 31) including (1) continuous wells 24 and 25 shown as vertical clusters at elevations around 1,380 and $1,550 \mathrm{ft}$ NAVD 88 (figs. 29B , D ), respectively, that had observations mostly during drought conditions in 2011-14, and (2) wells located near Fort Cobb Reservoir, also shown as vertical clusters at elevations around 1,400 ft NAVD 88 (figs. 29B, D), where irrigation demand is greatest. Large negative weighted residuals (fig. 31) occurred in a greater number of wells than the large positive weighted residuals. However, only 1 of the 15 wells with the largest negative weighted residuals had more than 9 groundwater-level observations (fig. 25), and 12 of the 15 largest negative weighted residuals occurred for wells with groundwater-level observations taken only during 2011-14 when drought conditions were present. The largest negative residuals occurred mostly between (1) the Canadian River and the model boundary in Blaine County and (2) between Fort Cobb Reservoir and the model boundary in eastern Caddo County (fig. 31). 


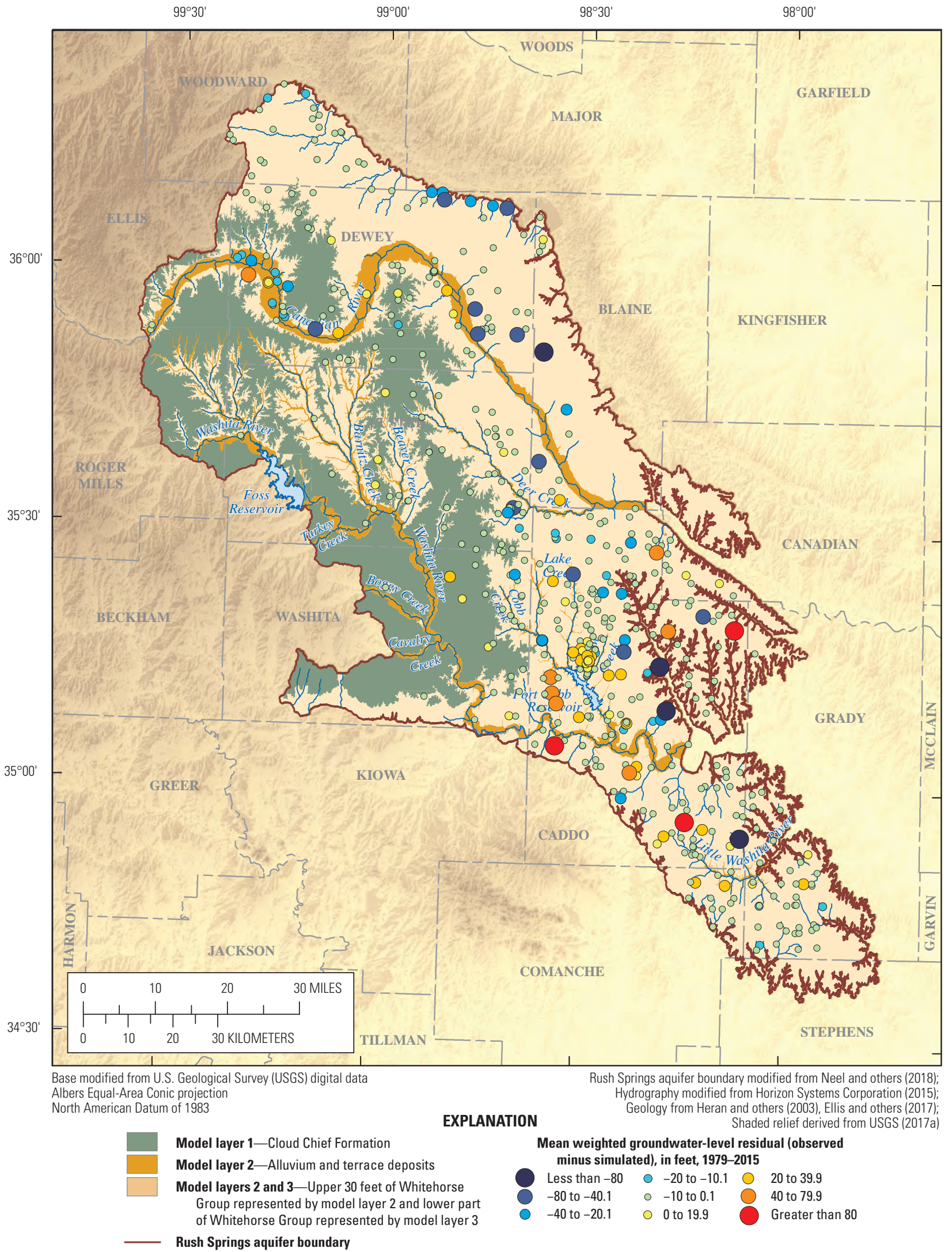

Figure 31. Spatial distribution of mean weighted groundwater-level residuals for the numerical groundwater-flow model of the Rush Springs aquifer, western Oklahoma, 1979-2015. 
Groundwater-level residuals for each year of the transient simulation are shown in figure 32. The mean residual in most years was between $\pm 11 \mathrm{ft}$ (fig. 32). The transient simulation contained larger negative groundwater-level residuals between 1983 and 1989 compared to the subsequent years of the simulation. Those larger residuals are probably caused by (1) the transition from averaged groundwater-level observations used for the steady-state stress period, (2) the overprediction of groundwater-level changes as a result of above-mean recharge during 1986-87, and (3) the greater number of groundwater-level observations prior to 1990 compared to the remaining period (fig. 26A). The 75-percent residual range for each month generally varied by less than $6 \mathrm{ft}$, suggesting that groundwater-level observations during summer months (defined as June-August) do not show a systemic bias in underpredicting groundwater levels other than the area around Fort Cobb Reservoir. The 35 groundwater levels in 1999 were all measured at 27 wells in a 4-mi radius immediately north of Fort Cobb Reservoir where observed groundwater levels are underpredicted through the simulation period because of the large irrigation use in this area. These levels were measured in August when irrigation demand was greatest (fig. 19), whereas most groundwater levels for the model period were measured between January and March of each year (fig. 26B). Groundwater levels were also generally underpredicted between 2010 and 2014, when drought conditions were prevalent (fig. 32). During this period, only five wells had more than seven groundwater-level observations; thus, more than half of the observations between 2011 and 2015 occurred at these five wells (continuous wells 22-26, fig. 11). As a result, although positive and negative residuals were spatially distributed during the drought period, the mean residual was biased towards the underpredicted groundwater levels in these five wells.

Simulated well hydrographs generally match the trends of observed well hydrographs, but the magnitude of the simulated groundwater-level changes was typically greater than the observed changes for most wells (fig. 33). The overpredicted groundwater-level changes occurred for (1) substantial changes in inflow, such as the large recharge events in 2007 and 2015, and (2) changes in outflow, such as the 60- to 90-percent decrease in well pumping in a 1-mi radius around long-term well 18 (figs. 11, 33) between 2007 and 2010.

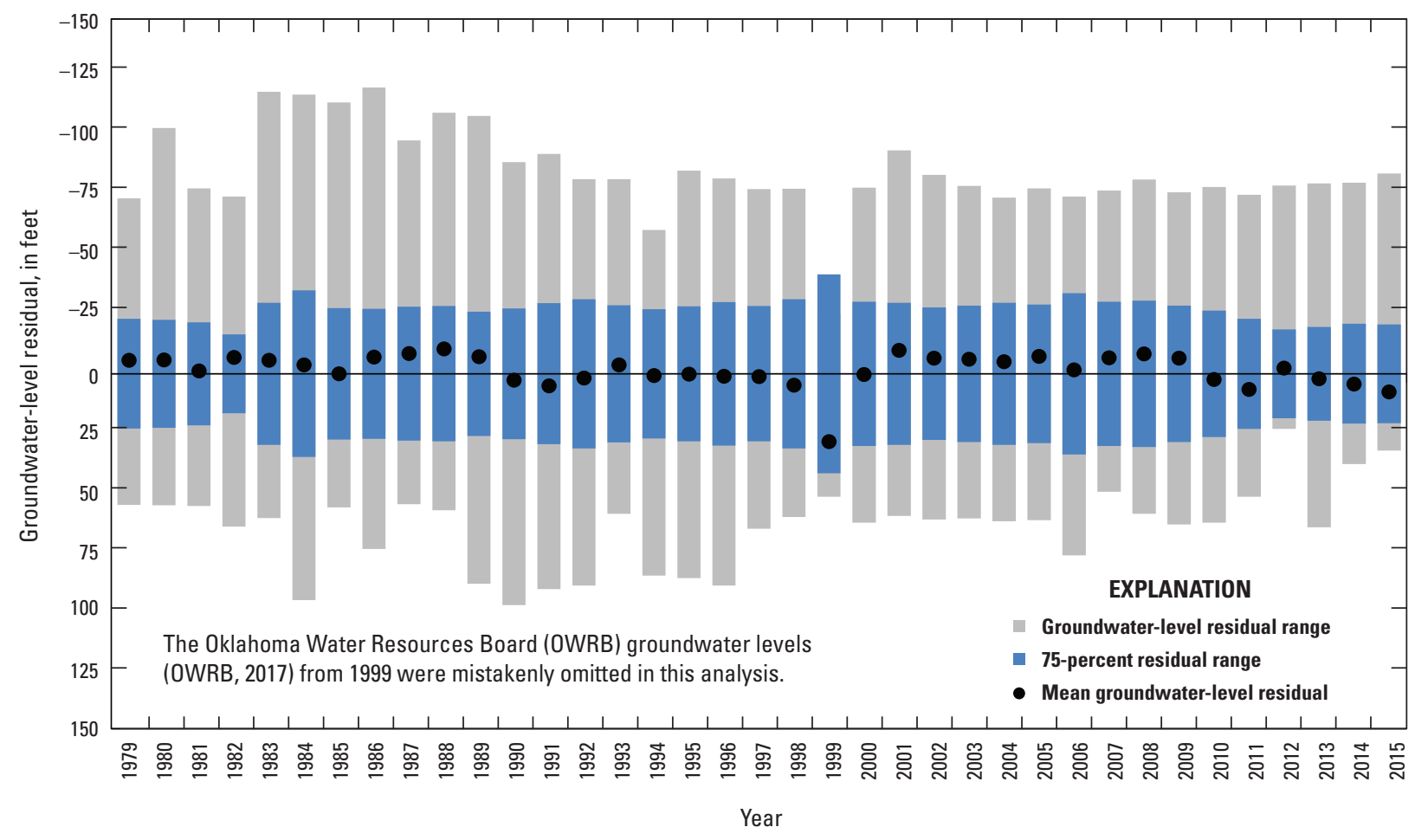

Figure 32. Temporal distribution of mean, minimum, and maximum groundwater-level residuals for the numerical groundwater-flow model of the Rush Springs aquifer, western Oklahoma, 1979-2015. 

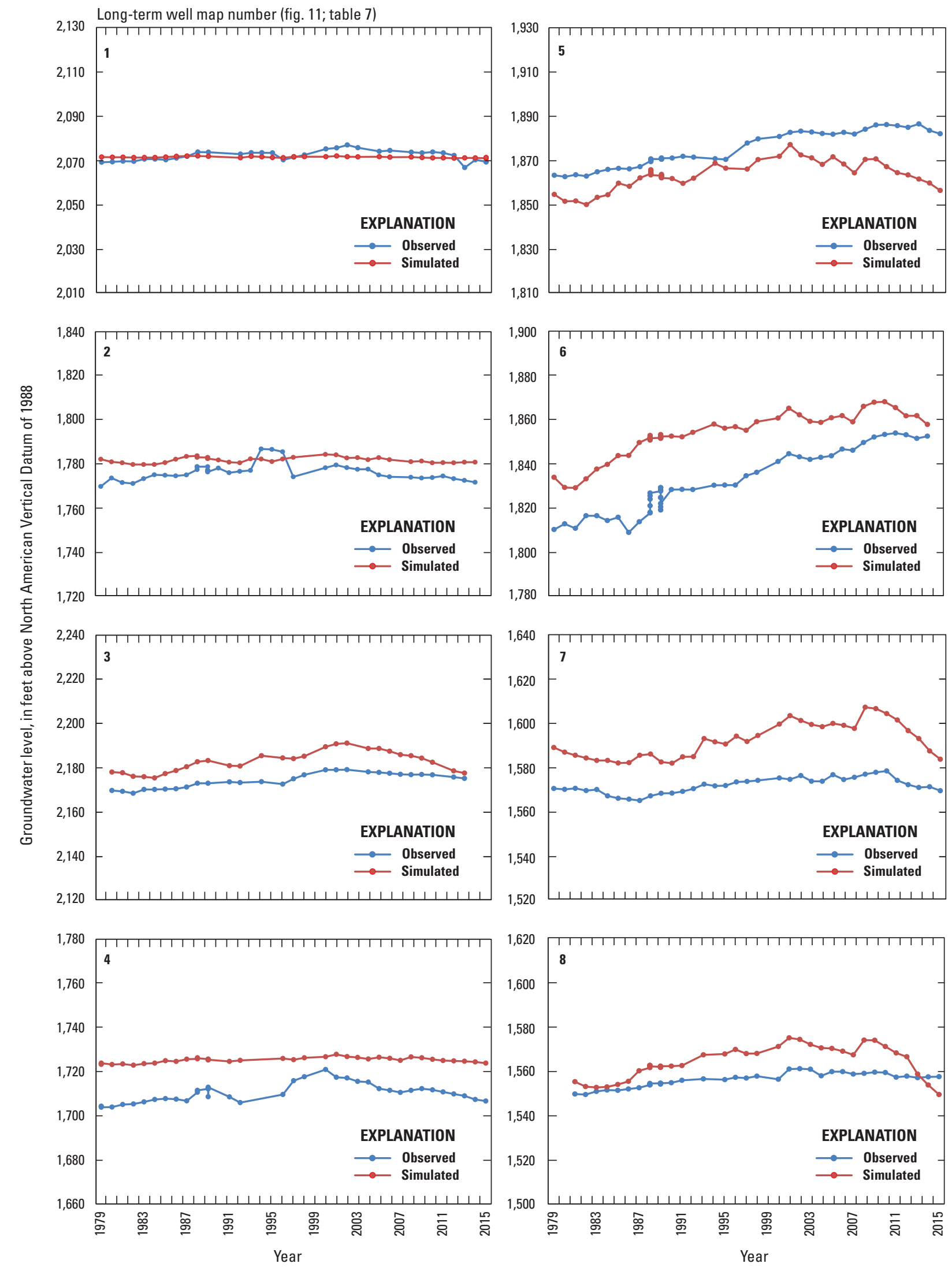

Figure 33. Observed and simulated groundwater levels in long-term and continuous groundwater-level observation wells for the Rush Springs aquifer, western Oklahoma, 1979-2015. 

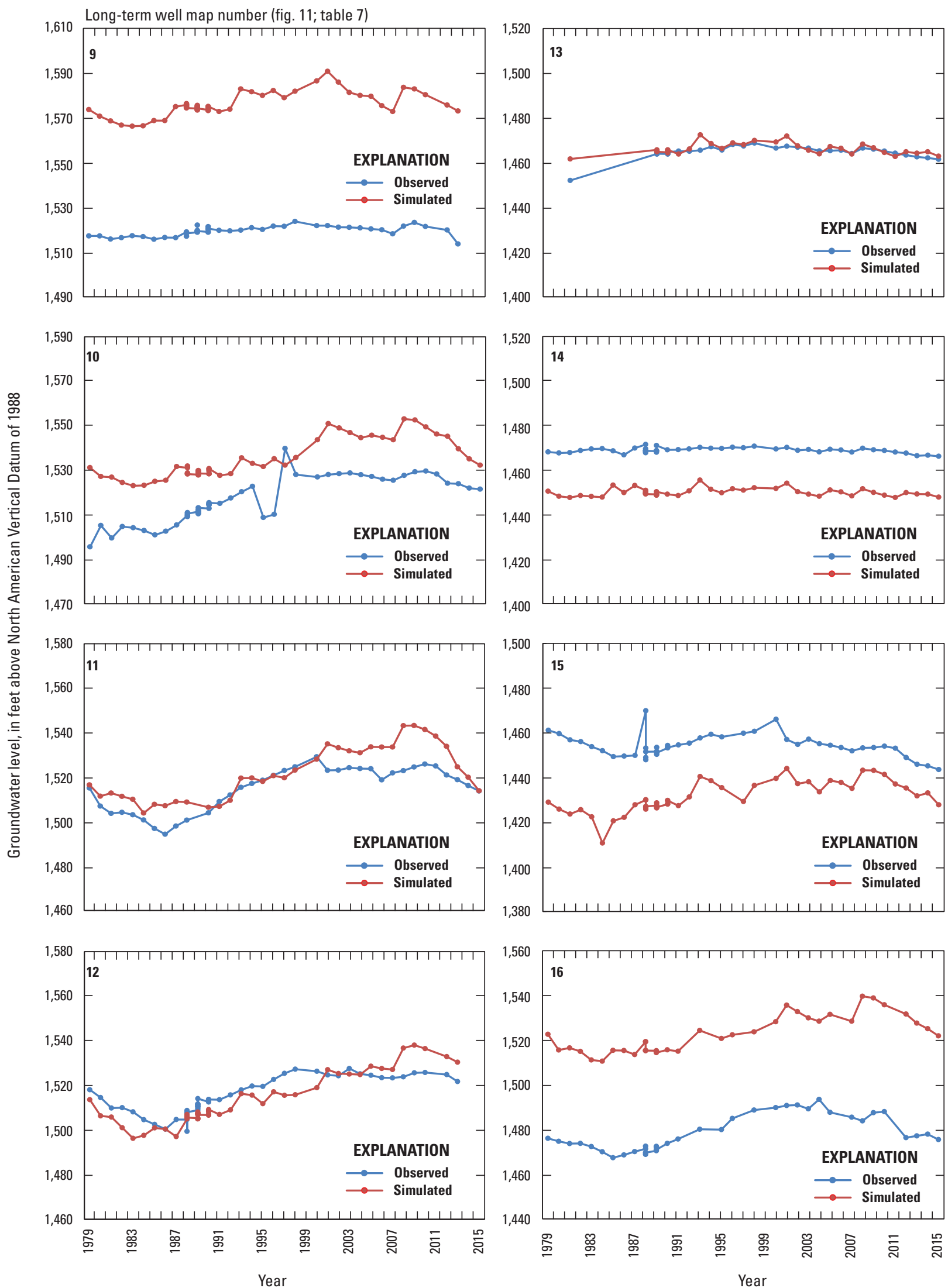

Figure 33. Observed and simulated groundwater levels in long-term and continuous groundwater-level observation wells for the Rush Springs aquifer, western Oklahoma, 1979-2015.—Continued 


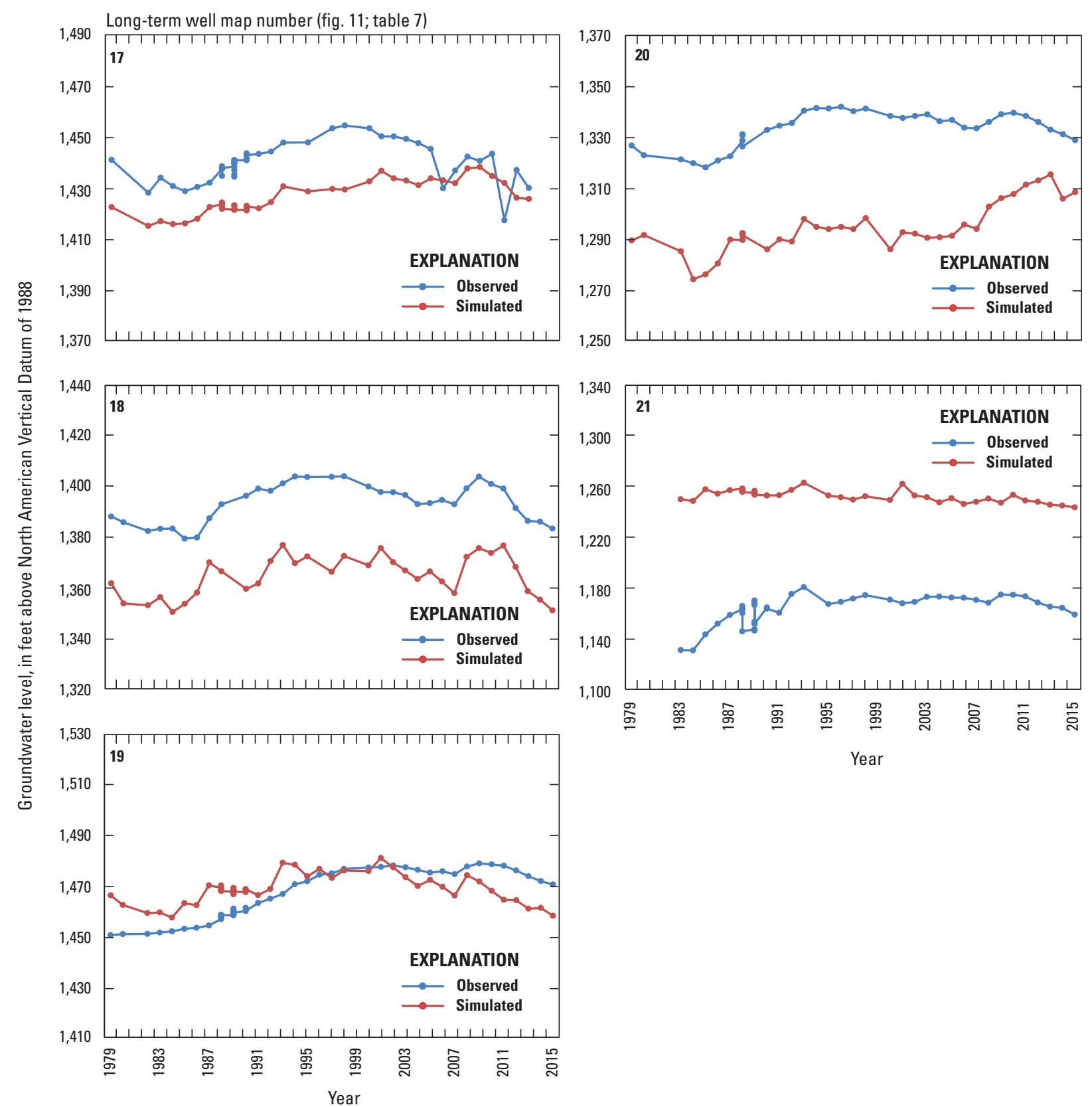

Figure 33. Observed and simulated groundwater levels in long-term and continuous groundwater-level observation wells for the Rush Springs aquifer, western Oklahoma, 1979-2015._Continued 
Continuous well map number (fig. 11; table 7)

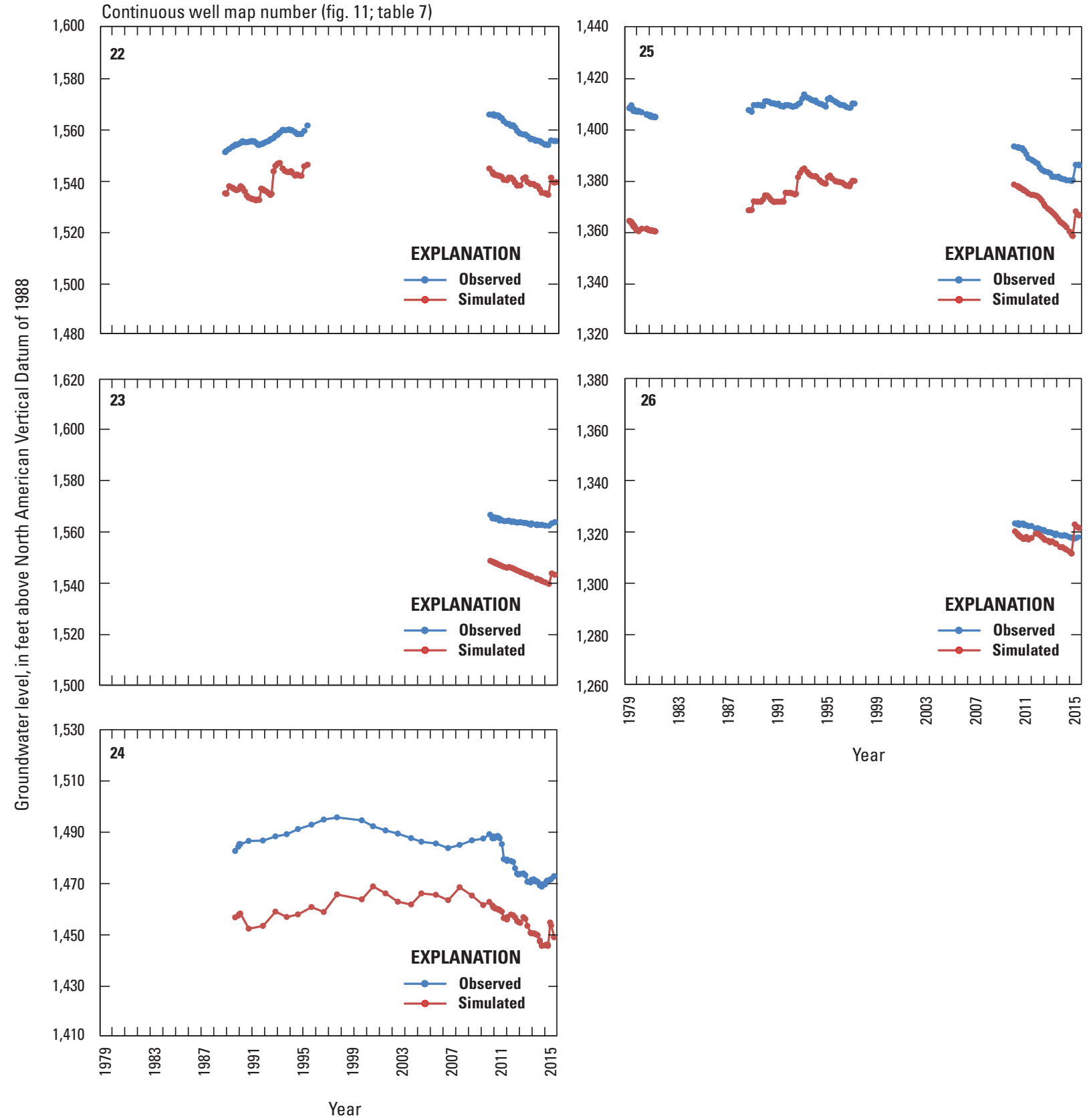

Figure 33. Observed and simulated groundwater levels in long-term and continuous groundwater-level observation wells for the Rush Springs aquifer, western Oklahoma, 1979-2015._Continued 
In the northern model area (long-term wells 1-3; fig. 11), simulated groundwater levels reasonably matched observed levels (fig. 33). Simulated groundwater levels in northern Caddo County northeast and northwest of Lake Creek (longterm wells 7-11; fig. 11) were overpredicted, while simulated levels near Fort Cobb Reservoir (long-term wells 15, 17, 18, 20 , and continuous wells 24-26; fig. 11) generally were underpredicted (fig. 33) because of the high pumping rate in this area. The location of long-term well 9 was interpolated from a topographic map; thus, there was more uncertainty for groundwater-level observations from this well than the other long-term wells. The Sy across the model area was generally similar; therefore, the simulated groundwater-level response is less likely to be caused by the variability in the storage parameters.

\section{Base Flow}

The pattern of simulated base flows was similar to that of estimated base flows at the nine streamgages used in the calibration, but mean simulated base flows were slightly lower than estimated mean base flows (fig. 34). With the exception of the Bridgeport streamgage (07228500), the mean base-flow residual was between 14.3 and $-1.1 \mathrm{ft}^{3} / \mathrm{s}$ for each streamgage (table 9). The mean base-flow residual at the Bridgeport streamgage (07228500) was $-23.4 \mathrm{ft}^{3} / \mathrm{s}$, primarily because of overpredicted simulated stream seepage west of Taloga (fig. 1). For the four Washita River streamgages, the RMSE was less than or equal to 9.0 percent of the range in estimated base flow, and the mean base flow was slightly underpredicted for the Clinton (07325000), Carnegie (07325500), and Anadarko (07326500) streamgages (table 9). For the Fort Cobb Reservoir tributary streamgages, the RMSE was between 7.6 and 26.1 percent of the range in estimated base flow because of small mean estimated base flows $\left(2.0-15.1 \mathrm{ft}^{3} / \mathrm{s}\right)$ at these streamgages that were difficult to reproduce at the scale of the model (table 9).

Table 9. Statistical summary of base-flow residuals for the numerical groundwater-flow model of the Rush Springs aquifer, western Oklahoma, 1979-2015.

[Residual is calculated as the estimated value minus the simulated value; thus, a negative number indicates higher simulated than estimated values. All units are in cubic feet per second; RMSE, root-mean-square error; \pm , plus or minus]

\begin{tabular}{|c|c|c|c|c|c|c|c|c|c|c|c|}
\hline \multirow[b]{2}{*}{$\begin{array}{l}\text { Station } \\
\text { number } \\
\text { (fig. 1) }\end{array}$} & \multirow[b]{2}{*}{ Station identifier } & \multicolumn{3}{|c|}{ Estimated base flow } & \multicolumn{3}{|c|}{ Simulated base flow } & \multicolumn{3}{|c|}{ Base-flow residuals } & \multirow{2}{*}{$\begin{array}{c}\text { RMSE } \\
\text { percent- } \\
\text { age of } \\
\text { range in } \\
\text { estimated } \\
\text { base flow }\end{array}$} \\
\hline & & $\begin{array}{l}\text { Mini- } \\
\text { mum }\end{array}$ & Mean & $\begin{array}{c}\text { Maxi- } \\
\text { mum }\end{array}$ & $\begin{array}{l}\text { Mini- } \\
\text { mum }\end{array}$ & Mean & $\begin{array}{c}\text { Maxi- } \\
\text { mum }\end{array}$ & Mean & RMSE & $\begin{array}{l}\text { 75th } \\
\text { per- } \\
\text { centile } \\
\text { range }\end{array}$ & \\
\hline 07228500 & $\begin{array}{l}\text { Bridgeport } \\
\text { streamgage on } \\
\text { Canadian River }\end{array}$ & 0.0 & 136.0 & 648.0 & 45.0 & 159.0 & 428.0 & -23.4 & 82.9 & \pm 84.1 & 12.8 \\
\hline 07324200 & $\begin{array}{c}\text { Hammon streamgage } \\
\text { on Washita River }\end{array}$ & 0.0 & 39.3 & 463.4 & 3.5 & 38.3 & 333.8 & -1.1 & 16.5 & \pm 11.1 & 3.6 \\
\hline 07325000 & $\begin{array}{l}\text { Clinton streamgage } \\
\text { on Washita River }\end{array}$ & 0.4 & 82.0 & $1,052.3$ & 16.6 & 80.0 & 628.4 & 2.0 & 62.0 & \pm 30.2 & 5.9 \\
\hline 07325500 & $\begin{array}{c}\text { Carnegie streamgage } \\
\text { on Washita River }\end{array}$ & 10.5 & 240.0 & $1,851.6$ & 102.9 & 225.6 & 780.1 & 14.3 & 164.9 & \pm 105.6 & 9.0 \\
\hline 07325800 & $\begin{array}{l}\text { Cobb Creek } \\
\text { streamgage on } \\
\text { Cobb Creek }\end{array}$ & 1.3 & 15.1 & 88.2 & 3.1 & 15.6 & 55.1 & -0.4 & 6.6 & \pm 5.8 & 7.6 \\
\hline 07325850 & $\begin{array}{l}\text { Lake Creek } \\
\text { streamgage on } \\
\text { Lake Creek }\end{array}$ & 0.2 & 4.0 & 16.6 & 1.7 & 4.7 & 21.3 & -0.7 & 2.8 & \pm 2.0 & 17.1 \\
\hline 07325860 & $\begin{array}{l}\text { Willow Creek } \\
\text { streamgage on } \\
\text { Willow Creek }\end{array}$ & 0.2 & 2.0 & 4.8 & 0.1 & 1.8 & 12.4 & 0.3 & 1.2 & \pm 1.0 & 26.1 \\
\hline 07326500 & $\begin{array}{l}\text { Anadarko } \\
\text { streamgage on } \\
\text { Washita River }\end{array}$ & 7.9 & 289.3 & $2,699.2$ & 99.3 & 281.3 & $1,186.5$ & 8.0 & 203.1 & \pm 106.2 & 7.5 \\
\hline 07327447 & $\begin{array}{l}\text { Cement streamgage } \\
\text { on Little Washita } \\
\text { River }\end{array}$ & 0.0 & 11.9 & 74.9 & 5.1 & 12.6 & 49.1 & -0.4 & 6.3 & \pm 5.7 & 8.4 \\
\hline
\end{tabular}


A. Hammon streamgage (07324200) on Washita River

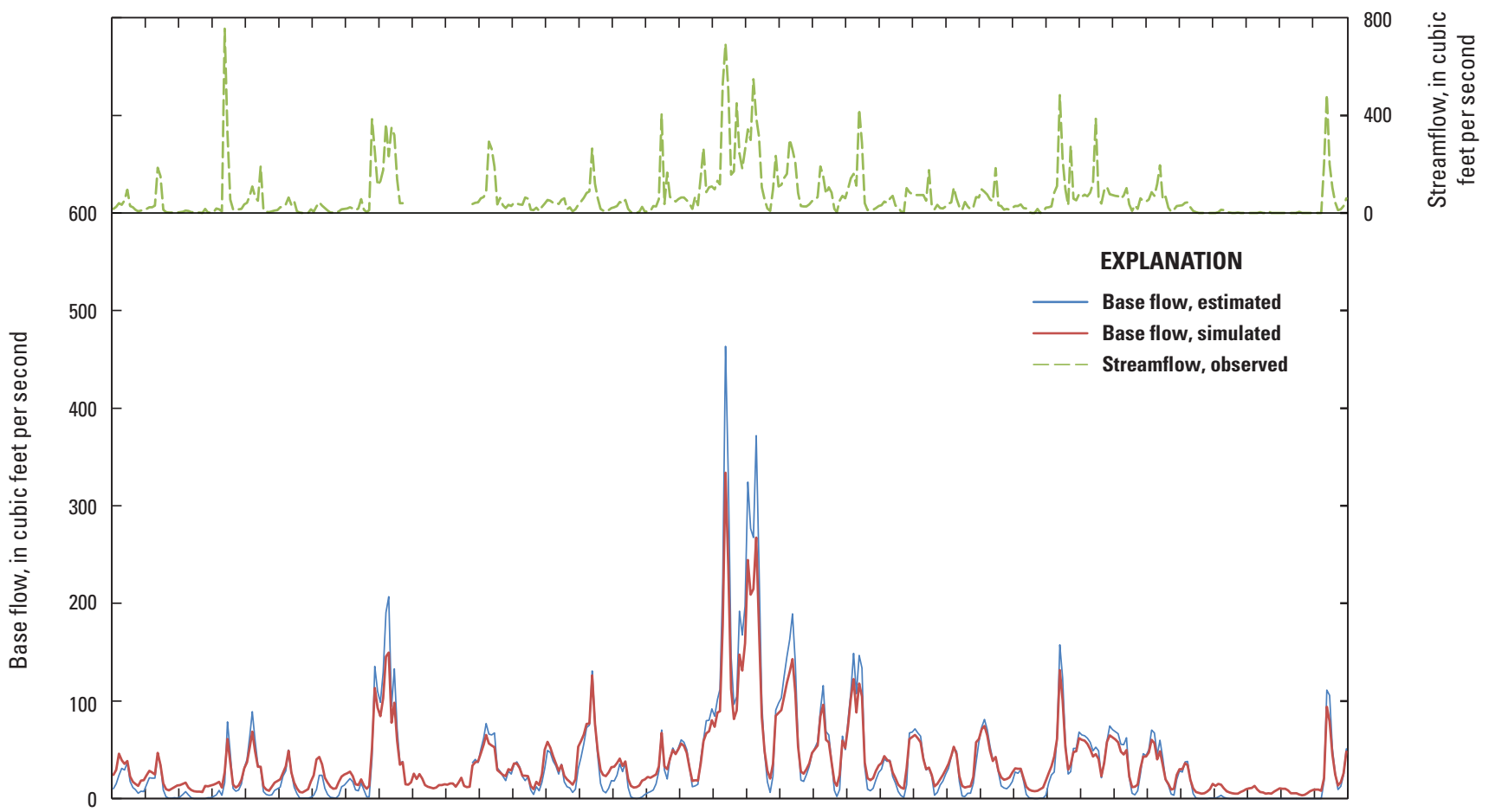

\section{B. Clinton streamgage (07325000) on Washita River}

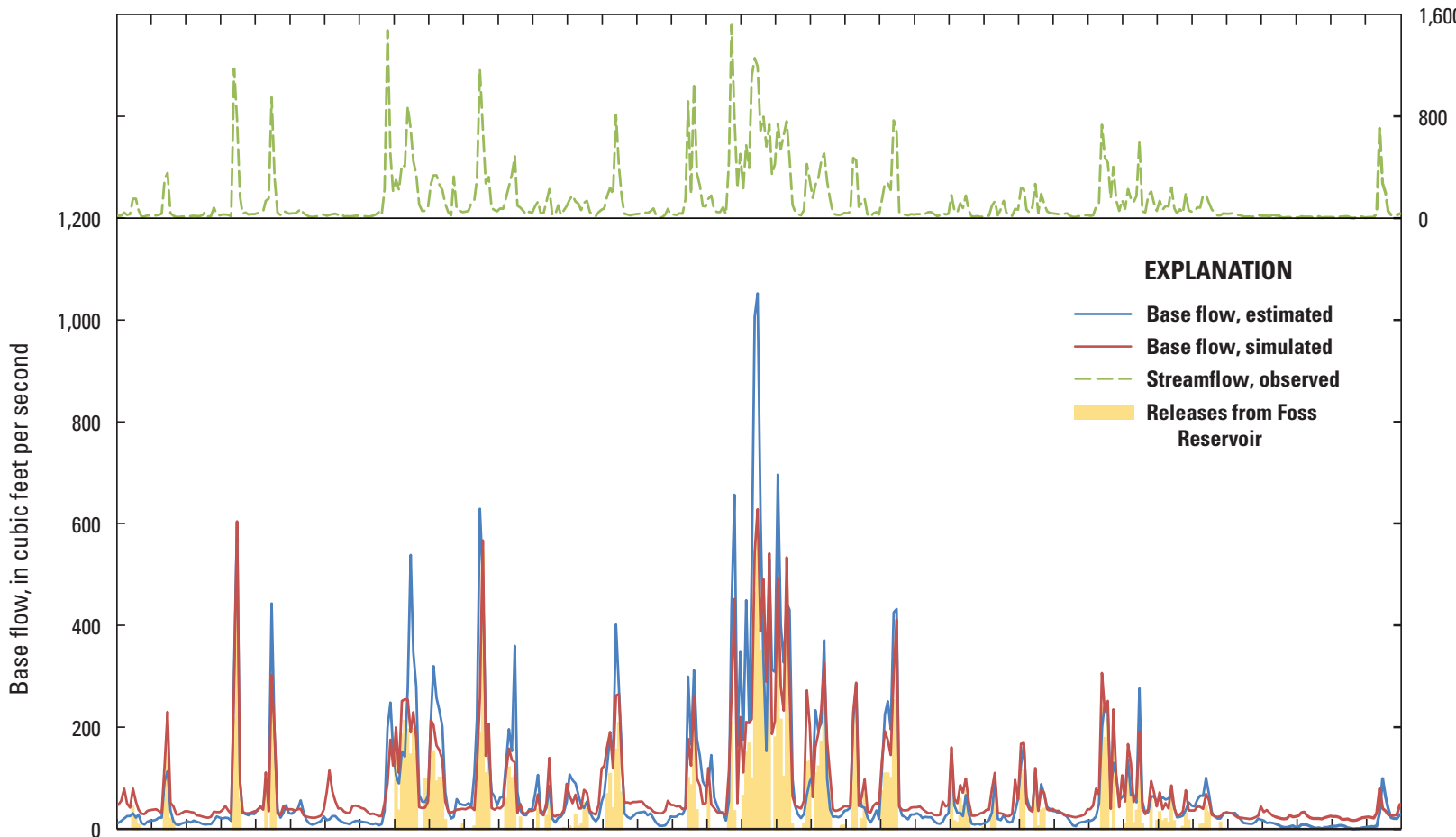

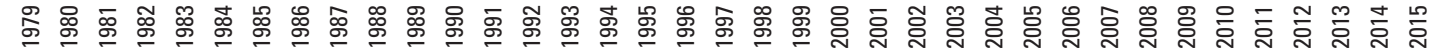

Figure 34. Observed streamflow, estimated base flow, and simulated base flow at $A$, Hammon streamgage (07324200) on Washita River; $B$, Clinton streamgage (07325000) on Washita River; $C$, Carnegie streamgage (07305500) on Washita River; $D$, Anadarko streamgage (07326500) on Washita River; $E$, Bridgeport streamgage (07228500) on Canadian River; $F$, Cement streamgage (07327447) on Little Washita River; $G$, Cobb Creek streamgage (07325800) on Cobb Creek; $H$, Lake Creek streamgage (07325850) on Lake Creek; and $I$, Willow Creek streamgage (07325860) on Willow Creek for the numerical groundwater-flow model of the Rush Springs aquifer, western Oklahoma, 1979-2015. 
C. Carnegie streamgage (07325500) on Washita River

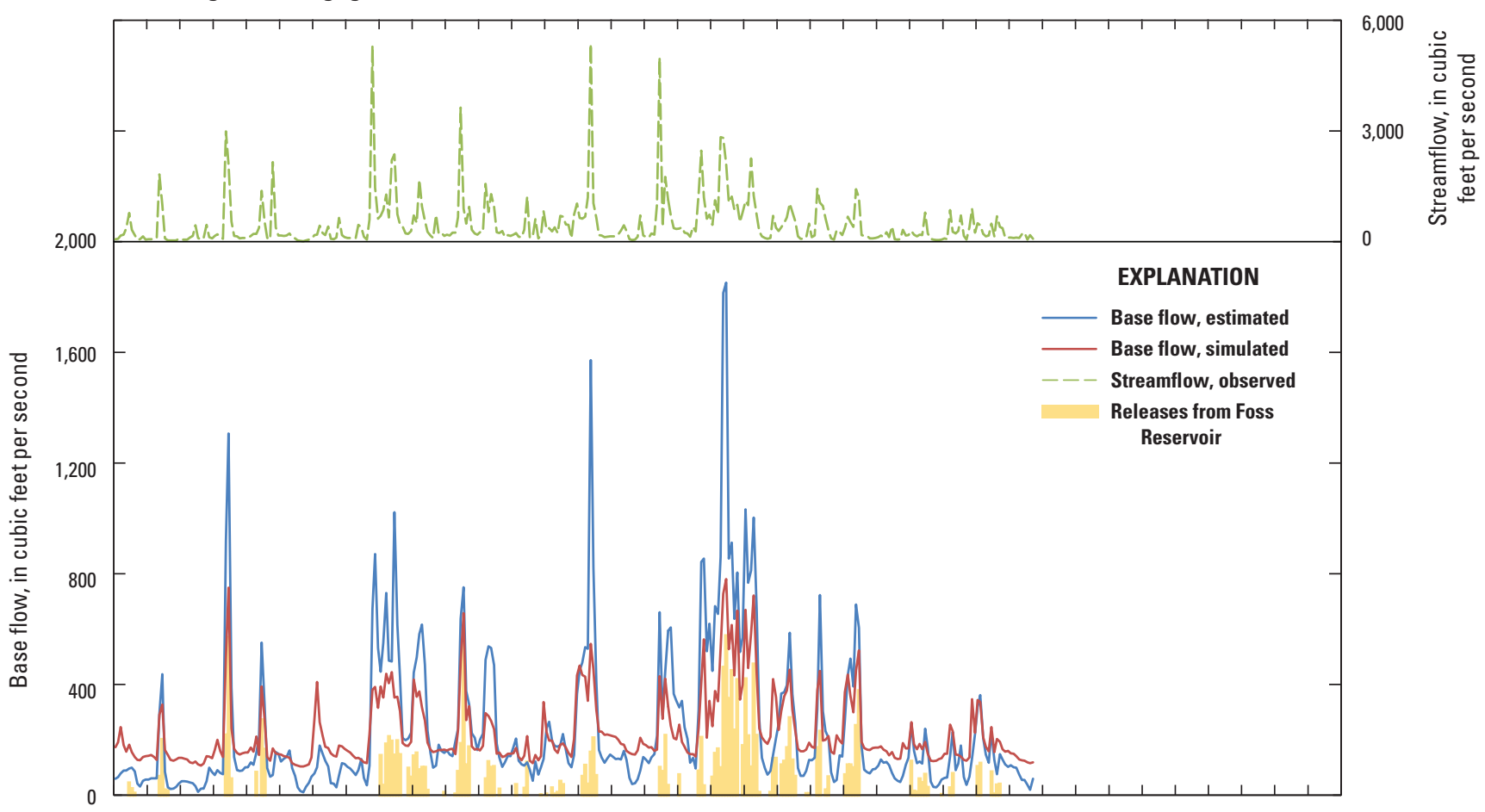

D. Anadarko streamgage (07326500) on Washita River

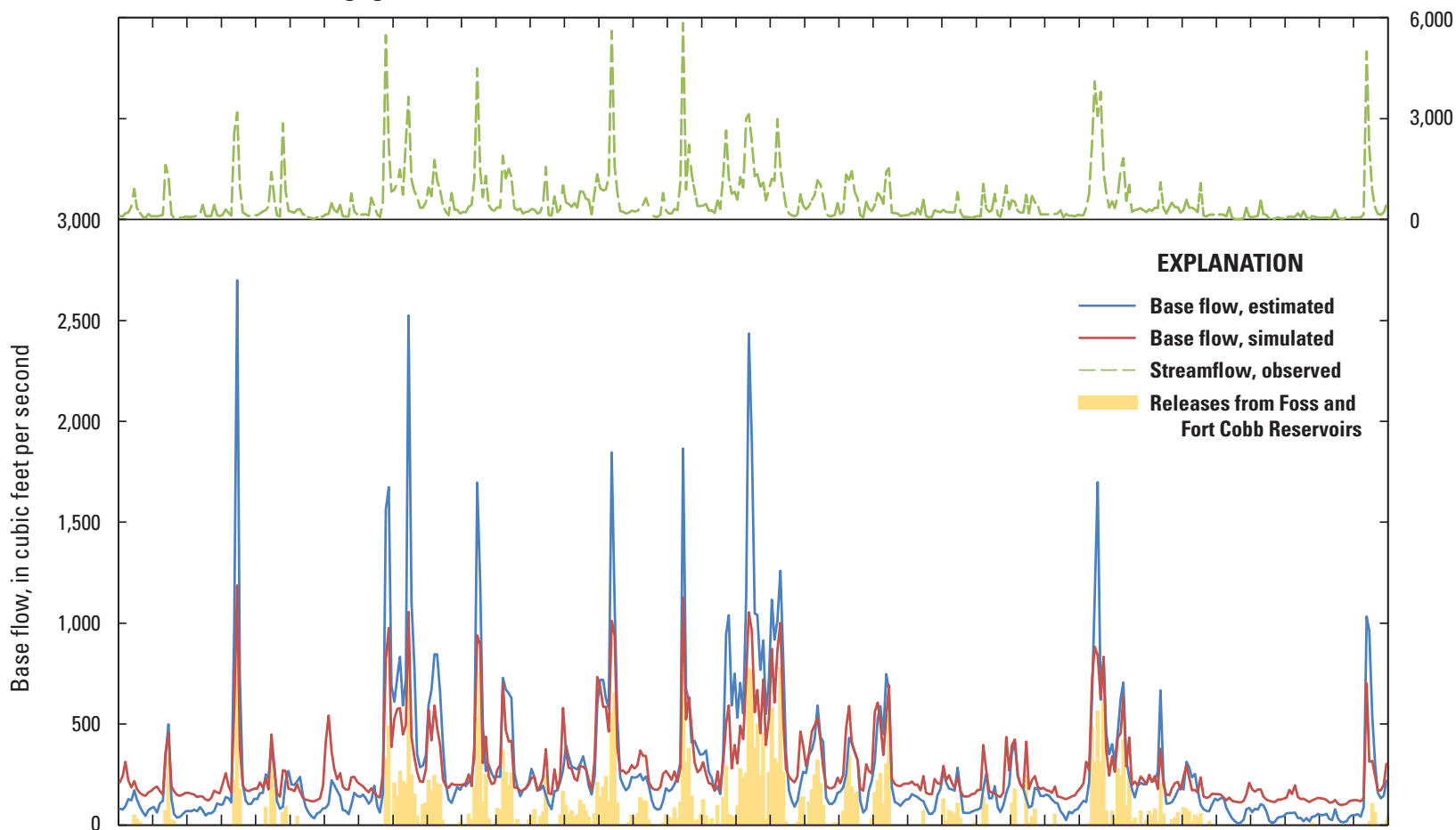

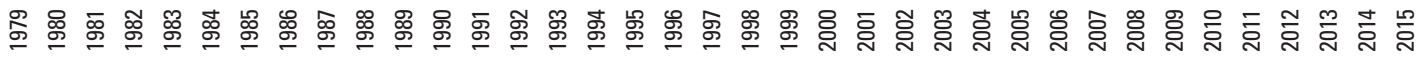

Year

Figure 34. Observed streamflow, estimated base flow, and simulated base flow at $A$, Hammon streamgage (07324200) on Washita River; $B$, Clinton streamgage (07325000) on Washita River; $C$, Carnegie streamgage (07305500) on Washita River; D, Anadarko streamgage (07326500) on Washita River; E, Bridgeport streamgage (07228500) on Canadian River; F, Cement streamgage (07327447) on Little Washita River; G, Cobb Creek streamgage (07325800) on Cobb Creek; $H$, Lake Creek streamgage (07325850) on Lake Creek; and I, Willow Creek streamgage (07325860) on Willow Creek for the numerical groundwater-flow model of the Rush Springs aquifer, western Oklahoma, 1979-2015.-Continued 
E. Bridgeport streamgage (07228500) on Canadian River

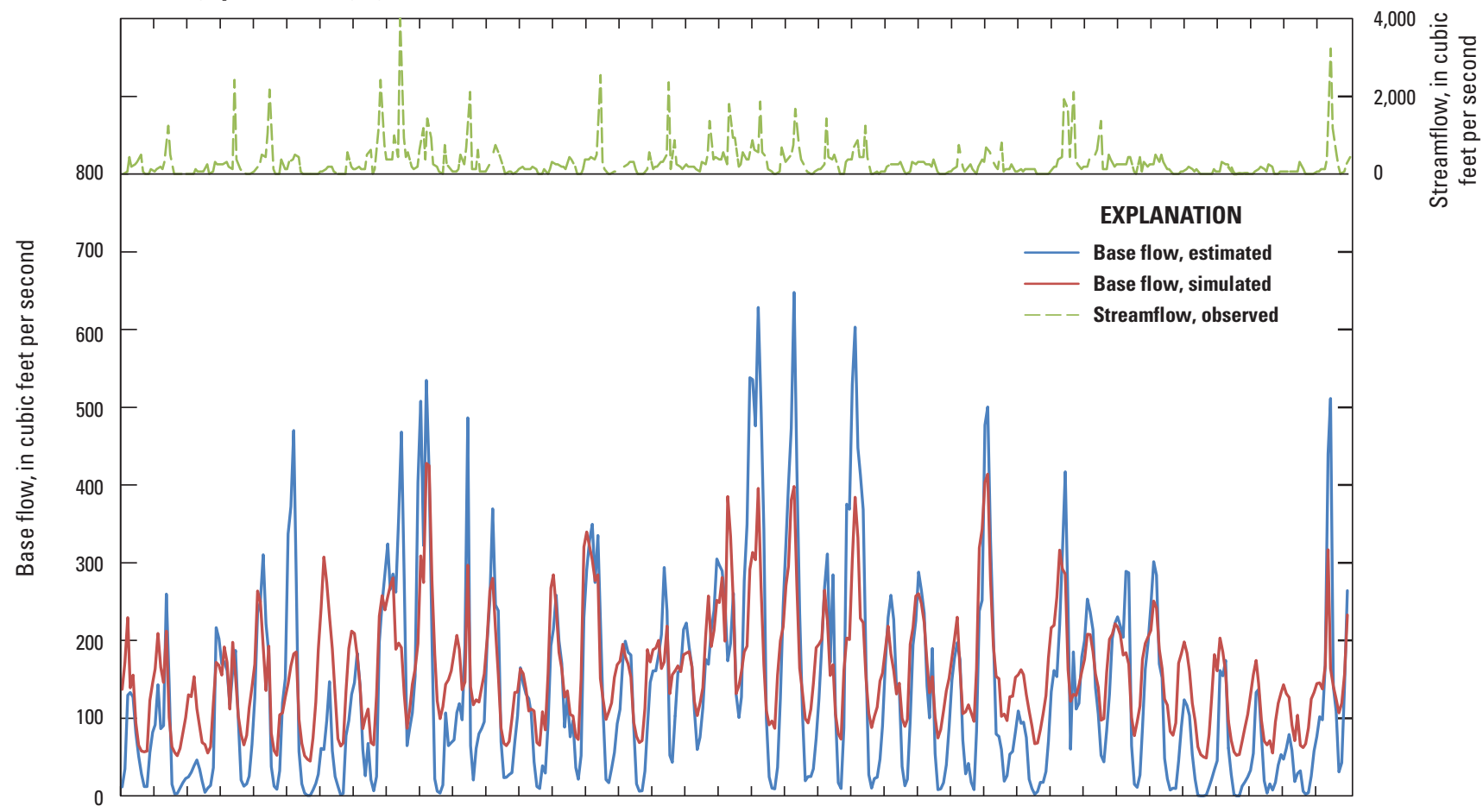

F. Cement streamgage (07327447) on Little Washita River

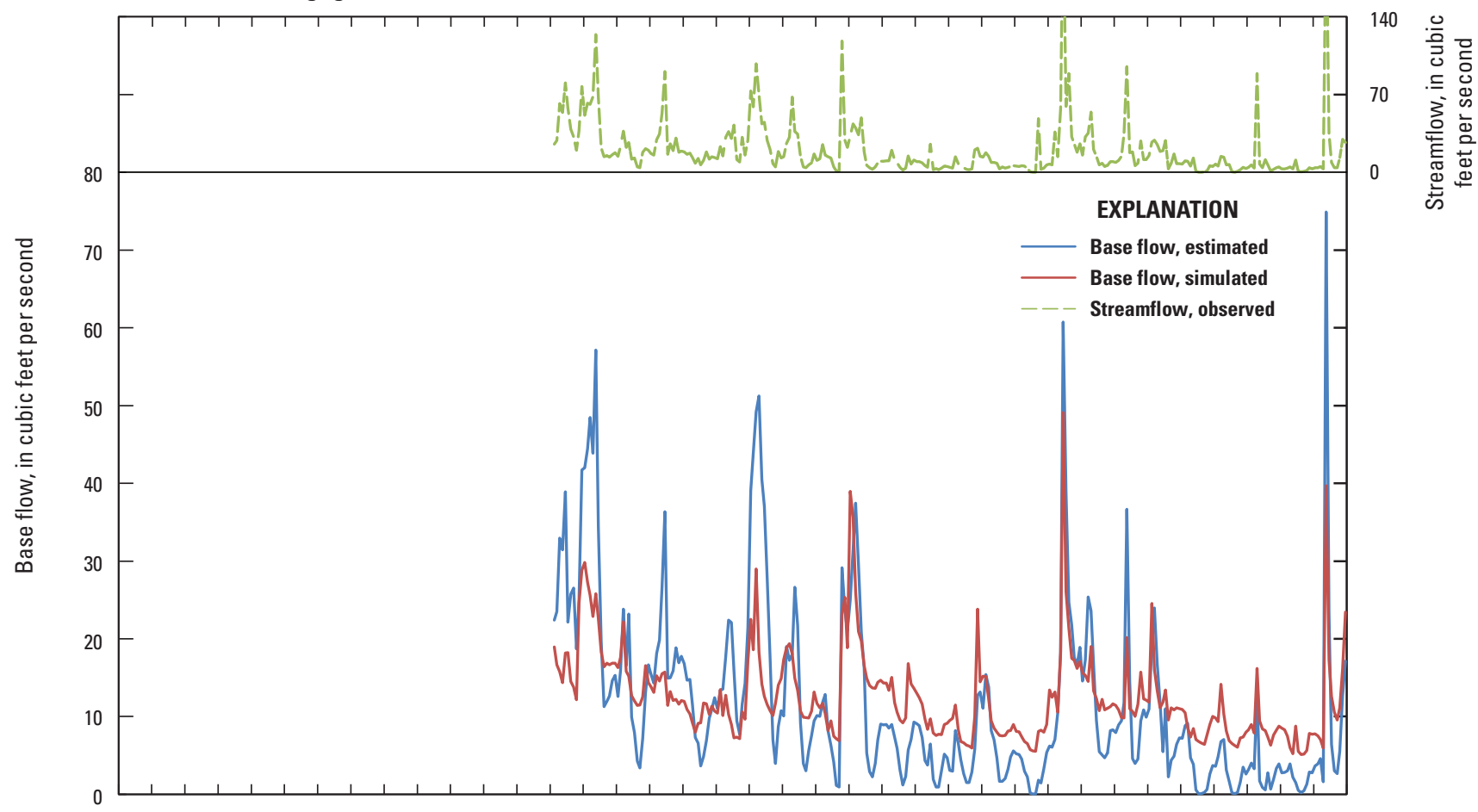

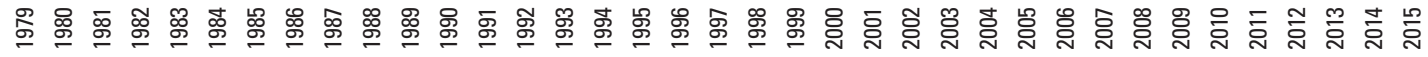

Year

Figure 34. Observed streamflow, estimated base flow, and simulated base flow at $A$, Hammon streamgage (07324200) on Washita River; $B$, Clinton streamgage (07325000) on Washita River; $C$, Carnegie streamgage (07305500) on Washita River; D, Anadarko streamgage (07326500) on Washita River; E, Bridgeport streamgage (07228500) on Canadian River; $F$, Cement streamgage (07327447) on Little Washita River; $G$, Cobb Creek streamgage (07325800) on Cobb Creek; H, Lake Creek streamgage (07325850) on Lake Creek; and $I$, Willow Creek streamgage (07325860) on Willow Creek for the numerical groundwater-flow model of the Rush Springs aquifer, western Oklahoma, 1979-2015.-Continued 
G. Cobb Creek streamgage (07325800) on Cobb Creek

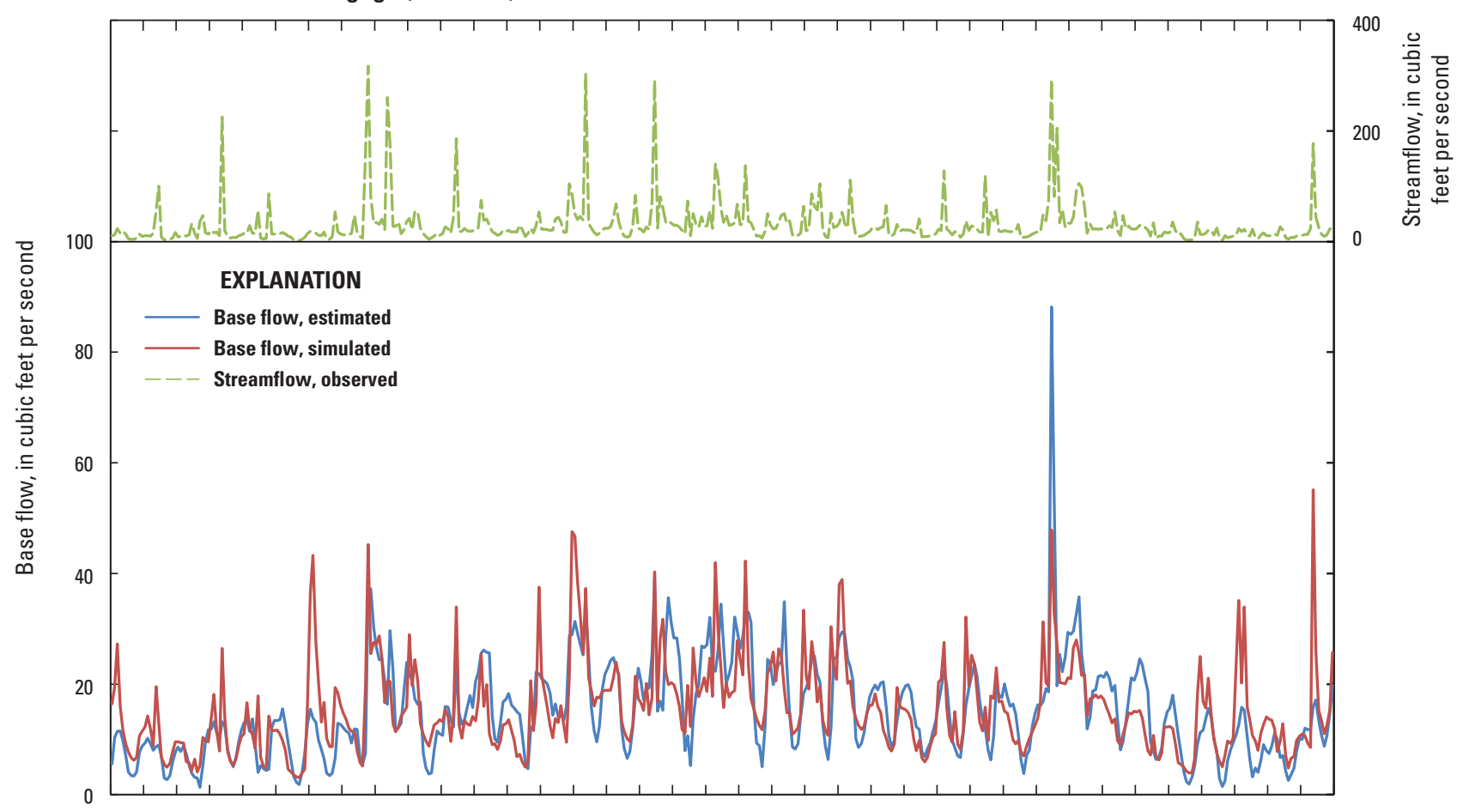

H. Lake Creek streamgage (07325850) on Lake Creek

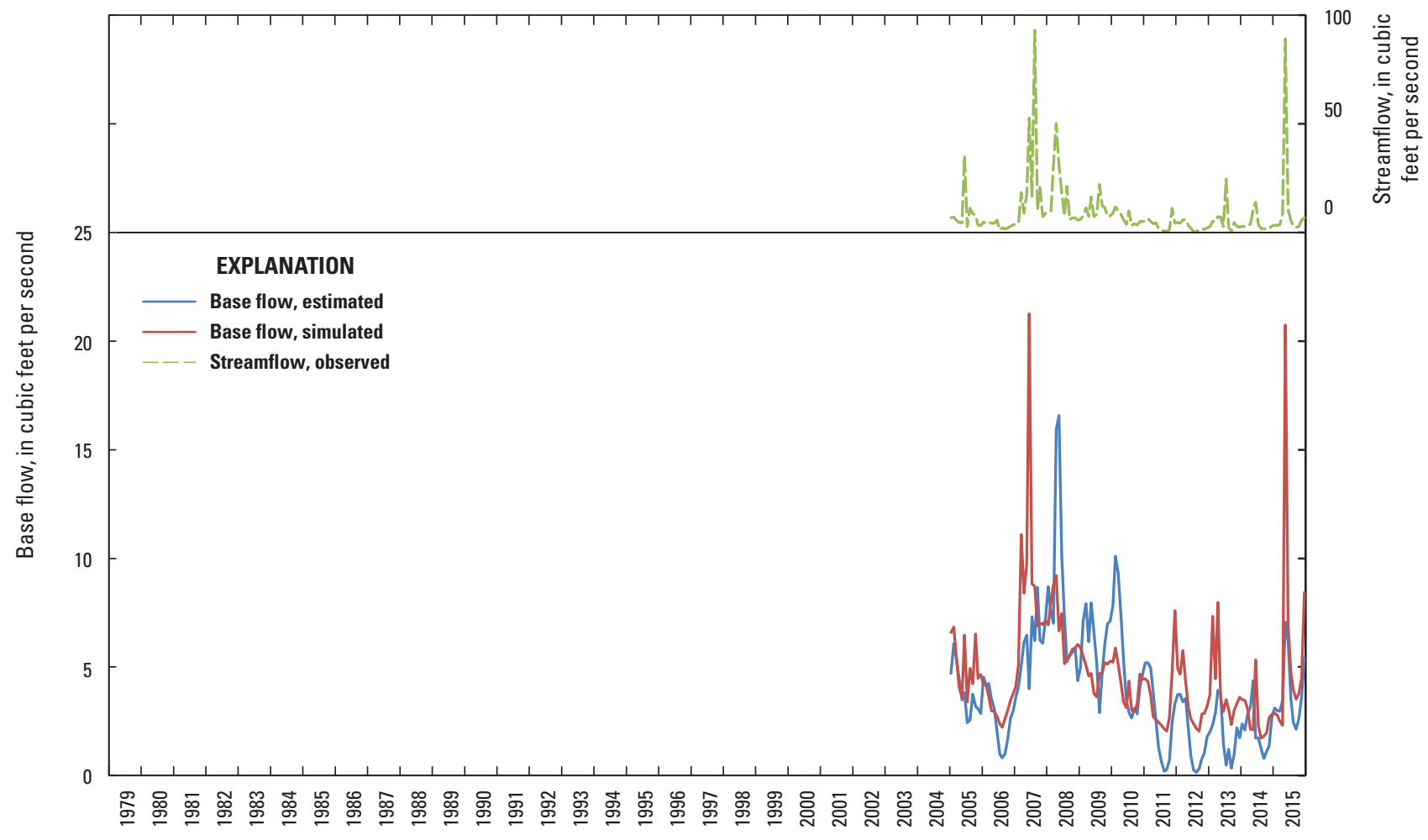

Year

Figure 34. Observed streamflow, estimated base flow, and simulated base flow at $A$, Hammon streamgage (07324200) on Washita River; $B$, Clinton streamgage (07325000) on Washita River; $C$, Carnegie streamgage (07305500) on Washita River; $D$, Anadarko streamgage (07326500) on Washita River; E, Bridgeport streamgage (07228500) on Canadian River; F, Cement streamgage (07327447) on Little Washita River; G, Cobb Creek streamgage (07325800) on Cobb Creek; H, Lake Creek streamgage (07325850) on Lake Creek; and I, Willow Creek streamgage (07325860) on Willow Creek for the numerical groundwater-flow model of the Rush Springs aquifer, western Oklahoma, 1979-2015.-Continued 
I. Willow Creek streamgage (07325860) on Willow Creek

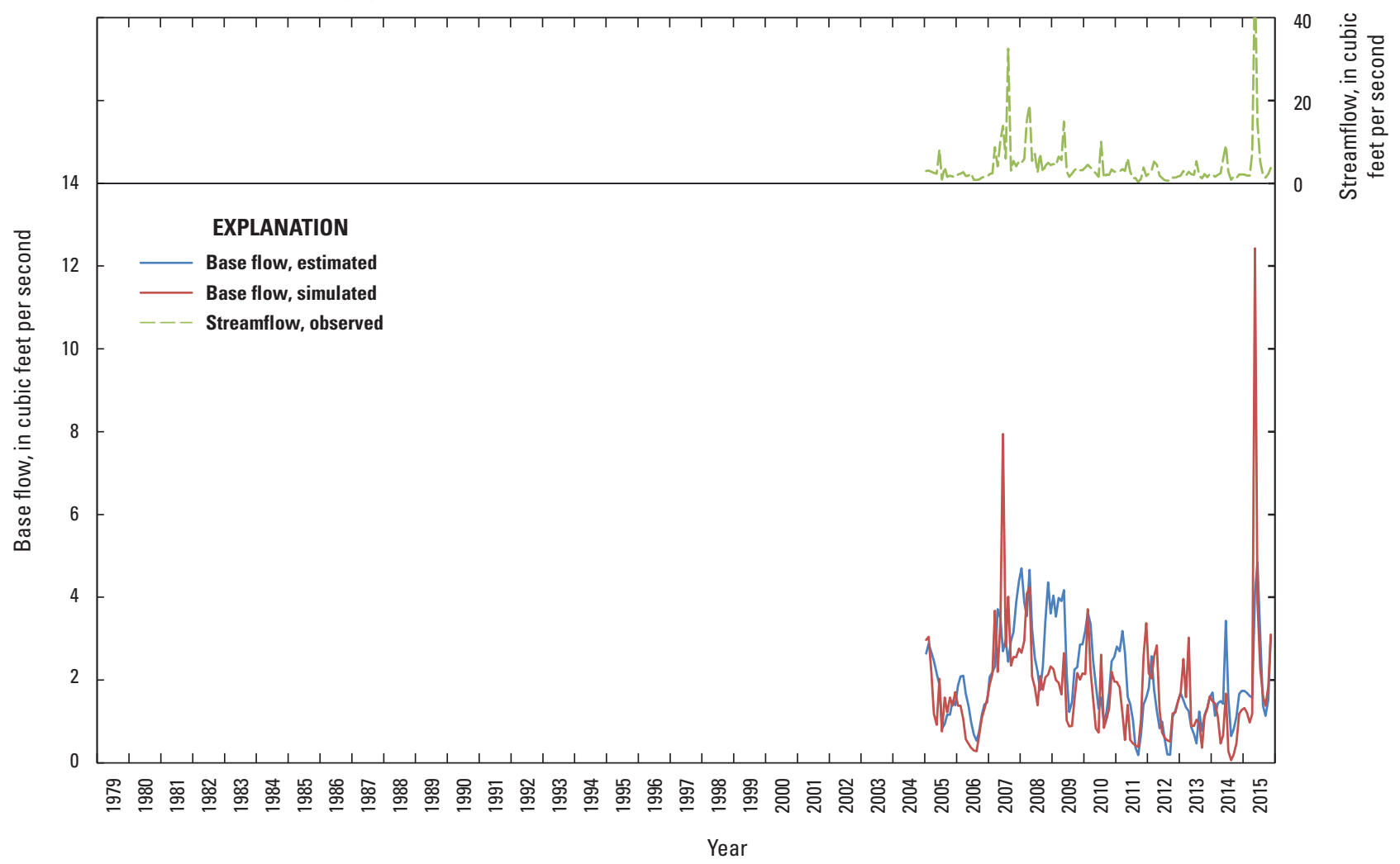

Figure 34. Observed streamflow, estimated base flow, and simulated base flow at $A$, Hammon streamgage (07324200) on Washita River; $B$, Clinton streamgage (07325000) on Washita River; $C$, Carnegie streamgage (07305500) on Washita River; $D$, Anadarko streamgage (07326500) on Washita River; $E$, Bridgeport streamgage (07228500) on Canadian River; F, Cement streamgage (07327447) on Little Washita River; G, Cobb Creek streamgage (07325800) on Cobb Creek; $H$, Lake Creek streamgage (07325850) on Lake Creek; and $I$, Willow Creek streamgage (07325860) on Willow Creek for the numerical groundwater-flow model of the Rush Springs aquifer, western Oklahoma, 1979-2015.-Continued

Base flows were somewhat overpredicted during periods of lower base flows (winter and summer months) and underpredicted during periods of higher base flows (fall and spring months). Overpredicted base flows were likely the result of undersimulated ETg because increases in ETg in the model reduced summer low-flow residuals. Underpredicted base flows at the Washita River streamgages during highflow periods indicate that estimated base flows probably were overestimated by BFI because of reservoir releases from Foss or Fort Cobb Reservoirs that could not easily be removed from the base-flow estimates. Reservoir releases from Foss and Fort Cobb Reservoirs did not occur for about half of the total number of stress periods. For these stress periods when reservoir releases did not occur, the RMSE for the Clinton (07325000), Carnegie (07325500), and Anadarko (07326500) streamgages decreased by 65 percent, 54 percent, and 68 percent, respectively; the 75-percent residual range decreased by 38 percent, 27 percent, and 28 percent, respectively. Thus, the model generally simulates patterns in estimated base flow with more error present in months in which reservoir releases occur. Recharge processes such as bank storage flow or interflow that mostly operate on a submonthly time scale also could contribute to underpredicted base flows. Bank storage flows (Chen, 2003), by which floodwater infiltrates the aquifer and is released days to weeks after the floodwater recedes, may increase base flows during periods of no new recharge. The primary source of water to the aquifer is recharge, so large positive base-flow residuals also could be caused by underpredicted or incorrectly distributed recharge. Additionally, maximum base-flow differences of $1,000-2,000 \mathrm{ft}^{3} / \mathrm{s}$ between consecutive stress periods could not easily be reproduced in the model.

\section{Reservoir Stage and Water Budget}

The mean Fort Cobb Reservoir stage residual was $0.1 \mathrm{ft}$ (table 10), indicating that the mean simulated stage was slightly lower than the mean observed stage (fig. 35A). The RMSE of Fort Cobb Reservoir stage residuals was $0.6 \mathrm{ft}$, and 75 percent of the simulated reservoir stage values were within $\pm 0.7 \mathrm{ft}$ of the observed stage values (table 10). The minimum simulated stage was $0.1 \mathrm{ft}$ lower than the minimum observed stage, and the maximum simulated stage was $0.2 \mathrm{ft}$ higher than 
the maximum observed stage. The largest Fort Cobb Reservoir stage residuals occurred in late 1984 and early 1986 when the observed reservoir stage was relatively low (fig. 35A). Fort Cobb Reservoir stage was also slightly overpredicted during drought conditions in 2011-14 when base flows at the Cobb Creek (07325800), Lake Creek (07325850), and Willow Creek (07325860) streamgages were generally overpredicted (figs. 34G - I and 35A).

Simulated storage in Fort Cobb Reservoir increased by about 4,000 acre-ft during the study period (fig. 36B). Storage in Fort Cobb Reservoir between 2001 and 2007 reflected precipitation trends, where large shifts in precipitation occurred during each subsequent year (fig. 7); thus, the stage and water budget in Fort Cobb Reservoir for these years tended to oscillate on a year-to-year basis more than in other periods. Between 2011 and 2014, actual withdrawals averaged about 60 percent of the permitted withdrawal volume
Table 10. Statistical summary of Fort Cobb Reservoir stage residuals for the numerical groundwater-flow model of the Rush Springs aquifer, western Oklahoma, 1979-2015.

[Observed and simulated stage values for Fort Cobb Reservoir are in feet relative to the North American Vertical Datum of 1988; RMSE, root-mean-square error; \pm , plus or minus]

\begin{tabular}{lcrc}
\hline \multirow{2}{*}{ Observation } & \multicolumn{3}{c}{ Fort Cobb Reservoir stage } \\
\cline { 2 - 4 } & Minimum & Mean & Maximum \\
\hline Observed & $1,334.8$ & $1,341.2$ & $1,349.3$ \\
Simulated & $1,334.7$ & $1,341.1$ & $1,349.5$ \\
Mean residual, in feet & & 0.1 & \\
RMSE, in feet & & 0.6 & \\
75-percentile residual & & \pm 0.7 & \\
range, in feet & & & \\
\hline
\end{tabular}
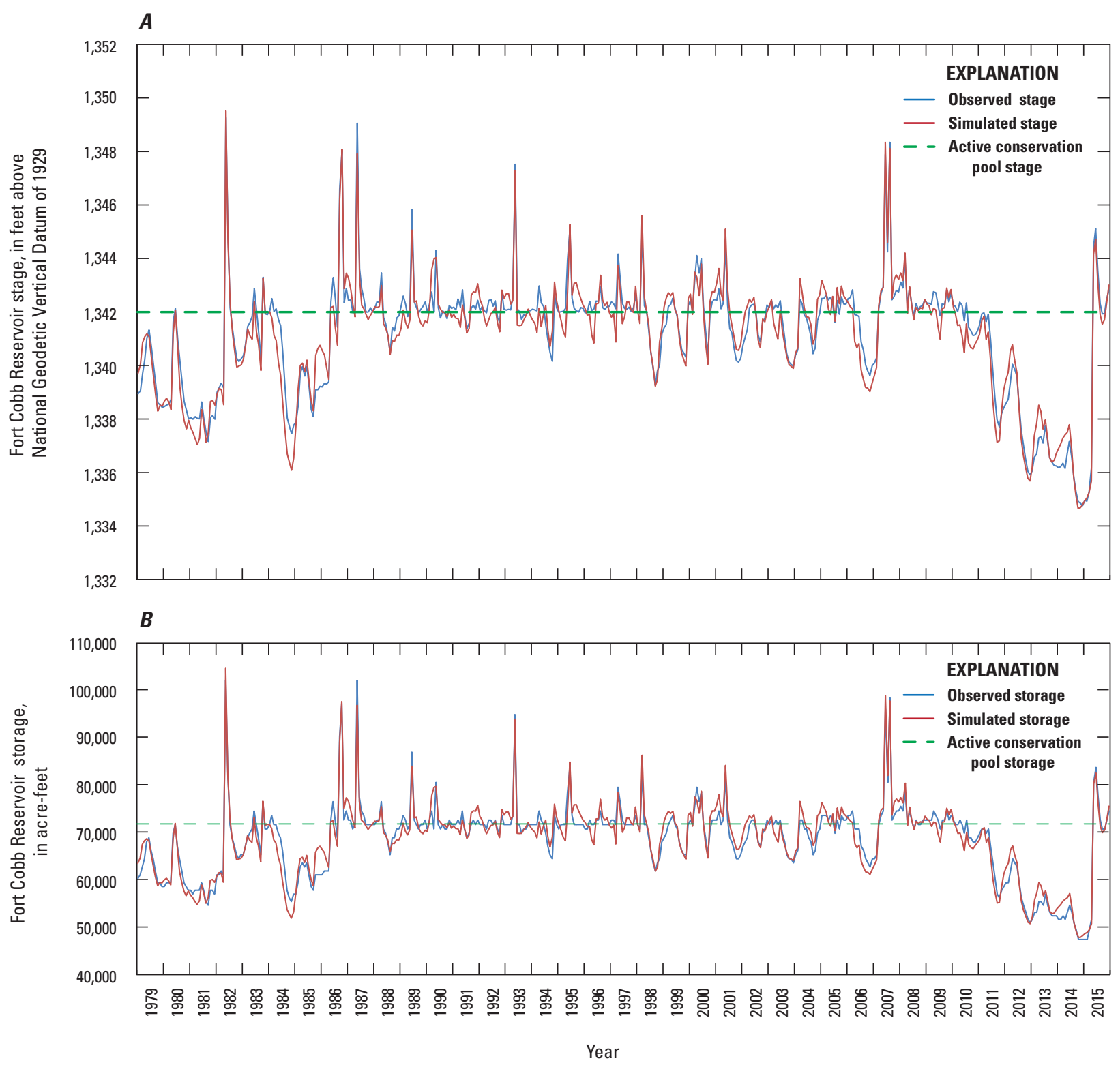

Figure 35. Fort Cobb Reservoir observed and simulated $A$, stage and $B$, storage for the numerical groundwater-flow model of the Rush Springs aquifer, western Oklahoma, 1979-2015. 
$\boldsymbol{A}$

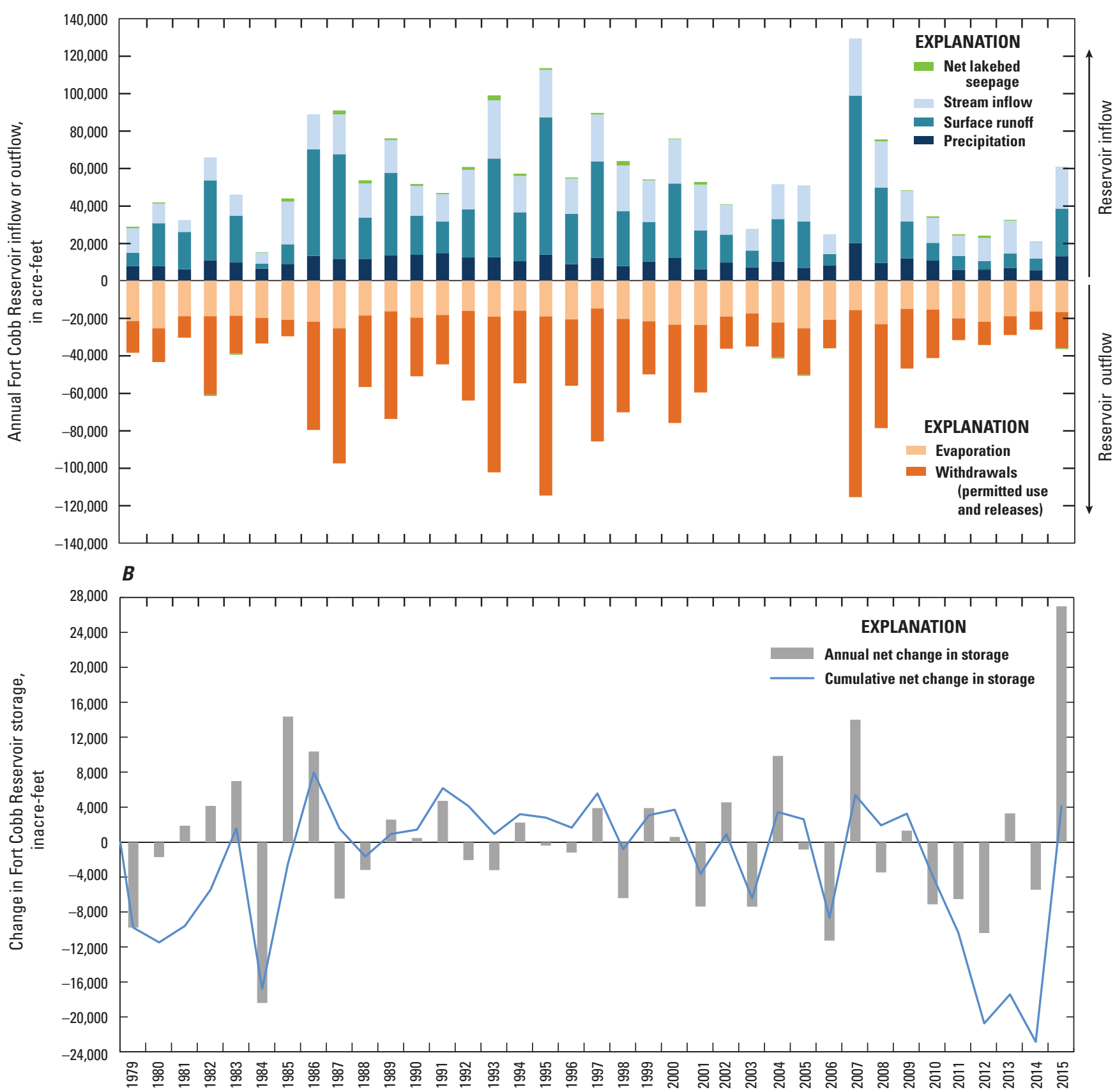

Year

Figure 36. A, Annual reservoir inflows and outflows and $B$, change in storage for Fort Cobb Reservoir in the numerical groundwater model of the Rush Springs aquifer, western Oklahoma, 1979-2015.

(18,000 acre-ft/yr), and stage in Fort Cobb Reservoir dropped to about 1,335 ft in 2014, or 68 percent of active conservation pool storage (fig. 35). This stage was the lowest since 1961 (Reclamation, 2017a). This decrease in stage corresponds with a decrease in base flow to Cobb, Lake, and Willow Creeks during this period (table 2). Because more than half of the streamflow in Cobb, Lake, and Willow Creeks upstream from Fort Cobb Reservoir occurs as base flow (table 2), groundwater-level declines in the aquifer upgradient from Fort
Cobb Reservoir greatly affect stage and storage. Therefore, Fort Cobb Reservoir storage for permitted withdrawals is dependent on base-flow inflows.

Fort Cobb Reservoir and the surrounding Rush Springs aquifer are hydrologically connected; therefore, declines in Fort Cobb Reservoir stage and storage were expected to occur during periods of declining groundwater levels in the aquifer. Although the simulated groundwater levels in the aquifer adjacent to the reservoir were lower than the observed 
groundwater levels (fig. 30), mean monthly lakebed seepage was less than 17 percent of the reservoir inflows or outflows in 95 percent of the stress periods. Additionally, the annual imbalances between lakebed seepage to the reservoir, which was greatest in April and September when the stage was typically low, and lakebed seepage from the reservoir, which was greatest in May and June when the stage was typically highest, were not large. Thus, simulated groundwater-level declines adjacent to Fort Cobb Reservoir had a lesser effect on stage and storage than declines in base flow.

\section{Calibrated Water Budget}

The calibrated water budget for the Rush Springs aquifer model (table 11; fig. 37) lists mean annual inflows and outflows for the model period. Simulated recharge was the largest inflow (91 percent); lateral groundwater inflow was about 5 percent, seepage from streams was about 4 percent, and lakebed seepage was less than 1 percent of total inflows. Seepage to streams was the largest outflow (56 percent); seeps and springs were about 20 percent, ETg was about 13 percent, groundwater use was about 9 percent, lateral groundwater

Table 11. Mean annual calibrated water budget for the numerical groundwater-flow model of the Rush Springs aquifer, western Oklahoma, 1979-2015.

[Net budget totals are calculated as inflow minus outflow; therefore, positive values indicate net inflow, and negative numbers indicate net outflow; may not sum to totals because of rounding; \%, percent; <, less than]

\begin{tabular}{|c|c|c|}
\hline Water-budget category & $\begin{array}{l}\text { Amount } \\
\text { (acre-feet } \\
\text { per year) }\end{array}$ & $\begin{array}{c}\text { Percentage } \\
\text { of water } \\
\text { budget }\end{array}$ \\
\hline \multicolumn{3}{|c|}{ Inflow } \\
\hline Recharge $^{1}$ & 578,676 & $91 \%$ \\
\hline Lateral groundwater inflow & 30,586 & $5 \%$ \\
\hline Seepage from streams & 24,415 & $4 \%$ \\
\hline Lakebed seepage & 1,244 & $<1 \%$ \\
\hline Total inflow & 634,921 & $100 \%$ \\
\hline \multicolumn{3}{|c|}{ Outflow } \\
\hline Seepage to streams & 353,329 & $56 \%$ \\
\hline Seeps and springs & 122,779 & $20 \%$ \\
\hline $\begin{array}{l}\text { Saturated-zone evapotranspirati } \\
\text { (ETg) }\end{array}$ & 78,319 & $13 \%$ \\
\hline Groundwater use & 57,719 & $9 \%$ \\
\hline Lateral groundwater outflow & 12,349 & $2 \%$ \\
\hline Lakebed seepage & 1,873 & $<1 \%$ \\
\hline Total outflow & 626,368 & $100 \%$ \\
\hline \multicolumn{3}{|c|}{ Net water-budget totals } \\
\hline Stream seepage & $-328,914$ & \\
\hline Lakebed seepage & -629 & \\
\hline Lateral groundwater flow & 18,237 & \\
\hline Change in groundwater storage & 8,553 & \\
\hline
\end{tabular}

${ }^{1}$ Equals about 2.2 inches per year over the aquifer area of 3,181,003 acres. outflow was about 2 percent, and lakebed seepage was less than 1 percent of total outflows.

The mean annual recharge for the calibrated water budget (578,676 acre-ft/yr; table 11) was about 4 percent greater than that of the conceptual water budget (556,675 acre-ft/yr; table 3). This difference corresponds to a rate of $0.1 \mathrm{in} / \mathrm{yr}$.

Rush Springs aquifer inflows, in percent (table 11)

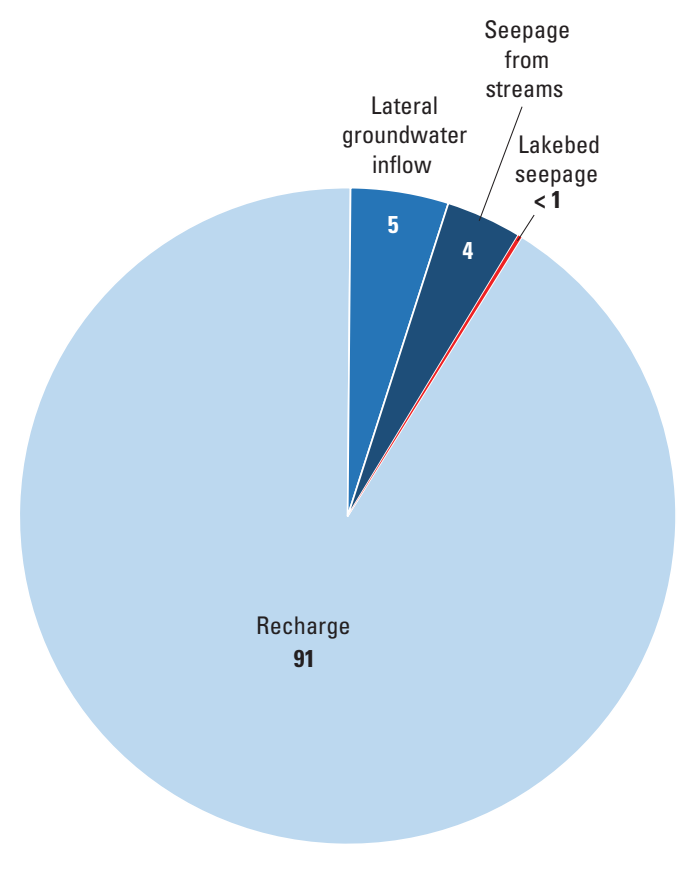

Rush Springs aquifer outflows, in percent (table 11)

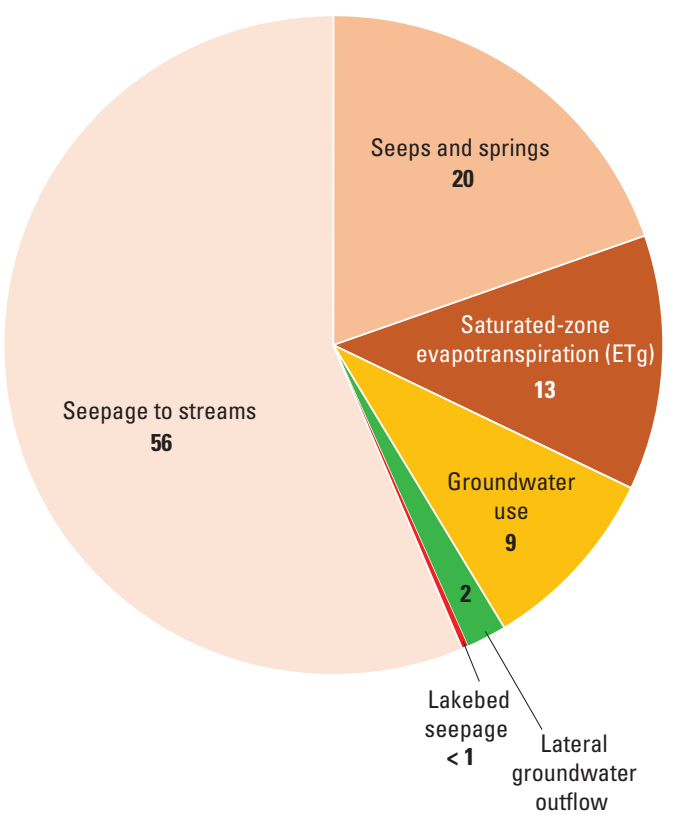

Note: Components may not sum to totals because of rounding.

Figure 37. Mean annual calibrated water budget for the numerical groundwater model of the Rush Springs aquifer, western Oklahoma, 1979-2015. 
Mean annual stream seepage (fig. 38) for the calibrated water budget (328,914 acre-ft/yr; table 11) was about 27 percent greater than that of the conceptual water budget $(259,161 \mathrm{acre}-\mathrm{ft} / \mathrm{yr}$; table 3$)$. However, this stream seepage value for the calibrated water budget includes several ungaged streams in various areas of the model that are not tributaries to the Canadian or Washita Rivers (fig. 38). The sum of the calibrated mean annual stream seepage (258,465 acre-ft/yr; fig. 38) for the gaged streams (Washita River and tributaries, Canadian River and tributaries, Little Washita River and tributaries, and Fort Cobb Reservoir tributaries) was about 15 percent greater than the BFI-estimated mean annual stream seepage (225,357 acre-ft/yr; see "Streamflow Characteristics and Seepage" section).

The simulated mean annual stream seepage for the Canadian River and tributaries (69,688 acre-ft/yr; fig. 38) was about 37 percent greater than that of the BFI-estimated mean annual stream seepage (51,016 acre-ft/yr). Similar patterns occurred between the simulated stream seepage and seepage measurements conducted in 2013 (Ellis and others, 2017, fig. 14). When compared with the seepage measurements, the simulated stream seepage was overpredicted west of Taloga (fig. 1) and underpredicted between Taloga and the Bridgeport streamgage (07228500) (fig. 38). The two stream segments north of the confluence of Deer Creek and the Canadian River are the only losing stream segments in the model located on a gaged stream other than a segment between the Willow Creek streamgage (07325860) and Fort Cobb Reservoir (fig. 38). The simulated losing stream segments were caused by underpredicted groundwater levels in the area that are below the bottom of the streambed in these segments.

The simulated mean annual stream seepage for the Washita River (150,956 acre-ft/yr; fig. 38) was within 3 percent of the BFI-estimated mean annual stream seepage (146,914 acre-ft/yr). The simulated stream seepage was underpredicted between the Clinton (07325000) and Carnegie (07305500) streamgages, and overpredicted between the Carnegie (07325500) and Anadarko (07326500) streamgages. Stream seepage in the northeastern, eastern, southeastern, southern, and western areas of the model (fig. 38) were typically less than $1 \mathrm{ft}^{3} / \mathrm{s}$ (724 acre-ft/yr) in each segment with the exception of several stream segments located at the northern and southern extremes of the model. These segments drained areas that had persistently high simulated groundwater levels.
Simulated seeps and springs (122,779 acre-ft/yr; table 11$)$ were about 21 percent less than that of the conceptual water budget $(155,507$ acre-ft/yr; table 3$)$, reflecting uncertainty in estimating this component for which published discharge rates were unavailable. Mean annual net lateral groundwater flow for the calibrated model (18,237 acre-ft/yr; table 11) was about 9 percent greater than that of the conceptual water budget (16,700 acre-ft/yr; table 3). Mean annual ETg for the calibrated model (78,319 acre-ft/yr; table 11) was about 16 percent less than that of the conceptual water budget (92,945 acre-ft/yr; table 3). Because unreasonably long model run times are associated with larger ETg areas and rates, the area where ETg was simulated and the simulated ETg rate were decreased in the simulation.

The mean simulated annual groundwater use (57,719 acre-ft/yr; table 11$)$ was about 12 percent less than the conceptual water budget $(65,763$ acre-ft/yr; table 3) because of the threshold applied to large pumping rates and because of a lack of saturation in some cells where groundwater use occurred. Additionally, groundwater use may be overestimated for the Rush Springs aquifer, particularly the Fort Cobb Reservoir watershed (fig. 10), where 52 percent of mean annual groundwater use occurs. Groundwater use for the irrigation of winter wheat, which is the predominant crop overlying the Rush Springs aquifer and the Fort Cobb Reservoir watershed (NASS, 2017), may be overestimated by approximately 10 percent (Masoner and others, 2003).

Simulated groundwater storage at the end of the model period (2015) was 44,837,437 acre-ft, and mean simulated groundwater storage for the model period was $44,830,760$ acre-ft (Ellis, 2018). Because of the difficulty associated with estimating total recoverable groundwaterwhereby groundwater pumping cannot extract the entire volume of water from the aquifer-these simulated groundwater storage values represent theoretical volumes. However, these values are useful for comparisons of changes in groundwater storage caused by aquifer stresses.

For the model period 1979-2015, mean annual simulated inflows exceeded outflows by 8,553 acre-ft/yr (table 11). This difference corresponds to a cumulative net storage increase of about 353,581 acre-ft (fig. 39), or a cumulative net groundwater-level increase of $1.6 \mathrm{ft}$. This increase in storage occurred largely as a result of (1) a period of sustained greater than mean annual recharge between 1985 and 2000 and (2) recharge in 2007 and 2015, which are the first and third largest recharge events during the model period (fig. 39) that were substantially greater than the mean annual recharge. 


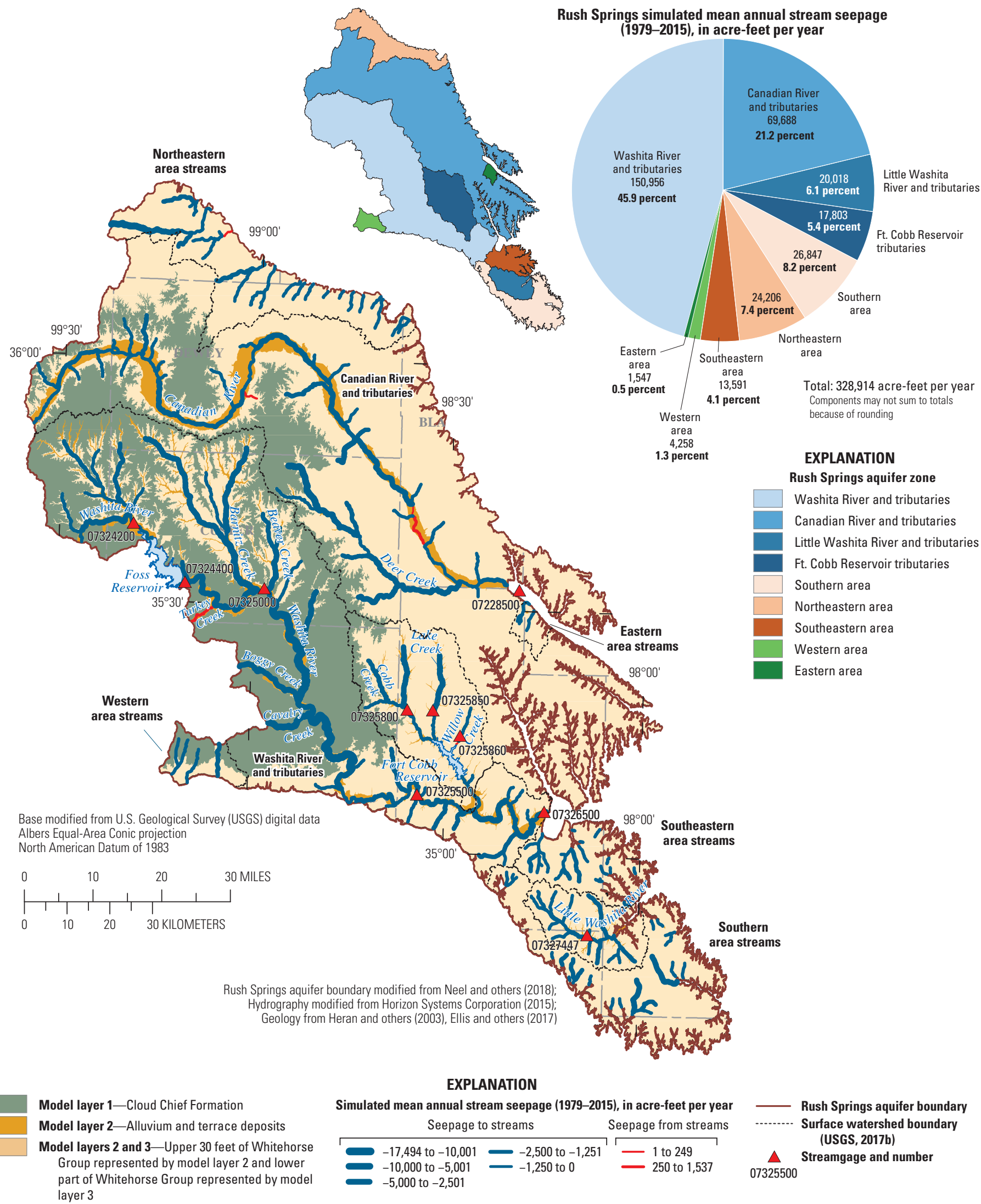

Figure 38. Simulated stream seepage for the numerical groundwater-flow model of the Rush Springs aquifer, western Oklahoma, 1979-2015. 


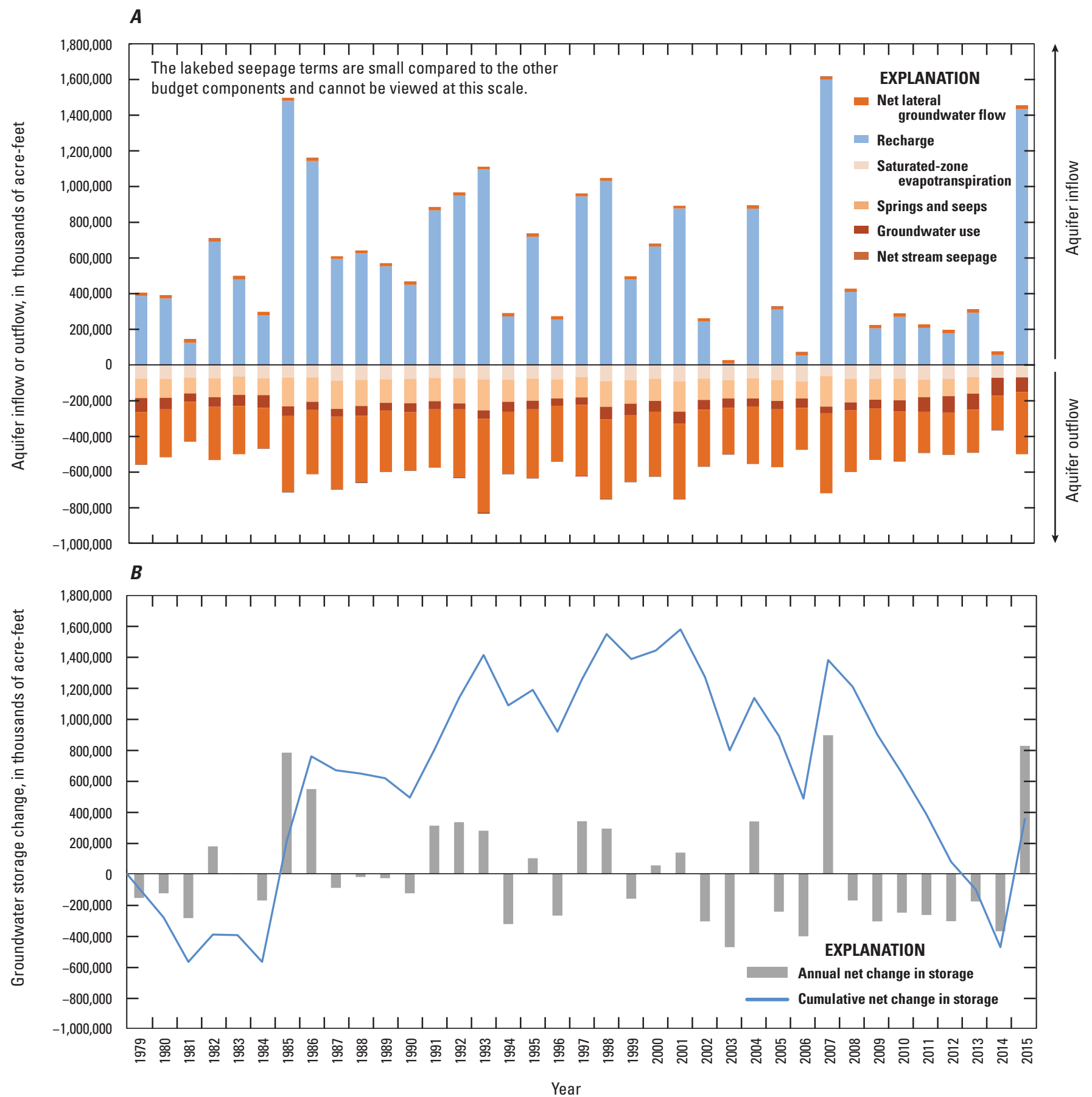

Figure 39. $A$, Annual mean inflows and outflows and $B$, annual change in groundwater storage for the numerical groundwater-flow model of the Rush Springs aquifer, western Oklahoma, 1979-2015.

Simulated annual groundwater storage changes reflect climatic trends during the model period (fig. 39). From 1979 to 1984, cumulative storage decreased (fig. 39) because of a period of mean to lower than mean precipitation (fig. 7). A relatively long period of above-mean precipitation occurred between 1985 and 2000 (fig. 7), which provided a substantial amount of recharge to the aquifer, resulting in a cumulative storage increase (fig. 39). This period was followed by a period of generally below-mean precipitation between 2001 and 2006 (fig. 7), whereby cumulative storage decreased (fig. 39). The drought conditions between 2009 and 2014 (fig. 7) resulted in a sustained decrease of groundwater in storage (fig. 39). By comparison, the cumulative storage change between 2009 and 2014 (about 1,376,000 acre-ft; fig. 39) is slightly greater than 19 times the volume of water stored in Fort Cobb Reservoir at the active conservation pool stage.

Recharge composes 91 percent of the total simulated inflow to the aquifer (fig. 39; table 11). Therefore, precipitation 
changes greatly affect groundwater storage and the annual water budget, which is several times larger in years with substantial precipitation events compared with years of belowmean precipitation. During extended periods of below-mean precipitation, groundwater use substantially increased — such as during 2014 and 2015, when groundwater use was 92 and 53 percent greater, respectively, than the average (Neel and others, 2018, fig. 16) - which compounded the effects on groundwater storage. Because simulated groundwater levels were overpredicted during and after large precipitation events, the simulated inflows in these years may also be overestimated.

Mean simulated aquifer inflows, primarily from recharge and seepage from streams, tended to be greatest during January through March (fig. 40A), which corresponds to months of above-mean recharge (fig. 8B). Mean simulated aquifer outflows, primarily from seepage to streams, ETg, and groundwater use, were greatest in July and August (fig. 40A). During those summer months, seepage to streams was reduced by groundwater-level declines from large ETg outflows and groundwater use, which was primarily for irrigation. Mean monthly outflows exceeded mean monthly inflows in 4 of 12 months (fig. 40B).

\section{Calibrated Parameter Values}

The calibrated parameter values for the model (table 6) represent updates to the initial values estimated from available hydraulic data or from the conceptual water budget. Only 753 of 842 parameters remained adjustable throughout the calibration process (table 6). A total of 89 parameters were fixed during the calibration process - mostly because of stability-related issues. Five of the 753 parameters had no effect on model calibration; each of these parameters were in the Washita River alluvium (layer 2) in the western part of the model where few calibration targets were available (fig. 25).

\section{Calibrated GHB and Drain Conductance}

Calibrated mean and maximum GHB conductances for the six GHB conductance zones (fig. 15) were 660 and $2,000 \mathrm{ft}^{2} / \mathrm{d}$, respectively (table 6). Increases in the GHB conductance resulted in increased flow to the western area of the model underlying the Cloud Chief Formation, where most groundwater levels were underpredicted. However, these GHB conductance increases also resulted in (1) larger base flow and stream seepage residuals for the Canadian River, when the simulated base flow could not match the lower estimated base flow (fig. 34E ), and (2) larger groundwater-level residuals in the northern area of the model where most groundwater levels were somewhat overpredicted (fig. 30).
Calibrated mean and maximum drain conductances for the 11 drain conductance zones were 207 and $501 \mathrm{ft}^{2} / \mathrm{d}$, respectively (table 6). Although drain conductance increases for zone 10 (drn10; fig. 15) reduced the groundwater-level residuals near that zone, increases in the groundwater-level residuals occurred for simulated groundwater levels around Fort Cobb Reservoir. A similar number of groundwater-level observations were available for the Fort Cobb Reservoir watershed, where groundwater levels were underpredicted, and the area around zone 10, where levels were overpredicted (fig. 30). However, the 445 monthly stage observations at Fort Cobb Reservoir provided a greater contribution to the objective function than these groundwater-level observations; therefore, no objective function improvement was seen when this drain conductance was increased.

\section{Calibrated Recharge}

Calibrated recharge was increased from the conceptual water budget by using recharge multipliers applied to the 23 recharge zones (fig. 20). Calibrated recharge was increased and decreased in 11 zones each and was unchanged in 1 zone (table 6). The recharge multiplier zones were substantially different in areal extent, whereby 4 of the 23 zones (zones 14, 15,17 , and 19; fig. 20) account for just over half of the aquifer area. Although spatially distributed recharge could have been further discretized into smaller zones, there was no apparent geologic or hydrologic basis for doing so. Additionally, further increases in the number of parameters, when combined with the lengthy model run times (approximately 9 hours), would have been impractical.

Spatially, calibrated mean annual recharge (fig. 41) decreased from the initial mean annual recharge (fig. 9) in the northern, eastern, and alluvium and terrace areas because groundwater levels were mostly overpredicted in those areas (fig. 30). Calibrated recharge increased in the southern and western model areas and Fort Cobb Reservoir watershed because groundwater levels were mostly underpredicted in those areas (fig. 30). These calibrated recharge changes generally resulted in increased recharge in areas of greater groundwater development and decreased recharge in areas of lesser development. Calibrated mean annual recharge in the Fort Cobb Reservoir watershed was 3.6 in/yr. The increase in mean annual recharge from the initial SWB estimate (1.8 in/yr) to the calibrated value (3.6 in/yr) was comparable but slightly greater than the mean annual increase in estimated recharge from crop irrigation (1.3 to $1.6 \mathrm{in} / \mathrm{yr}$ ) compared to rangeland (McMahon and others, 2006) that is not irrigated. Therefore, when accounting for the effects of recharge from irrigation, the calibrated mean annual recharge of $3.6 \mathrm{in} / \mathrm{yr}$ may be more indicative of recharge to the Fort Cobb Reservoir watershed. 
$\boldsymbol{A}$

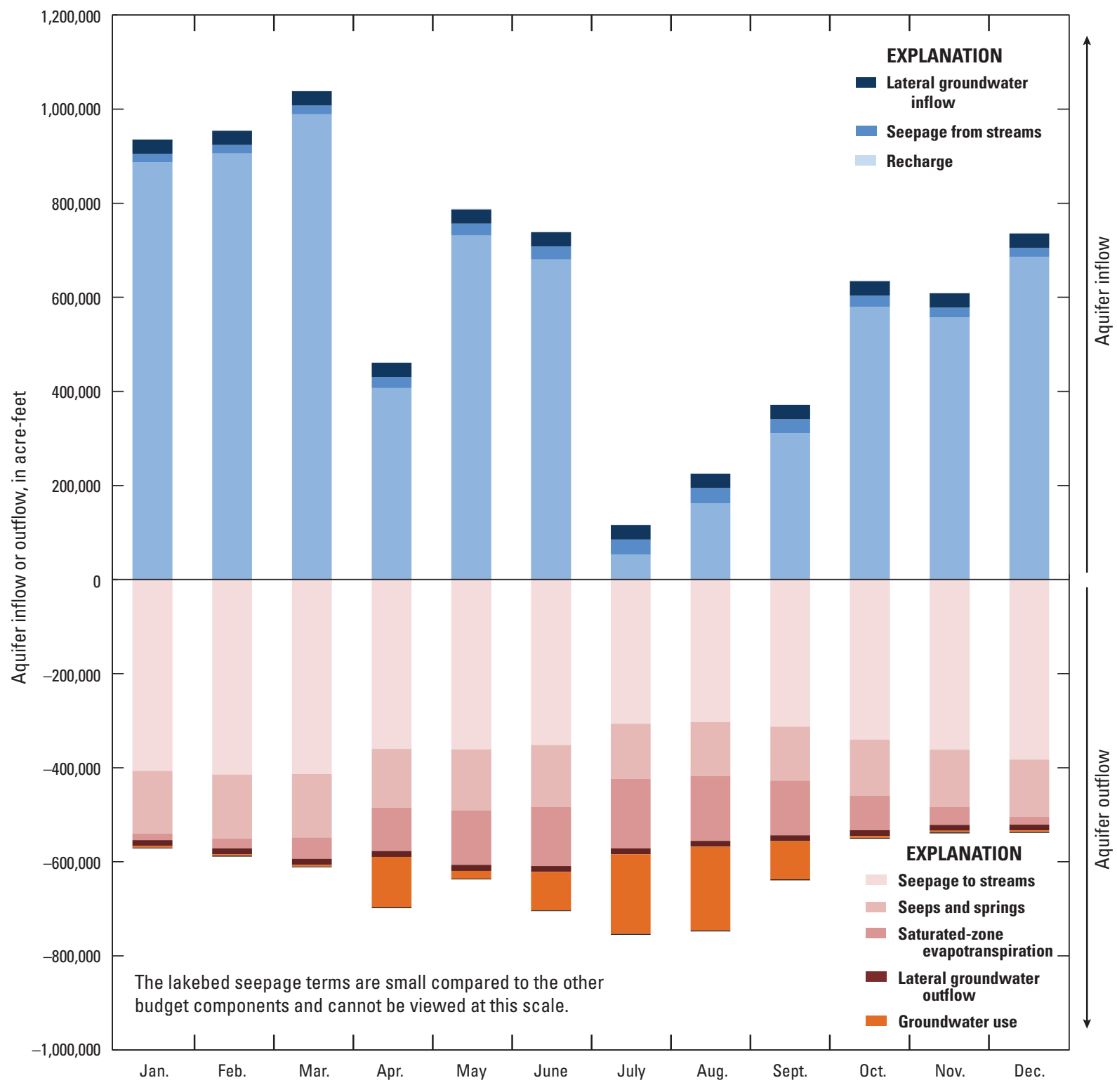

B

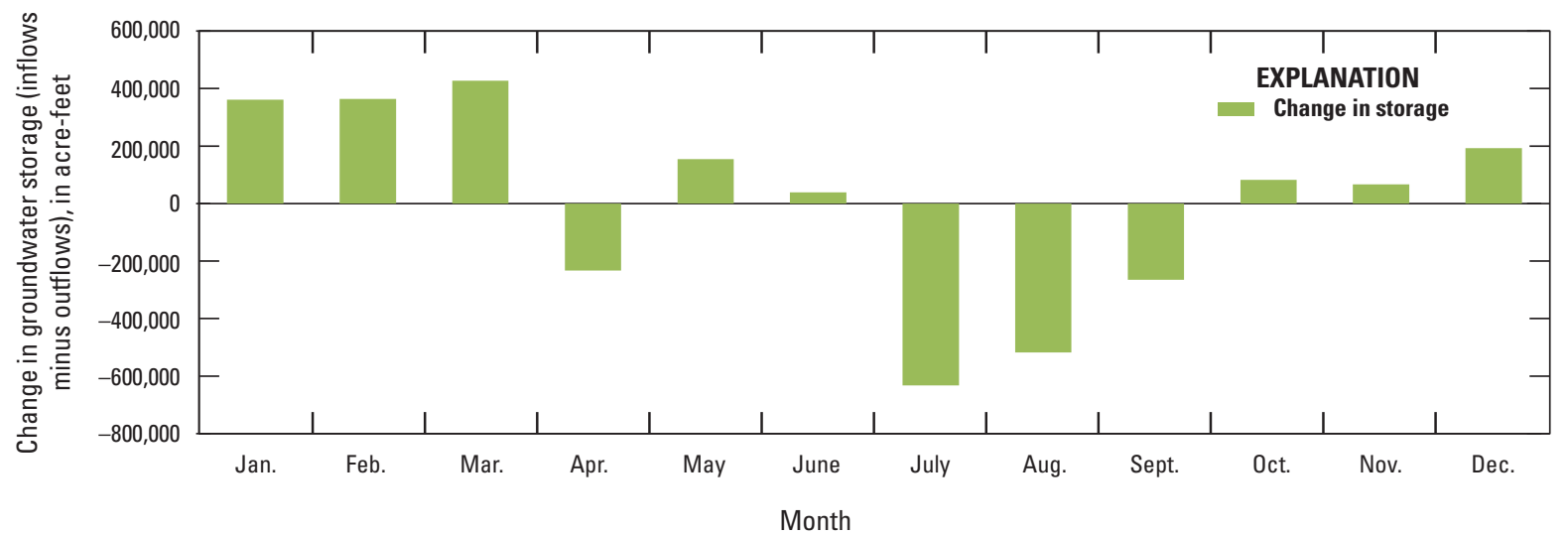

Figure 40. A, Mean monthly aquifer inflows and outflows and $B$, mean monthly change in groundwater storage for the Rush Springs aquifer, western Oklahoma, 1979-2015. 


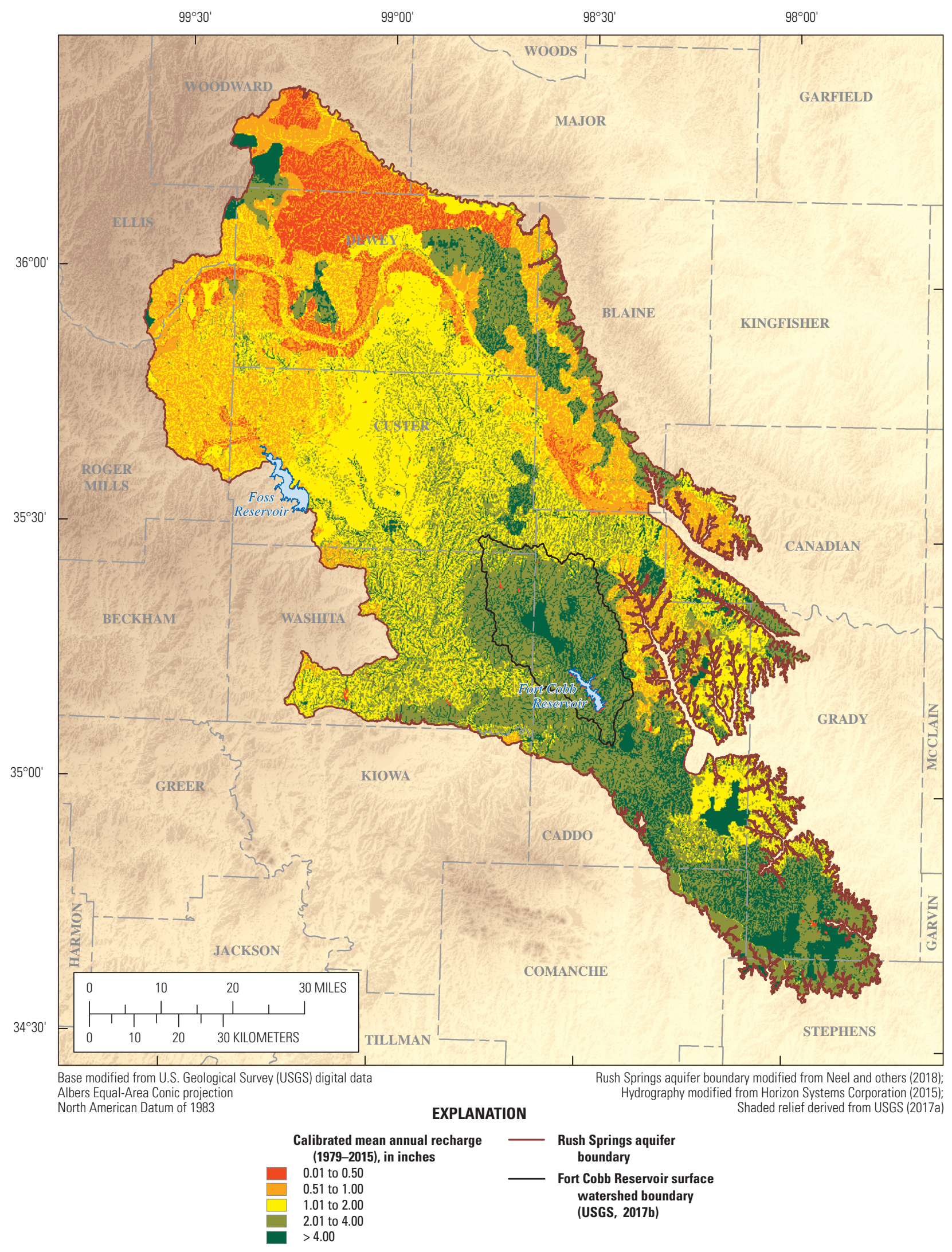

Figure 41. Calibrated mean annual recharge for the numerical groundwater-flow model of the Rush Springs aquifer, western Oklahoma, 1979-2015. 


\section{Calibrated Evapotranspiration from Groundwater}

The calibrated ETg rate multiplier was reduced to a value of 0.4 (40 percent) (table 6) in all areas where ETg was simulated. Although further increases in the ETg rate multiplier may have improved the calibration to base flows and groundwater levels, larger ETg rates could not be simulated without model stability issues. Because of these stability issues and extended run times during automated calibration, the following changes were made during calibration: (1) the ETg area_originally defined by using National Wetlands Inventory data (U.S. Fish and Wildlife Service, 2017) — was reduced to a narrower zone adjoining the simulated stream channel in the alluvium, and (2) an annual threshold of $75 \mathrm{in} / \mathrm{yr}$ was applied to the ETg rate.

Following the automated calibration, the rate multipliers for the Canadian River, Fort Cobb Reservoir tributaries, and the Little Washita River ETg areas were adjusted by using manual calibration zones to further reduce base-flow and groundwater-level residuals. In these ETg areas where manual adjustments occurred, the final rate multiplier was equivalent to a value between 0.8 (80 percent) and 1.2 (120 percent) of the initial ETg rate.

\section{Calibrated Reservoir Inputs}

Precipitation, evaporation, surface runoff, and withdrawal inputs for Fort Cobb Reservoir were adjusted manually following the automated calibration. During each stress period, precipitation and evaporation were varied between \pm 20 percent until a match was obtained between the observed and simulated stage. Because of the uncertainty inherent in estimating surface runoff to Fort Cobb Reservoir - particularly overland flows - surface runoff was varied between \pm 30 percent in each stress period.

Fort Cobb Reservoir stage was generally underpredicted during summer months (fig. 35); thus, precipitation and surface runoff were increased and evaporation was decreased during these months (fig. 42). The required increase in surface runoff, particularly in May and June when precipitation was greatest (fig. 8A), suggests that this input was underestimated-or that ETg was overestimated-during the generation of inputs to the Lake package. During the 2009-14 drought period, stream inflows from Cobb Creek, Lake Creek, and Willow Creek to Fort Cobb Reservoir were overpredicted (fig. 34G-I). Therefore, recharge and surface runoff were decreased, and evaporation was increased in order to match the observed stage (fig. 42). Large reservoir releases during 12 of the 445 stress periods between 1989 and 1991 were reduced by an average of 50 percent because of substantial declines in the simulated reservoir stage that occurred when the full release amount was simulated.

\section{Calibrated Hydraulic Conductivity and Vertical Anisotropy}

Layer 1 was minimally saturated throughout the simulation; thus, Kh in this layer was not adjusted during calibration and represents interpolated values from Neel and others (2018). The mean Kh for layer 1 was $1.6 \mathrm{ft} / \mathrm{d}$, and the values ranged between 0.1 and $4.0 \mathrm{ft} / \mathrm{d}$ (fig. 43A).

Mean calibrated Kh from the interpolated pilot points in the layer 2 alluvium and terrace was $48.6 \mathrm{ft} / \mathrm{d}$, and the values ranged from 0.74 to $90.0 \mathrm{ft} / \mathrm{d}$ (fig. 43B). Spatially, Kh was greatest in the Washita River alluvium, particularly between the Clinton (07325000) and Carnegie (07325500) streamgages where simulated stream seepage was underpredicted (fig. 43B). Layer $2 \mathrm{Kh}$ values were generally lower in the Canadian River alluvium, where simulated stream seepage was overpredicted (fig. 38).

Literature describing the Kh of the alluvium and terrace of the Washita River or Fort Cobb Reservoir tributaries was limited. Therefore, calibrated Kh for the Canadian River alluvium and terrace was compared between this model and the Reach I model from Ellis and others (2017) (fig. 44A). The mean calibrated Kh for the Canadian River alluvium and terrace (45.6 ft/d) was within 3.4 percent of the mean calibrated Kh (44.1 ft/d) from Ellis and others (2017). A greater number of cells had calibrated Kh values between 80.0 and $90.0 \mathrm{ft} / \mathrm{d}$ in this model than in the Reach I model (Ellis and others, 2017) (fig. 44A). A number of these Kh values were at the upper Kh boundary of $90.0 \mathrm{ft} / \mathrm{d}$, indicating that additional

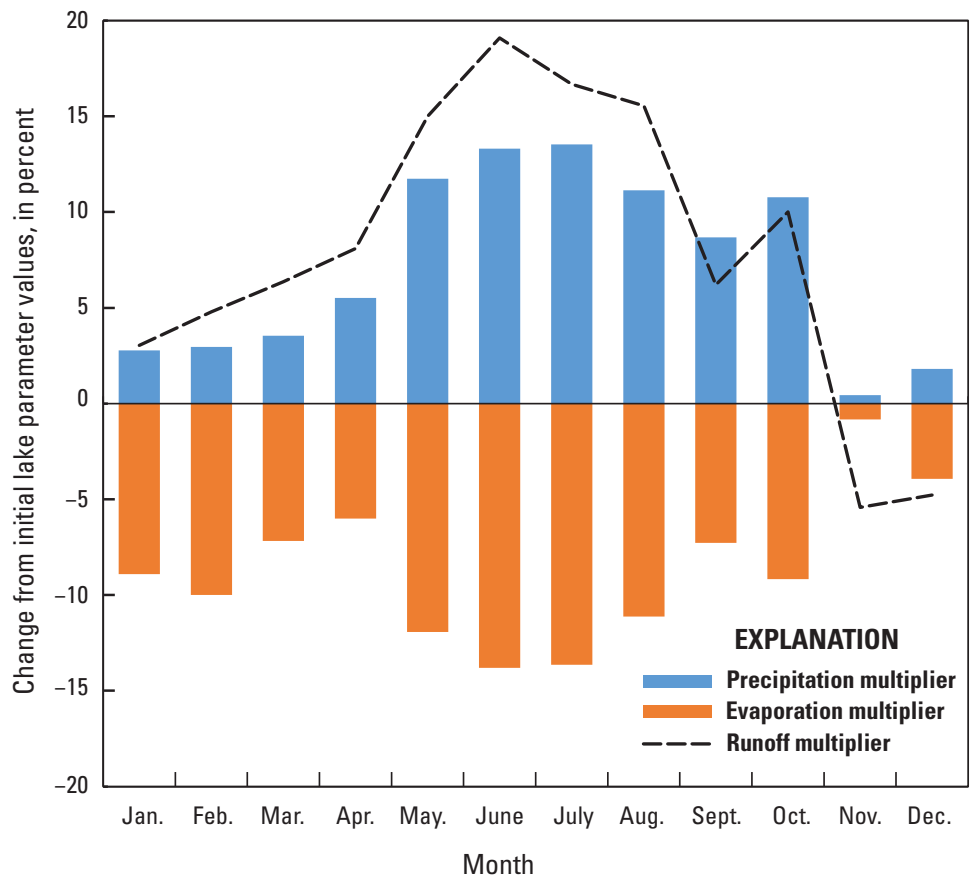

Figure 42. Change from initial Lake package inputs for the numerical groundwater-flow model of the Rush Springs aquifer, western Oklahoma, 1979-2015. 


\section{A. Cloud Chief Formation (layer 1)}

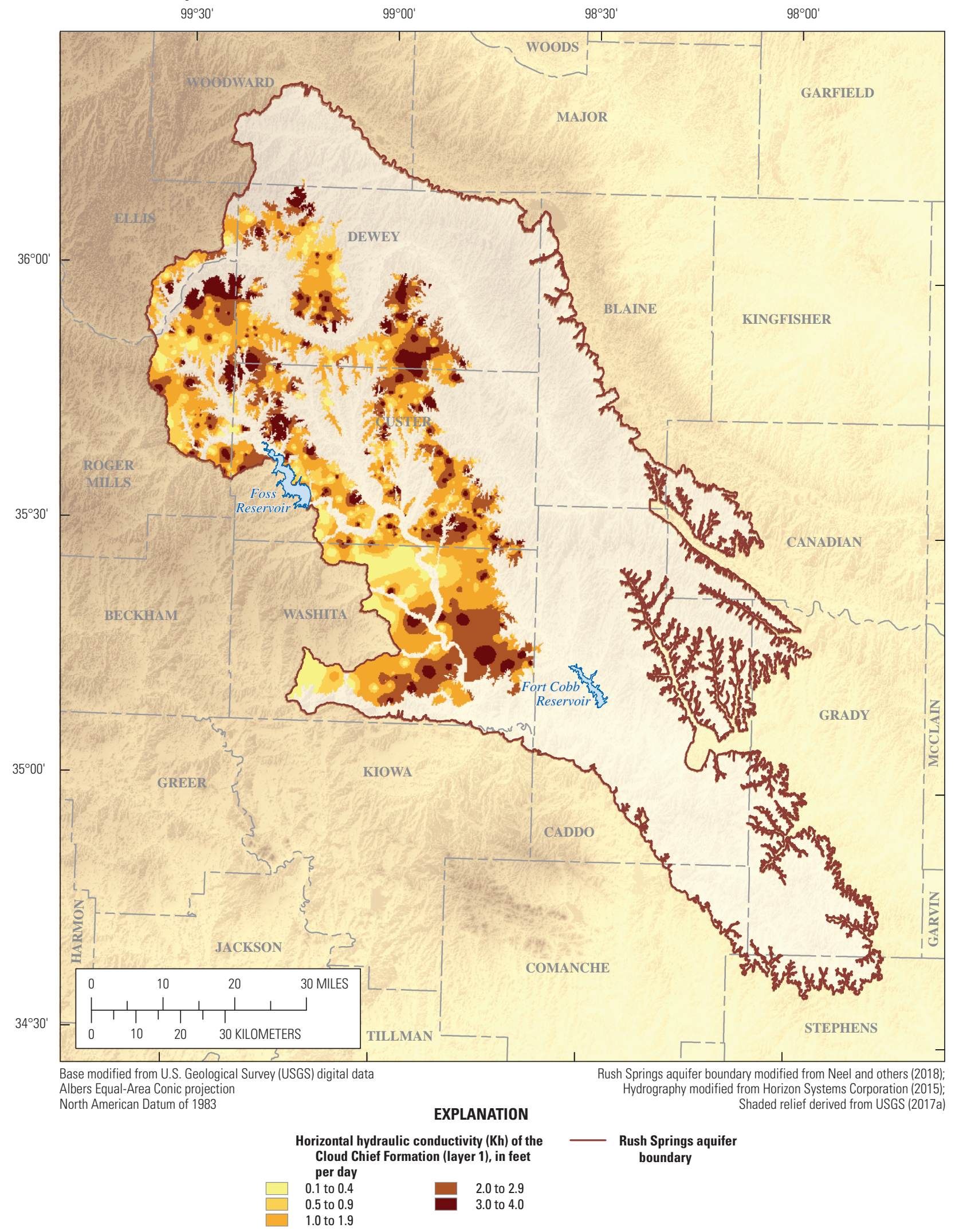

Figure 43. Calibrated horizontal hydraulic conductivity (Kh) of the $A$, Cloud Chief Formation (layer 1), $B$, alluvium and terrace (layer 2), and $C$, lower Whitehorse Group (layer 3) for the Rush Springs aquifer numerical groundwater-flow model, western Oklahoma. 
B. Alluvium and terrace deposits (layer 2)

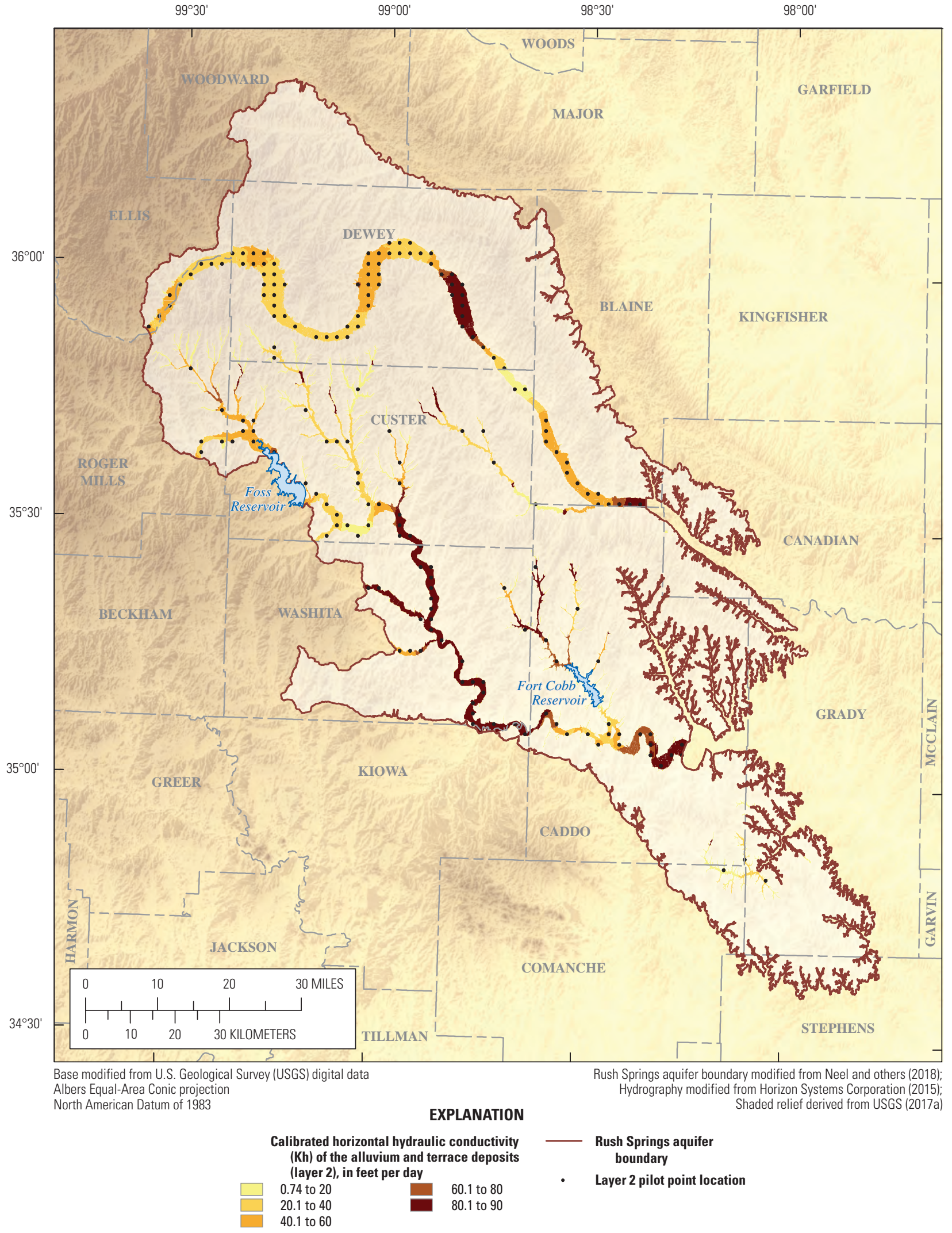

Figure 43. Calibrated horizontal hydraulic conductivity (Kh) of the $A$, Cloud Chief Formation (layer 1), $B$, alluvium and terrace (layer 2), and $C$, lower Whitehorse Group (layer 3 ) for the Rush Springs aquifer numerical groundwater-flow model, western Oklahoma.-Continued 


\section{Lower part of Whitehorse Group (layer 3)}

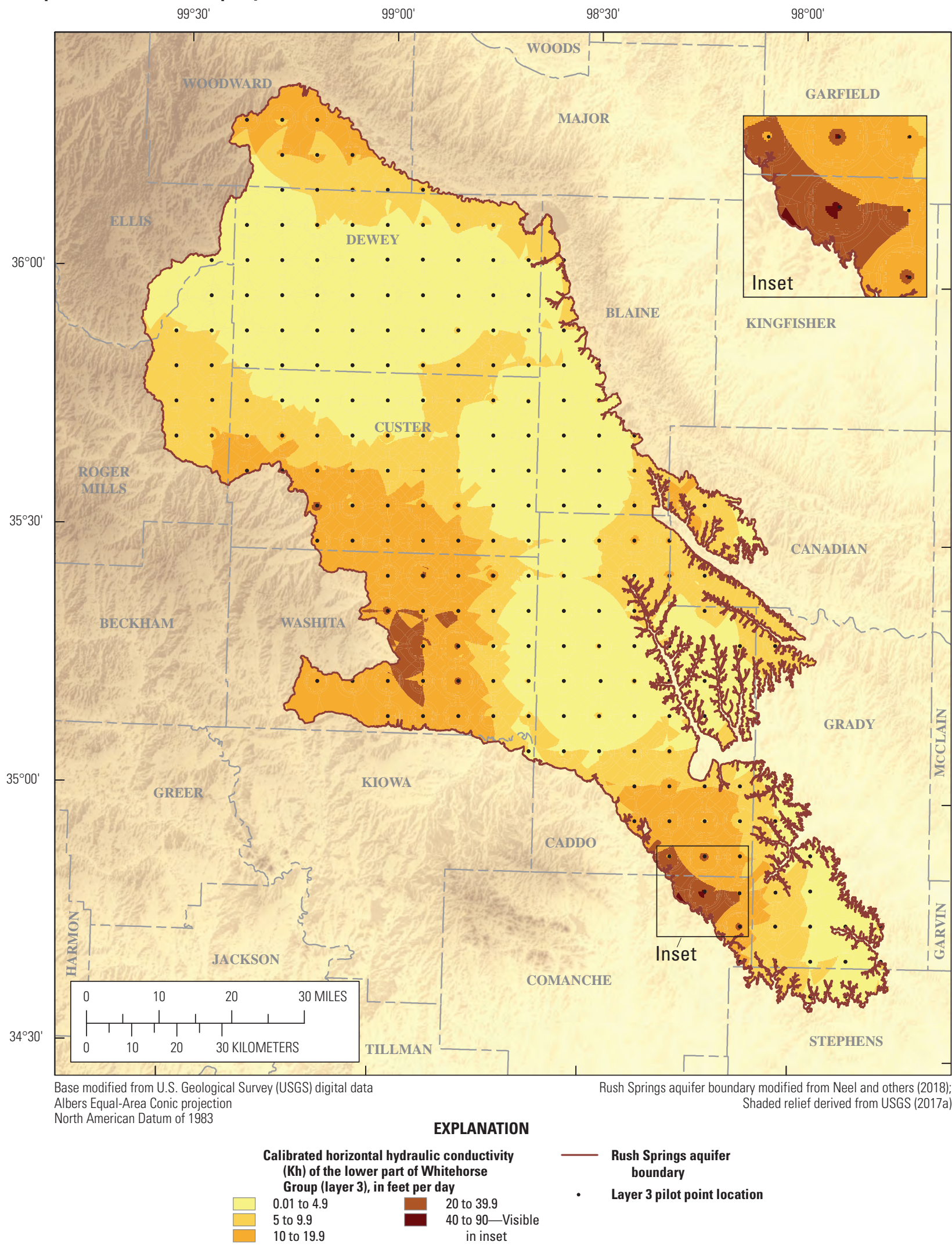

Figure 43. Calibrated horizontal hydraulic conductivity $(\mathrm{Kh})$ of the $A$, Cloud Chief Formation (layer 1), $B$, alluvium and terrace (layer 2), and $C$, lower Whitehorse Group (layer 3 ) for the Rush Springs aquifer numerical groundwater-flow model, western Oklahoma.-Continued 
upward adjustment of these Kh values using PEST may have yielded an improved calibration. In the Ellis and others (2017) groundwater model of the Canadian River, maximum calibrated Kh in the Reach I model was $176 \mathrm{ft} / \mathrm{d}$; thus, an increase in Kh may be reasonable. However, without the application of regularization techniques for the Kh values in the model, setting an upper limit greater than $90.0 \mathrm{ft} / \mathrm{d}$ may have resulted in an excessive percentage of $\mathrm{Kh}$ values greater than $90.0 \mathrm{ft} / \mathrm{d}$.

Mean calibrated vertical anisotropy in the alluvium and terrace was 9.9 (9.9:1 horizontal-tovertical ratio), and the values ranged from 8.7 to 20 . The vertical anisotropy of 9.7 for the Canadian River alluvium and terrace was greater than that of Ellis and others (2017), which was 3.

Mean calibrated Kh for the lower Whitehorse Group was $6.6 \mathrm{ft} / \mathrm{d}$, and the values ranged from 0.01 to $90.0 \mathrm{ft} / \mathrm{d}$ (fig. 43C). This mean Kh is within 5 percent of the initial mean $\mathrm{Kh}$ of $6.3 \mathrm{ft} / \mathrm{d}$ obtained from Neel and others (2018). The mean calibrated Kh for the lower Whitehorse Group under the Cloud Chief Formation was $8.3 \mathrm{ft} / \mathrm{d}$. Although the groundwater levels in this area were underpredicted, whereby Kh values would be expected to be lowered to compensate, the more numerous underpredicted monthly streamflow observations at the Carnegie streamgage (07225000) (fig. 34C) resulted in a slight increase in calibrated $\mathrm{Kh}$ in this area during automated calibration. The mean calibrated Kh for the lower Whitehorse Group where not overlain by the Cloud Chief Formation was $6.0 \mathrm{ft} / \mathrm{d}$.

The distribution of calibrated Kh values differed from Neel and others (2018) through (1) an increase in the number of cells with Kh values between 0.01 and $3.0 \mathrm{ft} / \mathrm{d}$ and between 9.1 and $30.0 \mathrm{ft} / \mathrm{d}$, and (2) a decrease in the number of cells with Kh values between 3.1 and $9.0 \mathrm{ft} / \mathrm{d}$ (fig. 44B). Of the Kh values from this calibrated model and from Neel and others (2018), 99 percent are less than $30 \mathrm{ft} / \mathrm{d}$ (fig. 44B); thus, the majority of Kh-value adjustments occurred within a constrained range.

The mean calibrated Kh of $6.6 \mathrm{ft} / \mathrm{d}$ is similar to most values from available aquifer-test results conducted in the Rush Springs aquifer. Although the results from these aquifer tests provide hydraulic parameter information pertaining to a relatively localized area, aquifer-test values in various locations of the aquifer were informative of overall aquifer properties. Kh values from these tests were (1) $1.6 \mathrm{ft} / \mathrm{d}$ for the town of Hydro (fig. 1) production well (Neel and others, 2018), (2) $6.4 \mathrm{ft} / \mathrm{d}$ for a single-well aquifer test in southern Grady County (Neel and others, 2018), (3) 3.8-4.4 ft/d for aquifer tests in Weatherford, OK (fig. 1) (Becker and Runkle, 1998), (4) $5.4 \mathrm{ft} / \mathrm{d}$ for a 2-week multi-well aquifer test in Caddo County (Neel and others, 2018), and (5) $45 \mathrm{ft} / \mathrm{d}$ for a Grady County production well
(Neel and others, 2018). The higher Kh value for the Grady County production well aquifer test relative to the others may be indicative of an uncemented sand versus more common descriptions of loosely cemented sand from published literature (Tanaka and Davis, 1963; Becker and Runkle, 1988; Neel and others, 2018).

Mean calibrated vertical anisotropy in the lower Whitehorse Group was 11.2 (11.2:1 horizontal-to-vertical ratio), or slightly greater than the initial 10:1 vertical

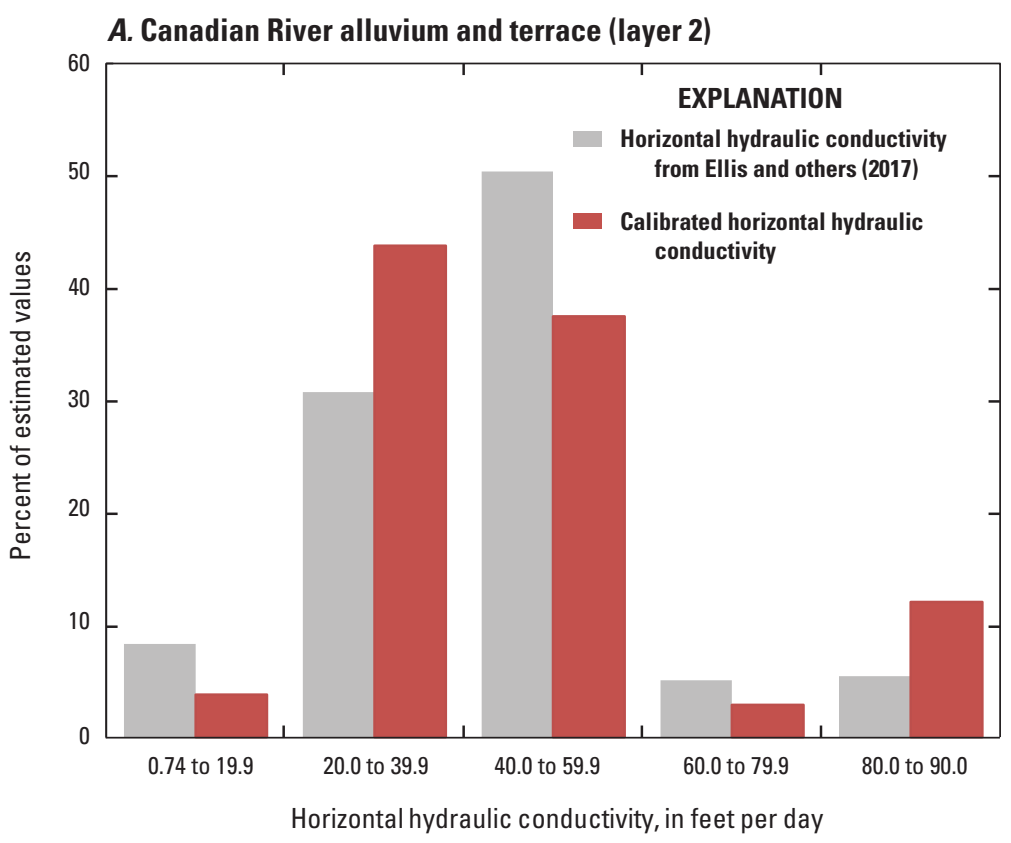

B. Lower Whitehorse Group (layer 3)

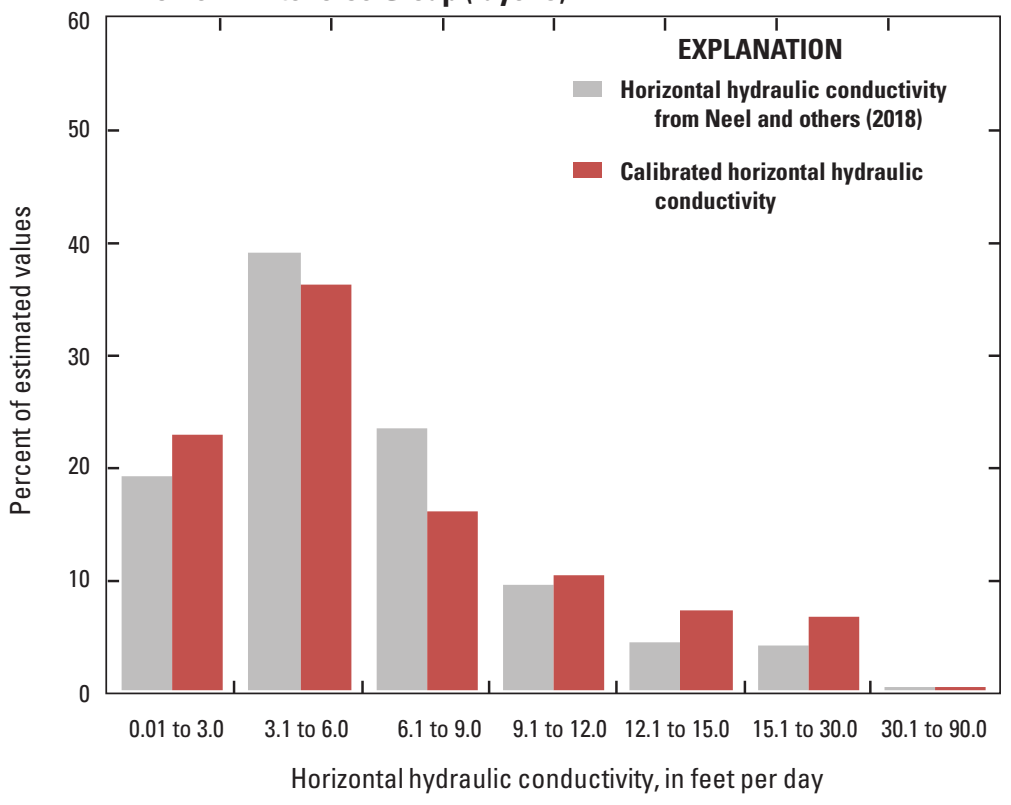

Figure 44. Horizontal hydraulic conductivity and calibrated horizontal hydraulic conductivity for $A$, Canadian River alluvium and terrace and $B$, lower Whitehorse Group for the groundwater-flow model of the Rush Springs aquifer, western Oklahoma. 
anisotropy, and the calibrated values ranged from 7.4 to 20. Cores examined from previous studies show subangular to subround grains and a moderate degree of cross bedding and cementation (Tanaka and Davis, 1963; Becker and Runkle, 1998; Neel and others, 2018); therefore, these values are thought to be reasonable.

\section{Storage Parameters}

The calibrated Sy values for each layer were unchanged from the initial Sy values from Neel and others (2018). The mean and maximum Sy values for layer 1 were 0.05 and 0.08 , respectively (figs. 45A and 46A). The mean values are similar to those of Johnson (1967), which lists values of 0.05 and 0.03 for silt and clay, respectively, based on a laboratory sediment analysis. The mean and maximum calibrated Sy values for the alluvium and terrace in layer 2 were 0.07 and 0.29 , respectively (figs. 45B and 46B). The calibrated Sy values for the Canadian River alluvium and terrace, for which the mean and maximum calibrated Sy values were 0.16 and 0.29 (Ellis and others, 2017), were somewhat greater than the Sy values for the Washita River alluvium and terrace and the Little Washita River alluvium (fig. 46B). The Washita River incises the fine-grained Cloud Chief Formation and relatively fine-grained Whitehorse Group, whereas the Canadian River incises coarser grained materials such as the Ogallala Formation (Hendricks, 1937); therefore, Sy values for the Washita River alluvium and terrace were expected to be lower than the Sy values for the Canadian River alluvium and terrace.

The mean and maximum Sy values for layer 3 were 0.07 and 0.23 , respectively, and 99 percent of the values were less than 0.11 (figs. 45C and 46C). Although Sy depends on the sorting, dominant size, and cementation of aquifer materials - textural properties that cannot always be derived from the lithologic logs analyzed-the Sy values used in the model also agree with the aquifer tests described in the "Calibrated Hydraulic Conductivity and Vertical Anisotropy" section of this report. The Sy values obtained from these tests were 0.09 (town of Hydro production well; Neel and others, 2018), 0.09 (single-well test in southern Grady County; Neel and others, 2018), 0.08 (aquifer test in Weatherford; Becker and Runkle, 1998), 0.07 (multi-well test in Caddo County; Neel and others, 2018), and 0.04 (Grady County production well; Neel and others, 2018).
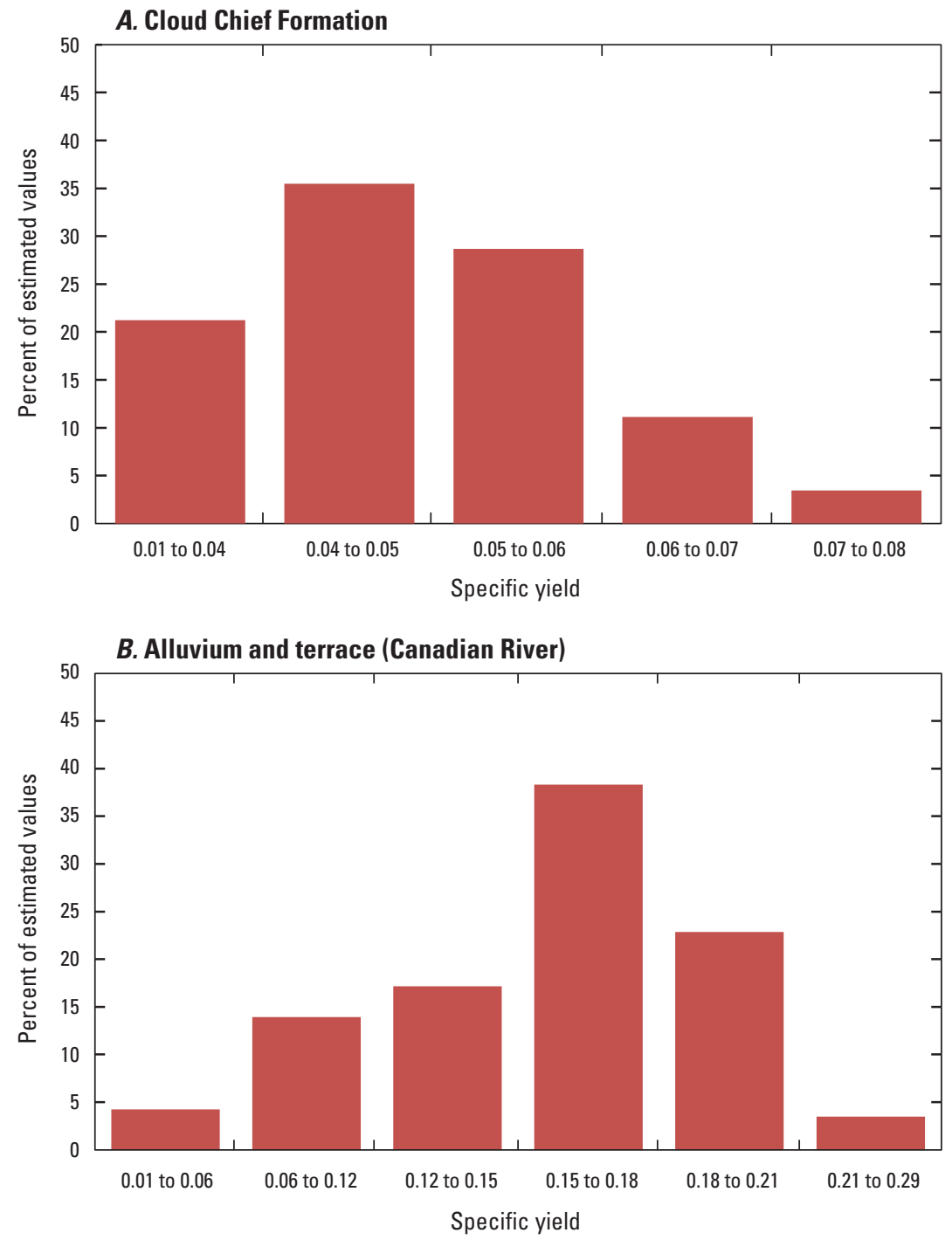

C. Lower Whitehorse Group

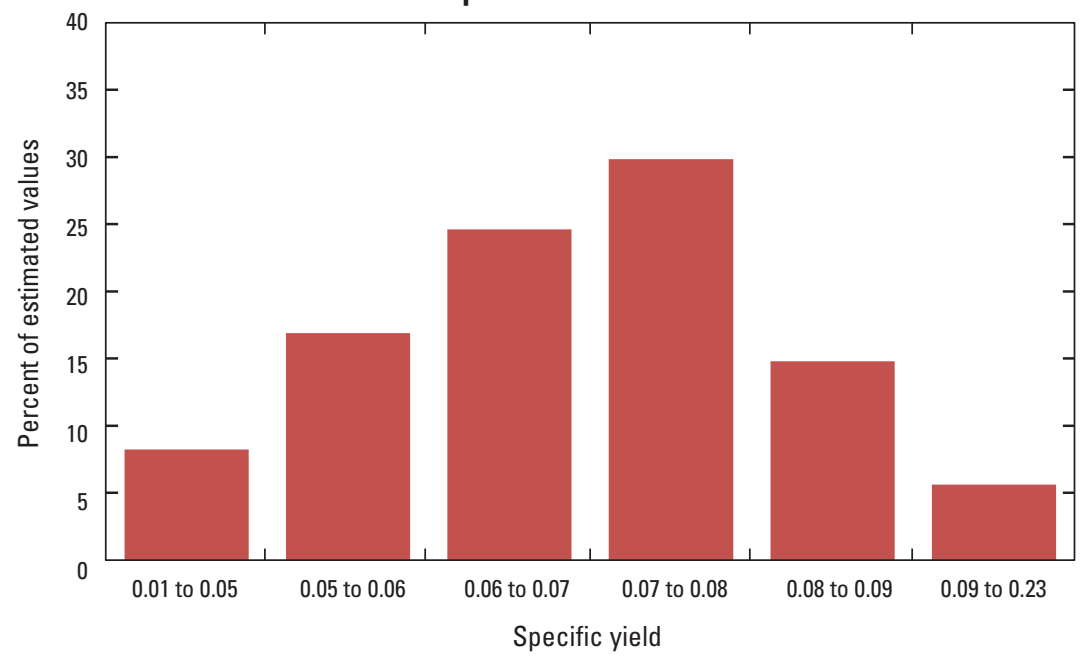

Figure 45. Specific yield for the $A$, Cloud Chief Formation; $B$, Canadian River alluvium and terrace; and $C$, lower Whitehorse Group for the Rush Springs aquifer, western Oklahoma. 


\section{A. Cloud Chief Formation (layer 1)}

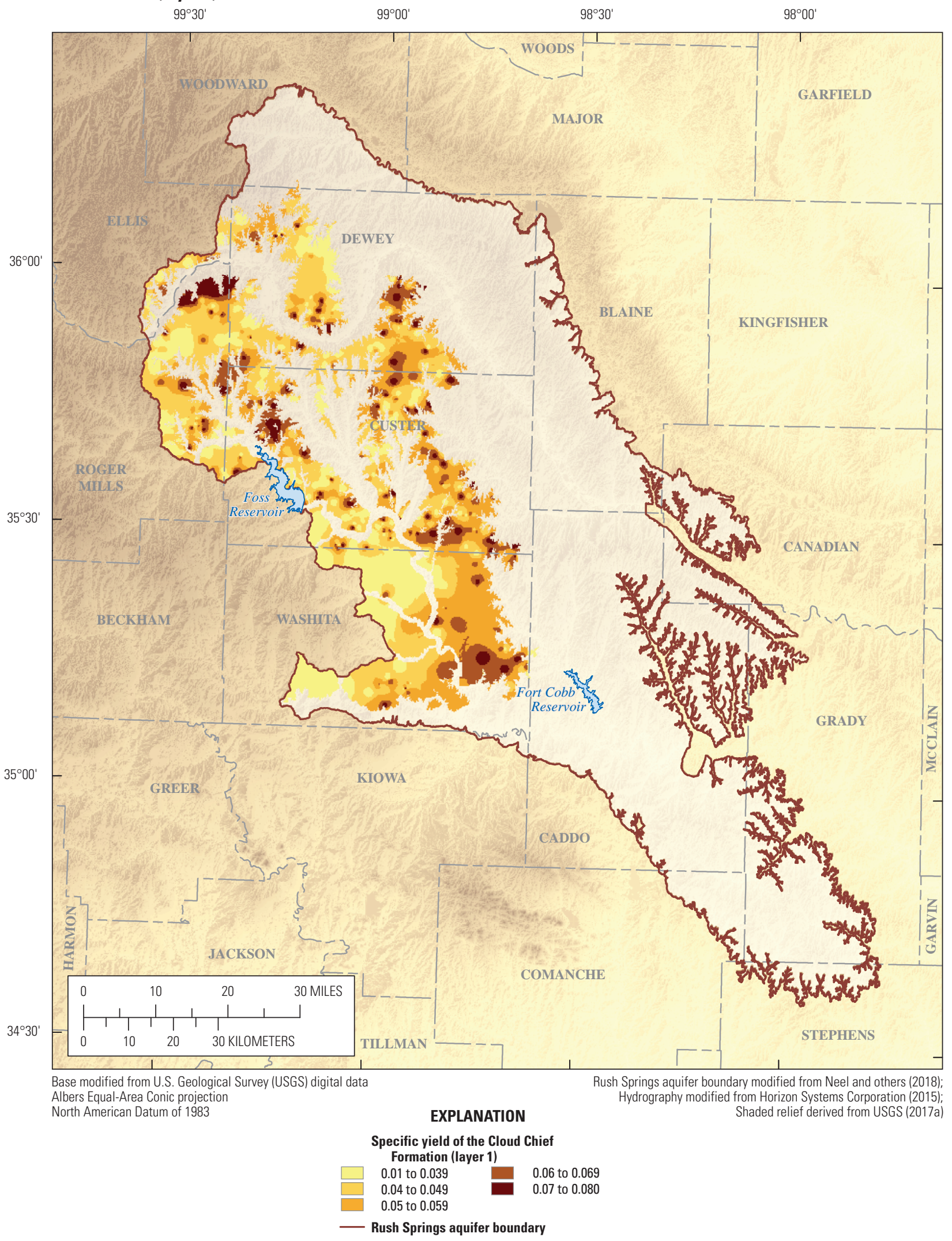

Figure 46. Specific yield of the $A$, Cloud Chief Formation (layer 1), $B$, alluvium and terrace (layer 2), and $C$, lower Whitehorse Group (layer 3) for the Rush Springs aquifer numerical groundwater-flow model, western Oklahoma. 


\section{B. Alluvium and terrace deposits (layer 2)}

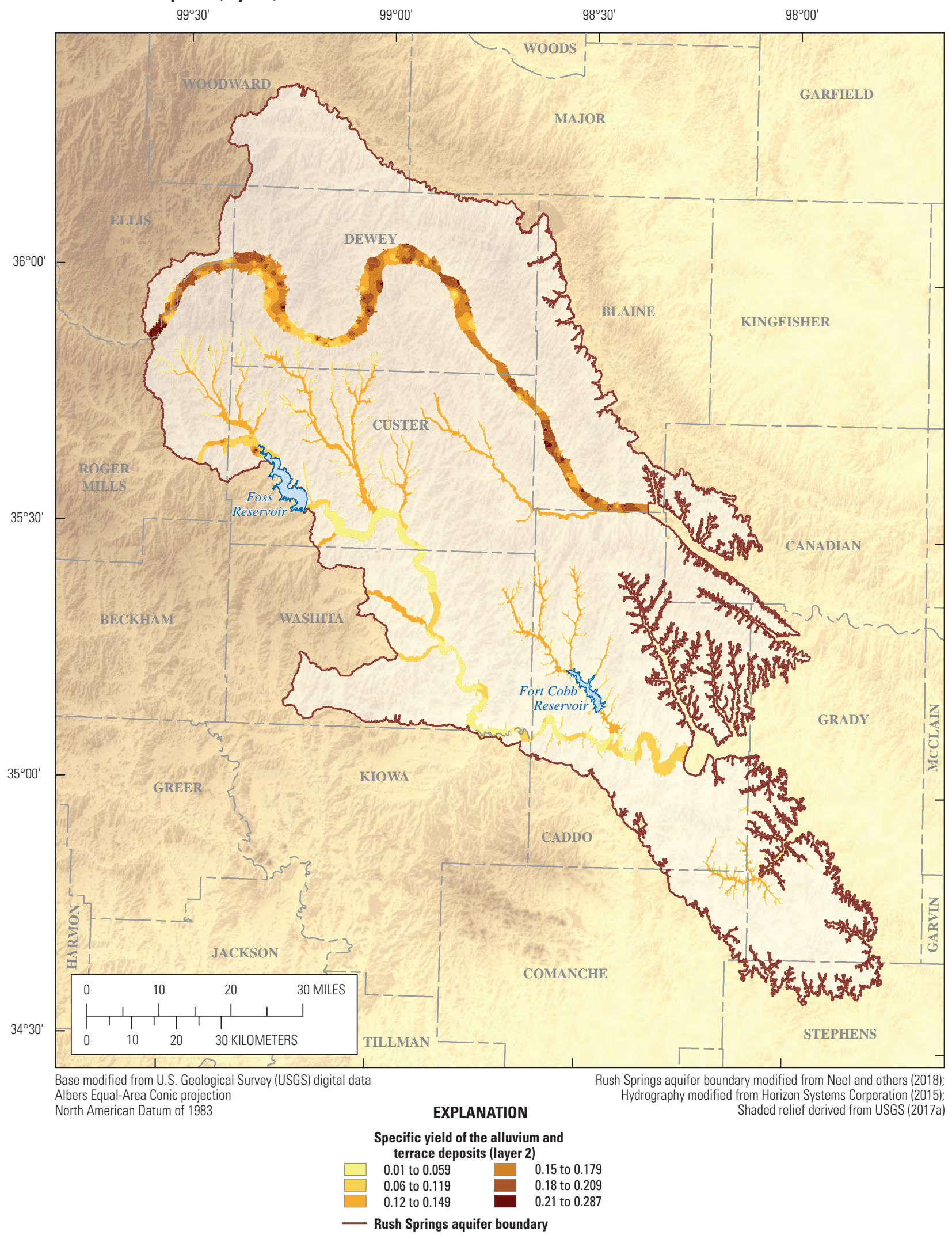

Figure 46. Specific yield of the $A$, Cloud Chief Formation (layer 1), $B$, alluvium and terrace (layer 2), and $C$, lower Whitehorse Group (layer 3 ) for the Rush Springs aquifer numerical groundwater-flow model, western Oklahoma.-Continued 


\section{Lower part of Whitehorse Group (layer 3)}

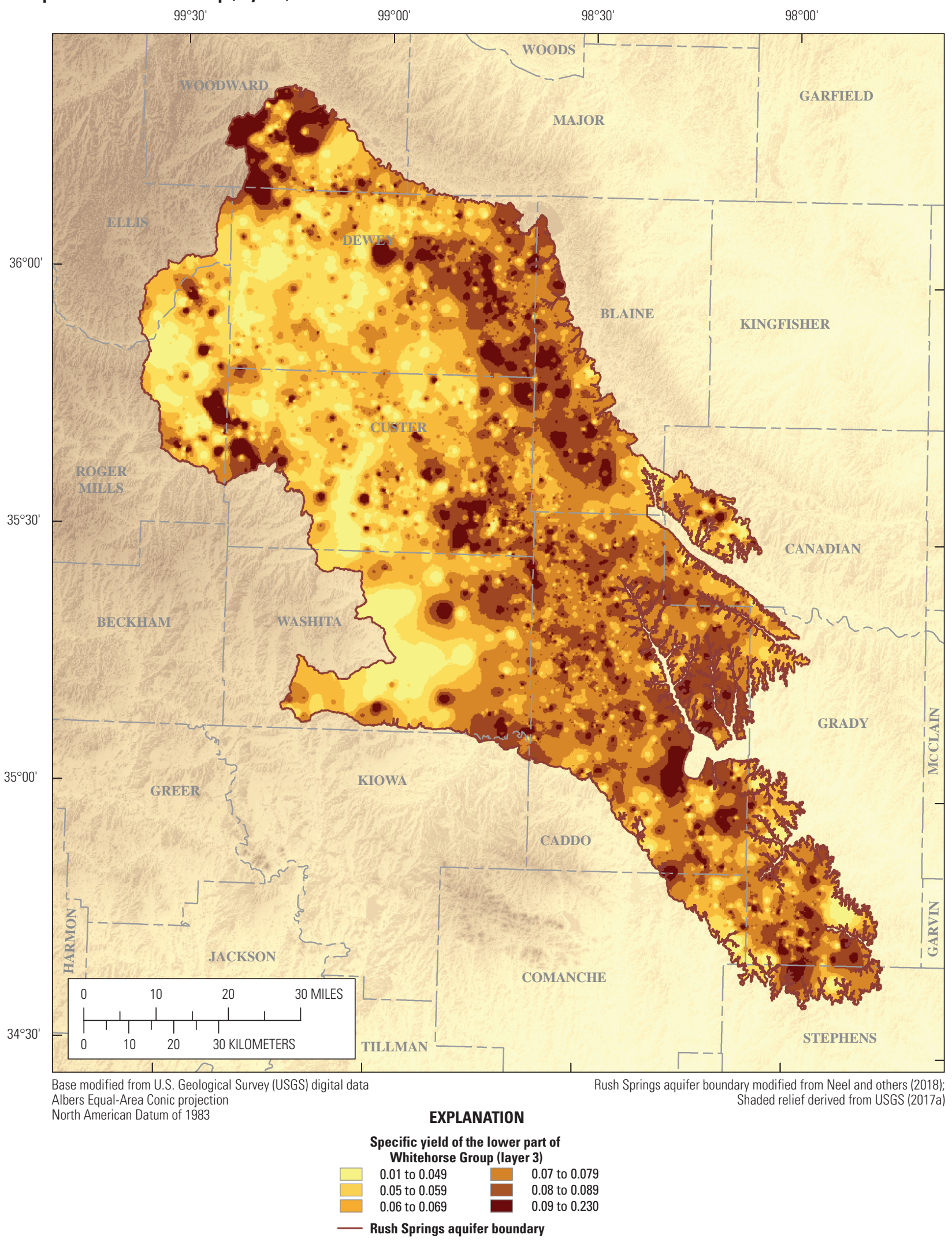

Figure 46. Specific yield of the $A$, Cloud Chief Formation (layer 1), $B$, alluvium and terrace (layer 2), and $C$, lower Whitehorse Group (layer 3 ) for the Rush Springs aquifer numerical groundwater-flow model, western Oklahoma.-Continued 


\section{Sensitivity and Identifiability}

Several analyses were performed to ensure that the parameters used were effective in reducing the objective function and to evaluate the correlation among parameters and identify parameters informed by the calibration process. During automated calibration, PEST computed the sensitivities of each parameter with respect to all observations by using 1-percent changes in parameters, which are contained in the Jacobian matrix. These sensitivities are a dimensionless measure of the change in residuals affected by adjustments to a parameter; thus, calibration-target residuals are more easily reduced by parameters with larger sensitivities. Sensitivities were calculated by using the Jacobian matrix output from PEST (table 6) and summed for each parameter group (fig. 47).

The observation groups were generally most sensitive to changes in recharge and hydraulic conductivity (fig. 47). Recharge was the largest aquifer inflow (table 11), whichalong with the pilot points used to adjust hydraulic conductivity and specific yield - affected the groundwater levels, base flows, stream seepage, and reservoir stage throughout the model. Out of the highest parameter sensitivities, recharge parameter zones represented the six largest. Two of the three most sensitive parameters, recharge zones 14 and 5 (table 6; fig. 20), were located in the Fort Cobb Reservoir watershed, which contained the largest concentration of base-flow estimates and groundwater-level observations in the model (figs. 1, 10) as well as the Fort Cobb Reservoir stage observations. Adjustments to Sy occurred as an entire-layer multiplier; thus, adjustments in this manner also resulted in a higher sensitivity relative to other parameter groups.

Changes in ETg applied to the alluvium and terrace (fig. 13) had a lesser effect on groundwater-level observations because most of the observations are distant from Evapotranspiration package cells. Changes in ETg also resulted in sensitivity for the Fort Cobb Reservoir stage observations because stream inflows contributed a large percentage of inflow to this reservoir. Drain cells representing seeps and springs compose a majority of the northeastern, eastern, and southeastern boundaries of the model (fig. 15). As a result, most observation groups were sensitive to changes in drain conductance. The "good" groundwaterlevel observations and base-flow estimates composed about 71 percent of all calibration targets in the model (table 5);

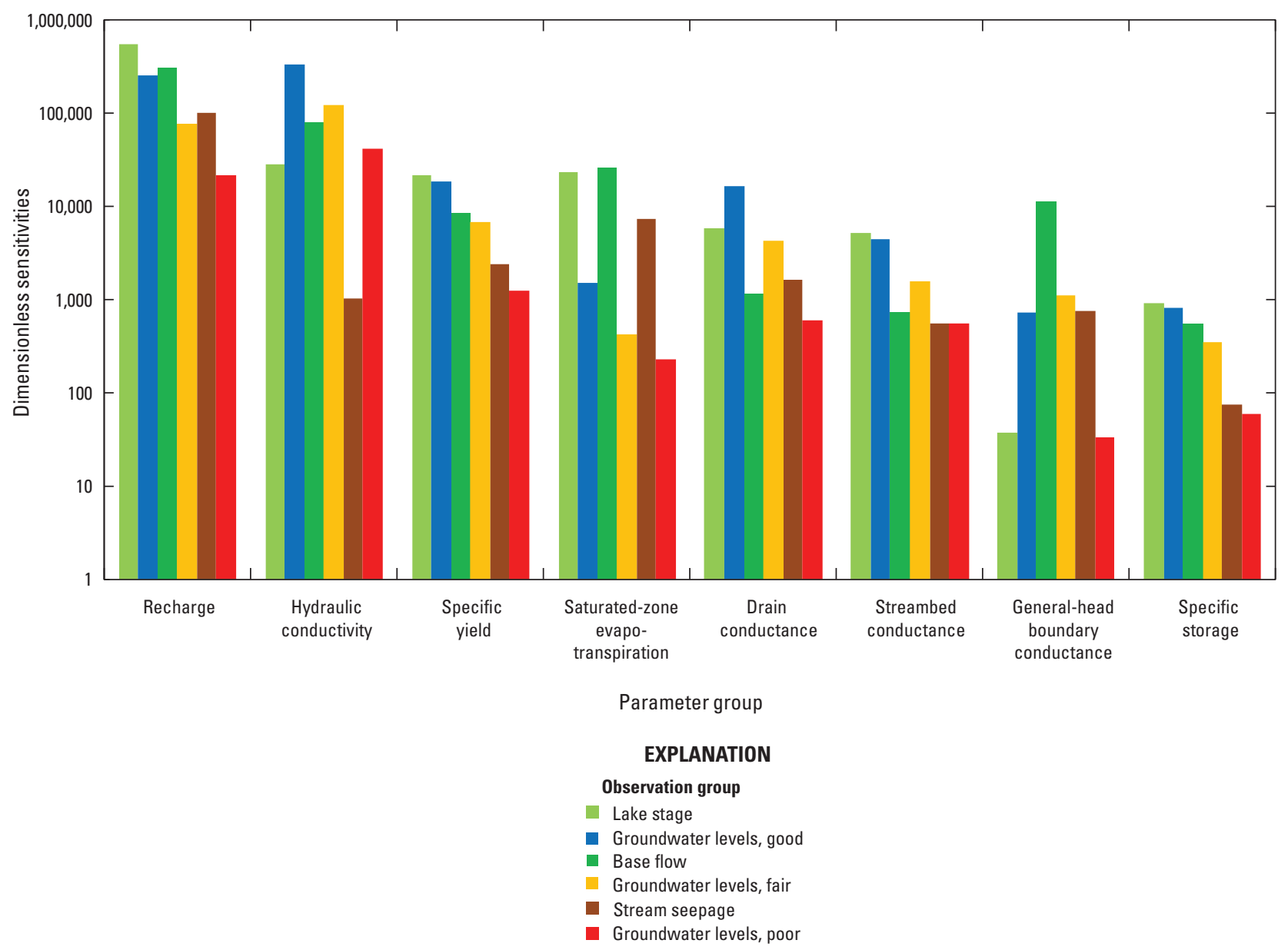

Figure 47. Observation group sensitivity by parameter group in the numerical groundwater-flow model for the Rush Springs aquifer, western Oklahoma. 
thus, these two calibration-target observation groups had among the highest sensitivities of any observation group. The sensitivities for the lakebed leakance were nearly zero for every observation group; therefore, they were not shown on figure 47.

Parameter sensitivities provide some insight regarding their value in the calibration process. However, they do not reflect the (1) degree of parameter correlation, whereby changes in one parameter value are offset by changes in another, negating any advantage in using these parameters to improve model fit, or (2) the ability to uniquely estimate each parameter based on the calibration dataset (Doherty and Hunt, 2009). Thus, another statistic - parameter identifiability - is used for highly parameterized models to quantify parameter correlation and the amount of information gained from the calibration dataset. Outputs using this method use a normalized scale range between zero and one. An identifiability of zero reveals that no information for a parameter is provided from the calibration dataset, resulting in (1) insensitivity of model outputs to changes in a parameter, and (2) a lack of reduction in the parameter uncertainty from the calibration process. An identifiability value of one indicates that a parameter incorporates substantial calibration information and that potential parameter error is caused by noise associated with the calibration-target dataset (Doherty and Hunt, 2009). Values between zero and one indicate some degree of parameter correlation whereby information is shared between parameters. Parameters with a high identifiability, and thus a lower uncertainty, can be viewed as favorable to the calibration process, but parameters with low identifiability retain prior uncertainty and are uninformed by the calibration process. Therefore, expert knowledge is required to assign values for parameters with lower identifiabilities. An identifiability value of 0.7 was chosen as a cutoff between parameters that are identifiable and those parameters that are not based on a similar cutoff chosen in other studies (Doherty and Hunt, 2009; Masterson and others, 2016).

Singular values identified by using SVD are associated with unit vectors that span parameter space (Doherty and Hunt, 2009). Parameter space includes the solution space, which contains parameters and parameter combinations that can be estimated, and the null space, which contains parameters that cannot be estimated. The number of identifiable parameters is directly related to the number of singular values contained in the solution space (Doherty and Hunt, 2009). A singular value boundary of 80 singular values identified by SVD was chosen to characterize the solution space by using pyEMU (White and others, 2016) and the PEST utility IDENTPAR (Doherty, 2010). Eighty super parameters were used for model calibration; thus, this analysis suggests that the super parameters associated with these singular values contained information from the model calibration dataset.

The singular value contributions to identifiability for each of the 24 parameters with an identifiability of greater than 0.7 are shown in figure 48. Identifiability is the sum of

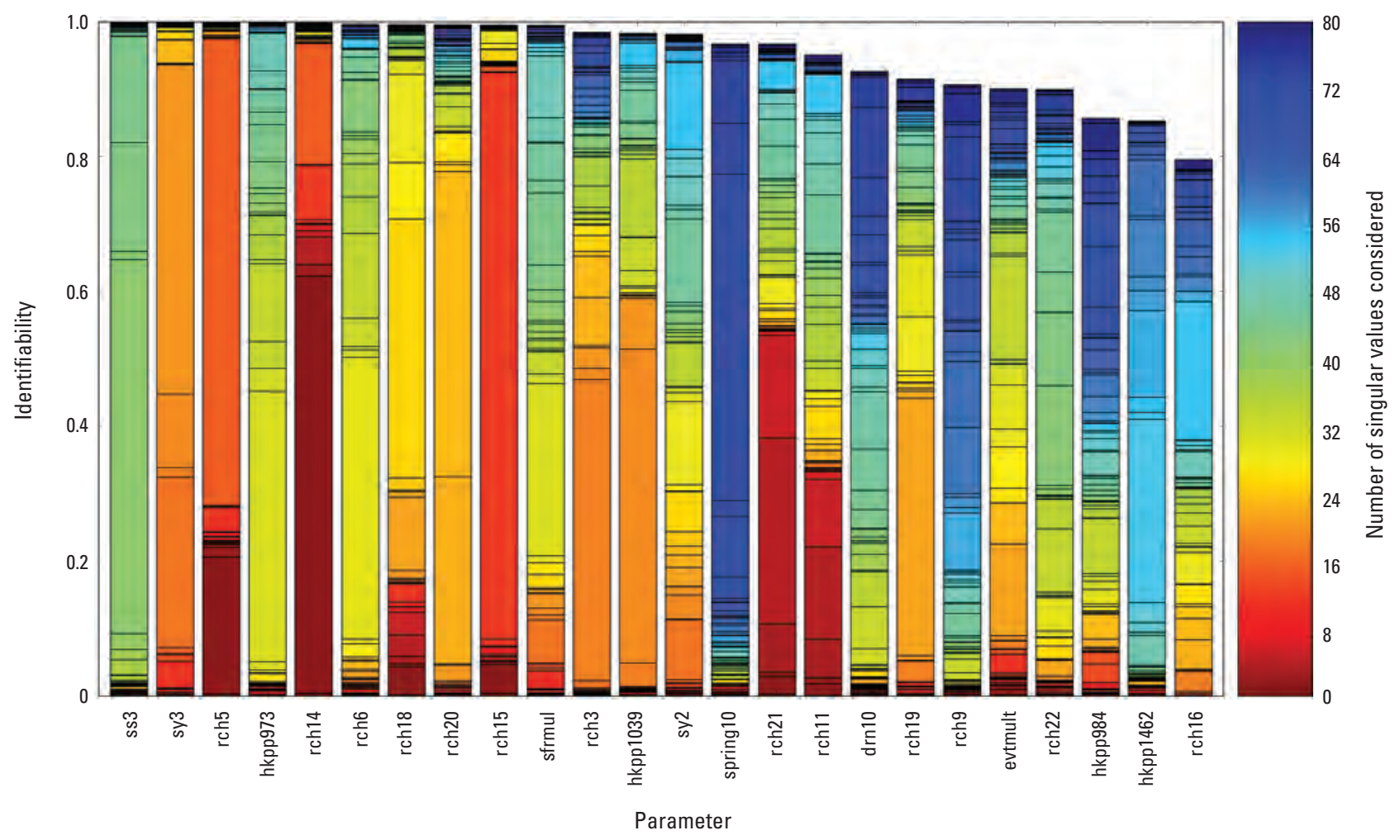

Figure 48. Parameter identifiability in the numerical groundwater-flow model for the Rush Springs aquifer, western Oklahoma. 
the contribution of the singular values-each represented by a separate color in figure 48 - to each parameter. Warm colors (reds, oranges, and yellows) denote identifiability attributable to more informative singular values, and the cool colors (greens and blues) indicate identifiability attributable to less informative singular values. The identifiability (total bar height) and singular value composition (individual bar colors) between two parameters can be compared whereby bars containing mostly warm colors indicate that these parameters can be estimated with less potential for error than those parameters with mostly cool colors.

The calibration parameters had a large range of identifiability (table 6). Some values were nearly equal to one, but other values were near zero, indicating little to no identifiability. Ten parameters were nearly identifiable (values near or at 1.0), and 14 parameters were identifiable (greater than 0.7), based on the calibration-target dataset (fig. 48). The recharge zones had 6 of the 10 largest identifiabilities because the spatial extent of these particular zones (fig. 20) encompassed a large percentage of the groundwater-level targets, generally near Fort Cobb Reservoir. Pilot points near Fort Cobb Reservoir (hkpp973, hkpp1039; table 6) were most identifiable, while the remainder of the pilot points were less identifiable because they were located further from calibration targets. The sensitivity analysis suggests that many parameters are useful for calibration. By comparison, the results of the identifiability analysis indicate that (1) the recharge and storage parameters were well informed and (2) some degree of correlation is present among many of the calibration parameters. The recharge and storage parameters are important controls on groundwater flow in the aquifer; therefore, a large identifiability for these parameters provides greater certainty in the modeled scenario results.

\section{Groundwater Availability Scenarios}

Three types of scenarios were formulated for the calibrated groundwater model. These scenarios were used to (1) estimate the EPS pumping rate that guarantees a minimum 20-year life of the aquifer, (2) quantify the effects of projected groundwater-use rates on aquifer storage over a 50-year period, and (3) evaluate the effects of (a) projected groundwater-use rates extended 50 years into the future and (b) sustained hypothetical drought conditions over a 10-year period on base flow and groundwater in storage. Additionally, an uncertainty analysis was performed for the EPS scenario.

\section{Equal Proportionate Share}

The EPS for the Rush Springs aquifer was defined as the pumping rate at which fresh groundwater can be withdrawn so that, after a minimum of 20 years of continuous EPS withdrawals, 50 percent of the aquifer retains a saturated thickness of at least $15 \mathrm{ft}$. To compute the EPS for the Rush
Springs aquifer, a similar approach to that of the model calibration was implemented. Whereas automated calibration of the Rush Springs aquifer model involved the adjustment of many model parameters based on available calibration targets, the determination of the EPS was based only on a uniform pumping rate parameter (EPS pumping rate) and an aquifer saturated thickness calibration target (15 ft). The EPS pumping rate parameter was composed of a hypothetical well placed in each active cell in layer 3. During each iteration of the calibration process, the pumping rate parameter was adjusted until the objective function was zero-when 50 percent of the basin retained a saturated thickness of $15 \mathrm{ft}$. The EPS was computed for time periods of 20,40 , and 50 years into the future.

The layer 2 alluvium and terrace was considered as a separate aquifer for the purposes of the EPS scenarios; thus, the EPS scenarios were evaluated for layer 3 only. The EPS scenarios also were evaluated based only on the modified extent of Neel and others (2018), which includes an area of about 4,616 $\mathrm{mi}^{2}$ (2,954,545 acres).

Annual stress periods with calibrated model mean stresses were used in the EPS scenarios instead of monthly stress periods to (1) shorten transient simulation run times, (2) minimize the iterative variability in the EPS pumping rate caused by monthly or seasonal stresses, and (3) improve model stability. The 2015 simulated water table from the calibrated groundwater model was used as the starting water table in each EPS scenario. The calibrated model mean recharge is referred to as "normal recharge" conditions. To account for potential climate variability, the EPS scenarios were run with recharge increased and decreased by 10 percent.

The 20-, 40-, and 50-year EPS pumping rates under normal recharge conditions were $0.82,0.49$, and 0.43 acrefoot per acre per year (acre-ft/acre/yr), respectively (table 12). Given the 2,954,545-acre aquifer area from Neel and others (2018), these rates correspond to annual yields of about $2,422,727,1,447,727$, and 1,270,454 acre-ft/yr, respectively. Increasing and decreasing recharge by 10 percent resulted in 20-year EPS pumping rates of 0.84 (2.4-percent increase) and 0.81 acre-ft/acre/yr (1.2-percent decrease), respectively. Increasing and decreasing recharge by 10 percent resulted in 40-year EPS pumping rates of 0.51 (4.1-percent increase) and 0.48 acre-ft/acre/yr (2.0-percent decrease), respectively. Increasing and decreasing recharge by 10 percent resulted in

Table 12. Equal-proportionate-share (EPS) pumping rates for the Rush Springs aquifer, western Oklahoma, 1979-2015.

EPS pumping rate

\begin{tabular}{cccc} 
Period & \multicolumn{3}{c}{ (acre-feet per acre per year) } \\
\cline { 2 - 4 } (years) & $\begin{array}{c}\text { Recharge } \\
\text { reduced by } \\
\text { 10 percent }\end{array}$ & $\begin{array}{c}\text { Normal re- } \\
\text { charge }\end{array}$ & $\begin{array}{c}\text { Recharge } \\
\text { increased by } \\
\text { 10 percent }\end{array}$ \\
\hline 20 & 0.81 & 0.82 & 0.84 \\
40 & 0.48 & 0.49 & 0.51 \\
50 & 0.41 & 0.43 & 0.45 \\
\hline
\end{tabular}


50-year EPS pumping rates of 0.45 (4.7-percent increase) and 0.41 acre-ft/acre/yr (4.7-percent decrease), respectively. At the end of the 20-year EPS scenario, saturated thickness remained primarily in the western parts of the aquifer (fig. 49). In most areas of Washita and Custer Counties, where the aquifer is thickest and had a shallow hydraulic gradient, saturated thickness remained through the end of the 20-year EPS scenario (figs. 49-50). Areas along the Canadian and Washita Rivers in Roger Mills, Ellis, and Dewey Counties remained saturated because of SFR stream inflows and corresponding seepage from streams (figs. 49-50). Other parts of the aquifer generally were unsaturated except for the area located between the Canadian and North Canadian Rivers, which remained saturated because of the (1) thickness of the sediment, (2) increase in calibrated recharge compared to the conceptual budget, and (3) reduction in drain cell outflows from the reduced groundwater levels.

In each EPS scenario, substantial percentages of groundwater storage were removed by the simulated wells in each model cell (fig. 51). Annual EPS groundwater pumping decreased as the thinner areas of the aquifer, including most of the alluvium and terrace, were dewatered and dropped below $15 \mathrm{ft}$ of saturated thickness or went dry (figs. 49-50). Annual groundwater storage changes decreased as annual EPS groundwater pumping decreased, whereby groundwater storage changes were more moderate during the last few years of each scenario (fig. 51). Therefore, the 40- and 50-year EPS pumping rates were closer in value than either of those rates compared to the 20-year EPS pumping rate.

Groundwater storage at the end of the 20-year EPS scenario was about 13,321,000 acre-ft, or about 31,516,437 acre-ft (70 percent) less than the starting storage (fig. 51). Given the 4,616- $\mathrm{mi}^{2}(2,954,545$-acre) aquifer area modified from Neel and others (2018) and a mean Sy of 0.07, this decrease in storage was equivalent to a mean groundwater-level decline of about $152 \mathrm{ft}$. This groundwater-level decline was generally greater than the aquifer thickness in the eastern and southern areas of the model where the aquifer was dewatered (figs. 49-50).

At the end of the 20-year EPS scenario, base flow had decreased to $0 \mathrm{ft}^{3} / \mathrm{s}$ in most model-area stream segments except the Washita River upstream of the Hammon streamgage (07324200) and below Foss Reservoir, and the Canadian River near the upstream model boundary where SFR inflows sustained streamflows (fig. 49). The aquifer groundwater level was below the bottom of the streams during most of the EPS scenarios promoting seepage from streams to the aquifer. This seepage is demonstrated near model column 75 (fig. 50) where the EPS groundwater altitude is greatest directly below the Washita River. By comparison, the Washita River near column 175 is dry; thus, no seepage occurs from the stream to the aquifer.

Fort Cobb Reservoir stage was below the dead-pool stage of 1,300 ft after about 5.5 years of pumping in the 20-year EPS scenario (fig. 52). The drying of the reservoir was caused by (1) the cessation of stream inflows from Cobb, Lake, and Willow Creeks - which constituted about one-third of inflows to Fort Cobb Reservoir - after about 2 years (fig. 52), and (2) the decline of groundwater levels around the reservoir compared to the calibrated model (fig. 49), resulting in large lakebed seepage outflows to the aquifer. Surface-water inflows composed a much larger percentage of the total reservoir inflow than lakebed seepage; thus, the precipitous decline in reservoir stage in the first 5 years is largely the result of the Fort Cobb Reservoir tributaries ceasing to flow. Precipitation and evaporation also decreased as cells representing Fort Cobb Reservoir became dry, but these decreases tended to offset each other. When the EPS scenarios were run without simulating Fort Cobb Reservoir, the change in EPS pumping rate was negligible; therefore, the 40- and 50-year EPS scenarios were run without the Lake package to save computation time. 


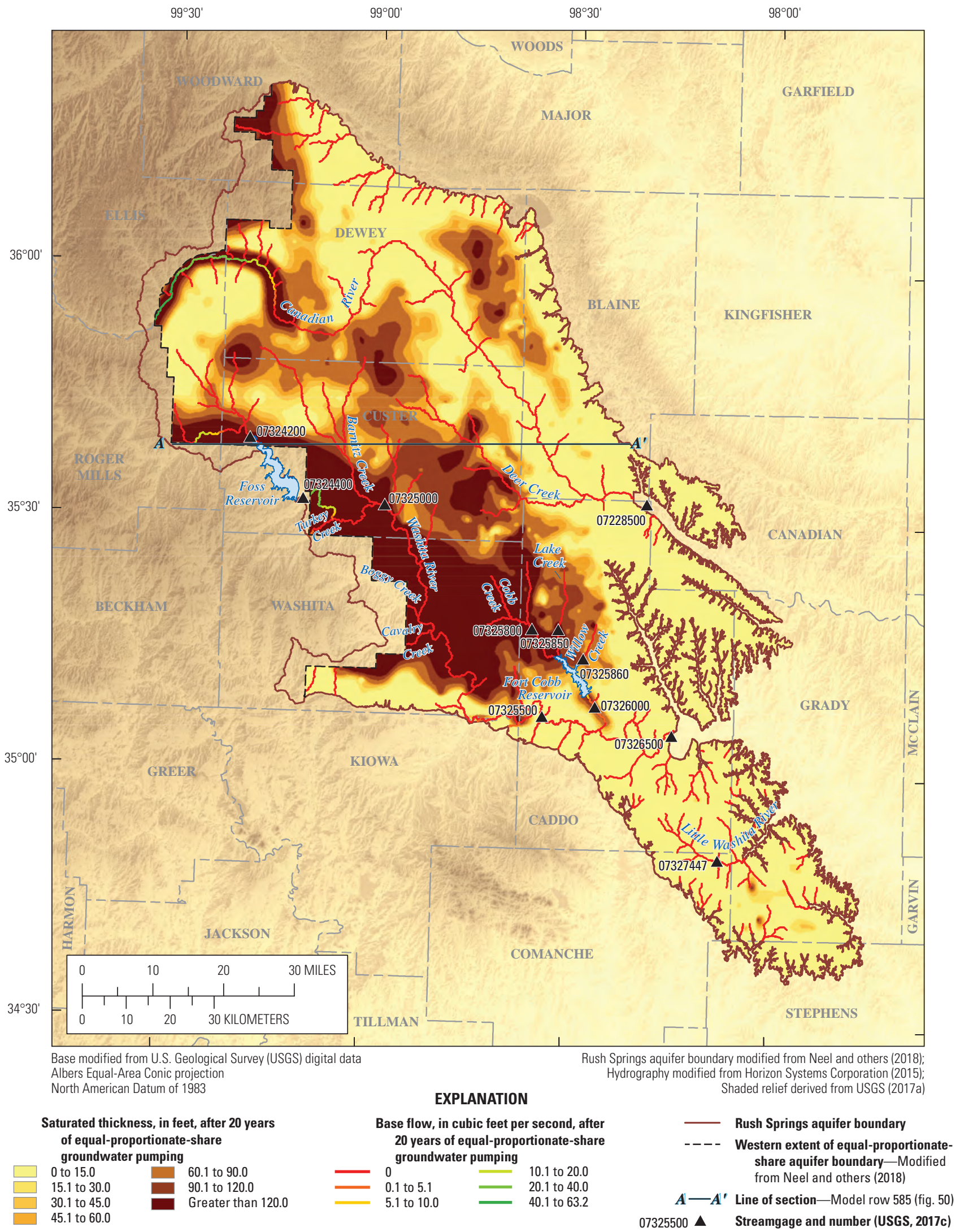

Figure 49. Simulated saturated thickness and simulated base flow after 20 years of continuous equal-proportionate-share groundwater pumping in the Rush Springs aquifer, western Oklahoma. 


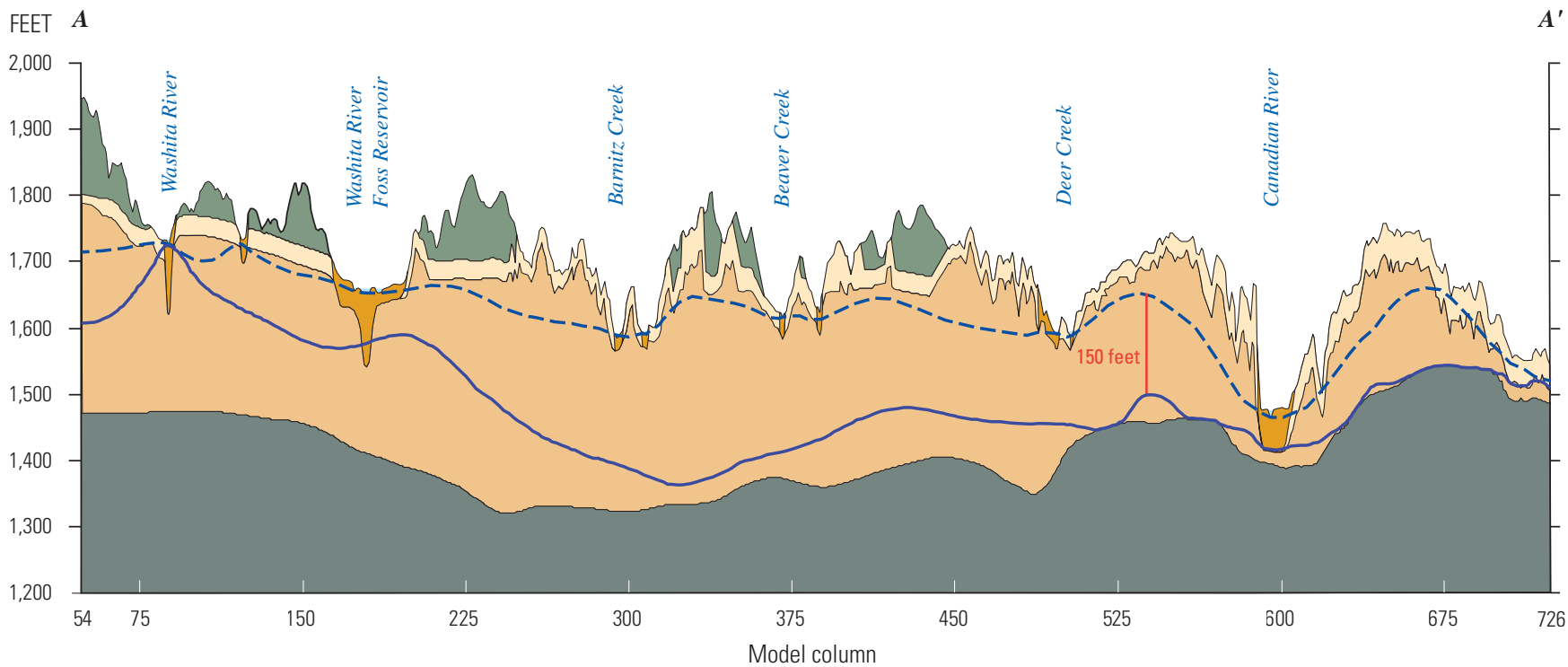

\section{EXPLANATION}

Model layer 1-Cloud Chief Formation Model layer 2-Alluvium and terrace deposits Model layers 2 and 3-Whitehorse Group Upper 30 feet (layer 2) Lower part (layer 3)

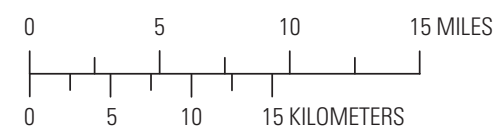

VERTICAL SCALE GREATLY EXAGGERATED

Dog Creek Shale and other bedrock (not modeled)

Potentiometric surface (2013; Neel and others, 2018)

20-year equal-proportionate-share potentiometric surface

Line of section for $\mathbf{A - A}$ ' (model row 585) shown on figure 49

Figure 50. Vertical cross section of the Rush Springs groundwater-flow model after 20 years of equal-proportionate-share groundwater pumping in the Rush Springs aquifer, western Oklahoma. 

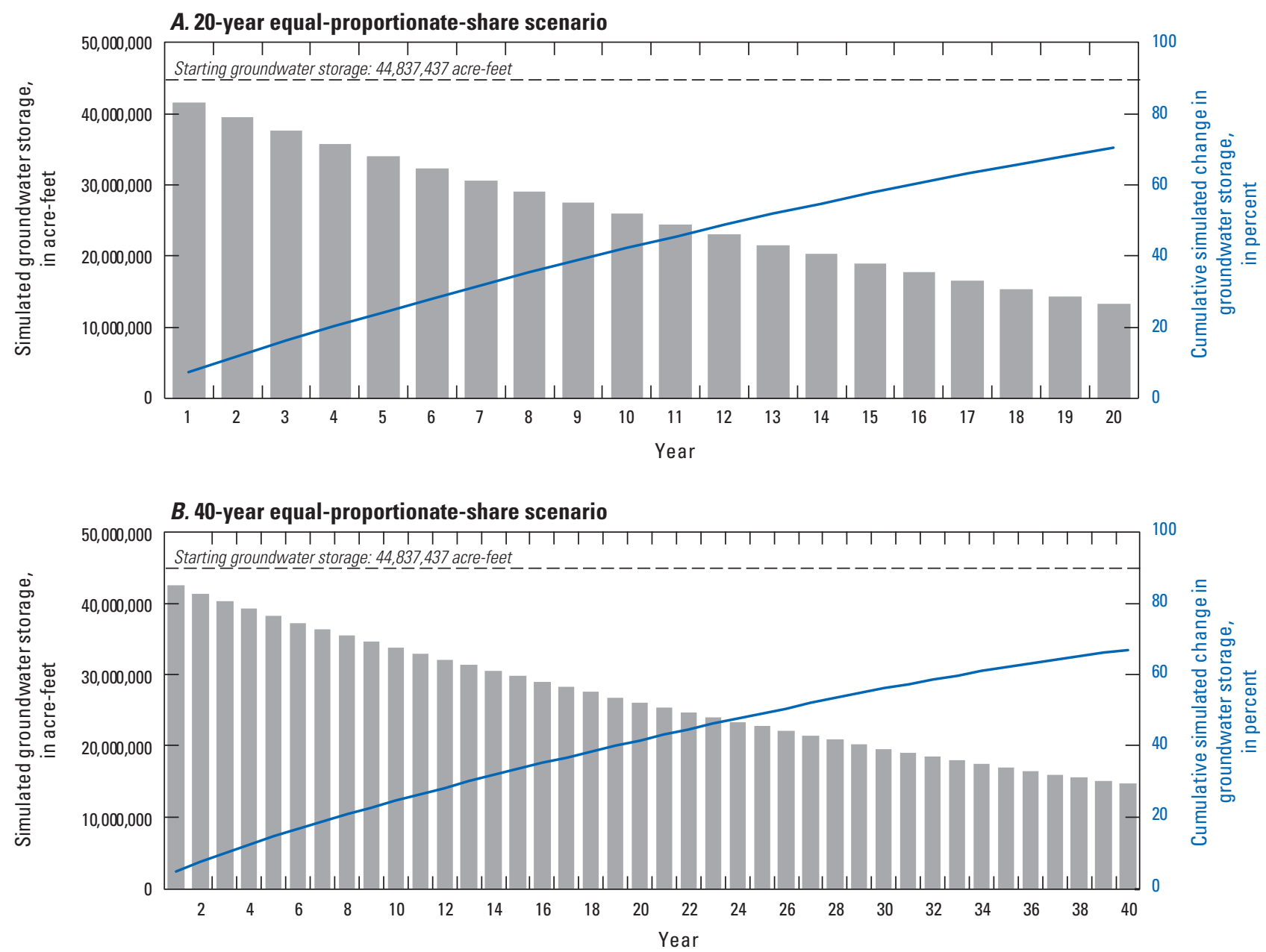

C. 50-year equal-proportionate-share scenario

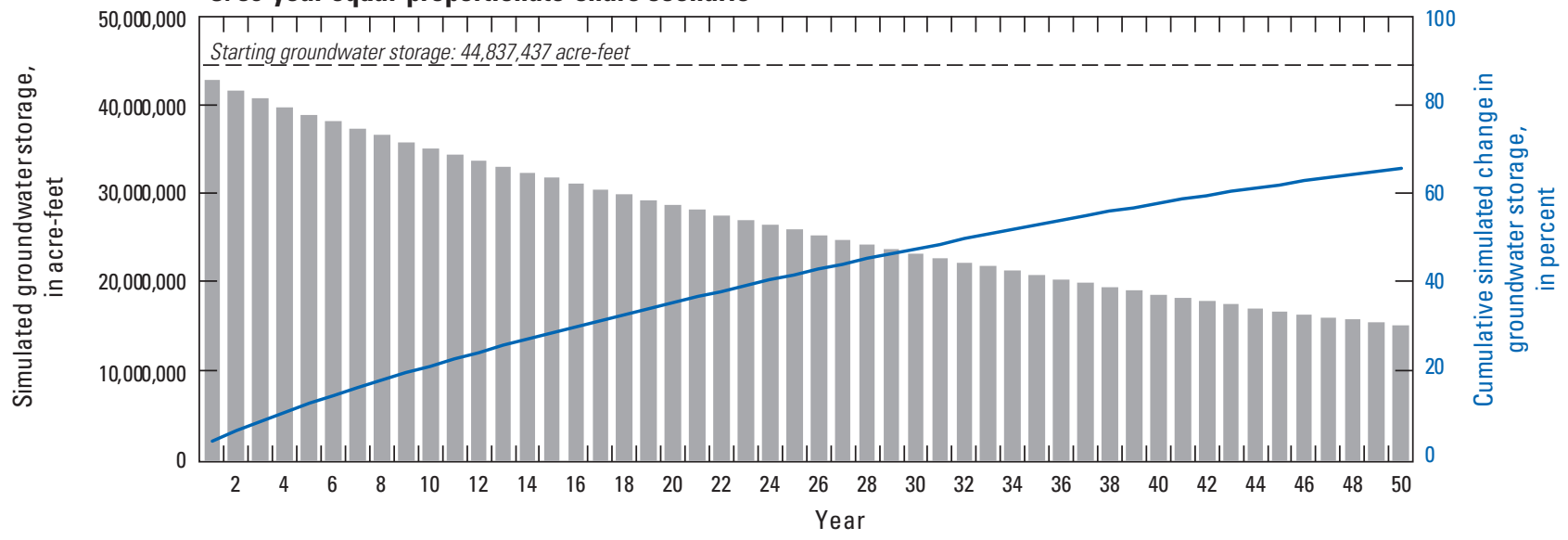

Figure 51. Changes in simulated groundwater storage during $A, 20, B, 40$, and $C, 50$ years of continuous equal-proportionate-share groundwater pumping in the Rush Springs aquifer, western Oklahoma. 


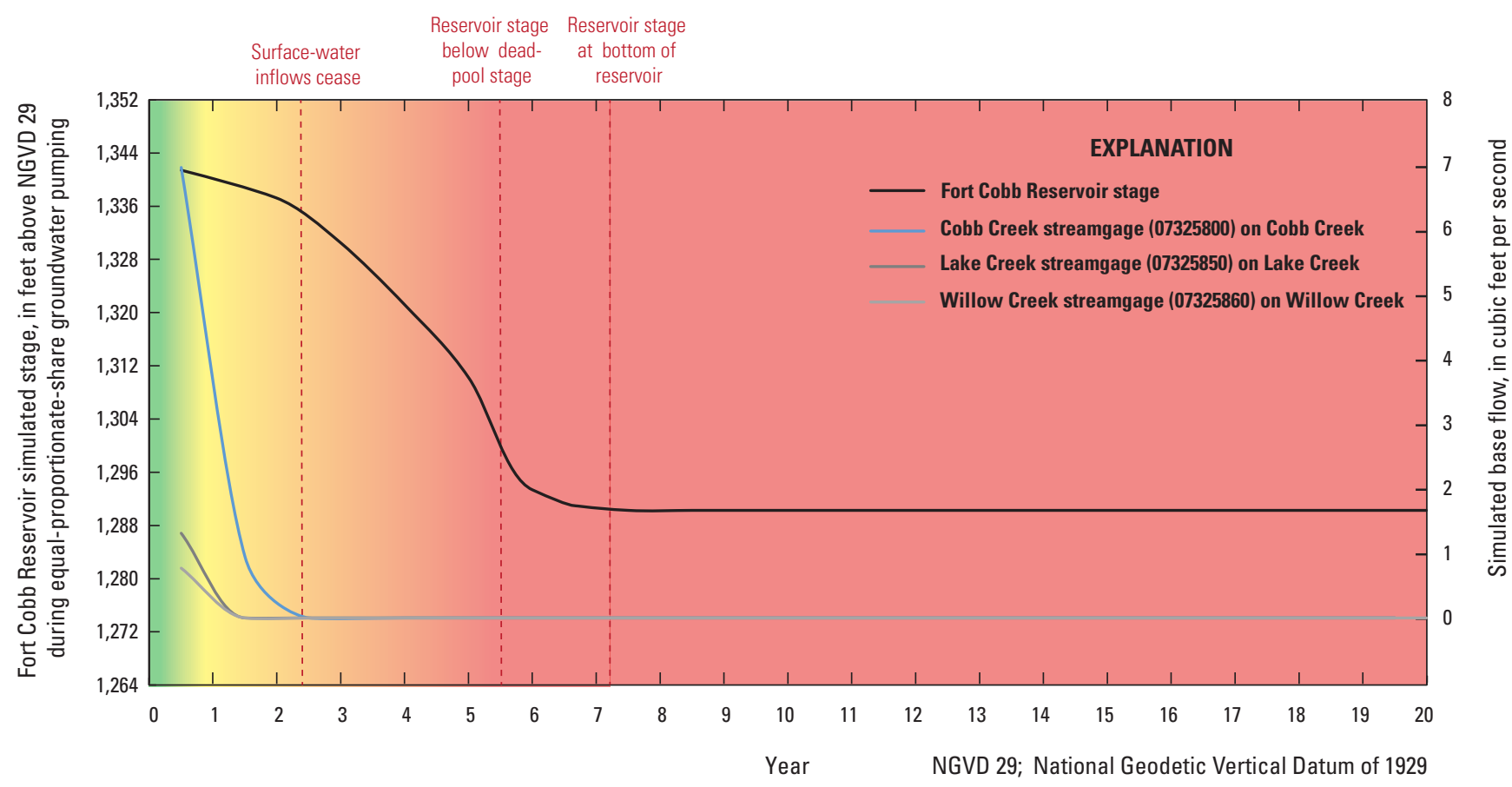

Figure 52. Changes in simulated base flow in Cobb, Lake, and Willow Creeks and in simulated stage in Fort Cobb Reservoir during 20 years of continuous equal-proportionate-share groundwater pumping in the Rush Springs aquifer, western Oklahoma.

\section{Uncertainty in Equal-Proportionate-Share Results}

A probabilistic approach was used to assess the uncertainty in the EPS scenario results. Uncertainty in the EPS results is related to uncertainty in the model, such as simplifications of the modeled natural system, spatial and temporal discretization, or uncertainty in the hydraulic parameter value estimates. Additionally, the process of inverse modeling, whereby parameter values are estimated from a limited amount of data, produces non-unique solutions. Thus, the scenario outputs can be viewed as more "probabilistic" than "deterministic" and may have a range of possible results. By exploring different combinations of likely parameter distributions - which correspond to possible scenario outcomes-the uncertainty can be expressed numerically.

A combined approach using Schur's compliment for linear analysis (Tarantola, 2005; Doherty, 2010; Fienen and others, 2010) to estimate the posterior covariance matrix followed by the Monte Carlo nonlinear-uncertainty technique was applied for the EPS scenario uncertainty analysis by using pyEMU (White and others, 2016). The posterior covariance matrix $\left(\bar{\Sigma}_{\theta}\right)$, which incorporates information gained during the calibration process, is

$$
\bar{\Sigma}_{\theta}=\Sigma_{\theta}-\Sigma_{\theta} \mathrm{J}^{\top}\left[\mathrm{J} \Sigma_{\theta} \mathrm{J}^{\top}+\Sigma_{\epsilon}\right]^{-1} \mathrm{~J} \Sigma_{\theta}
$$

where

$\Sigma_{\theta} \quad$ is the prior covariance matrix,
$\begin{array}{cl}\Sigma_{\epsilon} & \text { is the observation-noise covariance matrix, } \\ \mathrm{T} & \text { indicates the vector transpose, and } \\ \mathrm{J} & \text { is the Jacobian matrix. }\end{array}$

The prior covariance matrix $\left(\Sigma_{\theta}\right)$ contains uncertainty associated with adjustable parameters independent of the calibration process. By using pyEMU, the parameter distributions for this matrix were generated from the usersupplied parameter upper and lower bounds used during the PEST calibration that constitute reasonable value ranges for each parameter and reflect the expert knowledge of the parameters prior to calibration. The upper and lower bounds were the same for all similar parameter types in each parameter group during calibration. The observation-noise covariance matrix $\left(\sum_{\epsilon}\right)$ contains uncertainty in the calibration targets based on the observation weights discussed in the "Calibration-Target Uncertainty and Weighting" section of this report. The Jacobian matrix ( $\mathbf{J}$ ) contains the derivatives of each observation with respect to each parameter.

The posterior covariance matrix (eq. 8) generated by using Schur's complement is a full covariance matrix containing the posterior parameter uncertainty (as variances) and off-diagonal terms that characterize the correlation among parameters. That matrix was used to generate an ensemble of 400 sets (or "realizations") of possible random parameter values by using a multivariate normal distribution centered on the calibrated parameter values. While the Monte Carlo technique often uses realizations derived solely from the prior covariance matrix, use of the posterior covariance matrix 
allowed for the incorporation of knowledge gained during the calibration process.

The assumptions underlying the linear analysis include a normal parameter distribution and a linear sensitivity function between parameters and observations. The parameter distributions for calibrated $\mathrm{Kh}$ (fig. 43), vertical anisotropy, recharge, Sy (fig. 46), Ss, ETg rate multiplier, and SFR conductance were assumed to be normal and were included in the uncertainty analysis. The parameter distributions for other parameters, such as drain and GHB conductance, were not assumed to be normal. Additionally, with the exception of one drain parameter (drn10), identifiability values for these parameters were small (table 6) and were not included in the uncertainty analysis.

Comparison of the prior and posterior distributions provides an understanding of how well the observation dataset used in the model calibration informs the model parameters. The prior and posterior distributions for two selected parameters-layer 3 Sy multiplier (sy3) and the recharge multiplier for recharge zone 15 (rch15) - are shown in figure 53. These two parameters are representative of parameters where either (1) the height is increased and the width is decreased for the posterior distribution compared to the prior distribution, or (2) the posterior distribution is shifted laterally compared to the prior distribution.

The prior distribution for the layer 3 Sy multiplier was 0.8 to 1.3 (fig. 53A), equivalent to mean Sy values between 0.06 and 0.09. The Sy from four of the five pump tests from Neel and others (2018) was between 0.07 and 0.09; therefore, this constrained range was considered to best approximate Sy based on field-test data. The prior distribution for this parameter, whereby the parameter bounds are wider and the frequency (probability) is lower than the posterior, indicates a higher variance, and correspondingly, a higher parameter uncertainty. The posterior distribution for this parameter had a narrower calibration-constrained range between 0.8 and 1.2 (fig. 53A), equivalent to mean Sy values between 0.06 and 0.08 . The posterior distribution for this parameter, which incorporates information from the calibration process, had slightly more constrained parameter bounds and a higher probability, indicating a lower variance, and correspondingly, a lower parameter uncertainty. Thus, this parameter was highly estimable by the calibration process, which is also reflected in an identifiability of 1.0 (fig. 48; table 6).

The posterior distribution for the recharge zone 15 multiplier was shifted laterally compared to the prior distribution (fig. 53B). Lateral shifts in the posterior distribution in either direction occurred for most recharge zones in order to increase or decrease recharge to match the model calibration targets. The posterior distribution was much narrower and had a much greater probability than the prior distribution, indicating a greater level of certainty in the estimation of this parameter. This recharge zone (fig. 20) was the largest of 23 recharge zones and contained many groundwater-level observation wells (fig. 23) and base-flow estimates; thus, this parameter was both highly estimable (fig. 53B) and highly identifiable (0.99; fig. 48; table 6).

A. Layer 3 specific yield multiplier (sy3)

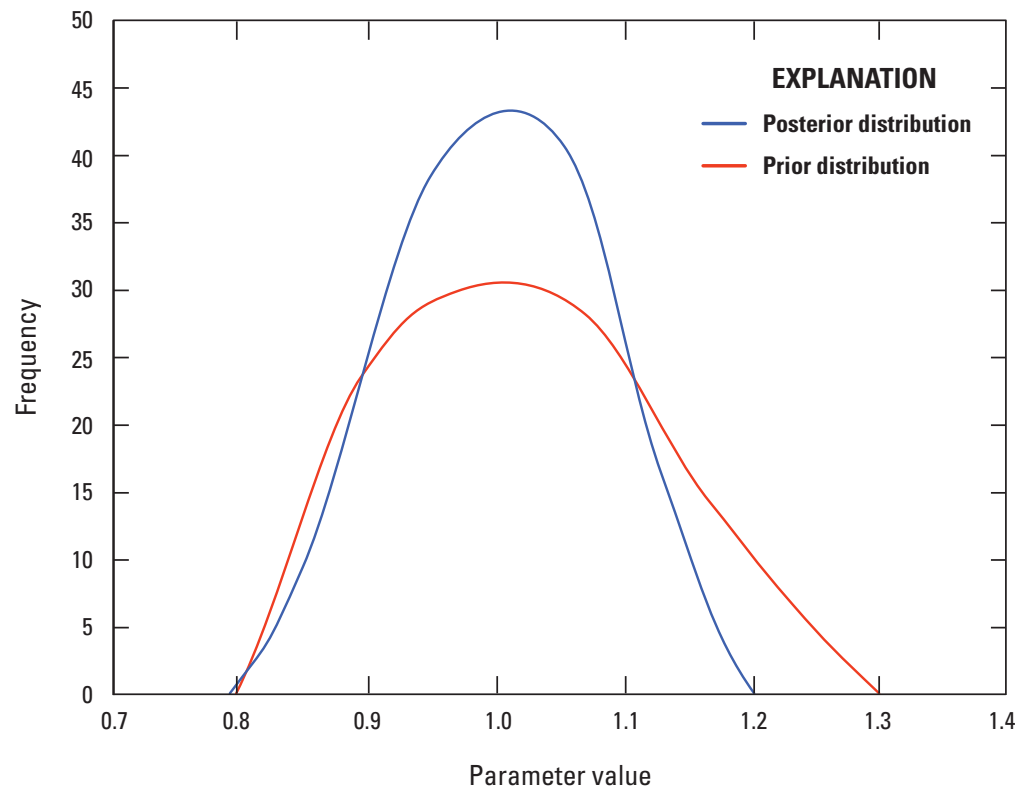

B. Recharge zone 12 multiplier (rch15)

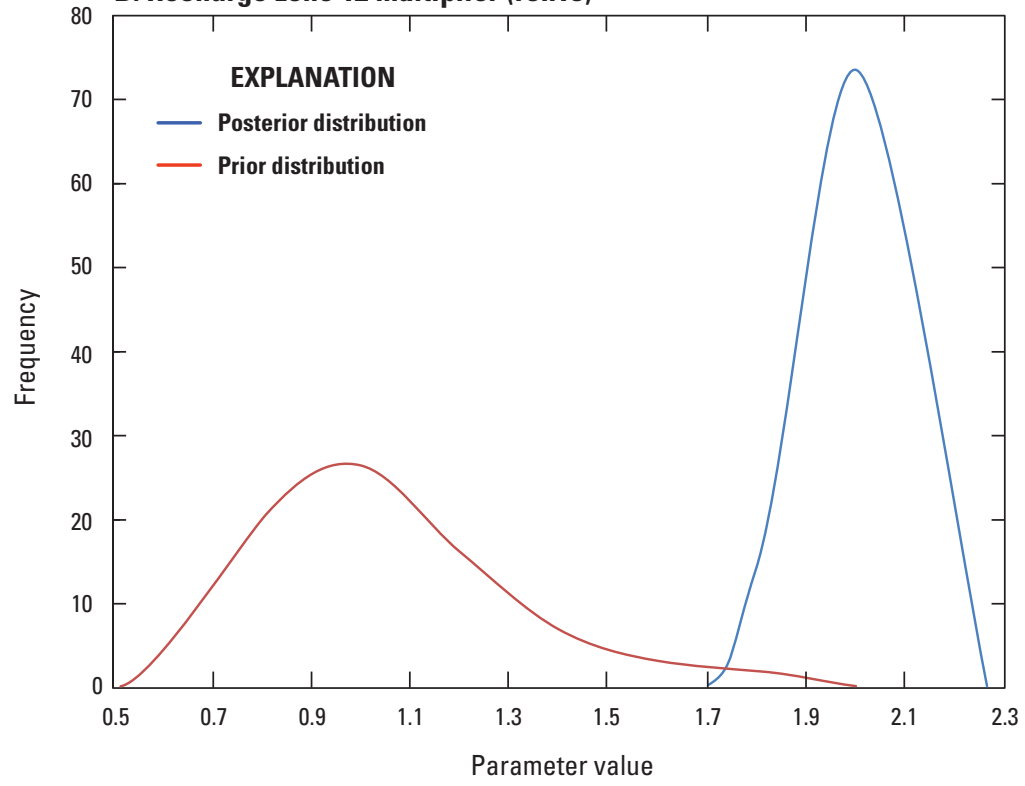

Figure 53. Parameter distribution of $A$, layer 3 specific yield multiplier and $B$, recharge zone 12 multiplier for the equalproportionate-share uncertainty analysis for the Rush Springs aquifer, western Oklahoma. 
Following the linear analysis, parameter files were created from the 400 realizations generated by using the posterior covariance matrix. These parameter files contained the random sets of possible parameter values that would be used by PEST for each realization and account for the correlation among parameters. The PEST control file was then modified so that all parameters except for the EPS pumping rate parameter were fixed, and their values were kept constant at the assigned random value generated for each realization from the posterior covariance matrix. Each realization was then run by using the same PEST setup as the EPS scenarios and by using the HTCondor software to coordinate run scheduling and manage output files. Output files for the 400 realizations were about 3.3 gigabytes each; therefore, all of the output files from each realization could not be saved because of storage limitations. Only the MODFLOW and PEST run records listing the value of the calibrated EPS pumping rate parameter were necessary for the analysis.

The 95-percent confidence interval $( \pm 2 \sigma)$ for the 20 -year EPS pumping rate, which is a common measure of uncertainty, was between 0.73 and 0.95 acre-ft/acre/yr (fig. 54). The 68-percent confidence interval $( \pm 1 \sigma)$ for the 20 -year EPS pumping rate was between 0.79 and 0.86 acre-ft/acre/yr. The distribution of the Monte Carlo results is approximately normal. The generation of more realizations, which were limited by the availability of processing cores and run time, may be needed. The largest frequency of realizations were clustered around the 20-year EPS result, indicating a high probability that the EPS pumping rate is closer to this result than for the less-frequent realizations that occurred near the boundaries of the 95-percent confidence interval.

\section{Projected (50-Year) Groundwater Use}

Projected 50-year groundwater-use scenarios were used to simulate the effects of selected well withdrawal rates on groundwater storage in the Rush Springs aquifer. The effects of well withdrawals were evaluated by comparing changes in groundwater storage between four 50 -year scenarios using (1) no groundwater use, (2) mean groundwater use for the model period, (3) increasing groundwater use, and (4) groundwater use at the 2015 rate. The increasing-use scenario assumed a 38-percent increase in pumping over 50 years based on 2010-60 demand projections for western

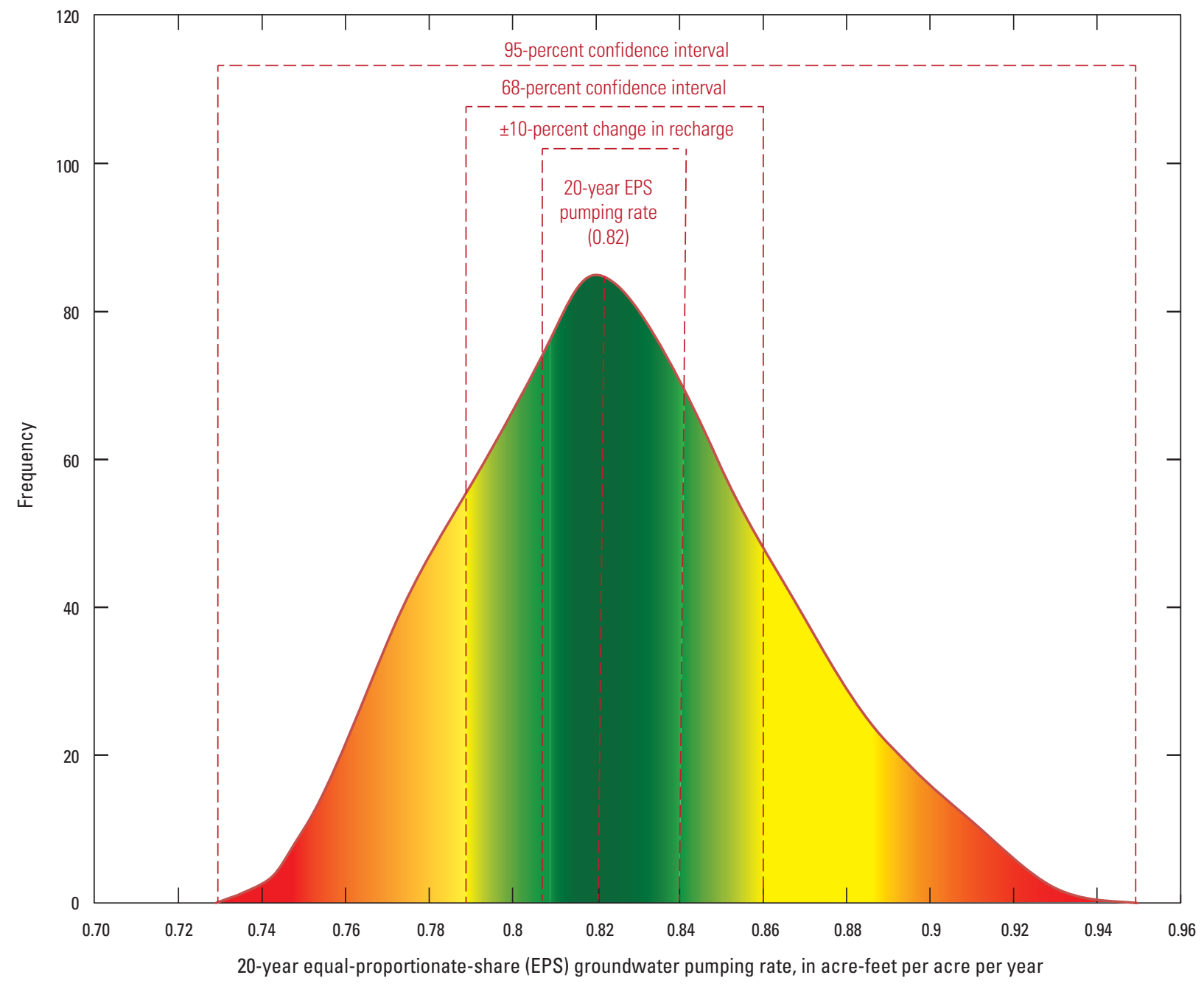

Figure 54. Probabilistic equal-proportionate-share pumping rates for the Rush Springs aquifer, western Oklahoma. 
Oklahoma (West Central Region, OWRB, 2012). Model stresses were configured as the mean of stresses in each month from the calibrated model, and the scenarios assumed that future climate conditions were similar to the climate of the 1979-2015 model period. The projected storage calculation uses the same method as the EPS scenarios, whereby the model Sy is multiplied by the saturated thickness in each active model cell.

For the Rush Springs aquifer, simulated groundwater storage at the end of the projected 50-year groundwater-use scenarios increased by 6.3 percent for the no groundwater-use scenario, 2.3 percent for the mean groundwater-use scenario, 1.3 percent for the increasing groundwater-use scenario, and 0.9 percent for the 2015 groundwater-use scenario (table 13; fig. 55A). The increase in groundwater storage that occurred for the no groundwater-use scenario was expected given that approximately 9 percent of the calibrated water budget is composed of groundwater use (table 11).

For the Fort Cobb Reservoir watershed, simulated groundwater storage at the end of the projected 50-year groundwater-use scenarios increased by 23.6 percent for the no groundwater-use scenario, increased by 1.2 percent for the mean groundwater-use scenario, decreased by 4.0 percent for the increasing groundwater-use scenario, and decreased by 3.5 percent for the 2015 groundwater-use scenario (table 13; fig. 55B).

The disparity in the simulated groundwater storage changes between the Rush Springs aquifer and the Fort Cobb
Reservoir watershed is caused by (1) the large percentage of groundwater use occurring in the Fort Cobb Reservoir watershed relative to the size of the Rush Springs aquifer (compared to the lower percentage of groundwater use relative to the size of the Rush Springs aquifer) and (2) the differences in groundwater-use rates in the Fort Cobb Reservoir watershed compared with those of the Rush Springs aquifer. Substantially more groundwater wells are completed in the Fort Cobb Reservoir watershed (2.6 wells per mile) compared to other areas of the Rush Springs aquifer ( 0.2 wells per mile) (fig. 10). Additionally, 52 percent of groundwater withdrawn from the Rush Springs aquifer is from the Fort Cobb Reservoir watershed. Thus, greater groundwater-level changes occurred primarily in the Fort Cobb Reservoir area and in other areas with large concentrations of groundwater wells and groundwater use.

For the scenario with no groundwater use, a simulated groundwater-level recovery occurred in nearly all areas of the aquifer (fig. 56A), particularly in the Fort Cobb Reservoir watershed where the mean groundwater-level recovery resulted in simulated groundwater levels approximately at or slightly above land surface. Groundwater storage also increased substantially in the area northeast of the Canadian River. Base flows for this scenario increased between $8.0 \mathrm{ft}^{3} / \mathrm{s}$ (50 percent) at the Cobb Creek streamgage (07325800) and $5.5 \mathrm{ft}^{3} / \mathrm{s}$ (354 percent) at the Willow Creek streamgage (07325860) (fig. 57).

Table 13. Changes in groundwater storage after 50 years of groundwater use at selected rates for the Rush Springs aquifer, western Oklahoma.

[Rush Springs aquifer area is 3,181,003 acres; Fort Cobb Reservoir surface watershed is 213,895 acres]

\begin{tabular}{|c|c|c|c|c|c|}
\hline \multicolumn{6}{|c|}{ Rush Springs aquifer } \\
\hline $\begin{array}{l}\text { 50-year groundwater- } \\
\text { use scenario }\end{array}$ & $\begin{array}{l}\text { Groundwater stor- } \\
\text { age at beginning } \\
\text { of scenario } \\
\text { (acre-feet) }\end{array}$ & $\begin{array}{l}\text { Groundwater stor- } \\
\text { age at end } \\
\text { of scenario } \\
\text { (acre-feet) }\end{array}$ & $\begin{array}{l}\text { Change in ground- } \\
\text { water storage } \\
\text { (acre-feet) }\end{array}$ & $\begin{array}{l}\text { Change in ground- } \\
\text { water storage } \\
\text { (percent) }\end{array}$ & $\begin{array}{l}\text { Mean change } \\
\text { in groundwater } \\
\text { levels } \\
\text { (feet) }\end{array}$ \\
\hline No groundwater use & $43,998,000$ & $46,790,000$ & $2,792,000$ & 6.3 & 12.5 \\
\hline $\begin{array}{l}\text { Mean groundwater use, } \\
\text { 1979-2015 }\end{array}$ & $43,998,000$ & $44,992,000$ & 994,000 & 2.3 & 4.5 \\
\hline $\begin{array}{l}\text { Increasing groundwater use } \\
\text { (38-percent increase) }\end{array}$ & $43,992,000$ & $44,567,000$ & 575,000 & 1.3 & 2.6 \\
\hline 2015 groundwater use & $43,998,000$ & $44,374,000$ & 376,000 & 0.9 & 1.7 \\
\hline \multicolumn{6}{|c|}{ Fort Cobb Reservoir surface watershed of the Rush Springs aquifer } \\
\hline $\begin{array}{l}\text { 50-year groundwater- } \\
\text { use scenario }\end{array}$ & $\begin{array}{l}\text { Groundwater stor- } \\
\text { age at beginning } \\
\text { of scenario } \\
\text { (acre-feet) }\end{array}$ & $\begin{array}{c}\text { Groundwater stor- } \\
\text { age at end } \\
\text { of scenario } \\
\text { (acre-feet) }\end{array}$ & $\begin{array}{l}\text { Change in ground- } \\
\text { water storage } \\
\text { (acre-feet) }\end{array}$ & $\begin{array}{c}\text { Change in ground- } \\
\text { water storage } \\
\text { (percent) }\end{array}$ & $\begin{array}{c}\text { Mean change } \\
\text { in groundwater } \\
\text { levels } \\
\text { (feet) }\end{array}$ \\
\hline No groundwater use & $3,942,000$ & $4,874,000$ & 932,000 & 23.6 & 62.2 \\
\hline $\begin{array}{l}\text { Mean groundwater use, } \\
\text { 1979-2015 }\end{array}$ & $3,942,000$ & $3,988,000$ & 46,000 & 1.2 & 3.1 \\
\hline $\begin{array}{l}\text { Increasing groundwater use } \\
\text { (38-percent increase) }\end{array}$ & $3,939,000$ & $3,781,000$ & $-158,000$ & -4.0 & -10.6 \\
\hline 2015 groundwater use & $3,942,000$ & $3,805,000$ & $-137,000$ & -3.5 & -9.2 \\
\hline
\end{tabular}




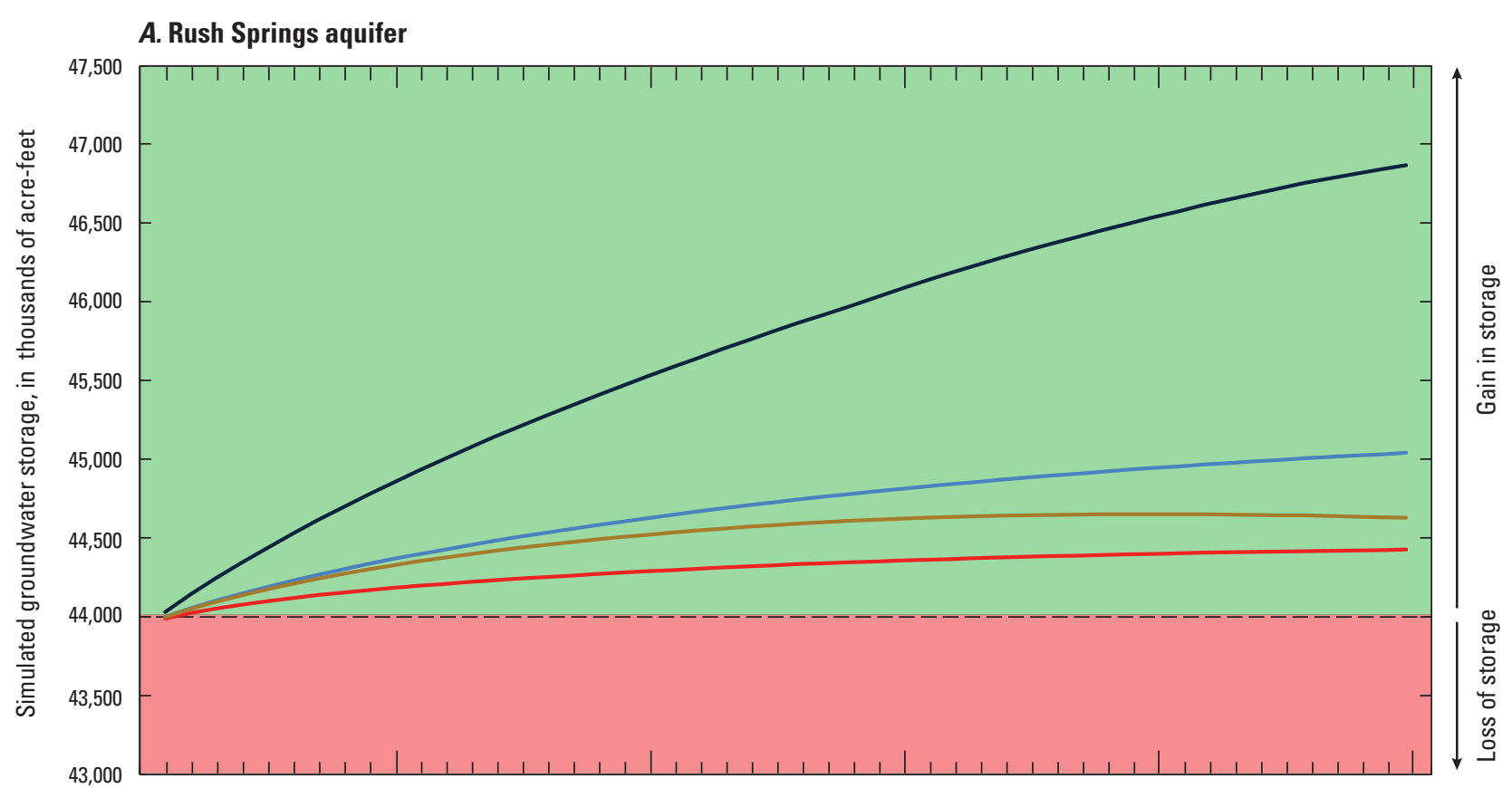

\section{B. Fort Cobb Reservoir surface watershed}

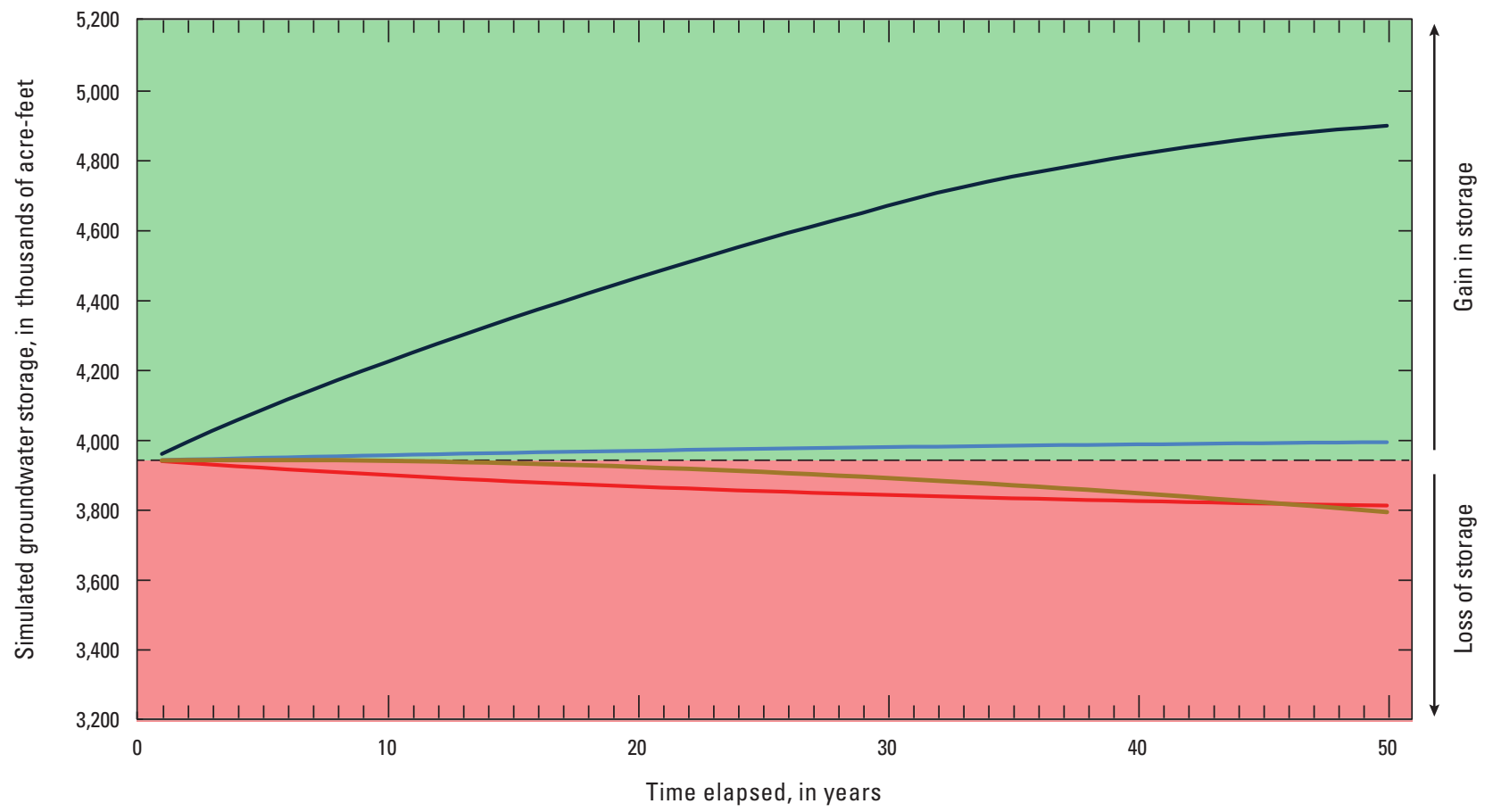

\section{EXPLANATION}

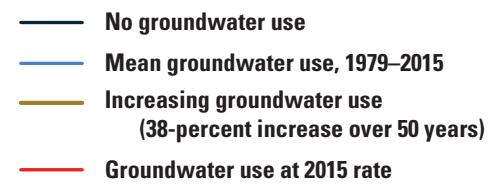

Figure 55. Simulated groundwater storage during 50 years of groundwater use at selected rates for the $A$, Rush Springs aquifer and B, Fort Cobb Reservoir watershed, western Oklahoma. 


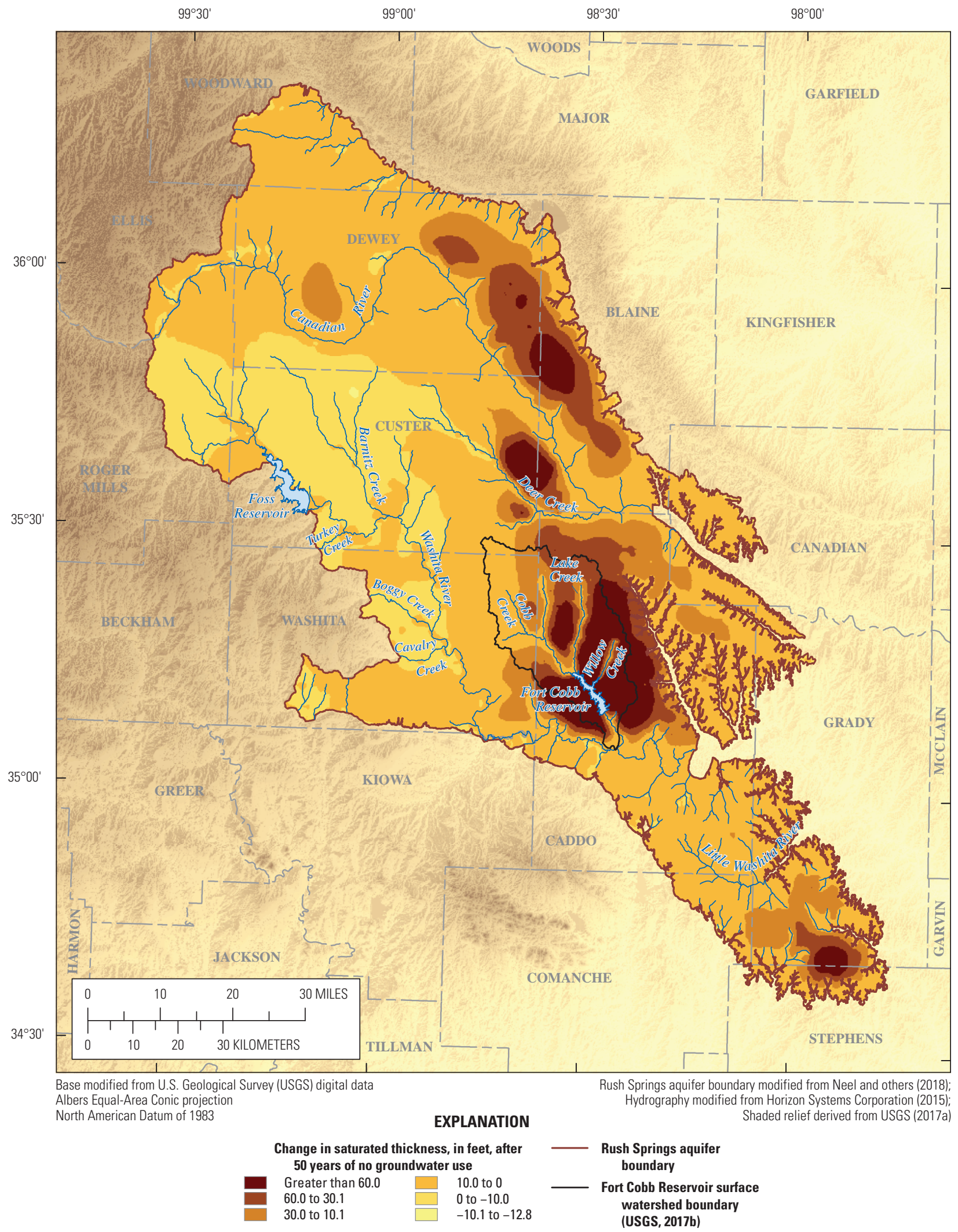

Figure 56. Simulated change in saturated thickness after 50 years of $A$, no groundwater use; $B$, mean groundwater use, 1979-2015; $C$, increasing groundwater use; and D, 2015 groundwater use for the Rush Springs aquifer, western Oklahoma. 


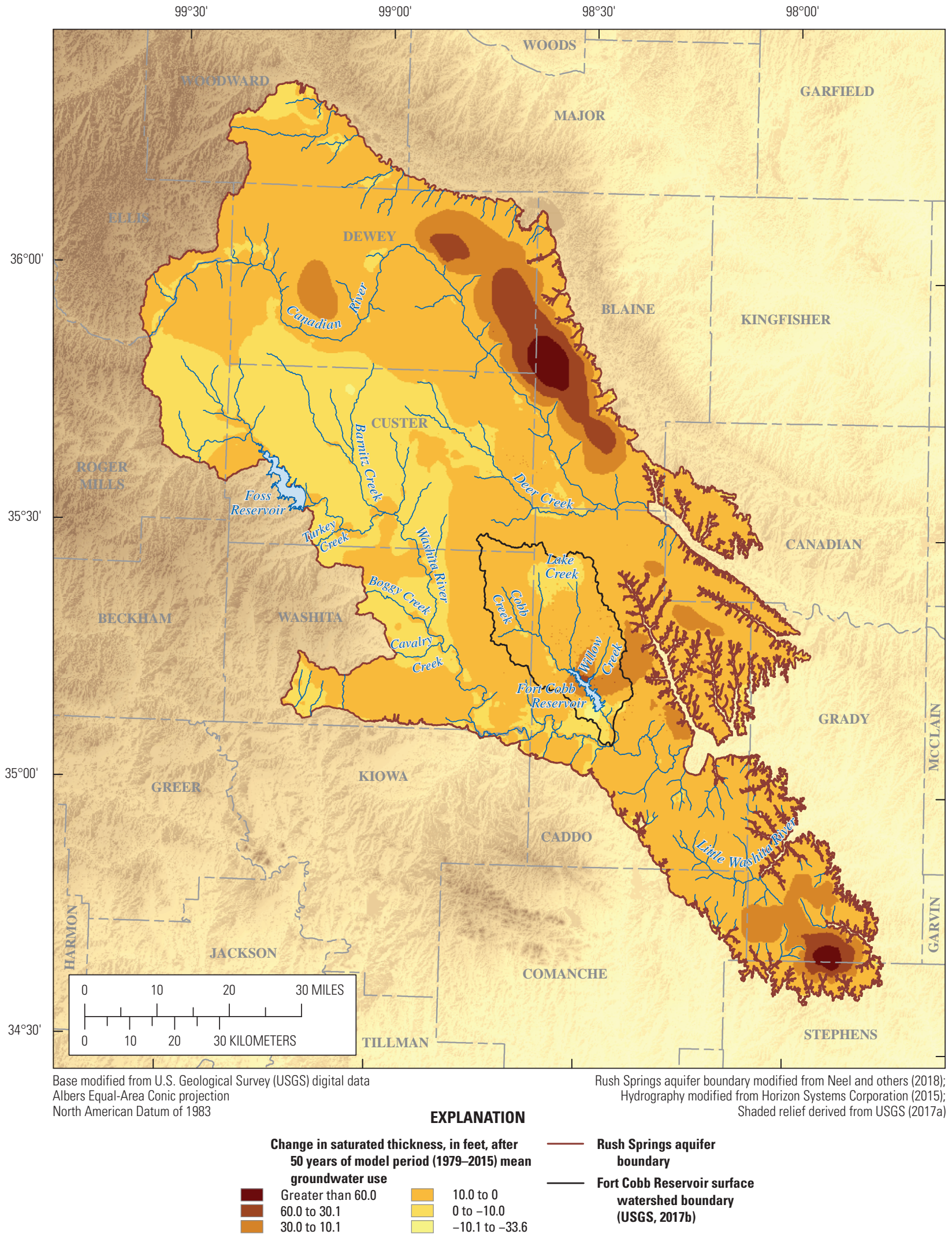

Figure 56. Simulated change in saturated thickness after 50 years of $A$, no groundwater use; $B$, mean groundwater use, 1979-2015; $C$, increasing groundwater use; and $D, 2015$ groundwater use for the Rush Springs aquifer, western Oklahoma.-Continued 


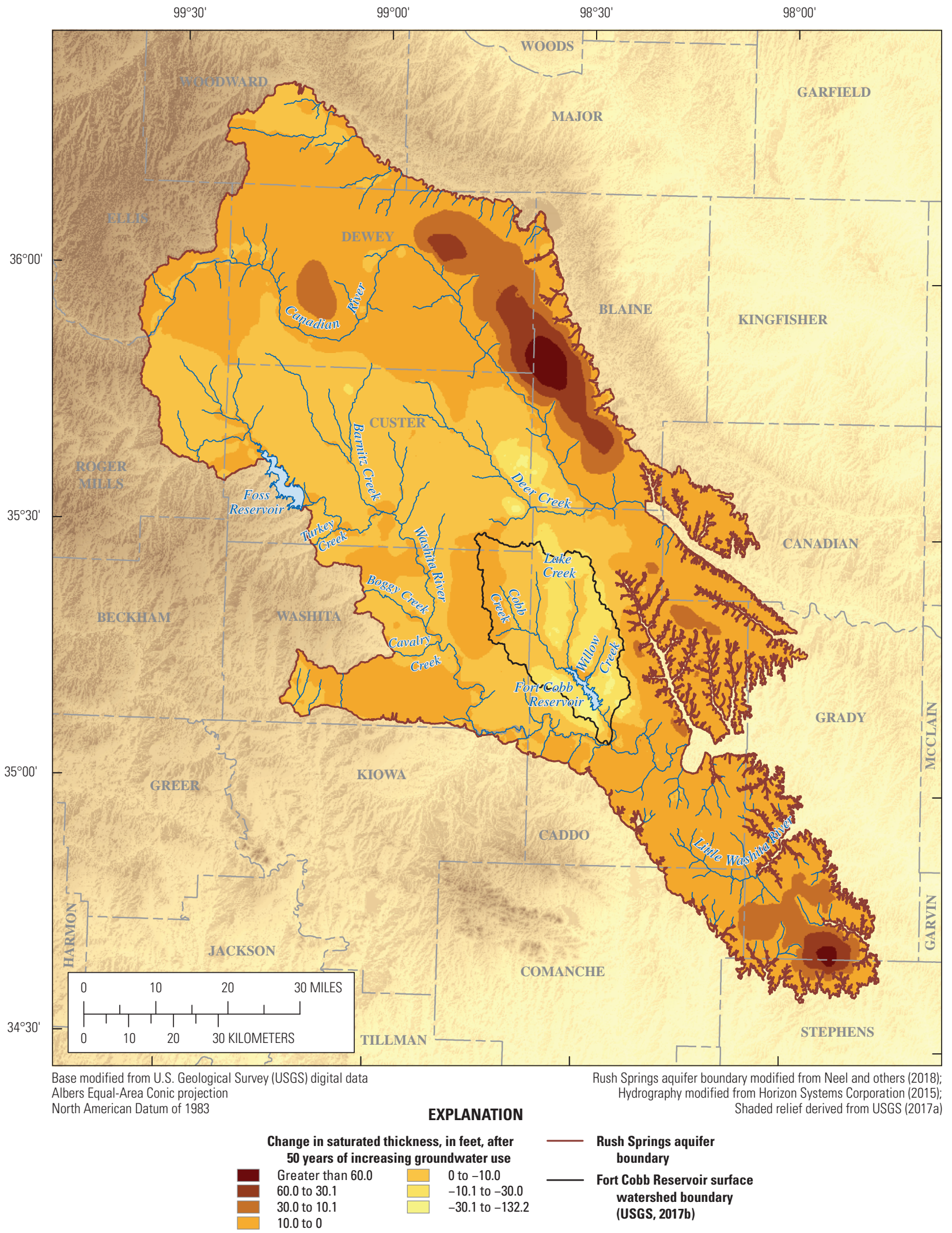

Figure 56. Simulated change in saturated thickness after 50 years of $A$, no groundwater use; $B$, mean groundwater use, 1979-2015; $C$, increasing groundwater use; and $D, 2015$ groundwater use for the Rush Springs aquifer, western Oklahoma.-Continued 


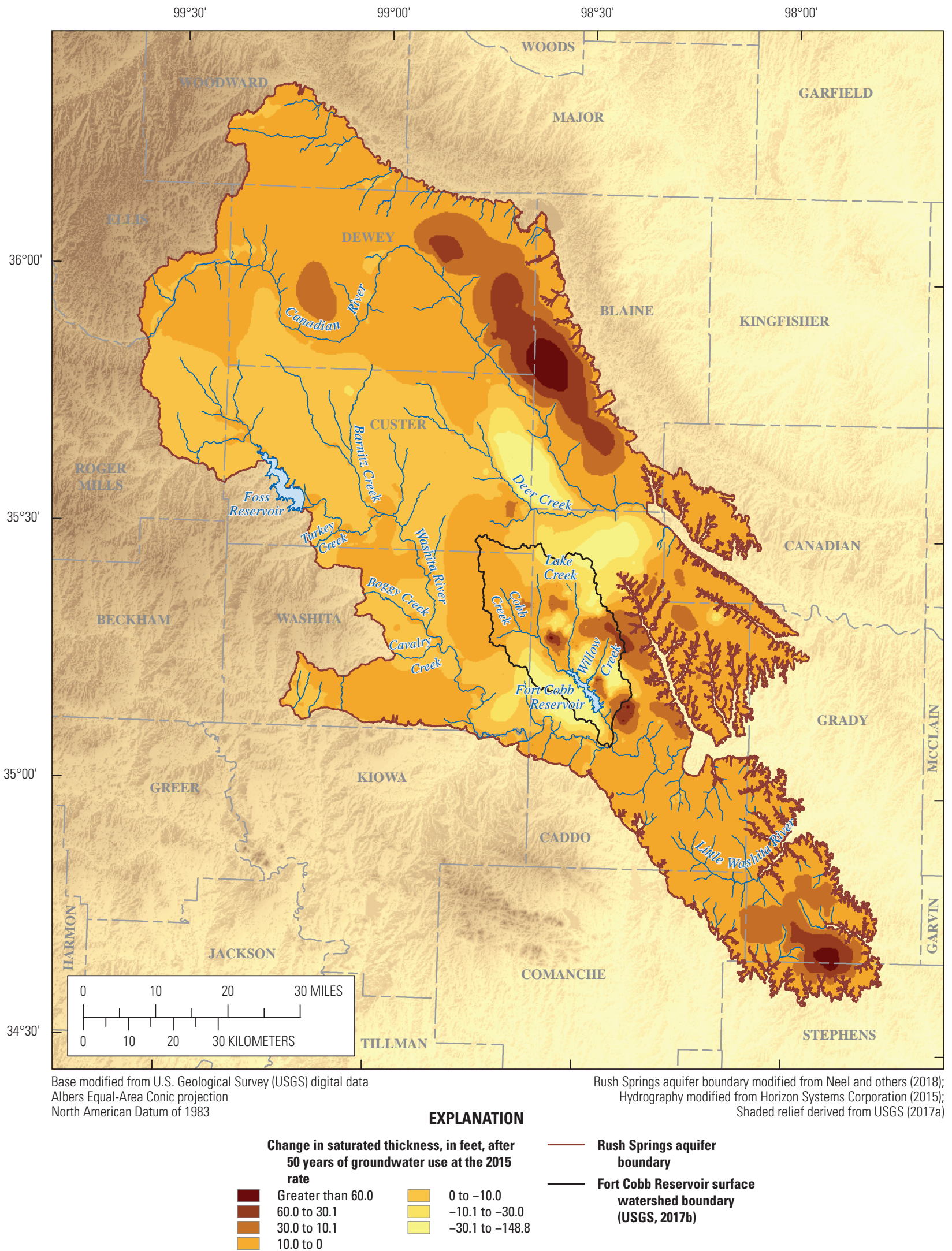

Figure 56. Simulated change in saturated thickness after 50 years of $A$, no groundwater use; $B$, mean groundwater use, 1979-2015; $C$, increasing groundwater use; and D, 2015 groundwater use for the Rush Springs aquifer, western Oklahoma.-Continued 

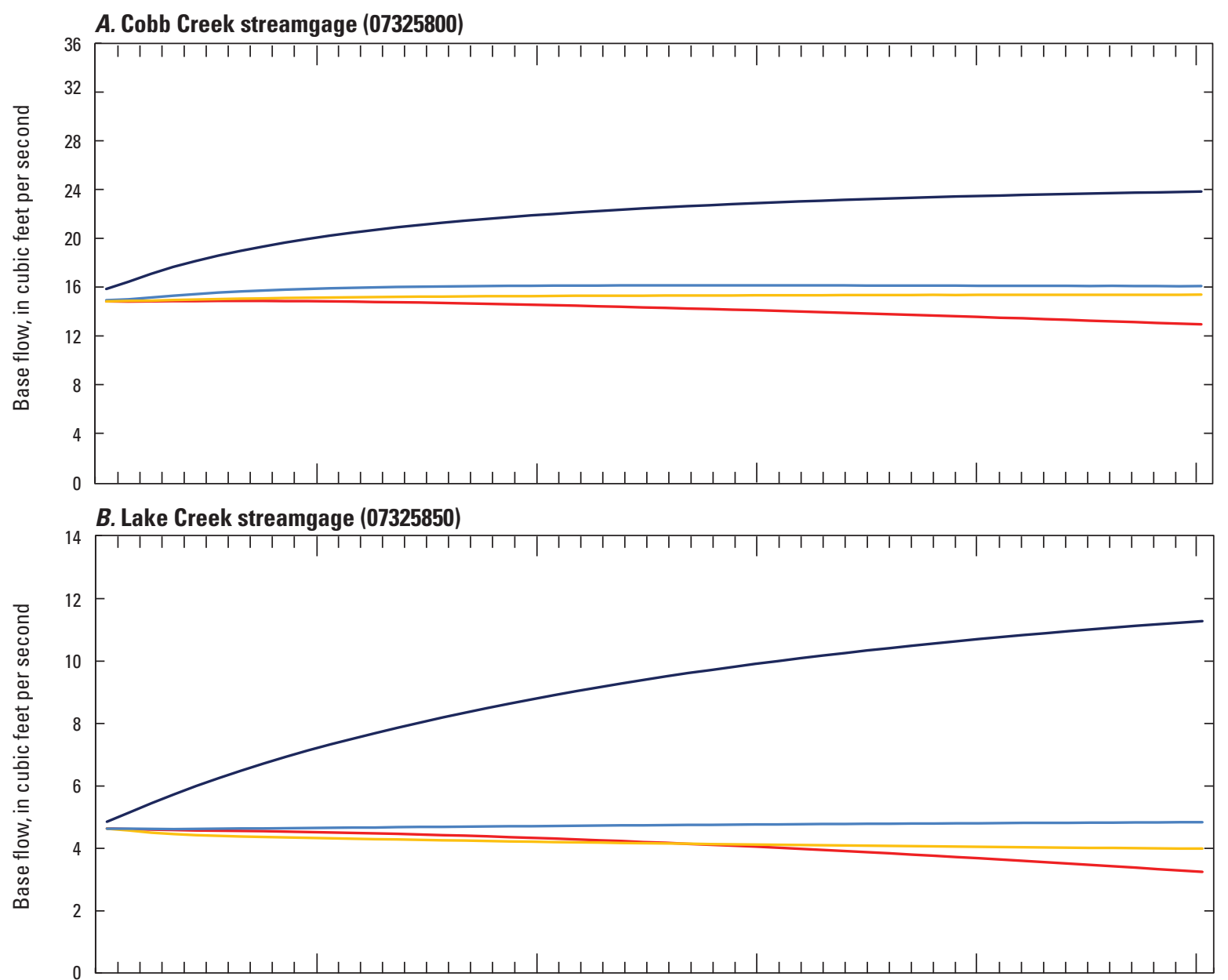

C. Willow Creek streamgage (07325860)

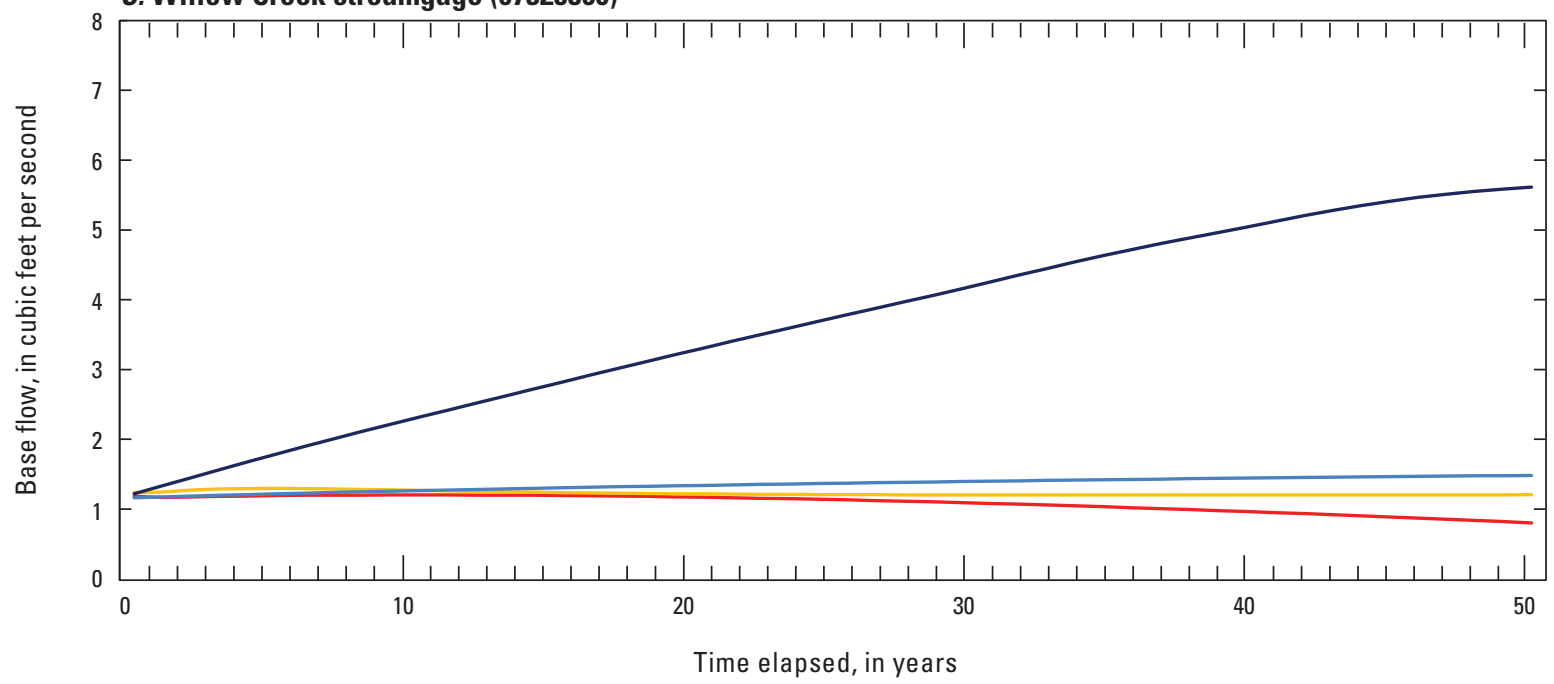

EXPLANATION

No groundwater use scenario

Mean groundwater-use rate (1979-2015) scenario

2015 groundwater-use rate scenario

Increasing demand groundwater-use rate scenario

(38-percent increase over 50 years)

Figure 57. Simulated annual mean base flow through 50 years of groundwater use at selected rates in the Rush Springs aquifer, western Oklahoma. 
For the mean groundwater-use scenario, groundwater storage increased slightly in most areas (fig. 56B), but increased the most in the area northeast of the Canadian River. A decrease in simulated storage occurred in a small area south of Fort Cobb Reservoir where high-capacity simulated pumping wells are concentrated. The mean pumping rate for these wells during the model period was more than double the mean pumping rate for all simulated wells in the aquifer. Base flows for this scenario increased between $0.6 \mathrm{ft}^{3} / \mathrm{s}$ (3.7 percent) at the Cobb Creek streamgage (07325800) and $0.4 \mathrm{ft}^{3} / \mathrm{s}$ (27 percent) at the Willow Creek streamgage (07325860) (fig. 57).

For the increasing-use scenario, groundwater storage in most parts of the aquifer was similar to storage at the beginning of the scenario, with increases occurring in the less-developed northern and southern areas of the aquifer (fig. 56C). Minor groundwater storage declines of about $1-3 \mathrm{ft}$ occurred throughout the central area of the aquifer, and storage declines were more pronounced in the vicinity of the Fort Cobb Reservoir watershed (fig. 56C). After about 10 years when groundwater-use rates had increased by about 6 percent in this area, groundwater storage losses began and continued through the end of the scenario (fig. 56C). Base flow for this scenario decreased between $1.9 \mathrm{ft}^{3} / \mathrm{s}$ (12.7 percent) at the Cobb Creek streamgage (07325800) and $0.5 \mathrm{ft}^{3} / \mathrm{s}$ (32 percent) at the Willow Creek streamgage (07325860) (fig. 57).

For the scenario using groundwater-use rates from 2015, groundwater storage changes were similar to changes in the increasing-use scenario (fig. 56D ). However, greater groundwater storage declines-particularly between the Canadian River and Deer Creek, and between the Canadian River and Lake Creek-occurred in the eastern area of the aquifer compared to the increasing-use scenario. The mean groundwater-use rate for the Rush Springs aquifer in 2015 was 48 percent greater than the mean groundwater-use rate for the model period; therefore, groundwater storage declines were expected in areas with large concentrations of wells (fig. 10). However, the mean groundwater-use rate in 2015 for the Fort Cobb Reservoir watershed was only 29 percent greater than the mean groundwater-use rate for the model period. Thus, groundwater-level declines in the Fort Cobb Reservoir watershed were smaller than the declines in the increasinguse scenario. The base-flow changes for this scenario ranged between a $0.2-\mathrm{ft}^{3} / \mathrm{s}$ increase (1.2 percent) at the Cobb Creek streamgage (07325800) and a $0.6 \mathrm{ft}^{3} / \mathrm{s}$ decrease (14 percent) at the Lake Creek streamgage (07325850) (fig. 57).

\section{Hypothetical (10-Year) Drought}

A hypothetical (10-year) drought scenario was used to simulate the effects of a prolonged period of reduced recharge on groundwater storage in the Rush Springs aquifer and Fort Cobb Reservoir stage and storage. The 10-year period of January 1983 to December 1992 was chosen as the drought period because mean annual base flows and recharge for that period were similar to those of the 1979-2015 model period and facilitates comparison of the hypothetical drought effects to assumed mean hydrologic conditions. Drought effects were quantified by comparing the results of the drought scenario to the calibrated model. To simulate the hypothetical drought, recharge in the calibrated model was reduced by 50 percent during the simulated drought period. Upstream inflows to the Canadian and Washita Rivers and associated tributaries were reduced by 37 percent, which was the mean decrease in annual base flow during the drought of years 1976-81 (Shivers and Andrews, 2013). The simulation was continued 15 years past the end of the drought period until 2007 to assess the recovery of aquifer storage.

The rates of precipitation, evaporation, and surface runoff to Fort Cobb Reservoir were unchanged from the calibrated groundwater model. Observed reservoir releases for each month prior to and during the drought period were included in the simulation. To assess the recovery of Fort Cobb Reservoir stage following the drought period, reservoir releases were suspended until the stage reached the top of the active conservation pool (1,342 ft). Once this stage was reached, reservoir releases were again included in the simulation.

Groundwater storage at the end of the drought period in December 1992 was about 42,983,000 acre-ft, or about 3,525,000 acre-ft (7.6 percent) less than the groundwater storage of the calibrated groundwater model (about 46,508,000 acre-ft) (fig. 58). Based on the 4,970--mi² $(3,181,003$-acre) aquifer area and specific yield of 0.07 , this change in groundwater storage was equivalent to a mean groundwater-level decline of $15.8 \mathrm{ft}$. By comparison, the drought conditions of 2009-14 resulted in a mean simulated groundwater-level decline of $9.5 \mathrm{ft}$ between January 2009 and December 2014. Although mean annual recharge during the hypothetical drought (1.05 in/yr) was greater than the mean annual recharge during the 2009-14 drought (0.6 in/yr), the extended length of the hypothetical drought resulted in greater groundwater-level declines than the 2009-14 drought. During the hypothetical drought, at the 72-month point (December 1988) when the length of the hypothetical drought equaled the length of the 2009-14 drought, the change in groundwater storage for the Rush Springs aquifer was about 1,669,000 acre-ft (fig. 58), or the equivalent of a mean groundwater-level decline of $7.5 \mathrm{ft}$. Thus, if the recharge during the hypothetical drought was set to the recharge during the actual drought, the decrease in groundwater levels between the hypothetical and actual drought would most likely be similar.

Groundwater storage at the end of the hypothetical drought for the Fort Cobb Reservoir watershed was about 3,729,000 acre-ft, or about 303,000 acre-ft (about 7.5 percent) less than the groundwater storage of the calibrated groundwater model (4,032,000 acre-ft). Based on the 213,895-acre Fort Cobb Reservoir watershed area and specific yield of 0.07 , this change in groundwater storage was equivalent to a mean groundwater-level decline of $20.2 \mathrm{ft}$. In comparison, for the Fort Cobb Reservoir watershed, the drought of 2009-14 


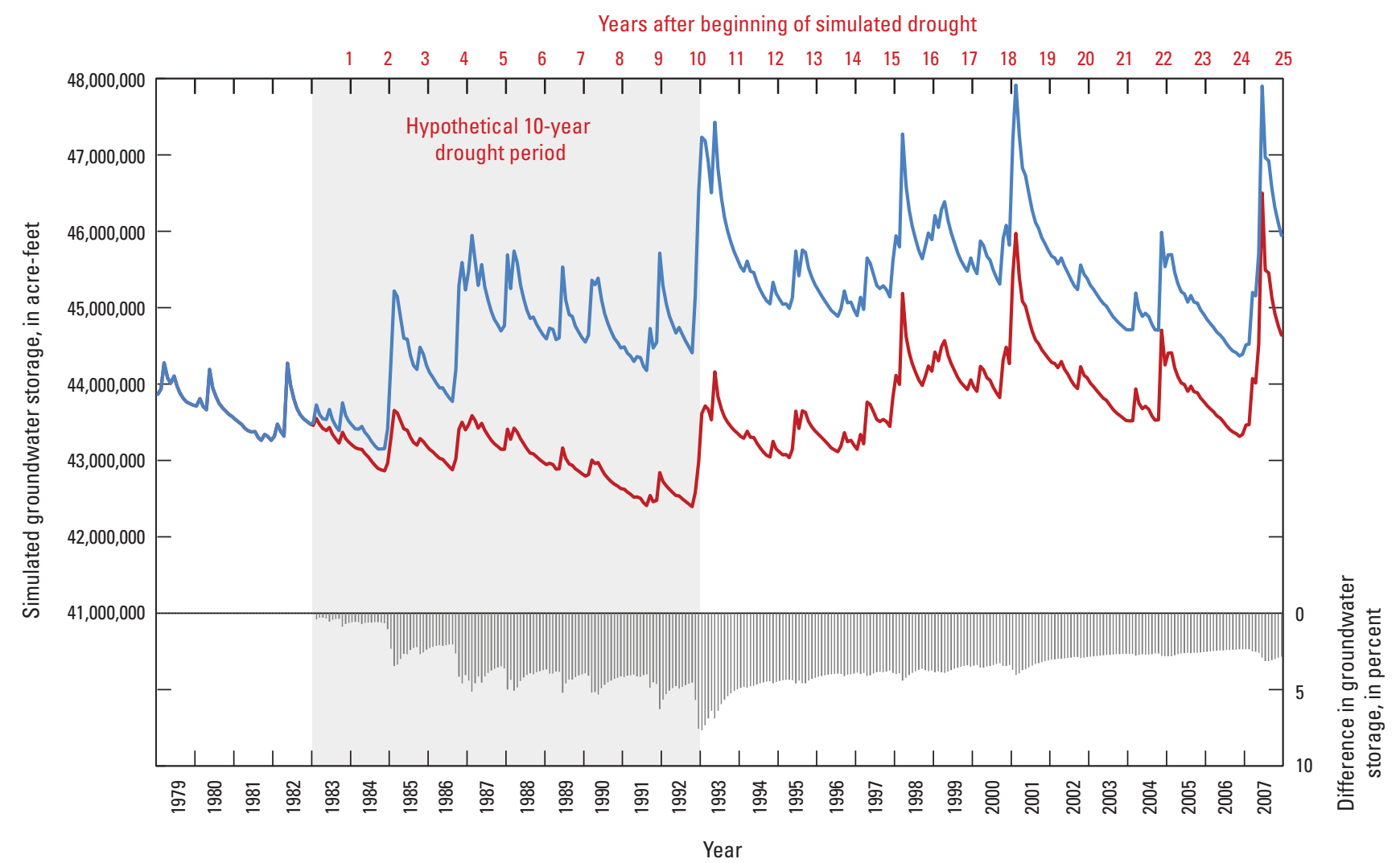

EXPLANATION

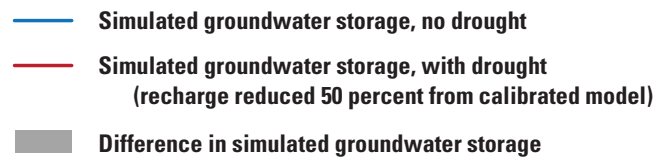

Figure 58. Change in groundwater storage during a hypothetical 10-year drought for the Rush Springs aquifer, western Oklahoma, 1979-2007.

resulted in a mean simulated groundwater-level decline of $15.4 \mathrm{ft}$ between January 2009 and December 2014. At the 72-month point (December 1988) of the hypothetical drought, the change in groundwater storage for the Fort Cobb Reservoir watershed was about 190,000 acre-ft, or the equivalent of a mean groundwater-level decline of $12.7 \mathrm{ft}$.

At the end of the hypothetical drought, the largest changes in saturated thickness occurred in the area northeast of the Canadian River, the area south of the Little Washita River, and in the Fort Cobb Reservoir watershed (fig. 59). In the area northeast of the Canadian River and south of the Little Washita River, groundwater storage was supplied entirely by recharge, so decreases in recharge had substantial effects on groundwater levels. The decreased saturated thickness in some areas resulted in a reduction in simulated well withdrawals as compared to the calibrated groundwater model. The saturated thickness of areas near the streams and associated tributaries changed little during the hypothetical drought; however, simulated base flows decreased at each simulated streamgage.
After the first 2 years of the hypothetical drought, baseflow declines at the Canadian and Washita River streamgages were similar (fig. 60). At the end of the hypothetical drought, simulated flows at the Bridgeport (07228500), Hammon (07324200), Clinton (07325000), Carnegie (07325500), and Anadarko (07326500) streamgages declined 39, 42, 48, 45, and 44 percent, respectively, during this period compared to the calibrated groundwater model. At the end of the 10-year hypothetical drought period, base-flow declines for the Fort Cobb Reservoir tributaries were the largest of the declines at model-area streamgages; base flow declined at the Cobb (07325800), Lake (07325850), and Willow (07325860) Creek streamgages by 53, 58, and 59 percent, respectively. Although groundwater-level declines in the immediate vicinity of the Fort Cobb Reservoir tributaries were not particularly large (fig. 59), these streams were relatively small; thus, minor groundwater-level changes have an effect on base flows. Simulated low-flow conditions in some months may be overpredicted during the drought scenario because periods of 


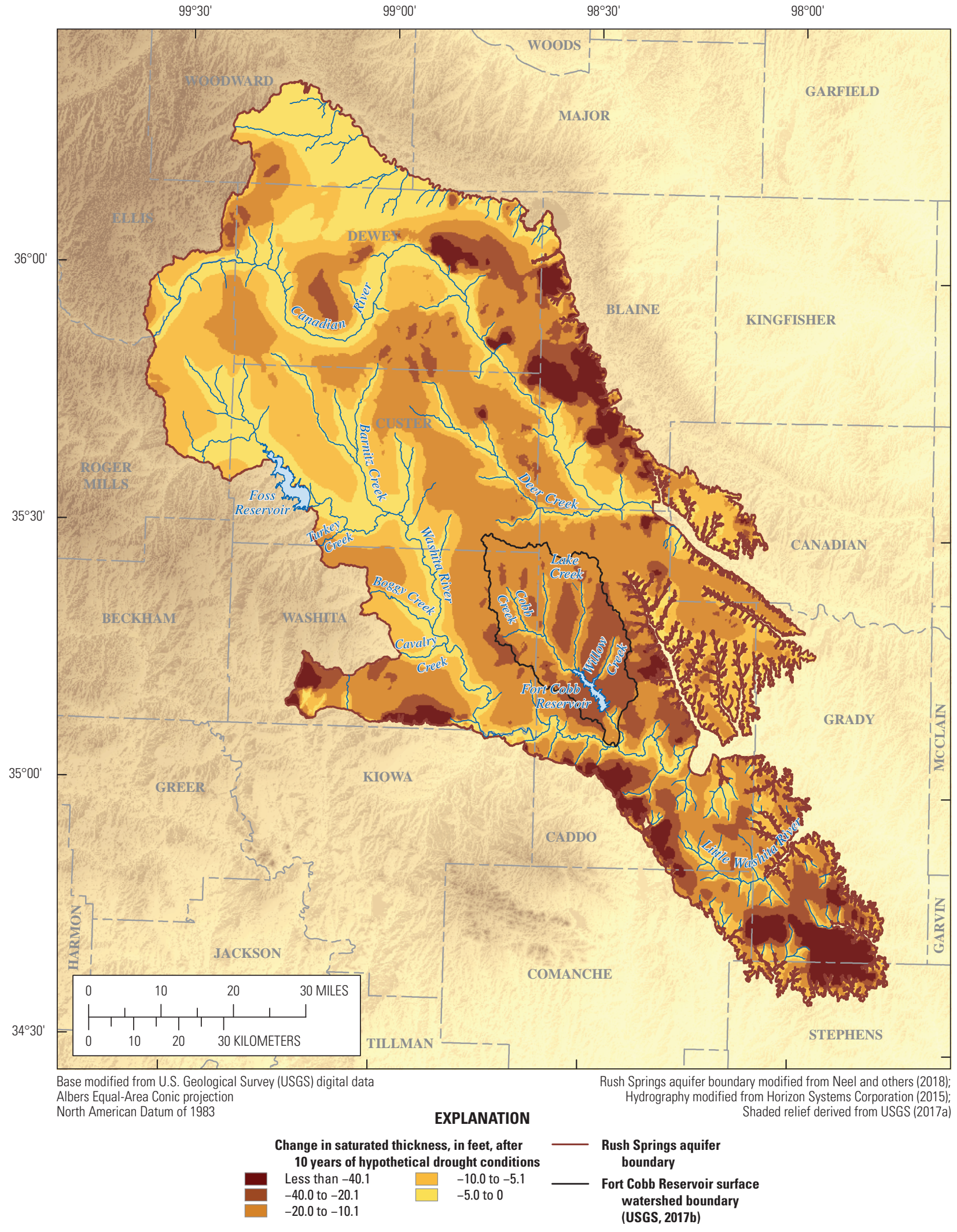

Figure 59. Simulated change in saturated thickness after a hypothetical 10-year drought for the Rush Springs aquifer, western Oklahoma, 1979-2007. 
A. Hammon streamgage (07324200) on Washita River
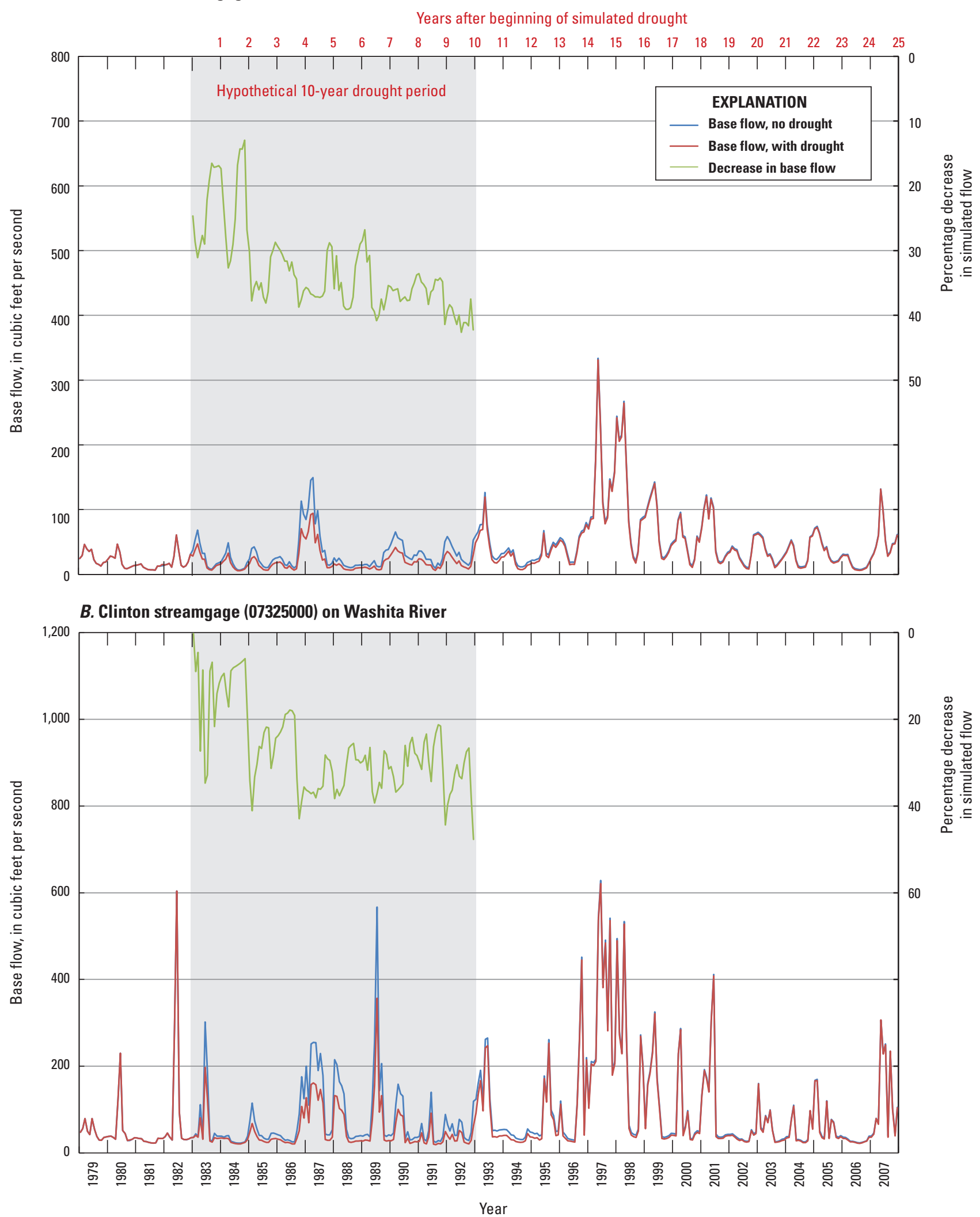

Figure 60. Changes in simulated base flow at $A$, Hammon streamgage (07324200) on Washita River; $B$, Clinton streamgage (07325000) on Washita River; $C$, Carnegie streamgage (07305500) on Washita River; $D$, Anadarko streamgage (07326500) on Washita River; E, Bridgeport streamgage (07228500) on Canadian River; F, Cement streamgage (07327447) on Little Washita River; G, Cobb Creek streamgage (07325800); H, Lake Creek streamgage (07325850); and I, Willow Creek streamgage (07325860) for the numerical groundwater-flow model of the Rush Springs aquifer, western Oklahoma, 1979-2007. 


\section{Carnegie streamgage (07325500) on Washita River}
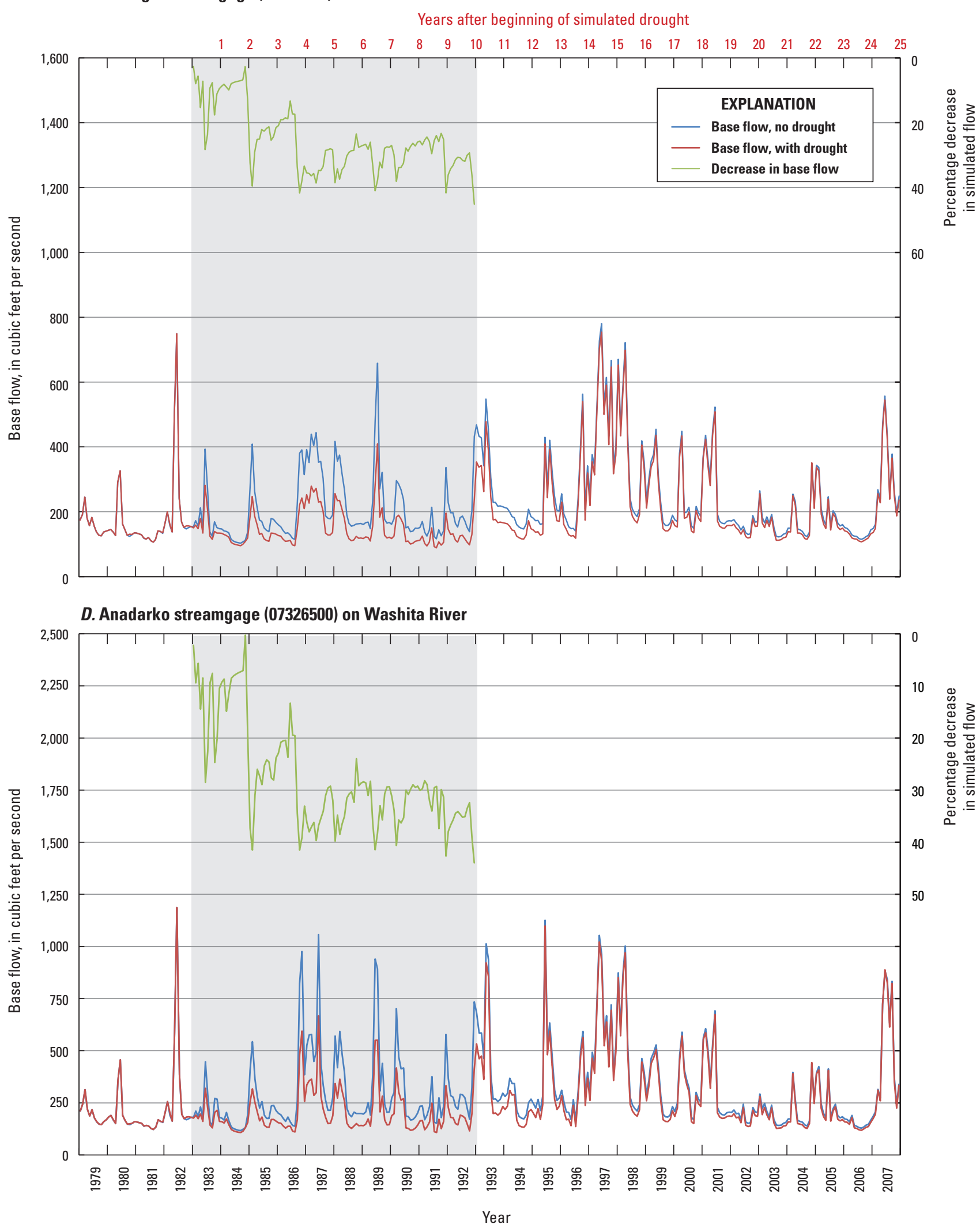

Figure 60. Changes in simulated base flow at $A$, Hammon streamgage (07324200) on Washita River; $B$, Clinton streamgage (07325000) on Washita River; $C$, Carnegie streamgage (07305500) on Washita River; $D$, Anadarko streamgage (07326500) on Washita River; E, Bridgeport streamgage (07228500) on Canadian River; $F$, Cement streamgage (07327447) on Little Washita River; G, Cobb Creek streamgage (07325800); H, Lake Creek streamgage (07325850); and I, Willow Creek streamgage (07325860) for the numerical groundwater-flow model of the Rush Springs aquifer, western Oklahoma, 1979-2007.-Continued 


\section{E. Bridgeport streamgage (07228500) on Canadian River}

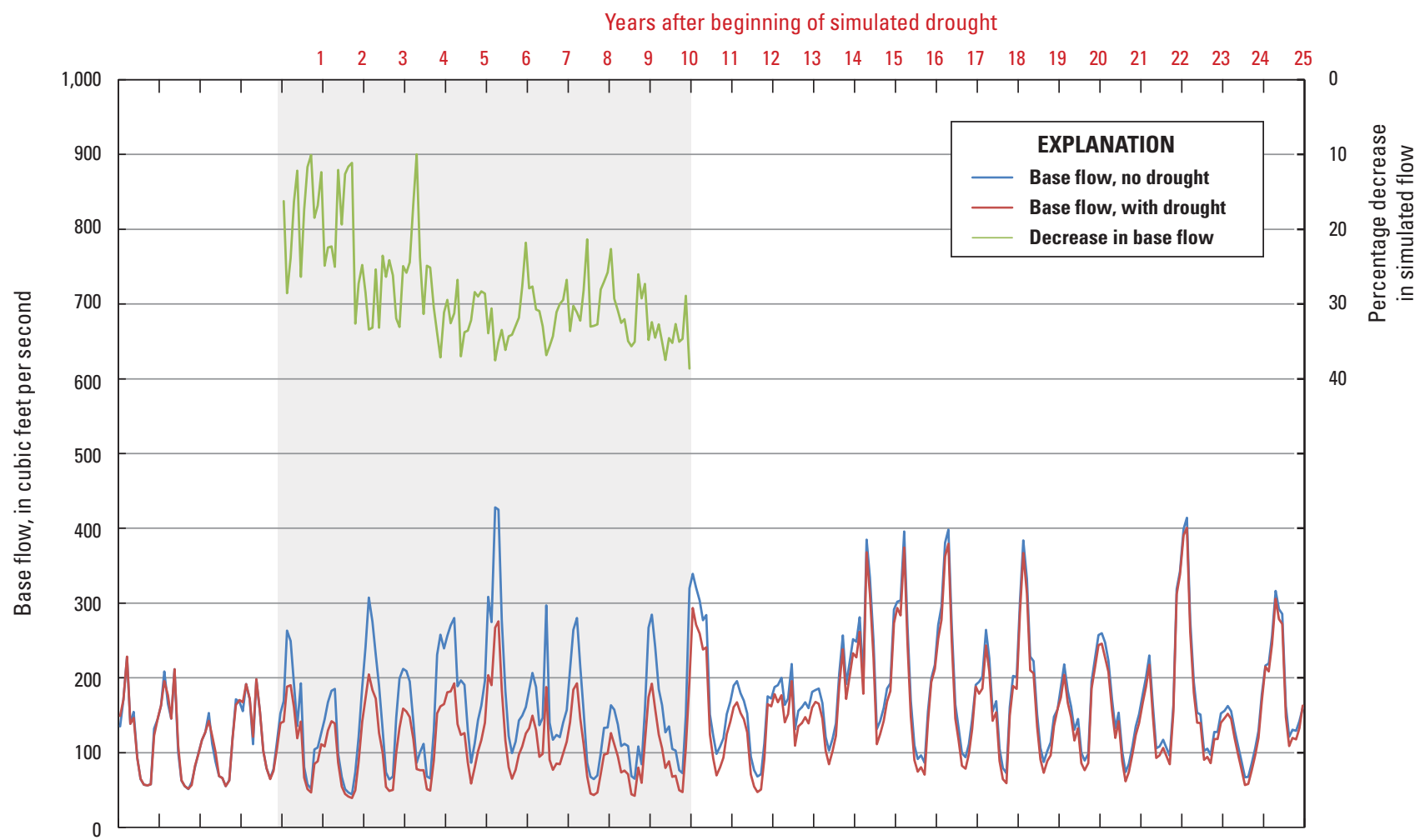

F. Cement streamgage (07327447) on Little Washita River

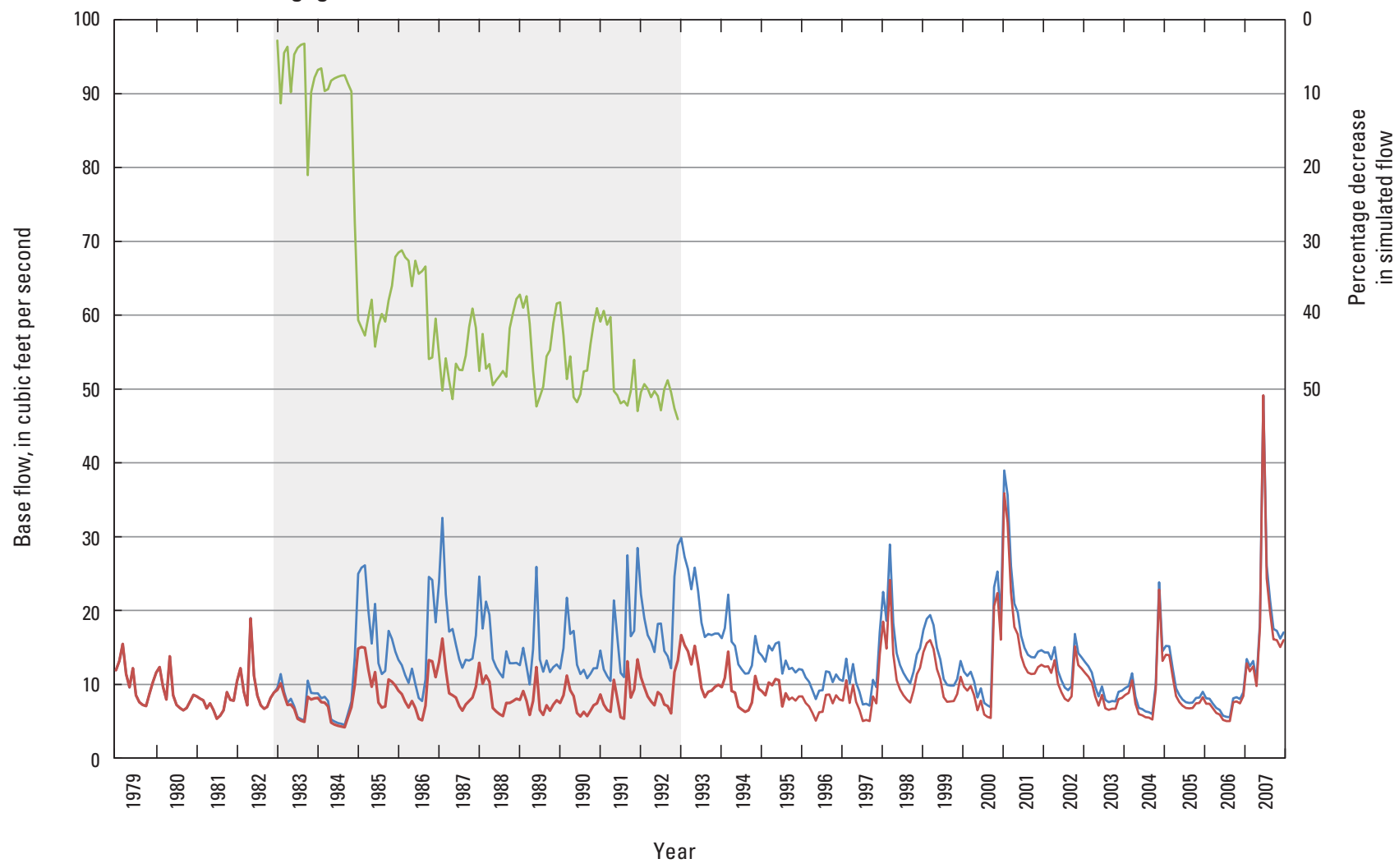

Figure 60. Changes in simulated base flow at $A$, Hammon streamgage (07324200) on Washita River; $B$, Clinton streamgage (07325000) on Washita River; $C$, Carnegie streamgage (07305500) on Washita River; $D$, Anadarko streamgage (07326500) on Washita River; E, Bridgeport streamgage (07228500) on Canadian River; F, Cement streamgage (07327447) on Little Washita River; G, Cobb Creek streamgage (07325800); H, Lake Creek streamgage (07325850); and I, Willow Creek streamgage (07325860) for the numerical groundwater-flow model of the Rush Springs aquifer, western Oklahoma, 1979-2007._-Continued 
G. Cobb Creek streamgage (07325800) on Cobb Creek

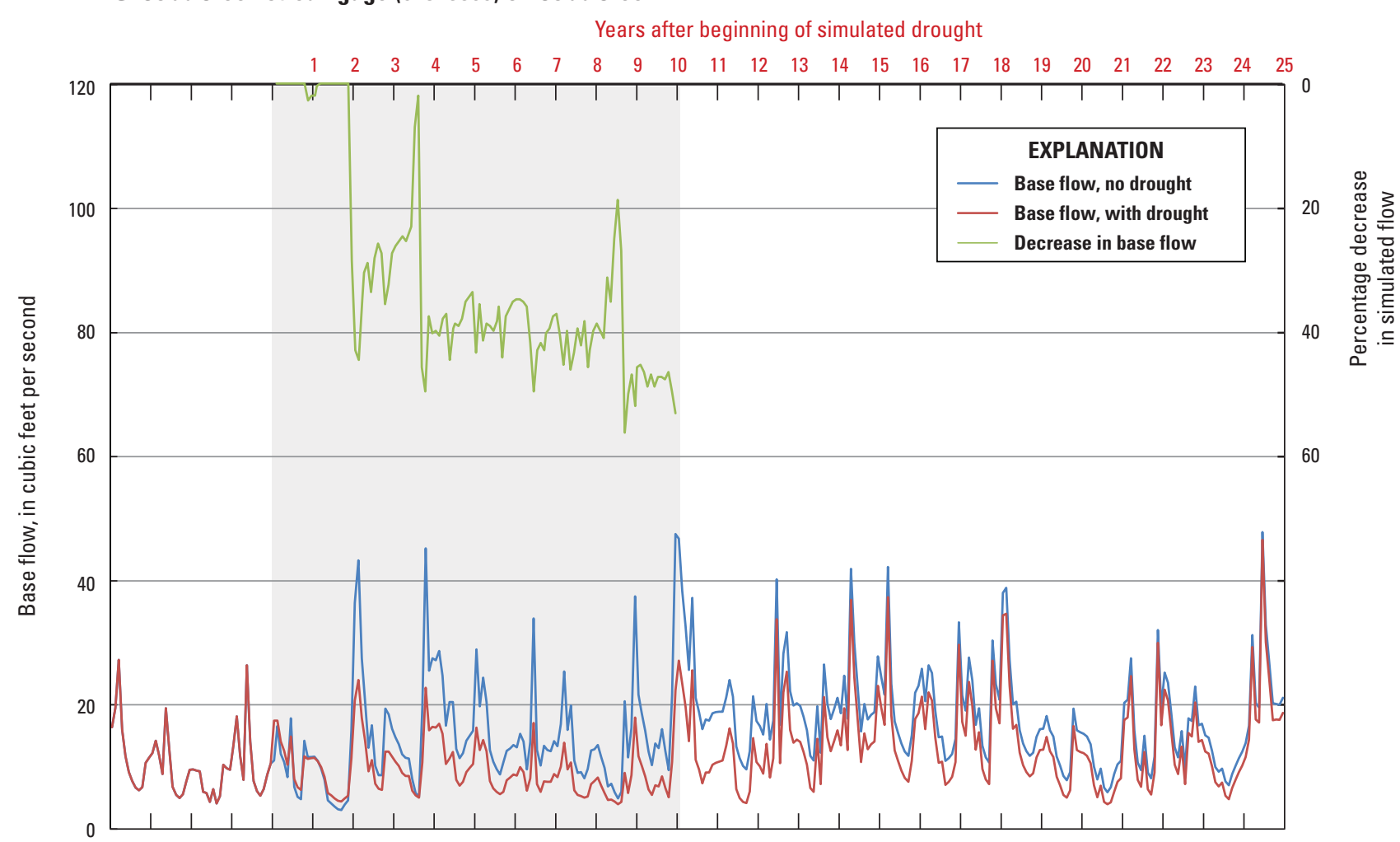

H. Lake Creek streamgage (07325850) on Lake Creek

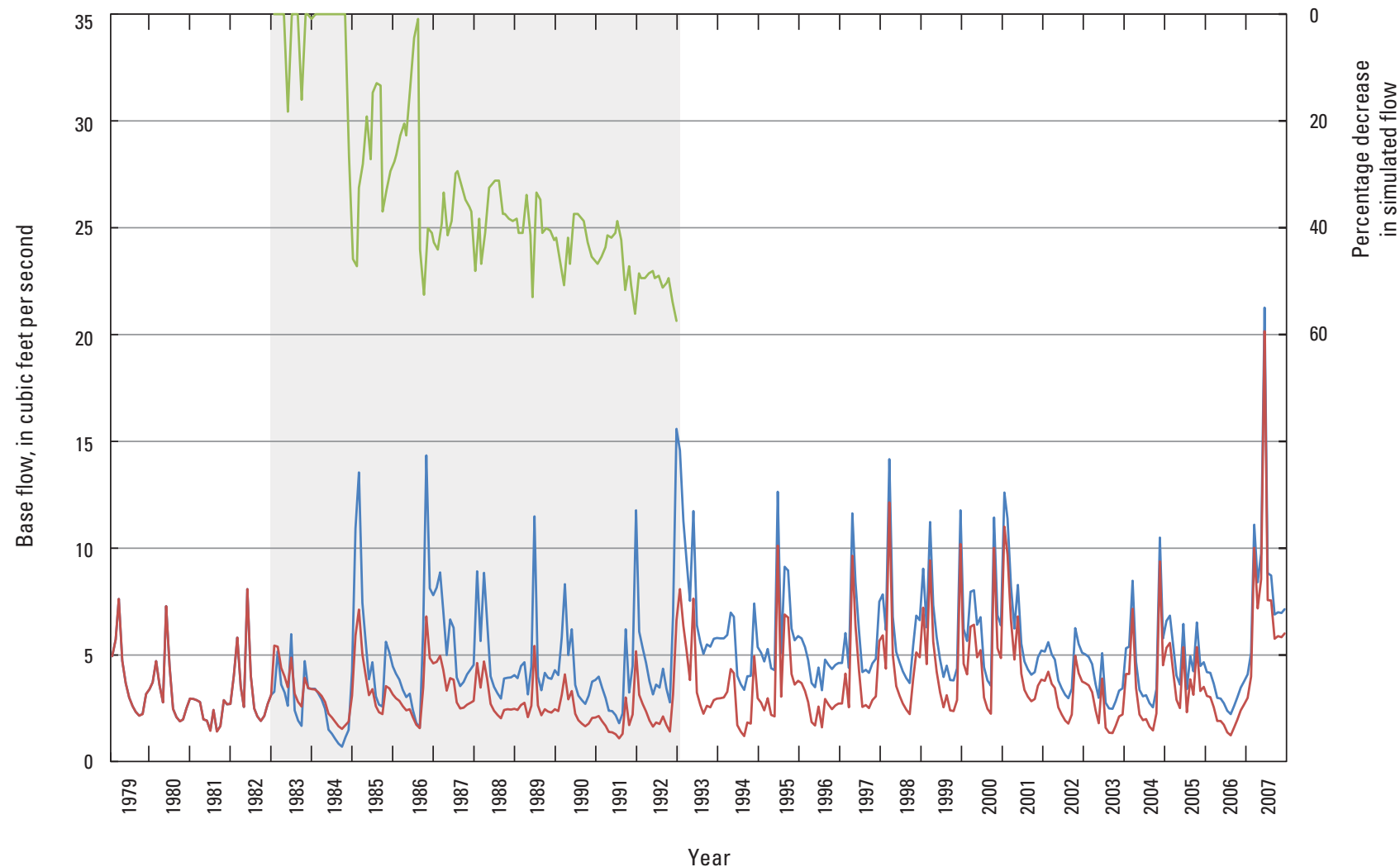

Figure 60. Changes in simulated base flow at $A$, Hammon streamgage (07324200) on Washita River; $B$, Clinton streamgage (07325000) on Washita River; $C$, Carnegie streamgage (07305500) on Washita River; $D$, Anadarko streamgage (07326500) on Washita River; E, Bridgeport streamgage (07228500) on Canadian River; $F$, Cement streamgage (07327447) on Little Washita River; G, Cobb Creek streamgage (07325800); H, Lake Creek streamgage (07325850); and I, Willow Creek streamgage (07325860) for the numerical groundwater-flow model of the Rush Springs aquifer, western Oklahoma, 1979-2007.—Continued 


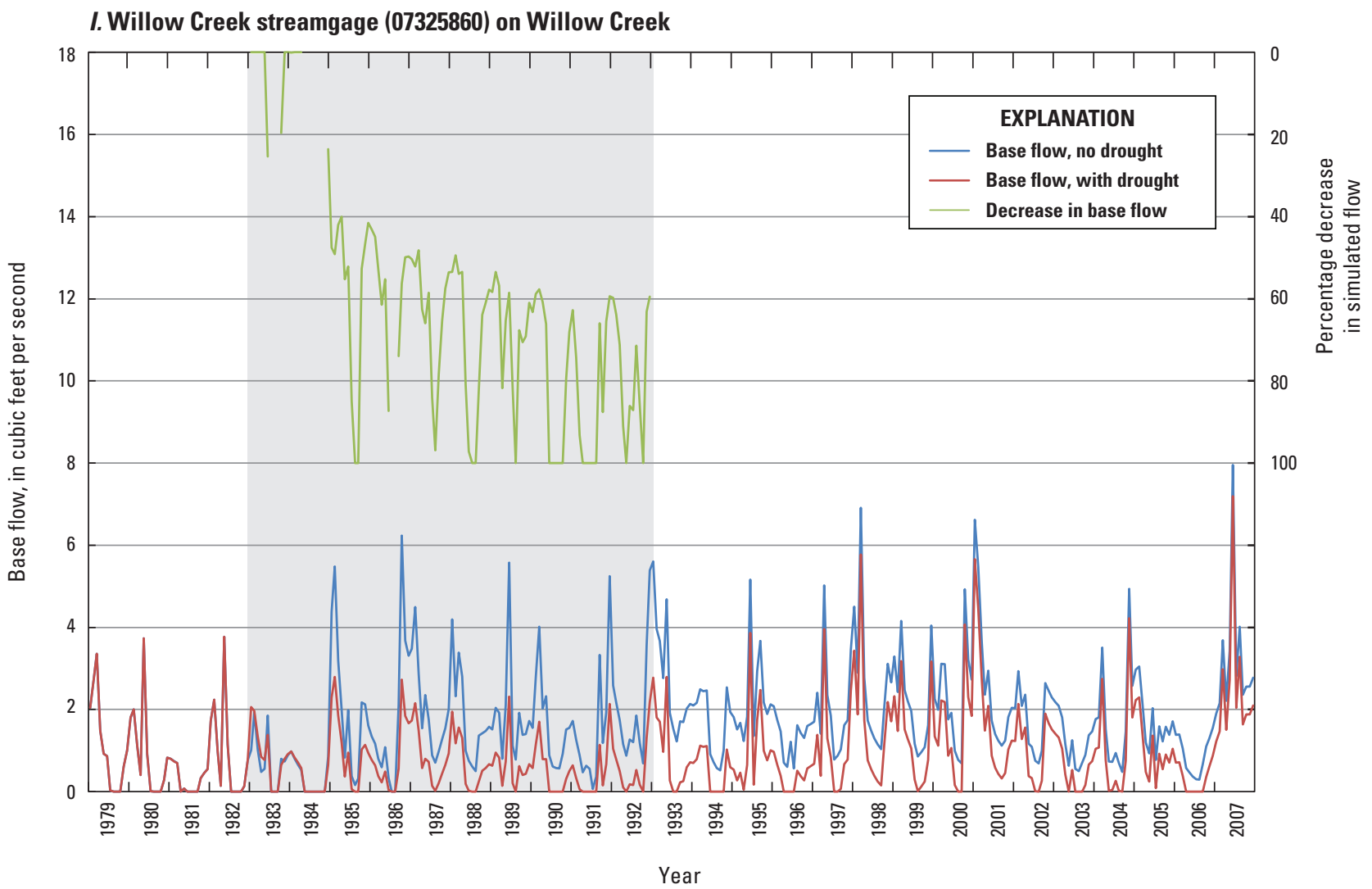

Figure 60. Changes in simulated base flow at $A$, Hammon streamgage (07324200) on Washita River; $B$, Clinton streamgage (07325000) on Washita River; $C$, Carnegie streamgage (07305500) on Washita River; $D$, Anadarko streamgage (07326500) on Washita River; E, Bridgeport streamgage (07228500) on Canadian River; F, Cement streamgage (07327447) on Little Washita River; $G$, Cobb Creek streamgage (07325800); $H$, Lake Creek streamgage (07325850); and I, Willow Creek streamgage (07325860) for the numerical groundwater-flow model of the Rush Springs aquifer, western Oklahoma, 1979-2007.—Continued

nearly zero flow periodically occur in the model period that could not be reproduced in the calibrated groundwater model.

Substantial decreases in the Fort Cobb Reservoir stage began in October 1986 in conjunction with baseflow decreases of more than 50 percent at the Cobb Creek (07325800), Lake Creek (07325850), and Willow Creek (07325860) streamgages (figs. 60-61). Annual lakebed seepage for Fort Cobb Reservoir was similar for the first 4 years of the hypothetical drought compared to the nondrought conditions. From July 1988 until the end of the hypothetical drought, the Fort Cobb Reservoir stage was below 1,331 ft (fig. 61A), which was generally below the groundwater levels in the surrounding bedrock. Thus, lakebed seepage between July 1988 and the end of the hypothetical drought was predominantly to the reservoir. However, as with the transient model simulation, lakebed seepage represented a relatively small percentage of the Fort Cobb Reservoir water budget. The minimum stage in Fort Cobb Reservoir was 1,311 ft in October 1992 (fig. 61A), near the end of the hypothetical drought period, indicating a storage capacity of only 10 percent of active conservation pool storage.

Large precipitation events totaling 14 in. in April and May 1993 (Reclamation, 2017a) resulted in a stage recovery to 1,339 ft at Fort Cobb Reservoir by June 1993. Similarly, large precipitation events occurred between April and May for 1995-1997 for Fort Cobb Reservoir; therefore, a rapid stage and storage recovery would have still occurred over a 60- to 90-day period if the drought scenario timeframe had been shifted to end during these years.

\section{Model Limitations and Assumptions}

The Rush Springs aquifer groundwater model is a simplification of a complex groundwater-flow system and, therefore, incorporates necessary limitations and assumptions. The model contains features such as the StreamflowRouting package, the Lake package, and a grid size that may represent localized features, but the model is best used to support groundwater management decisions at a regional to subregional scale. The 37-year model period included hydrologic and climatic variability. However, results from the groundwater model may not be representative of past hydrologic conditions and future climatic variability.

Although the spatial distribution of groundwater-level observations (fig. 25) was reasonable, some areas of the 

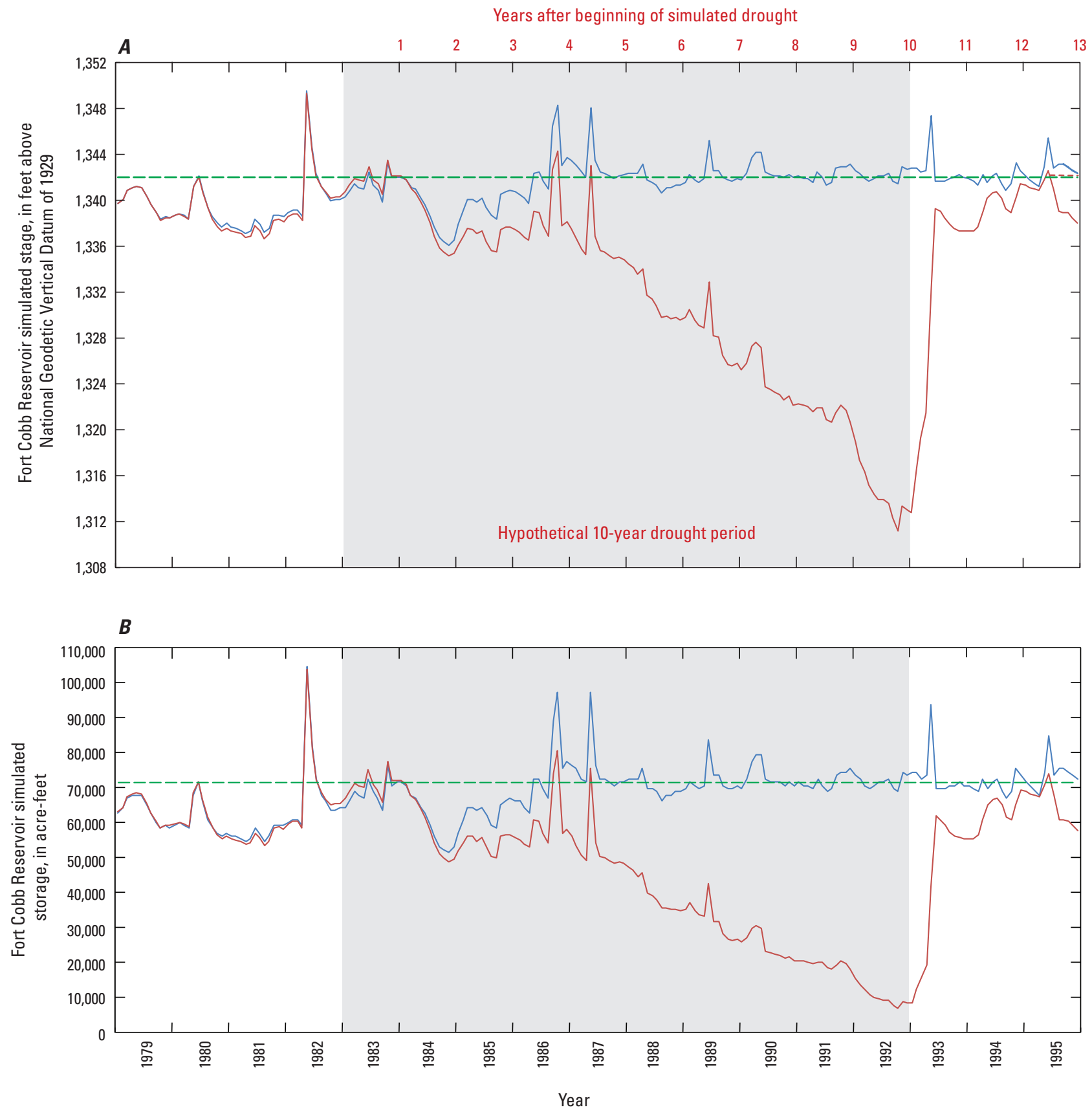

EXPLANATION

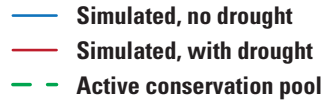

Figure 61. Changes in $A$, Fort Cobb Reservoir stage and $B$, Fort Cobb Reservoir storage during a hypothetical 10-year drought for the Rush Springs aquifer, 1979-2007. 
model—particularly near the western boundary—had few or no observations. Additionally, layer 1 did not contain any groundwater-level observations. The simulated water table in the western area of the model is in an expected water-table altitude range; however, more site-specific and local calibration-target data would facilitate a more detailed characterization of water-table conditions. As a result, in the western model areas, the calibration was only constrained by base-flow estimates, and any uses of the model simulation with regards to layer 1 are limited. The temporal distribution of groundwater observations resulted in a calibration bias towards earlier years in the model period (fig. 26A) and January-March (fig. 26B) of each year. Additionally, the groundwater levels have inherent uncertainty, some of which is discussed in the "Calibration-Target Uncertainty and Weighting" section of this report. The majority of wells had four or fewer observations during the model period (fig. 25) and had substantial location and altitude accuracy uncertainty, particularly for older observations. As a result, the groundwater-level mean calculated standard deviation was $4.9 \mathrm{ft}$, and about 95 percent of groundwater levels had a standard deviation as much as $12 \mathrm{ft}$; therefore, the simulation may be less representative of actual conditions in areas or time periods where data are less commonly available, and the uncertainties associated with the observation data are propagated into the modeled results.

Some uncertainties exist for input data used to estimate recharge for the Rush Springs aquifer with the SWB code. Soil properties from the STATSGO database used with the SWB code are generalized on a county scale and may not be representative of soil properties at a smaller scale. Surface-runoff routing is based on a 10-meter DEM (USGS, 2017a), which may contain inaccuracies in altitude and surface depressions even after postprocessing with digital mapping tools. Additionally, the climate data were not evenly distributed throughout each year; thus, uncertainty exists in the interpolated climate data used to estimate recharge. The SWB code also does not account for lag between precipitation and recharge caused by the distance between the plant root zone and the water-table surface. In the Rush Springs aquifer, the water-table altitude is commonly 30 to $50 \mathrm{ft}$ below the land-surface altitude. Therefore, the travel time for recharge to reach the water-table surface, which could be substantial some areas, is not incorporated. Additionally, the SWB code may not provide accurate estimates of recharge where the water table is near land surface; thus, recharge may be overestimated in these areas. As a result of these uncertainties, although the SWB-derived recharge agrees well with other estimates, the overall distribution of recharge from this method may be more accurate than the actual recharge values estimated at any given location.

Streamflow, and thus base-flow estimates, for Lake Creek and Willow Creek were not available until 2005 (table 2; fig. 27); therefore, base-flow inflows to Fort Cobb Reservoir contained in the Lake package from these creeks were estimated for the majority of the simulation period.
Additionally, the regulation of streamflow from upstream reservoirs alters the natural streamflow. Because regulation results in the more gradual and controlled release of water compared to a storm peak, it can introduce inaccuracies in base-flow separation techniques. As a result, surface runoff may be understated, while base flow may be overestimated for the Rush Springs aquifer conceptual water budget.

Exact amounts of annual groundwater use are unknown because groundwater wells are not metered, and groundwateruse data are based on estimates provided by the OWRB from permit holders. Additionally, groundwater use by domestic wells, though assumed to be relatively small, was not included in the groundwater model. Even if these wells were simulated, no known groundwater-use records exist for individual domestic wells for the Rush Springs aquifer.

Groundwater models representing hydrologic systems are discretized spatially and temporally. The model grid was spatially discretized with a cell size of $500 \mathrm{ft} \times 500 \mathrm{ft}$, and hydraulic properties are uniform in each cell. Hydraulic properties that change rapidly, such as hydraulic conductivity and land-surface altitude, are generalized and may not be fully represented. Monthly stress periods were assumed to provide an adequate temporal resolution to assess changes in storage, groundwater levels, and base flows. As a result, simulation of features or processes at a scale smaller than $500 \mathrm{ft}$ or less than 1 month in length would require model refinement.

The stream network used in the groundwater model is a simplification of the actual stream geometry and hydraulic properties. More could be done to refine the stream channel width, characterize the channel geometry, and estimate the streambed conductance and stream seepage exchange with the aquifer; these properties can vary substantially at the local scale. The groundwater model was calibrated primarily to base-flow estimates; therefore, collection of more streamflow data would further reduce uncertainty in simulation results.

Laboratory-determined Sy values for sandstone generally are larger than the mean Sy used in the groundwater model. The laboratory-derived Sy values may be more useful for evaluating groundwater reserves over a long period of time instead of evaluating shorter term groundwater-level responses to well pumping (Neuman, 1987). The determination of the aquifer response to groundwater use was investigated during this study; thus, the model mean Sy of 0.07 may provide a better estimate than the Sy value determined in the laboratory.

\section{Summary}

The U.S. Geological Survey, in cooperation with the Bureau of Reclamation and the Oklahoma Water Resources Board, (1) quantified the groundwater resources of the Rush Springs aquifer in western Oklahoma by developing a numerical groundwater-flow model, (2) evaluated the effects of estimated equal-proportionate-share (EPS) pumping rates on aquifer storage and on streamflow for time periods of 20 , 
40 , and 50 years into the future, (3) assessed the uncertainty in the EPS scenario results, and (4) evaluated the effects of (a) projected groundwater-use rates extended 50 years into the future and (b) sustained hypothetical drought conditions over a 10-year period on stream base flow and groundwater in storage.

The study area is composed of about 4,970 square miles (3,181,003 acres) of Rush Springs aquifer bedrock deposits located in 14 counties in Oklahoma. The study area includes the alluvium and terrace of the Canadian and Washita Rivers, as well as alluvium along the Little Washita River, Deer Creek, and a number of smaller tributaries of the Washita River that overlie the bedrock. The Rush Springs aquifer is an important source of water for municipal and irrigation use by many communities and agricultural users in the study area. Streamflow from Cobb, Lake, and Willow Creeks is the primary source of stream inflow to Fort Cobb Reservoir, a Bureau of Reclamation reservoir constructed to provide flood control, water supply, and recreation.

A conceptual water budget for the study period was developed for the Rush Springs aquifer to guide the construction and calibration of a groundwater model. The primary aquifer inflow was recharge derived from precipitation. Mean annual recharge estimated from the SoilWater-Balance code adjusted to 7 percent of precipitation was 2.1 inches. Stream seepage was the predominant outflow from the Rush Springs aquifer, primarily to the Washita and Canadian Rivers.

The numerical groundwater-flow model of the Rush Springs aquifer was constructed by using MODFLOW with the Newton solver. The groundwater model grid was spatially discretized into 1,362 rows, 1,083 columns, and 3 layers without rotation. Groundwater flow was simulated for January 1979-December 2015 by using monthly stress periods, and an initial steady-state stress period was configured to represent mean annual inflow and outflow. The model was calibrated to groundwater-level observations at selected wells, monthly base flow at nine streamgages, stream seepage as estimated for the conceptual water budget, and Fort Cobb Reservoir stage.

Equal proportionate share (EPS) scenarios for the Rush Springs aquifer were run for periods of 20, 40, and 50 years. The 20-, 40-, and 50-year EPS pumping rates under normal recharge conditions were $0.82,0.49$, and 0.43 acrefoot per acre per year (acre-ft/acre/yr), respectively. Given the 2,954,545-acre aquifer area used for the EPS scenarios, the 20-year rate corresponds to an annual yield of about 2,422,727 acre-feet per year (acre-ft/yr). Groundwater storage at the end of the 20-year EPS scenario was about 13,321,000 acre-ft, or about 31,516,437 acre-ft (70 percent) less than the starting EPS scenario storage. This decrease in storage was equivalent to a mean groundwater-level decline of about 152 feet (ft). Water availability under the EPS pumping rate was primarily from the western area of the model. Saturation was sustained though the entire EPS scenario where the aquifer was sufficiently thick or a shallow hydraulic gradient was present. Fort Cobb Reservoir stage was below the dead-pool stage after about 5 years of EPS pumping.
An uncertainty analysis was conducted to assess the uncertainty in the EPS scenario results. An ensemble of 400 random sets of possible parameter values was performed for the uncertainty analysis by using a multivariate normal distribution centered on the calibrated parameter values. The parameter bounds for the uncertainty analysis were determined by using the posterior covariance matrix, which allows for the incorporation of knowledge gained during the calibration process as well as observation uncertainty and the correlation between estimated parameters. The uncertainty results indicate a 95-percent confidence interval for the 20-year EPS pumping rate between 0.73 and 0.95 acre-foot per acre per year.

Projected 50-year pumping scenarios were used to simulate the effects of selected well withdrawal rates on groundwater storage of the Rush Springs aquifer. The effects of well withdrawals were evaluated by comparing changes in groundwater storage between four 50-year scenarios using (1) no groundwater use, (2) mean groundwater use for the study period (1979-2015), (3) increasing groundwater use, and (4) groundwater use at the 2015 rate. The increasinguse scenario assumed a 38-percent increase in pumping over 50 years based on 2010-60 demand projections for western Oklahoma. Simulated groundwater storage changes ranged between an increase of 6.3 percent for the scenario with no groundwater use and 0.9 percent for the scenario with 2015 groundwater-use rates. For the Fort Cobb Reservoir surface watershed, simulated groundwater storage changes ranged between an increase of 23.6 percent for the scenario with no groundwater use and a decrease of 4.0 percent for the increasing groundwater-use scenario. Groundwaterlevel changes were generally greater in areas with a large concentration of groundwater wells and groundwater use such as the Fort Cobb Reservoir surface watershed.

A hypothetical 10-year drought scenario was used to simulate the effects of a prolonged period of reduced recharge on the Rush Springs aquifer groundwater storage and Fort Cobb Reservoir stage and storage. Drought effects were quantified by comparing the results of the drought scenario to those of the calibrated numerical model. To simulate the hypothetical drought, recharge in the calibrated numerical model was reduced by 50 percent during the simulated drought period (1983-92), and upstream inflows to the Canadian and Washita Rivers and associated tributaries were reduced by 37 percent. Groundwater storage at the end of the hypothetical drought period was about 42,983,000 acre-ft, or about 3,525,000 acre-ft (7.6 percent) less than the groundwater storage of the calibrated numerical model. This change in groundwater storage is equivalent to a mean groundwaterlevel decline of $15.8 \mathrm{ft}$. Mean simulated base-flow declines at the Canadian and Washita River streamgages were between 39 and 59 percent during the drought period. The minimum stage in Fort Cobb Reservoir at the end of the hypothetical drought period was $1,311 \mathrm{ft}$, indicating a storage capacity of only 10 percent of active conservation pool storage. The Fort Cobb Reservoir storage declines mostly resulted from reduced base flows in Cobb, Lake, and Willow Creeks upstream from the reservoir. 


\section{References Cited}

Barlow, P.M., Cunningham, W.L., Zhai, Tong, and Gray, Mark, 2015, U.S. Geological Survey Groundwater Toolbox, a graphical and mapping interface for analysis of hydrologic data (version 1.0) - User guide for estimation of base flow, runoff, and groundwater recharge from streamflow data: U.S. Geological Survey Techniques and Methods, book 3, chap. B10, 27 p., accessed July 19, 2016, at https://dx.doi. org/10.3133/tm3B10.

Becker, M.F., 1998, Steady-state simulation of ground-water flow in the Rush Springs aquifer, western Oklahoma: U.S. Geological Survey Water-Resources Investigations Report 98-4082, 88 p.

Becker, M.F., and Runkle, D.L., 1998, Hydrogeology, water quality, and geochemistry of the Rush Springs aquifer, western Oklahoma: U.S. Geological Survey WaterResources Investigations Report 98-4081, 37 p. [Also available at https://pubs.er.usgs.gov/publication/wri984081.]

Bureau of Reclamation [Reclamation], 2017a, Reservoir release, storage, evaporation, and precipitation data for Fort Cobb Reservoir, Oklahoma, accessed March 15, 2017, at https://www.usbr.gov/gp-bin/custom.pl?SWE221A\&cobb.

Bureau of Reclamation [Reclamation], 2017b, Reservoir release, storage, evaporation, and precipitation data for Foss Reservoir, Oklahoma, accessed March 15, 2017, at https:// www.usbr.gov/gp-bin/custom.pl?SWE221A\&foss.

Carr, J.E., and Bergman, D.L, 1976, Reconnaissance of the water resources of the Clinton quadrangle, west-central Oklahoma: Oklahoma Geological Survey Hydrologic Atlas 5, 4 sheets, scale 1:250,000.

Chen, X., 2003, Stream water infiltration, bank storage, and storage zone changes due to stream-stage fluctuations: Journal of Hydrology, v. 280, p. 246-264.

Clark, B.R., and Hart, R.M., 2009, The Mississippi Embayment Regional Aquifer Study (MERAS) Documentation of a groundwater-flow model constructed to assess water availability in the Mississippi embayment: U.S. Geological Survey Scientific Investigations Report 2009-5172, 61 p.

Condor Team, 2012, Condor version 7.6.6 manual: Madison, Wisc., University of Wisconsin.

Darcy, H., 1856, Les Fontances publiques de la ville de Dijon: Paris, Victor Dalmont.

Doherty, J.E., 2010, PEST, model-independent parameter estimation and uncertainty analysis-Addendum to user manual (5th ed.): Brisbane, Australia, Watermark Numerical Computing, accessed March 5, 2012, at http:// pesthomepage.org/.
Doherty, J.E., and Hunt, R.J., 2009, Two statistics for evaluating parameter identifiability and error reduction: Journal of Hydrology, v. 366, no. 1-4, p. 119-127, accessed October 3, 2017, at https://doi. org/10.1016/j.jhydrol.2008.12.018.

Doherty, J.E., and Hunt, R.J., 2010, Approaches to highly parameterized inversion-A guide to using PEST for groundwater-model calibration: U.S. Geological Survey Scientific Investigations Report 2010-5169, 59 p.

Dugan, J.T., and Zelt, R.B., 2000, Simulation and analysis of soil-water conditions in the Great Plains and adjacent areas, central United States, 1951-80: U.S. Geological Survey Water-Supply Paper 2427, 81 p.

Ellis, J.H., 2018, MODFLOW model used in simulation of groundwater flow and analysis of projected water use for the Rush Springs aquifer, western Oklahoma: U.S. Geological Survey data release, https://doi.org/10.5066/ F7Q52NXK.

Ellis, J.H., Mashburn, S.L, Graves, G.M., Peterson, S.M., Smith, S.J., Fuhrig, L.F., Wagner, D.L., and Sanford, J.E., 2017, Hydrogeology and simulation of groundwater flow and analysis of projected water use for the Canadian River alluvial aquifer, western and Central Oklahoma: U.S. Geological Survey Scientific Investigations Report 2016-5180, 64 p.

Fay, R.O., 1962, Stratigraphy and general geology of Blaine County, part 1 of Geology and mineral resources of Blaine County, Oklahoma: Oklahoma Geological Survey Bulletin 89, 258 p.

Fay, R.O., 1978, Geology and mineral resources (exclusive of petroleum) of Custer County, Oklahoma: Oklahoma Geological Survey Bulletin 114, 88 p.

Fienen, M.N., Doherty, J.E., Hunt, R.J., and Reeves, H.W., 2010, Using prediction uncertainty analysis to design hydrologic monitoring networks: Example applications from the Great Lakes Water Availability Pilot Project: U.S. Geological Survey Scientific Investigations Report 2010-5159, 44 p.

FTN Associates, 2009, Fort Cobb Reservoir 2007 sedimentation survey analysis. $16 \mathrm{p}$.

Harbaugh, A.W., 2005, MODFLOW-2005, The U.S. Geological Survey modular ground-water modelthe Ground-Water Flow Process: U.S. Geological Survey Techniques and Methods, book 6, chap. A16 [variously paged].

Hargreaves, G.H., and Samani, Z.A., 1985, Reference crop evapotranspiration from temperature: Applied Engineering in Agriculture, v. 1, no. 2, p. 96-99. 
Hendricks, T.A., 1937, History of the Canadian River of Oklahoma as indicated by the Gerty Sand: Geological Society of America Bulletin 48, no. 3, p. 365-372.

Heran, W.D., Green, G.N., and Stoeser, D.B., 2003, A digital geologic map database for the State of Oklahoma: U.S. Geological Survey Open-File Report 03-247, 10 p.

Hill, M.C., and Tiedeman, C.R., 2007, Effective groundwater model calibration-With analysis of data, sensitivities, predictions, and uncertainty: New York, Wiley and Sons, $455 \mathrm{p}$.

Horizon Systems Corporation, 2015, National Hydrography Dataset Plus (NHDPlus): Horizon Systems Corporation, accessed November 1, 2010, at http://www.horizonsystems.com/nhdplus/.

Johnson, A.I., 1967, Sy—Compilation of Sys for various materials: U.S. Geological Survey Water-Supply Paper 1662-D, $74 \mathrm{p}$.

Mashburn, S.L., and Smith, S.J., 2014, Evaluation of groundwater and surface-water interactions in the Caddo Nation Tribal Jurisdictional Area, Caddo County, Oklahoma, 2010-13: U.S. Geological Survey Scientific Investigations Report 2014-5082, 54 p.

Masoner, J.R., Mladinich, C.S., Konduris, A.M., and Smith, S.J., 2003, Comparison of irrigation water use estimates calculated from remotely sensed irrigated acres and State reported irrigated acres in the Lake Altus drainage basin, Oklahoma and Texas, 2000 growing season: U.S. Geological Survey Water-Resources Investigations Report 03-4155, 38 p.

Masterson, J.P., Pope, J.P., Fienen, M.N., Monti, Jack, Jr., Nardi, M.R., and Finkelstein, J.S., 2016, Documentation of a groundwater flow model developed to assess groundwater availability in the Northern Atlantic Coastal Plain aquifer system from Long Island, New York, to North Carolina (ver. 1.1, December 2016): U.S. Geological Survey Scientific Investigations Report 2016-5076, 70 p., accessed September 13, 2017, at https://doi.org/10.3133/sir20165076.

McMahon, P.B., Dennehy, K.F., Bruce, B.W., Böhlke, J.K., Michel, R.L., Gurdak, J.J., and Hurlbut, D.B., 2006, Storage and transit time of chemicals in thick unsaturated zones under rangeland and irrigated cropland, High Plains, United States: Water Resources Research, v. 42, accessed October 19, 2017, at https://doi.org/10.1029/2005WR004417.

McMahon, P.B., Plummer, L.N., Böhlke, J.K., Shapiro, S.D., and Hinkle, S.R., 2011, A comparison of recharge rates in aquifers of the United States based on groundwater-age data: Hydrogeology Journal, v. 19, accessed June 22, 2017, at https://doi.org/10.1007/s10040-011-0722-5.
Merritt, M.L., and Konikow, L.F., 2000, Documentation of a computer program to simulate lake-aquifer interaction using the MODFLOW ground-water flow model and the MOC3D solute-transport model: U.S. Geological Survey WaterResources Investigations Report 00-4167, 146 p.

Miller, G.W., and Stanley, T.M., comps., 2004, Geologic map of the Anadarko 30' X 60' quadrangle, Caddo, Canadian, Custer, Grady, Kiowa and Washita Counties, Oklahoma: Oklahoma Geological Survey Geologic Quadrangle Map OGQ-58, scale 1:100,000, accessed March 15, 2017, at http://ogs.ou.edu/docs/OGQ/OGQ-58-color.pdf.

Mogg, J.L., Schoff, S.L., and Reed, E.W., 1960, Groundwater resources of Canadian County, Oklahoma: Oklahoma Geological Survey Bulletin 87, 112 p.

Morris, D.A., and Johnson, A.I., 1967, Summary of hydrologic and physical properties of rock and soil materials, as analyzed by the Hydrologic Laboratory of the U.S. Geological Survey, 1948-60: U.S. Geological Survey Water-Supply Paper 1839-D, 42 p.

National Agricultural Statistics Service [NASS], 2017, CropScape-Cropland data layers, 2010-15, accessed February 5, 2017, at https://nassgeodata.gmu.edu/ CropScape/.

National Climatic Data Center, 2017, Climate data online, accessed March 25, 2017, at https://www7.ncdc.noaa.gov/ CDO/CDODivisionalSelect.jsp.

Natural Resources Conservation Service, 2015, Geospatial Data Gateway: Natural Resources Conservation Service, accessed March 14, 2013, at http://datagateway.nrcs.usda. gov/.

Neel, C.R., Wagner, D.L., Correll, J.S., Sanford, J.E., Hernandez, R.J., Spears, K.W., and Waltman, P.B, 2018, Hydrologic Investigations Report of the Rush Springs aquifer in west-central Oklahoma: Oklahoma Water Resources Board, accessed August 2, 2018, at http://www. owrb.ok.gov/reports/studies/RushSprings2015.pdf.

Neuman, S.P., 1987, On methods of determining specific yield: Ground Water, v. 25, no. 6, p. 683.

Niswonger, R.G., Panday, S., and Ibaraki, M., 2011, MODFLOW-NWT, A Newton formulation for MODFLOW-2005: U.S. Geological Survey Techniques and Methods, book 6, chap. A37, 44 p.

Niswonger, R.G., and Prudic, D.E., 2005, Documentation of the Streamflow-Routing (SFR) package to include unsaturated flow beneath streams-A modification to SFR1: U.S. Geological Survey Techniques and Methods, book 6, chap. A13, 50 p. 
Oklahoma Mesonet, 2017, Daily data retrieval, accessed March 25, 2017, at http://www.mesonet.org/index.php/ weather/daily_data_retrieval.

Oklahoma Water Resources Board [OWRB], 2012, Oklahoma comprehensive water plan: West-Central Watershed Planning Region Report, 168 p.

Oklahoma Water Resources Board [OWRB], 2017, Data \& maps-Groundwater: Oklahoma Water Resources Board, accessed February 2017 at http://www.owrb.ok.gov/maps/ pmg/owrbdata_GW.html.

Patrignani, A., Godsey, C.B., Ochsner, T.E., and Edwards., J.T., 2012, Soil water dynamics of conventional and no-till wheat in the southern great plains: Soil Science Society of America Journal, v. 76, p. 1768-1775, accessed December 11, 2017, at https://doi.org/10.2136/sssaj2012.0082.

Roark, D.M., and Healy, D.F., 1998, Quantification of deep percolation from two flood-irrigated alfalfa fields, Roswell Basin, New Mexico: U.S. Geological Survey WaterResources Investigations Report 98-4096, 32 p.

Rorabaugh, M.I., 1964, Estimating changes in bank storage and groundwater contribution to streamflow: International Association of Scientific Hydrology, publication 63, p. 432-441.

Rutledge, A.T., 1998, Computer programs for describing the recession of ground-water discharge and for estimating mean ground-water recharge and discharge from streamflow records-Update: U.S. Geological Survey Water-Resources Investigations Report 98-4148, 43 p.

Ryter, D.W., and Correll, J.S., 2016, Hydrogeological framework, numerical simulation of groundwater flow, and effects of projected water use and drought for the Beaver-North Canadian River alluvial aquifer, northwestern Oklahoma: U.S. Geological Survey Scientific Investigations Report 2015-5183, 63 p. [Also available at https://dx.doi. org/10.3133/sir20155183.]

Scanlon, B.R., Reedy, R.C., Stonestrom, D.A., Prudic, D.E., and Dennehy, K.F., 2005, Impact of land use and land cover change on groundwater recharge and quality in the southwestern U.S.: Global Change Biology, v. 11, p. 1,5771,593. [Also available at https://doi.org/10.1111/j.13652486.2005.01026.x]

Shivers, M.J., and Andrews, W.J., 2013, Hydrologic drought of water year 2011 compared to four major drought periods of the 20th century in Oklahoma: U.S. Geological Survey Scientific Investigations Report 2013-5018, 52 p., accessed August 9, 2017, at http://pubs.usgs.gov/sir/2013/5018/.
Six, R.L., 1930, Oil and gas in Oklahoma; Blaine, Dewey, Custer, and Roger Mills Counties: Oklahoma Geological Survey, Bulletin 40-UU, p. 22-23.

Smith, S.J., Ellis, J.H., Wagner, D.L., and Peterson, S.M., 2017, Hydrogeology and simulated groundwater flow and availability in the North Fork Red River aquifer, southwest Oklahoma, 1980-2013: U.S. Geological Survey Scientific Investigations Report 2017-5098, 107 p., accessed May 3, 2017, at https://doi.org/10.3133/sir20175098.

Stanton, J.S., Peterson, S.M., and Fienen, M.N., 2010, Simulation of groundwater flow and effects of groundwater irrigation on stream base flow in the Elkhorn and Loup River Basins, Nebraska, 1895-2055—Phase two: U.S. Geological Survey Scientific Investigations Report 2010-5149, 78 p.

Strahler, A.N., 1952, Hypsometric (area-altitude) analysis of erosional topology: Geological Society of America Bulletin, v. 63 , no. 11 , p. 1117-1142.

Tanaka, H.H., and Davis, L.V., 1963, Ground-water resources of the Rush Springs sandstone in the Caddo County area, Oklahoma: Oklahoma Geological Survey Circular 61, 63 p.

Tarantola, Albert, 2005, Inverse problem theory and methods for model parameter estimation: Society for Industrial and Applied Mathematics, $342 \mathrm{p}$.

Thornthwaite, C.W., and Mather, J.R., 1957, Instructions and tables for computing potential evapotranspiration and the water balance: Centerton, N.J., Laboratory of Climatology, Publications in Climatology, v. 10, no. 3, p. 185-311.

Tonkin, M.J., and Doherty, J.E., 2005, A hybrid regularized inversion methodology for highly parameterized environmental models: Water Resources Research, v. 41, W10412, accessed July 10, 2017, at https://doi. org/10.1029/2005WR003995.

U.S. Fish and Wildlife Service, 2017, National Wetlands Inventory-Download seamless wetlands data by State, accessed May 5, 2017, at http://www.fws.gov/wetlands/ Data/State-Downloads.html.

U.S. Geological Survey [USGS], 2017a, National Elevation Dataset, accessed January 2017 at http://ned.usgs.gov/ index.html.

U.S. Geological Survey [USGS], 2017b, National Hydrography Dataset: U.S. Geological Survey database, accessed September 14, 2016, at http://nhd.usgs.gov/ data.html. 
U.S. Geological Survey [USGS], 2017c, U.S. Geological Survey water data for Oklahoma: U.S. Geological Survey National Water Information System database, accessed March 14, 2017, at http://waterdata.usgs.gov/ok/nwis/.

Wahl, K.L., and Wahl, T.L., 1995, Determining the flow of Comal Springs at New Braunfels, Texas, in Proceedings of Texas Water '95, A Component Conference of the First International Conference on Water Resources Engineering, San Antonio, Texas, August 16-17, 1995: American Society of Civil Engineers, p. 77-86.

Welter, D.E., White, J.T., Hunt, R.J., and Doherty, J.E., 2015, Approaches in highly parameterized inversionPEST++ Version 3, a Parameter ESTimation and uncertainty analysis software suite optimized for large environmental models: U.S. Geological Survey Techniques and Methods, book 7, chap. C12, $54 \mathrm{p}$.

Westenbroek, S.M., Kelson, V.A., Dripps, W.R., Hunt, R.J., and Bradbury, K.R., 2010, SWB-A modified Thornthwaite-Mather Soil-Water-Balance code for estimating groundwater recharge: U.S. Geological Survey Techniques and Methods, book 6, chap. A31, 60 p.
White, J.T., Fienen, M.N., and Doherty, J.E., 2016, pyEMU—A python framework for environmental model uncertainty analysis, version .01: U.S. Geological Survey software release, accessed July 13, 2018, at https://dx.doi. org/10.5066/F75D8Q01.

White, W.N., 1932, A method of estimating ground-water supplies based on discharge by plants and evaporation from soil—Results of investigations in Escalante Valley, Utah: U.S. Geological Survey Water-Supply Paper 659-A, p. 1-105, accessed April 20, 2017, at https://pubs.er.usgs. gov/publication/wsp659A.

Wood, P.R., and Stacy, B.L., 1965, Geology and ground-water resources of Woodward County, Oklahoma: Oklahoma Water Resources Board Bulletin 21, 79 p.

Wyatt, B.M., Ochsner, T.E., Fiebrich, C.A., Neel, C.R., and Wallace, D.S., 2017, Useful drainage estimates obtained from a large-scale soil moisture monitoring network by applying the unit-gradient assumption: Vadose Zone Journal, v. 16, no. 6, accessed June 9, 2017, at https://doi. org/10.2136/vzj2017.01.0016. 
Table 6. Calibration parameters, parameter values, parameter sensitivity, and parameter identifiability for the automated calibration of the numerical groundwater-flow model of the Rush Springs aquifer, western Oklahoma, 1979-2015.

[GHB, General-Head Boundary; ft²/d, foot squared per day; ft, foot; ft/d, foot per day; --, not computed; Kh, horizontal hydraulic conductivity. Layer 2 Kh and vertical anisotropy refer only to the pilot points in the alluvium and terrace; *, parameter with a fixed value during model calibration]

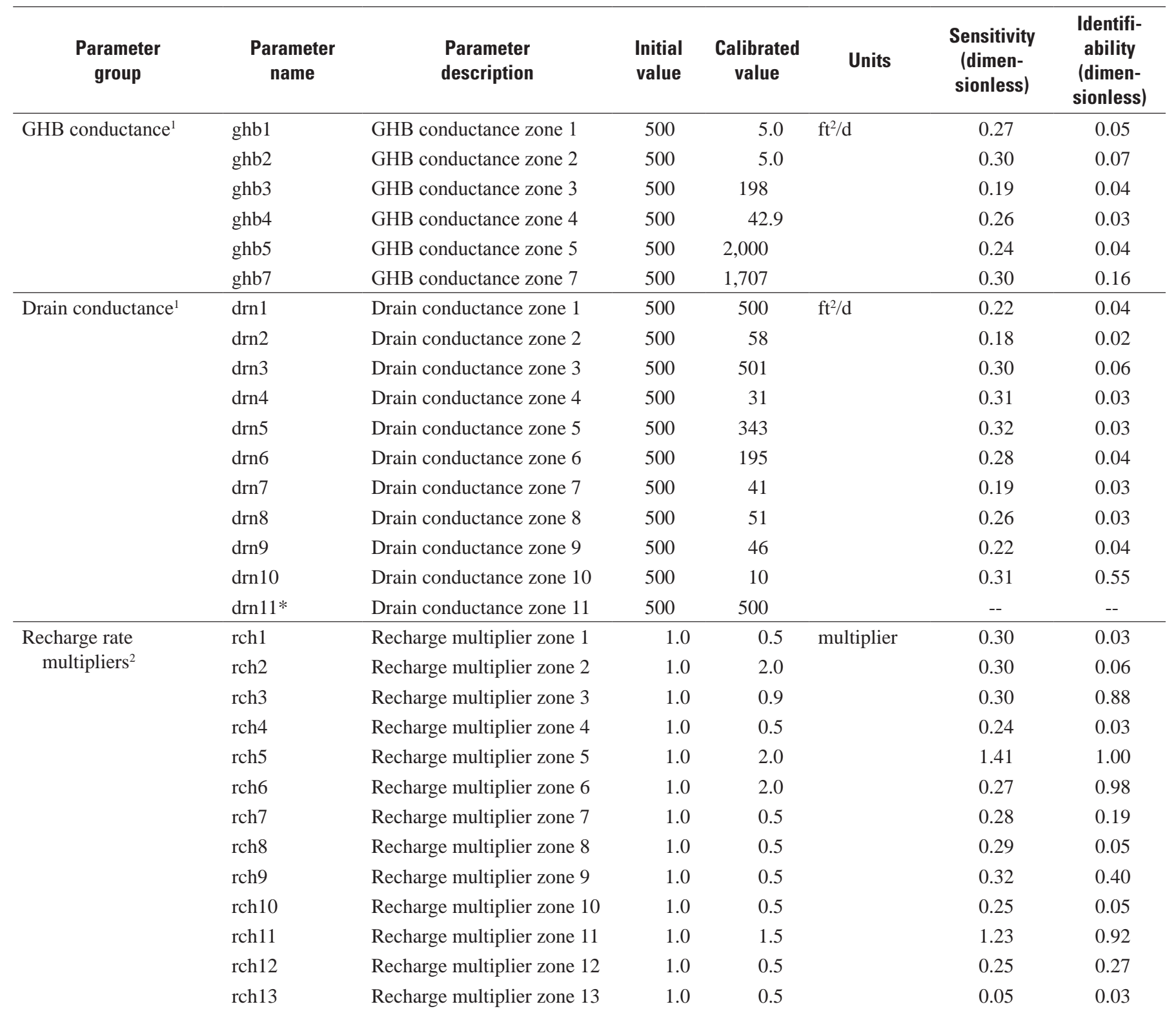


Table 6. Calibration parameters, parameter values, parameter sensitivity, and parameter identifiability for the automated calibration of the numerical groundwater-flow model of the Rush Springs aquifer, western Oklahoma, 1979-2015. - Continued

[GHB, General-Head Boundary; ft²/d, foot squared per day; ft, foot; ft/d, foot per day; --, not computed; Kh, horizontal hydraulic conductivity. Layer 2 Kh and vertical anisotropy refer only to the pilot points in the alluvium and terrace; *, parameter with a fixed value during model calibration]

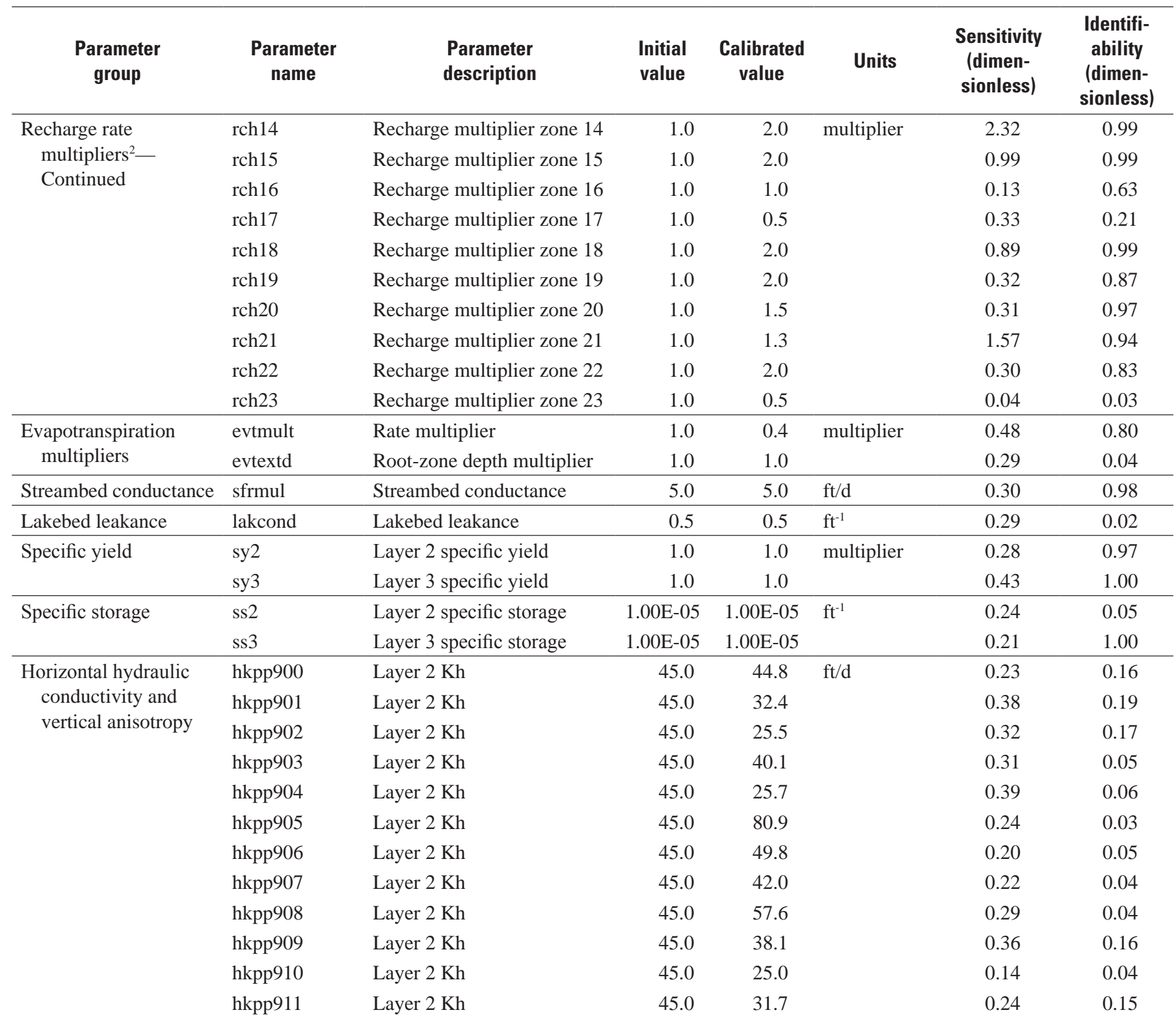


Table 6. Calibration parameters, parameter values, parameter sensitivity, and parameter identifiability for the automated calibration of the numerical groundwater-flow model of the Rush Springs aquifer, western Oklahoma, 1979-2015.—Continued

[GHB, General-Head Boundary; ft²/d, foot squared per day; ft, foot; ft/d, foot per day; --, not computed; Kh, horizontal hydraulic conductivity. Layer 2 Kh and vertical anisotropy refer only to the pilot points in the alluvium and terrace; *, parameter with a fixed value during model calibration]

\begin{tabular}{|c|c|c|c|c|c|c|c|}
\hline $\begin{array}{l}\text { Parameter } \\
\text { group }\end{array}$ & $\begin{array}{c}\text { Parameter } \\
\text { name }\end{array}$ & $\begin{array}{l}\text { Parameter } \\
\text { description }\end{array}$ & $\begin{array}{l}\text { Initial } \\
\text { value }\end{array}$ & $\begin{array}{l}\text { Calibrated } \\
\text { value }\end{array}$ & Units & $\begin{array}{l}\text { Sensitivity } \\
\text { (dimen- } \\
\text { sionless) }\end{array}$ & $\begin{array}{l}\text { Identifi- } \\
\text { ability } \\
\text { (dimen- } \\
\text { sionless) }\end{array}$ \\
\hline \multirow{18}{*}{$\begin{array}{l}\text { Horizontal hydraulic } \\
\text { conductivity and } \\
\text { vertical anisotropy- } \\
\text { Continued }\end{array}$} & hkpp913 & Layer 2 Kh & 45.0 & 39.6 & \multirow{18}{*}{$\mathrm{ft} / \mathrm{d}$} & 0.33 & 0.23 \\
\hline & hkpp914 & Layer 2 Kh & 45.0 & 25.8 & & 0.35 & 0.04 \\
\hline & hkpp916 & Layer $2 \mathrm{Kh}$ & 45.0 & 28.1 & & 0.32 & 0.05 \\
\hline & hkpp917 & Layer $2 \mathrm{Kh}$ & 45.0 & 31.9 & & 0.30 & 0.06 \\
\hline & hkpp918 & Layer 2 Kh & 45.0 & 47.6 & & 0.32 & 0.05 \\
\hline & hkpp919 & Layer 2 Kh & 45.0 & 50.8 & & 0.20 & 0.06 \\
\hline & hkpp920 & Layer 2 Kh & 45.0 & 42.7 & & 0.22 & 0.05 \\
\hline & hkpp924 & Layer 2 Kh & 45.0 & 36.3 & & 0.25 & 0.04 \\
\hline & hkpp925 & Layer 2 Kh & 45.0 & 36.4 & & 0.29 & 0.05 \\
\hline & hkpp926 & Layer 2 Kh & 45.0 & 25.7 & & 0.15 & 0.03 \\
\hline & hkpp927 & Layer 2 Kh & 45.0 & 64.2 & & 0.25 & 0.03 \\
\hline & hkpp928 & Layer 2 Kh & 45.0 & 56.9 & & 0.31 & 0.04 \\
\hline & hkpp929 & Layer 2 Kh & 45.0 & 93.0 & & 0.23 & 0.03 \\
\hline & hkpp930 & Layer 2 Kh & 45.0 & 92.5 & & 0.23 & 0.03 \\
\hline & hkpp931 & Layer $2 \mathrm{Kh}$ & 45.0 & 38.7 & & 0.15 & 0.04 \\
\hline & hkpp932 & Layer 2 Kh & 45.0 & 32.2 & & 0.24 & 0.03 \\
\hline & hkpp940 & Layer 2 Kh & 45.0 & 52.7 & & 0.22 & 0.06 \\
\hline & hkpp941 & Layer 2 Kh & 45.0 & 24.0 & & 0.23 & 0.04 \\
\hline
\end{tabular}


Table 6. Calibration parameters, parameter values, parameter sensitivity, and parameter identifiability for the automated calibration of the numerical groundwater-flow model of the Rush Springs aquifer, western Oklahoma, 1979-2015. - Continued

[GHB, General-Head Boundary; ft²/d, foot squared per day; ft, foot; ft/d, foot per day; --, not computed; Kh, horizontal hydraulic conductivity. Layer 2 Kh and vertical anisotropy refer only to the pilot points in the alluvium and terrace; *, parameter with a fixed value during model calibration]

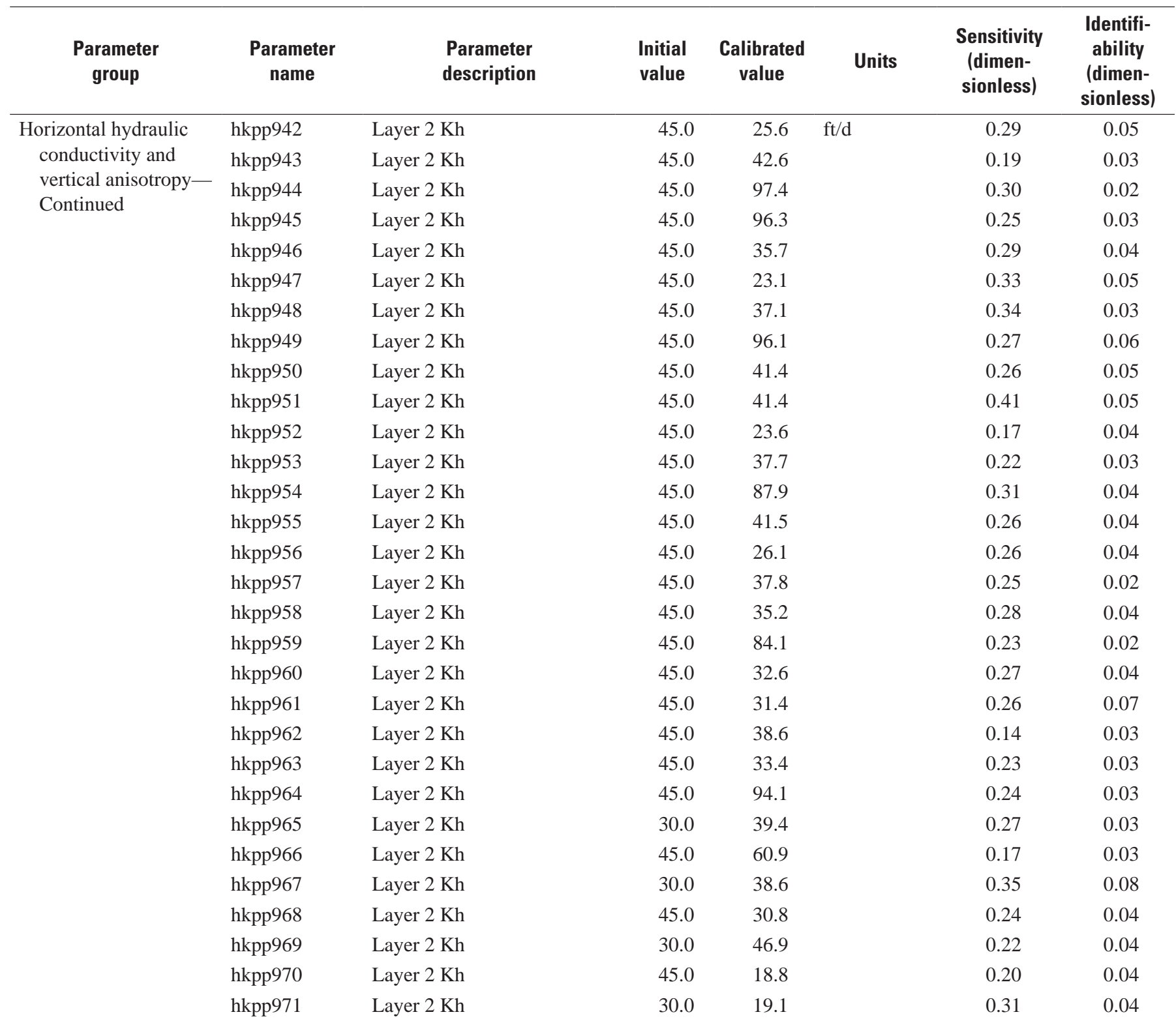


Table 6. Calibration parameters, parameter values, parameter sensitivity, and parameter identifiability for the automated calibration of the numerical groundwater-flow model of the Rush Springs aquifer, western Oklahoma, 1979-2015.—Continued

[GHB, General-Head Boundary; ft²/d, foot squared per day; ft, foot; ft/d, foot per day; --, not computed; Kh, horizontal hydraulic conductivity. Layer 2 Kh and vertical anisotropy refer only to the pilot points in the alluvium and terrace; *, parameter with a fixed value during model calibration]

\begin{tabular}{|c|c|c|c|c|c|c|c|}
\hline $\begin{array}{l}\text { Parameter } \\
\text { group }\end{array}$ & $\begin{array}{c}\text { Parameter } \\
\text { name }\end{array}$ & $\begin{array}{l}\text { Parameter } \\
\text { description }\end{array}$ & $\begin{array}{l}\text { Initial } \\
\text { value }\end{array}$ & $\begin{array}{l}\text { Calibrated } \\
\text { value }\end{array}$ & Units & $\begin{array}{l}\text { Sensitivity } \\
\text { (dimen- } \\
\text { sionless) }\end{array}$ & $\begin{array}{l}\text { Identifi- } \\
\text { ability } \\
\text { (dimen- } \\
\text { sionless) }\end{array}$ \\
\hline \multirow{18}{*}{$\begin{array}{l}\text { Horizontal hydraulic } \\
\text { conductivity and } \\
\text { vertical anisotropy- } \\
\text { Continued }\end{array}$} & hkpp973 & Layer 2 Kh & 45.0 & 13.5 & \multirow{18}{*}{$\mathrm{ft} / \mathrm{d}$} & 0.31 & 0.99 \\
\hline & hkpp974 & Layer 2 Kh & 30.0 & 62.5 & & 0.20 & 0.03 \\
\hline & hkpp976 & Layer $2 \mathrm{Kh}$ & 45.0 & 41.4 & & 0.18 & 0.04 \\
\hline & hkpp977 & Layer $2 \mathrm{Kh}$ & 45.0 & 46.7 & & 0.21 & 0.05 \\
\hline & hkpp978* & Layer 2 Kh & 45.0 & 59.4 & & -- & -- \\
\hline & hkpp979 & Layer 2 Kh & 45.0 & 48.9 & & 0.26 & 0.05 \\
\hline & hkpp980* & Layer 2 Kh & 46.0 & 52.8 & & -- & -- \\
\hline & hkpp984 & Layer $2 \mathrm{Kh}$ & 45.0 & 51.4 & & 0.35 & 0.48 \\
\hline & hkpp985 & Layer 2 Kh & 45.0 & 39.0 & & 0.20 & 0.04 \\
\hline & hkpp986 & Layer 2 Kh & 45.0 & 35.6 & & 0.30 & 0.04 \\
\hline & hkpp987 & Layer 2 Kh & 45.0 & 36.7 & & 0.22 & 0.05 \\
\hline & hkpp988 & Layer 2 Kh & 45.0 & 49.0 & & 0.22 & 0.04 \\
\hline & hkpp989 & Layer 2 Kh & 30.0 & 35.1 & & 0.17 & 0.03 \\
\hline & hkpp990 & Layer 2 Kh & 30.0 & 29.2 & & 0.22 & 0.03 \\
\hline & hkpp991 & Layer $2 \mathrm{Kh}$ & 30.0 & 26.5 & & 0.31 & 0.04 \\
\hline & hkpp992 & Layer 2 Kh & 45.0 & 46.5 & & 0.22 & 0.04 \\
\hline & hkpp1000 & Layer 2 Kh & 30.0 & 21.5 & & 0.16 & 0.03 \\
\hline & hkpp1001 & Layer 2 Kh & 45.0 & 49.4 & & 0.31 & 0.06 \\
\hline
\end{tabular}


Table 6. Calibration parameters, parameter values, parameter sensitivity, and parameter identifiability for the automated calibration of the numerical groundwater-flow model of the Rush Springs aquifer, western Oklahoma, 1979-2015.—Continued

[GHB, General-Head Boundary; $\mathrm{ft}^{2} / \mathrm{d}$, foot squared per day; ft, foot; ft/d, foot per day; --, not computed; Kh, horizontal hydraulic conductivity. Layer 2 Kh and vertical anisotropy refer only to the pilot points in the alluvium and terrace; *, parameter with a fixed value during model calibration]

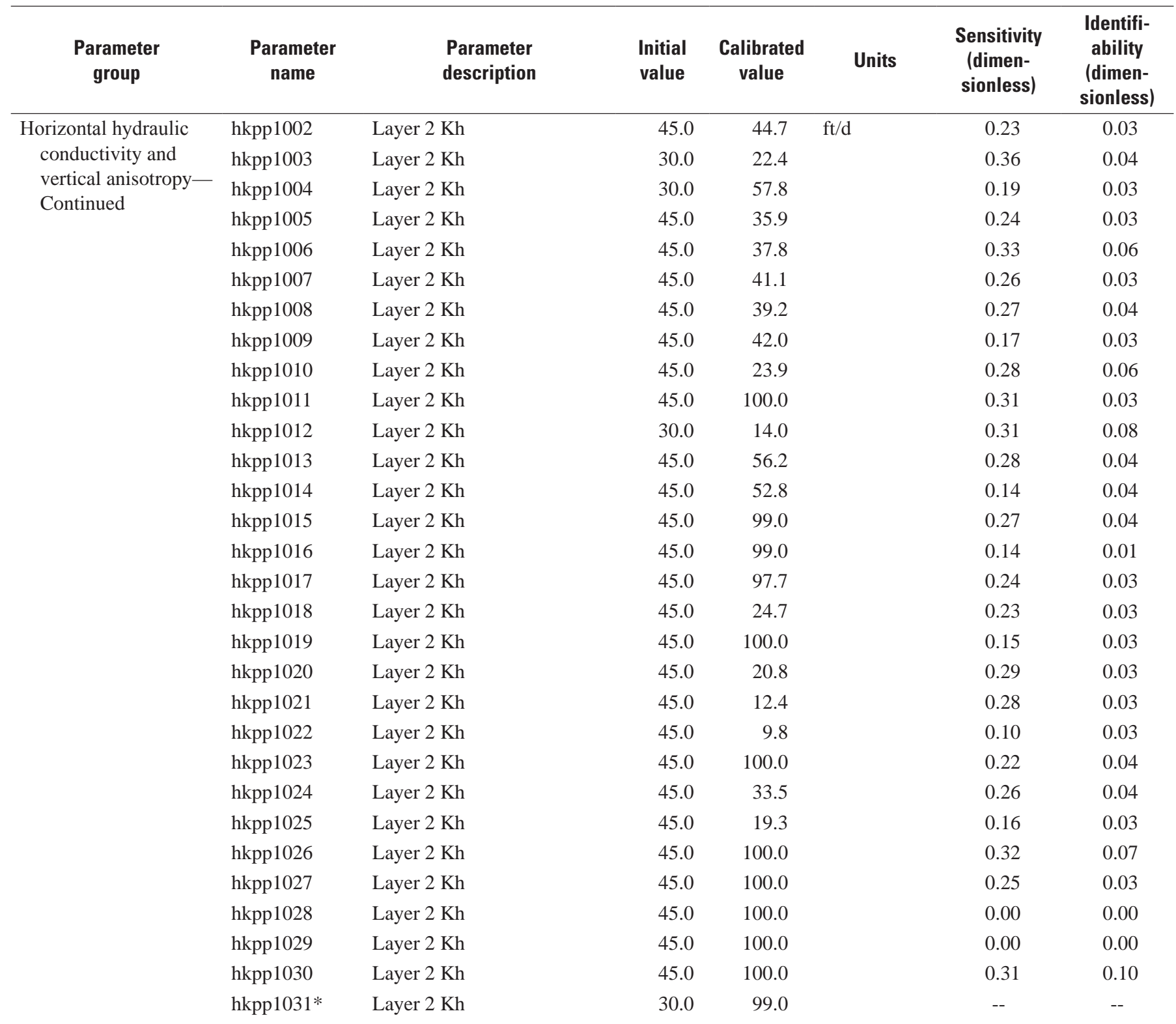


Table 6. Calibration parameters, parameter values, parameter sensitivity, and parameter identifiability for the automated calibration of the numerical groundwater-flow model of the Rush Springs aquifer, western Oklahoma, 1979-2015.—Continued

[GHB, General-Head Boundary; ft²/d, foot squared per day; ft, foot; ft/d, foot per day; --, not computed; Kh, horizontal hydraulic conductivity. Layer 2 Kh and vertical anisotropy refer only to the pilot points in the alluvium and terrace; *, parameter with a fixed value during model calibration]

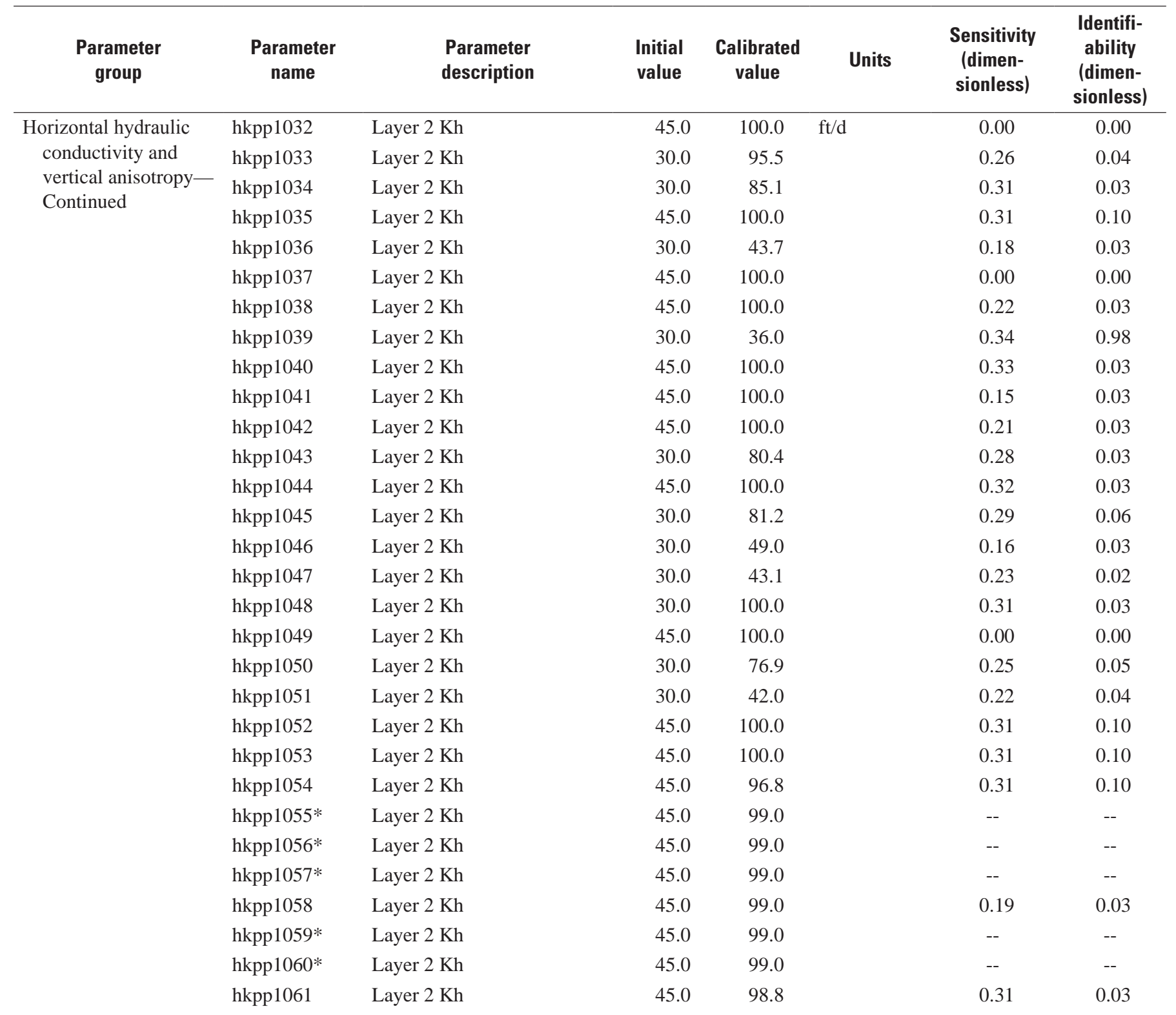


Table 6. Calibration parameters, parameter values, parameter sensitivity, and parameter identifiability for the automated calibration of the numerical groundwater-flow model of the Rush Springs aquifer, western Oklahoma, 1979-2015. - Continued

[GHB, General-Head Boundary; $\mathrm{ft}^{2} / \mathrm{d}$, foot squared per day; ft, foot; ft/d, foot per day; --, not computed; Kh, horizontal hydraulic conductivity. Layer 2 Kh and vertical anisotropy refer only to the pilot points in the alluvium and terrace; *, parameter with a fixed value during model calibration]

\begin{tabular}{|c|c|c|c|c|c|c|c|}
\hline $\begin{array}{c}\text { Parameter } \\
\text { group }\end{array}$ & $\begin{array}{c}\text { Parameter } \\
\text { name }\end{array}$ & $\begin{array}{l}\text { Parameter } \\
\text { description }\end{array}$ & $\begin{array}{l}\text { Initial } \\
\text { value }\end{array}$ & $\begin{array}{l}\text { Calibrated } \\
\text { value }\end{array}$ & Units & $\begin{array}{l}\text { Sensitivity } \\
\text { (dimen- } \\
\text { sionless) }\end{array}$ & $\begin{array}{l}\text { Identifi- } \\
\text { ability } \\
\text { (dimen- } \\
\text { sionless) }\end{array}$ \\
\hline \multirow{18}{*}{$\begin{array}{l}\text { Horizontal hydraulic } \\
\text { conductivity and } \\
\text { vertical anisotropy- } \\
\text { Continued }\end{array}$} & hkpp1063 & Layer 2 Kh & 45.0 & 5.4 & \multirow{18}{*}{$\mathrm{ft} / \mathrm{d}$} & 0.31 & 0.06 \\
\hline & hkpp1064 & Layer 2 Kh & 45.0 & 89.1 & & 0.22 & 0.03 \\
\hline & hkpp1066 & Layer 2 Kh & 45.0 & 28.6 & & 0.17 & 0.04 \\
\hline & hkpp1067 & Layer 2 Kh & 45.0 & 52.2 & & 0.27 & 0.03 \\
\hline & hkpp1068 & Layer 2 Kh & 45.0 & 67.9 & & 0.34 & 0.03 \\
\hline & hkpp1069 & Layer 2 Kh & 45.0 & 67.1 & & 0.21 & 0.04 \\
\hline & hkpp1070 & Layer 2 Kh & 45.0 & 73.0 & & 0.16 & 0.04 \\
\hline & hkpp1074 & Layer 2 Kh & 45.0 & 87.4 & & 0.28 & 0.03 \\
\hline & hkpp1075 & Layer 2 Kh & 45.0 & 86.5 & & 0.24 & 0.03 \\
\hline & hkpp1076 & Layer 2 Kh & 45.0 & 80.5 & & 0.24 & 0.03 \\
\hline & hkpp1077 & Layer 2 Kh & 45.0 & 88.4 & & 0.23 & 0.04 \\
\hline & hkpp1078 & Layer 2 Kh & 45.0 & 81.1 & & 0.25 & 0.03 \\
\hline & hkpp1079 & Layer 2 Kh & 30.0 & 30.1 & & 0.30 & 0.04 \\
\hline & hkpp1080 & Layer 2 Kh & 30.0 & 13.3 & & 0.22 & 0.04 \\
\hline & hkpp1081 & Layer 2 Kh & 30.0 & 29.3 & & 0.24 & 0.03 \\
\hline & hkpp1104 & Layer 3 Kh & 6.3 & 16.5 & & 0.34 & 0.04 \\
\hline & hkpp1137 & Layer 3 Kh & 6.3 & 15.3 & & 0.30 & 0.03 \\
\hline & hkpp1139 & Layer 3 Kh & 6.3 & 5.0 & & 0.31 & 0.07 \\
\hline
\end{tabular}


Table 6. Calibration parameters, parameter values, parameter sensitivity, and parameter identifiability for the automated calibration of the numerical groundwater-flow model of the Rush Springs aquifer, western Oklahoma, 1979-2015.—Continued

[GHB, General-Head Boundary; ft²/d, foot squared per day; ft, foot; ft/d, foot per day; --, not computed; Kh, horizontal hydraulic conductivity. Layer 2 Kh and vertical anisotropy refer only to the pilot points in the alluvium and terrace; *, parameter with a fixed value during model calibration]

\begin{tabular}{|c|c|c|c|c|c|c|c|}
\hline $\begin{array}{l}\text { Parameter } \\
\text { group }\end{array}$ & $\begin{array}{l}\text { Parameter } \\
\text { name }\end{array}$ & $\begin{array}{l}\text { Parameter } \\
\text { description }\end{array}$ & $\begin{array}{l}\text { Initial } \\
\text { value }\end{array}$ & $\begin{array}{c}\text { Calibrated } \\
\text { value }\end{array}$ & Units & $\begin{array}{c}\text { Sensitivity } \\
\text { (dimen- } \\
\text { sionless) }\end{array}$ & $\begin{array}{l}\text { Identifi- } \\
\text { ability } \\
\text { (dimen- } \\
\text { sionless) }\end{array}$ \\
\hline \multirow{18}{*}{$\begin{array}{l}\text { Horizontal hydraulic } \\
\text { conductivity and } \\
\text { vertical anisotropy- } \\
\text { Continued }\end{array}$} & hkpp1160 & Layer 3 Kh & 6.3 & 0.1 & \multirow{18}{*}{$\mathrm{ft} / \mathrm{d}$} & 0.32 & 0.06 \\
\hline & hkpp1162* & Layer 3 Kh & 6.3 & 2.8 & & -- & -- \\
\hline & hkpp1168 & Layer 3 Kh & 6.3 & 4.8 & & 0.24 & 0.05 \\
\hline & hkpp1170 & Layer 3 Kh & 6.3 & 7.3 & & 0.36 & 0.07 \\
\hline & hkpp1172 & Layer 3 Kh & 6.3 & 10.0 & & 0.24 & 0.11 \\
\hline & hkpp1174 & Layer 3 Kh & 6.3 & 10.5 & & 0.31 & 0.17 \\
\hline & hkpp1203 & Layer 3 Kh & 6.3 & 6.5 & & 0.32 & 0.05 \\
\hline & hkpp1205* & Layer $3 \mathrm{Kh}$ & 6.3 & 1.1 & & -- & -- \\
\hline & hkpp1207 & Layer 3 Kh & 6.3 & 1.2 & & 0.28 & 0.14 \\
\hline & hkpp1209 & Layer 3 Kh & 6.3 & 2.0 & & 0.23 & 0.04 \\
\hline & hkpp1211 & Layer 3 Kh & 6.3 & 2.6 & & 0.26 & 0.18 \\
\hline & hkpp1213 & Layer 3 Kh & 6.3 & 2.6 & & 0.10 & 0.12 \\
\hline & hkpp1215 & Layer 3 Kh & 6.3 & 5.4 & & 0.32 & 0.12 \\
\hline & hkpp1217 & Layer 3 Kh & 6.3 & 18.6 & & 0.19 & 0.06 \\
\hline & hkpp1243* & Layer $3 \mathrm{Kh}$ & 6.3 & 5.3 & & -- & -- \\
\hline & hkpp1245 & Layer 3 Kh & 6.3 & 3.1 & & 0.34 & 0.05 \\
\hline & hkpp1259 & Layer $3 \mathrm{Kh}$ & 6.3 & 2.3 & & 0.29 & 0.15 \\
\hline & hkpp1261 & Layer 3 Kh & 6.3 & 2.1 & & 0.13 & 0.11 \\
\hline
\end{tabular}


Table 6. Calibration parameters, parameter values, parameter sensitivity, and parameter identifiability for the automated calibration of the numerical groundwater-flow model of the Rush Springs aquifer, western Oklahoma, 1979-2015. - Continued

[GHB, General-Head Boundary; $\mathrm{ft}^{2} / \mathrm{d}$, foot squared per day; ft, foot; ft/d, foot per day; --, not computed; Kh, horizontal hydraulic conductivity. Layer 2 Kh and vertical anisotropy refer only to the pilot points in the alluvium and terrace; *, parameter with a fixed value during model calibration]

\begin{tabular}{|c|c|c|c|c|c|c|c|}
\hline $\begin{array}{c}\text { Parameter } \\
\text { group }\end{array}$ & $\begin{array}{c}\text { Parameter } \\
\text { name }\end{array}$ & $\begin{array}{l}\text { Parameter } \\
\text { description }\end{array}$ & $\begin{array}{l}\text { Initial } \\
\text { value }\end{array}$ & $\begin{array}{l}\text { Calibrated } \\
\text { value }\end{array}$ & Units & $\begin{array}{l}\text { Sensitivity } \\
\text { (dimen- } \\
\text { sionless) }\end{array}$ & $\begin{array}{l}\text { Identifi- } \\
\text { ability } \\
\text { (dimen- } \\
\text { sionless) }\end{array}$ \\
\hline \multirow{18}{*}{$\begin{array}{l}\text { Horizontal hydraulic } \\
\text { conductivity and } \\
\text { vertical anisotropy- } \\
\text { Continued }\end{array}$} & hkpp1290 & Layer 3 Kh & 6.3 & 3.7 & \multirow{18}{*}{$\mathrm{ft} / \mathrm{d}$} & 0.15 & 0.03 \\
\hline & hkpp1292 & Layer $3 \mathrm{Kh}$ & 6.3 & 4.5 & & 0.29 & 0.04 \\
\hline & hkpp1296 & Layer 3 Kh & 6.3 & 3.7 & & 0.23 & 0.04 \\
\hline & hkpp1298* & Layer 3 Kh & 6.3 & 0.9 & & -- & -- \\
\hline & hkpp1300* & Layer 3 Kh & 6.3 & 1.1 & & -- & -- \\
\hline & hkpp1302 & Layer 3 Kh & 6.3 & 6.3 & & 0.30 & 0.14 \\
\hline & hkpp1304 & Layer 3 Kh & 6.3 & 6.8 & & 0.23 & 0.06 \\
\hline & hkpp1312 & Layer 3 Kh & 6.3 & 4.3 & & 0.26 & 0.31 \\
\hline & hkpp1340 & Layer 3 Kh & 6.3 & 7.8 & & 0.03 & 0.03 \\
\hline & hkpp1342 & Layer 3 Kh & 6.3 & 13.2 & & 0.25 & 0.07 \\
\hline & hkpp1344 & Layer 3 Kh & 6.3 & 2.5 & & 0.26 & 0.04 \\
\hline & hkpp1346 & Layer 3 Kh & 6.3 & 1.2 & & 0.26 & 0.04 \\
\hline & hkpp1348 & Layer 3 Kh & 6.3 & 3.3 & & 0.26 & 0.04 \\
\hline & hkpp1350* & Layer 3 Kh & 6.3 & 2.2 & & -- & -- \\
\hline & hkpp1352* & Layer 3 Kh & 6.3 & 0.9 & & -- & -- \\
\hline & hkpp1354 & Layer 3 Kh & 6.3 & 17.2 & & 0.20 & 0.08 \\
\hline & hkpp1396 & Layer 3 Kh & 6.3 & 17.3 & & 0.27 & 0.04 \\
\hline & hkpp1398 & Layer 3 Kh & 6.3 & 2.2 & & 0.25 & 0.04 \\
\hline
\end{tabular}


Table 6. Calibration parameters, parameter values, parameter sensitivity, and parameter identifiability for the automated calibration of the numerical groundwater-flow model of the Rush Springs aquifer, western Oklahoma, 1979-2015. - Continued

[GHB, General-Head Boundary; ft²/d, foot squared per day; ft, foot; ft/d, foot per day; --, not computed; Kh, horizontal hydraulic conductivity. Layer 2 Kh and vertical anisotropy refer only to the pilot points in the alluvium and terrace; *, parameter with a fixed value during model calibration]

\begin{tabular}{|c|c|c|c|c|c|c|c|}
\hline $\begin{array}{l}\text { Parameter } \\
\text { group }\end{array}$ & $\begin{array}{c}\text { Parameter } \\
\text { name }\end{array}$ & $\begin{array}{l}\text { Parameter } \\
\text { description }\end{array}$ & $\begin{array}{l}\text { Initial } \\
\text { value }\end{array}$ & $\begin{array}{l}\text { Calibrated } \\
\text { value }\end{array}$ & Units & $\begin{array}{l}\text { Sensitivity } \\
\text { (dimen- } \\
\text { sionless) }\end{array}$ & $\begin{array}{l}\text { Identifi- } \\
\text { ability } \\
\text { (dimen- } \\
\text { sionless) }\end{array}$ \\
\hline \multirow{18}{*}{$\begin{array}{l}\text { Horizontal hydraulic } \\
\text { conductivity and } \\
\text { vertical anisotropy- } \\
\text { Continued }\end{array}$} & hkpp1402* & Layer $3 \mathrm{Kh}$ & 6.3 & 1.1 & \multirow{18}{*}{$\mathrm{ft} / \mathrm{d}$} & -- & -- \\
\hline & hkpp1404 & Layer $3 \mathrm{Kh}$ & 6.3 & 1.9 & & 0.22 & 0.04 \\
\hline & hkpp1408 & Layer $3 \mathrm{Kh}$ & 6.3 & 4.1 & & 0.34 & 0.30 \\
\hline & hkpp1410 & Layer $3 \mathrm{Kh}$ & 6.3 & 18.5 & & 0.18 & 0.08 \\
\hline & hkpp1412 & Layer $3 \mathrm{Kh}$ & 6.3 & 8.5 & & 0.22 & 0.08 \\
\hline & hkpp1414* & Layer $3 \mathrm{Kh}$ & 7.3 & 1.1 & & -- & -- \\
\hline & hkpp1416 & Layer 3 Kh & 6.3 & 16.7 & & 0.19 & 0.04 \\
\hline & hkpp1450 & Layer $3 \mathrm{Kh}$ & 6.3 & 39.3 & & 0.21 & 0.05 \\
\hline & hkpp1452 & Layer 3 Kh & 6.3 & 5.9 & & 0.18 & 0.04 \\
\hline & hkpp1454 & Layer $3 \mathrm{Kh}$ & 6.3 & 3.3 & & 0.36 & 0.09 \\
\hline & hkpp1456 & Layer 3 Kh & 6.3 & 41.6 & & 0.28 & 0.04 \\
\hline & hkpp1458* & Layer $3 \mathrm{Kh}$ & 6.3 & 3.7 & & -- & -- \\
\hline & hkpp1460 & Layer $3 \mathrm{Kh}$ & 6.3 & 5.1 & & 0.27 & 0.53 \\
\hline & hkpp1462 & Layer $3 \mathrm{Kh}$ & 6.3 & 7.4 & & 0.27 & 0.71 \\
\hline & hkpp1464 & Layer $3 \mathrm{Kh}$ & 6.3 & 0.3 & & 0.32 & 0.17 \\
\hline & hkpp1466 & Layer $3 \mathrm{Kh}$ & 6.3 & 0.4 & & 0.30 & 0.11 \\
\hline & hkpp1508 & Layer 3 Kh & 6.3 & 10.0 & & 0.25 & 0.14 \\
\hline & hkpp1510 & Layer 3 Kh & 6.3 & 6.4 & & 0.27 & 0.06 \\
\hline
\end{tabular}


Table 6. Calibration parameters, parameter values, parameter sensitivity, and parameter identifiability for the automated calibration of the numerical groundwater-flow model of the Rush Springs aquifer, western Oklahoma, 1979-2015. - Continued

[GHB, General-Head Boundary; ft²/d, foot squared per day; ft, foot; ft/d, foot per day; --, not computed; Kh, horizontal hydraulic conductivity. Layer 2 Kh and vertical anisotropy refer only to the pilot points in the alluvium and terrace; *, parameter with a fixed value during model calibration]

\begin{tabular}{|c|c|c|c|c|c|c|c|}
\hline $\begin{array}{l}\text { Parameter } \\
\text { group }\end{array}$ & $\begin{array}{c}\text { Parameter } \\
\text { name }\end{array}$ & $\begin{array}{l}\text { Parameter } \\
\text { description }\end{array}$ & $\begin{array}{l}\text { Initial } \\
\text { value }\end{array}$ & $\begin{array}{l}\text { Calibrated } \\
\text { value }\end{array}$ & Units & $\begin{array}{l}\text { Sensitivity } \\
\text { (dimen- } \\
\text { sionless) }\end{array}$ & $\begin{array}{l}\text { Identifi- } \\
\text { ability } \\
\text { (dimen- } \\
\text { sionless) }\end{array}$ \\
\hline \multirow{18}{*}{$\begin{array}{l}\text { Horizontal hydraulic } \\
\text { conductivity and } \\
\text { vertical anisotropy- } \\
\text { Continued }\end{array}$} & hkpp1514 & Layer $3 \mathrm{Kh}$ & 6.3 & 0.1 & \multirow{18}{*}{$\mathrm{ft} / \mathrm{d}$} & 0.21 & 0.11 \\
\hline & hkpp1516 & Layer 3 Kh & 6.3 & 0.3 & & 0.37 & 0.12 \\
\hline & hkpp1520 & Layer $3 \mathrm{Kh}$ & 6.3 & 9.0 & & 0.29 & 0.05 \\
\hline & hkpp1544 & Layer $3 \mathrm{Kh}$ & 6.3 & 100.0 & & 0.25 & 0.04 \\
\hline & hkpp1546 & Layer 3 Kh & 6.3 & 8.5 & & 0.31 & 0.03 \\
\hline & hkpp1548 & Layer 3 Kh & 6.3 & 13.2 & & 0.23 & 0.04 \\
\hline & hkpp1550 & Layer 3 Kh & 6.3 & 27.1 & & 0.24 & 0.65 \\
\hline & hkpp1558 & Layer $3 \mathrm{Kh}$ & 6.3 & 0.5 & & 0.20 & 0.07 \\
\hline & hkpp1560 & Layer 3 Kh & 6.3 & 3.8 & & 0.27 & 0.07 \\
\hline & hkpp1562 & Layer 3 Kh & 6.3 & 16.3 & & 0.21 & 0.08 \\
\hline & hkpp1564 & Layer $3 \mathrm{Kh}$ & 6.3 & 9.7 & & 0.21 & 0.07 \\
\hline & hkpp1565 & Layer 3 Kh & 6.3 & 4.1 & & 0.26 & 0.06 \\
\hline & hkpp1589 & Layer 3 Kh & 6.3 & 10.3 & & 0.21 & 0.04 \\
\hline & hkpp1591 & Layer 3 Kh & 6.3 & 10.0 & & 0.20 & 0.03 \\
\hline & hkpp1593 & Layer 3 Kh & 6.3 & 12.5 & & 0.27 & 0.05 \\
\hline & hkpp1595 & Layer 3 Kh & 6.3 & 5.1 & & 0.25 & 0.06 \\
\hline & hkpp1611 & Layer 3 Kh & 6.3 & 3.1 & & 0.26 & 0.04 \\
\hline & hkpp1635 & Layer 3 Kh & 6.3 & 11.7 & & 0.27 & 0.06 \\
\hline
\end{tabular}


Table 6. Calibration parameters, parameter values, parameter sensitivity, and parameter identifiability for the automated calibration of the numerical groundwater-flow model of the Rush Springs aquifer, western Oklahoma, 1979-2015._Continued

[GHB, General-Head Boundary; ft²/d, foot squared per day; ft, foot; ft/d, foot per day; --, not computed; Kh, horizontal hydraulic conductivity. Layer 2 Kh and vertical anisotropy refer only to the pilot points in the alluvium and terrace; *, parameter with a fixed value during model calibration]

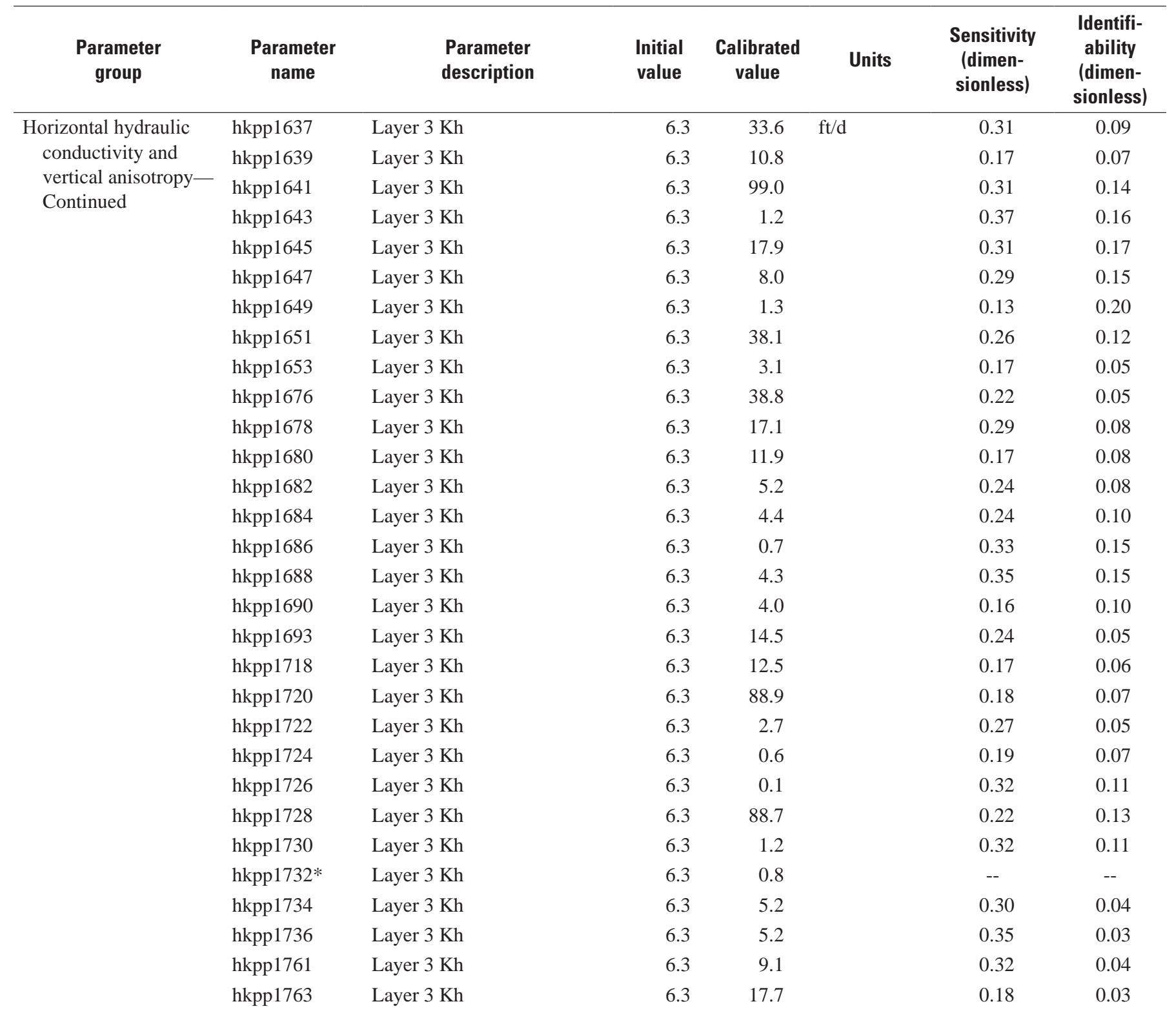


Table 6. Calibration parameters, parameter values, parameter sensitivity, and parameter identifiability for the automated calibration of the numerical groundwater-flow model of the Rush Springs aquifer, western Oklahoma, 1979-2015. - Continued

[GHB, General-Head Boundary; $\mathrm{ft}^{2} / \mathrm{d}$, foot squared per day; ft, foot; ft/d, foot per day; --, not computed; Kh, horizontal hydraulic conductivity. Layer 2 Kh and vertical anisotropy refer only to the pilot points in the alluvium and terrace; *, parameter with a fixed value during model calibration]

\begin{tabular}{|c|c|c|c|c|c|c|c|}
\hline $\begin{array}{c}\text { Parameter } \\
\text { group }\end{array}$ & $\begin{array}{c}\text { Parameter } \\
\text { name }\end{array}$ & $\begin{array}{l}\text { Parameter } \\
\text { description }\end{array}$ & $\begin{array}{l}\text { Initial } \\
\text { value }\end{array}$ & $\begin{array}{l}\text { Calibrated } \\
\text { value }\end{array}$ & Units & $\begin{array}{l}\text { Sensitivity } \\
\text { (dimen- } \\
\text { sionless) }\end{array}$ & $\begin{array}{l}\text { Identifi- } \\
\text { ability } \\
\text { (dimen- } \\
\text { sionless) }\end{array}$ \\
\hline \multirow{18}{*}{$\begin{array}{l}\text { Horizontal hydraulic } \\
\text { conductivity and } \\
\text { vertical anisotropy- } \\
\text { Continued }\end{array}$} & hkpp1767 & Layer 3 Kh & 6.3 & 17.4 & \multirow{18}{*}{$\mathrm{ft} / \mathrm{d}$} & 0.29 & 0.29 \\
\hline & hkpp1769 & Layer 3 Kh & 6.3 & 99.0 & & 0.29 & 0.06 \\
\hline & hkpp1773 & Layer 3 Kh & 6.3 & 15.3 & & 0.29 & 0.05 \\
\hline & hkpp1775* & Layer 3 Kh & 6.3 & 1.2 & & -- & -- \\
\hline & hkpp1777 & Layer 3 Kh & 6.3 & 0.0 & & 0.35 & 0.10 \\
\hline & hkpp1779 & Layer 3 Kh & 6.3 & 39.6 & & 0.37 & 0.11 \\
\hline & hkpp1781 & Layer 3 Kh & 6.3 & 0.3 & & 0.29 & 0.06 \\
\hline & hkpp1814 & Layer 3 Kh & 6.3 & 19.6 & & 0.20 & 0.28 \\
\hline & hkpp1816 & Layer 3 Kh & 6.3 & 8.8 & & 0.28 & 0.04 \\
\hline & hkpp1818 & Layer 3 Kh & 6.3 & 7.2 & & 0.37 & 0.06 \\
\hline & hkpp1820 & Layer 3 Kh & 6.3 & 9.7 & & 0.33 & 0.05 \\
\hline & hkpp1822 & Layer 3 Kh & 6.3 & 2.5 & & 0.03 & 0.04 \\
\hline & hkpp1824 & Layer 3 Kh & 6.3 & 40.9 & & 0.17 & 0.05 \\
\hline & hkpp1826* & Layer 3 Kh & 6.3 & 1.0 & & -- & -- \\
\hline & hkpp1828 & Layer 3 Kh & 6.3 & 5.7 & & 0.27 & 0.05 \\
\hline & hkpp1830 & Layer 3 Kh & 6.3 & 0.5 & & 0.25 & 0.04 \\
\hline & hkpp1871 & Layer 3 Kh & 6.3 & 13.4 & & 0.31 & 0.03 \\
\hline & hkpp1872 & Layer 3 Kh & 6.3 & 6.1 & & 0.26 & 0.04 \\
\hline
\end{tabular}


Table 6. Calibration parameters, parameter values, parameter sensitivity, and parameter identifiability for the automated calibration of the numerical groundwater-flow model of the Rush Springs aquifer, western Oklahoma, 1979-2015.—Continued

[GHB, General-Head Boundary; ft²/d, foot squared per day; ft, foot; ft/d, foot per day; --, not computed; Kh, horizontal hydraulic conductivity. Layer 2 Kh and vertical anisotropy refer only to the pilot points in the alluvium and terrace; *, parameter with a fixed value during model calibration]

\begin{tabular}{|c|c|c|c|c|c|c|c|}
\hline $\begin{array}{l}\text { Parameter } \\
\text { group }\end{array}$ & $\begin{array}{l}\text { Parameter } \\
\text { name }\end{array}$ & $\begin{array}{l}\text { Parameter } \\
\text { description }\end{array}$ & $\begin{array}{l}\text { Initial } \\
\text { value }\end{array}$ & $\begin{array}{l}\text { Calibrated } \\
\text { value }\end{array}$ & Units & $\begin{array}{l}\text { Sensitivity } \\
\text { (dimen- } \\
\text { sionless) }\end{array}$ & $\begin{array}{l}\text { Identifi- } \\
\text { ability } \\
\text { (dimen- } \\
\text { sionless) }\end{array}$ \\
\hline \multirow{18}{*}{$\begin{array}{l}\text { Horizontal hydraulic } \\
\text { conductivity and } \\
\text { vertical anisotropy- } \\
\text { Continued }\end{array}$} & hkpp1887 & Layer 3 Kh & 6.3 & 17.7 & \multirow{16}{*}{$\mathrm{ft} / \mathrm{d}$} & 0.33 & 0.03 \\
\hline & hkpp1889 & Layer $3 \mathrm{Kh}$ & 6.3 & 5.7 & & 0.26 & 0.03 \\
\hline & hkpp1893 & Layer $3 \mathrm{Kh}$ & 6.3 & 7.4 & & 0.20 & 0.03 \\
\hline & hkpp1904 & Layer $3 \mathrm{Kh}$ & 6.3 & 15.5 & & 0.30 & 0.03 \\
\hline & hkpp1906 & Layer $3 \mathrm{Kh}$ & 6.3 & 91.4 & & 0.25 & 0.04 \\
\hline & hkpp1908 & Layer $3 \mathrm{Kh}$ & 6.3 & 23.0 & & 0.29 & 0.04 \\
\hline & hkpp1911 & Layer 3 Kh & 6.3 & 2.7 & & 0.20 & 0.03 \\
\hline & hkpp1929 & Layer 3 Kh & 6.3 & 1.7 & & 0.22 & 0.04 \\
\hline & hkpp1942 & Layer 3 Kh & 6.3 & 70.2 & & 0.16 & 0.05 \\
\hline & hkpp1944 & Layer $3 \mathrm{Kh}$ & 6.3 & 7.8 & & 0.17 & 0.05 \\
\hline & hkpp1946 & Layer 3 Kh & 6.3 & 5.1 & & 0.29 & 0.06 \\
\hline & hkpp1948 & Layer $3 \mathrm{Kh}$ & 6.3 & 4.8 & & 0.25 & 0.05 \\
\hline & hkpp1950 & Layer $3 \mathrm{Kh}$ & 6.3 & 6.3 & & 0.25 & 0.03 \\
\hline & hkpp1959 & Layer $3 \mathrm{Kh}$ & 6.3 & 15.2 & & 0.24 & 0.04 \\
\hline & hkpp1961 & Layer $3 \mathrm{Kh}$ & 6.3 & 6.6 & & 0.22 & 0.04 \\
\hline & hkpp1963 & Layer $3 \mathrm{Kh}$ & 6.3 & 2.7 & & 0.20 & 0.06 \\
\hline & hkpp903_vk & Layer 2 vertical anisotropy & 10.0 & 10.0 & \multirow{2}{*}{$\begin{array}{l}\text { Horizontal } \\
\text { to vertical } \\
\text { ratio }\end{array}$} & 0.20 & 0.04 \\
\hline & hkpp904_vk & Layer 2 vertical anisotropy & 10.0 & 10.0 & & 0.34 & 0.06 \\
\hline
\end{tabular}


Table 6. Calibration parameters, parameter values, parameter sensitivity, and parameter identifiability for the automated calibration of the numerical groundwater-flow model of the Rush Springs aquifer, western Oklahoma, 1979-2015. - Continued

[GHB, General-Head Boundary; ft²/d, foot squared per day; ft, foot; ft/d, foot per day; --, not computed; Kh, horizontal hydraulic conductivity. Layer 2 Kh and vertical anisotropy refer only to the pilot points in the alluvium and terrace; *, parameter with a fixed value during model calibration]

\begin{tabular}{|c|c|c|c|c|c|c|c|}
\hline $\begin{array}{l}\text { Parameter } \\
\text { group }\end{array}$ & $\begin{array}{l}\text { Parameter } \\
\text { name }\end{array}$ & $\begin{array}{l}\text { Parameter } \\
\text { description }\end{array}$ & $\begin{array}{l}\text { Initial } \\
\text { value }\end{array}$ & $\begin{array}{l}\text { Calibrated } \\
\text { value }\end{array}$ & Units & $\begin{array}{l}\text { Sensitivity } \\
\text { (dimen- } \\
\text { sionless) }\end{array}$ & $\begin{array}{l}\text { Identifi- } \\
\text { ability } \\
\text { (dimen- } \\
\text { sionless) }\end{array}$ \\
\hline \multirow{18}{*}{$\begin{array}{l}\text { Horizontal hydraulic } \\
\text { conductivity and } \\
\text { vertical anisotropy- } \\
\text { Continued }\end{array}$} & hkpp906_vk & Layer 2 vertical anisotropy & 10.0 & 9.5 & \multirow{18}{*}{$\begin{array}{l}\text { Horizontal } \\
\text { to vertical } \\
\text { ratio }\end{array}$} & 0.34 & 0.08 \\
\hline & hkpp907_vk & Layer 2 vertical anisotropy & 10.0 & 9.5 & & 0.17 & 0.03 \\
\hline & hkpp910_vk & Layer 2 vertical anisotropy & 10.0 & 9.1 & & 0.23 & 0.04 \\
\hline & hkpp911_vk & Layer 2 vertical anisotropy & 10.0 & 9.5 & & 0.05 & 0.03 \\
\hline & hkpp912_vk & Layer 2 vertical anisotropy & 10.0 & 9.0 & & 0.29 & 0.03 \\
\hline & hkpp913_vk & Layer 2 vertical anisotropy & 10.0 & 9.3 & & 0.19 & 0.03 \\
\hline & hkpp917_vk & Layer 2 vertical anisotropy & 10.0 & 10.0 & & 0.28 & 0.02 \\
\hline & hkpp918_vk & Layer 2 vertical anisotropy & 10.0 & 9.3 & & 0.24 & 0.04 \\
\hline & hkpp919_vk & Layer 2 vertical anisotropy & 10.0 & 10.0 & & 0.22 & 0.03 \\
\hline & hkpp920_vk & Layer 2 vertical anisotropy & 10.0 & 10.2 & & 0.30 & 0.03 \\
\hline & hkpp921_vk & Layer 2 vertical anisotropy & 10.0 & 10.1 & & 0.28 & 0.06 \\
\hline & hkpp922_vk & Layer 2 vertical anisotropy & 10.0 & 9.8 & & 0.14 & 0.02 \\
\hline & hkpp923_vk & Layer 2 vertical anisotropy & 10.0 & 9.6 & & 0.34 & 0.04 \\
\hline & hkpp924_vk & Layer 2 vertical anisotropy & 10.0 & 9.5 & & 0.29 & 0.03 \\
\hline & hkpp925_vk & Layer 2 vertical anisotropy & 10.0 & 9.8 & & 0.26 & 0.03 \\
\hline & hkpp926_vk & Layer 2 vertical anisotropy & 10.0 & 9.3 & & 0.09 & 0.02 \\
\hline & hkpp933_vk & Layer 2 vertical anisotropy & 10.0 & 10.0 & & 0.35 & 0.03 \\
\hline & hkpp934_vk & Layer 2 vertical anisotropy & 10.0 & 9.7 & & 0.34 & 0.04 \\
\hline
\end{tabular}


Table 6. Calibration parameters, parameter values, parameter sensitivity, and parameter identifiability for the automated calibration of the numerical groundwater-flow model of the Rush Springs aquifer, western Oklahoma, 1979-2015. - Continued

[GHB, General-Head Boundary; ft²/d, foot squared per day; ft, foot; ft/d, foot per day; --, not computed; Kh, horizontal hydraulic conductivity. Layer 2 Kh and vertical anisotropy refer only to the pilot points in the alluvium and terrace; *, parameter with a fixed value during model calibration]

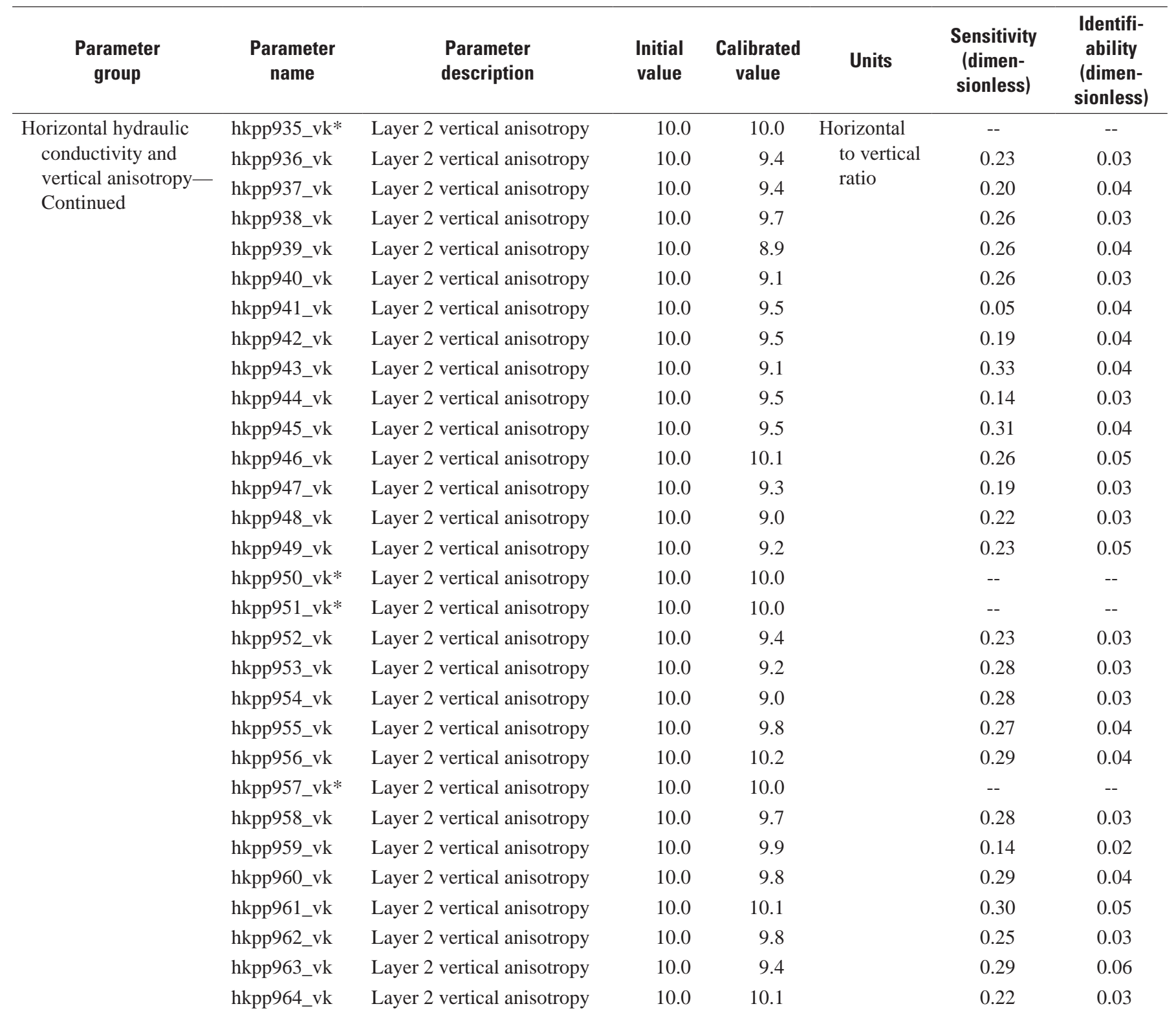


Table 6. Calibration parameters, parameter values, parameter sensitivity, and parameter identifiability for the automated calibration of the numerical groundwater-flow model of the Rush Springs aquifer, western Oklahoma, 1979-2015. - Continued

[GHB, General-Head Boundary; ft²/d, foot squared per day; ft, foot; ft/d, foot per day; --, not computed; Kh, horizontal hydraulic conductivity. Layer 2 Kh and vertical anisotropy refer only to the pilot points in the alluvium and terrace; *, parameter with a fixed value during model calibration]

\begin{tabular}{|c|c|c|c|c|c|c|c|}
\hline $\begin{array}{l}\text { Parameter } \\
\text { group }\end{array}$ & $\begin{array}{l}\text { Parameter } \\
\text { name }\end{array}$ & $\begin{array}{l}\text { Parameter } \\
\text { description }\end{array}$ & $\begin{array}{l}\text { Initial } \\
\text { value }\end{array}$ & $\begin{array}{l}\text { Calibrated } \\
\text { value }\end{array}$ & Units & $\begin{array}{l}\text { Sensitivity } \\
\text { (dimen- } \\
\text { sionless) }\end{array}$ & $\begin{array}{l}\text { Identifi- } \\
\text { ability } \\
\text { (dimen- } \\
\text { sionless) }\end{array}$ \\
\hline \multirow{18}{*}{$\begin{array}{l}\text { Horizontal hydraulic } \\
\text { conductivity and } \\
\text { vertical anisotropy- } \\
\text { Continued }\end{array}$} & hkpp966_vk & Layer 2 vertical anisotropy & 10.0 & 10.4 & \multirow{18}{*}{$\begin{array}{l}\text { Horizontal } \\
\text { to vertical } \\
\text { ratio }\end{array}$} & 0.23 & 0.03 \\
\hline & hkpp967_vk & Layer 2 vertical anisotropy & 10.0 & 10.7 & & 0.28 & 0.03 \\
\hline & hkpp970_vk & Layer 2 vertical anisotropy & 10.0 & 10.0 & & 0.20 & 0.03 \\
\hline & hkpp971_vk & Layer 2 vertical anisotropy & 10.0 & 9.2 & & 0.21 & 0.04 \\
\hline & hkpp972_vk & Layer 2 vertical anisotropy & 10.0 & 9.8 & & 0.27 & 0.03 \\
\hline & hkpp973_vk & Layer 2 vertical anisotropy & 10.0 & 9.8 & & 0.22 & 0.04 \\
\hline & hkpp977_vk & Layer 2 vertical anisotropy & 10.0 & 9.8 & & 0.32 & 0.04 \\
\hline & hkpp978_vk & Layer 2 vertical anisotropy & 10.0 & 10.0 & & 0.26 & 0.06 \\
\hline & hkpp979_vk & Layer 2 vertical anisotropy & 10.0 & 9.7 & & 0.14 & 0.05 \\
\hline & hkpp980_vk & Layer 2 vertical anisotropy & 10.0 & 9.7 & & 0.16 & 0.03 \\
\hline & hkpp981_vk & Layer 2 vertical anisotropy & 10.0 & 9.7 & & 0.24 & 0.04 \\
\hline & hkpp982_vk* & Layer 2 vertical anisotropy & 10.0 & 10.0 & & -- & -- \\
\hline & hkpp983_vk & Layer 2 vertical anisotropy & 10.0 & 10.4 & & 0.21 & 0.07 \\
\hline & hkpp984_vk & Layer 2 vertical anisotropy & 10.0 & 9.5 & & 0.24 & 0.03 \\
\hline & hkpp985_vk & Layer 2 vertical anisotropy & 10.0 & 10.2 & & 0.17 & 0.03 \\
\hline & hkpp986_vk & Layer 2 vertical anisotropy & 10.0 & 9.7 & & 0.11 & 0.04 \\
\hline & hkpp993_vk & Layer 2 vertical anisotropy & 10.0 & 10.1 & & 0.26 & 0.07 \\
\hline & hkpp994_vk & Layer 2 vertical anisotropy & 10.0 & 9.9 & & 0.18 & 0.03 \\
\hline
\end{tabular}


Table 6. Calibration parameters, parameter values, parameter sensitivity, and parameter identifiability for the automated calibration of the numerical groundwater-flow model of the Rush Springs aquifer, western Oklahoma, 1979-2015. - Continued

[GHB, General-Head Boundary; ft²/d, foot squared per day; ft, foot; ft/d, foot per day; --, not computed; Kh, horizontal hydraulic conductivity. Layer 2 Kh and vertical anisotropy refer only to the pilot points in the alluvium and terrace; *, parameter with a fixed value during model calibration]

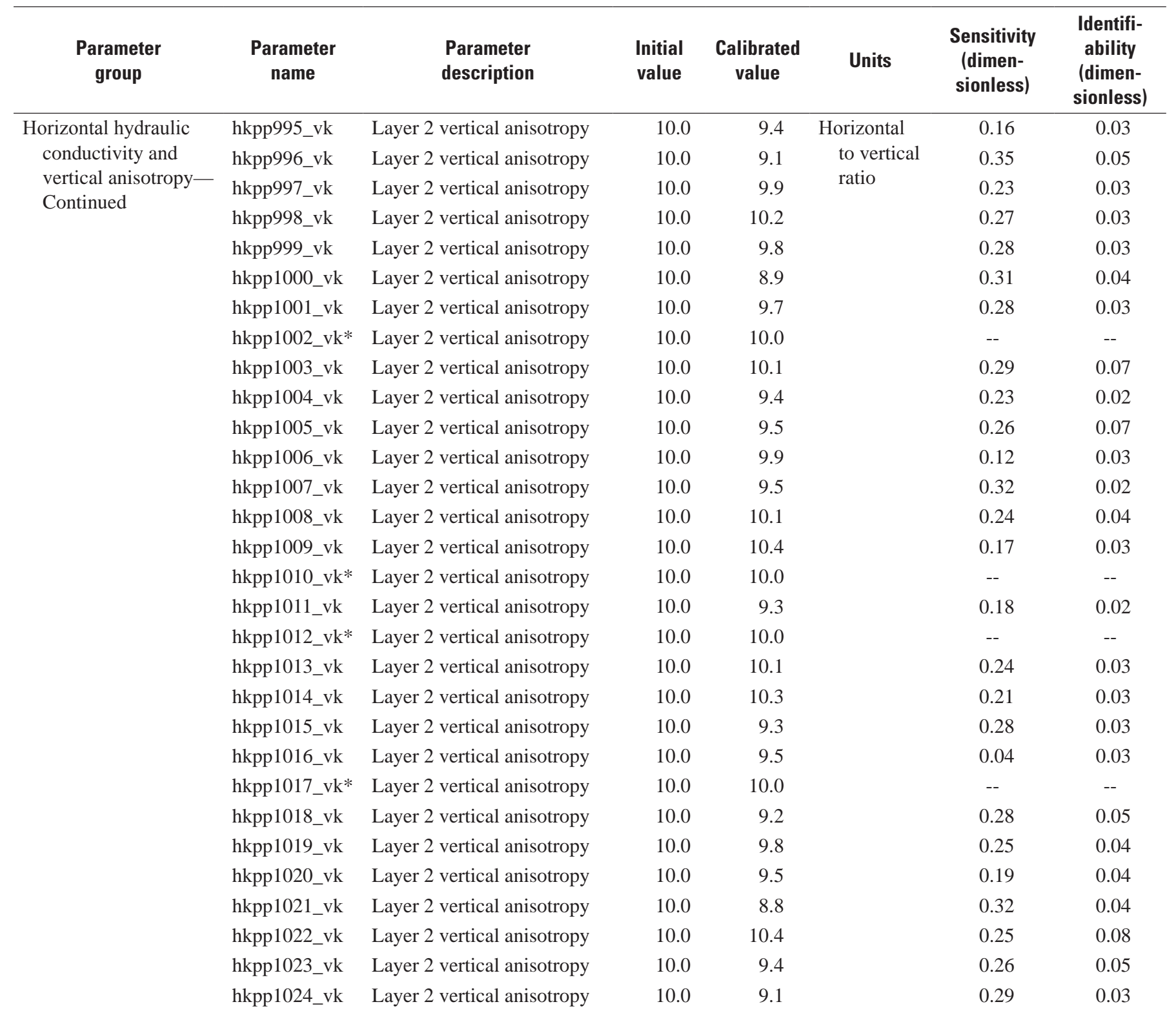


Table 6. Calibration parameters, parameter values, parameter sensitivity, and parameter identifiability for the automated calibration of the numerical groundwater-flow model of the Rush Springs aquifer, western Oklahoma, 1979-2015.—Continued

[GHB, General-Head Boundary; ft²/d, foot squared per day; ft, foot; ft/d, foot per day; --, not computed; Kh, horizontal hydraulic conductivity. Layer 2 Kh and vertical anisotropy refer only to the pilot points in the alluvium and terrace; *, parameter with a fixed value during model calibration]

\begin{tabular}{|c|c|c|c|c|c|c|c|}
\hline $\begin{array}{l}\text { Parameter } \\
\text { group }\end{array}$ & $\begin{array}{l}\text { Parameter } \\
\text { name }\end{array}$ & $\begin{array}{l}\text { Parameter } \\
\text { description }\end{array}$ & $\begin{array}{l}\text { Initial } \\
\text { value }\end{array}$ & $\begin{array}{l}\text { Calibrated } \\
\text { value }\end{array}$ & Units & $\begin{array}{l}\text { Sensitivity } \\
\text { (dimen- } \\
\text { sionless) }\end{array}$ & $\begin{array}{l}\text { Identifi- } \\
\text { ability } \\
\text { (dimen- } \\
\text { sionless) }\end{array}$ \\
\hline \multirow{18}{*}{$\begin{array}{l}\text { Horizontal hydraulic } \\
\text { conductivity and } \\
\text { vertical anisotropy- } \\
\text { Continued }\end{array}$} & hkpp1026_vk & Layer 2 vertical anisotropy & 10.0 & 10.2 & \multirow{18}{*}{$\begin{array}{l}\text { Horizontal } \\
\text { to vertical } \\
\text { ratio }\end{array}$} & 0.20 & 0.03 \\
\hline & hkpp1027_vk & Layer 2 vertical anisotropy & 10.0 & 9.9 & & 0.30 & 0.09 \\
\hline & hkpp1030_vk* & Layer 2 vertical anisotropy & 10.0 & 10.0 & & -- & -- \\
\hline & hkpp1031_vk & Layer 2 vertical anisotropy & 10.0 & 9.9 & & 0.26 & 0.03 \\
\hline & hkpp1032_vk* & Layer 2 vertical anisotropy & 10.0 & 10.0 & & -- & -- \\
\hline & hkpp1033_vk & Layer 2 vertical anisotropy & 10.0 & 9.8 & & 0.28 & 0.03 \\
\hline & hkpp1037_vk & Layer 2 vertical anisotropy & 10.0 & 9.2 & & 0.25 & 0.04 \\
\hline & hkpp1038_vk & Layer 2 vertical anisotropy & 10.0 & 9.4 & & 0.25 & 0.03 \\
\hline & hkpp1039_vk & Layer 2 vertical anisotropy & 10.0 & 10.0 & & 0.27 & 0.04 \\
\hline & hkpp1040_vk & Layer 2 vertical anisotropy & 10.0 & 9.4 & & 0.28 & 0.04 \\
\hline & hkpp1041_vk & Layer 2 vertical anisotropy & 10.0 & 9.2 & & 0.33 & 0.06 \\
\hline & hkpp1042_vk & Layer 2 vertical anisotropy & 10.0 & 9.9 & & 0.24 & 0.04 \\
\hline & hkpp1043_vk & Layer 2 vertical anisotropy & 10.0 & 9.9 & & 0.22 & 0.04 \\
\hline & hkpp1044_vk & Layer 2 vertical anisotropy & 10.0 & 9.5 & & 0.28 & 0.04 \\
\hline & hkpp1045_vk & Layer 2 vertical anisotropy & 10.0 & 10.3 & & 0.27 & 0.04 \\
\hline & hkpp1046_vk & Layer 2 vertical anisotropy & 10.0 & 9.4 & & 0.19 & 0.03 \\
\hline & hkpp1053_vk & Layer 2 vertical anisotropy & 10.0 & 9.4 & & 0.23 & 0.04 \\
\hline & hkpp1054_vk & Layer 2 vertical anisotropy & 10.0 & 9.5 & & 0.27 & 0.04 \\
\hline
\end{tabular}


Table 6. Calibration parameters, parameter values, parameter sensitivity, and parameter identifiability for the automated calibration of the numerical groundwater-flow model of the Rush Springs aquifer, western Oklahoma, 1979-2015. - Continued

[GHB, General-Head Boundary; ft²/d, foot squared per day; ft, foot; ft/d, foot per day; --, not computed; Kh, horizontal hydraulic conductivity. Layer 2 Kh and vertical anisotropy refer only to the pilot points in the alluvium and terrace; *, parameter with a fixed value during model calibration]

\begin{tabular}{|c|c|c|c|c|c|c|c|}
\hline $\begin{array}{l}\text { Parameter } \\
\text { group }\end{array}$ & $\begin{array}{l}\text { Parameter } \\
\text { name }\end{array}$ & $\begin{array}{l}\text { Parameter } \\
\text { description }\end{array}$ & $\begin{array}{l}\text { Initial } \\
\text { value }\end{array}$ & $\begin{array}{l}\text { Calibrated } \\
\text { value }\end{array}$ & Units & $\begin{array}{l}\text { Sensitivity } \\
\text { (dimen- } \\
\text { sionless) }\end{array}$ & $\begin{array}{l}\text { Identifi- } \\
\text { ability } \\
\text { (dimen- } \\
\text { sionless) }\end{array}$ \\
\hline \multirow{18}{*}{$\begin{array}{l}\text { Horizontal hydraulic } \\
\text { conductivity and } \\
\text { vertical anisotropy- } \\
\text { Continued }\end{array}$} & hkpp1056_vk & Layer 2 vertical anisotropy & 10.0 & 9.0 & \multirow{18}{*}{$\begin{array}{l}\text { Horizontal } \\
\text { to vertical } \\
\text { ratio }\end{array}$} & 0.25 & 0.03 \\
\hline & hkpp1057_vk & Layer 2 vertical anisotropy & 10.0 & 10.0 & & 0.18 & 0.03 \\
\hline & hkpp1059_vk* & Layer 2 vertical anisotropy & 10.0 & 10.0 & & -- & -- \\
\hline & hkpp1060_vk & Layer 2 vertical anisotropy & 10.0 & 9.4 & & 0.16 & 0.04 \\
\hline & hkpp1061_vk* & Layer 2 vertical anisotropy & 10.0 & 10.0 & & -- & -- \\
\hline & hkpp1062_vk & Layer 2 vertical anisotropy & 10.0 & 9.9 & & 0.19 & 0.13 \\
\hline & hkpp1063_vk & Layer 2 vertical anisotropy & 10.0 & 9.8 & & 0.35 & 0.04 \\
\hline & hkpp1067_vk & Layer 2 vertical anisotropy & 10.0 & 9.4 & & 0.14 & 0.04 \\
\hline & hkpp1068_vk & Layer 2 vertical anisotropy & 10.0 & 9.7 & & 0.23 & 0.04 \\
\hline & hkpp1069_vk & Layer 2 vertical anisotropy & 10.0 & 10.0 & & 0.29 & 0.02 \\
\hline & hkpp1070_vk* & Layer 2 vertical anisotropy & 10.0 & 10.0 & & -- & -- \\
\hline & hkpp1071_vk & Layer 2 vertical anisotropy & 10.0 & 9.6 & & 0.27 & 0.03 \\
\hline & hkpp1072_vk & Layer 2 vertical anisotropy & 10.0 & 9.7 & & 0.19 & 0.04 \\
\hline & hkpp1073_vk & Layer 2 vertical anisotropy & 10.0 & 9.8 & & 0.28 & 0.03 \\
\hline & hkpp1074_vk & Layer 2 vertical anisotropy & 10.0 & 9.8 & & 0.28 & 0.03 \\
\hline & hkpp1075_vk & Layer 2 vertical anisotropy & 10.0 & 9.9 & & 0.26 & 0.04 \\
\hline & hkpp1106_vk & Layer 3 vertical anisotropy & 10.0 & 9.3 & & 0.27 & 0.03 \\
\hline & hkpp1108_vk & Layer 3 vertical anisotropy & 10.0 & 10.0 & & 0.17 & 0.03 \\
\hline
\end{tabular}


Table 6. Calibration parameters, parameter values, parameter sensitivity, and parameter identifiability for the automated calibration of the numerical groundwater-flow model of the Rush Springs aquifer, western Oklahoma, 1979-2015. - Continued

[GHB, General-Head Boundary; ft²/d, foot squared per day; ft, foot; ft/d, foot per day; --, not computed; Kh, horizontal hydraulic conductivity. Layer 2 Kh and vertical anisotropy refer only to the pilot points in the alluvium and terrace; *, parameter with a fixed value during model calibration]

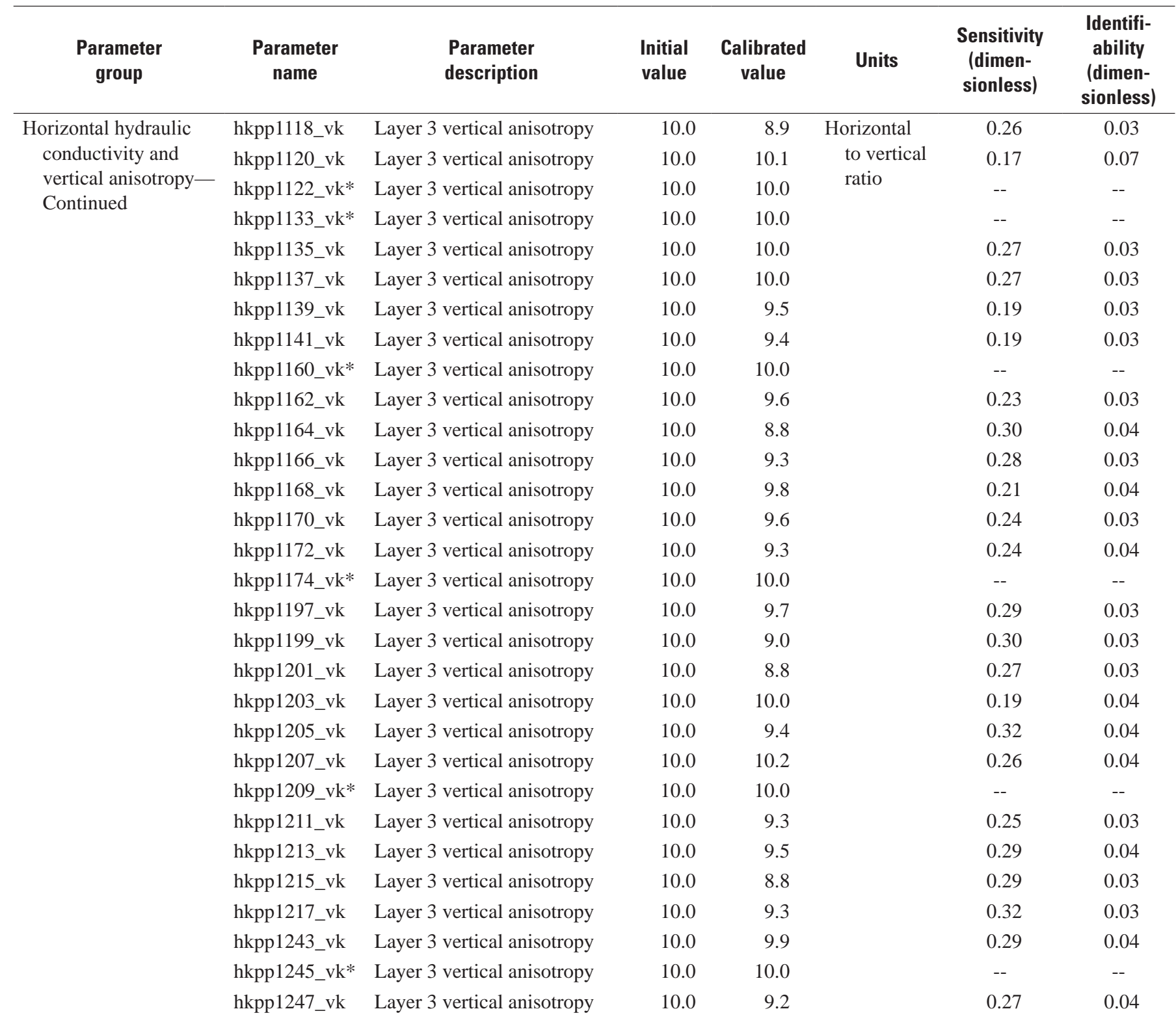


Table 6. Calibration parameters, parameter values, parameter sensitivity, and parameter identifiability for the automated calibration of the numerical groundwater-flow model of the Rush Springs aquifer, western Oklahoma, 1979-2015._-Continued

[GHB, General-Head Boundary; ft²/d, foot squared per day; ft, foot; ft/d, foot per day; --, not computed; Kh, horizontal hydraulic conductivity. Layer 2 Kh and vertical anisotropy refer only to the pilot points in the alluvium and terrace; *, parameter with a fixed value during model calibration]

\begin{tabular}{|c|c|c|c|c|c|c|c|}
\hline $\begin{array}{l}\text { Parameter } \\
\text { group }\end{array}$ & $\begin{array}{l}\text { Parameter } \\
\text { name }\end{array}$ & $\begin{array}{l}\text { Parameter } \\
\text { description }\end{array}$ & $\begin{array}{l}\text { Initial } \\
\text { value }\end{array}$ & $\begin{array}{l}\text { Calibrated } \\
\text { value }\end{array}$ & Units & $\begin{array}{l}\text { Sensitivity } \\
\text { (dimen- } \\
\text { sionless) }\end{array}$ & $\begin{array}{l}\text { Identifi- } \\
\text { ability } \\
\text { (dimen- } \\
\text { sionless) }\end{array}$ \\
\hline \multirow{18}{*}{$\begin{array}{l}\text { Horizontal hydraulic } \\
\text { conductivity and } \\
\text { vertical anisotropy- } \\
\text { Continued }\end{array}$} & hkpp1251_vk & Layer 3 vertical anisotropy & 10.0 & 9.0 & \multirow{18}{*}{$\begin{array}{l}\text { Horizontal } \\
\text { to vertical } \\
\text { ratio }\end{array}$} & 0.21 & 0.05 \\
\hline & hkpp1253_vk & Layer 3 vertical anisotropy & 10.0 & 7.4 & & 0.24 & 0.05 \\
\hline & hkpp1257_vk* & Layer 3 vertical anisotropy & 10.0 & 10.0 & & -- & -- \\
\hline & hkpp1259_vk & Layer 3 vertical anisotropy & 10.0 & 9.9 & & 0.26 & 0.04 \\
\hline & hkpp1261_vk & Layer 3 vertical anisotropy & 10.0 & 9.8 & & 0.36 & 0.06 \\
\hline & hkpp1263_vk & Layer 3 vertical anisotropy & 10.0 & 9.6 & & 0.29 & 0.03 \\
\hline & hkpp1290_vk & Layer 3 vertical anisotropy & 10.0 & 10.3 & & 0.20 & 0.05 \\
\hline & hkpp1298_vk & Layer 3 vertical anisotropy & 10.0 & 8.9 & & 0.05 & 0.04 \\
\hline & hkpp1300_vk & Layer 3 vertical anisotropy & 10.0 & 9.8 & & 0.11 & 0.03 \\
\hline & hkpp1302_vk* & Layer 3 vertical anisotropy & 10.0 & 10.0 & & -- & -- \\
\hline & hkpp1304_vk & Layer 3 vertical anisotropy & 10.0 & 10.8 & & 0.29 & 0.04 \\
\hline & hkpp1306_vk & Layer 3 vertical anisotropy & 10.0 & 10.0 & & 0.22 & 0.03 \\
\hline & hkpp1308_vk & Layer 3 vertical anisotropy & 10.0 & 9.3 & & 0.33 & 0.03 \\
\hline & hkpp1310_vk & Layer 3 vertical anisotropy & 10.0 & 9.2 & & 0.21 & 0.03 \\
\hline & hkpp1312_vk* & Layer 3 vertical anisotropy & 10.0 & 10.0 & & -- & -- \\
\hline & hkpp1340_vk* & Layer 3 vertical anisotropy & 10.0 & 10.0 & & -- & -- \\
\hline & hkpp1356_vk & Layer 3 vertical anisotropy & 10.0 & 10.2 & & 0.34 & 0.05 \\
\hline & hkpp1358_vk & Layer 3 vertical anisotropy & 10.0 & 9.6 & & 0.24 & 0.07 \\
\hline
\end{tabular}


Table 6. Calibration parameters, parameter values, parameter sensitivity, and parameter identifiability for the automated calibration of the numerical groundwater-flow model of the Rush Springs aquifer, western Oklahoma, 1979-2015. - Continued

[GHB, General-Head Boundary; ft²/d, foot squared per day; ft, foot; ft/d, foot per day; --, not computed; Kh, horizontal hydraulic conductivity. Layer 2 Kh and vertical anisotropy refer only to the pilot points in the alluvium and terrace; *, parameter with a fixed value during model calibration]

\begin{tabular}{|c|c|c|c|c|c|c|c|}
\hline $\begin{array}{l}\text { Parameter } \\
\text { group }\end{array}$ & $\begin{array}{l}\text { Parameter } \\
\text { name }\end{array}$ & $\begin{array}{l}\text { Parameter } \\
\text { description }\end{array}$ & $\begin{array}{l}\text { Initial } \\
\text { value }\end{array}$ & $\begin{array}{l}\text { Calibrated } \\
\text { value }\end{array}$ & Units & $\begin{array}{l}\text { Sensitivity } \\
\text { (dimen- } \\
\text { sionless) }\end{array}$ & $\begin{array}{l}\text { Identifi- } \\
\text { ability } \\
\text { (dimen- } \\
\text { sionless) }\end{array}$ \\
\hline \multirow{18}{*}{$\begin{array}{l}\text { Horizontal hydraulic } \\
\text { conductivity and } \\
\text { vertical anisotropy- } \\
\text { Continued }\end{array}$} & hkpp1362_vk & Layer 3 vertical anisotropy & 10.0 & 9.5 & \multirow{18}{*}{$\begin{array}{l}\text { Horizontal } \\
\text { to vertical } \\
\text { ratio }\end{array}$} & 0.05 & 0.02 \\
\hline & hkpp1364_vk & Layer 3 vertical anisotropy & 10.0 & 10.0 & & 0.26 & 0.03 \\
\hline & hkpp1396_vk & Layer 3 vertical anisotropy & 10.0 & 9.8 & & 0.09 & 0.03 \\
\hline & hkpp1398_vk & Layer 3 vertical anisotropy & 10.0 & 10.4 & & 0.28 & 0.04 \\
\hline & hkpp1400_vk & Layer 3 vertical anisotropy & 10.0 & 9.8 & & 0.27 & 0.04 \\
\hline & hkpp1402_vk* & Layer 3 vertical anisotropy & 10.0 & 10.0 & & -- & -- \\
\hline & hkpp1410_vk & Layer 3 vertical anisotropy & 10.0 & 10.4 & & 0.27 & 0.05 \\
\hline & hkpp1412_vk & Layer 3 vertical anisotropy & 10.0 & 9.7 & & 0.18 & 0.03 \\
\hline & hkpp1414_vk & Layer 3 vertical anisotropy & 10.0 & 10.0 & & 0.28 & 0.03 \\
\hline & hkpp1416_vk* & Layer 3 vertical anisotropy & 10.0 & 10.0 & & -- & -- \\
\hline & hkpp1444_vk & Layer 3 vertical anisotropy & 10.0 & 9.9 & & 0.16 & 0.02 \\
\hline & hkpp1446_vk & Layer 3 vertical anisotropy & 10.0 & 9.3 & & 0.28 & 0.04 \\
\hline & hkpp1448_vk & Layer 3 vertical anisotropy & 10.0 & 9.1 & & 0.15 & 0.02 \\
\hline & hkpp1450_vk & Layer 3 vertical anisotropy & 10.0 & 10.0 & & 0.30 & 0.03 \\
\hline & hkpp1452_vk & Layer 3 vertical anisotropy & 10.0 & 8.7 & & 0.09 & 0.02 \\
\hline & hkpp1454_vk & Layer 3 vertical anisotropy & 10.0 & 9.5 & & 0.30 & 0.05 \\
\hline & hkpp1468_vk & Layer 3 vertical anisotropy & 10.0 & 10.0 & & 0.32 & 0.05 \\
\hline & hkpp1470_vk & Layer 3 vertical anisotropy & 10.0 & 9.9 & & 0.28 & 0.03 \\
\hline
\end{tabular}


Table 6. Calibration parameters, parameter values, parameter sensitivity, and parameter identifiability for the automated calibration of the numerical groundwater-flow model of the Rush Springs aquifer, western Oklahoma, 1979-2015. - Continued

[GHB, General-Head Boundary; ft²/d, foot squared per day; ft, foot; ft/d, foot per day; --, not computed; Kh, horizontal hydraulic conductivity. Layer 2 Kh and vertical anisotropy refer only to the pilot points in the alluvium and terrace; *, parameter with a fixed value during model calibration]

\begin{tabular}{|c|c|c|c|c|c|c|c|}
\hline $\begin{array}{l}\text { Parameter } \\
\text { group }\end{array}$ & $\begin{array}{l}\text { Parameter } \\
\text { name }\end{array}$ & $\begin{array}{l}\text { Parameter } \\
\text { description }\end{array}$ & $\begin{array}{l}\text { Initial } \\
\text { value }\end{array}$ & $\begin{array}{l}\text { Calibrated } \\
\text { value }\end{array}$ & Units & $\begin{array}{l}\text { Sensitivity } \\
\text { (dimen- } \\
\text { sionless) }\end{array}$ & $\begin{array}{l}\text { Identifi- } \\
\text { ability } \\
\text { (dimen- } \\
\text { sionless) }\end{array}$ \\
\hline \multirow{18}{*}{$\begin{array}{l}\text { Horizontal hydraulic } \\
\text { conductivity and } \\
\text { vertical anisotropy- } \\
\text { Continued }\end{array}$} & hkpp1500_vk & Layer 3 vertical anisotropy & 10.0 & 20.0 & \multirow{18}{*}{$\begin{array}{l}\text { Horizontal } \\
\text { to vertical } \\
\text { ratio }\end{array}$} & 0.32 & 0.03 \\
\hline & hkpp1502_vk & Layer 3 vertical anisotropy & 10.0 & 20.0 & & 0.24 & 0.04 \\
\hline & hkpp1506_vk & Layer 3 vertical anisotropy & 10.0 & 8.8 & & 0.17 & 0.04 \\
\hline & hkpp1508_vk & Layer 3 vertical anisotropy & 10.0 & 10.0 & & 0.25 & 0.03 \\
\hline & hkpp1510_vk & Layer 3 vertical anisotropy & 10.0 & 20.0 & & 0.17 & 0.04 \\
\hline & hkpp1512_vk* & Layer 3 vertical anisotropy & 10.0 & 10.0 & & -- & -- \\
\hline & hkpp1514_vk & Layer 3 vertical anisotropy & 10.0 & 20.0 & & 0.34 & 0.05 \\
\hline & hkpp1544_vk & Layer 3 vertical anisotropy & 10.0 & 20.0 & & 0.30 & 0.03 \\
\hline & hkpp1546_vk & Layer 3 vertical anisotropy & 10.0 & 20.0 & & 0.26 & 0.03 \\
\hline & hkpp1548_vk & Layer 3 vertical anisotropy & 10.0 & 8.8 & & 0.23 & 0.04 \\
\hline & hkpp1550_vk & Layer 3 vertical anisotropy & 10.0 & 9.0 & & 0.29 & 0.05 \\
\hline & hkpp1552_vk & Layer 3 vertical anisotropy & 10.0 & 20.0 & & 0.37 & 0.04 \\
\hline & hkpp1554_vk & Layer 3 vertical anisotropy & 10.0 & 10.0 & & 0.27 & 0.03 \\
\hline & hkpp1556_vk* & Layer 3 vertical anisotropy & 10.0 & 10.0 & & -- & -- \\
\hline & hkpp1558_vk & Layer 3 vertical anisotropy & 10.0 & 10.0 & & 0.27 & 0.04 \\
\hline & hkpp1560_vk* & Layer 3 vertical anisotropy & 10.0 & 10.0 & & -- & -- \\
\hline & hkpp1597_vk & Layer 3 vertical anisotropy & 10.0 & 8.2 & & 0.20 & 0.02 \\
\hline & hkpp1599_vk & Layer 3 vertical anisotropy & 10.0 & 20.0 & & 0.20 & 0.03 \\
\hline
\end{tabular}


Table 6. Calibration parameters, parameter values, parameter sensitivity, and parameter identifiability for the automated calibration of the numerical groundwater-flow model of the Rush Springs aquifer, western Oklahoma, 1979-2015.—Continued

[GHB, General-Head Boundary; ft²/d, foot squared per day; ft, foot; ft/d, foot per day; --, not computed; Kh, horizontal hydraulic conductivity. Layer 2 Kh and vertical anisotropy refer only to the pilot points in the alluvium and terrace; *, parameter with a fixed value during model calibration]

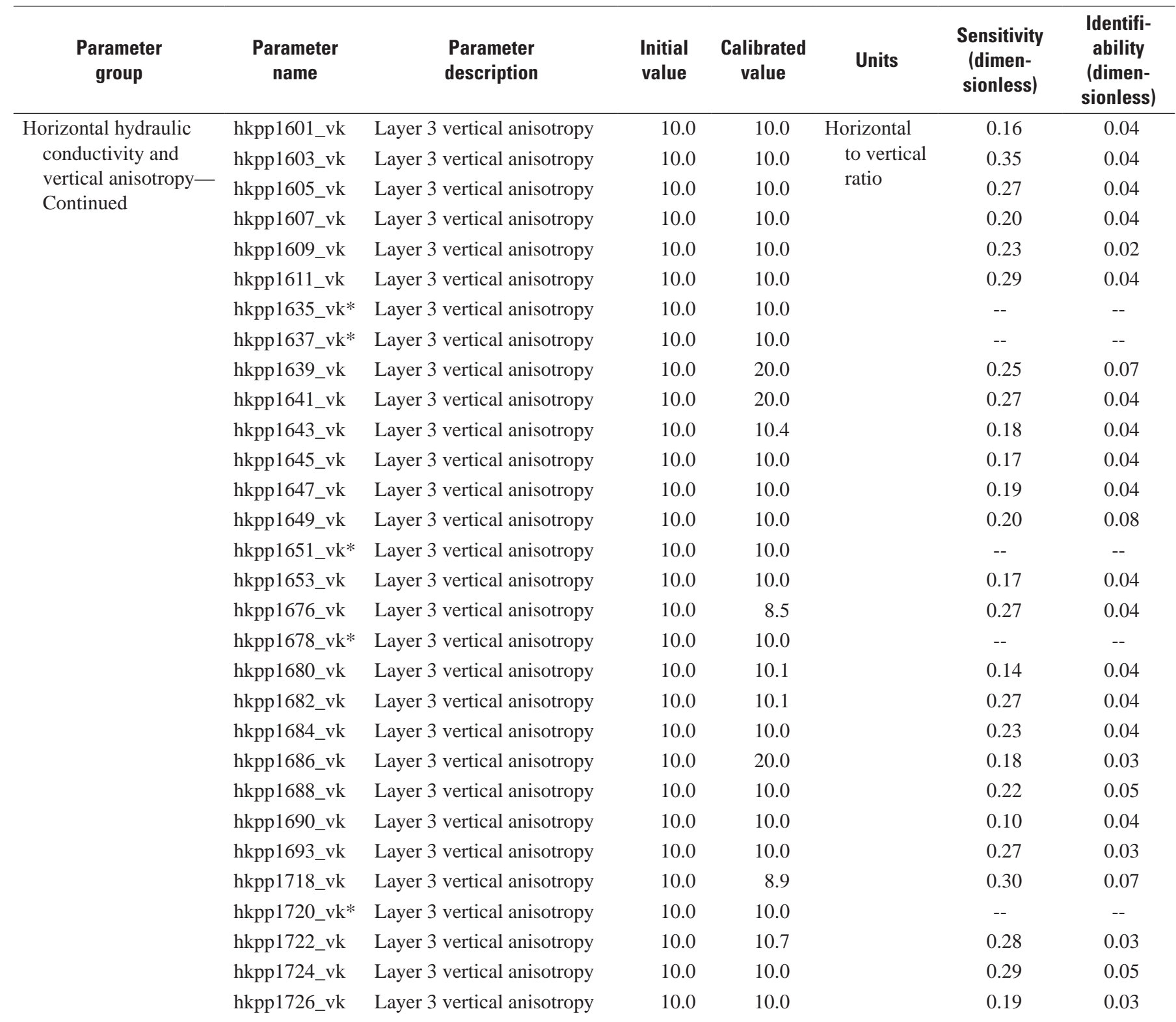


Table 6. Calibration parameters, parameter values, parameter sensitivity, and parameter identifiability for the automated calibration of the numerical groundwater-flow model of the Rush Springs aquifer, western Oklahoma, 1979-2015. - Continued

[GHB, General-Head Boundary; ft²/d, foot squared per day; ft, foot; ft/d, foot per day; --, not computed; Kh, horizontal hydraulic conductivity. Layer 2 Kh and vertical anisotropy refer only to the pilot points in the alluvium and terrace; *, parameter with a fixed value during model calibration]

\begin{tabular}{|c|c|c|c|c|c|c|c|}
\hline $\begin{array}{l}\text { Parameter } \\
\text { group }\end{array}$ & $\begin{array}{l}\text { Parameter } \\
\text { name }\end{array}$ & $\begin{array}{l}\text { Parameter } \\
\text { description }\end{array}$ & $\begin{array}{l}\text { Initial } \\
\text { value }\end{array}$ & $\begin{array}{l}\text { Calibrated } \\
\text { value }\end{array}$ & Units & $\begin{array}{l}\text { Sensitivity } \\
\text { (dimen- } \\
\text { sionless) }\end{array}$ & $\begin{array}{l}\text { Identifi- } \\
\text { ability } \\
\text { (dimen- } \\
\text { sionless) }\end{array}$ \\
\hline \multirow{19}{*}{$\begin{array}{l}\text { Horizontal hydraulic } \\
\text { conductivity and } \\
\text { vertical anisotropy- } \\
\text { Continued }\end{array}$} & hkpp1730_vk & Layer 3 vertical anisotropy & 10.0 & 10.0 & \multirow{19}{*}{$\begin{array}{l}\text { Horizontal } \\
\text { to vertical } \\
\text { ratio }\end{array}$} & 0.28 & 0.04 \\
\hline & hkpp1732_vk & Layer 3 vertical anisotropy & 10.0 & 10.0 & & 0.29 & 0.03 \\
\hline & hkpp1736_vk & Layer 3 vertical anisotropy & 10.0 & 10.0 & & 0.28 & 0.07 \\
\hline & hkpp1761_vk & Layer 3 vertical anisotropy & 10.0 & 9.4 & & 0.23 & 0.02 \\
\hline & hkpp1763_vk & Layer 3 vertical anisotropy & 10.0 & 9.5 & & 0.28 & 0.03 \\
\hline & hkpp1765_vk & Layer 3 vertical anisotropy & 10.0 & 9.2 & & 0.21 & 0.04 \\
\hline & hkpp1767_vk & Layer 3 vertical anisotropy & 10.0 & 8.7 & & 0.32 & 0.03 \\
\hline & hkpp1775_vk & Layer 3 vertical anisotropy & 10.0 & 10.3 & & 0.28 & 0.04 \\
\hline & hkpp1777_vk & Layer 3 vertical anisotropy & 10.0 & 10.0 & & 0.22 & 0.04 \\
\hline & hkpp1779_vk & Layer 3 vertical anisotropy & 10.0 & 10.0 & & 0.28 & 0.03 \\
\hline & hkpp1781_vk & Layer 3 vertical anisotropy & 10.0 & 10.0 & & 0.22 & 0.04 \\
\hline & hkpp1782_vk & Layer 3 vertical anisotropy & 10.0 & 10.0 & & 0.28 & 0.03 \\
\hline & hkpp1783_vk & Layer 3 vertical anisotropy & 10.0 & 10.0 & & 0.23 & 0.03 \\
\hline & hkpp1812_vk* & Layer 3 vertical anisotropy & 10.0 & 10.0 & & -- & -- \\
\hline & hkpp1814_vk & Layer 3 vertical anisotropy & 10.0 & 9.3 & & 0.28 & 0.04 \\
\hline & hkpp1816_vk & Layer 3 vertical anisotropy & 10.0 & 9.0 & & 0.26 & 0.04 \\
\hline & hkpp1846_vk & Layer 3 vertical anisotropy & 10.0 & 10.7 & & 0.34 & 0.06 \\
\hline & hkpp1848_vk & Layer 3 vertical anisotropy & 10.0 & 10.3 & & 0.16 & 0.03 \\
\hline & hkpp1850_vk & Layer 3 vertical anisotropy & 10.0 & 10.0 & & 0.25 & 0.04 \\
\hline
\end{tabular}


Table 6. Calibration parameters, parameter values, parameter sensitivity, and parameter identifiability for the automated calibration of the numerical groundwater-flow model of the Rush Springs aquifer, western Oklahoma, 1979-2015. - Continued

[GHB, General-Head Boundary; ft²/d, foot squared per day; ft, foot; ft/d, foot per day; --, not computed; Kh, horizontal hydraulic conductivity. Layer 2 Kh and vertical anisotropy refer only to the pilot points in the alluvium and terrace; *, parameter with a fixed value during model calibration]

\begin{tabular}{|c|c|c|c|c|c|c|c|}
\hline $\begin{array}{l}\text { Parameter } \\
\text { group }\end{array}$ & $\begin{array}{l}\text { Parameter } \\
\text { name }\end{array}$ & $\begin{array}{l}\text { Parameter } \\
\text { description }\end{array}$ & $\begin{array}{l}\text { Initial } \\
\text { value }\end{array}$ & $\begin{array}{l}\text { Calibrated } \\
\text { value }\end{array}$ & Units & $\begin{array}{l}\text { Sensitivity } \\
\text { (dimen- } \\
\text { sionless) }\end{array}$ & $\begin{array}{l}\text { Identifi- } \\
\text { ability } \\
\text { (dimen- } \\
\text { sionless) }\end{array}$ \\
\hline \multirow{19}{*}{$\begin{array}{l}\text { Horizontal hydraulic } \\
\text { conductivity and } \\
\text { vertical anisotropy- } \\
\text { Continued }\end{array}$} & hkpp1854_vk* & Layer 3 vertical anisotropy & 10.0 & 10.0 & \multirow{19}{*}{$\begin{array}{l}\text { Horizontal } \\
\text { to vertical } \\
\text { ratio }\end{array}$} & -- & -- \\
\hline & hkpp1867_vk & Layer 3 vertical anisotropy & 10.0 & 10.0 & & 0.17 & 0.04 \\
\hline & hkpp1872_vk & Layer 3 vertical anisotropy & 10.0 & 10.0 & & 0.28 & 0.03 \\
\hline & hkpp1885_vk* & Layer 3 vertical anisotropy & 10.0 & 10.0 & & -- & -- \\
\hline & hkpp1887_vk & Layer 3 vertical anisotropy & 10.0 & 10.0 & & 0.31 & 0.03 \\
\hline & hkpp1889_vk & Layer 3 vertical anisotropy & 10.0 & 10.0 & & 0.26 & 0.03 \\
\hline & hkpp1906_vk & Layer 3 vertical anisotropy & 10.0 & 10.0 & & 0.32 & 0.03 \\
\hline & hkpp1908_vk & Layer 3 vertical anisotropy & 10.0 & 10.0 & & 0.28 & 0.03 \\
\hline & hkpp1911_vk & Layer 3 vertical anisotropy & 10.0 & 10.0 & & 0.22 & 0.06 \\
\hline & hkpp1923_vk & Layer 3 vertical anisotropy & 10.0 & 10.0 & & 0.20 & 0.04 \\
\hline & hkpp1925_vk & Layer 3 vertical anisotropy & 10.0 & 10.0 & & 0.24 & 0.04 \\
\hline & hkpp1927_vk & Layer 3 vertical anisotropy & 10.0 & 10.0 & & 0.21 & 0.03 \\
\hline & hkpp1929_vk & Layer 3 vertical anisotropy & 10.0 & 10.0 & & 0.21 & 0.02 \\
\hline & hkpp1942_vk & Layer 3 vertical anisotropy & 10.0 & 10.0 & & 0.24 & 0.03 \\
\hline & hkpp1944_vk & Layer 3 vertical anisotropy & 10.0 & 10.0 & & 0.28 & 0.04 \\
\hline & hkpp1946_vk & Layer 3 vertical anisotropy & 10.0 & 10.0 & & 0.28 & 0.03 \\
\hline & hkpp1967_vk & Layer 3 vertical anisotropy & 10.0 & 10.0 & & 0.26 & 0.03 \\
\hline & hkpp1972_vk* & Layer 3 vertical anisotropy & 10.0 & 10.0 & & -- & -- \\
\hline & hkpp1973_vk & Layer 3 vertical anisotropy & 10.0 & 10.0 & & 0.20 & 0.03 \\
\hline
\end{tabular}

${ }^{1}$ See figure 15 .

${ }^{2}$ See figure 20 . 
Table 7. Selected groundwater-level observation wells in the Rush Springs aquifer study area, western Oklahoma.

[OWRB ID is the well identifier used by the Oklahoma Water Resources Board (OWRB) and the U.S. Geological Survey (USGS) databases; Some differences may occur for the long-term groundwater-level observation well begin and end dates between the OWRB and the USGS well databases; the number of groundwater-level observations does not include the period of record averaged observation used in the steady-state groundwater-flow model; MM/YYYY, month/year; --, not available; *, observation well used for approximating the maximum seasonal groundwater-level range (seasonal approximation)]

\begin{tabular}{|c|c|c|c|c|c|c|c|c|c|c|}
\hline \multirow[t]{2}{*}{$\begin{array}{c}\text { Well } \\
\text { number }\end{array}$} & \multirow[t]{2}{*}{$\begin{array}{l}\text { OWRB } \\
\text { ID }\end{array}$} & \multirow[t]{2}{*}{$\begin{array}{c}\text { Map } \\
\text { number } \\
\text { (fig. 11) }\end{array}$} & \multirow[t]{2}{*}{ Station name } & \multirow[t]{2}{*}{$\begin{array}{l}\text { Latitude } \\
\text { (decimal } \\
\text { degrees) }\end{array}$} & \multirow[t]{2}{*}{$\begin{array}{c}\text { Longitude } \\
\text { (decimal } \\
\text { degrees) }\end{array}$} & \multicolumn{2}{|c|}{$\begin{array}{l}\text { Period of record } \\
\text { (may contain } \\
\text { gaps) or single } \\
\text { measurement } \\
\text { date } \\
\text { (MM/YYYY) }\end{array}$} & \multirow[t]{2}{*}{$\begin{array}{c}\text { Well } \\
\text { or hole } \\
\text { depth } \\
\text { (feet) }\end{array}$} & \multirow{2}{*}{$\begin{array}{c}\text { Number } \\
\text { of ground- } \\
\text { water- } \\
\text { level obser- } \\
\text { vations dur- } \\
\text { ing study } \\
\text { period } \\
\text { (1979-2015) }\end{array}$} & \multirow{2}{*}{$\begin{array}{c}\text { Standard } \\
\text { deviation } \\
\text { of ground- } \\
\text { water-level } \\
\text { observa- } \\
\text { tions during } \\
\text { study period } \\
\text { (1979-2015) }\end{array}$} \\
\hline & & & & & & Begin & End & & & \\
\hline \multicolumn{11}{|c|}{ Long-term groundwater-level observation wells (Oklahoma Water Resources Board, 2017; U.S. Geological Survey, 2017c) } \\
\hline 361833099192201 & 5385 & 1 & 21N-20W-10 DBD 1 & 36.30921 & -99.32316 & $10 / 1979$ & $01 / 2016$ & 58 & 34 & 7.46 \\
\hline 361610099070901 & 9871 & 2 & 21N-18W-27 BCB 1 & 36.26948 & -99.11955 & $10 / 1955$ & $01 / 2014$ & 54 & 41 & 0.60 \\
\hline 360759099195601 & 9293 & 3 & 19N-20W-09 DDB 1 & 36.13310 & -99.33261 & $12 / 1979$ & $01 / 2013$ & 430 & 28 & 13.70 \\
\hline 360454098395601 & 9290 & 4 & 19N-14W-35 BDB 1 & 36.08171 & -98.66592 & 03/1978 & 01/2018 & 291 & 43 & 4.46 \\
\hline 360316098442001 & 9289 & 5 & 18N-14W-07 BBD 1 & 36.05449 & -98.73926 & 03/1979 & $01 / 2018$ & 400 & 51 & 1.40 \\
\hline 355816098432401 & 9288 & 6 & 17N-14W-05 CCC 1 & 35.97115 & -98.72537 & 03/1976 & $01 / 2018$ & 350 & 48 & 4.64 \\
\hline 352924098335601 & 9160 & 7 & 12N-13W-27 BAC 1 & 35.49005 & -98.56590 & 04/1955 & $01 / 2018$ & 300 & 36 & 1.05 \\
\hline 352922098225801 & 9159 & 8 & 12N-11W-29 ACA 1 & 35.48950 & -98.38312 & 02/1956 & $01 / 2018$ & 260 & 41 & 10.30 \\
\hline 352551098343901 & 9157 & 9 & 11N-13W-16 ACA 1 & 35.43089 & -98.57784 & 07/1955 & 02/2013 & 353 & 54 & 15.80 \\
\hline 352515098263001 & 9156 & 10 & 11N-12W-14 CDC 1 & 35.42089 & -98.44201 & 01/1956 & $01 / 2018$ & 320 & 57 & 1.26 \\
\hline 352225098274001 & 9151 & 11 & 10N-12W-03 BBD 1 & 35.37367 & -98.46145 & $11 / 1955$ & 01/2018 & 335 & 35 & 4.80 \\
\hline 352107098273801 & 4017 & 12 & 10N-12W-10 CCA 1 & 35.35200 & -98.46089 & 06/1955 & $01 / 2013$ & 340 & 54 & 1.69 \\
\hline 352017098401701 & 27649 & 13 & 10N-14W-15 CAC 1 & 35.33811 & -98.67173 & 06/1981 & $01 / 2018$ & 300 & 34 & 8.75 \\
\hline 351939098394101 & 9844 & 14 & 10N-14W-22 ADD 1 & 35.32755 & -98.66173 & 03/1979 & $01 / 2016$ & -- & 48 & 11.40 \\
\hline 351952098332801 & 9146 & 15 & 10N-13W-22 AAC 1 & 35.33117 & -98.55812 & 06/1956 & $01 / 2018$ & 328 & 46 & 6.47 \\
\hline 352015098253001 & 9147 & 16 & 10N-12W-13 CCA 1 & 35.33756 & -98.42534 & 06/1954 & $01 / 2018$ & 350 & 38 & 8.37 \\
\hline 351730098300301 & 9140 & 17 & 10N-12W-31 DDB 2 & 35.29172 & -98.50117 & 02/1956 & $01 / 2013$ & 307 & 45 & 10.39 \\
\hline 351623098312001 & 3899 & 18 & 09N-13W-12 AAC 1 & 35.27311 & -98.52256 & $12 / 1974$ & $01 / 2018$ & 285 & 33 & 2.92 \\
\hline 351308098395701 & 9842 & 19 & 09N-14W-27 DCD 1 & 35.21895 & -98.66618 & 05/1955 & $01 / 2018$ & 312 & 53 & 5.48 \\
\hline 350902098235501 & 9133 & 20 & 08N-11W-19 CAC 1 & 35.15061 & -98.39895 & 01/1955 & $01 / 2018$ & 287 & 36 & 5.37 \\
\hline 344630098083201 & 9274 & 21 & 04N-09W-33 DAA 1 & 34.77507 & -98.14255 & 03/1983 & $01 / 2018$ & 700 & 45 & 10.46 \\
\hline \multicolumn{11}{|c|}{ Continuous groundwater-level observation wells (U.S. Geological Survey, 2017c) } \\
\hline 352423098341701* & & 22 & $\begin{array}{l}\text { Eakly } 11 \mathrm{~N}-13 \mathrm{~W}-21 \\
\text { DDD } 1\end{array}$ & 35.40686 & -98.57116 & $04 / 1965$ & present & 210 & 183 & 0.52 \\
\hline 352802098191601 & & 23 & $\begin{array}{l}\text { Hinton } 12 \mathrm{~N}-11 \mathrm{~W}-36 \\
\text { CCA } 1\end{array}$ & 35.46732 & -98.32112 & 08/2010 & present & 225 & 35 & 0.28 \\
\hline 351727098290401* & 27655 & 24 & $\begin{array}{l}\text { Core } 2 \text { 10N-12W-32 } \\
\text { DDD } 1\end{array}$ & 35.29080 & -98.48389 & 12/1989 & present & 257 & 69 & 1.26 \\
\hline $351308098341601 *$ & & 25 & $\begin{array}{l}\text { Alfalfa } 09 \mathrm{~N}-13 \mathrm{~W}-28 \\
\text { DDD } 1\end{array}$ & 35.21887 & -98.57098 & 08/1948 & present & 335 & 153 & 0.52 \\
\hline 350748098231101 & & 26 & $\begin{array}{l}\text { Gracemont 08N- } \\
11 \mathrm{~W}-32 \text { BBA } 1\end{array}$ & 35.13006 & -98.38644 & 08/2010 & present & 350 & 36 & 0.28 \\
\hline
\end{tabular}

Groundwater-level observation wells from the Mass Measurement Program (Oklahoma Water Resources Board, 2017)

\begin{tabular}{rllllrrrrr}
\hline 351302098351501 & 9135 & 09N-13W-33 BBB 1 & 35.21728 & -98.58784 & $04 / 1948$ & $02 / 1997$ & 199 & 42 & 3.93 \\
361856099112401 & 9876 & 21N-19W-12 BBD 1 & 36.31559 & -99.19038 & $09 / 1949$ & $03 / 2000$ & 30 & 24 & 1.33 \\
353210098423001 & 43007 & 12N-14W-08 BBA 1 & 35.53616 & -98.70869 & $01 / 1955$ & $03 / 2010$ & 425 & 10 & 14.50 \\
351950098263601 & 9145 & $10 N-12 W-23$ BBD 1 & 35.33061 & -98.44367 & $08 / 1955$ & $03 / 2007$ & 288 & 50 & 1.56
\end{tabular}


Table 7. Selected groundwater-level observation wells in the Rush Springs aquifer study area, western Oklahoma.—Continued

[OWRB ID is the well identifier used by the Oklahoma Water Resources Board (OWRB) and the U.S. Geological Survey (USGS) databases; Some differences may occur for the long-term groundwater-level observation well begin and end dates between the OWRB and the USGS well databases; the number of groundwater-level observations does not include the period of record averaged observation used in the steady-state groundwater-flow model; MM/YYYY, month/year; --, not available; *, observation well used for approximating the maximum seasonal groundwater-level range (seasonal approximation)]

\begin{tabular}{|c|c|c|c|c|c|c|c|c|c|c|}
\hline \multirow[t]{2}{*}{$\begin{array}{c}\text { Well } \\
\text { number }\end{array}$} & \multirow[t]{2}{*}{$\begin{array}{l}\text { OWRB } \\
\text { ID }\end{array}$} & \multirow[t]{2}{*}{$\begin{array}{c}\text { Map } \\
\text { number } \\
\text { (fig. 11) }\end{array}$} & \multirow[t]{2}{*}{ Station name } & \multirow[t]{2}{*}{$\begin{array}{l}\text { Latitude } \\
\text { (decimal } \\
\text { degrees) }\end{array}$} & \multirow[t]{2}{*}{$\begin{array}{c}\text { Longitude } \\
\text { (decimal } \\
\text { degrees) }\end{array}$} & \multicolumn{2}{|c|}{$\begin{array}{l}\text { Period of record } \\
\text { (may contain } \\
\text { gaps) or single } \\
\text { measurement } \\
\text { date } \\
\text { (MM/YYYY) }\end{array}$} & \multirow[t]{2}{*}{$\begin{array}{c}\text { Well } \\
\text { or hole } \\
\text { depth } \\
\text { (feet) }\end{array}$} & \multirow{2}{*}{$\begin{array}{c}\text { Number } \\
\text { of ground- } \\
\text { water- } \\
\text { level obser- } \\
\text { vations dur- } \\
\text { ing study } \\
\text { period } \\
\text { (1979-2015) }\end{array}$} & \multirow{2}{*}{$\begin{array}{c}\text { Standard } \\
\text { deviation } \\
\text { of ground- } \\
\text { water-level } \\
\text { observa- } \\
\text { tions during } \\
\text { study period } \\
\text { (1979-2015) }\end{array}$} \\
\hline & & & & & & Begin & End & & & \\
\hline \multicolumn{11}{|c|}{ Groundwater-level observation wells from the Mass Measurement Program (Oklahoma Water Resources Board, 2017)—Continued } \\
\hline 350832098282101 & 9132 & & 08N-12W-28 BDB 1 & 35.14228 & -98.47284 & 08/1955 & 02/1997 & 245 & 34 & 2.68 \\
\hline 352046098285901 & 4039 & & 10N-12W-17 AAD 1 & 35.34617 & -98.48340 & $12 / 1955$ & $02 / 2003$ & 328 & 33 & 5.17 \\
\hline 352017098263301 & 9148 & & 10N-12W-14 CBD 1 & 35.33811 & -98.44284 & 01/1956 & 05/1988 & 320 & 10 & 2.79 \\
\hline 352316098284101 & 9154 & & 11N-12W-04 CAC 1 & 35.38783 & -98.47840 & 06/1956 & 03/2006 & 309 & 41 & 6.52 \\
\hline 351805098281201 & 4093 & & 10N-12W-33 ABC 1 & 35.30144 & -98.47034 & 06/1956 & $03 / 2000$ & 290 & 28 & 1.47 \\
\hline 351923098291301 & 9144 & & $10 \mathrm{~N}-12 \mathrm{~W}-20 \mathrm{DAC} 1$ & 35.32311 & -98.48728 & 06/1956 & 02/1996 & 340 & 22 & 1.52 \\
\hline 351630098432401 & 9843 & & 09N-14W-07 BAA 1 & 35.27506 & -98.72368 & 06/1956 & 01/1998 & 52 & 43 & 5.28 \\
\hline 353137098265801 & 9162 & & $12 \mathrm{~N}-12 \mathrm{~W}-10 \mathrm{DAD} 1$ & 35.52700 & -98.44979 & 06/1956 & 01/1990 & -- & 14 & 2.39 \\
\hline 350930098352501 & 9134 & & 08N-13W-20 ABA 1 & 35.15839 & -98.59062 & 06/1958 & 01/1995 & 300 & 36 & 6.31 \\
\hline 352715098234901 & 9158 & & 11N-11W-06 DAC 1 & 35.45422 & -98.39728 & 07/1964 & 02/1998 & 285 & 39 & 16.93 \\
\hline 352514098223501 & 9075 & & 11N-11W-21 BBB 1 & 35.42061 & -98.37673 & 03/1971 & $01 / 2010$ & 120 & 39 & 9.74 \\
\hline 351755098265801 & 9142 & & 10N-12W-34 ADD 1 & 35.29867 & -98.44978 & 01/1973 & 01/1995 & 268 & 33 & 3.85 \\
\hline 344349097575801 & 4627 & & 03N-07W-17 CBC 1 & 34.73035 & -97.96643 & 02/1973 & 03/2010 & 165 & 38 & 3.92 \\
\hline 351439098263401 & 9137 & & 09N-12W-23 BAC 1 & 35.24422 & -98.44311 & $12 / 1974$ & 02/1998 & 235 & 18 & 2.60 \\
\hline 351459098260201 & 9138 & & 09N-12W-14 DDB 1 & 35.24978 & -98.43422 & $12 / 1974$ & $02 / 2003$ & 294 & 22 & 1.97 \\
\hline 352229098300901 & 9152 & & 10N-12W-06 AAD 1 & 35.37478 & -98.50284 & $12 / 1974$ & 01/1995 & 306 & 13 & 2.22 \\
\hline 351748098264201 & 9141 & & 10N-12W-35 CBA 1 & 35.29672 & -98.44534 & $12 / 1974$ & $10 / 1988$ & 230 & 13 & 5.91 \\
\hline 354401098434901 & 9286 & & 15N-14W-31 BDD 1 & 35.73366 & -98.73064 & 02/1976 & 02/1998 & -- & 40 & 5.35 \\
\hline 361611099171401 & 5407 & & 21N-20W-25 ACA 1 & 36.27171 & -99.28761 & 03/1977 & 03/2004 & 125 & 14 & 13.28 \\
\hline 353613099065601 & 9216 & & 13N-18W-16 ACD 1 & 35.60366 & -99.11592 & $12 / 1977$ & 03/1997 & 500 & 15 & 16.32 \\
\hline 354015098423001 & 9212 & & 14N-14W-20 DCA 1 & 35.67088 & -98.70869 & 01/1978 & 03/2010 & 225 & 27 & 4.42 \\
\hline 352603098453701 & 27651 & & 11N-15W-14 BBA 1 & 35.43422 & -98.76063 & 08/1978 & 01/1996 & 365 & 8 & 4.92 \\
\hline 344446097551501 & 9427 & & 03N-07W-10 DBB 1 & 34.74618 & -97.92115 & 03/1979 & 03/2010 & 180 & 45 & 8.10 \\
\hline 344222098030101 & 4686 & & 03N-08W-28 BCA 1 & 34.70618 & -98.05060 & 03/1979 & $01 / 2004$ & 670 & 25 & 3.12 \\
\hline 352749098422001 & 9847 & & 11N-14W-05 BAA 1 & 35.46422 & -98.70313 & 03/1979 & $01 / 2006$ & -- & 37 & 8.55 \\
\hline 352229098384601 & 9846 & & 10N-14W-02 AAC 1 & 35.37478 & -98.64646 & 03/1979 & 03/1988 & 352 & 10 & 2.77 \\
\hline 360850099141001 & 9294 & & 19N-19W-04 CCA 1 & 36.14726 & -99.23649 & 08/1979 & 02/1998 & 85 & 13 & 10.00 \\
\hline 355552098404301 & 23373 & & 17N-14W-22 CBD 1 & 35.93115 & -98.67897 & 09/1979 & 01/2010 & 295 & 20 & 5.88 \\
\hline 361221099182601 & 5275 & & 20N-20W-14 CCA 1 & 36.20587 & -99.30761 & $10 / 1979$ & 02/1998 & 180 & 20 & 9.93 \\
\hline 353119098273501 & 9029 & & 12N-12W-15 BAB 1 & 35.52200 & -98.46007 & 01/1980 & $01 / 2010$ & 238 & 38 & 1.98 \\
\hline 352203098472201 & 9845 & & 10N-15W-04 DBD 1 & 35.36755 & -98.78980 & 03/1980 & 03/1988 & -- & 5 & 2.64 \\
\hline 354555098593001 & 9249 & & 15N-17W-22 ACA 1 & 35.76532 & -98.99204 & 03/1980 & 03/2010 & 360 & 26 & 2.84 \\
\hline 353504099003201 & 9220 & & 13N-17W-21 DBD 1 & 35.58449 & -99.00926 & 03/1980 & $03 / 2002$ & 362 & 12 & 5.36 \\
\hline 352834098415201 & 9246 & & 12N-14W-32 AAC 1 & 35.47616 & -98.69813 & $12 / 1981$ & 03/2010 & 320 & 27 & 3.68 \\
\hline 353616098334601 & 9204 & & 13N-13W-15 ADA 1 & 35.60449 & -98.56313 & 01/1982 & 03/1998 & 275 & 11 & 18.71 \\
\hline 352948098443101 & 9241 & & 12N-15W-24 CDB 1 & 35.49672 & -98.74230 & 02/1982 & 03/1997 & 400 & 14 & 5.01 \\
\hline
\end{tabular}


Table 7. Selected groundwater-level observation wells in the Rush Springs aquifer study area, western Oklahoma.—Continued

[OWRB ID is the well identifier used by the Oklahoma Water Resources Board (OWRB) and the U.S. Geological Survey (USGS) databases; Some differences may occur for the long-term groundwater-level observation well begin and end dates between the OWRB and the USGS well databases; the number of groundwater-level observations does not include the period of record averaged observation used in the steady-state groundwater-flow model; MM/YYYY, month/year; --, not available; *, observation well used for approximating the maximum seasonal groundwater-level range (seasonal approximation)]

\begin{tabular}{|c|c|c|c|c|c|c|c|c|c|c|}
\hline \multirow[t]{2}{*}{$\begin{array}{c}\text { Well } \\
\text { number }\end{array}$} & \multirow[t]{2}{*}{$\begin{array}{l}\text { OWRB } \\
\text { ID }\end{array}$} & \multirow[t]{2}{*}{$\begin{array}{c}\text { Map } \\
\text { number } \\
\text { (fig. 11) }\end{array}$} & \multirow[t]{2}{*}{ Station name } & \multirow[t]{2}{*}{$\begin{array}{l}\text { Latitude } \\
\text { (decimal } \\
\text { degrees) }\end{array}$} & \multirow[t]{2}{*}{$\begin{array}{l}\text { Longitude } \\
\text { (decimal } \\
\text { degrees) }\end{array}$} & \multicolumn{2}{|c|}{$\begin{array}{l}\text { Period of record } \\
\text { (may contain } \\
\text { gaps) or single } \\
\text { measurement } \\
\text { date } \\
\text { (MM/YYYY) }\end{array}$} & \multirow[t]{2}{*}{$\begin{array}{c}\text { Well } \\
\text { or hole } \\
\text { depth } \\
\text { (feet) }\end{array}$} & \multirow{2}{*}{$\begin{array}{l}\text { Number } \\
\text { of ground- } \\
\text { water- } \\
\text { level obser- } \\
\text { vations dur- } \\
\text { ing study } \\
\text { period } \\
\text { (1979-2015) }\end{array}$} & \multirow{2}{*}{$\begin{array}{c}\text { Standard } \\
\text { deviation } \\
\text { of ground- } \\
\text { water-level } \\
\text { observa- } \\
\text { tions during } \\
\text { study period } \\
\text { (1979-2015) }\end{array}$} \\
\hline & & & & & & Begin & End & & & \\
\hline \multicolumn{11}{|c|}{ Groundwater-level observation wells from the Mass Measurement Program (Oklahoma Water Resources Board, 2017)—Continued } \\
\hline 353319098393401 & 9234 & & 13N-14W-35 CAD 1 & 35.55533 & -98.65980 & $02 / 1982$ & $01 / 2006$ & 285 & 24 & 2.09 \\
\hline 353926098505801 & 9211 & & 14N-16W-25 DBD 1 & 35.65727 & -98.84981 & 04/1982 & 06/1990 & 400 & 5 & 5.06 \\
\hline 353346098582301 & 9217 & & 13N-17W-35 AAC 1 & 35.56283 & -98.97342 & 06/1982 & 03/1997 & 470 & 12 & 7.72 \\
\hline 352306098282401 & 9067 & & 11N-12W-33 ACC 1 & 35.38505 & -98.47367 & 07/1982 & 01/1995 & 275 & 30 & 3.80 \\
\hline 344630098095901 & 9275 & & 04N-09W-32 DBB 1 & 34.77507 & -98.16671 & 01/1983 & 03/2010 & 640 & 24 & 11.67 \\
\hline 352804098401801 & 9244 & & 12N-14W-34 CCA 1 & 35.46783 & -98.67202 & 04/1983 & 03/2010 & 440 & 27 & 8.95 \\
\hline 355114099011101 & 9309 & & 16N-17W-21 BBD 1 & 35.85393 & -99.02010 & 09/1983 & 01/2010 & 400 & 25 & 17.83 \\
\hline 353033099014801 & 9238 & & 12N-17W-18 DDD 1 & 35.50922 & -99.03036 & 09/1983 & $02 / 2000$ & 520 & 19 & 11.49 \\
\hline 353645098440401 & 9235 & & 13N-14W-07 CCA 1 & 35.61255 & -98.73480 & $12 / 1983$ & 03/2010 & 300 & 28 & 8.93 \\
\hline 354545098514101 & 9248 & & 15N-16W-24 BCC 1 & 35.76255 & -98.86176 & 01/1984 & 03/1997 & 305 & 16 & 4.47 \\
\hline 353436098464201 & 9225 & & 13N-15W-27 ACA 1 & 35.57672 & -98.77869 & 02/1984 & 03/2010 & 360 & 26 & 2.21 \\
\hline 354949099062101 & 9308 & & 16N-18W-27 CDB 1 & 35.83032 & -99.10621 & 07/1984 & $01 / 2010$ & 405 & 22 & 11.06 \\
\hline 355500098590001 & 19912 & & 17N-17W-26 DAC 1 & 35.91671 & -98.98371 & 09/1984 & $01 / 2010$ & 400 & 19 & 18.77 \\
\hline 354311098540401 & 24882 & & 15N-16W-33 DDB 1 & 35.71977 & -98.90148 & 07/1986 & 03/2010 & 280 & 25 & 7.54 \\
\hline 353019098501801 & 9240 & & 12N-16W-24 АAB 1 & 35.50533 & -98.83869 & 08/1986 & 03/2010 & 300 & 26 & 14.41 \\
\hline 352238098384301 & 9194 & & 10N-14W-02 AAB 1 & 35.37728 & -98.64562 & 05/1988 & $01 / 2010$ & 395 & 40 & 4.26 \\
\hline 360256098373101 & 9196 & & 18N-13W-07 BBA 1 & 36.04893 & -98.62564 & 06/1988 & 03/1995 & 85 & 13 & 9.72 \\
\hline 353241098500201 & 9243 & & 12N-15W-06 BCC 1 & 35.54477 & -98.83425 & 06/1988 & 03/2010 & 340 & 28 & 4.55 \\
\hline 355352098391401 & 9310 & & 16N-14W-02 ABA 1 & 35.89782 & -98.65425 & $11 / 1988$ & $02 / 2000$ & 253 & 22 & 6.41 \\
\hline 361525099104101 & 25665 & & 21N-19W-36 CAA 1 & 36.25337 & -99.18510 & 01/1989 & 04/1998 & 120 & 7 & 4.22 \\
\hline 351340098234701 & 9028 & & 09N-11W-30 ADA 1 & 35.22784 & -98.39672 & 01/1989 & $01 / 2010$ & 266 & 20 & 3.20 \\
\hline 360243098484401 & 27665 & & 18N-15W-09 BCC 1 & 36.04532 & -98.81259 & 01/1989 & 01/2010 & 360 & 18 & 14.30 \\
\hline 361742099103301 & 25661 & & 21N-19W-13 AAD 1 & 36.30226 & -99.17621 & 02/1989 & $01 / 2010$ & 80 & 18 & 6.31 \\
\hline 361604099080801 & 25660 & & 21N-18W-28 DCB 1 & 36.26782 & -99.13593 & 02/1989 & $01 / 2010$ & 180 & 16 & 4.73 \\
\hline 361137099064501 & 25659 & & 20N-18W-22 ABC 1 & 36.19948 & -99.10538 & 02/1989 & $01 / 2010$ & 180 & 19 & 6.13 \\
\hline 360959099020501 & 25652 & & 20N-17W-32 CCA 1 & 36.16143 & -99.04149 & 02/1989 & 03/2000 & 160 & 10 & 8.59 \\
\hline 360015098573601 & 9252 & & 18N-17W-25 DBD 1 & 36.00421 & -98.96037 & 10/1989 & 03/1997 & -- & 13 & 8.76 \\
\hline 344807097575101 & 9191 & & $\begin{array}{l}\text { CORE } 4 \text { 04N-07W-20 } \\
\text { CBCD } 1\end{array}$ & 34.80174 & -97.96532 & 10/1989 & $03 / 2010$ & 197 & 21 & 10.79 \\
\hline 350153098212101 & 27653 & & $\begin{array}{l}\text { CORE } 507 N-11 W-34 \\
\text { CCB } 1\end{array}$ & 35.03132 & -98.35626 & 11/1989 & $01 / 2011$ & 135 & 29 & 0.52 \\
\hline 354109098431501 & 9214 & & $\begin{array}{l}\text { CORE } 6 \text { 14N-14W-18 } \\
\text { DADD } 1\end{array}$ & 35.68588 & -98.72119 & 03/1990 & $01 / 2006$ & 148 & 16 & 6.06 \\
\hline 354238099094801 & 9209 & & $\begin{array}{l}\text { CORE } 1 \text { 14N-18W-07 } \\
\text { BBBB } 1\end{array}$ & 35.71060 & -99.16371 & 03/1990 & $01 / 2006$ & 186 & 17 & 7.50 \\
\hline 352307098583401 & 27652 & & $\begin{array}{l}\text { CORE } 3 \text { 11N-17W-34 } \\
\text { DAAA } 1\end{array}$ & 35.38533 & -98.97647 & 04/1990 & 02/1998 & 670 & 10 & 7.04 \\
\hline
\end{tabular}


Table 7. Selected groundwater-level observation wells in the Rush Springs aquifer study area, western Oklahoma.-Continued

[OWRB ID is the well identifier used by the Oklahoma Water Resources Board (OWRB) and the U.S. Geological Survey (USGS) databases; Some differences may occur for the long-term groundwater-level observation well begin and end dates between the OWRB and the USGS well databases; the number of groundwater-level observations does not include the period of record averaged observation used in the steady-state groundwater-flow model; MM/YYYY, month/year; --, not available; *, observation well used for approximating the maximum seasonal groundwater-level range (seasonal approximation)]

\begin{tabular}{|c|c|c|c|c|c|c|c|c|c|c|}
\hline \multirow[t]{2}{*}{$\begin{array}{c}\text { Well } \\
\text { number }\end{array}$} & \multirow[t]{2}{*}{$\begin{array}{l}\text { OWRB } \\
\text { ID }\end{array}$} & \multirow[t]{2}{*}{$\begin{array}{c}\text { Map } \\
\text { number } \\
\text { (fig. 11) }\end{array}$} & \multirow[t]{2}{*}{ Station name } & \multirow[t]{2}{*}{$\begin{array}{l}\text { Latitude } \\
\text { (decimal } \\
\text { degrees) }\end{array}$} & \multirow[t]{2}{*}{$\begin{array}{c}\text { Longitude } \\
\text { (decimal } \\
\text { degrees) }\end{array}$} & \multicolumn{2}{|c|}{$\begin{array}{l}\text { Period of record } \\
\text { (may contain } \\
\text { gaps) or single } \\
\text { measurement } \\
\text { date } \\
\text { (MM/YYYY) }\end{array}$} & \multirow[t]{2}{*}{$\begin{array}{c}\text { Well } \\
\text { or hole } \\
\text { depth } \\
\text { (feet) }\end{array}$} & \multirow{2}{*}{$\begin{array}{c}\text { Number } \\
\text { of ground- } \\
\text { water- } \\
\text { level obser- } \\
\text { vations dur- } \\
\text { ing study } \\
\text { period } \\
\text { (1979-2015) }\end{array}$} & \multirow{2}{*}{$\begin{array}{c}\text { Standard } \\
\text { deviation } \\
\text { of ground- } \\
\text { water-level } \\
\text { observa- } \\
\text { tions during } \\
\text { study period } \\
\text { (1979-2015) }\end{array}$} \\
\hline & & & & & & Begin & End & & & \\
\hline \multicolumn{11}{|c|}{ Groundwater-level observation wells from the Mass Measurement Program (Oklahoma Water Resources Board, 2017)—Continued } \\
\hline 354950098583301 & 24883 & & 16N-17W-26 DBC 1 & 35.83060 & -98.97621 & 08/1990 & $01 / 2006$ & 460 & 21 & 6.52 \\
\hline 351032098523201 & 27648 & & $\begin{array}{l}\text { OW-5 08N-16W-10 } \\
\text { CDC } 1\end{array}$ & 35.17561 & -98.87590 & 08/1990 & $01 / 2010$ & 305 & 20 & 5.04 \\
\hline 350658098350801 & 27654 & & $\begin{array}{l}\text { OW-4 07N-13W-04 } \\
\text { BBBB } 1\end{array}$ & 35.11617 & -98.58590 & 08/1990 & 03/2000 & 114 & 9 & 11.50 \\
\hline 352240098440101 & 27650 & & $\begin{array}{l}\text { OW-3 10N-15W-01 } \\
\quad \text { AAB } 1\end{array}$ & 35.37783 & -98.73396 & 09/1990 & 01/2010 & 400 & 24 & 24.85 \\
\hline 353907098525101 & 24881 & & 14N-16W-34 AAA 1 & 35.65199 & -98.88120 & 01/1991 & 03/2010 & 420 & 17 & 15.11 \\
\hline 353321098553901 & 24880 & & 13N-16W-32 CAC 1 & 35.55588 & -98.92786 & 01/1991 & 03/2010 & 400 & 16 & 14.44 \\
\hline 354933099050601 & 24884 & & 16N-18W-35 АAB 1 & 35.82588 & -99.08537 & 01/1991 & 02/1998 & 278 & 5 & 10.58 \\
\hline 350829098180301 & 3572 & & 08N-10W-30 BCВ 1 & 35.14145 & -98.30116 & $02 / 2001$ & $01 / 2010$ & 200 & 10 & 0.92 \\
\hline 352435098491501 & 20923 & & 11N-15W-19 DDB 1 & 35.40978 & -98.82119 & $02 / 2001$ & $01 / 2010$ & 520 & 10 & 1.83 \\
\hline 345437098125901 & 3471 & & 05N-10W-14 AAD 1 & 34.91034 & -98.21672 & $02 / 2001$ & $01 / 2010$ & 110 & 10 & 3.40 \\
\hline 351744098233501 & 3994 & & 10N-11W-32 CBC 1 & 35.29561 & -98.39339 & $02 / 2001$ & $01 / 2010$ & 268 & 10 & 2.04 \\
\hline 351828098193001 & 39787 & & 10N-10W-26 DDA 1 & 35.30783 & -98.32533 & $02 / 2001$ & 03/2006 & 130 & 6 & 4.84 \\
\hline 352012098104801 & 3952 & & 10N-09W-17 CCA 1 & 35.33672 & -98.18033 & 02/2001 & 03/2010 & 180 & 10 & 3.55 \\
\hline 360423098370301 & 4944 & & 19N-13W-32 CCC 1 & 36.07310 & -98.61786 & 03/2001 & $01 / 2006$ & 200 & 5 & 0.60 \\
\hline 354432098325601 & 4894 & & 15N-13W-26 DCA 1 & 35.74227 & -98.54924 & 03/2001 & $01 / 2006$ & 300 & 6 & 0.64 \\
\hline 354142098323001 & 4858 & & 14N-13W-14 AAA 1 & 35.69505 & -98.54202 & 03/2001 & $01 / 2010$ & 145 & 10 & 4.79 \\
\hline 345851098143701 & 3499 & & 06N-10W-22 BDA 1 & 34.98090 & -98.24394 & 03/2001 & $01 / 2010$ & 205 & 10 & 1.37 \\
\hline 353821098364501 & 31405 & & 14N-13W-32 CCC 1 & 35.63922 & -98.61285 & 03/2001 & 01/2008 & 294 & 8 & 0.60 \\
\hline 344914098081601 & 21771 & & 04N-09W-10 CCA 1 & 34.82062 & -98.13810 & 03/2001 & $01 / 2010$ & 80 & 10 & 1.59 \\
\hline 360737098570701 & 20143 & & 19N-16W-18 BBD 1 & 36.12699 & -98.95232 & 03/2001 & $01 / 2010$ & 200 & 10 & 3.05 \\
\hline 355721099024201 & 29012 & & 17N-17W-18 AAA 1 & 35.95588 & -99.04538 & 03/2001 & 01/2006 & 80 & 6 & 1.37 \\
\hline 360127099173701 & 20075 & & 18N-20W-23 ADA 1 & 36.02421 & -99.29399 & 03/2001 & $01 / 2010$ & 47 & 10 & 1.88 \\
\hline 360332099080901 & 20049 & & 18N-18W-05 DDC 1 & 36.05893 & -99.13621 & 03/2001 & $01 / 2010$ & 345 & 9 & 1.73 \\
\hline 360051098581801 & 20044 & & 18N-17W-25 BBB 1 & 36.01421 & -98.97204 & 03/2001 & 01/2006 & 150 & 6 & 2.81 \\
\hline 355820099171001 & 19943 & & 17N-20W 01 CDC 2 & 35.97227 & -99.28649 & 03/2001 & $01 / 2010$ & 276 & 10 & 0.84 \\
\hline 355821099171001 & 19943 & & 17N-20W-01 CDC 1 & 35.97255 & -99.28649 & 03/2001 & 03/2001 & 276 & 1 & 1.63 \\
\hline 355544099162201 & 19934 & & 17N-19W-19 CCC 2 & 35.92893 & -99.27316 & 03/2001 & $01 / 2010$ & 95 & 10 & 1.02 \\
\hline 355544099162301 & 19934 & & 17N-19W-19 CCC 1 & 35.92893 & -99.27344 & 03/2001 & 03/2001 & 95 & 1 & 1.61 \\
\hline 352504098395001 & 20907 & & 11N-14W-22 ABD 1 & 35.41783 & -98.66424 & 01/2003 & 03/2010 & 327 & 8 & 1.68 \\
\hline 352759098173801 & 5066 & & 12N-10W-31 DCA 1 & 35.46644 & -98.29423 & 03/2003 & $01 / 2010$ & 180 & 8 & 6.38 \\
\hline \multicolumn{11}{|c|}{ Groundwater-level observation wells (U.S. Geological Survey, 2017c) } \\
\hline $344656098031401 *$ & & & 04N-08W-33 BBB 1 & 34.782294 & -98.054210 & 06/1948 & $10 / 1995$ & 254 & 176 & 2.21 \\
\hline 353252098401901 & & & 12N-14W-03 BBD 1 & 35.547830 & -98.672296 & 07/1953 & 01/1986 & 275 & 7 & 0.57 \\
\hline 352933098340701 & & & 12N-13W-27 BBA 1 & 35.49255 & -98.56896 & 04/1955 & 05/1990 & 267 & 21 & 4.33 \\
\hline
\end{tabular}


Table 7. Selected groundwater-level observation wells in the Rush Springs aquifer study area, western Oklahoma.-Continued

[OWRB ID is the well identifier used by the Oklahoma Water Resources Board (OWRB) and the U.S. Geological Survey (USGS) databases; Some differences may occur for the long-term groundwater-level observation well begin and end dates between the OWRB and the USGS well databases; the number of groundwater-level observations does not include the period of record averaged observation used in the steady-state groundwater-flow model; MM/YYYY, month/year; --, not available; *, observation well used for approximating the maximum seasonal groundwater-level range (seasonal approximation)]

\begin{tabular}{|c|c|c|c|c|c|c|c|c|c|c|}
\hline \multirow[t]{2}{*}{$\begin{array}{c}\text { Well } \\
\text { number }\end{array}$} & \multirow[t]{2}{*}{$\begin{array}{c}\text { OWRB } \\
\text { ID }\end{array}$} & \multirow[t]{2}{*}{$\begin{array}{c}\text { Map } \\
\text { number } \\
\text { (fig. 11) }\end{array}$} & \multirow[t]{2}{*}{ Station name } & \multirow[t]{2}{*}{$\begin{array}{l}\text { Latitude } \\
\text { (decimal } \\
\text { degrees) }\end{array}$} & \multirow[t]{2}{*}{$\begin{array}{l}\text { Longitude } \\
\text { (decimal } \\
\text { degrees) }\end{array}$} & \multicolumn{2}{|c|}{$\begin{array}{l}\text { Period of record } \\
\text { (may contain } \\
\text { gaps) or single } \\
\text { measurement } \\
\text { date } \\
\text { (MM/YYYY) }\end{array}$} & \multirow[t]{2}{*}{$\begin{array}{c}\text { Well } \\
\text { or hole } \\
\text { depth } \\
\text { (feet) }\end{array}$} & \multirow{2}{*}{$\begin{array}{c}\text { Number } \\
\text { of ground- } \\
\text { water- } \\
\text { level obser- } \\
\text { vations dur- } \\
\text { ing study } \\
\text { period } \\
\text { (1979-2015) }\end{array}$} & \multirow{2}{*}{$\begin{array}{c}\text { Standard } \\
\text { deviation } \\
\text { of ground- } \\
\text { water-level } \\
\text { observa- } \\
\text { tions during } \\
\text { study period } \\
\text { (1979-2015) }\end{array}$} \\
\hline & & & & & & Begin & End & & & \\
\hline \multicolumn{11}{|c|}{ Groundwater-level observation wells (U.S. Geological Survey, 2017c)_Continued } \\
\hline 351342098240001 & & & 09N-11W-30 ACA 1 & 35.228391 & -98.400335 & 05/1955 & 02/1988 & 266 & 8 & 0.61 \\
\hline 351334098234701 & & & 09N-11W-30 ADD 1 & 35.226169 & -98.396724 & 05/1955 & 05/1990 & 266 & 23 & 2.21 \\
\hline 352828098475401 & & & 12N-15W-33 BDBC 1 & 35.474497 & -98.795076 & 07/1955 & 03/1988 & 335 & 8 & 4.67 \\
\hline 354112098430601* & & & 14N-14W-17 CBD 1 & 35.686716 & -98.718692 & 03/1971 & 08/1995 & 320 & 194 & 3.61 \\
\hline 361256099102101* & & & 20N-19W-13 ABB 1 & 36.215874 & -99.177880 & 02/1972 & 09/1990 & 40 & 289 & 1.45 \\
\hline 352321098281001 & & & 11N-12W-33 AAC 1 & 35.389221 & -98.469785 & $12 / 1974$ & 03/1988 & 400 & 10 & 6.20 \\
\hline 352203098322401 & & & 10N-13W-02 DAC 1 & 35.367554 & -98.540342 & $12 / 1975$ & 01/1986 & 300 & 5 & 1.62 \\
\hline 355328098441301 & & & 16N-14W-06 CBB 1 & 35.891156 & -98.737309 & 03/1976 & 03/1985 & 217 & 2 & 1.93 \\
\hline 344353097572201 & & & 03N-07W-17 DBB 1 & 34.731463 & -97.956428 & $12 / 1976$ & 02/1986 & -- & 7 & 4.11 \\
\hline 361643099103001 & & & 21N-19W-24 DDA 1 & 36.278650 & -99.175380 & 01/1978 & 05/1979 & 38 & 5 & 4.01 \\
\hline 361249099042801 & & & 20N-18W-13 BAC 1 & 36.213651 & -99.074822 & 01/1978 & 02/1979 & 77 & 2 & 4.58 \\
\hline 362139099155101 & & & 22N-19W-30 AAD 1 & 36.360871 & -99.264549 & 01/1978 & 05/1979 & 36 & 5 & 3.34 \\
\hline 361615099071401 & & & 21N-18W-27 BCB 2 & 36.270872 & -99.120934 & 02/1978 & 05/1979 & 48 & 5 & 2.75 \\
\hline 360834098544101 & & & 19N-16W-09 BAA 1 & 36.142818 & -98.911761 & 02/1978 & 05/1979 & 60 & 5 & 3.32 \\
\hline 360659098373701 & & & 19N-13W-18 DCC 1 & 36.116428 & -98.627307 & 03/1978 & 05/1979 & 100 & 4 & 3.84 \\
\hline 360753098423001 & & & 19N-14W-08 DDD 1 & 36.131686 & -98.708250 & 03/1978 & $10 / 2012$ & 42 & 29 & 0.28 \\
\hline 360931098515801 & & & 20N-16W-36 CCC 1 & 36.158800 & -98.866481 & 03/1978 & 01/2012 & 11 & 1 & 0.49 \\
\hline 360644098455301 & & & 19N-15W-23 ABD 1 & 36.112263 & -98.765090 & 03/1978 & 05/1979 & 260 & 4 & 7.33 \\
\hline 360340098370901 & & & 18N-13W-06 DDA 1 & 36.061151 & -98.619529 & 03/1978 & 05/1979 & 46 & 5 & 2.82 \\
\hline 350844098281901 & & & 08N-12W-28 BAB 1 & 35.145615 & -98.472281 & 04/1978 & 06/1991 & 238 & 11 & 6.56 \\
\hline 362044099125401 & & & 22N-19W-34 ABD 1 & 36.345594 & -99.215381 & 03/1979 & 03/1979 & 68 & 1 & 4.40 \\
\hline 353650098430901 & & & 13N-14W-08 CBC 1 & 35.613940 & -98.719523 & 03/1979 & 06/1989 & 265 & 21 & 3.37 \\
\hline 353920098415701 & & & 14N-14W-28 CCA 1 & 35.655606 & -98.699523 & 03/1979 & 03/1988 & 332 & 8 & 1.56 \\
\hline 353927098402101 & & & 14N-14W-27 DBD 1 & 35.657550 & -98.672856 & 03/1979 & 01/1986 & 315 & 5 & 3.18 \\
\hline 354144098410901 & & & 14N-14W-16 AAA 1 & 35.695605 & -98.686191 & 03/1979 & 03/1979 & -- & 1 & 2.89 \\
\hline 353716098384501 & & & 13N-14W-12 BBD 1 & 35.621161 & -98.646187 & 03/1979 & 03/1988 & 240 & 9 & 1.54 \\
\hline 360039098454001 & & & 18N-15W-26 AAD 1 & 36.010876 & -98.761479 & 03/1979 & 03/1986 & 260 & 4 & 3.77 \\
\hline 355803098472901 & & & 17N-15W-10 B 1 & 35.967544 & -98.791757 & 06/1979 & 06/1979 & 220 & 1 & 20.07 \\
\hline 352637098175401 & & & 11N-10W-07 BDA 1 & 35.443664 & -98.298669 & 07/1979 & 05/1990 & 300 & 25 & 6.61 \\
\hline 360846099205401 & & & 19N-20W-05 DDB 1 & 36.146153 & -99.348718 & 08/1979 & 08/1979 & 101 & 1 & 2.56 \\
\hline 361530099233401 & & & 21N-21W-36 AAC 1 & 36.258373 & -99.393164 & 08/1979 & 08/1979 & -- & 1 & 9.84 \\
\hline 361047099201101 & & & 20N-20W-28 DBB 1 & 36.179764 & -99.336773 & $10 / 1979$ & $10 / 1979$ & 102 & 1 & 6.57 \\
\hline 361239099185601 & & & 20N-20W-15 ACD 1 & 36.210874 & -99.315940 & $10 / 1979$ & $10 / 1979$ & 220 & 1 & 4.31 \\
\hline 360447099110801 & & & 19N-19W-36 CBB 1 & 36.079765 & -99.185936 & $12 / 1979$ & $12 / 1979$ & -- & 1 & 3.99 \\
\hline 360640099130701 & & & 19N-19W-22 BAC 1 & 36.111153 & -99.218992 & $12 / 1979$ & 03/1983 & 290 & 3 & 6.05 \\
\hline 360903099110201 & & & 19N-19W-02 DAA 1 & 36.150875 & -99.184269 & $12 / 1979$ & 03/1983 & 68 & 3 & 6.77 \\
\hline
\end{tabular}


Table 7. Selected groundwater-level observation wells in the Rush Springs aquifer study area, western Oklahoma.—Continued

[OWRB ID is the well identifier used by the Oklahoma Water Resources Board (OWRB) and the U.S. Geological Survey (USGS) databases; Some differences may occur for the long-term groundwater-level observation well begin and end dates between the OWRB and the USGS well databases; the number of groundwater-level observations does not include the period of record averaged observation used in the steady-state groundwater-flow model; MM/YYYY, month/year; --, not available; *, observation well used for approximating the maximum seasonal groundwater-level range (seasonal approximation)]

\begin{tabular}{|c|c|c|c|c|c|c|c|c|c|}
\hline \multirow[t]{2}{*}{$\begin{array}{c}\text { Well } \\
\text { number }\end{array}$} & \multirow[t]{2}{*}{$\begin{array}{l}\text { OWRB } \\
\text { ID }\end{array}$} & \multirow[t]{2}{*}{$\begin{array}{c}\text { Map } \\
\text { number } \\
\text { (fig. 11) }\end{array}$} & \multirow[t]{2}{*}{$\begin{array}{l}\text { Latitude } \\
\text { (decimal } \\
\text { degrees) }\end{array}$} & \multirow[t]{2}{*}{$\begin{array}{l}\text { Longitude } \\
\text { (decimal } \\
\text { degrees) }\end{array}$} & \multicolumn{2}{|c|}{$\begin{array}{l}\text { Period of record } \\
\text { (may contain } \\
\text { gaps) or single } \\
\text { measurement } \\
\text { date } \\
\text { (MM/YYYY) }\end{array}$} & \multirow[t]{2}{*}{$\begin{array}{l}\text { Well } \\
\text { or hole } \\
\text { depth } \\
\text { (feet) }\end{array}$} & \multirow[t]{2}{*}{$\begin{array}{c}\text { Number } \\
\text { of ground- } \\
\text { water- } \\
\text { level obser- } \\
\text { vations dur- } \\
\text { ing study } \\
\text { period } \\
\text { (1979-2015) }\end{array}$} & \multirow{2}{*}{$\begin{array}{c}\text { Standard } \\
\text { deviation } \\
\text { of ground- } \\
\text { water-level } \\
\text { observa- } \\
\text { tions during } \\
\text { study period } \\
\text { (1979-2015) }\end{array}$} \\
\hline & & & & & Begin & End & & & \\
\hline \multicolumn{10}{|c|}{ Groundwater-level observation wells (U.S. Geological Survey, 2017c)_Continued } \\
\hline 344453097551801 & & 03N-07W-10 ACC 1 & 34.748129 & -97.921983 & $01 / 1980$ & $01 / 1980$ & 122 & 1 & 8.27 \\
\hline 355850098522701 & & 17N-16W-02 ACB 1 & 35.980599 & -98.874538 & 03/1980 & 08/1995 & 240 & 33 & 12.34 \\
\hline 361452099230401 & & 21N-20W-31 CDC 1 & 36.247818 & -99.384830 & 04/1980 & 04/1980 & 200 & 1 & 4.88 \\
\hline 355730099060501 & & 17N-18W-10 DDC 1 & 35.958377 & -99.101766 & 08/1980 & 08/1980 & 220 & 1 & 24.48 \\
\hline 360708099174801 & & 19N-20W-14 DDB 1 & 36.118931 & -99.297050 & $10 / 1980$ & $10 / 1980$ & 465 & 1 & 12.33 \\
\hline 360457099113601 & & 19N-19W-35 ACB 1 & 36.082543 & -99.193714 & 10/1980 & 10/1980 & 450 & 1 & 9.68 \\
\hline 361955099181301 & & 21N-20W-11 ADB 1 & 36.331983 & -99.303995 & $10 / 1980$ & 10/1980 & 335 & 1 & 2.30 \\
\hline 352308098241101 & & 11N-11W-31 ACC 1 & 35.385610 & -98.403394 & 01/1981 & 01/1987 & 246 & 4 & 2.83 \\
\hline 353012098225901 & & 12N-11W-20 ACA 1 & 35.503385 & -98.383396 & 01/1981 & 05/1988 & 240 & 9 & 8.68 \\
\hline 360913099174101 & & 19N-20W-02 ADD 1 & 36.153653 & -99.295106 & 02/1981 & 03/1988 & 136 & 4 & 9.85 \\
\hline 355546098390001 & & 17N-14W-24 CCA 1 & 35.929488 & -98.650362 & 02/1981 & 03/1983 & -- & 1 & 4.04 \\
\hline 360132098525301 & & 18N-16W-23 BBD 1 & 36.025598 & -98.881760 & 02/1981 & 03/1983 & -- & 1 & 2.72 \\
\hline 345536098101601 & & 05N-09W-08 ABB 1 & 34.926733 & -98.171437 & 03/1981 & 03/1981 & 360 & 1 & 16.26 \\
\hline 353222098385401 & & 12N-14W-02 DCB 1 & 35.539496 & -98.648684 & 03/1981 & 03/1981 & 240 & 1 & 6.33 \\
\hline 344426098095101 & & 03N-09W-08 DCD 1 & 34.740627 & -98.164491 & 03/1981 & 03/1982 & -- & 1 & 3.75 \\
\hline 355501098444901 & & $17 \mathrm{~N}-15 \mathrm{~W}-25 \mathrm{D} 1$ & 35.916989 & -98.747310 & 07/1981 & 07/1981 & 320 & 1 & 20.11 \\
\hline 354140098442501 & & $14 \mathrm{~N}-15 \mathrm{~W}-13$ AA 1 & 35.694494 & -98.740637 & 01/1982 & 01/1982 & 357 & 1 & 6.63 \\
\hline 353319098554401 & & 13N-16W-32 C 1 & 35.555328 & -98.929251 & 03/1982 & 06/1991 & 400 & 13 & 7.43 \\
\hline 355041098465901 & & 16N-15W-22 CAD 1 & 35.844769 & -98.783421 & 03/1982 & 03/1982 & 240 & 1 & 21.03 \\
\hline 344710097580501 & & 04N-07W-30 DDA 1 & 34.786183 & -97.968374 & 05/1982 & $05 / 1982$ & 210 & 1 & 7.96 \\
\hline 345857098055401 & & 06N-09W-24 ABD 1 & 34.982565 & -98.098658 & 05/1982 & 05/1982 & 140 & 1 & 18.87 \\
\hline 350925098113201 & & 08N-09W-19 B 1 & 35.157005 & -98.192551 & 07/1982 & 07/1982 & 130 & 1 & 16.64 \\
\hline 355107098474601 & & 16N-15W-21 A 1 & 35.851991 & -98.796477 & 10/1982 & 10/1982 & 280 & 1 & 29.60 \\
\hline 355648098580401 & & 17N-17W-13 CAC 1 & 35.946710 & -98.968151 & 11/1982 & 11/1982 & 360 & 1 & 25.54 \\
\hline 344926097553901 & & 04N-07W-15 BBD 1 & 34.823960 & -97.927818 & $12 / 1982$ & 12/1982 & 260 & 1 & 17.81 \\
\hline 355439099085801 & & 17N-18W-32 BBC 1 & 35.910878 & -99.149822 & $12 / 1982$ & 12/1982 & 500 & 1 & 25.63 \\
\hline 344407097591501 & & 03N-08W-13 ADB 1 & 34.735351 & -97.987818 & 04/1983 & 04/1983 & 200 & 1 & 15.61 \\
\hline 345112097585201 & & 04N-07W-06 BBD 1 & 34.853403 & -97.981431 & 06/1983 & 06/1983 & 72 & 1 & 20.53 \\
\hline 355737098580701 & & $17 \mathrm{~N}-17 \mathrm{~W}-12 \mathrm{C} 1$ & 35.960321 & -98.968985 & 08/1983 & 08/1983 & 420 & 1 & 4.99 \\
\hline 350250098083101 & & 07N-09W-27 CBD 1 & 35.04728549 & -98.1422709 & 11/1983 & 11/1983 & 200 & 1 & 22.16 \\
\hline 350253098271701 & & 07N-12W-27 CAD 1 & 35.04811658 & -98.4550579 & 11/1983 & 11/1983 & 207 & 1 & 15.58 \\
\hline 344414097553301 & & 03N-07W-15 BAC 1 & 34.73729585 & -97.9261496 & $12 / 1983$ & 12/1983 & 160 & 1 & 9.53 \\
\hline 355705098562301 & & 17N-16W-18 AD 1 & 35.95143265 & -98.9400947 & $12 / 1983$ & $12 / 1983$ & 380 & 1 & 33.15 \\
\hline 355531099074601 & & 17N-18W-28 BBD 1 & 35.92532256 & -99.1298218 & 02/1984 & 02/1984 & 520 & 1 & 10.88 \\
\hline 355754099072901 & & 17N-18W-09 BDD 1 & 35.96504419 & -99.1251002 & 02/1984 & 02/1984 & 415 & 1 & 12.81 \\
\hline 355358098441401 & & 17N-15W-36 AC 1 & 35.89948956 & -98.7375871 & 03/1984 & 03/1984 & 218 & 1 & 6.02 \\
\hline
\end{tabular}


Table 7. Selected groundwater-level observation wells in the Rush Springs aquifer study area, western Oklahoma.—Continued

[OWRB ID is the well identifier used by the Oklahoma Water Resources Board (OWRB) and the U.S. Geological Survey (USGS) databases; Some differences may occur for the long-term groundwater-level observation well begin and end dates between the OWRB and the USGS well databases; the number of groundwater-level observations does not include the period of record averaged observation used in the steady-state groundwater-flow model; MM/YYYY, month/year; --, not available; *, observation well used for approximating the maximum seasonal groundwater-level range (seasonal approximation)]

\begin{tabular}{|c|c|c|c|c|c|c|c|c|c|c|}
\hline \multirow[t]{2}{*}{$\begin{array}{c}\text { Well } \\
\text { number }\end{array}$} & \multirow[t]{2}{*}{$\begin{array}{l}\text { OWRB } \\
\text { ID }\end{array}$} & \multirow[t]{2}{*}{$\begin{array}{c}\text { Map } \\
\text { number } \\
\text { (fig. 11) }\end{array}$} & \multirow[t]{2}{*}{ Station name } & \multirow[t]{2}{*}{$\begin{array}{l}\text { Latitude } \\
\text { (decimal } \\
\text { degrees) }\end{array}$} & \multirow[t]{2}{*}{$\begin{array}{l}\text { Longitude } \\
\text { (decimal } \\
\text { degrees) }\end{array}$} & \multicolumn{2}{|c|}{$\begin{array}{l}\text { Period of record } \\
\text { (may contain } \\
\text { gaps) or single } \\
\text { measurement } \\
\text { date } \\
\text { (MM/YYYY) } \\
\end{array}$} & \multirow[t]{2}{*}{$\begin{array}{c}\text { Well } \\
\text { or hole } \\
\text { depth } \\
\text { (feet) }\end{array}$} & \multirow{2}{*}{$\begin{array}{l}\text { Number } \\
\text { of ground- } \\
\text { water- } \\
\text { level obser- } \\
\text { vations dur- } \\
\text { ing study } \\
\text { period } \\
\text { (1979-2015) }\end{array}$} & \multirow{2}{*}{$\begin{array}{c}\text { Standard } \\
\text { deviation } \\
\text { of ground- } \\
\text { water-level } \\
\text { observa- } \\
\text { tions during } \\
\text { study period } \\
\text { (1979-2015) }\end{array}$} \\
\hline & & & & & & Begin & End & & & \\
\hline \multicolumn{11}{|c|}{ Groundwater-level observation wells (U.S. Geological Survey, 2017c) —Continued } \\
\hline 355355098575601 & & & 16N-17W-01 BBA 1 & 35.8986558 & -98.965928 & 05/1984 & $05 / 1984$ & 200 & 1 & 3.94 \\
\hline 360934098592801 & & & 20N-17W-34 DDD 1 & 36.15948457 & -98.9914859 & $06 / 1984$ & $06 / 1984$ & 60 & 1 & 9.25 \\
\hline 353249098404401 & & & 12N-14W-03 BDB 2 & 35.5469962 & -98.6792408 & $06 / 1984$ & $06 / 1984$ & 160 & 1 & 3.91 \\
\hline 352854098183701 & & & 12N-11W-25 DDB 1 & 35.48171894 & -98.3106149 & 08/1984 & 08/1984 & 240 & 1 & 2.02 \\
\hline 353254098405201 & & & 12N-14W-04 ABD 1 & 35.54838509 & -98.6814631 & 08/1984 & 08/1984 & 160 & 1 & 4.98 \\
\hline 353216098404601 & & & 12N-14W-04 DDC 1 & 35.5378297 & -98.679796 & 09/1984 & 09/1984 & 180 & 1 & 3.88 \\
\hline 355345098450501 & & & 16N-15W-01 B 1 & 35.89587868 & -98.7517543 & $10 / 1984$ & $10 / 1984$ & 180 & 1 & 9.10 \\
\hline 355345098450502 & & & 16N-15W-01 В 2 & 35.89587868 & -98.7517543 & $10 / 1984$ & $10 / 1984$ & 165 & 1 & 9.10 \\
\hline 354914099082501 & & & 16N-18W-32 BDC 1 & 35.82060186 & -99.1406535 & $11 / 1984$ & $11 / 1984$ & 405 & 1 & 15.26 \\
\hline 350639098250801 & & & 07N-12W-01 BDC 1 & 35.11089338 & -98.4192238 & $12 / 1984$ & $12 / 1984$ & 250 & 1 & 25.06 \\
\hline 352058098080801 & & & 10N-09W-10 DCD 1 & 35.349501 & -98.1358853 & $12 / 1984$ & $12 / 1984$ & 56 & 1 & 4.38 \\
\hline 352157098142401 & & & 10N-10W-03 DDB 1 & 35.3658888 & -98.2403328 & $12 / 1984$ & $12 / 1984$ & 138 & 1 & 4.76 \\
\hline 352529098145401 & & & 11N-10W-15 CAC 2 & 35.424776 & -98.2486674 & $12 / 1984$ & $12 / 1984$ & 160 & 1 & 2.76 \\
\hline 355341098454201 & & & 16N-15W-02 ACA 1 & 35.89476756 & -98.7620324 & $12 / 1984$ & $12 / 1984$ & 180 & 1 & 19.45 \\
\hline 350927098174501 & & & 08N-10W-19 BBC 1 & 35.15756004 & -98.2961648 & $12 / 1984$ & $12 / 1984$ & 200 & 1 & 1.45 \\
\hline 351310098102501 & & & 09N-09W-29 DCC 1 & 35.2195043 & -98.17394 & $12 / 1984$ & $12 / 1984$ & 100 & 1 & 3.68 \\
\hline 351544098143401 & & & 09N-10W-10 DCC 1 & 35.26228059 & -98.2431087 & $12 / 1984$ & $12 / 1984$ & 60 & 1 & 3.34 \\
\hline 351714098100001 & & & 09N-09W-05 AAD 1 & 35.28728047 & -98.1669962 & $12 / 1984$ & $12 / 1984$ & 75 & 1 & 4.36 \\
\hline 352146098192001 & & & 10N-11W-12 BBB 1 & 35.36283305 & -98.3225574 & $12 / 1984$ & $12 / 1984$ & 168 & 1 & 1.77 \\
\hline 352234098140801 & & & 10N-10W-02 BBB 1 & 35.3761663 & -98.2358884 & $12 / 1984$ & $12 / 1984$ & 46 & 1 & 2.30 \\
\hline 352437098100201 & & & 11N-09W-20 DAD 1 & 35.41033235 & -98.1675538 & $12 / 1984$ & $12 / 1984$ & 129 & 1 & 1.98 \\
\hline 352542098192701 & & & 11N-11W-14 ADDD 1 & 35.42838696 & -98.3245032 & $12 / 1984$ & $12 / 1984$ & 77 & 1 & 5.44 \\
\hline 352933098192801 & & & 12N-11W-26 AAA 1 & 35.492552 & -98.3247822 & $12 / 1984$ & $12 / 1984$ & 127 & 1 & 2.09 \\
\hline 352646098382901 & & & $11 \mathrm{~N}-14 \mathrm{~W}-11$ ADAA 1 & 35.44616434 & -98.6417364 & $12 / 1984$ & $12 / 1984$ & 133 & 1 & 1.64 \\
\hline 353030098392101 & & & 12N-14W-14 CCC 1 & 35.5083857 & -98.656183 & $12 / 1984$ & $12 / 1984$ & 130 & 1 & 2.73 \\
\hline 353455098344601 & & & 13N-13W-21 DDD 1 & 35.5819951 & -98.5797938 & $12 / 1984$ & $12 / 1984$ & 143 & 1 & 0.71 \\
\hline 353755098364901 & & & 13N-13W-05 BCC 1 & 35.6319943 & -98.6139635 & $12 / 1984$ & $12 / 1984$ & 123 & 1 & 1.36 \\
\hline 354205098431501 & & & 14N-14W-07 DAD 1 & 35.7014383 & -98.7211924 & $12 / 1984$ & $12 / 1984$ & 104 & 1 & 1.49 \\
\hline 352150098352601 & & & 10N-13W-05 DDC 1 & 35.36394334 & -98.5908992 & $12 / 1984$ & $12 / 1984$ & 65 & 1 & 3.16 \\
\hline 352500098403201 & & & 11N-14W-21 AADD 1 & 35.41672029 & -98.6759035 & $12 / 1984$ & $12 / 1984$ & 190 & 1 & 3.86 \\
\hline 352926098285201 & & & $12 \mathrm{~N}-12 \mathrm{~W}-28 \mathrm{BBC} 1$ & 35.49060784 & -98.481454 & $12 / 1984$ & $12 / 1984$ & 140 & 1 & 1.50 \\
\hline 350834098295801 & & & 08N-12W-30 AACCC & 35.1428366 & -98.4997819 & 01/1985 & 01/1985 & 300 & 1 & 1.49 \\
\hline 351108098211201 & & & 08N-11W-10 BCВ 1 & 35.18561464 & -98.3536667 & 01/1985 & 01/1985 & 107 & 1 & 1.42 \\
\hline 351109098252201 & & & 08N-12W-12 BBC 1 & 35.1858919 & -98.4231132 & 01/1985 & 01/1985 & 260 & 1 & 4.44 \\
\hline 351116098335901 & & & 08N-13W-09 AAA 1 & 35.18783528 & -98.5667286 & $01 / 1985$ & 01/1985 & 300 & 1 & 0.55 \\
\hline 351451098184301 & & & 09N-11W-13 DCD 1 & 35.2475582 & -98.312277 & 01/1985 & 01/1985 & 43 & 1 & 2.49 \\
\hline
\end{tabular}


Table 7. Selected groundwater-level observation wells in the Rush Springs aquifer study area, western Oklahoma.—Continued

[OWRB ID is the well identifier used by the Oklahoma Water Resources Board (OWRB) and the U.S. Geological Survey (USGS) databases; Some differences may occur for the long-term groundwater-level observation well begin and end dates between the OWRB and the USGS well databases; the number of groundwater-level observations does not include the period of record averaged observation used in the steady-state groundwater-flow model; MM/YYYY, month/year; --, not available; *, observation well used for approximating the maximum seasonal groundwater-level range (seasonal approximation)]

\begin{tabular}{|c|c|c|c|c|c|c|c|c|c|c|}
\hline \multirow[t]{2}{*}{$\begin{array}{c}\text { Well } \\
\text { number }\end{array}$} & \multirow[t]{2}{*}{$\begin{array}{l}\text { OWRB } \\
\text { ID }\end{array}$} & \multirow[t]{2}{*}{$\begin{array}{c}\text { Map } \\
\text { number } \\
\text { (fig. 11) }\end{array}$} & \multirow[t]{2}{*}{ Station name } & \multirow[t]{2}{*}{$\begin{array}{l}\text { Latitude } \\
\text { (decimal } \\
\text { degrees) }\end{array}$} & \multirow[t]{2}{*}{$\begin{array}{l}\text { Longitude } \\
\text { (decimal } \\
\text { degrees) }\end{array}$} & \multicolumn{2}{|c|}{$\begin{array}{l}\text { Period of record } \\
\text { (may contain } \\
\text { gaps) or single } \\
\text { measurement } \\
\text { date } \\
\text { (MM/YYYY) }\end{array}$} & \multirow[t]{2}{*}{$\begin{array}{l}\text { Well } \\
\text { or hole } \\
\text { depth } \\
\text { (feet) }\end{array}$} & \multirow{2}{*}{$\begin{array}{c}\text { Number } \\
\text { of ground- } \\
\text { water- } \\
\text { level obser- } \\
\text { vations dur- } \\
\text { ing study } \\
\text { period } \\
\text { (1979-2015) }\end{array}$} & \multirow{2}{*}{$\begin{array}{c}\text { Standard } \\
\text { deviation } \\
\text { of ground- } \\
\text { water-level } \\
\text { observa- } \\
\text { tions during } \\
\text { study period } \\
\text { (1979-2015) }\end{array}$} \\
\hline & & & & & & Begin & End & & & \\
\hline \multicolumn{11}{|c|}{ Groundwater-level observation wells (U.S. Geological Survey, 2017c)—Continued } \\
\hline 351657098234201 & & & 09N-11W-06 DAA 1 & 35.2825568 & -98.3953356 & $01 / 1985$ & $01 / 1985$ & 258 & 1 & 1.42 \\
\hline 350255098212601 & & & 07N-11W-28 DAD 1 & 35.04867278 & -98.3575549 & 01/1985 & 01/1985 & 127 & 1 & 1.48 \\
\hline 350339098272201 & & & 07N-12W-22 CDB 1 & 35.0608941 & -98.4564469 & 01/1985 & 01/1985 & 64 & 1 & 3.28 \\
\hline 350459098333001 & & & 07N-13W-15 ACB 1 & 35.0831151 & -98.5586722 & 01/1985 & 01/1985 & 120 & 1 & 1.61 \\
\hline 350515098292001 & & & 07N-12W-08 CDD 2 & 35.08756 & -98.4892258 & 01/1985 & 01/1985 & 60 & 1 & 1.75 \\
\hline 350758098450401 & & & 08N-15W-26 CDC 1 & 35.1328349 & -98.7514559 & 01/1985 & 01/1985 & 48 & 1 & 2.61 \\
\hline 350832098400501 & & & 08N-14W-27 BCB 1 & 35.1422798 & -98.668398 & 01/1985 & 01/1985 & 160 & 1 & 1.22 \\
\hline 345450098171701 & & & 05N-10W-07 DDD 1 & 34.91395434 & -98.288385 & 01/1985 & 01/1985 & 86 & 1 & 2.02 \\
\hline 345800098135901 & & & 06N-10W-26 BCB 1 & 34.96673104 & -98.2333837 & 01/1985 & 01/1985 & 32 & 1 & 1.92 \\
\hline 350000098243601 & & & 06N-12W-13 AAA 1 & 35.00006225 & -98.410334 & 01/1985 & 01/1985 & 40 & 1 & 1.42 \\
\hline 350019098170901 & & & 06N-10W-08 CBC 1 & 35.00534075 & -98.2861634 & 01/1985 & 01/1985 & 131 & 1 & 2.04 \\
\hline 350524098170101 & & & 07N-10W-08 CCC 1 & 35.0900614 & -98.2839418 & 01/1985 & 01/1985 & 47 & 1 & 3.19 \\
\hline 345724098055201 & & & 06N-09W-25 DCD 1 & 34.9567324 & -98.098102 & 01/1985 & 01/1985 & 77 & 1 & 3.39 \\
\hline 345959098043301 & & & 06N-08W-07 DDD 1 & 34.99978687 & -98.0761575 & 01/1985 & 01/1985 & 41 & 1 & 2.24 \\
\hline 350050098112601 & & & 06N-09W-07 BAA 1 & 35.01395239 & -98.190883 & 01/1985 & 01/1985 & 107 & 1 & 3.98 \\
\hline 350234098062601 & & & 07N-09W-36 BBA 1 & 35.0428414 & -98.1075477 & 01/1985 & 01/1985 & 124 & 1 & 2.34 \\
\hline 350320098094701 & & & 07N-09W-28 BBC 1 & 35.0556185 & -98.1633826 & 01/1985 & 01/1985 & 46 & 1 & 2.84 \\
\hline 344930098123201 & & & 04N-10W-13 BBA 1 & 34.82506859 & -98.209215 & 01/1985 & 01/1985 & 45 & 1 & 1.77 \\
\hline 345302098140801 & & & 05N-10W-27 AAB 1 & 34.88395557 & -98.235883 & 01/1985 & 01/1985 & 62 & 1 & 2.24 \\
\hline 345353098073501 & & & 05N-09W-23 BBB 1 & 34.89812278 & -98.1267133 & $01 / 1985$ & 01/1985 & 110 & 1 & 2.08 \\
\hline 345542098114201 & & & 05N-09W-06 CCD 1 & 34.9283991 & -98.1953267 & 01/1985 & 01/1985 & 10845 & 1 & 1.73 \\
\hline 344702098540201 & & & 04N-07W-26 DDC 1 & 34.7839613 & -97.900872 & 01/1985 & 01/1985 & 78 & 1 & 1.77 \\
\hline 344748098065401 & & & 04N-09W-26 ABBB 1 & 34.79673696 & -98.1153228 & 01/1985 & 01/1985 & 144 & 1 & 1.45 \\
\hline 344810098010801 & & & 04N-08W-23 CBC 1 & 34.8028488 & -98.0192086 & 01/1985 & 01/1985 & 44 & 1 & 3.35 \\
\hline 344931098041701 & & & 04N-08W-17 BBB 1 & 34.82534764 & -98.0717106 & 01/1985 & 01/1985 & 79 & 1 & 1.91 \\
\hline 344936098565201 & & & 04N-07W-16 BBB 1 & 34.82673754 & -97.948096 & 01/1985 & 01/1985 & 90 & 1 & 2.38 \\
\hline 345028098091801 & & & 04N-09W-04 CCD 1 & 34.84117974 & -98.1553246 & 01/1985 & 01/1985 & 50 & 1 & 2.17 \\
\hline 345306098562001 & & & 05N-07W-21 DDC 1 & 34.88506924 & -97.9392079 & $01 / 1985$ & 01/1985 & 126 & 1 & 2.48 \\
\hline 353441098391901 & & & 13N-14W-26 ABD 1 & 35.57810666 & -98.6556299 & 07/1985 & 07/1985 & 140 & 1 & 13.92 \\
\hline 350035098115701 & & & 06N-10W-12 ADA 1 & 35.00978574 & -98.1994943 & 10/1985 & 10/1985 & 140 & 1 & 11.27 \\
\hline 361235099034101 & & & 20N-17W-18 BCC 1 & 36.20976187 & -99.0617657 & $11 / 1985$ & 11/1985 & 140 & 1 & 3.89 \\
\hline 345816098003001 & & & 06N-08W-23 DDC 1 & 34.97117714 & -98.0086553 & 06/1986 & 06/1986 & 86 & 1 & 7.27 \\
\hline 345441098012201 & & & 05N-08W-15 AAA 1 & 34.9114566 & -98.0230992 & 06/1986 & 06/1986 & 229 & 1 & 12.04 \\
\hline 345732098064801 & & & 06N-09W-26 DDB 1 & 34.95895444 & -98.113658 & 06/1986 & 06/1986 & 90 & 1 & 10.34 \\
\hline 345833098042401 & & & 06N-08W-20 CBB 1 & 34.9758987 & -98.0736572 & 06/1986 & 06/1986 & 50 & 1 & 7.30 \\
\hline 344159097572701 & & & 03N-07W-29 DCB 1 & 34.6997968 & -97.9578164 & 06/1986 & 06/1986 & 109 & 1 & 8.67 \\
\hline
\end{tabular}


Table 7. Selected groundwater-level observation wells in the Rush Springs aquifer study area, western Oklahoma.-Continued

[OWRB ID is the well identifier used by the Oklahoma Water Resources Board (OWRB) and the U.S. Geological Survey (USGS) databases; Some differences may occur for the long-term groundwater-level observation well begin and end dates between the OWRB and the USGS well databases; the number of groundwater-level observations does not include the period of record averaged observation used in the steady-state groundwater-flow model; MM/YYYY, month/year; --, not available; *, observation well used for approximating the maximum seasonal groundwater-level range (seasonal approximation)]

\begin{tabular}{|c|c|c|c|c|c|c|c|c|c|c|}
\hline \multirow[t]{2}{*}{$\begin{array}{c}\text { Well } \\
\text { number }\end{array}$} & \multirow[t]{2}{*}{$\begin{array}{c}\text { OWRB } \\
\text { ID }\end{array}$} & \multirow[t]{2}{*}{$\begin{array}{c}\text { Map } \\
\text { number } \\
\text { (fig. 11) }\end{array}$} & \multirow[t]{2}{*}{ Station name } & \multirow[t]{2}{*}{$\begin{array}{l}\text { Latitude } \\
\text { (decimal } \\
\text { degrees) }\end{array}$} & \multirow[t]{2}{*}{$\begin{array}{l}\text { Longitude } \\
\text { (decimal } \\
\text { degrees) }\end{array}$} & \multicolumn{2}{|c|}{$\begin{array}{l}\text { Period of record } \\
\text { (may contain } \\
\text { gaps) or single } \\
\text { measurement } \\
\text { date } \\
\text { (MM/YYYY) }\end{array}$} & \multirow[t]{2}{*}{$\begin{array}{c}\text { Well } \\
\text { or hole } \\
\text { depth } \\
\text { (feet) }\end{array}$} & \multirow{2}{*}{$\begin{array}{c}\text { Number } \\
\text { of ground- } \\
\text { water- } \\
\text { level obser- } \\
\text { vations dur- } \\
\text { ing study } \\
\text { period } \\
\text { (1979-2015) }\end{array}$} & \multirow{2}{*}{$\begin{array}{c}\text { Standard } \\
\text { deviation } \\
\text { of ground- } \\
\text { water-level } \\
\text { observa- } \\
\text { tions during } \\
\text { study period } \\
\text { (1979-2015) }\end{array}$} \\
\hline & & & & & & Begin & End & & & \\
\hline \multicolumn{11}{|c|}{ Groundwater-level observation wells (U.S. Geological Survey, 2017c)_Continued } \\
\hline 344211097544601 & & & 03N-07W-26 CBB 1 & 34.7031303 & -97.9130932 & 06/1986 & 06/1986 & 100 & 1 & 9.45 \\
\hline 344433097545301 & & & 03N-07W-10 DDA 1 & 34.7425735 & -97.9150384 & 06/1986 & 06/1986 & 90 & 1 & 8.13 \\
\hline 344433097572501 & & & 03N-07W-08 DCB 1 & 34.74257329 & -97.9572616 & 06/1986 & 06/1986 & 100 & 1 & 7.44 \\
\hline 345448098071401 & & & 05N-09W-11 CDD 1 & 34.91340016 & -98.1208799 & 06/1986 & 06/1986 & 57 & 1 & 13.17 \\
\hline 345602098035201 & & & 05N-08W-05 DCC 1 & 34.93395558 & -98.0647674 & 06/1986 & 06/1986 & 122 & 1 & 10.19 \\
\hline 344709097575301 & & & 04N-07W-33 BAB 1 & 34.78590529 & -97.9650402 & 06/1986 & 06/1986 & 50 & 1 & 6.59 \\
\hline 345812098102401 & & & 06N-09W-29 BAA 1 & 34.97006475 & -98.1736598 & 06/1986 & 06/1986 & 195 & 1 & 10.01 \\
\hline 344939097554201 & & & 04N-07W-22 BBA 1 & 34.82757099 & -97.9286512 & 06/1986 & 06/1986 & 126 & 1 & 11.77 \\
\hline 345815098160601 & & & 06N-10W-28 BBB 1 & 34.9708973 & -98.2686626 & 06/1986 & 06/1986 & 157 & 1 & 8.13 \\
\hline 344939097575601 & & & 04N-07W-08 CCC 1 & 34.8275707 & -97.9658743 & 07/1986 & 07/1986 & 74 & 1 & 8.07 \\
\hline 345055097545701 & & & 04N-07W-03 ADD 1 & 34.84868159 & -97.9161513 & 07/1986 & 07/1986 & 375 & 1 & 16.57 \\
\hline 345517098160501 & & & 05N-10W-09 BCC 1 & 34.92145427 & -98.2683844 & 07/1986 & 07/1986 & 78 & 1 & 6.10 \\
\hline 344701098031101 & & & 04N-08W-28 CCC 1 & 34.78368239 & -98.0533761 & 07/1986 & 07/1986 & 131 & 1 & 6.03 \\
\hline 344703097591501 & & & 04N-08W-25 DDC 1 & 34.7842385 & -97.9878185 & 07/1986 & 07/1986 & 150 & 1 & 8.44 \\
\hline 344939098000701 & & & 04N-08W-11 DDD 1 & 34.82757044 & -98.002264 & 07/1986 & 07/1986 & 61 & 1 & 14.64 \\
\hline 345445098144301 & & & 05N-11W-14 ABB 1 & 34.9125658 & -98.2456058 & 07/1986 & 07/1986 & 58 & 1 & 3.90 \\
\hline 345750098201801 & & & 06N-11W-26 CBB 1 & 34.9639526 & -98.3386648 & 07/1986 & 07/1986 & 40 & 1 & 2.93 \\
\hline 344946098041101 & & & 04N-08W-08 CCB 1 & 34.8295142 & -98.070044 & 07/1986 & 07/1986 & 135 & 1 & 10.31 \\
\hline 345054098072301 & & & 04N-09W-02 BCC 2 & 34.84840204 & -98.1233792 & 07/1986 & 07/1986 & 87 & 1 & 6.55 \\
\hline 350235098082401 & & & 07N-09W-34 BAB 1 & 35.0431189 & -98.1403263 & 07/1986 & 07/1986 & 102 & 1 & 16.14 \\
\hline 344147098032801 & & & 03N-08W-29 DDC 1 & 34.6964628 & -98.058097 & 07/1986 & 07/1986 & 400 & 1 & 2.41 \\
\hline 344234098003601 & & & 03N-08W-26 ABB 1 & 34.7095184 & -98.0103178 & 07/1986 & 07/1986 & 58 & 1 & 10.71 \\
\hline 350043098094301 & & & 06N-09W-09 BCB 1 & 35.0120082 & -98.162271 & 07/1986 & 07/1986 & 46 & 1 & 12.29 \\
\hline 350053098074901 & & & 06N-09W-10 DDC 1 & 35.01478617 & -98.1306036 & 07/1986 & 07/1986 & 78 & 1 & 4.81 \\
\hline 344431098031801 & & & 03N-08W-08 DDA 1 & 34.74201696 & -98.05532 & 07/1986 & 07/1986 & 105 & 1 & 9.02 \\
\hline 344442098001001 & & & 03N-08W-11 DAD 1 & 34.74507294 & -98.003096 & 07/1986 & 07/1986 & 100 & 1 & 9.18 \\
\hline 344509098070801 & & & 03N-09W-11 BAB 1 & 34.75257155 & -98.1192113 & 07/1986 & 07/1986 & 188 & 1 & 7.86 \\
\hline 344715098072101 & & & 04N-09W-26 CBC 1 & 34.78757049 & -98.122823 & 07/1986 & 07/1986 & 109 & 1 & 8.45 \\
\hline 350542098135901 & & & 07N-10W-10 DAA 1 & 35.09506167 & -98.2333848 & 07/1986 & 07/1986 & 40 & 1 & 26.61 \\
\hline 345201098031601 & & & 05N-08W-29 DCD 1 & 34.8670132 & -98.0547662 & 07/1986 & 07/1986 & 59 & 1 & 14.40 \\
\hline 345212097572301 & & & 05N-07W-29 DDD 1 & 34.8700695 & -97.956708 & 07/1986 & 07/1986 & 500 & 1 & 8.45 \\
\hline 350626098260401 & & & 07N-12W-02 CAD 1 & 35.1072822 & -98.4347798 & 07/1986 & 07/1986 & 74 & 1 & 11.54 \\
\hline 350253098263701 & & & 07N-12W-26 CBC 1 & 35.04811665 & -98.4439465 & 07/1986 & 07/1986 & 115 & 1 & 6.35 \\
\hline 350319098284901 & & & 07N-12W-29 AAD 1 & 35.05533849 & -98.4806143 & 07/1986 & 07/1986 & 49 & 1 & 11.15 \\
\hline 344743098132401 & & & 04N-10W-26 BAA 1 & 34.79534707 & -98.2236597 & 07/1986 & 07/1986 & 70 & 1 & 2.47 \\
\hline 344747098101401 & & & 04N-09W-29 BAB 1 & 34.79645866 & -98.1708802 & 07/1986 & 07/1986 & 58 & 1 & 5.07 \\
\hline
\end{tabular}


Table 7. Selected groundwater-level observation wells in the Rush Springs aquifer study area, western Oklahoma.—Continued

[OWRB ID is the well identifier used by the Oklahoma Water Resources Board (OWRB) and the U.S. Geological Survey (USGS) databases; Some differences may occur for the long-term groundwater-level observation well begin and end dates between the OWRB and the USGS well databases; the number of groundwater-level observations does not include the period of record averaged observation used in the steady-state groundwater-flow model; MM/YYYY, month/year; --, not available; *, observation well used for approximating the maximum seasonal groundwater-level range (seasonal approximation)]

\begin{tabular}{|c|c|c|c|c|c|c|c|c|c|c|}
\hline \multirow[t]{2}{*}{$\begin{array}{c}\text { Well } \\
\text { number }\end{array}$} & \multirow[t]{2}{*}{$\begin{array}{l}\text { OWRB } \\
\text { ID }\end{array}$} & \multirow[t]{2}{*}{$\begin{array}{c}\text { Map } \\
\text { number } \\
\text { (fig. 11) }\end{array}$} & \multirow[t]{2}{*}{ Station name } & \multirow[t]{2}{*}{$\begin{array}{l}\text { Latitude } \\
\text { (decimal } \\
\text { degrees) }\end{array}$} & \multirow[t]{2}{*}{$\begin{array}{l}\text { Longitude } \\
\text { (decimal } \\
\text { degrees) }\end{array}$} & \multicolumn{2}{|c|}{$\begin{array}{l}\text { Period of record } \\
\text { (may contain } \\
\text { gaps) or single } \\
\text { measurement } \\
\text { date } \\
\text { (MM/YYYY) }\end{array}$} & \multirow[t]{2}{*}{$\begin{array}{l}\text { Well } \\
\text { or hole } \\
\text { depth } \\
\text { (feet) }\end{array}$} & \multirow[t]{2}{*}{$\begin{array}{c}\text { Number } \\
\text { of ground- } \\
\text { water- } \\
\text { level obser- } \\
\text { vations dur- } \\
\text { ing study } \\
\text { period } \\
\text { (1979-2015) }\end{array}$} & \multirow{2}{*}{$\begin{array}{c}\text { Standard } \\
\text { deviation } \\
\text { of ground- } \\
\text { water-level } \\
\text { observa- } \\
\text { tions during } \\
\text { study period } \\
\text { (1979-2015) }\end{array}$} \\
\hline & & & & & & Begin & End & & & \\
\hline \multicolumn{11}{|c|}{ Groundwater-level observation wells (U.S. Geological Survey, 2017c)_Continued } \\
\hline 350002098231301 & & & 06N-11W-08 CDC 1 & 35.00061795 & -98.3872778 & 07/1986 & 07/1986 & 36 & 1 & 8.56 \\
\hline 350519098232501 & & & 07N-11W-07 DDD 1 & 35.08867179 & -98.3906117 & 07/1986 & 07/1986 & 78 & 1 & 6.19 \\
\hline 344936098131301 & & & 04N-10W-11 DCC 1 & 34.8267351 & -98.2206044 & 07/1986 & 07/1986 & 84 & 1 & 4.66 \\
\hline 350254098191801 & & & 07N-11W-26 DAD 1 & 35.04839525 & -98.3219982 & 07/1986 & 07/1986 & 39 & 1 & 9.34 \\
\hline 350310098230001 & & & 07N-11W-29 BDA 1 & 35.05283919 & -98.3836668 & 07/1986 & $07 / 1986$ & 156 & 1 & 6.50 \\
\hline 350525098170101 & & & 07N-10W-08 CCB 1 & 35.09033917 & -98.2839418 & 07/1986 & 07/1986 & 67 & 1 & 11.07 \\
\hline 350549098315701 & & & 07N-11W-12 BCC 1 & 35.0970039 & -98.5328382 & 07/1986 & 07/1986 & 90 & 1 & 9.40 \\
\hline 350831098390801 & & & 08N-14W-26 BCB 1 & 35.14200217 & -98.6525642 & 07/1986 & 07/1986 & 123 & 1 & 4.97 \\
\hline 351125098384301 & & & 08N-14W-02 CDD 1 & 35.1903347 & -98.6456199 & 07/1986 & 07/1986 & 225 & 1 & 8.14 \\
\hline 350312098161801 & & & 07N-10W-29 ADB 1 & 35.0533955 & -98.2719967 & 07/1986 & 07/1986 & 131 & 1 & 22.91 \\
\hline 350516098292001 & & & 07N-12W-08 CDD 1 & 35.08783779 & -98.4892258 & 07/1986 & 07/1986 & 98 & 1 & 8.06 \\
\hline 351311098102401 & & & 09N-09W-26 DCC 1 & 35.21978208 & -98.1736622 & 07/1986 & 07/1986 & 50 & 1 & 12.51 \\
\hline 351345098140601 & & & 09N-10W-26 BBC 1 & 35.2292258 & -98.2353304 & 07/1986 & 07/1986 & 96 & 1 & 18.26 \\
\hline 351109098130401 & & & 08N-10W-11 AAC 1 & 35.18589345 & -98.2181074 & 07/1986 & 07/1986 & 72 & 1 & 13.08 \\
\hline 350819098191101 & & & 08N-11W-26 DAA 1 & 35.13867134 & -98.3200543 & 07/1986 & 07/1986 & 191 & 1 & 3.58 \\
\hline 351027098285301 & & & 08N-12W-17 AAB 1 & 35.174225 & -98.4817259 & 07/1986 & 07/1986 & 101 & 1 & 10.24 \\
\hline 351049098221901 & & & 08N-11W-08 DAD 1 & 35.1803368 & -98.3722783 & 07/1986 & 07/1986 & 145 & 1 & 3.81 \\
\hline 351332098254701 & & & 09N-12W-26 DAA 1 & 35.2256133 & -98.430058 & 07/1986 & 07/1986 & 123 & 1 & 2.19 \\
\hline 351357098201001 & & & 09N-11W-26 BAB 1 & 35.2325583 & -98.3364443 & 07/1986 & 07/1986 & 240 & 1 & 5.93 \\
\hline 350753098330001 & & & 08N-13W-34 AAB 1 & 35.13144758 & -98.5503389 & 07/1986 & 07/1986 & 125 & 1 & 3.41 \\
\hline 350819098254701 & & & 08N-11W-26 DBA 1 & 35.13867055 & -98.4300576 & 07/1986 & 07/1986 & 49 & 1 & 7.78 \\
\hline 350845098284101 & & & $08 \mathrm{~N}-12 \mathrm{~W}-29$ AAA 1 & 35.14589228 & -98.4783924 & 07/1986 & 07/1986 & 131 & 1 & 2.59 \\
\hline 351112098350101 & & & 08N-13W-08 AAD 1 & 35.18672408 & -98.5839513 & 07/1986 & 07/1986 & 126 & 1 & 4.54 \\
\hline 350516098361501 & & & 07N-13W-07 DDD 1 & 35.08783685 & -98.6045068 & 07/1986 & 07/1986 & 96 & 1 & 4.39 \\
\hline 351308098330801 & & & 09N-13W-26 CCC 1 & 35.2189459 & -98.5525616 & 07/1986 & 07/1986 & 268 & 1 & 7.91 \\
\hline 351401098381601 & & & 09N-14W-24 CCD 1 & 35.2336673 & -98.63812 & 07/1986 & 07/1986 & 116 & 1 & 3.94 \\
\hline 345234098115601 & & & 05N-10W-25 DAA 1 & 34.87617834 & -98.1992152 & 07/1986 & 07/1986 & 94 & 1 & 6.54 \\
\hline 345302098125801 & & & 05N-10W-26 AAA 1 & 34.88395574 & -98.216438 & 07/1986 & 07/1986 & 120 & 1 & 9.01 \\
\hline 345342098105201 & & & 05N-09W-19 AAD 1 & 34.89506655 & -98.2147714 & 07/1986 & 07/1986 & 110 & 1 & 9.02 \\
\hline 345245098130601 & & & 05N-10W-26 ADB 1 & 34.8792336 & -98.2186603 & 07/1986 & 07/1986 & 97 & 1 & 10.53 \\
\hline 345251098123601 & & & 05N-10W-25 BAC 1 & 34.8809003 & -98.2103267 & 07/1986 & 07/1986 & 117 & 1 & 10.04 \\
\hline 345346098125801 & & & 05N-10W-23 AAD 1 & 34.8961776 & -98.2164382 & 07/1986 & 07/1986 & -- & 1 & 13.04 \\
\hline 352626098361501 & & & 11N-13W-08 CBC 1 & 35.44060884 & -98.6045127 & 08/1986 & 08/1986 & 104 & 1 & 6.37 \\
\hline 352937098320701 & & & 12N-13W-23 DDD 1 & 35.49366345 & -98.5356227 & 08/1986 & 08/1986 & 90 & 1 & 3.17 \\
\hline 353208098290501 & & & 12N-12W-08 AАВ 1 & 35.53560684 & -98.4850666 & 08/1986 & 08/1986 & 111 & 1 & 4.08 \\
\hline 353211098232001 & & & 12N-11W-08 BAB 1 & 35.5364399 & -98.38923 & 08/1986 & 08/1986 & 82 & 1 & 3.02 \\
\hline
\end{tabular}


Table 7. Selected groundwater-level observation wells in the Rush Springs aquifer study area, western Oklahoma.-Continued

[OWRB ID is the well identifier used by the Oklahoma Water Resources Board (OWRB) and the U.S. Geological Survey (USGS) databases; Some differences may occur for the long-term groundwater-level observation well begin and end dates between the OWRB and the USGS well databases; the number of groundwater-level observations does not include the period of record averaged observation used in the steady-state groundwater-flow model; MM/YYYY, month/year; --, not available; *, observation well used for approximating the maximum seasonal groundwater-level range (seasonal approximation)]

\begin{tabular}{|c|c|c|c|c|c|c|c|c|c|c|}
\hline \multirow[t]{2}{*}{$\begin{array}{c}\text { Well } \\
\text { number }\end{array}$} & \multirow[t]{2}{*}{$\begin{array}{c}\text { OWRB } \\
\text { ID }\end{array}$} & \multirow[t]{2}{*}{$\begin{array}{c}\text { Map } \\
\text { number } \\
\text { (fig. 11) }\end{array}$} & \multirow[t]{2}{*}{ Station name } & \multirow[t]{2}{*}{$\begin{array}{l}\text { Latitude } \\
\text { (decimal } \\
\text { degrees) }\end{array}$} & \multirow[t]{2}{*}{$\begin{array}{l}\text { Longitude } \\
\text { (decimal } \\
\text { degrees) }\end{array}$} & \multicolumn{2}{|c|}{$\begin{array}{l}\text { Period of record } \\
\text { (may contain } \\
\text { gaps) or single } \\
\text { measurement } \\
\text { date } \\
\text { (MM/YYYY) }\end{array}$} & \multirow[t]{2}{*}{$\begin{array}{c}\text { Well } \\
\text { or hole } \\
\text { depth } \\
\text { (feet) }\end{array}$} & \multirow{2}{*}{$\begin{array}{c}\text { Number } \\
\text { of ground- } \\
\text { water- } \\
\text { level obser- } \\
\text { vations dur- } \\
\text { ing study } \\
\text { period } \\
\text { (1979-2015) }\end{array}$} & \multirow{2}{*}{$\begin{array}{c}\text { Standard } \\
\text { deviation } \\
\text { of ground- } \\
\text { water-level } \\
\text { observa- } \\
\text { tions during } \\
\text { study period } \\
\text { (1979-2015) }\end{array}$} \\
\hline & & & & & & Begin & End & & & \\
\hline \multicolumn{11}{|c|}{ Groundwater-level observation wells (U.S. Geological Survey, 2017c)_Continued } \\
\hline 351548098351301 & & & 09N-13W-09 CCC 1 & 35.26338934 & -98.5872855 & 08/1986 & 08/1986 & 97 & 1 & 7.84 \\
\hline 351902098383501 & & & 10N-14W-26 AAC 1 & 35.31727719 & -98.6433998 & 08/1986 & 08/1986 & 100 & 1 & 7.71 \\
\hline 352059098412701 & & & 10N-14W-09 CCD 1 & 35.3497766 & -98.69118 & 08/1986 & 08/1986 & 115 & 1 & 8.58 \\
\hline 352407098320601 & & & 11N-13W-26 ADA 1 & 35.40199836 & -98.5353427 & 08/1986 & 08/1986 & 91 & 1 & 12.89 \\
\hline 352742098413701 & & & 11N-14W-05 AAD 1 & 35.46171975 & -98.6939609 & 08/1986 & 08/1986 & 109 & 1 & 13.44 \\
\hline 352934098383001 & & & 12N-14W-26 AAA 1 & 35.49283038 & -98.6420154 & 08/1986 & 08/1986 & 162 & 1 & 13.23 \\
\hline 351914098255101 & & & 10N-12W-23 DDD 1 & 35.32061134 & -98.4311708 & 08/1986 & 08/1986 & 103 & 1 & 8.52 \\
\hline 352425098392501 & & & 11N-14W-23 CCC 1 & 35.4069982 & -98.6572915 & 08/1986 & 08/1986 & 85 & 1 & 13.51 \\
\hline 351852098331201 & & & 10N-13W-27 ADA 1 & 35.31449979 & -98.5536745 & 08/1986 & 08/1986 & 84 & 1 & 6.73 \\
\hline 351907098070101 & & & 10N-09W-26 AAB 1 & 35.31866877 & -98.1172733 & 08/1986 & 08/1986 & 70 & 1 & 9.66 \\
\hline 352314098075601 & & & 11N-09W-34 ADA 1 & 35.38727767 & -98.1325525 & 08/1986 & 08/1986 & 56 & 1 & 15.86 \\
\hline 353206098352101 & & & 12N-13W-08 AAD 1 & 35.53505166 & -98.5895148 & 08/1986 & 08/1986 & 128 & 1 & 3.00 \\
\hline 351610098234001 & & & 09N-11W-07 ADD 1 & 35.26950155 & -98.3947798 & 08/1986 & 08/1986 & 177 & 1 & 2.12 \\
\hline 351630098043701 & & & 09N-08W-08 BBB 1 & 35.2750593 & -98.0772717 & 08/1986 & 08/1986 & 53 & 1 & 12.10 \\
\hline 352056098360301 & & & 10N-13W-08 CDC 1 & 35.34894354 & -98.601177 & 08/1986 & 08/1986 & 98 & 1 & 12.25 \\
\hline 352145098232101 & & & 10N-11W-08 BAB 1 & 35.36255505 & -98.3895038 & 08/1986 & 08/1986 & 145 & 1 & 12.27 \\
\hline 352145098290201 & & & 10N-12W-08 AAA 1 & 35.3625547 & -98.4842289 & 08/1986 & 08/1986 & 229 & 1 & 8.79 \\
\hline 351637098275101 & & & 09N-12W-03 CCC 1 & 35.2770009 & -98.4645042 & 08/1986 & 08/1986 & 210 & 1 & 12.96 \\
\hline 351908098220101 & & & 10N-11W-28 AAB 1 & 35.318945 & -98.36728 & 08/1986 & 08/1986 & 157 & 1 & 13.42 \\
\hline 352056098095901 & & & 10N-09W-08 DDD 1 & 35.3489453 & -98.1667194 & 08/1986 & 08/1986 & 55 & 1 & 9.02 \\
\hline 352216098162101 & & & 10N-10W-05 ADD 1 & 35.3711663 & -98.2728338 & 08/1986 & 08/1986 & 167 & 1 & 10.82 \\
\hline 352338098283001 & & & 11N-11W-27 DDA 1 & 35.393943 & -98.4753405 & 08/1986 & 08/1986 & 149 & 1 & 4.11 \\
\hline 352517098230401 & & & 11N-11W-17 DCC 1 & 35.4214426 & -98.3847827 & 08/1986 & 08/1986 & 135 & 1 & 22.37 \\
\hline 352604098172201 & & & $11 \mathrm{~N}-10 \mathrm{~W}-18$ AAAA 1 & 35.43449794 & -98.28978 & 08/1986 & 08/1986 & 142 & 1 & 9.38 \\
\hline 352655098290501 & & & 11N-12W-08 AAA 1 & 35.4486642 & -98.4850643 & 08/1986 & 08/1986 & 260 & 1 & 10.02 \\
\hline 352843098202701 & & & 12N-11W-26 CCC 1 & 35.47866349 & -98.3411714 & 08/1986 & 08/1986 & 105 & 1 & 3.10 \\
\hline 352435098140901 & & & 11N-10W-23 CBCC 1 & 35.4097765 & -98.2361668 & 08/1986 & 08/1986 & 131 & 1 & 6.14 \\
\hline 353217098410701 & & & 12N-14W-04 CDD 1 & 35.5381075 & -98.6856296 & 08/1986 & 08/1986 & 151 & 1 & 1.69 \\
\hline 350018098031301 & & & 06N-08W-09 CBD 1 & 35.0050647 & -98.0539348 & 08/1986 & 08/1986 & 23 & 1 & 13.91 \\
\hline 353356098333601 & & & 13N-13W-35 CCC 1 & 35.56560647 & -98.5603481 & 08/1986 & 08/1986 & 140 & 1 & 1.76 \\
\hline 353725098364401 & & & 13N-13W-08 CCC 1 & 35.6236611 & -98.6125743 & 08/1986 & 08/1986 & 132 & 1 & 1.91 \\
\hline 351109098104601 & & & 08N-09W-07 AAD 1 & 35.18589377 & -98.1797731 & 08/1986 & 08/1986 & 56 & 1 & 11.23 \\
\hline 351655098424001 & & & 09N-14W-05 CBB 1 & 35.28199956 & -98.7114567 & 08/1986 & 08/1986 & 172 & 1 & 2.77 \\
\hline 351724098155501 & & & 09N-10W-04 BAB 1 & 35.29005745 & -98.2656099 & 08/1986 & 08/1986 & 47 & 1 & 14.29 \\
\hline 352427098254801 & & & 11N-12W-23 DDD 1 & 35.40755396 & -98.4303394 & 08/1986 & 08/1986 & 38 & 1 & 10.71 \\
\hline 352846098263601 & & & 12N-12W-26 CCD 1 & 35.4794969 & -98.4436748 & 08/1986 & 08/1986 & 140 & 1 & 2.49 \\
\hline
\end{tabular}


Table 7. Selected groundwater-level observation wells in the Rush Springs aquifer study area, western Oklahoma.—Continued

[OWRB ID is the well identifier used by the Oklahoma Water Resources Board (OWRB) and the U.S. Geological Survey (USGS) databases; Some differences may occur for the long-term groundwater-level observation well begin and end dates between the OWRB and the USGS well databases; the number of groundwater-level observations does not include the period of record averaged observation used in the steady-state groundwater-flow model; MM/YYYY, month/year; --, not available; *, observation well used for approximating the maximum seasonal groundwater-level range (seasonal approximation)]

\begin{tabular}{|c|c|c|c|c|c|c|c|c|c|c|}
\hline \multirow[t]{2}{*}{$\begin{array}{c}\text { Well } \\
\text { number }\end{array}$} & \multirow[t]{2}{*}{$\begin{array}{l}\text { OWRB } \\
\text { ID }\end{array}$} & \multirow[t]{2}{*}{$\begin{array}{c}\text { Map } \\
\text { number } \\
\text { (fig. 11) }\end{array}$} & \multirow[t]{2}{*}{ Station name } & \multirow[t]{2}{*}{$\begin{array}{l}\text { Latitude } \\
\text { (decimal } \\
\text { degrees) }\end{array}$} & \multirow[t]{2}{*}{$\begin{array}{c}\text { Longitude } \\
\text { (decimal } \\
\text { degrees) }\end{array}$} & \multicolumn{2}{|c|}{$\begin{array}{l}\text { Period of record } \\
\text { (may contain } \\
\text { gaps) or single } \\
\text { measurement } \\
\text { date } \\
\text { (MM/YYYY) }\end{array}$} & \multirow[t]{2}{*}{$\begin{array}{c}\text { Well } \\
\text { or hole } \\
\text { depth } \\
\text { (feet) }\end{array}$} & \multirow{2}{*}{$\begin{array}{c}\text { Number } \\
\text { of ground- } \\
\text { water- } \\
\text { level obser- } \\
\text { vations dur- } \\
\text { ing study } \\
\text { period } \\
\text { (1979-2015) }\end{array}$} & \multirow{2}{*}{$\begin{array}{c}\text { Standard } \\
\text { deviation } \\
\text { of ground- } \\
\text { water-level } \\
\text { observa- } \\
\text { tions during } \\
\text { study period } \\
\text { (1979-2015) }\end{array}$} \\
\hline & & & & & & Begin & End & & & \\
\hline \multicolumn{11}{|c|}{ Groundwater-level observation wells (U.S. Geological Survey, 2017c)_Continued } \\
\hline 354225098111201 & & & 08N-14W-07 AAD 1 & 35.1867232 & -98.7072884 & 08/1986 & 08/1986 & 85 & 1 & 13.75 \\
\hline 361741099112901 & & & 21N-19W-13 CBC 2 & 36.29476109 & -99.1917693 & 02/1987 & 02/1987 & 75 & 1 & 3.38 \\
\hline 355032098541401 & & & 16N-16W-21 DCD 1 & 35.8422682 & -98.9042583 & 05/1989 & 05/1989 & 200 & 1 & 5.63 \\
\hline 355254098573201 & & & $16 \mathrm{~N}-17 \mathrm{~W}-12$ ABC 1 & 35.8817117 & -98.9592608 & 05/1989 & 05/1989 & 166 & 1 & 6.17 \\
\hline 354417098461301 & & & 15N-15W-35 BDA 1 & 35.7381045 & -98.7706402 & 05/1989 & 05/1989 & 79 & 1 & 11.27 \\
\hline 354549098552501 & & & 15N-16W-20 DCC 1 & 35.76365858 & -98.9239797 & 05/1989 & 05/1989 & 240 & 1 & 7.91 \\
\hline 352754098453301 & & & 12N-15W-35 CDC 1 & 35.465053 & -98.7595189 & 06/1989 & 06/1989 & 157 & 1 & 9.65 \\
\hline 353555098420801 & & & 13N-14W-16 CBC 1 & 35.5986621 & -98.7025768 & 06/1989 & 06/1989 & 91 & 1 & 6.56 \\
\hline 353755099001901 & & & 13N-17W-04 ADA 1 & 35.6339373 & -99.0050899 & 06/1989 & 06/1989 & 119 & 1 & 6.06 \\
\hline 355936098533701 & & & 18N-16W-34 BDD 1 & 35.99337629 & -98.893983 & 06/1989 & 06/1989 & -- & 1 & 6.68 \\
\hline 352935098172001 & & & 12N-10W-19 DDD 1 & 35.4931075 & -98.2892255 & 06/1989 & 06/1989 & 75 & 1 & 12.01 \\
\hline 353357098570202 & & & 13N-16W-31 BBB 2 & 35.56588298 & -98.950919 & 06/1989 & 06/1989 & 150 & 1 & 8.26 \\
\hline 353909098524901 & & & $\begin{array}{l}\text { OW-2 14N-16W-34 } \\
\text { AAAA } 1\end{array}$ & 35.65254928 & -98.8806413 & 07/1990 & 07/1990 & 420 & 1 & 9.38 \\
\hline 354936099043801 & & & $\begin{array}{l}\text { OW-1 16N-18W-35 } \\
\text { AAB } 1\end{array}$ & 35.8267127 & -99.0775965 & 07/1990 & 07/1990 & 278 & 2 & 8.15 \\
\hline 351322098285701 & & & 9N-12W-29 DAD 1 & 35.22283518 & -98.4828373 & 12/1998 & 08/1999 & -- & 2 & 4.69 \\
\hline 351409098283901 & & & 9N-12W-21 CDB 1 & 35.2358905 & -98.4778372 & 12/1998 & 08/1999 & 305 & 2 & 2.02 \\
\hline 351411098290401 & & & 9N-12W-20 DD 1 & 35.236446 & -98.4847818 & 12/1998 & 08/1999 & 305 & 2 & 2.87 \\
\hline 351416098275301 & & & 9N-12W-21 DAD 1 & 35.23777778 & -98.4647222 & 12/1998 & 08/1999 & 75 & 2 & 1.36 \\
\hline 351453098295801 & & & 9N-12W-17 CCC 1 & 35.2481123 & -98.4997823 & 12/1998 & 08/1999 & 100 & 2 & 4.13 \\
\hline 351514098285301 & & & $9 \mathrm{~N}-12 \mathrm{~W}-16 \mathrm{CBB} 1$ & 35.2541111 & -98.4815833 & 12/1998 & 08/1999 & -- & 2 & 1.36 \\
\hline 351328098285801 & & & 9N-12W-29 DAA 1 & 35.2245018 & -98.483115 & 12/1998 & 08/1999 & 150 & 2 & 3.95 \\
\hline 351414098295801 & & & $9 \mathrm{~N}-12 \mathrm{~W}-20 \mathrm{CBC} 1$ & 35.2372222 & -98.4994444 & 12/1998 & 08/1999 & 150 & 2 & 2.33 \\
\hline 351453098290701 & & & 9N-12W-17 DDC 1 & 35.24866798 & -98.4856152 & 12/1998 & 08/1999 & 100 & 2 & 3.45 \\
\hline 351454098290501 & & & 9N-12W-17 DD 1 & 35.2483902 & -98.4850597 & 12/1998 & 08/1999 & -- & 2 & 1.36 \\
\hline 351505098291401 & & & 9N-12W-17 D 1 & 35.25089015 & -98.487282 & 12/1998 & $12 / 1998$ & 315 & 1 & 1.80 \\
\hline 351543098285701 & & & 9N-12W-8 DDD 1 & 35.26219444 & -98.4825833 & $12 / 1998$ & 08/1999 & 150 & 2 & 1.36 \\
\hline 351555098291101 & & & 9N-12W-8 D 1 & 35.2653343 & -98.4867267 & $12 / 1998$ & 08/1999 & 300 & 2 & 5.45 \\
\hline 351628098284401 & & & 9N-12W-9 BB 1 & 35.27450087 & -98.4792267 & $12 / 1998$ & 08/1999 & 300 & 2 & 2.59 \\
\hline 351633098292601 & & & 9N-12W-8 ABB 1 & 35.27588966 & -98.4897826 & $12 / 1998$ & 08/1999 & 100 & 2 & 3.27 \\
\hline 351635098300301 & & & 9N-12W-5 CCC 1 & 35.2767229 & -98.4986718 & $12 / 1998$ & 08/1999 & -- & 2 & 1.81 \\
\hline 351507098284101 & & & 9N-12W-16 C 1 & 35.25144576 & -98.4783928 & 12/1998 & 08/1999 & -- & 2 & 1.36 \\
\hline 351512098295501 & & & $9 \mathrm{~N}-12 \mathrm{~W}-17 \mathrm{CBB} 1$ & 35.2533333 & -98.4988611 & $12 / 1998$ & 08/1999 & -- & 2 & 1.36 \\
\hline 351523098285501 & & & 9N-12W-16 BCB 1 & 35.25644564 & -98.482282 & $12 / 1998$ & 08/1999 & -- & 2 & 6.92 \\
\hline 351608098274901 & & & $9 \mathrm{~N}-12 \mathrm{~W}-10 \mathrm{CBBB} 1$ & 35.2690833 & -98.4636389 & 12/1998 & 08/1999 & -- & 2 & 1.36 \\
\hline
\end{tabular}


Table 7. Selected groundwater-level observation wells in the Rush Springs aquifer study area, western Oklahoma.-Continued

[OWRB ID is the well identifier used by the Oklahoma Water Resources Board (OWRB) and the U.S. Geological Survey (USGS) databases; Some differences may occur for the long-term groundwater-level observation well begin and end dates between the OWRB and the USGS well databases; the number of groundwater-level observations does not include the period of record averaged observation used in the steady-state groundwater-flow model; MM/YYYY, month/year; --, not available; *, observation well used for approximating the maximum seasonal groundwater-level range (seasonal approximation)]

\begin{tabular}{|c|c|c|c|c|c|c|c|c|c|c|}
\hline \multirow[t]{2}{*}{$\begin{array}{c}\text { Well } \\
\text { number }\end{array}$} & \multirow[t]{2}{*}{$\begin{array}{l}\text { OWRB } \\
\text { ID }\end{array}$} & \multirow[t]{2}{*}{$\begin{array}{c}\text { Map } \\
\text { number } \\
\text { (fig. 11) }\end{array}$} & \multirow[t]{2}{*}{ Station name } & \multirow[t]{2}{*}{$\begin{array}{l}\text { Latitude } \\
\text { (decimal } \\
\text { degrees) }\end{array}$} & \multirow[t]{2}{*}{$\begin{array}{l}\text { Longitude } \\
\text { (decimal } \\
\text { degrees) }\end{array}$} & \multicolumn{2}{|c|}{$\begin{array}{l}\text { Period of record } \\
\text { (may contain } \\
\text { gaps) or single } \\
\text { measurement } \\
\text { date } \\
\text { (MM/YYYY) }\end{array}$} & \multirow[t]{2}{*}{$\begin{array}{l}\text { Well } \\
\text { or hole } \\
\text { depth } \\
\text { (feet) }\end{array}$} & \multirow{2}{*}{$\begin{array}{c}\text { Number } \\
\text { of ground- } \\
\text { water- } \\
\text { level obser- } \\
\text { vations dur- } \\
\text { ing study } \\
\text { period } \\
\text { (1979-2015) }\end{array}$} & \multirow{2}{*}{$\begin{array}{c}\text { Standard } \\
\text { deviation } \\
\text { of ground- } \\
\text { water-level } \\
\text { observa- } \\
\text { tions during } \\
\text { study period } \\
\text { (1979-2015) }\end{array}$} \\
\hline & & & & & & Begin & End & & & \\
\hline \multicolumn{11}{|c|}{ Groundwater-level observation wells (U.S. Geological Survey, 2017c)—Continued } \\
\hline 351618098285301 & & & $9 N-12 W-9$ BCB 1 & 35.2717231 & -98.4817267 & $12 / 1998$ & 08/1999 & -- & 2 & 2.75 \\
\hline 351622098294201 & & & 9N-12W-8 B 1 & 35.2728341 & -98.4953383 & $12 / 1998$ & 08/1999 & 300 & 2 & 3.92 \\
\hline 351630098275301 & & & 9N-12W-09 AAA 1 & 35.2751111 & -98.4647778 & 12/1998 & 08/1999 & 150 & 2 & 1.36 \\
\hline 351650098285301 & & & 9N-12W-4 CBC 1 & 35.28061185 & -98.481727 & $12 / 1998$ & 08/1999 & 100 & 2 & 3.91 \\
\hline 351712098284101 & & & $9 \mathrm{~N}-12 \mathrm{~W}-4$ B 1 & 35.28672286 & -98.4783937 & $12 / 1998$ & 12/1998 & 305 & 1 & 3.51 \\
\hline 351341098285401 & & & 9N-12W-28 BCB 1 & 35.22811286 & -98.4820039 & $12 / 1998$ & $12 / 1998$ & -- & 1 & 2.41 \\
\hline 351421098285301 & & & 9N-12W-21 CBB 1 & 35.23927778 & -98.4814722 & $12 / 1998$ & 08/1999 & -- & 2 & 1.36 \\
\hline 351421098285302 & & & 9N-12W-21 CBB 2 & 35.23927778 & -98.4814722 & $12 / 1998$ & 12/1998 & 320 & 1 & 1.36 \\
\hline 351531098310101 & & & 9N-12W-18 BBC 1 & 35.25866759 & -98.517283 & $12 / 1998$ & 08/1999 & -- & 2 & 7.34 \\
\hline 351607098310201 & & & 9N-13W-12 DAA 1 & 35.26880556 & -98.5174722 & $12 / 1998$ & 08/1999 & -- & 2 & 1.36 \\
\hline 351452098290601 & & & 09N-12W-17 DDD 1 & 35.24783467 & -98.4853374 & 04/1999 & $07 / 2000$ & 73 & 13 & 2.29 \\
\hline 351542098282501 & & & $\begin{array}{l}\text { MW-C 9N-12W-16 } \\
\text { BAAA } 1\end{array}$ & 35.2614456 & -98.4739485 & $04 / 2000$ & $04 / 2000$ & 70 & 1 & 1.42 \\
\hline 351545098285701 & & & $\begin{array}{l}\text { MW-B 9N-12W-8 } \\
\text { DDD } 2\end{array}$ & 35.2625566 & -98.4828377 & $04 / 2000$ & $04 / 2000$ & 72 & 1 & 1.50 \\
\hline 351502098284001 & & & BD-3 9N-12W-16 C 2 & 35.2508902 & -98.478115 & $04 / 2000$ & $04 / 2000$ & 55 & 1 & 4.64 \\
\hline 351506098284001 & & & $\begin{array}{l}\text { BD-1 9N-12W-16 } \\
\text { CBAD } 1\end{array}$ & 35.2531124 & -98.4783929 & $04 / 2000$ & $04 / 2000$ & 55 & 1 & 1.72 \\
\hline 351504098284601 & & & $\begin{array}{l}\text { BD-2 9N-12W-16 } \\
\quad \text { CB } 1\end{array}$ & 35.25311238 & -98.4806152 & $04 / 2000$ & $04 / 2000$ & 55 & 1 & 2.17 \\
\hline 352515098312001 & & & 11N-13W-13 DCD 1 & 35.42109444 & -98.5224361 & 07/2010 & $01 / 2011$ & 240 & 7 & 0.28 \\
\hline 352907098230501 & & & 12N-11W-29 DBB 1 & 35.48554444 & -98.3847472 & 07/2010 & 01/2011 & 208 & 7 & 0.28 \\
\hline 353014098202601 & & & 12N-11W-23 BBC 1 & 35.50410278 & -98.3407083 & $07 / 2010$ & $12 / 2010$ & 88 & 6 & 2.00 \\
\hline 351850098171901 & & & 10N-10W-29 BCC 1 & 35.314025 & -98.2886583 & 07/2010 & $01 / 2011$ & 124 & 7 & 0.52 \\
\hline 351850098283301 & & & 10N-12W-28 BDD 2 & 35.31395556 & -98.47595 & 07/2010 & 08/2010 & 320 & 2 & 0.49 \\
\hline 353002098340701 & & & 12N-13W-22 BCC 1 & 35.5006722 & -98.568775 & 07/2010 & 01/2011 & 200 & 7 & 0.76 \\
\hline 345443098061701 & & & 05N-09W-13 ВАВ 1 & 34.91217778 & -98.1049083 & 07/2010 & 01/2011 & 77 & 7 & 0.28 \\
\hline 345633098141901 & & & 06N-10W-34 DCD 1 & 34.94266389 & -98.2388417 & 07/2010 & 01/2011 & 56 & 7 & 0.52 \\
\hline 345728098185401 & & & 06N-11W-25 CDC 1 & 34.9579861 & -98.3150389 & $07 / 2010$ & $01 / 2011$ & 50 & 7 & 0.76 \\
\hline 350157098082501 & & & 07N-09W-34 CDB 1 & 35.03261944 & -98.1403972 & 07/2010 & 01/2011 & -- & 7 & 2.75 \\
\hline 350211098222701 & & & 07N-11W-33 BCC 1 & 35.03649444 & -98.3741889 & 07/2010 & $01 / 2011$ & 120 & 7 & 0.28 \\
\hline 350510098332501 & & & 07N-13W-15 ABB 1 & 35.0862333 & -98.55695 & 07/2010 & 01/2011 & 130 & 7 & 0.28 \\
\hline 350856098253101 & & & 08N-12W-23 DDA 1 & 35.14914444 & -98.4255111 & 07/2010 & 01/2011 & 70 & 7 & 0.28 \\
\hline 351243098141201 & & & 09N-10W-34 ADD 1 & 35.21212778 & -98.2366944 & $07 / 2010$ & $01 / 2011$ & 60 & 7 & 0.28 \\
\hline 351907098074201 & & & 10N-09W-26 BBB 1 & 35.318775 & -98.1283528 & 07/2010 & 01/2011 & 92 & 7 & 0.28 \\
\hline 352039098121801 & & & 10N-10W-13 ADB 1 & 35.3442972 & -98.2050889 & $07 / 2010$ & $01 / 2011$ & 206 & 6 & 0.28 \\
\hline 351005098332001 & & & 08N-13W-15 ACC 1 & 35.16816667 & -98.5558306 & 07/2010 & $01 / 2011$ & 370 & 7 & 0.28 \\
\hline 352143098310601 & & & 10N-13W-12 AAA 1 & 35.3620333 & -98.5185889 & 07/2010 & $01 / 2011$ & 137 & 7 & 0.49 \\
\hline
\end{tabular}


Table 7. Selected groundwater-level observation wells in the Rush Springs aquifer study area, western Oklahoma.—Continued

[OWRB ID is the well identifier used by the Oklahoma Water Resources Board (OWRB) and the U.S. Geological Survey (USGS) databases; Some differences may occur for the long-term groundwater-level observation well begin and end dates between the OWRB and the USGS well databases; the number of groundwater-level observations does not include the period of record averaged observation used in the steady-state groundwater-flow model; MM/YYYY, month/year; --, not available; *, observation well used for approximating the maximum seasonal groundwater-level range (seasonal approximation)]

\begin{tabular}{|c|c|c|c|c|c|c|c|c|c|}
\hline \multirow[t]{2}{*}{$\begin{array}{c}\text { Well } \\
\text { number }\end{array}$} & \multirow[t]{2}{*}{$\begin{array}{l}\text { OWRB } \\
\text { ID }\end{array}$} & \multirow[t]{2}{*}{$\begin{array}{c}\text { Map } \\
\text { number } \\
\text { (fig. 11) }\end{array}$} & \multirow[t]{2}{*}{$\begin{array}{l}\text { Latitude } \\
\text { (decimal } \\
\text { degrees) }\end{array}$} & \multirow[t]{2}{*}{$\begin{array}{c}\text { Longitude } \\
\text { (decimal } \\
\text { degrees) }\end{array}$} & \multicolumn{2}{|c|}{$\begin{array}{l}\text { Period of record } \\
\text { (may contain } \\
\text { gaps) or single } \\
\text { measurement } \\
\text { date } \\
\text { (MM/YYYY) }\end{array}$} & \multirow[t]{2}{*}{$\begin{array}{c}\text { Well } \\
\text { or hole } \\
\text { depth } \\
\text { (feet) }\end{array}$} & \multirow{2}{*}{$\begin{array}{l}\text { Number } \\
\text { of ground- } \\
\text { water- } \\
\text { level obser- } \\
\text { vations dur- } \\
\text { ing study } \\
\text { period } \\
\text { (1979-2015) }\end{array}$} & \multirow{2}{*}{$\begin{array}{c}\text { Standard } \\
\text { deviation } \\
\text { of ground- } \\
\text { water-level } \\
\text { observa- } \\
\text { tions during } \\
\text { study period } \\
\text { (1979-2015) }\end{array}$} \\
\hline & & & & & Begin & End & & & \\
\hline \multicolumn{10}{|c|}{ Groundwater-level observation wells (U.S. Geological Survey, 2017c)_Continued } \\
\hline 352315098265501 & & 11N-12W-34 ADA 1 & 35.38753889 & -98.4487972 & $07 / 2010$ & $01 / 2011$ & 185 & 7 & 0.28 \\
\hline 352812098244401 & & 12N-12W-36 DAA 1 & 35.4702722 & -98.4124278 & 07/2010 & $01 / 2011$ & 178 & 7 & 0.52 \\
\hline 351442098182401 & & 09N-11W-24 AAD 1 & 35.24517778 & -98.30685 & $07 / 2010$ & $01 / 2011$ & 35 & 7 & 0.28 \\
\hline 351620098234101 & & 09N-11W-07 ADA 1 & 35.27230556 & -98.3949083 & 07/2010 & $01 / 2011$ & 160 & 7 & 0.28 \\
\hline 350933098172101 & & 08N-10W-19 ABA 1 & 35.15937778 & -98.2893472 & $07 / 2010$ & $01 / 2011$ & 170 & 7 & 0.28 \\
\hline 351100098232501 & & 08N-11W-07 ADD 1 & 35.1834111 & -98.3903722 & 07/2010 & $01 / 2011$ & 130 & 7 & 0.28 \\
\hline 352147098195401 & & 10N-11W-02 DCC 1 & 35.36319444 & -98.3316694 & 07/2010 & $01 / 2011$ & 100 & 7 & 0.76 \\
\hline 345357098181101 & & 05N-10W-18 CCC 1 & 34.89941667 & -98.3031139 & 07/2010 & 01/2011 & 120 & 7 & 2.50 \\
\hline 345910098233701 & & 06N-11W-18 DDD 1 & 34.98622778 & -98.3937833 & 07/2010 & 01/2011 & 95 & 8 & 0.52 \\
\hline 350714098232701 & & 08N-11W-31 DDA 1 & 35.12064167 & -98.3908944 & 08/2010 & 08/2010 & 82 & 1 & 0.49 \\
\hline 350757098230401 & & 08N-11W-29 CDC 1 & 35.13269167 & -98.3845222 & 08/2010 & $01 / 2011$ & 145 & 7 & 0.28 \\
\hline 350804098230501 & & 08N-11W-29 CDB 1 & 35.13451389 & -98.3847306 & 08/2010 & 08/2010 & 232 & 1 & 0.49 \\
\hline 350809098230401 & & 08N-11W-29 CAC 1 & 35.13585278 & -98.3845528 & 08/2010 & 08/2010 & 400 & 1 & 0.49 \\
\hline 352423098221601 & & $11 \mathrm{~N}-11 \mathrm{~W}-21 \mathrm{CDC} 1$ & 35.4065333 & -98.3711667 & 08/2010 & 01/2011 & 120 & 7 & 0.28 \\
\hline 351726098353801 & & 09N-13W-05 ABA 0 & 35.2905611 & -98.5939528 & 07/2011 & 08/2012 & 7 & 6 & 0.48 \\
\hline 351726098353501 & & 09N-13W-05 ABA 5 & 35.2906083 & -98.5932056 & 09/2011 & 08/2012 & 34 & 6 & 0.48 \\
\hline 351726098353601 & & 09N-13W-05 ABA 3 & 35.2905833 & -98.5935028 & 09/2011 & 08/2012 & 43 & 6 & 0.48 \\
\hline 351726098353701 & & 09N-13W-05 ABA 2 & 35.29058056 & -98.593675 & 09/2011 & 08/2012 & 23 & 6 & 0.48 \\
\hline 351727098353801 & & 10N-13W-32 DCD 1 & 35.2908972 & -98.5938833 & 09/2011 & 07/2012 & 21 & 5 & 0.48 \\
\hline 351727098353701 & & 10N-13W-32 DCD 4 & 35.2909722 & -98.5935806 & $12 / 2011$ & 07/2012 & 46 & 4 & 0.48 \\
\hline 360809098443501 & & 19N-15W-12 DAA 2 & 36.13595556 & -98.7430833 & $01 / 2012$ & $01 / 2012$ & -- & 1 & 0.49 \\
\hline 360835098475401 & & 19N-15W-09 AAA 1 & 36.1431861 & -98.7982 & 01/2012 & 01/2012 & 51 & 1 & 0.49 \\
\hline 360842098514201 & & 19N-16W-01 CDC 1 & 36.1448972 & -98.861725 & $01 / 2012$ & $01 / 2012$ & 90 & 1 & 0.49 \\
\hline 360931098533701 & & 19N-16W-03 ABB 1 & 36.1586111 & -98.8936528 & $01 / 2012$ & $10 / 2012$ & 48 & 2 & 0.49 \\
\hline 362035099123901 & & 22N-19W-34 ADD 1 & 36.343 & -99.2109472 & 02/2012 & 02/2012 & 54 & 1 & 0.49 \\
\hline 355909099200801 & & 18N-20W-33 CCD 1 & 35.98606389 & -99.3357389 & $01 / 2013$ & $01 / 2014$ & 250 & 2 & 0.49 \\
\hline 355221099341001 & & 16N-22W-07 DAC 1 & 35.87260556 & -99.5696944 & 02/2013 & $01 / 2014$ & 36 & 2 & 0.49 \\
\hline 355256099335901 & & 16N-22W-08 BBB 1 & 35.88231389 & -99.5665083 & 02/2013 & $01 / 2014$ & 24 & 2 & 0.49 \\
\hline 360050099194701 & & 18N-20W-28 AAA 1 & 36.01396389 & -99.3298278 & 02/2013 & $01 / 2014$ & 53 & 2 & 0.49 \\
\hline 360128099211501 & & 18N-20W-20 ACB 1 & 36.02449444 & -99.3542056 & 02/2013 & 01/2014 & 60 & 2 & 0.49 \\
\hline 355242099064001 & & 16N-18W-10 BCD 1 & 35.8784722 & -99.1113861 & 02/2013 & $01 / 2014$ & 183 & 2 & 0.49 \\
\hline 355304099100401 & & 16N-18W-06 CCC 1 & 35.8844861 & -99.1678278 & 02/2013 & $01 / 2014$ & 36 & 2 & 0.49 \\
\hline 355424099143501 & & 17N-19W-32 ADC 1 & 35.9068861 & -99.2431722 & 02/2013 & 02/2013 & 89 & 1 & 0.49 \\
\hline 355441099145101 & & 17N-19W-32 ABB 1 & 35.9115333 & -99.2475667 & 02/2013 & $01 / 2014$ & 41 & 2 & 0.49 \\
\hline 355500099144701 & & 17N-19W-29 DCB 1 & 35.9168361 & -99.2466167 & 02/2013 & $01 / 2014$ & 78 & 2 & 0.49 \\
\hline 355538099145901 & & 17N-19W-29 BAA 1 & 35.92734444 & -99.2499333 & 02/2013 & $01 / 2014$ & 72 & 2 & 0.49 \\
\hline
\end{tabular}


Table 7. Selected groundwater-level observation wells in the Rush Springs aquifer study area, western Oklahoma.—Continued

[OWRB ID is the well identifier used by the Oklahoma Water Resources Board (OWRB) and the U.S. Geological Survey (USGS) databases; Some differences may occur for the long-term groundwater-level observation well begin and end dates between the OWRB and the USGS well databases; the number of groundwater-level observations does not include the period of record averaged observation used in the steady-state groundwater-flow model; MM/YYYY, month/year; --, not available; *, observation well used for approximating the maximum seasonal groundwater-level range (seasonal approximation)]

\begin{tabular}{|c|c|c|c|c|c|c|c|c|c|c|}
\hline \multirow[t]{2}{*}{$\begin{array}{c}\text { Well } \\
\text { number }\end{array}$} & \multirow[t]{2}{*}{$\begin{array}{l}\text { OWRB } \\
\text { ID }\end{array}$} & \multirow[t]{2}{*}{$\begin{array}{c}\text { Map } \\
\text { number } \\
\text { (fig. 11) }\end{array}$} & \multirow[t]{2}{*}{ Station name } & \multirow[t]{2}{*}{$\begin{array}{l}\text { Latitude } \\
\text { (decimal } \\
\text { degrees) }\end{array}$} & \multirow[t]{2}{*}{$\begin{array}{c}\text { Longitude } \\
\text { (decimal } \\
\text { degrees) }\end{array}$} & \multicolumn{2}{|c|}{$\begin{array}{l}\text { Period of record } \\
\text { (may contain } \\
\text { gaps) or single } \\
\text { measurement } \\
\text { date } \\
\text { (MM/YYYY) }\end{array}$} & \multirow[t]{2}{*}{$\begin{array}{l}\text { Well } \\
\text { or hole } \\
\text { depth } \\
\text { (feet) }\end{array}$} & \multirow{2}{*}{$\begin{array}{c}\text { Number } \\
\text { of ground- } \\
\text { water- } \\
\text { level obser- } \\
\text { vations dur- } \\
\text { ing study } \\
\text { period } \\
\text { (1979-2015) }\end{array}$} & \multirow{2}{*}{$\begin{array}{c}\text { Standard } \\
\text { deviation } \\
\text { of ground- } \\
\text { water-level } \\
\text { observa- } \\
\text { tions during } \\
\text { study period } \\
\text { (1979-2015) }\end{array}$} \\
\hline & & & & & & Begin & End & & & \\
\hline \multicolumn{11}{|c|}{ Groundwater-level observation wells (U.S. Geological Survey, 2017c)—Continued } \\
\hline 355759099141801 & & & 17N-19W-09 BCB 1 & 35.96643056 & -99.2386056 & $02 / 2013$ & $01 / 2014$ & 51 & 2 & 0.49 \\
\hline 355831099155101 & & & 17N-19W-06 DBC 1 & 35.9752833 & -99.2642306 & $02 / 2013$ & $02 / 2013$ & 68 & 1 & 0.49 \\
\hline 355934099161301 & & & 18N-19W-31 BDC 1 & 35.992875 & -99.2703222 & $02 / 2013$ & $01 / 2014$ & 41 & 2 & 0.49 \\
\hline 355358099154901 & & & 17N-19W-31 DCC 1 & 35.8995583 & -99.2637083 & 02/2013 & $01 / 2014$ & 92 & 2 & 0.49 \\
\hline 355558099162901 & & & 17N-20W-24 DAD 1 & 35.9330111 & -99.2747333 & $02 / 2013$ & $02 / 2013$ & -- & 1 & 0.49 \\
\hline 353310098223101 & & & 13N-11W-33 DCC 1 & 35.55281944 & -98.3753917 & $03 / 2013$ & $01 / 2014$ & 18 & 2 & 0.49 \\
\hline 355725098584701 & & & 17N-17W-11 DCD 1 & 35.95701944 & -98.9798667 & 03/2013 & 03/2013 & -- & 1 & 0.49 \\
\hline 360052098590701 & & & 18N-17W-26 BAB 1 & 36.0146 & -98.9854333 & $03 / 2013$ & $01 / 2014$ & 65 & 2 & 0.49 \\
\hline 355113098363001 & & & 16N-13W-20 BAB 1 & 35.8537083 & -98.6086 & 03/2013 & $01 / 2014$ & 250 & 2 & 0.49 \\
\hline 355305098461501 & & & 16N-15W-02 DDC 1 & 35.88488889 & -98.7709417 & 03/2013 & 03/2013 & 62 & 1 & 0.49 \\
\hline 355307098402901 & & & 16N-14W-03 DCC 1 & 35.8853333 & -98.6748333 & 03/2013 & $01 / 2014$ & 250 & 2 & 0.49 \\
\hline 355359098491101 & & & 17N-15W-32 DCD 1 & 35.89994444 & -98.8199528 & 03/2013 & $01 / 2014$ & 130 & 2 & 0.49 \\
\hline 355523098495501 & & & 17N-15W-30 ADA 1 & 35.92309444 & -98.8320944 & $03 / 2013$ & $01 / 2014$ & 132 & 2 & 0.49 \\
\hline 355559098464401 & & & 17N-15W-22 DAA 1 & 35.9332722 & -98.7790583 & 03/2013 & $01 / 2014$ & 107 & 2 & 0.49 \\
\hline 355803098505601 & & & 17N-15W-07 ABC 1 & 35.9676222 & -98.8490833 & 03/2013 & $01 / 2014$ & 56 & 2 & 0.49 \\
\hline 360012098525801 & & & 18N-16W-26 CCB 1 & 36.00351944 & -98.8828083 & 03/2013 & $01 / 2014$ & 91 & 2 & 0.49 \\
\hline 360014098525801 & & & 18N-16W-26 CBC 1 & 36.00395 & -98.8827861 & 03/2013 & 03/2013 & 139 & 1 & 0.49 \\
\hline 360022098525501 & & & $\begin{array}{l}\text { Taloga } 18 N-16 W-26 \\
\text { CBA } 1\end{array}$ & 36.0060472 & -98.8820222 & $10 / 2014$ & $04 / 2016$ & 19 & 6 & 0.49 \\
\hline 360110099215001 & & & $\begin{array}{l}\text { Camargo 18N- } \\
\text { 20W-20 CBC } 1\end{array}$ & 36.01950556 & -99.3640139 & $10 / 2014$ & $04 / 2016$ & 24 & 6 & 0.49 \\
\hline 353215099004101 & & & $\begin{array}{l}\text { WSH05 12N-17W-09 } \\
\text { BBB } 1\end{array}$ & 35.5374611 & -99.0113056 & 04/2015 & 03/2017 & 124 & 3 & 1.36 \\
\hline 354022099202701 & & & $\begin{array}{l}\text { WSH04 14N-21W-21 } \\
\text { CDC } 1\end{array}$ & 35.6728 & -99.3409139 & $04 / 2015$ & 03/2017 & 75 & 2 & 1.36 \\
\hline
\end{tabular}


For more information about this report, contact

Director, U.S. Geological Survey

202 NW 66th Street, Building 7

Oklahoma City, OK 73116

https://www.usgs.gov/centers/ok-water/

Publishing support provided by

Lafayette Publishing Service Center

Lafayette, Louisiana 


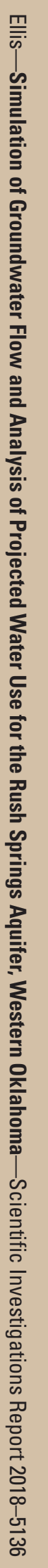

